\title{
Appartementsrecht en de welstandsbepalingen : een rechtsvergelijkende studie
}

Citation for published version (APA):

Mertens, R. F. H. (1989). Appartementsrecht en de welstandsbepalingen : een rechtsvergelijkende studie. [Doctoral Thesis, Maastricht University]. Kluwer. https://doi.org/10.26481/dis.19891123rm

Document status and date:

Published: 01/01/1989

DOI:

10.26481/dis.19891123rm

Document Version:

Publisher's PDF, also known as Version of record

\section{Please check the document version of this publication:}

- A submitted manuscript is the version of the article upon submission and before peer-review. There can be important differences between the submitted version and the official published version of record.

People interested in the research are advised to contact the author for the final version of the publication, or visit the DOI to the publisher's website.

- The final author version and the galley proof are versions of the publication after peer review.

- The final published version features the final layout of the paper including the volume, issue and page numbers.

Link to publication

\footnotetext{
General rights rights.

- You may freely distribute the URL identifying the publication in the public portal. please follow below link for the End User Agreement:

www.umlib.nl/taverne-license

Take down policy

If you believe that this document breaches copyright please contact us at:

repository@maastrichtuniversity.nl

providing details and we will investigate your claim.
}

Copyright and moral rights for the publications made accessible in the public portal are retained by the authors and/or other copyright owners and it is a condition of accessing publications that users recognise and abide by the legal requirements associated with these

- Users may download and print one copy of any publication from the public portal for the purpose of private study or research.

- You may not further distribute the material or use it for any profit-making activity or commercial gain

If the publication is distributed under the terms of Article $25 \mathrm{fa}$ of the Dutch Copyright Act, indicated by the "Taverne" license above, 
APPARTEMENTSRECHT EN DE WELSTANDSBEPALINGEN 
Aan de nagedachtenis van mijn vader 


\title{
APPARTEMENTSRECHT EN DE WELSTANDSBEPALINGEN
}

Een rechtsvergelijkende studie

\author{
PROEFSCHRIFT \\ ter verkrijging van de graad van doctor \\ aan de Rijksuniversiteit Limburg te Maastricht, \\ op gezag van de Rector Magnificus, Prof. Dr. F.I.M. Bonke, \\ volgens het besluit van het College van Dekanen, \\ in het openbaar te verdedigen op \\ donderdag, 23 november 1989 om 14.00 uur
}

door

\section{Roland Ferdinand Hubert Mertens}

geboren te Reuver in 1964

Kluwer - Deventer - 1989 
Promotores:

Prof. mr. J.L.M. Elders

Prof. mr. G.R. de Groot

Beoordelingscommissie:

Prof. mr. C.A. Adriaansens (voorzitter)

Prof. mr. C.A. Schwarz

Prof. mr. A.A. van Velten

Van dit proefschrift is een handelseditie verschenen in de serie Ars Notariatus (deel XLIII) bij Kluwer, Deventer, onder ISBN 9026819706

(c) 1989 R.F.H. Mertens, Maastricht

Behoudens de in of krachtens de Auteurswet van 1912 gestelde uitzonderingen mag niets wit deze uitgave worden verveelvoudigd en of openbaar gemaakt door middel van druk, fotocopie, microfulm of op welke andere wijze dan ook, en evenmin in een retrieval systeem worden opgeslagen, zonder de voorafgaande schriftelijke toestemming van Uitgeverij Kluwer B.V. te Deventer, die daartoe door de auteursrechthebbende met uitsluiting van ieder ander is gemachtigd.

No part of this book may be reproduced in any form, by print, photoprint, microfilm or any other means without written permission from the publisher. 
Toen ik in 1984 als tweedejaars student samen met mijn jaargenote Caroline Smeets besloot een werkstuk over "de welstandsbepalingen in het appartementsrecht" te schrijven, wist ik niet dat het onderwerp mij dermate zou boeien dat ik er ooit een proefschrift over zou schrijven.

Dat de voorliggende studie ooit tot stand heeft kunnen komen, is in grote mate te danken aan de juridische faculteit van de Rijksuniversiteit Limburg, die mij na mijn afstuderen een aio-plaats ter beschikking stelde, waardoor ik de kans kreeg het grootste gedeelte van mijn tijd aan mijn onderzoek te besteden. Niet alleen de juridische faculteit van de Rijksuniversiteit Limburg heeft het schrijven van dit proefschrift mogelijk gemaakt. Een onderzoeker kan zijn werk waarschijnlijk niet succesvol afronden zonder de hulp van andere mensen. Ik wil in dit woord vooraf daarom niet nalaten die mensen bedanken, die mij bij het verrichten van mijn onderzoek behulpzaam zijn geweest.

Ten eerste ben ik aan prof. mr. J.L.M. Elders veel dank verschuldigd, enerzijds omdat hij bereid was om mijn promotor te zijn, anderzijds omdat hij de afgelopen jaren steeds tijd had of maakte om met mij over mijn proefschrift te discussiëren en hij mij met zijn zeer grote kennis veel waardevolle ideeën aan de hand heeft gedaan. Als prof. mr. G.R. de Groot mij niet al tijdens mijn studie had gemotiveerd om over appartementsrecht te publiceren, was het voorliggende werk waarschijnlijk nooit tot stand gekomen. In eerste instantie ben ik prof. De Groot dan ook veel dank verschuldigd voor deze stimulering. In tweede instantie verdient hij echter ook mijn dank voor de vele uren die hij heeft vrijgemaakt om mij bij het schrijven van dit proefschrift te begeleiden. Ik ben blij, dat ook hij erin heeft toegestemd om als promotor op te treden.

Behalve mijn promotoren hebben verschillende andere mensen nog recht op mijn dank. In het bijzonder verdient mijn goede vriend en collega mr. Matjaž Tratnik vermelding voor zijn bereidheid om als "sparring-partner" op te treden, telkens wanneer ik de strijd moest aanbinden met juridische problemen. Jean Dohmen, student-assistent aan de Rijksuniversiteit Limburg, en mijn broer Ron Mertens verdienen mijn dank voor de taalkundige correcties, die zij met grote nauwgezetheid in mijn manuscript aanbrachten. Verder mag in dit lijstje van te bedanken personen prof. dr. B. GroBfeld, hoogleraar internationaal ondernemingsrecht aan de juridische faculteit van de Westfälische Wilhelmsuniversität te Münster in Westfalen (BRD), niet ontbreken. Zonder aarzeling verleende hij mij een maand lang gastvrijheid in zijn instituut, hetgeen mij de mogelijkheid bood om binnen korte tijd aan mijn rechtsvergelijkende hoofdstukken vorm te geven.

Ook de professoren mrs. C.A. Adriaansens, C.A. Schwarz en A.A. van Velten ben ik dank verschuldigd, omdat zij bereid waren in mijn beoordelingscommissie zitting te nemen. Prof. mr. J.E. Spruit verdient mijn dank voor zijn opmerkingen bij paragraaf 2.1, en mrs. R. de Winter en A.W. Heringa, alsmede prof. mr. C. Flinterman voor hun uitbundige en waardevolle kritiek bij mijn paragrafen over grondrechten. Mevrouw ass. iur. Hildegard Schneider was zo vriendelijk om de 
Duitse samenvatting te corrigeren, waarvoor ik haar heel hartelijk bedank. Mr. Rejean Pinckaers nam de ondankbare taak op zich om mij te helpen bij de omvorming tot een boek van hetgeen ik op diskettes had getypt. Zonder zijn hulp zou dit boek niet half zo mooi zijn.

Zonder secretariële ondersteuning kan welhaast geen enkel boek tot stand komen. Ik ben de juridische faculteit van de Rijksuniversiteit Limburg dan ook dankbaar voor het feit dat zij mij een personal computer ter beschikking heeft gesteld.

De hulp en de motivering, die ik van mijn lieve vrouw Anita tijdens het schrijven aan dit boek ontving, kan niet worden gewogen. Ook mijn ouders hebben mij altijd zoveel zij konden gestimuleerd en ondersteund. Mijn vader was het, die mij leerde dat je steeds tot aan de einder door kunt gaan. Helaas heeft hij de totstandkoming van dit boek niet meer kunnen meemaken. Daarom draag ik deze dissertatie aan zijn nagedachtenis op.

Maastricht, 20 mei 1989 
Voorwoord

Inthoud

Lijst van afkortingen

1.1 Omschrijwing van de begrippen "appartementsrecht"

1.2 Doel "wan het onderzoek

1.3 Onderzoeksmethode en de opzet van het onderzoek

1.3.1 Rechtsvergelijking als onderzoeksmethode

1.3.2 Verantwoording van de gekozen rechtsstelsels

1.3.3 De opzet van het onderzoek

II NEDERLANDS RECHT

Horizontale splitsing van eigendom

De periode tussen de eerste en tweede wereldoorlog; appartementen en NV's (BV's)

2.1.3 De noodzaak van een wettelijke regeling

De inhoud van het oorspronkelijke ontwerp (Oo) van 1947 en de plaats van het appartementsrecht binnen het vermogensrecht

2.2.2 De redenen die aan de herziening ten grondslag lagen

2.3 Dogmatische opmerkingen ten aanzien van de structuur van appartementseigendom 
2.4 Hoofdlijnen van het geldende appartementsrecht

2.4.1 Algemene opmerkingen

242 Ontstaan en tenietgaan van appartementsrechten

242.1 Ontstalan 44

2.4 .2 Tenietgaan 54

24.3 Administratie en beheer 55

$2.4 .4 \quad$ Rechten en verplichtingen van de appartementseigenaars 60

2.4.5 Tot slot: appartementsrechten en verzekeringen 69

DE WELSTANDSBEPALINGEN IN HET APPARTEMENTSRECHT

De welstandsbepalingen in de standaardreglementen van de Koninklijke Notariële Broederschap

3.6.2.4 Dwaling/ontbindende voorwaarde 102

$\begin{array}{ll}\text { 3.6.2.5 Aanvullende opmerkingen } & 103\end{array}$

3.6.3 Toestemming tot ingebruikneming - specifieke criteria (praktijkvoorbeelden)

$\begin{array}{ll}3.6 .3 .2 & 105\end{array}$

$\begin{array}{ll}\text { 3.6.3.3 Financiële criteria } & 108\end{array}$

3.6.3.4 Lichamelijke en geestelijke gezondheid 110

3.6.3.5 Voorwaarden op moreel gebied 110

$\begin{array}{lll}3.6 .3 .6 & \text { Twee andere voorbeelden } & 111\end{array}$

$\begin{array}{lll}3.7 & \text { Ontzegging van verder gebruik } & 112\end{array}$

$\begin{array}{lll}3.7 .1 & \text { Het Van der Leen-arrest } & 114\end{array}$

3.7.2 Beroep tegen ontzegging van verder gebruik 116

3.7.3 Intermezzo: Het Van Maarsseveen-arrest 117 
3.7.4 Onrechtmatige daad

3.8 De vervreemdingsbeperking, een mogelijk alternatief voor de toelatingsregeling?

4.2 Gewone verenigingen en coöperaties

4.2.1 Gewone verenigingen

4.2.3.3 Rechterlijke toetsing van niet-toelating door "gewone" verenigingen en coöperaties

4.2.4 Einde van het lidmaatschap: opzegging en royement

4.2.4.4 Rechterlijke toetsing bij opzegging en royement door de gewone of coöperatie

4.2.5.3 Toelating en opzegging (inclusief ontzetting) 138

4.3.2.1 Rechten van deelgenoten ten aanzien van de goederen

4.3.2.2 Verhaalsmogelijkheden van een schuldeiser op een deelgenoot

4.3.2.3 Scheiding en deling/verdeling

4.3.3 Toelating van nieuwe deelgenoten en controle van deelgenoten onderling

\section{Huur}

\subsubsection{De Binderen-casus}


4.4.4.1 Toestemming tot ingebruikneming van een gehuurde service-flat

4.4.4.2 Toestemming tot ingebruikneming van een gehuurd gewoon appartement

4.4.4.3 Ontzegging van verder gebruik van verhuurde service-flat

4.4.4.4 Ontzegging van verder gebruik van een gehuurd gewoon appartement

Algemene structuur van appartementseigendom 
$7.1 \quad$ Inlẹiding

7.4.3 Beroep tegen ontzegging van verder gebruik

Inleiding

8.3.3.3 Algemene conclusies over het voorkeursrecht en het recht van bezwaar

8.3.3 Ontzegging van verder gebruik uitsluiting uit de gemeenschap 
9.2.2 Ontstaan en tenietgaan van appartementseigendom of appartementsrechiten

9.2 .2 .1

Ontstaan

9.22 .2

"Papieren splitsing"

9.2 .2 .3

9.2 .3

Tenietgaan

9.2 .4

9.3

9.3 .1

Administratie en beheer van appartementsgebouwen

Rechten en verplichtingen van appartementseigenaars appartementseigenaars

Samenvattingen

Nederlandse samenvatting 


\section{AFKORTINGEN}

A.A.

Aant.

$\mathrm{AB}$

Abs.

AcP

Afd. Rechtspr.

$A G$

Alg.

ALV

AMvB

Ann. Not.

Art(t).

AS

AWGB

$B$.

B.A.

Bay. ObLG

BGB

BGBL.

BGH

Bijl. Hand. I/II

Bijv.

BIGBW

BLR

Blz.

BRD

Bull.

BV

BW

B \& W

Cass.

Cass.civ

C.c.

C.C.H.

$\mathrm{CEDH}$

\section{CFV}

C.N.

Code urb.

C.q.

C.s.
Ars Aequi

Aantekening

Administratiefrechtelijke beslissingen (voorheen ARB)

Absatz

Archiv für die civilistische Praxis

Afdeling Rechtspraak van de Raad van State

Amtsgericht; Aktiengesellschaft

Algemeen

Algemene Ledenvergadering

Algemene Maatregel van Bestuur

Annales du Notariat et de l'Enrégistrement

Artikel(en)

Sammlung der eidgenössischen Gesetze, amtliche

Sammlung der Bundesgesetze und Verordnungen

Algemene wet gelijke behandeling

Beslissingen in belastingzaken

Beperkte aansprakelijkheid

Bayrisches Oberstes Landesgericht

Bürgerliches Gesetzbuch

Bundesgesetzblatt

Bundesgerichtshof

Bijlagen bij de Handelingen van de Eerste/Tweede

kamer der Staten-Generaal

Bijvoorbeeld

Blätter für Grundstücks-, Bau- und Wohnungsrecht

Badisches Landrecht

Bladzijde

Bondsrepubliek Duitsland

Bulletin Officiel

Besloten vennootschap met beperkte aansprakelijkheid Burgerlijk Wetboek

Burgemeester en Wethouders

Hof van Cassatie (Belgiè)

Cassation civile (Hof van Cassatie)

Code civil

Code de la Construction et de l'Habitation

Publications de la Cour Européenne des Droits de

l'Homme

Coöperatieve flatexploitatievereniging

Code Napoleon

Code de l'urbanisme

Casu quo

Cum suis 
Dall. J/L/IR/Chr.

D.d.

Dig.

Diss.

DNotZ

DTV

D.w.z.

E.a.

E.d.

EEG

EGBGB

EHRM

ESB

E.v.

EVRM

F.D.P.

Ff.

Gaz. Pal.

GBO

GBV

GmbH

GVG

Hand. I/II

HNJV

HR

IVESCR

J.C.P.

J.J.P.

J.L.

Jo.

J.T.

$\mathrm{KB}$

$\mathrm{KG}$

LG

M.b.t.

MDR

MvA

MvT

NBW

NJ

NJB

NJCM

NJW

NJW-RR

N.m.m.
Recueil Dalloz Jurisprudence/Lois/Information

Rapide/Chroniques

De dato

Digesten

Dissertatie

Deutsche Notar-Zeitschrift

Deutscher Taschenbuch Verlag

Dat wil zeggen

En anderen

En dergelijke

Europese Economische Gemeenschap

Einführungsgesetz zum Bürgerlichen Gesetzbuch

Europees Hof voor de Rechten van de Mens

Entscheidungen des Schweizerischen Bundesgerichts

En volgende

Europees Verdrag voor de Rechten van de Mens

Freie Demokratische Partei

Folgende

Gazette du Palais

Grundbuchordnung

Verordnung betreffend das Grundbuch

Gesellschaft mit beschränkter Haftung

Gerichtsverfassungsgesetz

Handelingen van de Eerste/Tweede kamer der Staten-

Generaal

Handelingen van de Nederlandse Juristenvereniging

Hoge Raad

Internationaal Verdrag inzake Economische, Sociale en

Culturele rechten

Juris Classeur Périodique

Journal des Juges de Paix

Jurisprudence de Liège

Juncto

Journal des Tribunaux

Koninklijk Besluit

Kammergericht

Landgericht

Met betrekking tot

Monatschrift für deutsches Recht

Memorie van Antwoord

Memorie van Toelichting

Nieuw Burgerlijk Wetboek

Nederlandse Jurisprudentie

Nederlands Juristenblad

Nederlands Juristencomité voor de Mensenrechten

Neue Juristische Wochenschrift

NJW-Rechtsprechungs-Report

Naar mijn mening 


\begin{tabular}{|c|c|}
\hline $\operatorname{Nr}(\mathrm{s})$ & Nummer(s) \\
\hline NV & Naamloze Vennootschap \\
\hline $\mathrm{OG}$ & Organisationsgesetz \\
\hline O.g.v. & Op grond van \\
\hline O. i. & Onzes inziens \\
\hline OINBW & Ontwerp Invoeringswet Nieuw Burgerlijk Wetboek \\
\hline OLG & Oberlandesgericht \\
\hline Oo & Oorspronkelijk ontwerp \\
\hline Par. & Paragraaf \\
\hline Pas. & Pasicrisie \\
\hline Pasin. & Pasinomie \\
\hline PIG & Partner in Gespräch \\
\hline Pres. & President \\
\hline PW & $\begin{array}{l}\text { Periodiek Woordenboek van administratieve en } \\
\text { gerechtelijke beslissingen }\end{array}$ \\
\hline Rb. & Rechtbank; Rechtbank van eerste aanleg \\
\hline Rec. Gén. Enr. Not. & Recueil Général de l'Enrégistrement et du Notariat \\
\hline Red. & Redactie \\
\hline Rev. Crit. Jur. B. & Revue Critique de Jurisprudence Bellge \\
\hline Rev. Liège & Revue de Jurisprudence de Liège, Mons et Bruxelles \\
\hline Rev. Not. B. & Revue du Notariat Belge \\
\hline Rev. Prat. Not & Revue Pratique du Notariat Belge \\
\hline R.G.A.R. & Revue Générale des Assurances et des Responsabilités \\
\hline R.M. & Rechtsgeleerd Magazijn \\
\hline R.M. Themis & Rechtsgeleerd Magazijn Themis \\
\hline RO & Recueil Officiel \\
\hline Rpfleger & Der deutsche Rechtspfleger \\
\hline Rv & Wetboek van Burgerlijke Rechtsvordering \\
\hline RudW & Rechtspraak van de Week \\
\hline RW & Rechtskundig Weekblad \\
\hline SchlHA & Schleswig-Holsteinische Anzeigen \\
\hline SJZ & Schweizerische JuristenZeitung \\
\hline Sr. & Wetboek van Strafrecht \\
\hline Stb. & Staatsblad \\
\hline Stcrt. & Staatscourant \\
\hline Stenbull. NR & $\begin{array}{l}\text { Amtliches stenographisches Bulletin der } \\
\text { Bundesversammlung, Nationalrat }\end{array}$ \\
\hline Stenbull. Str. & $\begin{array}{l}\text { Amtliches stenographisches Bulletin der } \\
\text { Bundesversammlung, Ständerat }\end{array}$ \\
\hline T.a.v. & Ten aanzien van \\
\hline TPR & Tijdschrift voor Privaatrecht \\
\hline Trb. & Tractatenblad \\
\hline Trib. gr. inst. & Tribunal de grande instance \\
\hline TVVS & $\begin{array}{l}\text { Tijdschrift voor Vennootschappen, Verenigingen en } \\
\text { Stichtingen }\end{array}$ \\
\hline U.A. & Uitgesloten Aanspakelijkheid \\
\hline Vgl. & Vergelijk \\
\hline V.o.f. & Vennootschap onder firma \\
\hline
\end{tabular}


V.V.E.

W.

W.A.

Der WEer

WEG

WM

WPNR

WvK

ZGB

ZMR

ZPO

ZVG

8
Vereniging van Eigenaars

Weekblad van het Recht

Wettelijke aansprakelijkheid

Der Wohnungseigentûmer

Wohnungseigentumsgesetz

Wertpapier-Mittellungen

Weekblad voor Privaatrecht, Notariaat en Registratie

Wetboek van Koophandel

Zivilgesetzbuch

Zeitschrift für Miet- und Raumrecht

Zivilprozessordnung

Gesetz über die Zwangsversteigerung und die

Zwangsverwaltung

Paragraaf (wetsbepaling) 


\section{INLEIDEND GEDEELTE}




\section{Inleiding}

\subsection{Omschrijving van de begrippen "appartementsrecht" en "welstandsbepalingen"}

Het begrip "appartementsrecht" heeft in Nederland twee juridische betekenissen. Enerzijds is er het "appartementsrecht in ruime zin", anderzijds is er het "appartementsrecht in enge zin". Het appartementsrecht in enge zin is in het burgerlijk wetboek (BW) gedefinieerd. Volgens artikel 875 a lid 3 BW wordt onder appartementsrecht namelijk verstaan:

"een aandeel in de goederen die in de splitsing zijn betrokken, dat de
bevoegdheid omvat tot het uitsluitend gebruik van bepaalde gedeelten
van een gebouw die blijkens hun inrichting bestemd zijn om als afzonder-
lijk geheel te worden gebruikt. Het aandeel kan mede omvatten de
bevoegdheid tot uitsluitend gebruik van bepaalde gedeelten van de bij het
gebouw behorende grond."

In het kort betekent dit dat een appartementsrecht in enge zin een medeëigendomsrecht ${ }^{1}$ van grond en gebouw(en) omvat, gecombineerd met een beperkt zakelijk gebruiksrecht op bepaalde voor afzonderlijk gebruik bestemde gedeelten. Door splitsing in appartementsrechten in enge zin komt geen splitsing van onroerend goed in afzonderlijke (volle) eigendomsrechten tot stand. Dientengevolge kan niet worden gezegd dat eigendom van een gebouwd onroerend goed door splitsing in appartementsrechten in enge zin horizontaal wordt gesplitst.

Het appartementsrecht in ruime zin kan worden omschreven als het geheel van rechtsregels dat van toepassing is op appartementsrechten in enge zin. De onderscheiding van appartementsrecht in ruime en enge zin heeft slechts waarde ter verduidelijking van het feit dat het begrip appartementsrecht vanuit juridische optiek in Nederland twee betekenissen heeft. In deze studie hoeft verder geen uitdrukkelijk onderscheid tussen appartementsrecht in ruime zin en appartementsrecht in enge zin te worden gemaakt. Uit de context zal namelijk steeds duidelijk blijken in welke betekenis het begrip appartementrecht wordt gebruikt.

Tussen de appartementseigenaars bestaat, zoals blijkt uit de omschrijving van het appartementsrecht in enge zin, gemeenschap. Aan deze gemeenschap van appartementseigenaars is de vereniging van eigenaars (V.v.E.) als organisatiestructuur gekoppeld. Deze V.v.E. moet blijkens artikel $875 \mathrm{f} \mathrm{lid} 1$ sub e BW in elke akte van splitsing worden opgericht. Behalve deelgenoot in de appartements-

1. Naar NBW zal in een aantal gevallen van medegerechtigdheid tot een beperkt recht moeten worden gesproken, met name bij splitsing van een opstal- of erfpachtsrecht. 
gemeenschap is iedere appartementseigenaar daarom ook lid van de V.v.E. Dit lidmaatschap heeft de appartementseigenaar van rechtswege (art. 876 lid $1 \mathrm{BW}$ ). Naast dit wettelijk vastgestelde lidmaatschap van de V.v.E, kan aan alle of bepaalde appartementsrechten het lidmaatschap van een andere, nader in het reglement omschreven vereniging worden verbonden, voor zover dit lidmaatschap in overeenstemming is met de statuten van deze vereniging (art. $875 \mathrm{f}$ lid $3 \mathrm{BW}$ ). De V.v.E. is een rechtspersoon (art. 876 lid 2 BW), die als hoogste orgaan de vergadering van eigenaars kent (vgl. verder par. 2.4.3).

Uit het deelgenootschap in de gemeenschap en het lidmaatschap van de V.v.E. vloeit een onderlinge afhankelijkheid voort. Asser/Beekhuis merkt over deze onderlinge afhankelijkheid op:

"Het behoeft nauwelijks gezegd te worden, dat het samenbrengen van woningen in een gebouw het grote nadeel heeft, dat de bewoners in veel sterkere mate van elkaars gedrag afhankelijk zijn dan met bewoners van éngezinswoningen het geval is. Laatstgenoemden kunnen elk onderling contact, indien zij daar geen behoefte aan hebben, doorgaans geheel vermijden."

In zijn algemeênheid is deze stelling mijns inziens te ruim geformuleerd. Onder "het samenbrengen van woningen in een gebouw" vallen immers ook huurwoningen in torenflats. De huurders hebben hierbij in beginsel juridisch geen rechtstreekse onderlinge band en ook de onderlinge contacten zullen vaak zeer beperkt zijn. Weliswaar kunnen zij overlast van elkaar ondervinden, maar dit geldt naar mijn mening evenzeer voor bewoners van eengezinswoningen, vooral indien deze laatste - zoals tegenwoordig vaak het geval is - met velen "onder één kap" worden gebouwd. Het cruciale verschil tussen huurflats en eengezinswoningen aan de ene kant en appartementen (in de zin van het appartementsrecht) aan de andere kant, ligt besloten in het feit dat de appartementseigenaars in een directe juridische verhouding tot elkaar staan. Zij zijn immers medeëigenaar van (grond en) gebouwen en uit deze gemeenschap vloeit een zekere mate van (zowel juridische als sociale) onderlinge afhankelijkheid voort.

Deze onderlinge afhankelijkheid kan echter in de praktijk zeer gering zijn. Dit zal vooral het geval zijn in moderne grote appartementencomplexen, waarin de eigenaars weten dat er bijvoorbeeld zoiets als een vergadering van eigenaars is, maar uitnodigingen voor deze vergadering altijd ongeinteresseerd in de prullenmand doen belanden. Desalniettemin is ook in dergelijke gevallen sprake van een onderlinge rechtsverhouding en is er daarom een onderlinge afhankelijkheid, al bestaat deze alleen maar met betrekking tot het betalen van kosten van onderhoud. De onderlinge afhankelijkheid wordt groter, indien het appartementencomplex klein is of bijzondere regelingen, bijvoorbeeld betreffende gemeenschappelijke voorzieningen (zwembad, sauna, voedselverstrekking), worden getroffen.

Hoe groter de onderlinge afhankelijkheid is, des te sneller zal de gemeenschap behoefte hebben aan mogelijkheden om toezicht uit te oefenen op haar leden. In een appartementencomplex met zogenaamde service-flats, waarin allerlei diensten

2. Asser/Beekhuis II, blz. 328. 
aan de appartementseigenaars c.q. -gebruikers worden aangeboden en waarin de appartementseigenaars behalve juridisch vaak ook sociaal een gemeenschap vormen, lijken instrumenten voor onderling toezicht bijna onmisbaar.

Een zeer verstrekkende vorm van toezicht wordt mogelijk gemaakt door artikel $875 \mathrm{f}$ lid $4 \mathrm{BW}$. Ingevolge dit artikel kunnen in het reglement van splitsing van een appartementsgebouw of appartementencomplex regelingen worden getroffen, op grond waarvan het voor de gemeenschap van appartementseigenaars mogelijk is een lid van de gemeenschap het gebruik van zijn appartementsrecht te ontzeggen. In Nederland worden deze ontzeggingsregelingen aangeduid als "de welstandsbepalingen in het appartementsrecht ${ }^{43}$.

In de praktijk wordt de mogelijkheid om een appartementseigenaar het gebruik te ontzeggen, gesplitst in twee regelingen: een toelatingsregeling en een regeling voor ontzegging van verder gebruik. De toelatingsregeling dient om toezicht te houden op appartementseigenaars die hun appartement in gebruik willen nemen, terwijl met de regeling voor ontzegging van verder gebruik aan een appartementseigenaar die zijn appartement reeds gebruikt, het verdere gebruik van zijn appartement kan worden ontnomen 4 .

In zowel de toelatings- als de ontzeggingsregeling worden criteria gegeven, respectievelijk de toelatingscriteria en de ontzeggingscriteria. Deze criteria vormen de materiële welstandsbepalingen. Het zijn de inhoudelijke criteria voor toelating en ontzegging van verder gebruik. Daarnaast bevatten de welstandsbepalingen nog regels van formele aard. Deze procedurele bepalingen bevatten de procedureregels voor toelating van een nieuwe bewoner of voor ontzegging van verder gebruik aan een reeds "zittende" bewoner. De toelatings- en ontzeggingscriteria zijn de uitwerking van de ingevolge artikel $875 \mathrm{f}$ lid 4 vereiste gewichtige reden voor ontzegging van gebruik.

Het is niet duidelijk : welke criteria mogen worden gehanteerd bij toelating of ontzegging van verder gebruik. Bij deze criteria kunnen immers verschillende belangen botsen. Enerzijds is er het gerechtvaardigde belang van de appartementseigenaars bij toelating, anderzijds mogen daarbij bijwoorbeeld de grondrechten van de individuele eigenaars c.q. gebruikers niet te zeer in het gedrang komen. Men kan zich in dit kader bijvoorbeeld afvragen of aan een persoon met homosexuele gerichtheid het gebruik van een appartement mag worden ontzegd, indien de andere eigenaars aan homosexualiteit aanstoot nemen. Ook echter het "recht" op huisvesting (vgl. art. 25 Universele verklaring van de rechten van de mens, art. 11

3. Vgl. Asser/Beekhuis II, blz. 328; Beekhuis/Linders, VI par. 6, nr. 5; De Groot, WPNR 5570; Pitlo/Brahn, Zakenrecht, blz. 390; Smarius, WPNR 5552/5570/5589; Schenk, WPNR 5570, 5589; Smeets/Mertens, De Notarisklerk 1985, no. 1204, 1205; Mertens, WPNR 5779. De mogelijklueid om welstandsbepalingen op te nemen in thet reglement van splitsing, wordt in Nederland nitet bestreden. De wet laat deze regelingen oolk uitdrukkelijk toe in art. $875 f$ lid $4 \mathrm{BW}$. Vgl. MVT bij de wet van 1972, Bijl. Hand. II, 1970-1971, 10987, nr. 3, blz. 15. Zile ook par. 3.2 .2 van deze studie.

4. Verdoes Kleijn meldt in zijn preadvies aan de Vereniging voor Bouwrecht dat welstandsbepalingen in ongeveer $40 \%$ van alle splitsingsreglementen voorkomen. Uit een onderzoek in Zuid-en Midden Limburg in 1984 bleck dat in 16 van 80 splitsingsaktes een toelatingsregeling was opgenomen, terwijl in alle gevallen de ontzeggingsregeling in de splitsingsakte was opgenomen. De tóelatingsregeling komt in Zuid-en Midden Limburg derhalve in ongeveer 20 \% van de splitsingsaktes voor en de regelling van ontzegging van verder gebruik in $100 \%$ van de gevallen. Zie Verdoes Kleijn (Preadvies 1979), blz 80; Smeets/Mertens, blz. 31. 
IVESCR en art. 22 lid 2 Grondwet, waaraan art. 8 EVRM en art. 12 Grondwet verwant zijn) en het recht op eigendom (art. 17 Universele verklaring van de rechten van de mens, art. 1 Eerste Protocol bij EVRM, zie ook art. 14 Grondwet) staan met de mogelijkheid van ontzegging van gebruik op gespannen voet. Mede gezien deze grondrechten moet bij ontzegging van gebruik van een appartement de nodige voorzichtigheid in acht moet worden genomen (zie par. 3.5).

Deze voorzichtigheid moet tot uitdrukking worden gebracht door de ontzeggingsregeling zodanig te construeren, dat de grondrechten van de individuele appartementseigenaar niet te zeer tekort wordt gedaan. Daarbij is het van belang om:

1. een verantwoorde keuze te maken bij het vaststellen van de manier waarop gebruik kan worden ontzegd en rechtsmiddelen daartegen te waarborgen;

2. naar duidelijkheid te streven omtrent de vraag welke criteria voor ontzegging wan gebruik toelaatbaar zijn.

Ten alanzien van het eerste punt heeft de Nederlandse wetgever gekozen voor een wijze van ontzegging van gebruik, waarbij de gerechtigdheid tot het appartementsrecht niet wordt aangetast. Degene aan wie het gebruik van zijn appartement wordt ontzegd blijft "eigenaar". Daarentegen had de wetgever bijvoorbeeld ook kunnen kiezen voor en constructie, waarbij de appartementseigenaar kan worden gedwongen zijn appartement te vervreemden dan wel dat hij het niet zonder toestemming van de overige appartementseigenaars mag (ver)kopen.

Met betrekking tot het tweede punt is reeds opgemerkt dat uit artikel $875 \mathrm{f}$ lid $4 \mathrm{BW}$ niet duidelijk blijkt welke criteria toelaatbaar zijn. De wet spreekt slechts over een "gewichtige reden" (art. $875 f$ lid 4 BW).

Overigens is de term welstandsbepalingen volgens meerdere auteurs weinig gelukkig als etiket voor de ontzeggingsregelingens. De term "welstand" duidt immers op financiële hoedanigheden, terwijl welstandsbepalingen niet of in zeer geringe mate bedoeld zijn om de appartementsgemeenschap te beschermen tegen onvoldoende draagkrachtige leden. Mijns inziens zijn de welstandsbepalingen daarvoor zelfs niet geschikt (zie par. 3.6.3.3) ${ }^{6}$.

Het bestaan van deze regelingen en de mogelijkheid van opneming ervan in het reglement van splitsing wordt, zoals hierboven al werd aangegeven, in de literatuur verdedigd met het argument dat eigenaars van appartementen sterker van elkaar afhankelijk zijn dan eigenaars van bijwoorbeeld eengezinswoningen? ${ }^{7}$. De welstandsbepalingen dienen aldus om toezicht mogelijk te maken op de appartementseigenaars onderling en de harmonie binnen de gemeenschap te waarborgen. Als een appartementseigenaar de harmonie in gevaar brengt kan hij immers van het gebruik van zijn appartementsrecht worden uitgesloten. Van welke aard dit gebruik is, doet in beginsel niet terzake. Het gebruik kan zowel gebruik voor bewoning als gebruik voor bedrijfsuitoefening inhouden. Als grens aan de mogelijkheid om het

5. Beekhuis/Linders, VI par. 6, nr. 5; Smeets/Mertens, blz 31.

6. Anders Beekhuis/Linders, VI par. 6, nr. 5 .

7. Asser/Beckhuis II, blz 328 . 
gebruik aan een appartementseigenaar te ontzeggen, heeft de wetgever de eis gesteld dat een gewichtige reden daarvoor aanwezig moet zijn.

\subsection{Doel van het onderzoek}

Het doel van de onderhavige studie is tweeledig.

A. De eerste doelstelling is om een beter inzicht te verschaffen in regelingen van ontzegging van gebruik van appartementen. Met betrekking tot de welstandsbepalingen in het appartementsrecht zal in deze studie worden onderzocht of voor ontzegging van gebruik (naar Nederlands recht) andere, wellicht betere, regelingen mogelijk zijn en welke criteria voor deze ontzegging kunnen worden gehanteerd. B. In de tweede plaats wordt beoogd een rechtsvergelijkende studie over het appartementsrecht in ruime zin te schrijven, waarbij een systematisch overzicht van de hoofdlijnen van het appartementsrecht van een aantal Westeuropese landen zal worden gegeven om overeenkomsten en verschillen tussen de verschillende regelingen vast te stellen.

De wenselijkheid van een allgemene rechtsvergelijkende studie op het gebied van het appartementsrecht - het tweede doel van deze studie - wordt door de eerste doelstelling nog onderstreept. Afhankelijk van de algemene regeling van thet appartementsrecht - in het bijzonder de structuur van de "appartementseigendom" - zullen de wijzen van ontzegging en de criteria voor ontzegging er namelijk anders uit kunnen zien'.

Behalve het Nederlandse appartementsrecht zal het appartementsrecht van België, West-Duitsland, Frankrijk en Zwitserland worden bestudeerd. Ik wil echter benadrukken dat het niet de bedoeling is het Nederlandse en het buitenlandse appartementsrecht uitputtend of uitgebreid te beschrijven. In zowel Nederland als de andere te bestuderen landen is het appartementsrecht door specialisten al uitgebreid en gedetailleerd becommentarieerd. Voor geïnteresseerden zij daarom verwezen naar de in de hoofdstukken over het appartementsrecht van de verschillende landen geciteerde handboeken.

Mede in verband met de algemene, beknopte beschrijving van het Nederlandse en buitenlandse appartementsrecht is niet getracht alle literatuur op dit rechtsgebied te verwerken. Voor Nederland geldt desalniettemin dat de literatuurverwerking redelijk compleet is. Dit hangt samen met het feit dat in ons land betrekkelijk weinig is gepubliceerd over het appartementsrecht. In het buitenland is dat anders. Met name in West-Duitsland (en in iets mindere mate geldt dit ook voor Belgie, Zwitserland en Frankrijk) is over het appartementsrecht dermate veel gepubliceerd, dat het onmogelijk is om binnen betrekkelijk beperkte tijd bij een korte beschrijving van het Westduitse appartementsrecht alle literatuur te verwerken.

8. Indien de wetgever bij de regeling van het appartementsrecht bijwoorbeeld had gekoxen voor een constructie die gebruik maakt van de coopperatie, had hij de gebruiksontzegging via de ontneming van of niet verlening van het lidmaatschap kunnen regelen. Welticht konden dan aan de criteria voor ontzegging in verband met de vrijheid van vereniging lichtere eisen worden gesteld, dan in het huidige Nederlandse appartementsrecht bij ontzegging het geval is. 
De welstandsbepalingen of daarmee vergelijkbare buitenlandse regelingen zullen als onderdeel van het te bestuderen appartementsrecht van de verschillende landen wel gedetailleerd worden beschreven. Dit is ook mogelijk omdat de problematiek van de ontzeggingsregelingen slechts een klein deel van het appartementsrecht van deze landen uitmaakt. Bij de literaturverwerking met betrekking tot de ontzeggingsregelingen is daarom ook naar volledigheid gestreefd. Voor de opzet van het onderzoek wordt verwezen naar paragraaf 1.3.3.

\subsection{Onderzoeksmethode en de opzet van het onderzoek}

\subsubsection{Rechtsvergelijking als onderzoeksmethode}

Zoals in paragraaf 1.2 is gesteld, heeft deze studie tot doel enerzijds de welstandsbepalingen in het appartementsrecht aan een gedetailleerd nader onderzoek te onderwerpen, anderzijds systematisch de hoofdlijnen van het appartementsrecht van vijf Westeuropese landen te beschrijven.

Voor de verwezenlijking van beide doelstellingen wordt de - aan het tweede doel uiteraard inherente - rechtsvergelijkende methode gehanteerd. Rechtsvergelijking kan echter verschillende vormen aannemen. Eén vorm van rechtsvergelijking kan worden omschreven als "interne rechtsvergelijking". Interne rechtsvergelijking komt neer op de vergelijking van twee of meer rechtsinstituten uit hetzelfde rechtssysteem van hetzelfde land".

Naast deze vorm van rechtsvergelijking is er hetgeen als "externe rechtsvergelijking" kan worden aangeduid. Deze vorm van rechtsvergelijking komt waarschijnlijk het meest overeen met hetgeen in het algemeen onder rechtsvergelijking wordt verstaan.

In dit onderzoek, waarin het appartementsrecht in hoofdlijnen en de welstandsbepalingen in detail rechtsvergelijkend zullen worden onderzocht, wordt zowel intern als extern vergeleken. In de eerste plaats zullen de respectievelijke onderzoeksobjecten in het recht van verschillende landen met verschillende rechtssystemen worden beschreven (externe rechtsvergelijking). Ten tweede zal er intern rechtsvergelijkend onderzoek worden verricht. Deze interne rechtsvergelijking heeft met name tot doel om het onderzoek op het gebied van de welstandsbepalingen te completeren. In hoofdstuk 4 zal aandacht worden besteed aan het verenigingsrecht, het medeëigendoms-/gemeenschapsrecht en het huurrecht en in het bijzonder aan controle en eventuele ontzeggingsmogelijkheden van leden, medeëigenaars/deelgenoten of huurders onderling. Een vergelijking van het appartementsrecht in ruime zin met het medeesigendomsrecht, het verenigingsrecht of het huurrecht zal niet worden gemaakt, omdat het appartementsrecht enerzijds medeëigendornsrecht en verenigingsrecht bevat, en anderzijds het appartementsrecht als onderdeel van het zakenrecht geheel anders gestructureerd is dan het huurrecht en het huurrecht bovendien binnen het appartementsrecht kan gelden (bij verhuurde appartementen). Op het gebied van toezicht- en ontzeggingsmogelijkheden is vergelijking echter zeer wel mogelijk en nuttig, omdat (de theorie

9. Vgl. Van der Ven, blz, 377, 378. Deze noemt de interne rechtsvergelijking "systeem-immanente rechtswergelijking". De term "interne rechtsvergelijking" is bedacht door Bloembergen (Interne rechtsvergelijking), blz 126. Zie cok Bloembergen, WPNR 5372, blz. 2. 
over de geldigheid van) criteria voor ontzegging bij het ene rechtsinstituut wellicht eveneens op enigerlei wijze kunnen (kan) worden toegepast bij het andere.

\subsubsection{Verantwoording van de gekozen rechtsstelsels}

De eerste hindernis die bij een extern rechtsvergelijkend onderzoek moet worden genomen, is de keuze van de rechtssystemen, waarvan het te bestuderen rechtsinstituut zal worden onderzocht. Behalve het Nederlandse appartementsrecht zal, zoals reeds is vermeld het appartementsrecht van België, de Bondsrepubliek Duitsland, Frankrijk en Zwitserland worden bestudeerd. Deze keuze hangt nauw samen met de mate van verwantschap van het Nederlandse privaatrecht met dat van deze vier landen.

België en Frankrijk hebben beide rechtsstelsels uit de Romaans/Franse rechtsfamilie ${ }^{10}$, terwijl ook het Nederlandse recht historisch gezien tot deze rechtsfamilie moet worden gerekend. West-Duitsland en Zwitserland hebben daarentegen rechtsstelsels uit de Germaanse rechtsfamilie.

De keuze van het Franse recht is gebaseerd op het feit dat het geldende Nederlandse privaatrecht sterk beïnvloed is door thet Franse recht, met name door de Code civil. Ook het Belgische privaatrecht heeft zijn wortels (nog sterker dan het Nederlandse $)^{11}$ in de Code civil. Bij de keuze van het Belgische recht heeft bovendien meegespeeld dat België een buurland van Nederland is en de taal van de onderzoeksbronnen, voor zover deze in het Nederlands zijn geschreven, voor een Nederlands jurist nauwelijks problemen oplevert.

Bij de keuze van het Westduitse recht heeft enerzijds ook het taalargument een rol gespeeld, anderzijds het feit dat ook West-Duitsland een buurland van Nederland is. Belangrijker nog is het feit dat het Westduitse privaatrecht in toenemende mate het Nederlandse privaatrecht beïnwloedt. Het Nieuw Burgerlijk Wetboek is immers in vele opzichten sterk geïnspireerd door het Westduitse "Bürgerliche Gesetzbuch" (BGB).

Het Nederlandse privaatrecht heeft dus sterke (historische) banden met het Franse recht, terwijl het tegenwoordig sterk beïnvloed wordt door het Duitse BGB.

Tot de keuze van het Zwitserse recht hebben twee factoren geleid. Ten eerste behoort Zwitserland tot de landen met rechtssystemen uit de Germaanse rechtsfamilie. Door opneming van een tweede rechtsstelsel uit die familie wordt meer evenwicht gebracht in het onderzoek, waarin (Nederland niet meegerekend) aan twee rechtssystemen uit de Romaanse rechtsfamilie aandacht wordt besteed. Ten tweede heeft bij de keuze van Zwitserland het feit dat het Zwitserse appartementsrecht een zelfde medeëigendomsstructuur kent als het Nederlandse, een zeer belangrijke rol gespeeld ${ }^{12}$.

Nu België en West-Duitsland als buurlanden van Nederland in deze rechtsvergelijkende studie worden betrokken, zou het wellicht voor de hand liggen ook

10. Zweigert/Kötz, blz. 116; Rheinstein, blz 83-88. Deze laatste beschouwt de Romaanse en Germaanse rechtsfamilie als subfamilies van de comtinentaal Europese rechtsfamilie. Zie ook David/Brierley, blz. 58-60. Deze deelt het Duitse recht in bij de Romaans-Germaanse rechtsfamilie.

11. In België gelden gedeelten van de oorspronkelijke Code civil immers nog steeds.

12. Beekhuis/Linders, IV par. 6. 
aandacht te besteden aan het Engelse recht. Om twee redenen heb ik echter besloten het Engelse recht in deze studie buiten beschouwing te laten. Ten eerste behoort het Engelse recht tot de Angelsaksische rechtsfamilie, die nawwelijks verwant is met de continentaal Europese rechtsfamilie(s). Een vergelijking tussen enerzijds het Nederlandse appartementsrecht en anderzijds het Engelse appartementsrecht kan door het verschil in rechtssystemen slechts moeizaam worden verricht. Ten tweede kent Engeland nog geen wettelijke regeling van het appartementsrecht. Een wettelijke regeling is wel in voorbereiding ${ }^{13}$, maar of, en zo ja wanneer, de wettelijke regeling tot stand zal komen, is vooralsnog niet duidelijk.

\subsubsection{De opzet van het onderzoek}

De globale indeling van de onderhavige studie is als volgt. $\mathrm{Na}$ dit inleidende hoofdstuk zullen eerst de hoofdlijnen van het Nederlandse appartementsrecht worden besproken (hoofdstuk 2). Hierbij zullen tevens de historische coulissen van de totstandkoming van het Nederlandse appartementsrecht uitvoerig worden belicht. Vervolgens zal uitgebreid aandacht worden besteed aan de welstandsbepalingen in het Nederlandse appartementsrecht (hoofdstuk 3). In dit hoofdstuk zal tevens worden ingegaan op de verhouding van ontzeggingscriteria tot grondrechten. Het vierde hoofdstuk staat in het teken van de interne rechtsvergelijking, met name met betrekking tot toezichts-, controle- en ontzeggingsmogelijkheden in het medeëigendomsrecht, verenigingsrecht en huurrecht.

Bij verwijzingen naar het toekomstige Nederlandse recht zal in het vervolg van deze studie steeds de tot op heden gehanteerde voorlopige nummering worden gebruikt. Daarnaast zal echter tevens de definitieve nummering worden gebruikt, zoals deze in het voorjaar van 1989 is bekend gemaakt.

In de vier extern vergelijkende hoofdstukken zullen de hoofdlijnen van het appartementsrecht van Belgie (hoofdstuk 5), de Bondsrepubliek Duitsland (hoofdstuk 6), Frankrijk (hoofdstuk 7) en Zwitserland (hoofdstuk 8) worden besproken, en zal nader worden ingegaan op regelingen van ontzegging van gebruik in deze landen. Bovendien zal telkens kort aandacht worden besteed aan de geschiedenis van het appartementsrecht van de verschillende landen. Deze historische beschrijvingen dienen echter slechts ter completering van de beschrijving en zullen in de conclusies nauwelijks worden verwerkt.

Bij de externe rechtsvergelijking dient zoals gezegd onderscheid te worden gemaakt ten aanzien van het algemene appartementsrecht en het recht betreffende de ontzeggingsregelingen. Bij het algemene appartementsrecht zullen slechts de hoofdlijnen worden aangegeven. Zo zal telkens bij alle landen (inclusief Nederland) aandacht worden besteed aan: 1. de algemene structuur van appartementseigendom, c.q. appartements-
rechten;

13. Vgl. het rapport van de Engelse Law Commission, Commonhold, Freehold Flats and freehold ownership of other interdependent buildings, report of a working group (chairman; T.M.
Aldridge), London July 1987 . 
2. ontstaan en tenietgaan van appartementseigendom, c.q. appartementsrechten;

3. administratie en beheer van de appartementsgebouwen;

4. rechten en verplichtingen van de appartementseigenaars.

De gedeelten van de hoofdstukken die handelen over de hoofdlijnen van de verschillende regelingen van het appartementsrecht, zijn aan de hand van de hier gegeven aandachtspunten gestructureerd.

Met betrekking tot de welstandsbepalingen en de daarmee vergelijkbare buitenlandse regelingen wordt aandacht besteed aan:

\section{A. toelatingsregelingen}

A.1 kan aan een (aspirant-)appartementseigenaar of (aspirant-)gebruiker op de een of andere wijze de ingebruikneming van een appartement worden ontzegd?

A.2 indien ontzegging van ingebruikneming mogelijk is, hoe is de ontzegging dan uitgewerkt?

A.3 welke criteria mogen voor ontzegging van ingebruikneming worden gehanteerd ${ }^{14}$ ?

B. ontzegging van verder gebruik

B.1 kan aan een "zittende" appartementseigenaar of appartementsgebruiker op een of andere wijze het verdere gebruik van zijn appartement worden ontnomen?

B.2 hoe is deze ontzegging van verder gebruik uitgewerkt?

B.3 welke criteria mogen voor ontzegging van verder gebruik worden gehanteerd ${ }^{15}$ ?

\section{C. beroepsmogelijkheden}

C.1 beroep tegen niet toelating.

- kan de (aspirant-) eigenaar een beroep op de rechter doen en/of is intern beroep bij de vereniging c.q. gemeenschap van appartementseigenaars mogelijk?

- indien beroep op de rechter mogelijk is, hoe toetst deze dan (marginaal of vol)?

14. Bij de bespreking van het Nederlandse recht zal tevens aandacht worden geschonken aan de toelaatbaarheid van deze criteria in het licht van de grondrechten.

15. Bij de bespreking van het Nederlandse recht zal, evenals bij de toelatingscriteria, ook aandacht worden geschonken aan de toelaatbaarheid van deze criteria in het licht van de grondrechten. 
C.2 beroep tegen ontzegging van verder gebruik.

- is beroep bij de rechter en/of bij de vereniging c.q. gemeenschap van appartementseigenaars mogelijk?

- indien beroep op de rechter mogelijk is, hoe toetst deze dan (marginaal of vol)?

Dit werk zal worden afgesloten met samenvattende vergelijkingen en conclusies ten aanzien van de hier gegeven aandachtspunten. 


\section{NEDERLANDS RECHT}




\section{Het Nederlandse appartementsrecht}

\subsection{Geschiedenis}

In het klassieke Rome was appartementseigendom ${ }^{1}$ door horizontale splitsing van onroerend goed ${ }^{2}$ niet mogelijk. Verticale splitsing kwam wel voor, waarbij tevens de toegang en soms zelfs het atrium gemeenschappelijk waren. Horizontale splitsing van onroerend goed was echter niet mogelijk door strikte toepassing van het beginsel "superficies solo cedit" ${ }^{3}$. Gaius schreef hierover:

Praeterea id, quod in solo nostro ab aliquo aedificatum est, quamuis ille suo nomine aedificauerit, iure naturali nostrum fit, quia superficies solo cedit (Bovendien wordt krachtens natuurrecht ons eigendom alles wat door iemand op onze grond gebouwd is, ook al heeft de betrokkene op eigen naam gebouwd; want de opstal wijkt voor de grond) ${ }^{4}$.

De eigenaar van de grond is volgens het "superficies solo cedit"-beginsel eigenaar van het daarop gebouwde ${ }^{5}$. In het oosten van het Romeinse rijk kwam apparte-

1. Opgemerkt moet worden dat appartementsrecht in enge zin niet gelijk is aan appartementseigendom. $\mathrm{Bij}_{\mathrm{ij}}$ appartementseigendom is immers sprake van horizontale splitsing van eigendom van onroerend goed, terwijl bij appartementsrecht in enge zin sprake is van medečigendom of medegerechtigdheid tot grond en gebouwen, gecombineerd met een zakelijk gebruiksrecht t.a.v. prive-gedeelten.

2. Met horizontale splitsing van onroerend goed wordt doorbreking van de natrekkingsregel bedoeld, waardoor grond en gebouw (of een gedeclte daarvan) in eigendom aan verschillende personen toekomen.

3. Niet in alle gevallen werd dit beginsel strikt toegepast. Zie Kaser 1, blz. 380, 381, 430.

4. Gaius, Institutiones II.73. Zie voor de vertaling: Spruit/Bongenaar, blu, 60, 61 .

5. Vgl. Ulpianus Dig. IX, 2,50: Qui domum alienum invito dorinino demolit et eo loco balneas exstruxit, praeter naturale ius, quod superficies ad dominum soli pertinet, etiam damni dati nomine actioni subicitur (Wue tegen de wil van de eigenaar andermans huis heeft afgebroken en op die plaats een badinrichting heeft gebouwd, is, afgezien van de natuurlijk regel, dat de opstal aan de eigenaar van de grond toebehoort, ook aan de actie wegens toegebrachte schade blootgesteld). Pomponius Dig. XLI, 1, 28: Si supra tuum parietem vicinus aedilicaverit, proprium eius id quod aedificaverit fieri Labeo et Sabinus aiunt: sed Proculus tuum proprium, quemadmodum tuum freret, quod in solo tuo alius aedificasset: quod verius est (Als uw buurman bovenop uw muur heeft gebouwd, wordt datgene wat hij heeft gebouwd zijn eigendom, beweren Labeo en Sabinus: maar Proculus zegt dat het van $U$ wordt, zoals datgene van $U$ zou worden, wat een ander op uw grond zou bouwen; dit is juist). Zie ook Fockema, blz. 1-20. Vgl. ook Bärmann (1958), blz. 1-3, 5. 
mentseigendom echter op vele plaatsen wel voor. Zo kende men deze vorm van eigendom van woningen in Syrië, Egypte, Palestina en Klein-Azië *

Vele jaren later werd in het huidige Nederland ook de appartements"eigendom" mogelijk gemaakt. Aanvankelijk doordat vanaf 1804 (1811 in de noordelijke provincies) tot 1838 (1842 in Limburg) hier te lande de Franse Code civil gold, waarin artikel 664 de eigendom van appartementen regelde, en later doordat in 1951 in het Nederlands Burgerlijk Wetboek een regeling met betrekking tot splitsing van én of meerdere gebouwen in appartementsrechten, werd opgenomen.

Al in 1941 was door de Algemeen Gemachtigde voor de Wederopbouw en voor de Bouwnijverheid opdracht gegeven om een wettelijke regeling van de afzonderlijke eigendom van appartementen voor te bereiden. Voor dit werk werden J.H. Beektuis, destijds hoogleraar in Groningen, en A.F. Schepel, verbonden aan de Dienst voor de Wederopbouw, benaderd. Later kwam P. Scholten dit team versterken?. Op 15 april 1947 werd vervolgens aan de Tweede Kamer der Staten Generaal een wetsvoorstel, houdende voorzieningen betreffende eigendom van appartementen aangeboden ${ }^{8}$. Dit voorstel bevatte een regeling wan het appartementsrecht, waarbij na splitsing van een gebouw volle eigendom van privégedeelten, gecombineerd met medeëigendom van de gemeenschappelijke gedeelten ontstond (zie par. 2.1.4).

Tien dagen na de aanbieding van de ontwerp-appartementenwet aan de Tweede Kamer, op $25^{\prime}$ april $1947^{\circ}$, kreeg de Leidse hoogleraar E.M. Meijers echter de opdracht een nieuw burgerlijk wetboek samen te stellen en Meijers achtte het wenselijk het wetsvoorstel houdende voorzieningen betreffende eigendom van appartementen voor te leggen aan de Staatscommissie tot herziening van de Nederlandse burgerlijke wetgeving, waarvan hij voorzitter was ${ }^{10}$.

Het wetsontwerp werd daarom aan de Staatscommissie voorgelegd en een aantal nieuwe bepalingen werden in thet voorstel ingevoegd. Bij Memorie van Antwoord van 22 september 1950 werd aan de Tweede Kamer een gewijzigd wetsvoorstel voorgelegd ${ }^{11}$. De wijzigingen behelsden dat het door Beekhuis c.s. gehanteerde systeem van volle eigendom van de privé-gedeelten ${ }^{12}$, werd vervangen door het systeem dat in het huidige appartementsrecht wordt gebruikt (zie hierover par. $2.1 .4,2.1 .5$ en 9.2 .1 ).

6. Kaser II, blz. 290; Bernard, blz. 19-21; Btarmann (Dogmatik), blz. 1; Draht, diss. Marburg/Lahn 1970. Zie over een verkoop van de heilt van een huis in Egypte in de graeco-egyptische periode: Lodder, blz. 386-390. Zie ook Wenger, ble 766,767. In de digesten werd teruggekeerd naar de klassieke opvattingen (zie noot 5). Ook na deze Justiniaanse wetgeving bleef appartements. eigendon voortbestaan. Zie daarover Taubenschlag I, blz: 286. Vgl. over het Germaanse en OudHollandse recht: Fockema, blz, 20-40.

7. Vgl. MVT bij de ontwerp-appartementenwet, $\mathbb{B i j l}$. Hand. II, 1946-1947, 451, nr. 3, algemene beschouwingen. Zie hierover ook Roos/Florijn (Interview met J.H. Beekhuis), blz 65 .

8. Bijl. Hand. II, 1946-1947, 451, nrs. 1-2, blz. 1 e.v.

9. Opgenomen in Parlementaire Geschiedenis van het NBW, Alg. Deel, blz. 6. Zie ook Hartkamp, blz. 1 en De Smidt, blz. 162 . Vgl. over de geschiedenis van de opdracht aan Meijers: Beekhuis (Herinneringen), blz. 328; Wiersma, (Meijers), blz 27.

10. Memorie van Antwoord (MvA) bij de ontwerp-appartementenwet, Bijl. Hand. II, 1950-1951, 451, nr. 5 , blz. 21.

11. Bijl. Hand. II, 1950-1951, 451, wr. 6 .

12. Beekhuis had zich bij zijn oorspronkelijk ontwerp laten inspireren door het Franse recht (vgl. hoofdstuk 7). Zie Van Dunne (Interview met J.H. Beekhuis), blz 14. 
Bij wet van 20 december 1951 werd vervolgens de wettelijke regeling op het gebied van de splitsing van een gebouw in appartementen vastgesteld ${ }^{13}$. Deze wet trad op 1 december 1952 in werking ${ }^{14}$

\subsection{Horizontale splitsing van eigendom}

Vóór de invoering van de appartementenwet was het volgens de Memorie van toelichting bij het wetsontwerp van 1947 naar Nederlands recht onzeker,

"of afzonderlijke verdiepingen en vertrekken van een huis aan verschillende personen in eigendom kunnen toebehoren." 15

De onzekerheid vloeide voort uit het feit dat artikel 664 C.c., waarin de mogelijkheid van eigendom van verdiepingen uitdrukkelijk was erkend, door de wetgever niet in het Burgerlijk Wetboek van 1838 was overgenomen. Reden voor het weglaten van dit artikel was er een van praktische aard. De behoefte aan een dergelijke wettelijke regeling ontbrak.

Asser schreef hierover:

"art. 664 van het Franse wetboek is niet overgenomen, ondat hetzelve van een geval spreekt, hetwelk meer bijzonder toepasselijk is op groote gebouwen in de steden van Frankrijk staande, waarvan de verschillende verdiepingen aan onderscheiden eigenaars toebehooren. Deze bepaling was alzoo binnen dit Koningrijk min noodzakelijk, en zal, wanneer zoodanig zelden voorkomend geval immer mocht plaatsgrijpen, aan de beoordeling des rechters, naarmate de bijzondere omstandigheden, kunnen worden overgelaten." 16

In Frankrijk had men artikel 664 C.c. opgenomen omdat in meerdere Franse streken de costumen al een regeling voor horizontale splitsing van gebouwen kenden. De costumen van Auxerre, Parijs, Nantes, Clermont-Ferrand en Orleans kenden bijvoorbeeld reeds zo'n regeling van horizontale splitsing van gebouwen. In Grenoble leidde het feit dat de stadswallen de ruimtelijke groei van de stad beletten, eveneens tot de uitwerking van zo'n regeling voor horizontale splitsing. In Saint Malo had een soortgelijke ontwikkeling plaats (vgl. verder par, 7.1) ${ }^{17}$.

Hoewel in Nederland het bouwen van boven- en benedenwoningen in de $19 \mathrm{de}$ eeuw snel was toegenomen, was er tot de eerste wereldoorlog geen grote behoefte

13. Stb. 1951, 571.

14. KB 27 september 1952 , Stb. 484 . In 1972 werd de appartementenwet op een aantal punten veranderd (vgl. par. 2.2.1). Beekhuis heeft inmiddels gepleit voor een hernieuwde aanpassing van het appartementsrecht, met name op het gebied van administratie en beheer. Zie Van Dunne (Interview met J.H. Beekhuis), blz 15.

15. MVT bij wetsontwerp 451, Bijl. Hand. II, 1946-1947, 451, nr. 3, algemene beschouwingen.

16. Asser, par. 376. Bij Voordwin en Noordziek lezen we niets over de reden van weglating van art. 664 C.c. uit ons BW.

17. Vgl. Kischinewski-Broquisse, blz. 8, 9; Aeby, blz. 63, 64. 
aan afzonderlijke eigendom van afzonderlijke verdiepingen ${ }^{18}$. De literatuur was voor de invoering van het appartementsrecht verdeeld over de vraag of de afzonderlijke eigendom van verschillende verdiepingen van een gebouw mogelijk was, nu een speciale regeling daarvoor, als neergelegd in artikel 664 C.c., in Nederland ontbrak. De discussie spitste zich toe op de vraag wat de betekenis van de artikelen 626 en $656 \mathrm{BW}$ was en of deze artikelen aan horizontale splitsing van eigendom in de weg stonden. Artikel 626 BW stelt immers:

"De eigendom van den grond bevat in zich den eigendom van hetgeen op en in den grond is."

Artikel $656 \mathrm{BW}$ bepaalt iets concreter dat alles dat op een erf gebouwd is, eigendom van de grondeigenaar is, mits het gebouwde met de grond verenigd is.

Bij de discussie over de vraag of deze artikelen aan horizontale splitsing in de weg stonden, speelde tevens de kwestie of - indien de artikelen 626 en $656 \mathrm{BW}$ niet aan horizontale splitsing van eigendom in de weg stonden - een verdieping als afzonderlijke zaak in de zin van artikel $555 \mathrm{BW}$ kon worden beschouwd ${ }^{19}$. Had de Nederlandse wetgever door niet opneming van artikel 664 C.c. naast de artikelen 626 en $656 \mathrm{BW}$, voor de leer van het Romeinse recht, uitgedrukt in de regel "superficies solo cedit", gekozen?

Voor de tweede wereldoorlog bestond er nogal wat verschil van mening in de Nederlandse rechtsgeleerde literatuur over de uitleg van de artikelen 626 en 656 BW. Bij Asser/Van Heusde, eerste druk uit 1885 kunnen we lezen ${ }^{20}$ :

"Art. 626 spreekt echter o.i. niet meer uit dan een beginsel, dat voor het bewijs van het tegendeel wijkt (...). Gelijk de wet zelve (art. 758 en v. BW) den toestand kent, dat de een eigenaar van den grond, de ander van de daarop staande gebouwen is, waarmede men nog de gevallen van art. 681, lid 2,685 en $687 \mathrm{BW}$ vergelijke, zoo verhindert o.i. geene wetsbepaling dat b.v. verschillende verdiepingen van een zelfde gebouw blijkens overeenkomst aan onderscheiden eigenaren toebehoren; een toestand die in Frankrijk algemeen voorkomt en bij art. 664 C.N. is geregeld; terwijl deze laatste bepaling ten onzent is weggelaten, niet omdat men een ander recht wilde doen gelden, maar alleen omdat regeling niet noodzakelijk werd geacht, wegens zeldzaamheid van het geval."

18. MvT bij wetsontwerp 451, Bijl. Hand. II, 1946-1947, 451, nr. 3, algemene beschouwingen. Zic cok Asser/Beckhuis II, blz. 391.

19. Zie over de verhouding tussen artt. 626 en $656 \mathrm{BW}$ en de mogelijkheid afzonderlijke verdiepingen in eigendom te hebben: De Witte van Citters, blz. 203 e.v.; Eyssell, blz 235-250; Moens (Reactie op Eyssell), blz 171-188. Zie ook Besier, blz. 449 e.w. Vgl. Goudeket, WPNR 2221-2223; Van den Dries, blz 445-447; Van Hasselt, blz 447, 448; Fockema, blz 59. Zie verder: Scholten (Uitbouw), WPNR 25sin-2552; Scholten, WPNR 2343; Scholten (Eigendom), WPNR 2521;
Beekhuis (Preadvies), blz 20, 21. 20. Asser/Van Heusde, blz. 60 . In de tweede druk uit 1890 en in de derde druk uilt 1896 staat nog
hetzelfde vermeld. 
In de vierde druk van hetzelfde werk, bewerkt door Paul Scholten wordt hetzelfde herhaald ${ }^{21}$. In de vijfde druk van Asser/Scholten uit 1913 zien we de aanzet tot een andere mening.

"Een afzonderlijke eigendom van verdiepingen als het Fransche recht kent (art. $664 \mathrm{C}$.) schijnt ook ons bedenkelijk, immers van deze valt niet als van gebouwen te zeggen, dat zij ten onzent door wet (vgl. art. 758) en rechtsverkeer als zelfstandige zaak los van den grond worden erkend. "22

In de zesde druk kunnen we vervolgens lezen:

\begin{abstract}
"Voor verdiepingen is de zaak uiterst twijfelachtig. Noch de wet noch de levenspractijk geven o.i. voldoenden grond om reeds thans de verdieping als een zaak te beschouwen en dus den afzonderlijken eigendom van verdiepingen voor mogelijk te houden. Het is echter zeer goed mogelijk dat de ontwikkeling dien kant uitgaat. In Frankrijk wordt die mogelijkheid wel erkend." 23
\end{abstract}

In de zevende en achtste druk van Asser/Scholten (1933 en 1945) werd hetzelfde betoogd ${ }^{24}$.

Andere auteurs waren echter andere meningen toegedaan. Opzoomer ${ }^{25}$ achtte in 1876 afzonderlijke eigendom van verdiepingen niet mogelijk, omdat volgens hem van artikel $626 \mathrm{BW}$ niet kon worden afgeweken en horizontale splitsing van eigendom derhalve niet mogelijk was. Ook N.F.K. Land was de mening toegedaan dat horizontale splitsing van eigendom niet mogelijk was. Volgens hem volgde uit artikel 626 dat de Nederlandse wetgever eenheid tussen grond en gebouw had aangenomen. De eigendom van de grond bracht heerschappij over alles wat daarop gebouwd was met zich mee. Bovendien zag Land in de artikelen 655 en 656 een bevestiging van zijn idee, omdat daar de regel dat eigendom van de grond eigendom van alles wat daarmee verenigd is, volgens hem zeer stellig was uitgesproken. Daarenboven voerde Land aan dat als de Nederlandse wetgever de mogelijkheid van horizontale splitsing van eigendom had willen erkennen, hij niet de bepalingen uit de Code civil, die die mogelijkheid openden, zou hebben weggelaten. Land was het derhalve niet met Carel Asser eens dat artikel 664 C.c. slechts daarom niet in het BW was opgenomen, omdat er geen behoefte aan bestond. Volgens Land was er dus alle aanleiding om aan te nemen dat onze wetgever de regel "superficies solo cedit" als dwingend recht had overgenomen ${ }^{26}$.

Diephuis en Hofmann echter meenden dat afzonderlijke eigendom van verdiepingen wel mogelijk was. Zo hechtte Diephuis ${ }^{27}$ geen gewicht aan het weglaten van artikel 664 C.c. Hij verklaarde deze weglating op dezelfde wijze als Carel Asser, namelijk dat er hier te lande geen behoefte aan had bestaan ten tijde van

21. Asser/Scholten, vierde druk, Zwolle 1905, blz. 75, 76.

22. Asser/Scholten, wijfde druk, Zwolle 1913, blz. 91.

23. Asser/Scholten, zesde druk, Zwolle 1927, blz. 4.

24. Asser/Scholten, zevende en achtste druk, Zwolle 1933, 1945, bliz 4 en 5.

25. Opzoomer, blz, 241.

26. Land, blz 108.

27. Diephuis, blz 31 en 32. 
de vaststelling van het $\mathrm{BW}$. Verder meende Diephuis dat als de wetgever werkelijk had willen voorkomen dat men eigendom van afzonderlijke verdiepingen zou krijgen, hij een verbod in de wet had moeten opnemen. Het weglaten van een bepaling uit het Franse wetboek was niet voldoende. Volgens Hofmann ${ }^{28}$ kon een verdieping naar verkeersopvattingen als een zelfstandige zaak worden beschouwd. Impliciet ging hij er derhalve van uit dat artikelen 626 en 656 niet aan horizontale splitsing van eigendom in de weg stonden. Veegens ${ }^{29}$ lijkt op dezelfde lijn als Hofmann en Diephuis te zitten, evenals Suyling, die van mening was dat afzonderlijke eigendom van verdiepingen in beginsel mogelijk was ${ }^{30}$.

De Hoge Raad heeft zich nooit over de mogelijkheid van afzonderlijke eigendom van verdiepingen hoeven uitspreken. Wel heeft hij in meerdere arresten bepaald dat artikel 626 slechts een rechtsvermoeden inhoudt dat voor tegenbewijs vatbaar is ${ }^{31}$ Zo bepaalde hij in het arrest van 1891
"dat art. 626, eerste lid BW, waarop het in deze hoofdzakelijk aankomt, niet bevat een beginsel waarvan niet zou mogen worden afgeweken, maar enkel een wettelijk vermoeden uitspreekt, waartegen blijkens art. 1958 B.W., behalve in de daar uitgezonderde hier niet aanwezige gevallen, tegenbewijs is toegelaten."

Ten aanzien van de vraag of afzonderlijke verdiepingen aan verschillende eigenaars konden toebehoren, overwoog de Hoge Raad in hetzelfde arrest dat dit in het Franse recht mogelijk werd geacht en dat de bepaling uit het Franse recht - artikel 664 C.c. - niet in het Nederlandse wetboek was overgenomen omdat daar geen behoefte aan bestond. Hij meende derhalve dat het weglaten van artikel 664 C.c. niet aan eigendom van verdiepingen in de weg stond. Over de vraag of een verdieping als zelfstandige zaak kon worden beschouwd, liet de Hoge Raad zich echter niet uit. Het was echter wel duidelijk dat eigendom van verdiepingen niet a priori onmogelijk was wegens strijd met artikel $626 \mathrm{BW}$, nu dit artikel slechts een praesumptio juris tantum inhoudt ${ }^{32}$.

Over de uitleg van artikel $656 \mathrm{BW}$ kwam meer duidelijkheid door het bekende Arena-arrest van 4 december $1903^{33}$. Op een van de gemeente gehuurd stuk grond had circusmaatschappij Arena een voor permanent gebruik bestemd circusgebouw gezet. De circusmaatschappij verleende een hypotheek op het gebouw. Vervolgens

28. Hofmann, ble. 110, 111.

29. Veegens, blz. 35. Anders echter Veegens/Pitlo (Oppenheim), blz. 69, 70.

30. Suyling (Inleiding), blz 47; Suyling, bespreking van diss. Fockema, blz. 344-360. Een bellangrijke auteur uit de negentiende eeuw, De Pinto, laat zich niet expliciet uit over de eventuele mogelijkheid van horizontale splitsing van eigendom.

31. HR 7 febr. 1860, W 2143; HR 22 dec. 1882, W 4861; HR 16 mei 1884, W 5053; HR 13 febr. 1891, W 5993; HR 1 febr. 1901, W 7559; HR 11 april 1913, W 9499; HR $10 \mathrm{dec}$. 1937, NJ 1938, 335
(bloembollen arrest).

32. Zie echter Beekhuis (Preadvies), blz, 20, 21. Deze betoogt dat de Hoge Raad hier een onjuiste beslissing ten aanzien van art. $626 \mathrm{BW}$ had genomen. Hij schrijf: "Ik meen echter dat de zienswijze van de H.R. een gevolg is van de zoo dikwijls gemaakte fout, dat men regels van materieel recht wil kneden in den vorm van vermoedens. (....) De vraag, waar het om gaat, is (..) niet: is art. 626 B.W. cen bewijsrechtelijke of materieelrechtelijke bepaling, maar: bevat art. 626

33. HR 4 dec. 1903, W 8004 . Vi C.c. slechts aanvullend recht, of is de bepaling van openbare orde". 
failleerde Arena en wilde de hypotheekhouder van zijn positie als separatist gebruik maken. De Hoge Raad ontzegde hem dit recht echter, aangezien het gebouw - dat onroerend was en derhalve in beginsel kon worden verhypothekeerd door natrekking op grond van artikel 656 eigendom van de gemeente was geworden. De gemeente was immers eigenaar van de grond. De hypotheek was daarom nietig. Dit was niet anders geweest wanneer de gemeente en Arena waren overeengekomen dat Arena eigenaar van het gebouw zou zijn. Door persoonlijke overeenkomsten konden geen uit de wet voortvloeiende zakenrechtelijke gevolgen, met werking tegenover derden, opzij worden gezet. De Hoge Raad besliste:

"Dat alleen dan, wanneer bleek dat de gefailleerde had wat zij blijkt te missen, - nl. een zakelijk recht als dat van opstal, door hetwelk eene uitzondering op de rechtsregel van art. 656 voormeld kan worden geschapen - het eigendomsrecht van de grondeigenaar op hetgeen hij Arena had veroorloofd te bouwen zou zijn uitgesloten geworden."

Uitkomst van de discussie was dat de artikelen 626 lid 1 en $656 \mathrm{BW}$ een wettelijk vermoeden behelzen, dat voor tegenbewijs vatbaar is. Dit tegenbewijs kan worden geleverd door aantoning van een zakelijk recht als het opstalrecht. De eigenaar van de grond wordt derhalve door natrekking eigenaar van hetgeen daarop wordt gebouwd, maar door vestiging van een zakelijk (opstal)recht of door verjaring kan deze eigendom(-sverkrijging) worden gesplitst of voorkomen ${ }^{34}$. De vraag of verdiepingen aan verscheidene eigenaars zouden kunnen toebehoren, hangt af van de beantwoording van de vraag of verdiepingen als afzonderlijke zaak in de zin van artikel 555 BW zouden kunnen worden beschouwd. Beekhuis schreef in 1940 in het slot van zijn preadvies dat eigendom van verdiepingen in beginsel mogelijk was:

"Het resultaat, waartoe ik kom is derhalve, dat hoewel ons recht zich in principe tegen een eigendom van flatwoningen niet verzet, er in de praktijk onoverkomelijke moeilijkheden uit zouden voortvloeien, omdat onze wet er niet voldoende op is ingesteld. ${ }^{1135}$

Kennelijk vond Beekhuis dat een verdieping als afzonderlijke zaak kon worden gezien ${ }^{36}$. Dit was blijkbaar (in 1942) ook de mening van de directie van het kadaster ${ }^{37}$. In de Memorie van Toelichting bij het wetsontwerp van $1947^{38}$, werd echter expliciet vermeld dat het onzeker was of afzonderlijke verdiepingen van een huis aan verscheidene personen in eigendom konden toebehoren. Waarschijnlijk moet echter worden aangenomen dat het, zoals Beekhuis stelde, inderdaad mogelijk was (en is) de eigendom van afzonderlijke verdiepingen te verkrijgen.

34. Pitlo/Brahn, blx. 115.

35. Beekhuis (Preadvies), slot.

36. Vgl. Asser/Beckhuis. II, blz 391.

37. Art. 472 van de Algemene instructie regelende de dienst van het kadaster, zie NJB 1942, blx. 396.

38. MVT bij wetsontwerp 451, Bijl. Hand. II, 1946-1947, 451, nr. 3, blz 4. 


\subsubsection{De stand van zaken naar huidig recht}

Zoals vermeld heeft in Nederland lange tijd onzekerheid geheerst omtrent de vraag of afzonderlike eigendom van verdiepingen, los van de appartementenwet gezien, mogelink is.

Bij de in het voorgaande beschreven discussie schuilde het eerste probleem in de onzekerheid ten aanzien van de kwestie of een verdieping c.q. appartement als een afzonderlijke zaak in de zin van artikel $555 \mathrm{BW}$ kan worden beschouwd. Alleen afzonderlijke zaken kunnen immers op grond van dit artikel voorwerp van eigendom zijn. Wat kan echter als afzonderlijke zaak worden beschouwd? ${ }^{39}$ Pitlo ziet de verkeersopvattingen als doorslaggevende factor ${ }^{40}$.

"Als de samenleving behoefte heeft aan goodwill of verdieping als zelfstandig object van recht, dan dient het recht deze als zodanig te erkennen", aldus Pitlo.

Het begrip afzonderlijke zaak is owerigens synoniem met het begrip zelfstandige zaak. Het begrip zelfstandige zaak kan het best negatief worden gedefinieerd als een zaak die niet onzelfstandig is ${ }^{41}$. Voor de bepaling van onzelfstandigheid worden de yerkeersopvattingen en het aard-en nagelvastheidscriterium gebruikt ${ }^{42}$. Een zaak kan derhalve onzelfstandig zijn op grond van de verkeersopvattingen of op grond van het feit dat zij aard- en nagelvast met een andere zaak, die als hoofdzaak wordt beschouwd, is verbonden. Bij onroerende goederen is de grond altijd de hoofdzaak. Het criterium aard- en nagelvastheid (organische of mechanische verbinding) leidt niet altijd tot onzelfstandigheid van een zaak. Als dit wel het geval zou zijn, zou eigendom van een huis, los van de eigendom van de grond, niet mogelijk zijn.

Artikel $656 \mathrm{BW}$ bepaalt immers dat een huis door aard-en nagelvastheid bijzaak van de hoofdzaak (de grond) is en daarom in eigendom toekomt aan de eigenaar van de grond. Tot zover zou het criterium aard- en nagelvastheid nog kunnen worden gehanteerd om te bepalen of een zaak onzelfstandig is. Het huis is hier immers niet zelfstandig, maar slechts bijzaak. Het wordt echter algemeen aangenomen dat deze natrekkingsregel van artikel $656 \mathrm{BW}$ door bijvoorbeeld een opstalrecht kan worden doorbroken. Indien een opstalrecht wordt gevestigd is het huis geen bijzaak meer, maar een zelfstandige zaak. Alleen een zelfstandige zaak kan immers ingevolge artikel $555 \mathrm{BW}$ voorwerp van eigendom zijn. Dit neemt niet weg dat een gebouwde zelfstandige zaak aard- en nagelvast met de grond verbonden is en daarom ook onroerend blijft (art. 562 laatste zin BW). Hieruit moge blijken dat een zaak die aard- en nagelvast met een andere zaak verbonden is, zowell zelfstandig als onzelfstandig (bijzaak) kan zijn. De verkeersopvattingen zijn derhalve inderdaad, zoals Pitlo stelde, doorslaggevend ${ }^{43}$.

39. Beekhuis/Linders, I par. 2.

40. Pitlo, blz. 111. Vgl. ook Pitlo/Gerver, blz, 133, 134.

41. Vgl. ook de MVT bij wetsontwerp 451, Bijl. Hand. II, 1946-1947, 451, mr. 3, blz. 4.

42. Vgl. Drion/Hijma/Olthof, ble 14,15 . 43. Zie HR 11 dec. 1953, NJ 1954, 115 met noot J. Drion (stafmateriaalarrest); Asser/Beekhuis I,
blz. 50. 
De vraag die nu opkont is of verdiepingen eveneens een zelfstandige zaak kunnen zijn. Volgens het aard-en nagelvastheidscriterium zou een verdieping altijd onzelfstandig zijn. Hierboven werd echter al gesteld dat de verkeersopvattingen in deze van doorslaggevende betekenis zijn. Volgens Pitlo/Brahn kan een verdieping niet als zelfstandige zaak in de zin van artikel $555 \mathrm{BW}$ worden beschouwd ${ }^{44}$. Beekhuis, de "vader" van het Nederlandse appartementsrecht, meende zoals vermeld in 1940 al dat een verdieping wel als zelfstandige zaak kan worden gezien ${ }^{45}$. Meerdere auteurs (vgl. par. 2.1.1) waren dezelfde mening toegedaan. Ook de Directie van het kadaster was in 1942 van mening dat verdiepingen afzonderlijke zaken kunnen zijn ${ }^{46}$. In elk geval is de opvatting dat een verdieping als een zelfstandige zaak kan worden beschouwd, mijns inziens zeer wel verdedigbaar.

Ervan uitgaande dat een verdieping, c.q. appartement een zelfstandige zaak kan zijn, moet worden geconcludeerd dat een verdieping in beginsel voorwerp van eigendom kan zijn, los van de eigendom van de grond ${ }^{47}$. De vraag die dan echter onmiddellijk rijst (en waarover blijkens het in par. 2.1.1 vermelde lang gediscussieerd is), is of artikelen 626 en $656 \mathrm{BW}$ hierbij geen roet in het eten gooien.

Als deze beide artikelen dwingend van aard zouden zijn, zou de verkeersopvattingen ten spijt, geen afzonderlijke eigendom van verdiepingen mogelijk zijn ${ }^{48}$. De Hoge Raad heeft echter zoals in paragraaf 2.1.1 werd vermeld, bepaald dat artikelen 626 en $656 \mathrm{BW}$ slechts een praesumptio juris tantum inhouden ${ }^{49}$. Men kan derhalve bij beide artikelen het tegendeel aantonen. Voor dit tegenbewijs is een enkele overeenkomst niet voldoende. In het bloembollen-arrest ${ }^{50}$ eiste de Hoge Raad voor dit tegenbewijs een overeenkomst die overgeschreven is in de openbare registers. Dat een inschrijving in de openbare registers noodzakelijk was, hing samen met de onroerende aard van de bloembollen. De Hoge Raad overwoog dat de eigendom van de bloembollen niet op de koper was overgegaan,

"daar het in de Nederlandsche wetgeving gehuldigde stelsel van openbaarheid van onroerend goed niet kent verkrijging van eigendom of ander zakelijk recht op zodanig goed alleen door een daartoe strekkende overeenkomst, doch daarbij eischt, dat de titel, waarbij het recht wordt overgedragen of gevestigd, wordt overgeschreven in de daartoe bestemde openbare registers."

Dit had de Hoge Raad in zekere zin in het Arena-arrest ${ }^{51}$ ook al beslist ${ }^{52}$.

44. Pillo/Brahn, blz, 11.

45. Beekhuis (Preadvies), slot.

46. NJB 1942, blz. 396.

47. Anders Asser/Beckhuis II, blz 84. Volgens deze kan nooit sprake zijn van zellstandige zaken bij "aan de grond verbonden gebouwen, werken en beplantingen."

48. Dat afwijkingen mogelijk zijn blijkt echter al uit het opstalrecht.

49. HR 11 april 1913, NJ 1913, 682 (Kelder); HR 27 maart 1914, W 9682 (Kachelpijp). Voor art. 656 BW werd dit in deze arresten niet expliciet beslist. Uit het feit dat tegenbewijs mogelijk is, blijkens het bloembollen-arrest en het Arena-arrest, moet worden geconcludeerd dat art. $656 \mathrm{BW}$, in samenhang met art. $626 \mathrm{BW}$, slechts een rechtsvermoeden inhoudt. Vgl. Drion/Hijma/Olthof, blz. $16,17$.

50. HR 10 dec. 1037, NJ 1938, 335 .

51. HR 4 dec. 1903 , W 8004 . 
Naast tegenbewijs door ingeschreven overeenkomst is de eigendom van eer gedeelte van een onroerend goed, los van de eigendom van de grond, ook nog door horizontale natrekking mogelijk ${ }^{53}$. Op grond van het kelder-arrest is daarom een oplossing voor volle (horizontalle) eigendom van appartementswoningen denkbaar, waarbij de artikelen 555, 626 en $656 \mathrm{BW}$ geen roet in het eten kunnen gooien. Het is namelijk mogelijk dat een perceel in twee kavels wordt verdeeld, waarbij éen persoon (A) een kavel verkrijgt en een ander (B) de tweede kavel verkrijgt. De kavel van A ligt op de begane grond en strekt zich uit over nagenoeg het gehele perceel. De kavel van $B$ heeft op de begane grond slechts een toegangsweg en een trappehuis. De eigendom van de toegangsweg en het trappehuis van $B$ is verticaal gesplitst van het eraan vastgebouwde woongedeelte van $A$. Het trappehuis verschaft toegang tot de woning van $\mathrm{B}$, die zich uitstrekt boven de woning van $\mathrm{A}$. Door horizontale natrekking behoort de woning van B bij de kavel van B.

$\mathrm{Bij}$ twee woningen is deze constructie nog zeer wel denkbaar. Bij grote aantallen lijkt deze constructie architectonisch echter zeer moeilijk te verwezenlijken. Voor horizontale splitsing van onroerend goed zal men bij grote complexen aangewezen zijn op doorbreking van de natrekkingsregels van de artikelen 626 en $656 \mathrm{BW}$, die door een in de openbare registers ingeschreven overeenkomst kunnen worden ontkracht.

\section{"Veelal zal' een dergelijke overeenkomst een recht van opstal of enigerlei erfdienstbaarheden inhouden, maar noodzakelijk lijkt dit niet", aldus Drion/Hijma/Olthof ${ }^{54}$.}

Dit zou betekenen dat het naar huidig Nederlands burgerlijk recht mogelijk zou zijn de eigendom van een gebouwd onroerend goed horizontaal te splitsen door bijvoorbeeld een overdracht (conform artt. 639, 671 en 671a BW) van een verdieping. Het gevolg hiervan zou zijn, dat overdracht van een gebouwd onroerend goed in zijn geheel, los van de grond, a fortiori mogelijk zou zijn. Het opstalrecht zou dan elk praktisch belang verliezen $\$ 5$.

Deze visie vloeit echter mijns inziens voort uit een onjuiste lezing van het Bloembollen-arrest ${ }^{56}$. In deze zaak had het gerechtshof voor eigendom van de bloembollen, los van de eigendom van de grond, een opstalrecht geëist. De Hoge Raad verwierp het cassatieberoep tegen het arrest van het gerechtshof en gaf de hierboven geciteerde overweging slechts als algemene overweging over verkrijging van eigendom van onroerend goed en van zakelijke rechten met betrekking tot onroerend goed. Voor de doorbreking van de natrekkingsregel, althans voor bewijs dat accessie niet heeft plaatsgevonden, blijft naar mijn mening het in het Arena-

52. Voor 1904 achtte de HR voor dit tegenbewijs een simpele owereenkomst voldoende. Vgl. HR 7 febr. 1860, W 2143; HR 25 maart 1892, W 6166; HR 1 febr. 1901, W 7559.

53. Vgl. HR 11 april 1913, NJ 1913, 628 (Kelder). Artt. 626 en 656 BW worden dan doorbrokem door de regels van artt. 556 en $643 \mathrm{BW}$. "De billijkheid en de logica schrijwen deze oplossing voor", aldus Pitlo/Brahn, blz. 121. Vgl. ook Brandenburg, blz. 885, 886 .

54. Drion/Hijma/Olthof, blz. 17 .

55. Naar NBW is dit anders. Art. 5.3.1 is dwingend recht. Alleen de wet kan hiervan afwijkingen toelaten, zoals door middell van het recht van opstal.

56. HR 10 dec. 1937, NJ 1938, 335. 
arrest $^{57}$ bepaalde van kracht. Zelfs als deze interpretatie echter niet juist zou zijn en Drion/Hijma/Olthof de juiste visie weergeeft, dan verliest het opstalrecht nog niet zijn betekenis.

De oplossing ligt dan mijns inziens in de wettelijke omschrijving van het recht van opstal. Artikel 758 BW luidt:

"Het regt van opstal is een zakelijk regt om gebouwen, werken of beplantingen op eens anders grond te hebben."

Overdracht van een gebouwd onroerend goed, los van de overdracht van de eigendom van de grond, valt mijns inziens altijd onder deze omschrijving. Overdracht van een huis zou daarom moeten worden beschouwd als vestiging van een eeuwigdurend recht van opstal ${ }^{58}$.

Bij overdracht van verdiepingen zou de constructie dan bijvoorbeeld kunnen zijn dat grondeigenaar A aan B een opstalrecht verleent. B bouwt op de grond een huis en de eigendom van dit huis wordt vervolgens weer bezwaard met een opstalrecht ten behoeve van $C$, die op het huis een extra verdieping bouwt. Aangenomen mag worden dat een dergelijk veelvoud van opstallrechten mogelijk is ${ }^{59}$.

Afzonderlijke eigendom van verdiepingen moet dus, los van het appartementsrecht bezien en afgezien van de hierboven beschreven constructie die gebruik makt van horizontale natrekking, mogelijk worden geacht ${ }^{60}$. Dergelijke afzonderlijke eigendom gaat echter met grote problemen gepaard. Beekhuis/Linders vermeldt hierover:

"het gebruik van een etagewoning is immers niet mogelijk, wanneer men niet tevens bepaalde bevoegdheden kan doen gelden met betrekking tot de grond waarop gebouwd is en andere delen van het huis die voor gemeenschappelijk gebruik bestemid zijn."

Het probleem zal duidelijk zijn. Hoe kan de eigenaar van een bovenverdieping bijvoorbeeld uit of in zijn verdieping geraken. Daarvoor zou vaak medeëigendom van het trappehuis nodig zijn of de vestiging van een erfdienstbaarheid. We zouden dan wellicht een variant op het recht van overpad krijgen, misschien een recht van "beklimming".

\subsection{De periode tussen de eerste en tweede wereldoorlog; appartementen en NV's $(B V s)$}

$\mathrm{Na}$ de eerste wereldoorlog begon zich het verschijnsel van de zogenaamde llatwoningen voor te doen. Over het algemeen werden hier luxueuzere woningen in ondergebracht, die geheel anders dan de bestaande boven- en benedenwoningen

57. HR 4 dec. 1903, W 8004.

58. Vgl. Pitlo/Brahn, blz. 317, 318 (vgl. ook art. 5.8.1 NBW).

59. Berenschot/Hoekstra/Vegter, blz, 121; Pitlo/Gerver, blz. 134.

60. Dit was ook het uitgangspunt van de wetgever in 1947. Zie de MvT bij wetsontwerp 451, Bijl. Hand. II, 1946-1947, 451, nr. 3, blz, 5.

61. Beekhuis/Linders, 1 par، 2. 
waren ingericht. Aangezien de flats bestemd waren voor welgestelden, konden de toekomstige bewoners zelf bijdragen in de bouw van hun woning. Hiertoe richtte men meestal een naamloze vennootschap (NV) op die zorg droeg voor de uitvoering van de bouw, terwijl de toekomstige bewoners door het nemen van aandelen of obligaties in de NV de benodigde financiële middelen verschaften. De bewoners huurden vervolgens de flats van de $\mathrm{NV}^{62}$.

Om verscheidene redenen bleek deze constructie echter niet bijzonder goed te functioneren ${ }^{63}$. Volgens de Memorie van Toelichting bij het wetsontwerp uit 1947 bracht de crisis in de dertiger jaren met zich mee dat veel bewoners waardeloze aandelen of obligaties overhielden waardoor het vaak moeilijk werd om een opvolger te vinden die de aandelen of obligaties wilde overnemen wanneer men wilde verhuizen ${ }^{64}$. Daar kwam nog bij dat de bouwondernemers vaak bij de oprichting van de NV een groot aantal aandelen voor zichzelf reserveerden, orm zo een grote invloed in het bestuur van de NV te waarborgen ${ }^{65}$.

Beekhuis/Linders voegt hier een ook voor de huidige tijd nog relevant derde bezwaar aan toe, namelijk dat de rechtsvorm van de NV minder geschikt is om een appartementencomplex te beheren

"omdat het dikwijls nodig zal zijn dat de gerechtigden voor het onderhoud en de eventuele verbetering van het gebouw aanvullende bedragen storten, hetgeen bij een NV moeilijkheden oplevert." ${ }^{* 6}$

Hierbij wordt gedoeld op artikel 38b WvK (nu art. 81 boek $2 \mathrm{BW}$ ) dat bepaalt dat een aandeelhouder niet tegen zijn wil kan worden verplicht om meer dan het nominale bedrag van zijn aandeel te storten, zelfs niet door wijziging van statuten ${ }^{67}$.

In sporadische gevallen wordt de NV-vorm ook thans nog gehanteerd. Van Velten noemt hierbij als voorbeeld de "Maatschappij tot exploitatie van het 'Parkflat 't Velthuys' $N V^{\prime \prime}$. Deze NV verhuurt flatwoningen die gelegen zijn in het op haar naam staande flatgebouw en verleent service

" - alles tegen vergoeding - aan houders van obligaties te haren laste" 68

In plaats van de NV-vorm kan tegenwoordig in principe ook de BV-vorm worden gehanteerd. De juridische problemen die aan deze rechtsvorm gekoppeld zijn,
komen grosso modo overeen met die bij de NV 69

Een variant op de hier beschreven NV-vorm is de "certificering van onroerend goed". Deze certificering kwam in Nederland voor het eerst in de jaren dertig voor.

62. MrT bij wetsontwerp 451, Bijl. Hand. II, 1946-1947, 451, nr. 3, blz. 4 linkerkolom.

63. Zie hierover ook Van Velten (CFV), blz 125 .

64. MVT bij wetsontwerp 451, Bijl. Hand. II, 1946-1947, 451., nr. 3, blz. 4 linkerkolom.

65. MvT bij wetsontwerp 451, Bijl. Hand. II, 1946-1947, 451, nr. 3, blz 4 linkerkolom.

66. Beckhuis/Linders, I par. 3.

67. Beektuis/Linders, I par. 3. Beekhuis/Linders wijst er ook nog op dat er fiscalle bezwaren tegen
de NV vorm bestonden.

68. Van Velten (Diss), blz. 150; dezellde (CFV), blz, 125 .
69. Vgl. over de BV- en NV-vorm uitgebreider: Van Velten (Diss.), blz. 146-152. 
Door het ontbreken van voldoende inspraak van de economische eigenaars en vanwege fiscale redenen, was deze rechtsvorm echter minder aantrekkelijk ${ }^{70}$

\subsubsection{De woningstichting}

Tussen de eerste en de tweede wereldoorlog werd nog een andere rechtsvorm bedacht, waarmee werd bereikt dat individuele personen economisch gerechtigd werden tot een flatwoning. Bij deze constructie werd gebruik gemaakt van de stichting als rechtsvorm. Aan de aldus ontstane woningstichtingen kleefde op zichzelf echter het bezwaar dat het bestuur in beginsel (bij ontbreken van statutaire bepalingen daaromtrent) geen rekening en verantwoording behoefde af te leggen. Bovendien ontbrak, evenals bij certificering van onroerend goed, de inspraak van de economisch gerechtigde bewoners. Daar kwam nog bij dat het niet zeker was of voor exploitatie van een gebouw de stichting wel als rechtsworm kon worden gehanteerd en tot 1956 elke wettelijke regeling ontbrak.

Ondanks deze nadelen werden woningstichtingen in het leven geroepen, die obligaties uitgaven, waaraan voor de obligatiehouder het recht was verbonden om tegen een zeer lage huurprijs een woning te huren. Dit recht was voor overdracht en vererving vatbaar. De vraag die hierbij onmiddellijk rees was of het huurvoordeel niet als inkomen voor de inkomstenbelasting moest worden beschouwd. De Hoge Raad beantwoordde deze vraag bevestigend ${ }^{71}$. Een andere vraag was of een obligatiehouder zijn gedeelte van de rente voor de door de stichting afgesloten hypothecaire lening, van de belasting mocht aftrekken.

"Door deze bezwaren geraakte deze vorm weer geheel op de achtergrond" 72

Af en toe wordt deze rechtsvorm ook tegenwoordig nog gehanteerd, met name bij "bijzondere vormen van samenleving, zoals woongroepen" ${ }^{\text {"73. }}$.

\subsection{De noadzaak van een wettelijke regeling}

De noodzaak om na de tweede wereldoorlog tot een wettelijke regeling betreffende de eigendom van appartementen over te gaan, had dus kennelijk eigenlijk drie redenen. Ten eerste de. gesignaleerde onzekerheid omtrent de mogelijkheid van eigendom van verdiepingen, die samerhing met het ontbreken van een bepaling als artikel 664 C.c. en de vraag naar de aard van de artikelen 626 en $656 \mathrm{BW}$, welke vraag in de literatuur verschillend werd beantwoord. Ten tweede bleek de NV vorm niet bijzonder goed te voldoen. Ten derde bestond er juist in die periode een enorme behoefte aan woningen. De huizenproductie was door de oorlog jaren achterop gekomen terwijl bovendien grote delen van Nederlandse steden door bombardementen waren vernield ${ }^{74}$. Door de woningnood was er een dringende behoefte ontstaan aan afzonderlijke eigendom van appartementen. Deze grote

70. Zie hierover Van Velten (Diss.), blz. 152-161; dezellde (CFV), blz. 126.

71. HR 5 dec. 1934, B. 5742 .

72. Van Veltem (Diss.), blz. 162.

73. Zie hierover uitgebreider: Van Velten (Diss.), blz 162-164, dezelfde (CFV), blz. 126.

74. MNT bij wetsontwerp 451, Bijl. Hand. II, 1946-1947, 451, ar. 3, blz, 4 linkerkolom 
behoefte ontstond vanwege de omstandigheid dat men voor de bouw van woonappartementen minder grond en materiaal nodig heeft dan voor normale huizen, waardoor ook de stichtingskosten lager zjjin ${ }^{75}$.

In Rotterdam bestond bijwoorbeeld na de oorlog een regeling op grond waarvan eigenaars van panden in de Rotterdamse binnenstad die door de oorlog waren verwoest, een bijdrage in de door hen geleden oorlogsschade kregen, die overeenkwam met de waarde van hun pand op 9 mei $1940^{76}$. Aangezien de panden echter veelal oud waren geweest en dus een lage taxatiewaarde hadden gehad, was de rijksbijdrage vaak te laag - mede in verband met sinds mei 1940 gestegen bouwkosten - om een soortgelijk pand als het verloren gegane te bouwen. Men moest in het kader van de wederopbouw van de stad bovendien aan voorschriften van goothoogte en gevelbreedte voldoen, die vaak niet overeenkwamen met de goothoogte en gevelbreedte van het verwoeste pand. Het was om deze redenen uit financieel oogpunt zeer moeilijk nieuwe woningen te bouwen. Appartementseigendom kon hiervoor een oplossing bieden, aangezien meerdere personen gezamenlijk nieuwbouw gemakkelijker konden financieren. In de Memorie van Toelichting bij het wetsvoorstel van 1947 staat dan ook:

"De aangewezen oplossing voor deze moeilijkheden is het combineren van voormalige eigenaren." 77

\subsubsection{De inhoud van het oorspronkelijke ontwerp (Oo) van 1947 en de plaats van het appartementsrecht binnen het vermogensrecht}

Men koos in het oorspronkelijke wetsontwerp houdende voorzieningen betreffende eigendom van appartementen voor een appartementseigendomsconstructie die voorzag in een combinatie van volle eigendom van ruimten die blijkens bouw of inrichting waren bestemd om als afzonderlijk geheel te worden gebruikt en medeëigendom van de gedeelten van het gebouw die voor gemeenschappelijk gebruik bestemd waren ${ }^{78}$. De verdeling in appartementen moest volgens het oorspronkelijke ontwerp geschieden bij notariële akte die moest worden overgeschreven in de daartoe bestemde openbare registers. Ieder appartement zou na overschrijving als zelfstandige onroerende zaak worden beschouwd.

Het oorspronkelijke ontwerp voorzag bovendien in een regeling op grond waarvan de kantonrechter op verzoek van de meest gerede belanghebbende een vertegenwoordiger kon benoemen voor een persoon die met anderen was overeengekomen de eigendom van een gebouw in appartementen te splitsen, maar die vervolgens weigerde of nalatig was om mee te werken aan het opmaken van de akte van verdeling (art. $638 \mathrm{c} \mathrm{Oo}$ ). Indien het te verdelen goed op het moment van de overschrijving van de akte van verdeling met grondrente of hypotheek was belast, rustte die grondrente of hypotheek vanaf dat moment op elk appartement voor het geheel van de som, waarvoor het goed was verbonden. Hetzelfde gold voor de verplichting tot betaling van de erfpachtscanon, indien het gebouw was

75. MvT bij wetsontwerp 451, Bijl. Hand. II, 1946-1947, 451, nr. 3, blz. 4 linkerkolom.

76. MVT bij wetsontwerp 451, Bijl. Hand. II, 1946-1947, 451, nr. 3, blz. 4 linkerkolom.

77. MvT bij wetsontwerp 451, Bijt. Hiand. If, 1946-1947, 451, nr. 3, blz 4 rechterkolom.
78 . Vgl. art. 638a van het ontwerp 15 april 1947 . 
geplaatst op in erfpacht uitgegeven grond (art. 638d Oo). Artikel 638e gaf vervolgens een uitzondering op artikel $628 \mathrm{BW}$ jo. $1112 \mathrm{BW}$ op grond waarvan ieder der medeëigenaars te allen tijde scheiding en deling kan vorderen van de gemeenschappelijke zaken. De inhoud van de akte van verdeling werd in artikel $638 \mathrm{f}$ gegeven. De akte moest onder andere een reglement bevatten dat een regeling kon inhouden omtrent de vorming van een fonds ter voldoening van lasten die de gemeenschappelijke zaken betroffen en voor welk fonds de eigenaars gezamenlijk aansprakelijk zouden zijn. Daarnaast kon het reglement de oprichting van een vereniging van eigenaars en een regeling omtrent het gebruik van afzonderlijke appartementen inhouden (638g Oo).

Vervolgens werden de verplichtingen van opvolgers onder bijzondere titel genoemd in de artikelen $638 \mathrm{~h}$ en $638 \mathrm{i}$. Artikel $638 \mathrm{j}$ regelde dat vervreemding, bezwaring en wijziging van de bestemming van de gemeenschappelijke zaken niet mocht gebeuren zonder toestemming van de eigenaars. In de navolgende artikelen werd de gezamenlijke aansprakelijkheid van de eigenaars voor verbintenissen die de gemeenschappelijke zaken betroffen geregeld, alsmede de bevoegdheden van een eventuele administrateur (artt. 638k-638n Oo).

Ingevolge artikel 6380 kon een der eigenaars vernietiging van een besluit van de vergadering van eigenaars vorderen om de in dat artikel genoemde redenen en kon voor handelingen waarvoor volgens de wet of reglement toestemming nodig was van een of meer eigenaars of de vergadering van eigenaars, door de kantonrechter vervangende machtiging worden verleend. De artikelen $638 \mathrm{p}$ tot $638 \mathrm{r}$ gaven regels voor de verzekering van het gebouw en de opheffing of sloping van het gebouw. Tenslotte regelde het ontwerp van 15 april 1947 nog enkele veranderingen van bestaande wetsartikelen, terwijl ook een artikel aan de faillissementswet werd toegevoegd.

Zoals uit de nummering van de artikelen blijkt, was het de bedoeling van de samenstellers van het ontwerp om het appartementsrecht te plaatsen in de derde titel van boek III BW over eigendom. Deze plaats in het vermogensrecht was ook logisch, gezien het feit dat men voor het appartementsrecht een constructie had gekozen die aan de koper van een appartement de volle eigendom van zijn privegedeelten verschafte en medeëigendom van de gemeenschappelijke gedeelten van het gebouw ${ }^{79}$.

\subsection{De hoofdlijnen van de wet van 20 december 1951}

De Staatscommissie tot herziening van de Nederlandse Burgerlijke Wetgeving, waaraan het wetsvoorstel van 1947 door Meijers was voorgelegd, was, zoals de Memorie van Antwoord verhaalt, van mening dat de rechtspositie van de flatbewoners hoofdzakelijk wordt bepaald door het medegerechtigd zijn in het gehele gebouw en de daaruit voortvloeiende verplichtingen.

"Uit dien hoofde achtte de Staatscommissie het op de voorgrond stellen van de alleen-eigendom op bepaalde gedeelten van het gebouw enigszins misleidend, terwijl hieraan bovendien het bezwaar kleeft, dat het

79. Vgl. MVT bij wetsontwerp 451, Bijl. Hand. II, 1946-1947, 451, nr. 3, algemene beschouwingen sub 4 , blz. 7. 
lichamelijk object van deze eigendom nauwelijks is aan te geven, daar de samenstellende delen vrijwel alle tot de gemeenschappelijke eigendom van alle flateigenaren moeten worden gerekend." 80

Derhalve adviseerde de Staatscommissie het ontwerp te herzien zodat de

"medeëigendom in het gehele gebouw op de voorgrond zou komen te staan. "81

De ontwerpers namen dit advies over, hetgeen tot resultaat had dat bij de Memorie van Antwoord een gewijzigd ontwerp van wet werd ingediend ${ }^{82}$. Artikel 638 a van het gewijzigd ontwerp bepaalde dat onder appartementsrecht wordt verstaan:

"een aandeel in het gebouw met toebehoren, zomede in de daarbij behorende grond met toebehoren, in welk aandeel is begrepen het recht op uitsluitend gebruik van een bepaald gedeelte van het gebouw, dat blijkens zijn inrichting bestemd is om als afzonderlijk geheel te worden gebruikt."

De laatste zin van artikel 638 a luidde als volgt:

"De erfpachter en degene, die recht van opstal heeft, zijn tot splitsing van het hun toekomende recht slechts na bekomen toestemming van de eigenaar van het perceel bevoegd."

Artikel $638 \mathrm{~b}$ regelde vervolgens dat de splitsing moest geschieden bij notariële akte die diende te worden overgeschreven in de openbare registers. In artikel $638 \mathrm{c}$ werd bepaald dat de kantonrechter een vertegenwoordiger kon benoemen voor een medeëigenaar die weigerde mee te werken aan het opmaken van de akte van splitsing, ondanks het feit dat was overeengekomen dat men het onroerende goed waarvan men medeëigenaar was zou splitsen. Indien op het ogenblik van de inschrijving van de akte van splitsing het goed was belast met grondrente of hypotheek, of het gebouw was geplaatst op in erfpacht uitgegeven grond, dan rustte de grondrente, hypotheek of de verplichting tot betaling van de erfpachtscanon vanaf dat moment op elk appartementsrecht voor het geheel. De schuldeiser behield in beginsel de bevoegdheid het goed in zijn geheel uit te winnen (638d). De eigenaars waren op grond van artikel 638e niet bevoegd scheiding en deling te vorderen van de tussen hen bestaande gemeenschap of van een gedeelte daarvan.

In artikel $638 \mathrm{f}$ werd bepaald wat de akte van splitsing op straffe van nietigheid moest inhouden. De akte van splitsing moest onder andere een reglement van splitsing bevatten, waarvan de inhoud ten dele verplicht, ten dele facultatief werd voorgeschreven in artikel $638 \mathrm{~g}$. Tot hetgeen in het reglement kon worden

80. Memorie van Antwoord bij het wetsontwerp houdende voorzieningen betreffende de splitsing van de cigendon van cen gebouw in appartementen d.d. 22 sept. 1950, Bijl. Hand II, 1950-1951, 451, nr. 5 , blz. 21 linkerkolom.

81. MWA bij wetsontwerp 451, Bijl. Hand. II, 1950-1951, 451, nr, 5, blz 21 linkerkolom.

82. Gewijzigd ontwerp van wet houdende voorzieningen betreffende de splitsing van eigendom in appartementen, Bijl. Hand. II, 1950-1951, 451, nr. 6 . 
opgenomen behoort onder meer de oprichting van een vereniging van eigenaars. Artikel $638 \mathrm{~h}$ bepaalde dat een in de openbare registers overgeschreven reglement mede verbindend was voor opvolgers onder bijzondere titel.

De artikelen $638 \mathrm{i}$ en $\mathrm{j}$ gaven vervolgens regelingen omtrent verplichtingen en bevoegdheden van appartementseigenaars. In artikel $638 \mathrm{k}$ werd bepaald dat het beheer en toezicht van de gemeenschappelijke delen van de appartementsgemeenschap berustte bij de vergadering van eigenaars.

Een besluit van de vergadering van eigenaars, dat naar het oordeel van een van de eigenaars in strijd met de wet of het reglement was, of waardoor de eigenaar op onredelijke wijze in zijn belangen werd aangetast, kon op verzoek van die eigenaar binnen een maand na dat tijdstip waarop het besluit was genomen, door de kantonrechter vernietigd worden. Een eigenaar die voor het verrichten van een bepaalde handeling toestemming nodig had van de vergadering van eigenaars, kon de kantonrechter bij weigering van toestemming verzoeken de toestemming te vervangen door een machtiging. De kantonrechter mocht deze machtiging verlenen, indien de vergadering zonder redelijke grond de toestemming had geweigerd of zich niet had verklaard of het benodigde stemmenaantal niet was gehaald (6381).

Artikel $638 \mathrm{~m}$ bepaalde dat eigendom van een appartementsrecht van rechtswege lidmaatschap van de eventuele vereniging van eigenaars meebracht, die voor de tenuitvoerlegging van haar besluiten een administrateur diende te benoemen. In artikel $638 \mathrm{n}$ werd vervolgens geregeld dat tot de schulden van de vereniging die op grond van artikel $638 \mathrm{~g}$ lid 2 sub 1 kon worden opgericht, die schulden werden gerekend, die volgens het reglement voor rekening van de gezamenlijke eigenaars komen. Voor de schulden van de vereniging waren zij die eigenaar waren ten tijde van het ontstaan van de schuld aansprakelijk.

De artikelen 6380 en p gaven nadere regelingen omtrent ontslag en taken en bevoegdheden van de administrateur. Artikel $638 \mathrm{r}$ bevatte bepalingen omtrent verzekering van een appartementsgebouw. De artikelen $638 \mathrm{~s}$ en $638 \mathrm{t}$ gaven vervolgens regelingen omtrent wijziging of aanvulling van de akte van splitsing of van het reglement en omtrent sloping en opheffing van de splitsing. Het gewijzigde ontwerp voorzag voorts in de aanpassing van een aantal andere artikelen van het Burgerlijk Wetboek.

Ondanks het feit dat in het gewijzigd ontwerp het recht van de appartementseigenaar geen bijzondere vorm van eigendom meer was,

"maar een aandeel in de eigendom of de erfpacht van de grond dan wel in het recht van opsta]",

werd de plaats die men voor het appartementsrecht in het oorspronkelijke wetsontwerp had uitgezocht, in het gewijzigde wetsontwerp niet veranderd ${ }^{83}$. De artikelen kregen de nummers 638a tot en met $638 \mathrm{t}$ en werden in het Burgerlijk Wetboek ingevoegd in de derde titel van het huidige derde boek.

Zoals reeds is vermeld trad de wet "houdende voorzieningen betreffende splitsing van de eigendom van een gebouw in appartementen", nadat ze was vastgesteld op 20 december 1951 , in werking op 1 december $1952^{84}$. De wet van 20 december

83. Vgl. Beekhuis/Linders, II par. 3.

84. Sib. 1952, nr. 484 . 
1951 week van het gewijzigde ontwerp slechts hier en daar in redactioneel opzicht af ${ }^{85}$.

\subsection{De vlucht in de coōperatieve verenigingen ${ }^{86}$}

\subsubsection{De opkomst van de coöperatieve flatexploitatieverenigingen}

Na de tweede wereldoorlog ontstond zoals vermeld een grote behoefte aan de mogelijkheid van juridische splitsing van een gebouw in appartementen, terwijl de appartementenwet op zich liet wachten. Hoewel het waarschijnlijk zo was dat het in beginsel inmiddels mogelijk was om naar Nederlands recht een verdieping in eigendom te hebben ${ }^{87}$, werd van deze mogelijkheid in de praktijk niet of nauwelijks gebruik gemaakt; omdat de gemeenschappelijke ruimten van een horizontaal gesplitst gebouw aan de eigenaars in medeëigendom zouden toebehoren, terwijl de medeëigendom in de wet zeer gebrekkig is geregeld ${ }^{88}$. Beekhuis/Linders wijst hierbij bijvoorbeeld op het feit dat in het huidige recht iedere regeling van hetgeen er dient te gebeuren bij onenigheid tussen de medeëigenaars, ontbreekt ${ }^{89}$. De reeds bedachte surrogaatvormen, zoals de NV en de woningstichting, bleken in de praktijk niet goed te voldoen (zie par. 2.1.2).

Er werd derhalve naarstig naar een andere oplossing gezocht en de Scheveningse notaris W.B. Bruijns bedacht hiervoor een nieuwe vorm van een coöperatieve vereniging, een coöperatieve flatexploitatievereniging (verder af te korten tot CFV) ${ }^{90}$. Kort weergegeven, kwam de doorsnee-opzet van de CFV erop neer dat twee of meer bouwers van een gebouw een coöperatieve vereniging oprichtten en een reglement vaststelden. Een persoon kon door verkrijging van het lidmaatschap het recht verkrijgen een flat te bewonen. Bij opzegging van het lidmaatschap diende hij de aan het lidmaatschap verbonden rechten te vervreemden ${ }^{91}$.

Anderen, met name Buining, propageerden als interim-oplossing voor eigendom van verdiepingen tot de totstandkoming van de appartementenwet een vrije-

85. Vgl. over de wet van 1951 ook Luijten/Pons.

86. Bij wet van 16 juni 1988 , Stb. 305, die in werking is getreden op 1 jan. 1989, is het recht met betrekking tot de coöperatieve vereniging enigszins gewijzigd. De belangrijkste wijzigingen behelzen de naamsverandering van "coöperatieve vereniging" in "coöperatie" en de introductie van de "structuur-coöperatie" en de "structuur-onderlinge waarborgmaatschappij". Aangezien in deze paragraaf een beschrijving wordt gegeven van de coopperatieve llatexploitatievereniging in het verleden, zal op deze plaats verder geen aandacht worden geschonken aan de wet van 16 juni 1988. Ook de naam "coöperatieve flatexploitatiewereniging" zal in deze paragraaf worden gehanteerd, hoewel naar huidig recht wellicht beter van een "flatexploitatie-coopperatie" of kortweg van een "flatcoöperatie" zou kunnen worden gesproken. In par. 4.2 zal wel aandacht worden besteed aan de nieuwe regeling.

87. Kennelijk ging de Nederlandse overheid ervan uit dat dit mogelijk was. Vgl. Beekhuis/Linders, I par. 5, over twee resolluties van het Ministerie van Financiën (van 13 nov. 1941 en 22 jan. 1942, PW 14596), die inhielden dat een hypotheekbewaarder zich niet meer tegen overschrijving van

88. Beekhuis/Linders, I par. 5 .

89. Beekhuis/Linders, I par. 5. Vgl. ook par. 4.3.3 van deze studie.

90. Bruijns, bli. 116 e.v. Vgl. ook De Vries (Preadvies), blz. 44; Beekhuis/Linders I par. 5; Commissic coöp. flatexploit, ver., blz. 506; Bos, blz. 537; Van Velten (Recente ontwikkelingen),
blz. 487 .

91. Vgl. De Vrïes, (Preadvies), blz. 53-55; Van Velten (Diss.), blz. 164. 
medeëigendomsregeling, voor de gevallen waarin er sprake was van drie of vier boven elkaar gelegen woningen ${ }^{92}$. Buining schreef:

"Wanneer mu de opgave luidt, dat drie boven elkaar gelegen etages aan drie verschillende personen moeten toebehoren, dan ligt toch de gedachte aan de medeëigendomsvorm meer voor de hand dan de oprichting van een coöperatieve vereniging." Daaraan voegde hij toe: "Voorts wordt natuurlijk overeengekomen, dat voor de splitsing geen scheiding gevorderd kan worden."

In zijn preadvies van 1965 wijst De Vries erop dat men in 1948 bepaald niet zeker kon weten, dat de appartementenwet binnen $S$ jaar tot stand zou komen. Hierdoor liep men het risico, dat een van de

"mede-eigenaren op grond van art. 628 jo. 1112 BW aan de gemeenschap, die als blijvend bedoeld was, onverhoeds een einde zou maken."

Daarnaast wijst De Vries op het feit dat ook vóor 1952, het jaar waarin Buining zijn gedachten opschreef, de meeste coöperaties tientallen appartementen omvatten in plaats van het door Buining genoemde aantal van drie. Bij tientallen medeeigenaars is het ondenkbaar dat het flatgebouw centraal wordt geëxploiteerd, tenzij hiervoor een aparte rechtspersoon wordt opgericht. Aan de andere kant was aan de medeëigendomsregeling wel het voordeel verbonden dat ieder der medeeigenaars (mede)eigendom van onroerend goed verkreeg ${ }^{93}$.

Als tweede alternatief was er dan nog de naamloze vennootschap, waarover echter al is opgemerkt dat deze rechtsvorm niet goed functioneerde. Daarnaast was er nog de mogelijkheid van de gewone rechtspersoonlijkheid bezittende vereniging. Nadeel van deze vorm was, dat men goedkeuring van de statuten nodig had, terwijl dit bij een coöperatieve vereniging niet het geval was. Aan de andere kant echter werden door het Ministerie van Wederopbouw na de oorlog enkele juridische bezwaren tegen de CFV geopperd, die behelsden dat:

1. een CFV een numerus clausus kent, terwijl in de wet op de coöperatieve vereniging van 1925 vrije in- en uittreding van leden werd vereist;

2. een coöperatieve vereniging een bedrijf moest uitoefenen, hetgeen bij een CFV dubieus is ${ }^{94}$. Deze bezwaren werden door Beekhuis tegengesproken ${ }^{95}$. Hoe het echter ook zij, de coöperatieveverenigingsvorm nam een grote vlucht in de periode tussen 1945 en $1952^{\circ}$.

92. Buining, bla 51,52 .

93. De Vries, (Preadvies), blz 48, 49. Vgl. ook Stille, WPNR 5406, blz. 577.

94. De Vries, (Preadvies), blz. 49.

95. Beekhuis (Eigendom), blz 25-28. Vgl, ook Van Velten (CFV), blz. 126 en dezelfde (Diss), blz. 165. Deze meldt dat ook E.M. Meijers meende dat de CFV mogelijk was.

96. De Vries, (Preadvies), blz. 45 geeft hierover een aantal getallen. Uit deze getallen blijkt dat de coöperatieve verenigingsvorm in 1951 zeer populair was, welke populariteit na de invoering van de appartementenwet in 1952 iets inzakte. 


\subsubsection{De vlucht in de coöperatieve verenigingen na 1952}

$\mathrm{Na}$ invoering van de appartementenwet in 1952 hadden velen het idee, dat de rechten van de leden van de CFV zouden worden omgezet in appartementsrechten. Deze omzetting had echter niet op een zo grote schaal plaats als wel was verwacht. Hiervoor zijn een aantal redenen te noemen.

Een belangrijke reden was dat overdracht van een appartementsrecht belast was met een registratierecht (thans overdrachtsbelasting) van $5 \%$, hetgeen niet het geval was bij overdracht van lidmaatschapsrechten van een CFV. Bos onderscheidde enkele gevallen van omzetting van CFV's in appartementsrechten en de registratierechten die daarover werden geheven ${ }^{97}$. Zo noemde hij bijvoorbeeld het geval dat een reeds bestaand of in aanbouw zijnd gebouw dat al in een coöperatieve verenigingsvorm was gegoten, in appartementsrechten werd gesplitst. De registratierechten waren weliswaar beperkt tot de waarde van de grond (als overgangsregeling), maar men kon desalniettemin op aanzienlijke bedragen uitkomen. Daarnaast noemde Bos nog het geval dat het appartementsrecht werd toegepast op een nog te stichten gebouw. Dit bracht voor de bouwer aanzienlijke kosten met zich mee, aangezien hij er zelden in slaagde voor voltooiing van het gebouw alle flats te verkopen. Bovendien bracht het appartementsrecht meer overdrachten met zich mee zodat vaker registratierecht moest worden betaald. De notariële kosten zouden door het grote aantal overdrachten bovendien ook hoger zijn. De Wet op de belastingen van rechtsverkeer van 1 januari 1972 maakte hieraan een eind ${ }^{98}$. Ingevolge deze wet werd ook overdracht van lidmatschapsrechten van een CFV met registratierechten belast.

Een andere reden waarom het niet stormliep met omzetting van CFV's in appartementsrechten was de mogelijkheid van het oprichten van de CFV voor of tijdens de bouw, hetgeen voor de bouwers het grote voordeel inhield dat ze de bouw aan de CFV konden overdragen en de CFV het benodigde kapitaal moest verschaffen door middel van het verlenen van hypotheek. De bouwers konden als leden van de vereniging optreden en derhalve ook als bestuur, terwijl in een vroeg stadium al aspirant-leden konden worden geworven. Deze aspirant-leden hadden wel een ongunstige positie omdat ze het lidmaatschap van de CFV niet verkregen voor voltooiing van het gebouw, waardoor ze ten aanzien van de CFV slechts contractuele rechten hadden en geen inspraak of controlerecht in de CFV ${ }^{99}$. Om deze mogelijkheid van het in een vroeg stadium werven van leden als een voordeel van de coöperatieve vereniging te zien lijkt mij echter niet geheel juist. De aspirant-leden hebben slechts contractuele rechten ten opzichte van de vereniging. Niets staat er echter in de weg voor een bouwer om in een vroeg stadium al appartementsrechten op tekening te verkopen aan gegadigden. Hij kan de appartementsrechten weliswaar nog niet leveren totdat de splitsing tot stand is gekomen, maar verkopen kan hij ze wel. De gegadigden hebben dan een even sterke (of zwakke) positie als de aspirant-leden van de CFV. $\mathrm{Zij}$ hebben immers

97. Bos, ble 538 .

98. Vgl. Simeets/Mertens, blz. 8 en noot 4 op blz. 21. Zie ook Beekhuis/Linders, III par. 1; Commissie coöp. Alatexploit. ver, blz. 506; Van Velten (CFV), blz. 129, 130; dezelfde (Diss.), blz.
169.

99. Beekthuis/Linders, I par. 5, III par. 1. 
net als de aspirant-leden van de CFV contractuele rechten, zij het niet ten aanzien van de CFV, maar ten aanzien van de bowwer ${ }^{100}$.

Een derde oorzaak van het voortbestaan van de CFV's was dat financiers van de bouwwerken aanvankelijk van mening waren, dat hypotheek op appartementsrechten te weinig zekerheid bood. $\mathrm{Zij}$ wilden zekerheid op het hele gebouw. Dit bracht met zich mee dat het zeer moeilijk was een kredietverlener te vinden die bereid was om de aankoop van een appartementsrecht te financieren ${ }^{101}$.

Ten vierde was in de appartementenwet van 1951 bepaald dat een vereniging van appartementseigenaars slechts het beheren van het gebouw ten doel mocht hebben. Verzorgingsflats, waar men bewoners van maaltijden en eventueel verpleging voorziet, waren dus niet zonder meer mogelijk. Wilde men een verzorgingsfunctie in een appartementencomplex, dan moest men derhalve naast de V.v.E. nog een andere vereniging oprichten ${ }^{102}$.

Voorts moest op grond van artikel 638a laatste volzin, de erfpachter of opstaller die tot splitsing van zijn recht wilde overgaan, toestemming voor deze splitsing vragen aan de eigenaar van de grond. Bepaalde grote gemeenten (o.a. Amsterdam) weigerden vaak om aan splitsing van gebouwen op in erfpacht uitgegeven grond medewerking te verlenen (art. 875a lid $6 \mathrm{BW})^{103}$.

De CFV kende al de hierboven genoemde problemen niet. Hierdoor liep het niet storm met de omzetting van de lidmaatschapsrechten van CFV's in appartementsrechten, terwijl bovendien na 1952 nog steeds nieuwe CFV's werden opgericht (zie over de CFV uitgebreid par. 4.2.5) ${ }^{104}$.

\subsection{Nieuw appartementsrecht 1972}

\section{Totstandkoming van de nieuwe appartementenwet 1972}

Bij koninklijk besluit van 27 oktober 1970 werd het wetsontwerp tot herziening van de regeling in het Burgerlijk Wetboek betreffende splitsing in appartementen aan het parlement aangeboden ${ }^{105}$. Op 17 maart 1971 werd het voorlopig verslag van de vaste commissie van justitie, waaraan het wetsontwerp was voorgelegd, vastgesteld 106 . In dit voorlopig verslag werd op enkele onduidelijkheden in het wetsontwerp gewezen. Bij de memorie van antwoord van 17 juni 1971 werd tengevolge hiervan

100. Vgl. hierbij Lubbers/Zweers, (Preadviezen). Vgl. ook Van Velten (CFV), blz. 129; dezelfde (Diss.), bli. 169.

101. Bieekhuis/Linders, III par. 1. Hierin is langzamerhand verandering gekomen. Vgl. De Vries (Onroerend goed), blz. 371; Van Velten (Recente ontwikkelingen), blz. 487, 488.

102. Beekhuis/Linders, III par. 1. Vgl. over de voordelen van de CFV-vorm ook Van Velten (Recente ontwikkelingen), bliz 487; dezelfde (Diss.), blz. 169-171.

103. Commissie coöp. Ilatexploit. wer., blz 506; Van Velten (Diss.), blz. 171.

104. Zie voor andere redenen Van Velten (Diss.), blz. 170; dezelfde (Recente ontwikkelingen), blz. 493 en (Subsidiëring), blz. 738. Deze vermeldt dat met mame bij projecten waarin het "ideële of sociale element belangrijk is, dan wel - in het bijzonder bij objecten in de recreatieve sfeer - de exploitatie bijzondere eisen van juridische aard stelt", de coöperatieve verenigingsvorm (lees: coöperatievorm) betere oplossingen blijkt te bieden dan de splitsing in appartementsrechten. Vgl. ower de voordelen van de CFV ook: Akkermans/Van lersel.

105. Bijl. Hand. II, 1970-1971, 10987 , nrs. 1-3.

106. Bijl. Hand. II, 1970-1971, 10987 , nr. 4 . 
een nota van wijzigingen aan de Tweede Kamer aangeboden ${ }^{107}$. Op 2 mei 1972 werd het wetsontwerp mondeling in de Tweede Kamer behandeld ${ }^{108}$. Tijdens de mondelinge behandeling uitte men zich veelal lovend over het voorliggende wetsontwerp. In het wetsontwerp werden echter nog enkele wijzigingen aangebracht tengevolge van amendementen van het kamerlid Wieringa. Het voorlopig verslag wan de Eerste Kamer en de memorie van antwoord volgden op resp. 2 juni 1972 en 9 juni $1972^{109}$. Op 5 september 1972 werd het wetsontwerp mondeling in de senaat behandeld ${ }^{110}$. Op 7 september werd de wet tot herziening van de regeling in het Burgerlijk Wetboek betreffende splitsing in appartementen vastgesteld ${ }^{111}$. Bij KB van 25 september 1972, houdende vaststelling van een algemene maatregel van bestuur als bedoeld in de artikelen $875 \mathrm{~d}$, tweede lid, tweede volzin en $875 \mathrm{e}$, eerste lid onder $c$ van het Burgerlijk Wetboek (Besluit betreffende splitsing in appartementsrechten), werd bepaald dat zowel de wet als het $\mathrm{KB}$ met ingang van 1 december 1972 in werking zouden treden ${ }^{112}$.

\section{De redenen die aan de herziening ten grondslag lagen}

Aan de herziening van het appartementsrecht lagen verscheidene redenen ten grondslag. Enkele ervan zijn al in het voorafgaande genoemd bij de bespreking van de vlucht in de coöperatieve verenigingen. Zij zullen hier kort opnieuw besproken worden.

Een van deze reeds genoemde redenen was dat splitsing van een gebouw in appartementsrechten slechts mogelijk was na voltooiing van het gebouw. Splitsing wan een nog te bouwen appartementsgebouw was derhalve niet mogelijk. Dit had tot gevolg dat appartementsrechten pas aan de kopers konden worden overgedragen, nadat het gebouw was voltooid. Dit had voor de eventuele bouwers het nadelige gevolg dat zij de bouw niet uit aanbetaling konden financieren. Zij zouden hun toevlucht moeten nemen tot een bouwkrediet, dat kostenverhogend werkt ${ }^{113}$. Dit nadeel zou aan de CFV niet kleven. In paragraaf 2.1.6.2 is reeds vermeld dat dit argument theoretisch niet opgaat. Aan de andere kant was het in praktijk kennelijk zo dat de bouwer er nauwelijks in slaagde alle appartementsrechten op papier te verkopen ${ }^{114}$. Natuurlijk is het wel zo dat een mogelijkheid van splitsing voor of tijdens de bouw en derhalve overdracht van appartementsrechten voor voltooiing van het gebouw, een aanzienlijk elegantere oplossing zou zijn. In deze oplossing werd bij de wet van 1972 dan ook voorzien in artikel $875 b^{115}$.

Een ander nadeel dat aan de appartementsrechtregeling van 1952 kleefde, was dat eigenaars van in erfpacht uitgegeven grond splitsing konden voorkomen door hun toestemming daarvoor te weigeren. Hierdoor werd men, indien men toch een

107. Bijl. Hand. II, 1971, 10987 , mr. 5,6 .

108. Hland. II, 1971-1972, blz, 3179-3187.

109. Bijl. Hand. I, 1971-1972, $10987,146,146 \mathrm{a}$.

110. Hand. I, 1971-1972, blz. 1191.

111. Sib. 1972,467 .

112. Stb. 1972,468 .

113. Conmissie coöp. Ilatexploit. ver., blz. 506 . Vgl. ook Beekhuis/Linders, III par. 1; Memorie van 114. Bos, blz. 538 .

115. Van Velten (Recente ontwikkelingen), blz 487; dezelfde (CFV), blz. 129. 
gebouw met afzonderlijke appartementen wilde creëren, in de CFV-vorm geperst ${ }^{116}$. Dit nadeel bleef ook in de wet van 1972 bestaan. In het oorspronkelijk herzieningsontwerp was deze mogelijkheid voor de eigenaar van de in erfpacht uitgegeven grond (of voor de verlener van het opstalrecht) weliswaar geschrapt, maar in de nota van wijzigingen behorende bij de memorie van antwoord van 17 juni 1971 werd een zesde lid aan artikel 875 a toegevoegd ${ }^{117}$. Hierin werd bepaald dat bij vestiging van een recht van erfpacht of opstal kon worden bepaald dat splitsing in appartementsrechten niet kon geschieden zonder toestemming van de eigenaar van de grond. De kantonrechter kon echter vervangende machtiging van deze toestemming verlenen, indien deze zonder redelijke grond werd geweigerd of de grondeigenaar zich niet verklaarde. Een amendement van het kamerlid Wieringa werd echter overgenomen, waardoor toestemming van de grondeigenaar telkens werd vereist, zij het dat de verzoekmogelijkheid aan de kantonrechter werd gehandhaafd ${ }^{118}$. Door deze verzoekmogelijkheid werd in elk geval het gevaar van willekeur van de grondeigenaar enigszins ingedamd. De grondeigenaar moest voortaan een redelijke grond hebben om toestemming tot splitsing te weigeren ${ }^{119}$.

Daarnaast bestond er voor 1972 het bezwaar dat overdracht van appartementsrechten was belast met $5 \%$ registratierecht. Overdracht van lidmaatschap van een CFV was niet belast. De Wet op de belastingen van rechtsverkeer maakte hieraan een eind, nu op grond daarvan overdracht van een lidmaatschap in gelijke mate als de overdracht van een appartementsrecht werd belast (zie par. 2.1.6.2) ${ }^{120}$.

Een andere reden voor herziening van het appartementsrecht in 1972 was dat er bezwaren aan de CFV-vorm verbonden waren, die in de toekomst voor moeilijkheden zouden kunnen zorgen. Daarom achtte men het noodzakelijk een goede appartementsrechtregeling te creëren. Een voorbeeld van een bezwaar dat de CFV meebracht was dat de CFV op het gehele gebouw een hypotheek moest vestigen, waaraan de leden moesten meebetalen. In de memorie van toelichting bij het wetsontwerp van 1971 lezen we:

"Wanneer over enige tijd door overwinning van de in een deel van ons land nog heersende woningnood de woningmarkt zich zodanig wijzigt, dat niet meer elke "flat" voor een hoge prijs onmiddellijk verkoopbaar is, valt te vrezen dat een deel van de leden dier coöperatieve verenigingen bij wanbetaling door hun medeleden het slachtoffer worden van de hypotheek die de vereniging op het flatgebouw in zijn geheel heeft moeten vestigen. Ook kan blijken dat een lid zijn "flat" (het lidmaatschapsrecht) moeilijk zal kunnen verkopen, omdat gegadigden niet in staat zijn zelfstandig hypothecair crediet op te nemen." 121

116. Commissie coöp. flatexploit. ver., blz. 506 .

117. Nota van wijzigingen bij wetsontwerp 10987, Bijl. Hand. II, 1971, nr. 6 .

118. Stb. 1976, 467. Zie ook art. 875a lid 6.

119. Vgl. hierbij HR 23 dec. 1976, NJ 1977, 409 met noot W.M.K. (Reggezuid-arrest), WPNR 5386, blz 236, 237 en WPNR 5422, bllz 111, 112. Zie verder par. 2.4.2.1.

120. Zie art. 4 lid 1 aanhef onder $b$ van de wet op belastingen van rechtsverkeer. Vgl. ook Van Velten (Recente ontwikkelingen), blz 487.

121. MVT bij wetsontwerp 10987, Bijl. Hand. II, 1970-1971, 10987, nr. 3, blz. 8. Zie ook Van Velten (CFV), blz 128, 129. De praktijk heeft voor dit probleem inmiddels een oplossing bedacht. Ondermeer- via hoofdelijke aansprakelijkheid van de afzonderlijke leden van de CFV en via 
In de jaren vijftig en zestig speelde dit probleem in veel mindere mate. In de praktijk bleek namelijk dat de CFV volgens de gebruikelijke statuten een insolvent lid uit het lidmaatschap kon ontzetten, de in gebruik gegeven flat kon doen ontruimen en het lidmaatschap aan een derde kon toebedelen, om zo uit de opbrengst de openstaande schulden te voldoen ${ }^{122}$. Bij instorting van de woningmarkt zou de CFV echter wel eens met een onverkoopbaar lidmaatschapsrecht kurnen blijven zitten ${ }^{123}$.

Bovenstaande redenen waren de belangrijkste voor herziening van het appartementsrecht in 1972. Het allerbelangrijkste nieuws was wel dat splitsing op papier mogelijk werd, hetgeen splitsing in appartementsrechten aanzienlijk aantrekkelijker maakte. Andere aanpassingen van het appartementsrecht in 1972 zullen in hoofdstuk 2.4 worden besproken.

\section{De regeling van het appartementsrecht in het $N B W$}

In het Ontwerp-Meijers kwam geen titel over appartementsrechten voor. Meijers wilde de regeling, neergelegd in artikelen $638 \mathrm{a}-638 \mathrm{t}$ met geringe wijzigingen overnemen in het NBW ${ }^{124}$. Bij Koninklijke Boodschap van 17 januari 1957 werd het "regeringsontwerp van Boek 5 ingediend ${ }^{125}$. In dit regeringsontwerp werd de appartementsrechtregeling uit de artikelen 638a-638t enigszins gewijzigd in het NBW ingevoeǵg in de tiende titel van Boek 5 . De wijzigingen strekten voornamelijk tot aanpassing aan de terminologie en bet systeem van het NBW. De titel over appartementsrechten zou de toen geldende regeling van de artikelen 638a638 t in het NBW moeten vervangen.

Door de wet van 1972 werd het appartementsrecht inhoudelijk echter gewijzigd (vgl. par. 2.2). De tekst van de tiende titel van het NBW werd bijgevolg ook aangepast ${ }^{126}$.

Bij wet van 9 mei 1980 werd Boek 5 NBW vastgesteld ${ }^{127}$. Bij Koninklijke Boodschap van 2 september 1982 werd vervolgens het ontwerp invoeringswet boeken 3-6 van het NBW aan de Tweede Kamer aangeboden. Hierin werd het appartementsrecht opnieuw gewijzigd ${ }^{128}$. Bij eerste nota van wijziging van 3 oktober 1983 werden weer enkele kleine wijzigingen in het appartementsrecht aangebracht ${ }^{129}$. Ook de daarop volgende nota van verbetering behelsde een lichte verandering van het appartementsrecht ${ }^{130}$. Een opnieuw gewijzigd ontwerp van de invoeringswet Boeken 3,5 en 6 NBW volgde hierop ${ }^{131}$.

verpanding van het lidmaatschapsrecht, wordt bereikt dat banken een tekort niet op de CFV hoeven te verhalen, maar rechtstreeks kunnen aankloppen bij degene die het tekort veroorzaakt. Zie hicrover uitgebreïd: Asser/Mijnssen/Van Velten, nrs. 141-143 en Van Velten (Recente ontwikkelingen), blz 492,493 .

122. Bos, bli. 538 .

123. Zie echter hetgeen hierboven in noot 121 werd opgemerkt.

124. MVT bij het ontwerp Boek 5 NBW, Bijl. Hand. II, 1956-1957, 4572, nr. 3, blz. 14.

125. Bijl. Hand. II, 1956-1957, 4572, nrs, 1-3.

126. Bijl. Hand. II, 1972, 4572, wr. 5, blz. 100 .

127. Stb. 1980, 431 .

128. Bijl. Hand. II, 1981-1982, 17541, nrs. 1-3.

129. Bijl. Hand. II, 1983-1984, 17541, nr. 4.

130. Bijl. Hand. II, 1983-1984, 17541, ar. 5 ,

131. Bijl. Hand. II, 1983-1984, 17541, $\operatorname{mar}^{\circ} 6$. 
Op 8 juli 1985 werd het voorlopig verslag bij het gewijzigd ontwerp van de invoeringswet door de Vaste Commissie van Justitie vastgesteld ${ }^{132}$. Hierin werden enige opmerkingen bij het appartementsrecht geplaatst. De Memorie van Antwoord die volgde, ging op de kritiek van het Voorlopig Verslag in ${ }^{133}$. Op 13 september 1985 volgde een tweede nota van wijzigingen waarin het appartementsrecht wederom werd veranderd ${ }^{134}$.

Het eindverslag van de Vaste Commissie voor Justitie over de memorie van antwoord en de tweede nota van wijzigingen ${ }^{135}$ werd vastgesteld op 14 januari 1986. Naar aanleiding van dit eindverslag bracht de Minister van Justitie een nota uit waarin werd ingegaan op de inhoud daarvan ${ }^{136}$, alsmede op de opmerkingen die werden gemaakt over het appartementsrecht. Vervolgens verscheen een derde nota van wijziging waarin het appartementsrecht werd gespaard ${ }^{137}$. Een nieuw gewijzigd voorstel van wet volgde echter, waarin opnieuw het appartementsrecht in geringe mate werd gewijzigd ${ }^{138}$. Daarna verscheen een tweede nota van verbetering waarin niets werd opgemerkt over het appartementsrecht ${ }^{139}$. Een vierde nota van wijzigingen ontzag het appartementsrecht eveneens ${ }^{140}$. In een amendement van de kamerleden Van der Burg en Korthals werd verwolgens een wijziging van artikel 5.10.1.8a voorgesteld ${ }^{141}$. De derde nota van verbetering bracht daarna enige redactionele wijzigingen in het gewijzigd wetsvoorstel (nr. 13) aan ${ }^{142}$. In het tweede nader gewijzigd voorstel van wet bij de invoeringswet Boeken 3,5 en 6 van het NBW, werd het amendement Van der Burg/Korthals vervolgens opgenomen en werden nog enige andere wijzigingen voorgesteld ${ }^{143}$.

Bij de bespreking van de hoofdlijnen van het geldende appartementsrecht (par. 2.4) zal tevens het appartementsrecht naar NBW worden besproken en zullen de verschillen tussen huidig en komend recht zoveel mogelijk aan de orde worden gesteld.

\subsection{Dogmatische opmerkingen ten aanzien van de structuur van appartements- eigendom}

\subsection{Algemene opmerkingen}

Het beginsel "superficies solo cedit" is in het BW niet als dwingend uitgangspunt geaccepteerd, maar slechts als praesumptio juris tantum neergelegd in de artikelen 626 en $656 \mathrm{BW}$. Hierdoor boden zich aan de wetgever, die bij het ontwerpen van de appartementenwet 1951 voor het probleem werd gesteld om een goede,

132. Bijl. Hand. II, 1984-1985, 17541, nr. 7 .

133. Bijl. Hand. II, 1984-1985, 17541, nr. 8.

134. Bijl. Hand. II, 1984-1985, 17541, nr. 9.

135. Bijl. Hand. II, 1985-1986, 17541, nr. 10.

136. Bijl. Hand. II, 1985-1986, 17541, nr. 11 .

137. Bijl. Hand. II, 1985-1986, 17541, nr. 12.

138. Bijl. Hand. II, 1985-1986, 17541, nr. 13.

139. Bijl. Hand. $\llbracket$, 1985-1986, 17541, nr. 14 .

140. Bijl. Hand. II, 1985-1986, 17541, n.r. 19.

141. Bijl. Hand. II, 1986-1987, 17541, nr. 18; Bijl. Hand. II, 1986-1987, 17541, nr. 20.

142. Bijl. Hand. II, 1986-1987, 17541, nr. 21.

143. Bijl. Hand. I, 1986-1987, 17541, nr. 226. 
dogmatisch verantwoorde constructie voor "appartementseigendom" te bedenken, verschillende opties aan.

Allereerst was het mogelijk om een regeling te creëren, waarin de bestaande mogelijkheid om afzonderlijke eigendom te verwerven (vgl. par. 2.1.1.1) in een juridisch kader werd gevat, met bepalingen om de te verwachten moeilijkheden te omzeilen. Een andere mogelijkheid die bij deze eerste nauw aansluit, is de constructie zoals die in het huidige appartementsrecht wordt gehanteerd, namelijk medeëigendom van (grond en) gebouwen en een beperkt zakelijk gebruiksrecht ten aanzien van de privé-gedeelten.

Bovendien bestond nog de mogelijkheid om de coöperatieve flatexploitatievereniging, die in de praktijk zijn sporen al had verdiend (vgl-par. 2.1.6), in een wettelijk geregeld appartementsrecht te consolideren. Tenslotte behoorde een constructie die gebruik maakte van de NV-vorm of de stichtingsvorm ook nog tot de mogelijkheden ${ }^{144}$.

\subsection{De mogelijke constructies nader beschouwd}

In het oorspronkelijke ontwerp (Oo) van 1947 (vgl. par. 2.1.4) kozen de ontwerpers voor een constructie van volle eigendom van de ruimten die blijkens bouw of inrichting waren bestemd om als afzonderlijk geheel te worden gebruikt en medeëigendom van de gedeelten van het gebouw die bestemd waren voor gemeenschappelijk gebruik (art. 638a Oo).

De Staatscommissie tot herziening van de Nederlandse Burgerlijke Wetgeving, waaraan het Oo werd voorgelegd (zie par. 2.1.5) meende echter dat

"de rechtspositie van de flatbewoners hoofdzakelijk wordt bepaald door het mede gerechtigd zijn in het hele gebouw en de daaruit voortvloeiende verplichtingen. Uit dien hoofde achtte de Staatscommissie het op de voorgrond stellen van alleen-eigendom op bepaalde gedeelten van het gebouw enigszins misleidend, terwijl hieraan bovendien het bezwaar kleeft, dat het lichamelijk object van deze eigendom nauwelijks is aan te geven, daar de samenstellende delen vrijwel alle tot de gemeenschappelijke eigendom van alle flateigenaren moeten worden gerekend. "145

De staatscommissie adviseerde daarom het wetsontwerp te reconstrueren, zodat de medeëigendom in het gehele gebouw op de voorgrond zou komen te staan. Om de ontwerper van het NBW, E.M. Meijers, die lid van de staatscommissie was, niet te binden aan een dogmatisch uitgangspunt "dat voor hem wellicht minder aannemelijk zou zijn", volgden de Ministers van Justitie en van Wederopbouw en Volkshuisvesting het "van dogmatische aard zijnde advies" van de staatscommissie ${ }^{146}$.

De kritiek van de staatscommissie spitste zich dus blijkbaar niet toe op het feit dat de "superficies solo cedit"-regel geweld zou zijn aangedaan. Dergelijke kritiek

144. In het algemeen zijjn dit ook de mogelijkheden die in het buitenland als potentiële constructies voor appartementseigendom worden gezien. Vgl. bijvoorbeeld: Hauger, blz 5-9; Bärmann (Dogmatik), blz 1-27.

145. MvA bij wetsontwerp 451, Bijl. Hand. Il, 1950-1951, 451, nr. 5, blz. 21.

146. MvA bij wetsontwerp 451, Bijl. Hand. II, 1950-1951, 451, nr. 5, blz 21. 
zou ook niet fundamenteel zijn geweest, nu de Nederlandse wetgever dit beginsel in de artikelen 626 en $656 \mathrm{BW}$ slechts als praesumptie heeft gecodificeerd. Dit beginsel is derhalve geen dwingend uitgangspunt van ons privaatrecht.

Belangrijk was de kritiek van de staatscommissie dat de rechtspositie van de appartementseigenaar voornamelijk wordt bepaald door het medegerechtigd zijn in het gehele gebouw. Deze kritiek lijkt gerechtvaardigd. Indien aan een appartementseigenaar de volle eigendom van zijn privé-gedeelten wordt toegekend, wordt de aard en omvang van dit eigendomsrecht in feite ingevuld door de rechten en verplichtingen die voortvloeien uit het lidmaatschap van de gemeenschap wan appartementseigenaars. De appartementseigenaar zal zich bij het gebruik van zijn eigendomsrecht altijd aan de regels die uit de gemeenschapsverhouding voortvloeien, moeten houden.

Even belangrijk is naar mijn mening het argument dat het lichamelijke object van de volle eigendom nauwelijks is aan te geven. Weliswaar moet een verdieping in beginsel als zelfstandige zaak kunnen worden beschouwd, maar de praktische problemen die daaruit voortvloeien zijn legio. Het eigendomsrecht zou zich immers moeten uitstrekken over de wanden, vloeren en plafonds van de privé-gedeelten. Ten aanzien van tussenwandjes e.d. kan verdedigd worden dat zij onder het volle eigendomsrecht zouden vallen. Hoe moet echter worden geoordeeld over dragende muren en vloeren en plafonds? Het probleem dat hierbij bestaat is dat het plafond van de benedenbuurman de vloer van de bovenbuurman is. Een muur of plafond zou aldus onder het volle eigendomsrecht van meerdere appartementseigenaars vallen. Zou de eigendom van de privé-gedeelten veel meer kunnen omvatten dan een kubus lucht ${ }^{147}$ ? De wet is machtig en had het kunnen regelen. Zeer fraai zou deze constructie echter niet zijn geweest.

Een en ander brengt mijns inziens met zich mee dat de voorkeur moet worden gegeven aan de tegenwoordig gehanteerde constructie, waarin het gebouw in zijn geheel in medeëigendom aan alle appartementseigenaars toekomt, terwijl iedere medeëigenaar zakelijk gerechtigd is om een bepaald gedeelte van het gebouw exclusief te gebruiken. Problemen over de eigendom (en bijvoorbeeld de uit de eigendom voortvloeiende aansprakelijkheid) van plafonds en wanden kunnen in deze constructie niet ontstaan.

De wetgever had in 1951 echter ook zijn toevlucht kunnen nemen tot de coöperatieve flatexploitatievereniging (CFV). Deze constructie was in praktijk al toegepast en bleek te voldoen. Aan de CFV kleeft echter, behalve de juridische bezwaren die in paragraaf 4.2.5.2 zullen worden besproken en die door de wetgever hadden kunnen worden opgelost, een psychologisch bezwaar. Degene die een lidmaatschap van een CFV verwierf, verkreeg immers geen eigendom of een daarop gelijkend recht ten aanzien van zijn woning. Over het algemeen zullen mensen sneller geneigd zijn geld uit te geven voor iets dat hen toebehoort, dan voor een lidmaatschapsrecht van een vereniging. Waarschijnlijk zou het appartementsrecht met een CFV-constructie minder succes hebben gekend, dan met de huidige medeëigendomsconstructie. Weliswaar werd in het begin desalniettemin nog vaak soelaas gezocht in de CFV-constructie in plaats van in de wettelijke

147. Vgl. Zurfluh/Traizet-Frot, blz. 142; Logeman, blz, 41, 94. 
appartementsrechtconstructie, maar dit hing vooral samen met financiële motieven (vgl. par. 2.1.6.2). Na 1972, toen aan de financiële bezwaren van het appartementsrecht tegemoet was gekomen, prefereerde men de wettelijke constructie boven die van de coöperatieve vereniging ${ }^{148}$.

Hetzelfde psychologische bezwaar als bij de CFV-constructie, geldt bij de NVen stichtingsconstructie. Aan deze appartementsstructuur kleefden nog meer bezwaren, zodat het begrijpelijk is dat de wetgever niet voor appartementsrecht met de naamloze vennootschap als hoofdingrediënt heeft gekozen ${ }^{149}$.

Het ligt mijns inziens voor de hand dat een wetgever, die op zoek is naar een constructie om appartements"eigendom" mogelijk te maken, zoveel mogelijk de volle-eigendomssituatie probeert te benaderen. Dit geldt des te meer nu aan andere mogelijke constructies het psychologische bezwaar kleeft, dat geen eigendom wordt verkregen. In landen als West-Duitsland, Frankrijk en België heeft dit geleid tot een structuur van volle eigendom van prive-gedeelten en medeeigendom van de gemeenschappelijke gedeelten (zie de hoofdstukken 5, 6 en 7). In Nederland koos men aanvankelijk ook voor deze constructie. De huidige structuur van "appartementseigendom" in Nederland is echter minder kunstmatig en dogmatisch (met name op het punt van het lichamelijke object van het eigendomsrecht) zuiverder. Aan de psychologische drang van mensen om eigendom te hebben wordt tegemoet gekomen door de medeëigendomsconstructie, gecombineerd met een zakelijk gebruiksrecht van de prive-gedeelten ${ }^{150}$. Deze combinatie bewerkstelligt in de praktijk mijns inziens dat de situatie waarin sprake is van volle eigendom, sterk wordt benaderd.

Als daarbij wordt opgeteld dat de wet de gerechtigde tot een appartementsrecht "appartementseigenaar" noemit, dan wordt in praktijk waarschijnlijk bereikt dat de meeste "appartementseigenaars" niet eens weten dat ze de titel "eigenaar" vanuit dogmatisch oogpunt ten onrechte voeren.

\subsection{Hoofdlijnen van het geldende appartementsrecht (met verwijzingen naar het Nieuw Burgerlijk Wetboek)}

\subsection{Algemene opmerkingen}

De privaatrechtelijke regeling van het appartementsrecht is neergelegd in de artikelen 875 a tot en met $876 \mathrm{t} \mathrm{BW}$, in de tiende titel $\mathrm{A}$ van het derde boek van het burgerlijk wetboek, tussen de tiende titel van gebruik en bewoning en de elfde titel over erfopvolging bij versterf. De wettelijke regeling kan worden aangevuld in het reglement van splitsing (art. $875 \mathrm{f} \mathrm{BW}$ ) en een eventueel huishoudelijk reglement.

148. Zie Van Velten (Recente ontwikkelingen), blz $487,488$.

149. Dat mensen de eigendomsconstructie prefereren boven een structuur die gebruik maakt van een rechtspersoon als eigenaar van de appartementen, blijkt uit de ervaringen die men in Frankrijk heeft opgedaan. In de Franse appartementenwet van 1938 had de wetgever twee constructies wettelijk geregeld. De ene bestond vit splitsing in appartementen, waarbij volle eigendom van de priwé-gedeelten aan de appartementseigenaars toekwam, de andere had een bouwmaatschappijstructuur. Deze lagtste constructie werd zo weinig toegepast, dat ze bij wet van 16 juli 1971 uit de appartementenwet werd gelicht. Vgl. par. 7.1.

150. Zo ook De Vries (Naschrift bij Van Velten (Recente ontwikkelingen)), blz 494. 
Het reglement van splitsing is een onderdeel van de akte van splitsing (art. 875e lid 1 sub d BW). Artikel $875 \mathrm{f}$ BW geeft aan wat in het reglement van splitsing moet en kan worden opgenomen. Zo moet in dit reglement worden bepaald welke schulden en kosten voor rekening van de gezamenlijke appartementseigenaars komen en moet een vereniging van eigenaars (V.v.E.) worden opgericht, waarvan de statuten eveneens in het reglement van splitsing moeten worden opgenomen (zie art. $875 \mathrm{f}$ lid $1 \mathrm{BW}$ ). Artikel $875 \mathrm{f}$ lid $2 \mathrm{BW}$ geeft nadere voorschriften ten aanzien van de inhoud van de statuten en de leden 3 en 4 van artikel $875 \mathrm{f} \mathrm{BW}$ noemen nog andere regelingen, die in het reglement kunnen worden opgenomen.

In artikel $875 \mathrm{e}$ lid 1 sub d BW wordt de mogelijkheid geopend om met betrekking tot het reglement, dat deel uitmaakt van de akte van splitsing (zie par. 2.4.2.1), te verwijzen naar een nauwkeurig aangeduid modelreglement dat in de openbare registers is overgeschreven. In het NBW komt deze bepaling terug in artikel 5.10.1.4. sub d. Een soortgelijke bepaling was in de wet van 1951 opgenomen in artikel $638 \mathrm{f} \mathrm{sub} \mathrm{4.} \mathrm{De} \mathrm{Koninklijke} \mathrm{Notariële} \mathrm{Broederschap} \mathrm{heeft} \mathrm{door}$ de jaren heen verscheidene van dergelijke model/standaardreglementen opgesteld. Het eerste verscheen in augustus 1953. In mei 1956 werd een wijziging aangebracht met betrekking tot de assurantiebepalingen. Naar aanleiding van de wetswijziging van 1972 bracht de Koninklijke Notariële Broederschap in februari 1973 een nieuw model-"reglement van splitsing van eigendom" uit. In januari 1975 kwam vervolgens een apart "reglement van splitsing van eigendom van een service-flatgebouw"' uit. Het "reglement van splitsing van eigendom" uit 1973 werd in november 1983 vervangen door het "modelreglement bij splitsing in appartementsrechten". Het "reglement van splitsing van eigendom van een service-flatgebouw" van 1975 werd in 1987 vervangen door het "modelreglement bij splitsing in appartementsrechten van een service-flatgebouw".

In het huishoudelijk reglement kunnen

"de regels van orde die bij het bewonen van een gebouw door twee of meer gezinnen vrijwel onmisbaar zullen zijn", aldus Beekhuis/Linders ${ }^{151}$,

worden vastgesteld. Het huishoudelijk reglement wordt niet in de openbare registers gepubliceerd en werkt in beginsel niet tegen rechtverkrijgers van appartementsrechten ${ }^{152}$.

De vaststelling van een huishoudelijk reglement is in principe niet verplicht (vgl. art. 44 lid 1 modelreglement 1983). In het reglement van splitsing kan de plicht om een huishoudelijk reglement vast te stellen, echter aan de vergadering van eigenaars worden opgelegd (bijv. art. 51 modelreglement 1987).

In het navolgende zal zoals in paragraaf 1.3 .3 al werd vermeld, evenals in de hoofdstukken over buitenlands appartementsrecht, aandacht worden besteed aan onstaan en tenietgaan van appartements"eigendom", administratie en beheer van

151. Beekhuis/Linders, VI par. 6, nr. 7.

152. In de praktijk wordt vaak in de akte van splitsing bepaald, dat de niewwe appartementseigenaar die zijn privé-gedeelte in gebruik will nemen, verpliclit is een verklaring te ondertekenen, dat hij de bepalingen van het huishoudelijk reglement zall naleven (art. 44 modelreglement 1983. Zie ook art. 24 lid 1 van dit modelreglement t.a.v. andere gebruikers). Vgl. Beckhuis/Linders, VI par. 6 , mar. 7. 
appartementsgebouwen en aan de rechten en verplichtingen van de appartementseigenaars.

In de hoofdstukken over buitenlands appartementsrecht zal, zoals in hoofdstuk 1 werd vermeld, bovendien de algemene structuur van de buitenlandse appartementseigendom worden besproken. Aangezien dit ten aanzien van het Nederlandse appartementsreclut reeds in de paragrafen $1.1 \mathrm{en} 2.3$ is gebeurd, zal in het navolgende geen aandacht meer worden besteed aan de algemene structuur van het Nederlandse appartementsrecht.

Hieronder zal het Nederlandse appartementsrecht naar BW en NBW worden beschreven, terwijl tevens (voor zover relevant) de bepalingen van de modelreglementen van splitsing (voor gewone appartementsgebouwen en voor serviceflatgebouwen) zullen worden verwerkt. Bij de verwijzingen naar het NBW zal zoals in paragraaf 1.3.3 al werd aangekondigd, niet allieen de tot op heden gehanteerde voorlopige nummering worden gebruikt, maar ook de definitieve nummering, zoals deze in het voorjaar van 1989 is bekend gemaakt. Bij de verwijzing naar de modelreglementen zal steeds worden verwezen naar de bepalingen van de meest recente modelreglementen, d.w.z. voor gewone appartementsrechten het reglement uit 1983 (aan te halen als modelreglement 1983) en voor service-flats het reglement uit 1987 (aan te halen als modelreglement 1987) ${ }^{153}$. Voor hetgeen in een huishoudelijk reglement kan worden geregeld, zij verwezen naar artikelen 44 modelreglement 1983 en 51 modelreglement 1987 en naar het huishoudelijk reglement behorende bij het reglement 1987.

\subsection{Ontstaan en tenietgaan van appartementsrechten}

\subsubsection{Ontstaan}

Bij wet van 12 september $1974^{154}$ werden in de Woningwet twee nieuwe artikelen ingevoegd, de artikelen $56 \mathrm{a}$ en $56 \mathrm{~b}$. Ingevolge deze artikelen moest een eígenaar van een gebouw voor splitsing in appartementsrechten een vergunning van burgemeester en wethouders verkrijgen indien het gebouw ouder was dan een bij AMvB vast te stellen aantal jaren en in een bij AMvB aan te wijzen gemeente lag. Doel van deze wet was speculatie met oude verkrotte gebouwen tegen te gaan ${ }^{155}$.

Bij wet van 28 oktober $1985^{156}$ werden de artikelen $56 \mathrm{a}$ en $56 \mathrm{~b}$ Woningwet echter vervallen verklaard en vervangen door de artikelen $56 \mathrm{a}-56 \mathrm{~h}$ Woningwet. De Wet van 12 maart 1987 (Stb. 95) bracht nog enige veranderingen aan in de wet van 1985. In 1987 trad de wet van 28 oktober 1985 , zoals gewijzigd bij wet van 12 maart 1987 , in werking. De hoofdregel van deze wet is aan die van de wet van 1974 gelijk gebleven: in bij AMvB aangewezen gemeenten of gedeelten van

153. Indien in de akte van splitsing van een appartementsgebouw wordt verwezen naar een bepaald modelreglement, blijft dit modelreglement van toepassing, ook indien de Koninklijke Notariële Broederschap daarna een nieuw modelreglement uitgeeft.

154. Stb. 1974, 526 .

155. Vgl. Neleman, blz. 37-43; Beekhuis/Linders, VI par. 2, nr. 11. Zie ook HR 9 dec. 1983, NJ 1984 273. De Wet op de woningsplitsing is ook toepasselijk, indien slechts é̉n appartementsrecht met woonbestemming in het leven wordt geroepen.

156. Stb. 1985,575 . 
gemeenten moet voor splitsing van een gebouw (van een bepaalde leeftijd) in appartementsrechten, een vergunning aan $\mathrm{B} \& W$ worden gevraagd ${ }^{15}$.

Artikel $56 \mathrm{~b}$ Woningwet bevat gronden waarop de vergunning moet worden geweigerd. In artikel 56c Woningwet zijn facultatieve weigeringsgronden neergelegd. De gemeente kan bovendien een splitsingsverordening vaststellen, waarin de weigeringsgronden zijn opgenomen. De artikelen $56 \mathrm{e}-56 \mathrm{~h}$ Woningwet bevatten procedurele bepalingen ${ }^{158}$.

In het ontwerp Huisvestingswet ${ }^{159}$ is in een nieuwe regeling met betrekking tot splitsingsvergunningen voorzien (artt. 41, 42). Een belangrijk novum is dat de gemeenteraad op grond van deze wet zelf zal kunnen of een vergunningenstelsel ten aanzien van splitsing in appartementsrechten zal worden gehanteerd.

Indien voor splitsing van een gebouw in appartementsrechten, een vergunning ingevolge de wet op de woningsplitsing (artt. 56a-56h Woningwet) is vereist, moet voordat appartementseigendom kan ontstaan, deze vergunning worden verkregen. Nadat een eventueel benodigde splitsingsvergunning is verkregen, kan tot splitsing zoals geregeld in het BW worden overgegaan.

Op grond van de bepalingen van het $\mathrm{BW}$ mag iedere eigenaar ${ }^{160}$, erfpachter of opstaller zijn recht op (grond en) een gebouw ${ }^{161}$ met hetgeen daartoe behoort, splitsen in appartementsrechten (art. 875a'lid 1 BW; art. 5.10.1.1/ 5:106 NBW). Als een erfpachter of opstaller tot splitsing wil overgaan, moet hij daartoe toestemming vragen van de eigenaar van de grond. Indien de eigenaar van de grond zich niet verklaart of de toestemming "kennelijk zonder redelijke grond weigert", kan de kantonrechter aan degene die tot splitsing wil overgaan, vervangende machtiging tot splitsing verlenen (art. 875a lid $6 \mathrm{BW}$; art. 5.10.1.1 lid 6 / 5:106 lid 6 NBW. Vgl. ook artikelen 5.10.1.8 / 5:115 en 5.10.1.8a / 5:116 NBW voor het geval een recht van erfpacht of opstal in de splitsing wordt betrokken) ${ }^{162}$.

Een interessante vraag is welke gevolgen het ontbreken van de toestemming van de eigenaar van de grond heeft voor de geldigheid van de splitsing? Onder de

157. Hetzelfde geldt overigens t.a.y. coöperat ieve flatexploitatieverenigingen en andere rechtspersonen die aan lidmaatschapsrechten of aandeelhouderschap verbonden gebruiksrechten van woningen willen verlenen (art. 56a lid 2 Woningwet).

158. In dit verband zal niet nader worden ingegaan op het in de Wet op de Woningsplitsing bepaalde. Vgl. over deze wet: Verdoes Kleijn/Wolfensperger, blz. 337-343; Creutzberg; blz. 355-360; Beekhuis/Linders, VI par. 5, nrs. 2b, 2c; Van Ham-Wagner, blz 2-4. Vgl. over de invloed van het vergunningenstelsel op de kwaliteit van de appartementen: Van Weesep c.s. (Splitsingsregime).

159. Bijl. Hand. II, 1987-1988, 20520, nr. 2.

160. Hieronder moeten tevens meerdere (mede) eigenaars van hetzelfde perceel en/of gebouw(en) worden verstaan.

161. Onder gebouwen moet tevens worden werstaan een "groep van gebouwen"; aldus art. 875 a lid 5 BW. Als een recht van erfpacht of een recht van opstal wordt gesplitst, wordt de daarna verschijnende canon of retributie conform art. $875 \mathrm{~g}$ lid 2 BW (art. 5.10.1.6 lid 2 / 5:113 lid 2 NBW) over de appartementsrechten verdeeld (art. 875i BW; art. 5.10.1.8 / 5:115 NBW. Vgll. ook par. 2.4.4).

162. Art. 875a lid 6 BW is in 1972 in de wet opgenomen door een amendement van het kamerlid Wierunga. Zie Hand. II, 1971-1972, blz. 3184, 3185. Zie ook HR 23 dec. 1976, NJ 1977, 409 met noot W.M.K (Reggezuid-arrest), WPNR 5386, blz 236, 237 en WPNR 5422, bLz 111, 112. Daarower Van Velten, blz. 745-749; Van Velten (Projectontwikkeling), blz 80; Kleijin, blz. $24 \mathrm{cn}$ Stolker, blz. 183 . 
vigeur van artikel 638a lid $3 \mathrm{BW}$ (oud) werd aangenomen dat het ontbreken van splitsingsbevoegdheid door ontbreken van toestemming van de eigenaar van de grond een relatieve nietigheid van de splitsing tot gevolg had. Ten opzichte van derden moest de splitsing geldig worden geacht, terwijl zij ten opzichte van de grondeigenaar nietig was i63. Voor het huidige recht moet eveneens een relatieve nietigheid als gewolg van splitsing door een onbevoegde worden aangenomen ${ }^{164}$.

Volgens Pitlo/Brahn ${ }^{165}$ kan ook een stadsmeier of een beklemde meier zijn stadsmeierrecht of beklemrecht in appartementsrechten splitsen. Deze mogelijkheid is echter niet expliciet in de wet erkend. Indien zij echter bestaat, moet ook de stadsmeier of beklemde meier bij een voorgenomen splitsing toestemming van de grondeigenaar vragen. Als artikel $875 \mathrm{a}$ lid 1 immers van toepassing moet worden geacht op het stadsmeierrecht en het beklemrecht, geldt mutatis mutandis ook artikel 875a lid 6 BW (art. 5.10.1.1 lid 1 en $6 / 5: 106$ lid 1 en $6 \mathrm{NBW}$ ) ${ }^{166}$.

Zoals vermeld kan de kantonrechter de toestemming van de grondeigenaar door een machtiging vervangen, indien deze zich niet verklaart of de toestemming "kennelijk zonder redelijke grond" weigert. Deze laatste zinsnede betekent dat de kantonrechter slechts marginaal mag toetsen ${ }^{167}$.

Een interessant probleem kan zich voordoen, indien de eigenaar van een gebouw (opstaller) of een erfpachter zijn recht wil splitsen en de gemeente eigenaar van de grond is. Als in de gemeente de artikelen $56 \mathrm{a}-56 \mathrm{~h}$ Woningwet van toepassing zijn, moet de erfpachter of opstaller enerzijds een splitsingsvergunning van B \& W verkrijgen (art. 56a Woningwet), anderzijds heeft hij van de gemeente als grondeigenaar tevens toestemmming tot splitsing nodig. Kan de gemeente nu de splitsingsvergunning verlenen, maar de toestemming als eigenaar van de grond weigeren? Waarschijnlijk moet deze vraag bevestigend worden beantwoord. De twee procedures moeten als geheel van elkaar losstaand worden gezien. Bij de verlening van de vergunning moet de gemeente zich laten leiden door de wet (in

163. Asser/Beekhuis II (1963), blz. 85; De Vries (Onroerend goed), blz. 383.

164. Beekhuis/Linders, VI par. 3, nr. 6; Pitlo/Brahn, blz. 386; Asser/Beekhuis Ir, blz. 307. Het gevolg van splitsing zonder een ingevolge de Wet op de Woningsplitsing vereiste vergunning, is geen (relatieve) nietigheid. De enige sanctie op het splitsen zonder vergunning is neergelegd in de strafbepalingen van artt. 96 en 97 Woningwet. Vgl. HR 9 dec. 1983, NJ 1984, 273; Hof 'sGravenhage 10 juni 1982, Bouwrecht 1982, bli. 851; Beekhuis/Linders, VI par. 5, nr. 2a; Neleman, blz, 41 .

165. Pitlo/Brahn, blz 385, Zie ook Beekhuis/Linders, VI par. 5, nr. 4.

166. Pitlo/Brahn, ble. 386 .

167. Pitlo/Brahn, blz. 385, 386; Beekhuis/Linders, VI par. 3, nr. 5 , is het met de stelling dat de kantonrechter marginaal dient te toetsen, kennelijk niet oneens. Asser/Beekhuis II, blz 306 , meent echter dat de kantonrechter silechts bij weigering door de gemeente als grondeigenaar, met het oog op door de gemeente te behartigen publieke belangen, marginaal moet toetsen. VgL. HR 24 april 1981, NJ 1982, 84; Kantongerecht Amsterdam 15 okt. 1974, NJ 1976, 22, daarover Santen, blz 511 en Sicheltema, blz. 521. De Amsterdamse kantonrechter overwoog dat "speciaal gelet op de in de tekst van art. 875 , lid 6 BW voorkomende woorden "kennelijk zonder redelijke grond", er hier slechts plasts is woor een marginale toetsing." Zo ook Kantongerecht "s-Gravenhage 11 april 1983, NJ 1984, 158. De kantonrechter meende in casu dat toetsing van weigering van thestemming ex art. 875 a lid $6 \mathrm{BW}$ altijd marginaal dient te geschieden. Zie tevens Kantongerecht "s-Gravenhage 17 okt. 1979, Praktijkgids 1980, nr. 1429, biz. 34. In beide gevallen werd een weigering van toestemming tot splitsing zonder redelijke grond geacht. Vgl. verder HR 23 dec. 1976, NJ 1977, 409 (Reggezuid-arrest). In dit arrest toetst de Hoge Raad de weigering blijkens haar besluit, dat "van een weigering "kennelijk zonder redelijke grond" niet is gebleken", eveneens marginaal. Zie ook de bespreking van dit arrest in WPNR 5422, blz 111 . 
het bijzonder artt. 56a-h Woningwet) en de algemene beginselen van behoorlijk bestuur. Belangen van de gemeente als eigenaar van de grond mogen bij de beslissing mijns inziens niet worden meegewogen ${ }^{168}$. Het is echter zeer wel mogelijk dat de gemeente bestuurlijk geen reden tot weigering van de splitsingsvergunning heeft, maar privaatrechtelijk door toestemming tot splitsing (art. 875a lid $6 \mathrm{BW}$ ) haar eigenaarsbelangen in de knel zou doen geraken. Het lijkt me dan ook mogelijk dat de gemeente een splitsingsvergunning verleent, c.q. moet verlenen, terwijl zij privaatrechtelijk de toestemming tot splitsing kan weigeren of aan voorwaarden kan binden. Zo zou de gemeente in bepaalde gevallen een verhoging van de erfpachtscanon kunnen verlangen, indien de splitsing een verhoging van door haar te maken kosten met zich mee zou brengen ${ }^{16 \%}$. Een en ander wordt mijns inziens niet anders, indien de gemeente de toestemming tot splitsing weigert met het oog op de door haar te behartigen publiekrechtelijke belangen. Gemeenten mogen zich bij de uitoefening van privaatrechtelijke bevoegdheden immers laten leiden door publiekrechtelijke belangen ${ }^{170}$. Zij zijn echter in alle gevallen gebonden aan de algemene beginselen van behoorlijk bestuur, waaronder het gelijkheidsbeginsel ${ }^{171}$.

Overigens kan ook een appartementsrecht op zijn beurt in appartementsrechten worden gesplitst. Deze bevoegdheid tot ondersplitsing komt aan de appartementseigenaar toe, voor zover in de akte van splitsing niet anders is bepaald (art. 876a lid 2 BW; art. 5.10.1.1. lid 2/5:106 lid 2 NBW). Van Velten wijst erop dat de bevoegdheid tot ondersplitsing de interessante mogelijkheid opent, om ten aanzien van een groep van gebouwen meerdere verenigingen van eigenaars tot stand te brengen. Een groot complex met meerdere gebouwen, kan bijvoorbeeld primair aldus worden gesplitst, dat ieder gebouw eén appartementsrecht vormt. Deze afzonderlijke gebouwen kunnen vervolgens worden ondergesplitst, waardoor in elk

168. Vgl. bijvoorbeeld het KB Mengsmeerpomp Amsterdam, 12 juni 1963, ARB 1963, blz. 899. Een verzoeker om een hinderwetvergunning werd niet ontvankelijk verklaard, omdat de gemeente Amsterdam als eigenares van de grond, waarop de hinderveroorzakende activiteiten zouden worden ontplooid, haar eigendom miet voor dat doel ter beschikking wilde stellen. De Kroon vernietigde de niet-ontvankelijkverklaring en overwoog daarbij dat de toestemming van de gemeente als eigenares niet relevant was, aangezien de aanvraag voor de hinderwetvergunning slechts aan de hinderwet mocht worden getoetst. Zie hierover Tak, blz, 388. Vgl. ook Scheltema, ble. 521 .

169. Vgl. Kantongerecht Amsterdam 15 okt. 1974, NJ 1976, 22, WPNR 5422, blz. 111, 112. De verhoging van de canon als voorwaarde, levert geen weigering op die kennelijk zonder redellijke grond tot stand komt. Zie hierover Santen, blz. 511 en Schellema, blz. 521. Vgl. ook HR 24 aprii 1981, NJ 1982, 84; Asser/Beekhuis II, blz. 306; Beekhuis/Linders, VI par. 3, nr. 5.

170. Vgl. bijv. HR 23 dec. 1976, NJ 1977, 409 met noot WMK (Reggezuid-arrest), WPNR 5386, blz. 236, 237 en WPNR 5422, bli. 111, 112. Daarover Van Velten, blz. 745-749; Van Velten (Projectontwikkeling), blz 80; Kleijn, blz. 24 en Stolker, blz. 183. Vgl. verder Beekhuis/Linders, blz 110, 111; Tak, blz, 296-300. Nolet, blz 4; Swart/Gerver, blz 282; Praktijkboek Onroerend Goed, ID-18; Kantongerecht 's-Gravenhage 11 april 1983, NJ 1984, 158. De kantonrechter meende dat hij slechts marginaal mocht toetsen en dat de gemeente in casu weliswaar bij de beslissing ex art. 875 a lid 6 rekening mocht houden met publiekrechtelijke belangen, maar dat in dit geval de toestemming kennelijk zonder redelijke grond was geweigerd. Zie verder Hof 's-Gravenhage 8 okt. 1987, Bouwrecht 1988, blz 609-611.

171. Zie HR 27 maart 1987, NJ 1987, 727 (Ikon) met noot MS. Vgl. verder Van Velten (Projectontwikkeling), blz 80. 
van die gebouwen een ondergeschikte vereniging van eigenaars ontstaat. Van Velten merkt hierbij echter op dat aan deze constructie nog de nodige problemen kleven. Men kan zich bij deze constructie bijvoorbeeld afvragen wie namens de "onderappartementseigenaars" in de hoofdvergadering zou moeten stemmen. De Commissie Beekhuis blijkt aan een modelreglement te werken, waarin de problemen zouden moeten worden opgelost ${ }^{172}$.

De splitsing in appartementsrechten geschiedt door een daartoe bestemde notariële akte (splitsingsakte), die ingeschreven wordt in de openbare registers. Aan de minuut van de splitsingsakte moet een tekening worden gehecht, waarin de begrenzing van de verschillende gedeelten van de grond en het gebouw wordt aangegeven en de prive-gedeelten worden omschreven (artt. $875 \mathrm{~d}$ lid $2 \mathrm{BW}$, 5.10 .1 .2 lid $2 / 5: 109$ lid 2 NBW) ${ }^{173}$.

In de akte van splitsing moet een aantal zaken worden geregeld en opgenomen, zoals bijvoorbeeld de plaatselijke ligging van het gebouw en de kadastrale aanduiding van de percelen die in de splitsing worden betrokken. Naast deze en nog enkele andere inhoudelijke eisen stelt art. 875e BW (art. 5.10.1.4 / 5:111 NBW) opname van een reglement van splitsing in de akte van splitsing verplicht (zie ook par. 2.4.1). In dit reglement van splitsing moeten globaal gesteld de onderlinge verhoudingen van de appartementseigenaars worden geregeld (art. 875f lid $1 \mathrm{BW}$; art. 5.10.1.5 / 5:112 NBW). Zo moet bijvoorbeeld in het reglement een vereniging van eigenaars (V.v.E.) worden opgericht, "die ten doel heeft het behartigen van de gemeenschappelijke belangen van de appartementseigenaars" en moeten de statuten van deze V.v.E. in het reglement worden opgenomen (art. 875f lid 1 sub e $\mathrm{BW}$ ). Wat vervolgens in de statuten moet worden geregeld, wordt vermeld in artikel $875 \mathrm{f}$ lid $2 \mathrm{BW}$. Artikel $875 \mathrm{f} \mathrm{BW}$ maakt in het derde en vierde lid nog enkele regelingen mogelijk die niet verplicht in het reglement van splitsing moeten worden opgenomen (art. $875 \mathrm{f}$ lid $4 \mathrm{BW}$ vormt bijvoorbeeld de grondslag voor de welstandsbepalingen in het appartementsrecht. Vgl. hoofdstuk 3).

Het reglement van splitsing werkt, als gevolg van het feit dat het deel uitmaakt van de akte van splitsing, tegen rechtsverkrijgers van degenen die de splitsing tot stand hebben gebracht (art. 875e lid 2 BW). In het NBW is dit niet meer expliciet bepaald ${ }^{174}$.

Behalve tegen rechtsverkrijgers, werkt het reglement ook tegen degenen die het gebruik verkrijgen, in elk geval voor zover het regelingen omtrent gebruik, beheer en onderhoud betreft. Andere reglementsbepalingen kunnen echter in het reglement zelf eveneens op de gebruiker van toepassing worden verklaard (art. $875 \mathrm{~m}$ lid 2 BW; art. 5.10.1.13 lid 2 / 5:120 lid 2 NBW). Ook de huurder is derhalve

172. Van Velten (Projectontwikkeling), blz. 73.

173. De vereisten waaraan deze tekening moet voldoen zijn neergelegd in KB 25 sept. 1972 en in de beschikking van de Minister van Financiën d.d. 25 sept. 1972, Stert. 205, d.d. 20 okt. 1972. Naar NBW moet de tekening voldoen aan krachtens art. 3.1.2.1 lid $2 / 3: 16$ lid 2 te stellen eisen.

174. Volgens de MNT bij art. 5.10.1.5 NBW, Parl. Gesch.y blz 386, is een bepaling als art $875 \mathrm{e}$ lid 2 BW in het NBW overbodig, aangezien het in de akte wan splitsing bepaalde blijkens het appartementsrecht voor alle appartementseigemaars geldt. Onder appartementseigenaars vallen zowel degenen die de splitsing tot stand hebben gebracht als hun latere rechtsverkrijgers. Zo ook Asser/Beekhuis II, blz, 327. 
aan de bepalingen van het reglement gebonden. Hierop maakt artikel $875 \mathrm{~m}$ lid 3 BW (art. 5.10.1.13 lid 3 / 5:120 lid 3 NBW) echter een uitzondering met betrekking tot reglementsbepalingen, die na totstandkoming van de huurovereenkomst in de openbare registers worden overgeschreven. Deze bepalingen werken slechts tegen de huurder, indien hij daarin heeft toegestemd of de kantonrechter heeft bepaald (op verzoek van een appartementseigenaar) dat de reglementsbepaling tegen hem werkt (zie over de inroepbaarheid van welstandsbepalingen tegen de huurder par. 4.4.4)

De vraag komt op welk gevolg aan het ontbreken van een van de krachtens artikelen 875d BW (art. 5.10.1.2 / 5:109 NBW) of 875e BW (art. 5.10.1.4 / 5:111 NBW) aan de splitsingsakte gestelde voorwaarden, moet worden verbonden. In artikel $638 \mathrm{f}$ BW (oud) was bepaald wat de akte van splitsing "op straffe van nietigheid" moest inhouden. Met uitzondering van deze zinsnede kwam artikel $638 \mathrm{f}$ BW (oud) verder overeen met het huidige artikel 875 e eerste lid BW. Volgens de memorie van toelichting ${ }^{175}$ bij de wet van 1972 werd de formule "op straffe van nietigheid" geschrapt, omdat nietigheid alleen te rechtvaardigen zou zijn,

"indien een essentiale woor de splitsing zou ontbreken. In zodanig geval is het ook zonder uitdrukkelijke vermelding duidelijk dat de akte van splitsing nietig is. In andere gevallen - bij voorbeeld wanneer in de vermelding in de akte van de kadastrale aanduiding van de appartementsrechten kennelijk een vergissing is geslopen -, heeft dit niet ongeldigheid van de splitsingsakte ten gevolge. "176

Dat nietigheid niet altijd intreedt volgt ook uit artikel 876q BW (art. 5.10.4.2d / 5:144 NBW) waarin staat vermeld dat de kantonrechter op verzoek van een persoon "wiens medewerking of toestemming tot de wijziging van de akte van splitsing of opheffing van de splitsing vereist is", kan bevelen dat de akte van splitsing wordt gewijzigd of de splitsing wordt opgeheven:

"wanneer de akte van splitsing niet voldoet aan de in de artikelen $875 \mathrm{e}$ en $875 \mathrm{f}$ gestelde eisen." ${ }^{177}$

175. MvT bij wetsontwerp 10987, Bijl. Hand. II, 1970-1971, 10987, nr. 3, blx. 14. Vgl. m.b.t. owergangsrecht bij de verschillen in splitsingswereisten tussen de wet van 1.951 en de wet van 1972: Hof Arnhem 28 okt. 1985, NJ 1988, 63.

176. Vgl over deze problematiek ook Konings.

177. Vgl. Beekhuis/Linders, VI, par. 5, nr. 7. De akte van splitsing kan in beginsel slechts bij unaniem besluit van alle appartementseigenaars, zakelijk gerechtigden en beslagleggers, worden gewijzigd (art. 876l lid $1 \mathrm{BW}$; art. 5.10.4.1 lid 1 / 5:139 lid 1 NBW). Als de wijziging uitsluitend betrekking heeft op het reglement wan splitsing is toestemming van de beslaglegger niet nodig (art. 8761 lid $2 \mathrm{BW}$; art. 5.10.4.1 lid 2/5:139 lid 2 NBW). De wijziging van de akte van splitsing moet geschieden op overeenkomstige wijze als de splitsing tol stand komt, dat wil zeggen bij notariele akte, gewolgd door overschrijving in de openbare registers (artt. $875 \mathrm{~d} \mathrm{BW}, 8761$ lid $3 \mathrm{BW}$; artt. 5.10.1.2 / 5:109 en 5.10.4.1 lid 3/5:139 lid 3 NBW). Het nalaten van de overschrijving van de wijziging van de akte van splitsing heeft geen nietigheid van de wijziging tot gevolg. Mijns inziens heeft de wijziging in dat geval sllechts obligatoire werking. Indien een van degenen wier toestemming voor de wijziging is vereist, deze toestemming weigert, kan beroep worden ingesteld ingevolge art. 876m BW (art. 5.10.4.2 / 5:140 NBW). Zie hierover vitgebreider par. 2.4.4. 
Aan het ontbreken van één van de in artikelen 875e BW (art. 5.10.1.4 / 5:111 NBW) en 875f BW (art. 5.10.1.5/5:112 NBW) aan de akte van splitsing gestelde voorwaarden, is derhalve niet noodzakelijkerwijze ongeldigheid van de akte verbonden. Van ongeldigheid is slechts sprake, als een van de essentialia voor de splitsing ontbreekt. Hiervan zou sprake kunnen zijn indien de kadastrale aanduiding van de appartementsrechten (conform art. 875e lid 1 sub c BW; art. 5.10.1.4 lid 1 sub c / 5:111 lid 1 sub $\mathrm{c}$ NBW) geheel ontbreekt.

$\mathrm{Nu}$ is echter nog geen antwoord gegeven op de vraag wat het gevolg is indien de akte van splitsing niet aan de eisen van artikel $875 \mathrm{~b}$ BW voldoet. Ook hier ligt de oplossing mijns inziens in het onderscheid tussen essentialia en niet-essentialia. De voorwaarden die in artikel $875 \mathrm{~d} \mathrm{BW}$ aan de splitsing worden gesteld, zijn echter primaire voorwaarden die alle als essentialia dienen te worden bestempeld. Ontbreken van een notariële akte leidt aldus tot ongeldigheid van de splitsing. Ook de splitsingstekening vormt een essentiale. Dit is kennelijk ook het oordeel van de wetgever, die in de MvT bij de wet van $1972^{178}$ opmerkt, dat

"de tekening die aan de splitsing ten grondslag ligt, van zo essentiële betekenis is..." etc.

Geconcludeerd kan derhalve worden dat een splitsingsakte die niet aan de vereisten van artikel $875 \mathrm{~d} B W$ voldoet, nietig is, terwijl een akte die niet aan de vereisten van artikel 875 e BW voldoet, hetzij nietig, hetzij gebrekkig is met de mogelijkheid van een vordering tot herstel (art. 876q BW; art. 5.10.4.2d / 5:144 NBW).

Een verdere voorwaarde voor een geldige splitsing is, dat degene die tot splitsing overgaat, daartoe bevoegd is. Hierbij is niet alleen de relatieve bevoegdheidseis van artikel 875a lid 6 BW (art. 5.10.1.1/ 5:106 NBW) van belang, maar ook de vraag naar de absolute bevoegdheid van degene die tot splitsing overgaat.

"Heeft de splitsing plaatsgevonden door iemand die niet bevoegd was, bijv. die ten onrechte meende eigenaar dan wel erfpachter of opstaller te zijn, dan leidt dit tot (absolute, R.M.) nietigheid van de splitsingshandeling", aldus Asser/Beekhuis ${ }^{179}$.

Deze nietigheid kan in beginsel worden geheeld door acquisitieve verjaring ex artikel $2000 \mathrm{BW}$. Daarvoor is echter wel vereist dat:

1. indien de splitsing door én persoon tot stand is gebracht, deze persoon te goeder trouw was op het moment van splitsing, of

2. indien de splitsing door meerdere personen is tot stand gebracht, zij allen te goeder trouw waren op het moment van de splitsing ${ }^{180}$.

Onder vigeur van het NBW zullen derden te goeder trouw zich onder omstandigheden op artikelen 3.1.2.8a / 3:26 en 3.1.2.9 / 3:27, of op 3.2.20 / 3:58 kunnen

178. MvT bij de wetsontwerp 10987, Bijl. Hand. II, 1970-1971, 10987, nr. 3, blz. 14.

179. Asser/Beekhuis II, blz. 317. Zie ook Beekhuis/Linders, VI par. 5, nr. 4. Naar toekomstig recht is de splitsing door een onbewoegde in bepaalde gewallen geldig. Vgl. art. 5.10.1.2a / 5:110 NBW.

180. Asser/Beekhuis II, blz 319. 
beroepen. Een beroep op verkrijgende verjaring exartikel. 3.4.3.1/3:99 NBW zal in beginsel eveneens mogelijk zijn.

In theorie kan de splitsingsakte ook deel uitmaken van een openbaar testament. Een geheim testament of holografisch testament is op zich zelf geen notariële akte en kan daarom geen splitsingsakte bevatten. Een openbaar testament is echter wel een notariële akte. Aangezien de wet geen termijn stelt voor de overschrijving van de splitsingsakte in de openbare registers, is "het feit dat het onzeker is of het testament ooit rechtskracht zal verkrijgen" niet van belang ${ }^{181}$. Overschrijving van de akte in de openbare registers zal na het openvallen van de nalatenschap van de erflater alsnog kunnen geschieden. In de praktijk zal het volgens Asser/Beekhuis veelal gebeuren, dat in het testament aan de erfgenamen de last wordt opgelegd om tot splitsing van de erfenis over te gaan ${ }^{182}$. Een dergelijke last kan ook in een geheim of in een holografisch testament aan de erfgenamen worden opgelegd.

Naast de hierboven besproken voorwaarden voor een geldige splitsing, zijn er materieel nog enkele voorwaarden waaraan moet zijn voldaan om tot splitsing in appartementsrechten over te kunnen gaan. Zo moet in de splitsing een gebouw betrokken zijn (al dan niet reeds bestaand, art. 875b BW; art. 5.10.1.1a / 5:107 NBW). Een lap grond kan niet zelfstandig, los van een gebouw, in appartementsrechten worden gesplitst. Verdoes-Kleijn ${ }^{183}$ heeft splitsing van percelen zonder gebouwen daarentegen wel mogelijk geacht. Hij baseerde zich voor deze opvatting op het feit dat artikel 875a lid 1 BW (art. 5.10.1.1 / 5:106 NBW) spreekt over een gebouw met toebehoren en de daarbij behorende grond met toebehoren. Beekhuis/Linders wijst erop dat Verdoes Kleijn hier echter voorbij gaat aan de woorden "daarbij behorende" 184 .

Een andere voorwaarde waaraan moet zijn voldaan om tot splitsing in appartementsrechten over te kunnen gaan, is neergelegd in artikel 875a lid $3 \mathrm{BW}$. Dit artikel bepaalt namelijk dat

"onder appartementsrecht wordt verstaan een aandeel in de goederen die in de splitsing zijn betrokken, dat de bevoegdheid omvat tot het uitsluitend gebruik van bepaalde gedeelten van het gebouw die blijkens hun inrichting bestemd zijn of worden om als afzonderlijk geheel te worden gebruikt" (curs. R.M.).

Dit heeft ondermeer tot gevolg dat parkeerplaatsen in een parkeergarage, indien deze slechts door een verfstreep van elkaar zijn gescheiden, wellicht geen afzonderlijke appartementsrechten kunnen vormen ${ }^{185}$. Dit wordt anders zodra de

181. Asser/Beekhuis II, blz 316.

182. Asser/Beekhuis II, blz. 316.

183. Verdoes Kleijn (Preadvies 1979), blz 86. Vgl. dezelfde: (Appartementsrecht), blz. 137. Dezelfde anders in: Dijk Bundel, blz 148. Zie ook Van Hal, blz. 648.

184. Beekhuis/Linders, VI par. 2, nr. 5. Zo inmiddels ook Verdoes Kleijn (Dijk-bundel), blz. 149.

185. Vgl. Kwakernaak, blz. 441, 442. Volgens Verdoes Kleijn, (Preadvies 1979) blz. 86 noot 18 is een dergelijke splitsing wel mogelijk. In WPNR $\$ 390$ werd over de mogelijkheid van parkeerplaatsen, afgescheiden door verfstrepen, als afzonderlijke appartementen, een rechtsvraag gesteld. De vraagsteller meende dat zodanige parkeerplaatsen wel zelfstandig onderwerp van appartements- 
parkeerplaatsen door muren of andere afscheidingen duidelijk en fysiek van elkaar gescheiden worden. Een en ander geldt uiteraard alleen voor zover de parkeerplaatsen niet verbonden zijn aan appartementsrechten. De laatste zin van artikel 875 a lid $3 \mathrm{BW}$ doorbreekt dan de "inrichtingseis".

Indien men echter niet duidelijk van elkaar gescheiden parkeerplaatsen in bijvoorbeeld een parkeergarage tot appartementsrechten wil omvormen, en derhalve de parkeergarage in appartementsrechten wil splitsen, zal men volgens Kwakernaak de parkeergarage zodanig moeten splitsen, dat de verschillende verdiepingen van de parkeergarage de appartementsrechten vormen, die vervolgens worden bezwaard met meerdere erfpachtsrechten ${ }^{185}$. Het recht om de parkeerplaats te bereiken zou via een erfdienstbaarheid of mandeligheidsconstructie kunnen worden gerealiseerd ${ }^{187}$. Bij deze door Kwakernaak voorgestelde constructie kan echter mijns inziens een kanttekening worden geplaatst.

De door Kwakernaak voorgestelde mandeligheidsconstructie voor de toegangsweg tot de parkeerplaatsen, is mijns inziens niet mogelijk. Mandeligheid houdt immers medeëigendom in van een gemeenschappelijke zaak van de volle eigenaars van twee of meer (BW: maburige) erven (vgl. art. 5.5.1 / 5:60 NBW; art. 681 BW). Bij de door Kwakernaak voorgestelde constructie is er geen sprake van eigenaars van verschillende erven, dus kan er ook van mandeligheid van een gemene weg geen sprake zijn.

Met betrekking tot het erfpachtsrecht kan worden opgemerkt, dat het inderdaad mogelijk is een appartementsrecht met én erfpachtsrecht te bezwaren ${ }^{188}$. Hierbij moet echter de vraag worden gesteld of éên appartementsrecht met meerdere erfpachtsrechten kan worden bezwaard. Ook deze vraag moet mijns inziens bevestigend worden beantwoord, nu het ook mogelijk is dat de erfpachter een gedeelte van zijn erfpachtsrecht aan een ander overdraagt ${ }^{189}$. Evenzeer is het mogelijk de gehele verdieping van een parkeergarage met een erfpachtsrecht te bezwaren en op dit erfpachtsrecht meerdere ondererfpachtsrechten te vestigen. Dit vloeit voort uit artikel $775 \mathrm{BW}^{190}$. In het toekomstige recht maakt artikel 5.7.1.5.b

rechten konden zijn. De auteur van het antwoord ontkende dit. In de praktijk blijken parkeerplaatsen, van elkaar gescheiden door verfstrepen, wel al als afzonderlijke appartementsrechten te bestaan. Zie WPNR 5412, blz. 684 .

186. Een appartementsrecht kan met een erfpachtsrecht worden bezwaard. Vgl. Beekhuis/Linders, VI par. 13, nir. 1; Swart/Gerver, blz. 281-285; De Jong, blz 166-170, 175, 176.

187. Kwakernaak, blz 442.

188. Beekhuis/Linders, VI par. 13, nr. 1, Vreede, bliz 273-276; Asser/Beekhuis II, blz. 238. Vgl. ook HR 8 dec. 1982, NJ 1983, 686 met noot WMK. Vgl. over de discussie of een appartementsrecht naar BW en NBW al dan niet een onroerend goed, resp. onroerende zaak is die met een erfpachtsrecht kan worden bezwaard: Beekhuis/Linders, VI par. 13, nr. 1.

189. Pitlo/Brahn, blz 11, 327, 331.

190. Vgl. Pitlo/Brahn, blz. 331; Berenschot/Hoekstra/Vegter, blz. 116. Volgens Pak, blz. 137-140, is het ondererfpachusrecht naar huidig recht geen zakelijk, maar een persoonlijk recht. Vgl. ook De Vries (Ondererfpacht) blz, 325, 326 met onderschrift Pak. Deze visie van Pak is inmiddels door HR 8 dec. 1982, NJ 1983; 686 met noot WMK, achterhaald. In lagere rechtspraak werd al eerder de bestaanbaarheid vaa een zakelijk ondererfpachtsrecht aangenomen. Zie Rb. Breda 24 dec. 1957, NJ 1958, 383, WPNR 4648, blx. 455. Zie over erfpacht in het algemeen: Plantenga/ Treurniet, Arnhem 1957. Vgl. over het ondererfpachtsrecht in het NBW: Fischer-Keuls, blz 1168; Kleijn/Olthof, blz. 252; Pleysier, blz. 298, 299. Naar aanleiding van de twijfels wan verschillende auteurs (Pak, Fischer-Keuls) over de mogelijkheid om naar toekomstig recht ondererfpachtsrechten te vestigen, is art. 5.7.1.5b / 5:93 in boek 5 van het NBW opgenomen. Zie Nota van 
/ 5:93 NBW ondererfpacht op een gedeelte van een goed expliciet mogelijk. De door Kwakernaak voorgestelde constructie, in combinatie met een erfdienstbaarheid voor de toegangswegen, is dus mogelijk.

Parkeerplaatsen in parkeergarages die niet als afzonderlijke inrichtingen in de zin van artikel 875a lid $3 \mathrm{BW}$ (art. 5.10.1.1 lid 3/5:106 lid 3 NBW) kunnen worden beschouwd, kunnen naar huidig recht alleen via de door Kwakernaak bedachte constructie aan verschillende personen worden overgedragen. De constructie op zichzelf is echter niet bijzonder fraai. De lege ferenda zou voor de "auto en zijn appartement" een oplossing moeten worden gecreëerd. Deze oplossing zou bijvoorbeeld kunnen worden gevonden in een nieuwe zin, die aan artikel 875a lid 3 BW (art. 5.10.1.1. lid 3 / 5:106 lid 3 NBW) na de tweede zin zou moeten worden toegevoegd. Deze zin zou als volgt kunnen luiden:

"Gedeelten van een gebouw zijn ondermeer blijkens hun inrichting bestemd om als afzonderlijk geheel te worden gebruikt, indien deze bestemming uit duurzame afscheidingen of duurzame duidelijke markeringen blijkt."

Wellicht is een dergelijke toevoeging overbodig en is het naar huidig recht toch mogelijk dat gedeelten die slechts met verfstrepen zijn gemarkeerd, als "blijkens hun inrichting bestemd tot afzonderlijk gebruik ${ }^{* 1}$ gelden ${ }^{191}$. De onzekerheid hieromtrent zou door een eenvoudige wetswijziging echter kunnen worden weggenomen ${ }^{192}$.

Na deze bespreking van de totstandkomingsvereisten, dient nog aandacht te worden besteed aan de mogelijkheid van splitsing van nog niet bestaande gebouwen. Zoals reeds is vermeld in de paragrafen 2.1.6.2 en 2.2.2 was onder vigeur van de appartementenwet 1951 een splitsing van een nog op te richten gebouw (papieren splitsing) niet mogelijk. In de wet van 1972 is daarom artikel $875 \mathrm{~b}$ BW (art. 5.10.1.1a / 5:107 NBW) opgenomen, waarin is bepaald dat een eigenaar, erfpachter of opstaller ook bevoegd is

"in verband met een door hem beoogde stichting of gewijzigde inrichting van een gebouw zijn recht op het gebouw met toebehoren en de daarbij behorende grond met toebehoren te splitsen in appartementsrechten."

Ook bij een dergelijke splitsing ontstaan de appartementsrechten op het moment dat de akte van splitsing in de openbare registers wordt ingeschreven. De appartementsrechten kunnen dus ook voor voltooling van het gebouw ontstaan. Deze fictie is van belang voor de overdraagbaarheid van de appartementsrechten ${ }^{193}$.

Wijzigingen bij de vaststelling van boek 5 van het Nieuwe Burgerlijk Wetboek, Bijl. Hand. II, $1976-1977,4572$, nr. 9 , blz. 10.

191. Zo oak Kwakernaak, blz 441.

192. Vgl. over de onzelkerheid ook Beekhuis/Linders, VI par. 2, nr. 13 sub $\mathrm{f}_{\text {. }}$

193. Zie ook de MVT bij wetsontwerp 10987, Bijl. Hand. II, 1970-1971, 10987, ar. 3, blz 13. Zie art. 875h BW (art. 5.10.1.7 NBW) ower de gevolgen van de splitsing woor een hypotheekrecht, grondrente (BW), beslag of voorrecht dat voor de splitsing op het goed rusite. Vgl. ook 
Appartementsrechten kunnen op verschillende wijzen tenietgaan. De belangrijkste wijze van tenietgaan van appartementsrechten is door opheffing van de splitsing. Deze opheffing van de splitsing kan verschillende oorzaken hebben (art. 876p BW; art. 5.10.4.2c/5:143 NBW).

Ten eerste wordt splitsing van rechtswege opgeheven bij het eindigen van een recht van erfpacht of opstal, dat in de splitsing is betrokken (art. 876p lid 1 sub a BW; art. 5.10.4.2c lid 1/ 5:143 lid $1 \mathrm{NBW}$. Zie voor uitzonderingen op deze regel ditzelfde artikellid). Ten tweede wordt de splitsing van rechtswege opgeheven door overschrijving in de openbare registers van een vonnis waarbij een in de splitsing betrokken perceel in zijn geheel is onteigend, en geen andere percelen in de splitsing betrokken zijn (art. 876p lid 1 sub b BW).

Volgens artikel $876 \mathrm{p}$ lid $2 \mathrm{BW}$ (art. 5.10.4.2c lid 2/5:143 lid $2 \mathrm{NBW}$ ) geschiedt de opheffing van de splitsing in alle andere gevallen door een daartoe bestemde notariële akte, die wordt overgeschreven in de openbare registers. De appartementseigenaars kunnen derhalve door unaniem (uitzondering zie art. $876 \mathrm{~m} \mathrm{BW}$; art. 5.10.4.2 / 5:140 NBW) besluit (art. 8761 BW; art. 5.10.4.1/5:139 NBW) tot opheffing van de splitsing overgaan ${ }^{194}$. De opheffing van de splitsing heeft tot gevolg dat gewone medeëigendom ontstaat tussen de ex-appartementseigenaars (zie ook art. 876t BW; art. 5.10.4.2g / 5:147 NBW). Zakelijke rechten, beslagen en voorrechten (art. 876s BW; art. 5.10.4.2f / 5:146 NBW) rusten na de opheffing op het aandeel van de ex-appartementseigenaar op wiens appartementsrecht deze rechten rustten ${ }^{195}$.

De splitsing wordt in beginsel niet opgeheven indien het appartementsgebouw geheel of gedeeltelijk tenietgaat. Dit volgt enerzijds uit artikel 876q lid $1 \mathrm{sub} g \mathrm{BW}$ (art. 5:10.4.2d lid 1 sub g / 5:144 lid 1 sub g NBW), waarin ondermeer is bepaald dat de kantonrechter op verzoek van een appartementseigenaar kan bevelen de splitsing op te heffen, indien het gebouw ernstig is beschadigd of geheel of gedeeltelijk is gesloopt (tenzij binnen redelijke termijn herstel te verwachten is) ${ }^{196}$. Anderzijds volgt dit mijns inziens ook indirect uit artikel 875b BW (art. 5.10.1.1a ( 5:107 NBW), dat splitsing van een niet bestaand gebouw mogelijk maakt. Het feitelijk bestaan van een gebouw is derhalve geen voorwaarde voor het bestaan van appartementsrechten.

Een interessante - zij het wellicht academische - vraag is of appartementsrechten wel tenietgaan door het tenietgaan van de grond en de gebouwen, of op andere wijzen waarop overige zakelijke gebruiksrechten tenietgaan.

Zoals vermeld gaan appartementsrechten niet teniet door het tenietgaan van het appartementsgebouw. Mijns inziens gaan appartementsrechten echter wel teniet door het verdwijnen van grond en gebouwen. Nu zal het niet vaak voorkomen dat de grond tenietgaat, maar helemaal uitgesloten is dit niet. Men denke aan aardbevingen, (duurzame) overstromingen, vulkaanuitbarstingen (in Nederland niet

Beekhuis/Linders, VT par. 7, nr. 3.

194. Vgl. Beekhuis/Linders, VI par. 18; Pitlo/Brahn, blz 400; Asser/Beekhuis II, blz 384, 385.

195. Asser/Beekhuis II, blz 385, 386; Pitlo/Brahn, blz. 401. Hetzelfde geldt mutatis mutandis in beginsel voor huurovereenkomsten (vgl. art. $875 \mathrm{~m}$ lid $4 \mathrm{BW}$; art. 5.10.1.13 lid $4 \mathrm{NBW}$ ).

196. Asser/Beekhuis II, blz. 386; Beekhuis/Linders, VI par. 18, nr. 2. 
voor de hand liggend) etc. Als de grond tenietgaat, gaat de gehele zaak die in appartementsrechten is gesplitst, teniet. In dat geval gaat het medeëigendomsrecht als component van het appartementsrecht teniet (een eigendomsrecht gaat immers teniet door het tenietgaan van de zaak waarop het rust), en moet worden aangenomen dat ook het beperkt zakelijk gebruiksrecht verdwijnt. Deze conclusie is mijns inziens niet in strijd met de bepalingen van het appartementsrecht. Voor deze conclusie kan worden aangeknoopt bij de artikelen $875 \mathrm{a}, 875 \mathrm{~b}$ en $876 \mathrm{q}$ BW (artt. 5.10.1.1, 5.10.1.1a, 5.10.4.2d / 5:106, 107 en 144 NBW). Deze artikelen maken slechts appartementsrechten mogelijk met betrekking tot (nog) niet (of niet meer) bestaande gebouwen. Over het niet of niet meer bestaan van het eigendomsrecht op de grond wordt niet gerept.

Een even interessante maar eveneens academische vraag is of appartementsrechten ook kunnen tenietgaan door non-usus, een wijze van tenietgaan van beperkt zakelijke gebruiksrechten (vgl. artt. 754, 765, 783, 801, 854, 865 BW). Rechten als erfdienstbaarheden, opstalrechten en vruchtgebruik kunnen door nietgebruik van 30 jaren tenietgaan. De reden voor opneming van deze wijze van tenietgaan is waarschijnlijk dezelfde als de reden voor opneming van de verjaringsregelingen in het BW. Het is immers wenselijk dat het recht aansluit (na verloop van tijd) bij de feitelijke toestand ${ }^{197}$.

Dit zou een argument kunnen zijn om ook bij appartementsrechten de non-usus als reden voor tenietgaan te aanvaarden. Indien bijvoorbeeld een appartementsgebouw in zijn geheel tenietgaat en de appartementseigenaars dertig jaar lang geen aanstalten maken om het gebouw te herbouwen, ligt het dan niet in de rede dat het beperkt zakelijke gebruiksrecht als component van het appartementsrecht, tenietgaat en vrije medeëigendom van de grond overblijft? Tegen deze aanname pleit artikel 876p lid 2 BW (art. 5.10.4.2c lid 2/ 5:143 lid 2 NBW), dat bepaalt dat appartementsrechten in alle gevallen die niet onder artikel 876p lid 1 BW (art. 5.10.4.2c lid 1 / 5:143 lid $1 \mathrm{NBW}$ ) vallen, door een notariële akte die wordt ingeschreven in de openbare registers, tenietgaan. Een ander argument tegen de non-usus als wijze van tenietgaan van appartementsrechten, is het feit dat de nonusus in het NBW als wijze van tenietgaan van beperkt zakelijke gebruiksrechten is afgeschaft ${ }^{198}$. Nu het huidige appartementsrecht is ingevoerd als voortrein van het NBW ${ }^{199}$, kan hieraan een argument worden ontleend voor de stelling dat appartementsrechten niet door non-usus kunnen tenietgaan.

\subsection{Administratie en beheer}

Zoals vermeld is iedere appartementseigenaar medeëigenaar van grond en gebouw(en). Hij is derhalve lid van de (gebonden) gemeenschap van appartementseigenaars. Aan de gemeenschap van appartementseigenaars is zoals in paragraaf 1.1 werd vermeld, de vereniging van eigenaars (V.v.E.) als organisatiestructuur

197. Vgl. over non-usus Pitlo/Hidma, blz. 249-253.

198. Vgl. over de redlenen van deze afschaffing Asser/Beekhuis $I_{n}$ blz. 385. Zie ook Memorie van Antwoord bij art. 3.4.3.8a NBW, Bijl. Hand II 1970-1971, 3770, nr. 5, ble.137-139. Art. 3.4.3.8a NBW zal mijns inziens niet van toepassing zijm bij appartementsrechten, omdat daarbij geen hoofdgerechligde in de zin van dit artikel is aan te wijzen.

199. Beekhuis/Linders, III par. 3. 
gekoppeld 200 . Deze V.v.E. moet blijkens artikel $875 f$ lid 1 sub e BW (art. 5.10.1.5 lid 1 sub e / 5:112 lid 1 sub e NBW) in elke akte van splitsing worden opgericht. Behalve deelgenoot in de appartementsgemeenschap is iedere appartementseigenaar daarom ook lid van de V.v.E. Dit lidmaatschap heeft de appartementseigenaar van rechtswege (art. 876 lid $1 \mathrm{BW}$; art. 5.10.2.1 lid 2 / 5:125 lid $2 \mathrm{NBW}$ ). Naast dit wettelijk vastgestelde lidmaatschap van de V.v.E, kan aan alle of bepaalde appartementsrechten het lidmaatschap van een andere, nader in het reglement omschreven vereniging worden verbonden, voor zover dit lidmaatschap in overeenstemming is met de statuten van deze vereniging (art. $875 \mathrm{f}$ lid $3 \mathrm{BW}$; art. 5.10.1.5 lid 3 / 5:112 lid 3 NBW).

De V.v.E. is een rechtspersoon (art. 876 lid 2 BW; art. 5.10.2.0 lid 1/ 5:124 lid $1 \mathrm{NBW}$, die ontstaat zodra de appartementsrechten aan verschillende personen toebehoren. Indien ten tijde van de overschrijving van de akte van splitsing alle appartementsrechten nog aan éen persoon of aan een groep personen gezamenlijk toebehoren, ontstaat op dat tijdstip derhalve nog geen V.w.E. Zodra één appartementsrecht aan een andere persoon is overgedragen, ontstaat de V.v.E. Voor het ontstaan van deze vereniging is derhalve vereist dat de appartementsrechten aan tenminste twee eigenaars afzonderlijk (dus niet in gemeenschap) toekomen.

De V.v.E. blijft daarentegen bestaan indien alle appartementsrechten na het ontstaan van deze vereniging weer in eén hand worden verenigd. Het vereiste van meerdere appartementseigenaars, neergelegd in artikel 876 lid $3 \mathrm{BW}$ (art. 5.10.2.1 lid 3 / 5:125 lid 3 NBW), is derhalve slechts een ontstaansvereiste, en geen bestaansvereiste. Dit volgt mijns inziens uit artikel 876 lid $3 \mathrm{BW}$, waarin slechts over het ontstaan van de V.v.E. wordt gesproken, en uit artikel 876t BW (art. 5.10.4.2g / 5:147 NBW), waarin wordt gesteld dat de V.v.E. na opheffing van de splitsing van rechtswege wordt ontbonden.

Een vraag die lange tijd de juristen die zich met appartementsrecht bezighouden, heeft geïntrigeerd, is of de V.v.E. een vereniging in de zin van boek $2 \mathrm{BW}$ is. Bevestigende beantwoording van deze vraag zou tot gevolg hebben dat de bepalingen van boek 2 , voor zover de speciale bepalingen van het appartementsrecht daaraan niet derogeren, van toepassing zouden zijn op de V.v.E. Dit zou op zijn beurt tot gevolg hebben dat de V.v.E. moet worden ingeschreven in het verenigingsregister. Bovendien zou voor de V.v.E. het zogenaamde richtlijnstelsel gelden (art. 2:45 lid $3 \mathrm{BW}$ ) ${ }^{201}$. De heersende mening lijkt te zijn dat de bepalingen uit boek $2 \mathrm{BW}$ niet op de V.v.E. van toepassing zijn ${ }^{202}$.

200. Het is niet mogelijk om in een flatgebouw met drie afzonderlijke trappenhuizen, betrokken in een splitsing, drie verschillende V.v.E.'s op te richten. Wel is het mogelijk dat maast de V.v.E. andere verenigingen worden opgericht, waarvan het lidmaatschap aan bepaalde appartementsrechten wordt verbonden (art. $875 f$ lid 3 BW). Vgl. HR 19 dec. 1986, NJ 1987, 947 met noot WMK.

201. Pitlo/Brahn, blz 398; Beekhuis/Linders, VI par. 15, ar. 1.

202. Beekhuis/Linders, VI par. 15, nr. 1; Asser/Beekhuis II, blz. 358; Stille, WPNR 5441, blz 448450; Dijk, blz. 185. Stille en vooral ook Dijk spreken zich niet duidelijk uit over het al dan niet toepasselijk zijn van Boek 2 BW op de V.v.E. Den Tonkelaar, WPNR 5467, blz 128-131, concludeert dat het verenigingsrecht well toepasselijk is op de V.v.E. Zo ook Kantongerecht Breda 21 sept. 1981, NJ 1982, 331. Van der Grinten, blz. 234, 235, bestrijdt dit. Pitlo/Brahn, blz. 398 meent dat het onzeker is of de bepalingen uit boek 2 BW op de V.v.E. wan toepassing zijn. Vgl. ook De Vries (Omzetting), blz 661-669. 
Om alle onzekerheid weg te nemen heeft de wetgever getracht de toepasselijkheid van het algemene verenigingsrecht op de V.v.E. wettelijk te regelen ${ }^{203}$. Hiervoor werd in 1979 een wetsontwerp ${ }^{204}$ ingediend. Dit wetsontwerp is in 1985 echter weer ingetrokken ${ }^{205}$. Bij de MvA van de Invoeringswet boeken 3, 5 en 6 NBW $2066_{\text {is }}$ een aanpassing van artikel 5.10.2.0 voorgesteld. Conform deze aanpassing komt dit artikel als volgt te luiden:

"1. De vereniging van eigenaars is rechtspersoon.

2. Titel 1 van boek 2 is slechts van toepassing behoudens de artikelen $4,6,13$ lid 2,17, 18, 19 leden 1-3, lid 5, tweede zin, en lid 6, 20, 21 en 22 met inachtneming van de in de navolgende artikelen van de onderhavige titel aangegeven afwijkingen.

3. Titel 2 van boek 2 is slechts van toepassing voor zover de onderhavige afdeling daarnaar verwijst."

Volgens dit artikel zijn onder de vigeur van het NBW derhalve een aantal van de allgemene bepalingen betreffende rechtspersonen op de V.v.E. van toepassing, terwijl het verenigingsrecht van boek $2 \mathrm{BW}$ in beginsel niet van toepassing is (tenzij uitdrukkelijk van toepassing verklaard).

De V.v.E. heeft ten doel de gemeenschappelijke belangen van de appartementseigenaars (de leden) te behartigen (art. 875f lid 1 sub e BW; art. 5.10.1.5 lid 1 sub e / 5:112 lid 1 sub e NBW). Zij voert het beheer over de gemeenschap, uitgezonderd de gedeelten die bestemd zijn om als afzonderlijk geheel te worden gebruikt (art. 876a lid $1 \mathrm{BW}$; art. 5.10.2.1a lid 1/5:126 lid 1 NBW). Bovendien is zij gerechtigd de gezamenlijke appartementseigenaars in en buiten rechte te vertegenwoordigen (art. 876a lid 2 BW; art. 5.10.2.1a lid $2 / 5: 126$ lid 2 NBW) ${ }^{207}$. Daarnaast legt de wet haar de taak op om toe te zien op de nakoming van de verplichtingen die de appartementseigenaars bij of krachtens de wet en het reglement van splitsing jegens elkaar hebben. Indien nodig kan de V.v.E. in rechte nakoming van de verplichtingen eisen (art. 876a lid $3 \mathrm{BW}$; art. 5.10.2.1a lid $3 /$ 5:126 lid 3 NBW) ${ }^{208}$.

De V.v.E. heeft verschillende organen:

1. de vergadering van eigenaars;

2. het bestuur, dat wil zeggen eén of meer administrateurs;

3. de voorzitter van de vergadering van eigenaars;

4. commissarissen (facultatief).

203. Bijl. Hand. II, 1979-1980, 15872, nr. 3, blz. 5.

204. Bijl. Hand. II, 1979-1980, 15872, nr. 1 .

205. Stert. 1985, nr. 50.

206. Bijl. Hand. II, 1984-1985, 17541, mrs. $8,9$.

207. Zie ook Raad van Arbitrage voor de Bouwbedrijven 26 okt. 1987, nr. 12.673, Bouwrecht 1988, blz. 310 .

208. Uit art. 876a lid 3 BW volgt niet dat de V.w.E. de belangen van huurders moet behartigen en evenmin dat de V.w.E. de verhuurder t.o.v. de huurder vertegenwoordigt als deze laatste klachten heeft. Uit art. $876 \mathrm{a}$ lid $3 \mathrm{BW}$ volgt wel "dat een vereniging van eigenaars ten behoeve van de appartementseigenaars erop toeziet dat ook huurders de reglementaire bepalingen naleven." Zic HR 23 jan. 1987, NJ 1987, 1001 met noot WMK. 
Ad 1) De vergadering van eigenaars vormt het belangrijkste orgaan van de V.v.E. Alle bevoegdheden, die niet door de wet of de statuten aan andere organen van de V.v.E. zijn toebedeeld, komen aan de vergadering van eigenaars toe (art. 876b lid $1 \mathrm{BW}$; art. 5.10.2.1/5:125 NBW). Zo is de vergadering bevoegd om regels te stellen met betrekking tot het gebruik van de gemeenschappelijke gedeelten, voor zover het reglement daarover tenminste geen bepalingen bevat (art. $876 \mathrm{clid} 1 \mathrm{BW}$; artt. 5.10.2.1 clid 1, 5.10.2.1 ca / 5:128, $129 \mathrm{NBW})^{209}$. Zij komt in beginsel een maal per jaar bijeen (vgl. art. 33 modelreglement 1983; art. 38 modelreglement 1987). ledere appartementseigenaar heeft stemrecht in de vergadering van eigenaars. Dit volgt uit het feit dat alle appartementseigenaars van rechtswege lid zijn van de V.v.E. (art. 876 lid 1 BW; art. 34 lid 1 modelreglement 1983; art. 39 lid 1 modelreglement 1987) en toegang hebben tot de vergadering van eigenaars (art. $876 \mathrm{~b}$ lid $2 \mathrm{BW}$; art. 5.10.2.1b / 5:127 NBW). In het reglement van splitsing is geregeld, welk aantal stemmen iedere appartementseigenaar heeft. Vaak zal aan alle appartementseigenaars een aantal stemmen toekomen naar evenredigheid van het aandeel in de gemeenschap. Deze aandelen in de gemeenschap zijn in beginsel gelijk, tenzij in de akte van splitsing anders is bepaald (art. $875 \mathrm{~g}$ lid $1 \mathrm{BW}$; art. 5.10.1.6 lid $1 / 5: 113 \mathrm{NBW})^{210}$. Niet in alle gevallen hebben de appartementseigenaars hetzelfde aantal stemmen. In het reglement van splitsing kan namelijk een afwijkende stemverhouding worden neergelegd ${ }^{211}$. Dit zal er niet toe kunnen leiden, dat aán bepaalde appartementseigenaars het stemrecht geheel wordt ontzegd. Een dergelijke ontzegging zou betekenen dat de appartementseigenaar het recht van medebestuur zou worden ontnomen. Dit zou in strijd zijn met artikel 876b lid 2 BW (art. 5.10.2.1b lid $1 / 5: 127$ lid $1 \mathrm{NBW}$ ), waarin staat dat iedere appartementseigenaar toegang tot de vergadering heeft (lees: stemrecht in de vergadering heeft).

Verdoes Kleijn heeft erop gewezen dat het aantal stemmen dat een eigenaar mag uitbrengen, in het reglement afhankelijk kan worden gesteld van het onderwerp waarover gestemd moet worden. Hij acht een "one man, one vote"-systeem voor sommige situaties zeer wel denkbaar, bijvoorbeeld bij het stemmen over de kleur van buitenschilderwerk ${ }^{212}$. In beginsel is een dergelijke regeling inderdaad mogelijk, maar daarbij kan wel de vraag worden gesteld of een eigenaar die een groter aandeel in de gemeenschap heeft en een groter aandeel in de kosten van het schilderwerk moet dragen, niet tevens meer inspraak bij de bepalling van de kleur verdient.

Indien een appartementsrecht aan meerdere personen gezamenlijk toekomt, kunnen deze hun gezamenlijk stemrecht slechts uitoefenen door schriftelijk uit hun midden een stemgerechtigde aan te wijzen of een derde schriftelijk te machtigen (art. 35 modelreglement 1983; art. 40 modelreglement 1987) ${ }^{213}$.

209. Overigens ziğn de appartementseigenaars gebonden aan de beslluiten van de vergadering, ook indien zili niet ter vergadering aanwezig waren of bebben tegengestemd. Een appartementseigenaar die het niet eens is met een besluit van de vergadering, kan echter wel wernietiging van dit besluit vragen ex art. 876d BW. Vgl. par. 2.4.4.

210. Vgl. art. 2 lid 1 modelreglement 1983; art. 2 lid 1 modelreglement 1987.

211. Bijvoorbeeld indien de appartementsrechten onderling in grootte verschillen.

212. Verdoes Kleijn (Stemrecht), blz. 280.

213. Vgl. hierover ook Verdoes Kleijn (Stemrecht), blz, 280. 
Zoals al blijkt uit het voorgaande is het stemrecht gekoppeld aan het aatndebl in de gemeenschap, en niet aan de persoon van de appartementseigenaxir. Dit kan tot gevolg hebben dat een eigenaar die tot meerdere appariemetutsrechten gerechtigd is, de vergadering van eigenaars beheerst. Dit geldt met name woot de algemene besluiten van de vergadering, die bij volstrekte meerdertheid van de uitgebrachte stemmen moeten worden genomen (art. $876 \mathrm{~b}$ lid $2 \mathrm{BW}$; art. $5,10.2,1 \mathrm{~b}$ lid 1/ 5:127 lid $1 \mathrm{NBW}$; art. 37 modelreglement 1983; art. 42 modelreglement 1987). In het reglement van splitsing kan echter van deze hoofdregel wordes afgeweken. Zo wordt bijvoorbeeld in artikel 27 van het modelreglement 1983 voor ontzegging van verder gebruik een meerderheid van tenminste tweederde van de uitgebrachte stemmen vereist, in een vergadering waarin tenminste tweederde vas het totaal aantal stemmen vertegenwoordigd is. Met name voor belangrijke beslissingen zal in het reglement al snel een dergelijk quorum worden geëist.

Het modelreglement van splitsing van 1987 bepaalt in artikel 43 lid 5 bijvoorbeeld, dat besluiten tot uitgaven die niet strekken tot gewoon onderhoud, net tweederde meerderheid in een vergadering, waarin tenminste tweederde van het totale aantal stemmen vertegenwoordigd is, moeten worden genomen (zo ook art. 38 lid 5 modelreglement 1983). In beginsel kan echter een ander meerderheidsvereiste in het reglement worden opgenomen.

Voor zeer belangrijke beslissingen is zelfs unanimiteit vereist. Dit is bijwoorbeeld het geval bij wijziging van de akte van splitsing (vgl. art. 8761 lid $1 \mathrm{BW}$ ) ${ }^{214}{ }_{\text {. Door }}$ de unanimiteitseis wordt het overwicht van bepaalde eigenaars met zeer veel stemmen enigszins gecompenseerd. Bij minder belangrijke beslissingen kunnen zij onder omstandigheden de dienst uitmaken, maar naarmate de te nemen beslissing belangrijker wordt, wordt het stemoverwicht enigermate tenietgedaan.

Ad 2) Het bestuur van de V.v.E. wordt gevormd door én of meer administrateurs (art. 876e lid $1 \mathrm{BW}$; art. 5.10.2.1e / 5:131 NBW). In praktijk is er meestal slechts één administrateur. Daarom zal in het navolgende steeds over de administrateur worden gesproken.

De administrateur wordt benoemd door de vergadering van eigenaars en kan te allen tijde door deze vergadering worden geschorst of ontslagen (art. 5.10.2.1e / 5:131 NBW; art. 876e lid $2 \mathrm{BW}$ ). In beginsel kan iedereen - natuurlijk persoon of rechtspersoon - tot administrateur worden benoemd. In praktijk wordt echter veelal een makelaar als administrateur aangewezen ${ }^{215}$.

De administrateur heeft tot taak de geldelijke middelen van de vereniging te beheren en zorg te dragen voor de tenuitvoerlegging van de besluiten van de vergadering van eigenaars. In de statuten kunnen nog andere bevoegdheden aan de administrateur worden toegekend (art. $876 \mathrm{e}$ lid 3 en $4 \mathrm{BW}$; art. 5.10.2.1e lid 3 en $4 / 5: 131$ lid 3 en 4 NBW). In elk geval moet de administrateur binnen zes maanden na afloop van elk boekjaar een jaarverslag uitbrengen en rekening en verantwoording afleggen voor het door hem gevoerde bestuur $(876 \mathrm{e} \mathrm{lid} 5 \mathrm{BW}$, art.

214. Vgl. Beekhuis/Linders, VI par. 15, nr. 5 sub a. Vgl. ook Kantongerecht Utrecht 16 dec. 1977, NJ 1979, 180. In casu was er sprake van een wijziging van het huishoudelijk reglement, welke wijziging in strijd werd bevonden met het in het reglement van splitsing bepaalde en met de goede trouw. De wijziging van het huishoudelijk reglement werdl ex art. 876d BW vernietigd; Beekhuis/Linders, VI par, 6, nr. 7 .

215. Beekhuis/Linders, VI par. 15, nr. 5 sub b. 
5.10.2.1i / 5:135 NBW jo. 2:48 BW). Bovendien is hij verantwoordelijk voor het bijeenroepen van de vergadering van eigenaars (art. 876b lid $3 \mathrm{BW}$; art. 5.10.2.1b lid 2 / 5:127 lid $2 \mathrm{NBW}$ ). In het modelreglement 1983 is de administrateur verder aangewezen om de opstallen te verzekeren (art. 8 modelreglement 1983). Naast deze verplichtingen heeft de administrateur, voor zover dit noodzakelijk is voor de vervulling wan zijn taak, de bevoegdheid om de privé-gedeelten van de appartementseigenaars te betreden (art. 876f BW; art. 5.10.2.1f / 5:132 NBW. Zie over de verdere rechten en verplichtingen van de administrateur art. 41 modelreglement 1983 en art. 47 modelreglement 1987).

Een interessante vraag is wat het gevolg is indien de vergadering van eigenaars geen administrateur benoemt. De wet stelt geen sanctie op het niet benoemen van een administrateur. Evenmin lijkt het voor een appartementseigenaar mogelijk om de benoeming van de administrateur in rechte af te dwingen. Feitelijk kan een appartementseigenaar dit echter wel door telkens handelingen die door de administrateur moeten worden verricht, aan te tasten via art. $876 \mathrm{~d}$ lid 1 sub a BW (art. 5.10.2.1d lid 1 sub a / 5:130 lid 1 sub a NBW).

Ad 3) De voorzitter van de vergadering van eigenaars wordt, tenzij de statuten anders bepalen, door de vergadering uit zijn midden benoemd. Behalve de administrateur heeft ook de voorzitter het recht de vergadering van eigenaars bijeen te roepen. De voorzitter vervangt verder de administrateur bij diens belet of ontstentenis, tenzij in de statuten of door de vergadering anders wordt bepaald (art. 876g lid $1 \mathrm{BW}$; art. 5.10.2.1g lid 1/5:133 lid $1 \mathrm{NBW}$ ).

Ad 4) Behalve de hierboven genoemde organen van de vereniging, die verplicht moeten worden ingesteld of op grond van de wet bestaan (de vergadering), kan in de statuten worden bepaald dat commissarissen toezicht uitoefenen op de administrateur (vgl. art. 876i BW). Naar toekomstig recht geeft de wet hiervoor geen aparte regeling. Artikel 5.10.2.1i / 5:135 NBW verwijst echter naar artikel 2:47 BW. Dit artikel regelt de instelling van een raad van commissarissen, die dezelfde taak heeft als de raad van commissarissen op grond van artikel $876 \mathrm{i} \mathrm{BW}{ }^{216}$.

\subsection{Rechten en verplichtingen van de appartementseigenaars}

ledere appartementseigenaar mag zijn appartementsrecht overdragen en bezwaren (art. 875k lid $1 \mathrm{BW}$; art. 5.10.1.9 lid 1 / 5:117 lid $1 \mathrm{NBW}$ ). Naast dit recht om een appartementsrecht vrij over te dragen of te bezwaren, mag de appartementseigenaar zijn privé-gedeelten vrij gebruiken of aan een ander in gebruik geven ${ }^{217}$. Deze bevoegdheid omvat tevens het aan iedere appartementseigenaar toekomende medegebruik van de gemeenschappelijke gedeelten (art. $875 \mathrm{~m}$ lid 1 BW; art. 5.10.1.13 lid 1/ 5:120 NBW).

In artikel 875n BW (art. 5.10.1.9a / 5:118 NBW) wordt de bevoegdheid van de appartementseigenaar om zijn appartementsrecht te bezwaren, nader uitgewerkt met betrekking tot vestiging van erfdienstbaarheden. Dit artikel bepaalt enerzijds

216. Vgll. t.av. huidig recht over de commissarissen: Kantongerecht Amsterdam 8 mei 1978, Praktijkgids 1978, nr. 1274. Daarover Stille, WPNR 5444, blz. 495; Stieglis, blz. 281.

217. Vgl. artt. 16 modelreglement 1983 en 17 modelreglement 1987. 
dat een appartementseigenaar bevoegd is om op zijn prive-gedeelten een erfdienstbaarheid te vestigen, anderzijds dat de appartementseigenaar vrij de vestiging van een erfdienstbaarheid ten behoeve van zijn privé-gedeelten mag aannemen (en er eventueel weer afstand van mag doen, vgl. art. $875 \mathrm{n}$ lid 2 BW en art. 5.10.1.9a lid 2 / 5:118 lid 2 NBW). Aldus tot stand gekomen erfdienstbaarlieden zijn overigens accessoir aan het beperkt zakelijke gebruiksrecht van de appartementseigenaars, op of ten behoeve van wier privé-gedeelten de erfdienstbaarheden zijn gevestigd (art. 875n lid 3 BW; art. 5.10.1.9a lid 3 / 5:118 lid 3 NBW).

Aan de hierboven genoemde bevoegdheid van de appartementseigenaar om zijn appartementsrecht vrij over te dragen of te bezwaren, worden in artikelen $875 \mathrm{a}$ 876t BW (artt. 5.10.1.1-5.10.4.2g / 5:106-147 NBW) niet expliciet grenzen gesteld. In beginsel is deze bevoegdheid daarom onbeperkt. Dit blijkt behalve uit de bevoegdheid om bijvoorbeeld erfdienstbaarheden te vestigen, tevens uit artikel 875a lid 2 BW (art. 5.10.1.1 lid 2 / 5:106 lid 2 NBW), waarin aan de appartementseigenaar het recht wordt toegekend (voor zover de akte van splitsing althans niet anders bepaalt) om zijn appartementsrecht "onder te splitsen" (vgl. par. 2.4.2.1). Aan deze vrije beschikkingsbevoegdheid verbindt artikel $875 \mathrm{k}$ lid $1 \mathrm{BW}$ (art. 5.10.1.9. lid 1 / 5:117 lid $1 \mathrm{NBW}$ ) echter tevens het recht voor schuldeisers, om een appartementsrecht uit te winnen.

Een appartementsrecht kan overigens ook met een recht van vruchtgebruik worden bezwaard. De vruchtgebruiker treedt dan in de plaats van de appartementseigenaar ten aanzien van de aansprakelijkheid voor de gezamenlijke schulden en de aan de V.v.E. verschuldigde bijdragen. Voor zover deze bijdragen geen betrekking hebben op gewone lasten en herstellingen, is de vruchtgebruiker bevoegd de door hem betaalde bedragen aan het einde van het vruchtgebruik van de appartementseigenaar terug te vorderen. De appartementseigenaar blijft in principe aansprakelijk voor de bijdragen die geen betrekking hebben op gewone lasten en herstellingen (art. 875q lid 1 en 2 BW; art. 5.10.1.15b lid 1 en 2 / 5:123 lid 1 en 2 NBW). De vruchtgebruiker heeft verder het recht om in de vergadering van eigenaars te stemmen (in plaats van de appartementseigenaar), tenzij bij de verlening van het vruchtgebruik anders is bepaald (art. $875 \mathrm{q}$ lid $3 \mathrm{BW}$; art. 5.10.1.15b lid $3 / 5: 123$ lid $3 \mathrm{NBW})^{218}$.

Een interessante vraag is, of de bevoegdheid van de appartementseigenaar om zijn appartementsrecht over te dragen, in thet reglement van splitsing kan worden beperkt. Meer concteet: kan de appartementseigenaar in het reglement in zijn bevoegdheid zijn appartementsrecht te vervreemden, worden beperkt?

De beantwoording van deze vraag is voor de praktijk "van groot belang" 219 . De Vries acht een absoluut vervreemdingsverbod ongeldig wegens strijd met de openbare orde 220 . Hij meent echter wel dat het mogelijk is om met zakelijke werking overeen te komen, dat overdracht slechts mogelijk is met toestemming van de andere appartementseigenaars. Beekhuis/Linders ${ }^{221}$ sluit zich voor het geldende recht bij De Vries aan. Als argument voor de mogelijkheid van een vervreemdings-

218. Zie over vruchtgebruik en appartementsrechten: Beekhuis/Linders, VI par. 14.

219. Beekhuis/Linders, VI par. 13, nr. 2.

220. De Vries (Onroerend goed), blz 388. Evenzo Pitlo/Brahn (1980), blz 193.

221. Beekhuis/Linders, VI par. 13, nr. 2. 
beperking wordt aangevoerd, dat ook een erfpachter in de erfpachtsovereenkomst op zodanige wijze in zijn bevoegdheid tot overdracht kan worden beperkt, dat voor de overdracht toestemming van de eigenaar van de grond nodig is ${ }^{222}$. Volgens Beekhuis/Linders zal een dergelijke vervreemdingsbeperking voor appartementsrechten, behalve bij een gesplitst recht van erfpacht, naar NBW echter geen zakelijke werking hebben (artt. 3.4.2.1 lid $1 / 3: 83$ lid 1 en 6.5.3.4 lid $5 / 6: 252$ lid $5 \mathrm{NBW})^{223}$. In paragraaf $3.8 \mathrm{zal}$ op de vervreemdingsbeperking naar huidig en toekomstig recht nader worden ingegaan.

Behalve het recht om een appartementsrecht vrij over te dragen of te bezwaren, mag de appartementseigenaar zijn privé-gedeelten vrij gebruiken of aan een ander in gebruik geven ${ }^{224}$. Deze bevoegdheid omvat tevens het aan iedere appartementseigenaar toekomende medegebruik van de gemeenschappelijke gedeelten (art. $875 \mathrm{~m}$.lid 1 BW; art. 5.10.1.13 lid 1/ 5:120 lid 1 NBW).

Dit in beginsel exclusieve gebruiks- en beschikkingsrecht komt ook tot uiting in de bepaling van artikel 875l lid $1 \mathrm{BW}$ (art. 5.10.1.12 lid 1/5:119 lid $1 \mathrm{NBW}$ ), waarin aan de appartementseigenaar de bevoegdheid wordt verleend in zijn privégedeelten veranderingen aan te brengen. Deze bevoegdheid wordt echter beperkt door de rechten van andere appartementseigenaars, d.w.z. de veranderingen mogen geen nadeel aan andere gedeelten toebrengen ${ }^{225}$. Aan dit veranderingsrecht is wel de plicht gekóppeld om veranderingen aan de V.v.E. te melden. Eventuele verhogingen van de verzekeringspremie (ten gevolge van de veranderingen) komen voor rekening van degene die de veranderingen heeft aangebracht (art. 8751 lid 2 BW; art. 5:10.1.12 lid 2/ 5:119 lid 2 NBW) ${ }^{226}$. Bovendien wordt na opheffing van de splitsing bij de verdeling van de gemeenschap een eventuele waardevermindering van de gesplitste goederen, die het gevolg is van door een appartementseigenaar aangebrachte veranderingen in zijn appartement, geheel op het aandeel van deze appartementseigenaar in mindering gebracht (art. 8751 lid $3 \mathrm{BW}$; art. 5.10.1.12 lid 3 / 5:119 lid 3 NBW).

De exclusieve gebruiksbevoegdheid, die aan iedere appartementseigenaar in principe toekomt (art. 875m lid 1 BW; art. 5.10.1.13 lid 1/ 5:120 lid $1 \mathrm{NBW}$ ), kan worden begrensd op grond van artikel $875 f$ lid 4 BW (art. 5.10.1.5 lid 4 / 5:112 lid $4 \mathrm{NBW})^{227}$. Dit artikellid bepaalt dat in het reglement van splitsing een regeling omtrent gebruik, beheer en onderhoud van de privé-gedeelten kan worden

222. Vgl. Asser/Beekhuis I, blz. 173; Pitlo/Brahn, blz. 174 .

223. Zie de MvA m.b.t. art. 5.7.1.5 NBW, Bijl. Hand. If, 1984-1985, 17541, nr. 8, bli. 8, 9.

224. Vgl. artt. 16 modelreglement 1983 en 17 modelreglement 1987.

225. Bovendien mag ingewolge art. 8751 lid 4 jo. $875 \mathrm{f} \mathrm{lid} 4 \mathrm{BW}$ de bewoegdheid tot het aanbrengen van veranderingen in het reglement worden beperkt. Zo kan deze bevoegdheid bijwoorbeeld afhankelijk worden gesteld van toestemming van de andere appartementseigenaars. Vgl. HR 7 mei 1971, NJ 1973, 15, Bouwrecht 1971, blz. 779, geannoteerd door Wiersma, Bouwtecht 1973, blz. 218. Tegen een besluit van de vergadering van eigenaars om toestemming tot verandering te verlenen, kan een vernietigingsverzoek ex art. $876 \mathrm{~d} \mathrm{BW}$ worden ingediend. Vgl. ook Beekhuis/Linders, VI par. 9, mr. 2. Vgl. ook artt. 13,14 modelreglement 1983 en 14,15 model-
reglement 1987 .

226. In geval van schade zullen de "extra" verzekeringspenningen ook aan deze appartementseigenaar ten goede moeten komen. Vgl. Kremer, blz. 37. 227. Vgl. artt. 17-19, 26-34 modeireglement 1987 en artt. 16-29 plus Annex I van het modelreglement
1983. 
opgenomen. Een zodanige regeling kan zelfs, zoals in paragraaf 1.1 werd vermeld, ontzegging van gebruik mogelijk maken (vgl. ook hoofdstuk 3). Een andere beperking van het gebruiksrecht dan op grond van artikel 875f lid 4 BW (art. 5.10 .15 lid $4 / 5: 112$ lid 4 NBW) is vanwege de exclusiviteit van dit recht niet mogelijk ${ }^{228}$.

De belangrijkste beperking van het gebruik, die in de modelreglementen 1983 en 1987 wordt geregeld, is de verplichting van de appartementseigenaar om zijn privé-gedeelten volgens de in de akte van splitsing neergelegde bestemming te gebruiken 229 . Volgens Beekhuis/Linders is bij "bestemming" primair aan de verdeling in woonruimte of bedrijfsruimte gedacht ${ }^{230}$. Beekhuis/Linders wijst er echter op dat sommigen de betekenis van dit begrip "bestemming" willen uitbreiden $^{231}$. In Beekhuis/Linders wordt er verder op gewezen dat bij de vaststelling van de bestemming van een appartementsrecht gelet moet worden op de bepalingen van het bestemmingsplan en eventuele bestemmingsbepalingen uit de erfpachtsvoorwaarden ${ }^{232}$. Behalve deze gebruiksbestemming geeft artikell 16 lid 1 van het modelreglement $1983^{233}$ nog een andere belangrijke gebruiksbeperkende regel. De appartementseigenaars of -gebruikers mogen hun privé-gedeelten volgens dit artikel gebruiken, mits zij aan de andere eigenaars en gebruikers geen onredelijke hinder toebrengen. Resumerend kan op het punt van de gebruiksbeperking worden gesteld, dat artikel $875 \mathrm{f}$ lid $4 \mathrm{BW}$ (art. 5.10.1.5 lid $4 / 5: 112$ lid 4 NBW) de basis biedt voor allerlei regelingen op het gebied van het gebruik, beheer en onderhoud van een appartement. De belangrijkste beperkingen van het gebruik vloeien echter voort uit de bestemming van het appartementsrecht en de reglementsbepaling, die het toebrengen van onredelijke hinder verbiedt ${ }^{234}$.

Behalve van de privé-gedeelten mag iedere appartementseigenaar gebruik maken van de gemeenschappelijke gedeelten, voor zover dit gebruik tenminste geen inbreuk maakt op rechten van andere deelgenoten en de in het reglement neergelegde bestemming van de gemeenschappelijke zaak ${ }^{235}$. Dit vloeit enerzijds voort uit artikel $875 \mathrm{~m}$ lid $1 \mathrm{BW}$ (art. 5.10.1.13 lid $1 / 5: 120$ lid $1 \mathrm{NBW}$ ), maar in het algemeen ook uit de rechten van medeëigenaars ten aanzien van de gemeenschappelijke zaak (vgl. par. 4.3.2.1 en art. 3.7.1.3/3:169 NBW) ${ }^{236}$.

Zoals in paragraaf 2.4.3 van dit hoofdstuk wordt vermeld, zijn de aandelen van de appartementseigenaars, die door splitsing in appartementsrechten ontstaan, in beginsel gelijk (art. 875g lid $1 \mathrm{BW}$; art. 5.10.1.6 lid 1 / 5:113 lid $1 \mathrm{NBW}$ ). Aan deze gelijkheid van aandelen is de verplichting gekoppeld om onderling en jegens de

228. Verdoes Kleijn (Dijk-bundel), blz. 150; Beekhuis/Linders, VI par, 9, nr. 1.

229. Art. 16 lid 4 modelreglement 1983; ant. 17 lid 5 modelreglement 1987.

230. Beekhuis/Linders, VI par. $9, \mathrm{nr} .1$.

231. Vgl. HR 2 dec. 1983, NJ 1984, 367. In casu werd door eiser ondermeer beweerd dat een appartementsrecht in strijd met de bestemming "woning" was verhuurd. Hof en Hoge Raad zagen hier echter geen discrepantie tussen de bestemming "woning" en het gebruik in casu (kamerverhuur). Pres. Rb. 's-Gravenhage 13 okt. 1983, NJ 1985, 542. In dit geval besliste de Haagse President van de rechtbank dat de bestemming "winkel" aan uitbating van een cafebedrijf in een appartementsrecht in de weg staat.

232. Beekhuis/Linders, VI par. 9, nr. 1.

233. Art. 17 lid 1 modelreglement 1987.

234. Vgl. hierbij HR 2 dec. 1983, NJ 1984, 367.

235. Art. 11 modelreglement 1983 en art. 12 modelreglement 1987.

236. Beekhais/Linders, VI par. 9, nr. 3. 
V.v.E. voor een gelijk deel in de schulden en kosten van de gezamenlijke appartementseigenaars en de V.v.E. bij te dragen (art. 875 glid 2 BW; art. 5.10.1.6 lid 2 / 5.113 lid $2 \mathrm{NBW}^{237}$. Deze gelijkheid van bijdragen (per appartement) kan, evenals de gelijkheid van de aandelen, in het reglement van splitsing worden aangepast. Het reglement van splitsing kan derhalve een andere kostenbijdrageverhouding bevatten dan wit artikel $875 \mathrm{~g}$ in beginsel voortwloeit. De kostenbijdrageverhouding wordt in artikel 2 lid 3 van de modelreglementen 1983 en 1987 gekoppeld aan het aandeel dat iedere appartementseigenaar in de gemeenschap heeft. Dit aandeel wordt in de akte van splitsing uitgedrakt in breukdelen. Het breukdeel geeft tevens aan voor welk deel de appartementseigenaar in de kosten moet bijdragen ${ }^{238}$. De kosten die voor rekening van de gezamenlijke appartementseigenaars komen, staan in de modelreglementen 1983 en 1987 opgenomen in artikel 3. De appartementseigenaars moeten maandelijks $1 / 12$ deel van hun bijdrage in de jaarlijkse kosten aan de V.v.E. voldoen ${ }^{239}$.

Tot nu toe zijn in deze paragraaf slechts de materiële rechten en plichten van de appartementseigenaar (die spiegelbeeldig de plichten en de rechten van de overige elgenaars en de V.v.E. inhouden), aan de orde geweest. De vraag die hierbij opkomt is welke rechtsmiddelen aan de appartementseigenaars afzonderlijk of gezamenlijk of aan de V.v.E. toekomen, indien een appartementseigenaar zich in zijn rechten aangetast voelt of spiegelbeeldig, indien hij zijn verplichtingen niet nakomt. Het appartementsrecht regelt hiervoor een aantal procedures, die door een of meer appartementseigenaars of door de V.v.E of een van haar organen, kunnen worden aangespannen tegen degene die zijn verpllichtingen niet nakomt (en dus inbreuk maakt op de rechten van een ander). Deze procedures worden geregeld in de artikelen 875o, 876c, 876d, 876m en 876q BW (artt. 5.10.1.15; $5.10 .2 .1 c ; 5.10 .2 .1 d ; 5.10 .4 .2 ; 5.10 .4 .2 d / 5: 121,128,130,140,144 \mathrm{NBW})^{240}$. In het onderstaande zullen deze procedures kort worden besproken.

237. Vgl. HR 8 jan. 1982, NJ 1982, 333 met noot WMK. De gezamenlijke appartementseigenaars züjn als zodanig niel gebonden aan een service-overcenkomst die voor het ontstaan van de V.v.E. tussen de bouwer en een derde werd gesloten. Alleen de vergadering van eigenaars kan een dergelijke overeenkonst aangaan. Nu van een dergelijk besluit niet bleek vielen de uit de overeenkomst voortvloeiende kosten niet onder de in het reglement conform art. $875 \mathrm{f} \mathrm{lid} 1$ sub a BW (art. 5.10.1.5 lid 1 sub a / 5:112 lid 1 sub a NBW) aangeduide schulden.

238. Vgll. ook art. 875i BW (art. 5.10.1.8/5:115 NBW) over de verdeling van canion of retributie bij gesplitste erfpachts- of opstalrechten.

239. Art. 5 lid 2 laatste zin modelreglementen $1983 \mathrm{cn} 1987$. Vgl. ower de kostenbijdrageplicht Beekhuis/Linders, VI par. 9, nr. 5. Bij overgang van een appartementsrecht treedt de nieuwe eigenaar in de rechten en plichten van degene die hij opvolgt. Voor de met betrekking tot het verkregen appartementsrecht verschuldigde bijdrage die in het lopende of voorafgaande kalenderjaar opeisbaar zijn geworden of opeisbaar worden, zjjn de verkrijger en de ex-eigenaar hoofdelijk aansprakelijk (art. $875 \mathrm{p} \mathrm{BW}$ ). Vgl. Hof 's-Hertogenbosch 28 okt. 1983, NJ 1985,
238 .

240. Ook in art. 876k BW; art. 5.10.3.1b / 5:138 NBW wordt nog een proceduremogelijkheid geschapen. Zie par. 2.4.5. 
Artikel 875o BW (art: 5.10.1.15/5:121 NBW) geeft een beroepsmogelijkheid aan:

1. een appartementseigenaar, in alle gevallen waarin hij medewerking of toestemming van een of meer appartementseigenaars of organen van de V.v.E. nodig heeft voor:

a. het verrichten van bepaalde handelingen met betrekking tot de gemeenschappelijke gedeelten, of

b. het verrichten van handelingen met betrekking tot gebruik, beheer en ondẹrhoud van de privé-gedeelten;

2. de V.v.E. of (een van) haar organen voor het verrichten van een handeling met betrekking tot de privé-gedeelten of de gemeenschappelijke gedeelten, toestemming of medewerking van een of meer appartementseigenaars behoeft.

De beroepsmogelijkheid in deze gevallen houdt in dat de appartementseigenaar of de V.v.E. (of een van haar organen) zich tot de kantonrechter kan wenden met het verzoek om de benodigde toestemming of medewerking te vervangen door een machtiging. De kantonrechter verleent deze machtiging alleen indien de medewerking of toestemming zonder redelijke grond is geweigerd of degene die haar zou moeten verlenen, zich niet verklaart (vgl. art. 8750 lid 2 en 3; art. 5.10.1.15 lid 2 en 3/5:121 lid 2 en 3 NBW, over vaststelling van de kostenbijdrage voor de te verrichten handelingen) ${ }^{241}$.

Indien een appartementseigenaar bijwoorbeeld in het appartementsgebouw veranderingen wil aanbrengen, die het architectonisch uiterlijk of de constructie van het gebouw zouden wijzigen, heeft hij hiervoor toestemming nodig van de vergadering van eigenaars ${ }^{242}$. Indien de vergadering de toestemming weigert of zich niet verklaart, zal de appartementseigenaar zich tot de kantonrechter kunnen wenden in de verzoekprocedure ex artikel $8750 \mathrm{BW}$. In geval van weigering van de toestemming zal de kantonrechter de vervangende machtiging kunnen verlenen, indien de toestemming zonder redelijke grond is geweigerd. Volgens Asser/Beekhuis II is artikel $8750 \mathrm{BW}$ te beschouwen

"als een bijzondere uitwerking van het beginsel, dat de verhouding tussen mede-eigenaars wordt beheerst door de goede trouw (art. 3.7.1.1 lid 3 NBW)." 243

Uit artikel 875o BW (art. 5.10.1.15 / 5:121 NBW) blijkt niet duidelijk, hoe de kantonrechter een weigering van de toestemming moet toetsen. Mag hij slechts marginaal toetsen, d.w.z. moet hij zich beperken tot een onderzoek of degene die

241. Vgl. HR 7 april $1978, N J 1978,545$ met noot W.H.H. (Van Maarssevcen-arrest). Op grond van art. 8750 lid $1 \mathrm{BW}$ kan de V.v.E. aan de kantonrechter geen vervangende machtiging tot ontruiming van een appartementsrecht vragen.

242. Zie art. 14 modelreglement 1983 en art. 15 modelreglement 1987.

243. Asser/Beekhwis II, blz. 343. Idem Beekhuis/Linders, VI par. 12, nr. 1. Overigens is het niet nodig om, voordat aan de kantonrechter vervangende machtiging wordi gevraagd, cerst vernietiging van het bestreden besluit te vorderen ex art. $876 \mathrm{~d} \mathrm{BW.} \mathrm{Asser/Beekhuis} \mathrm{II,} \mathrm{blz.} \mathrm{344,}$ HR 9 okt. 1958, NJ 1958, 84. Anders: Bloembergen, WPNR 4648, blz 451. 
de toestemming heeft geweigerd, in redelijkheid tot zijn beslissing heeft kunnen komen? Pitlo/Brahn lijkt deze mening te zijn toegedaan, zonder overigens expliciet te beweren dat de kantonrechter marginaal moet toetsen ${ }^{244}$. Bij de bespreking van de procedure ex artikel 875a lid 6 BW (vgl. par. 2.4.2.1) spreekt Pitlo/Brahn wel van marginale toetsing ${ }^{245}$. Dat de rechter in een procedure ingevolge artikel $875 \mathrm{a}$ lid $6 \mathrm{BW}$ (art. 5.10.1.1 lid 6/5:106 lid 6 NBW) marginaal dient te toetsen, lijkt mij juist ${ }^{246}$. Mijns inziens vloeit de plicht voor de kantonrechter om marginaal te toetsen in deze procedure voort uit de zinsnede "kennelijk zonder redelijke grond" in artikel $875 \mathrm{a}$ lid $6 \mathrm{BW}$. Met name het woord kennelijk is hier van belang. Door dit woord verschilt de toetsing ex artikel $875 \mathrm{a}$ lid $6 \mathrm{BW}$ met die in de procedure ingevolge artikel 875o BW (art. 5.10.1.15 / 5:121 NBW). Indien de rechter moet nagaan of een toestemming "kennelijk zonder redelijke grond" is geweigerd, moet hij nagaan of degene die de toestemming heeft geweigerd, in redelijkheid tot de conclusie heeft kunnen komen dat de weigeringsgrond redelijk was. De rechter moet anders gezegd nagaan of de weigeringsgrond als redelijk kan worden beschouwd, en niet of de weigeringsgrond naar zijn oordeel redelijk is.

Wiarda zegt hierover in zijn "Drie typen van rechtsvinding" het volgende:

"Waar de wet voor de beoordeling van bepaalde gedragingen naar normen als deze (billijkheid, redelijkheid, goede trouw, betamelijkheid etc., R.M.) verwijst of de rechter bij het zwijgen van de wet op dergelijke normen is aangewezen, wordt van hem in de regel een zelfstandige en volledige toetsing van zo'n gedragingen aan de hand van die normen verwacht. Hij kan zich daarbij niet beperken tot de vraag of in het desbetreffende geval van een zo kennelijk onredelijke gedraging kan worden gesproken, dat ieder die als onredelijk moet herkennen, maar moet op grond van zijn eigen oordeel over de redelijkheid of onredelijkheid daarvan zijn beslissing geven." 247

$\mathrm{Nu}$ het woord kennelijk in artikel $8750 \mathrm{BW}$ ontbreekt, moet de rechter toetsen of de weigeringsgrond redelijk is. Dit betekent dat de toetsing ex artikel $8750 \mathrm{BW}$ een volle toetsing is en geen marginale toetsing. De rechter moet dus niet nagaan of een weigeringsgrond als redelijk kan worden beschouwd, maar of a) objectief gezien de weigeringsgrond redelijk is en zo ja, b) of hij subjectief (in het concrete geval) ook redelijk is ${ }^{248}$. Deze gesubjectiveerde objectieve toets wordt door

244. Pitlo/Brahn, blz. 394.

245. Pitlo/Brahn, blz. 386.

246. Bij uitoefening van absolute rechten in het algeneen moet de rechter marginaal toetsen. Een bepaald gebruik van zo'n recht, bijv. het eigendomsrecht, is bijvoorbeeld pas onrechtmatig als het gebruilk als misbruik moet worden beschouwd. Aldus Van der Grinten (Marginale toetsing), blz. 115, 116. Vgl. ook HR 10 aug. 1984, NJ 1985, 229 met noot WMK (Pita-de Windt). In dit arrest werd beslist dat bekeken moest worden of de eigenaar "gezien de wederzijdse belangen naar redelijkbeid niet tot uitoefening van die (eigendoms-, R.M.) bevoegdheid" had kunnen komen.

247. Wiarda, blz 116.

248. Vgl. HR 20 dec. 1985, NJ 1987, 54 met noot EAAL. Volgens de Hoge Raad mag een rechter zich bij de beoordeling van de redelijkheid van een weigering door ouders om aan hun minderjarig kind toestemming te geven om te huwen, niet beperken tot de wraag of de weigering door de ouders "kennelijk onredelijk" is geweest. De rechter moet "onderzoeken of de weigering, alle omstandigheden van het geval in aanmerking genomen, redelijk is te achten." Vgl. ook HR 24 
Pitlo/Brahn bij de procedure ex artikel 8750 BW bij welstandsbepalingen voorgesteld, zij het dat uit de door Pitlo/Brahn gehanteerde formulering lijkt voort te vloeien dat de rechter hier marginaal zou moeten toetsen, terwijl de rechter ook bij welstandsbepalingen in een procedure ex artikel $8750 \mathrm{BW}$ mijns inziens altijd vol moet toetsen (vgl. hierover ook par. 3.6.2.1) ${ }^{249}$.

Hetzelfde als hier is besproken met betrekking tot de procedure op grond van artikel 875o BW, geldt voor de procedure ex artikel 876m BW (art. 5.10.4.2 / 5:140 NBW). Dit artikel is van toepassing indien appartementseigenaars de splitsingsakte willen wijzigen, maar niet alle appartementseigenaars, zakelijk gerechtigden of beslagleggers aan de wijziging meewerken. In dat geval kunnen een of meer appartementseigenaars aan wie tenminste de helft van het aantal stemmen in de vergadering van eigenaars toekomt (vgl. echter art. $876 \mathrm{~m}$ lid $3 \mathrm{BW}$; art. 5.10 .4 .2 lid 3 / 5:140 lid $3 \mathrm{NBW}$ ), de kantonrechter om een vervangende machtiging tot wijziging van de akte van splitsing verzoeken. De kantonrechter kan de machtiging verlenen, indien degenen wier medewerking nodig is, zich niet hebben verklaard of de medewerking zonder redelijke grond hebben geweigerd (art. $876 \mathrm{~m} \mathrm{lid} 1$ en $2 \mathrm{BW}$; art. 5.10.4.2 lid 1 en $2 / 5: 140$ lid 1 en $2 \mathrm{NBW}$ ) 250 .

Artikel 876q BW (art. 5.10.4.2d / 5:144 NBW) regelt beroep op de kantonrechter in geval van (ook weer) wijziging van de akte van splitsing of opheffing van de splitsing in de in dit artikel in lid 1 sub a-h opgesomde gevallen. Als een van deze opheffings-of wijzigingsredenen bestaat, kan de kantonrechter de opheffing van de splitsing of de wijziging van de akte van splitsing gebieden. Van marginale toetsing is in deze procedure geen sprake.

In artikel $876 \mathrm{c} \mathrm{BW}$ (art. 5.10.2.1c/5:128 NBW) is geregeld dat de vergadering van eigenaars bevoegd is gebruiksregels (bijvoorbeeld in een huishoudelijk reglement) voor de gemeenschappelijke gedeelten vast te stellen, voor zover het reglement daarin niet voorziet. Lid 2 van dit artikel geeft aan een appartementseigenaar de mogelijkheid een gebruiker van een appartementsrecht te vragen deze besluiten van de vergadering na te leven. Indien de gebruiker (bijv. huurder) daartoe niet bereid is of zich niet verklaart, kan de appartementseigenaar zich tot de kantonrechter wenden met het verzoek om te bepalen dat de regel ook voor de gebruiker geldt.

Tenslotte dient nog de regelling van artikel 876d BW (art. 5.10.2.1d / 5:130 NBW) aan de orde te komen. Dit artikel bepaalt dat een appartementseigenaar of andere stemgerechtigde aan de kantonrechter vernietiging van een besluit van de vergadering van eigenaars kan vragen wegens:

1. strijd met de wettelijke bepalingen die de bevoegdheid van de vergadering en de wijze van totstandkoming van besluiten regelen;

april 1987, NJ 1987, 792 en Wiarda, blz. 117.

249. Pitlo/Brahn, blz 393.

250. Zie HR 3 okt. 1986, NJ 1987, 40. Uit dit arrest blijkt mijns inziens dat de rechter bij het nagaan of een redelijke grond aanwezig is, niet marginaal behoeft te toetsen. $\mathrm{Vgl}$. ook Kantongerecht Amsterdam 24 maart 1980, Praktijikgids 1980, nr. 1465. Hier achtte de kantonrechter de weigering om aan de wijziging van de akte van splitsing mee te werken, niet zonder redelijke grond. 
2. strijd met de akte van splitsing;

3. strijd met de goede trouw ${ }^{251}$.

Dit verzoek tot vernietiging "moet worden gedaan binnen een maand na de dag waarop de verzoeker van het beslüt heeft kennis genomen of heeft kunnen kennis nemen" (art. 876d lid 2 BW; art. 5.10.2.1d lid 2/5:130 lid 2 NBW). Het artikel spreekt voor zichzelf. De kantonrechter dient het gewraakte besluit te toetsen aan de in artikel $876 \mathrm{~d}$ lid 1 sub a-c (art. 5.10.2.1d lid 1 sub a-c/5:130 lid 1 sub a-c NBW) genoemde vernietigingsgronden. Als een van deze vernietigingsgronden

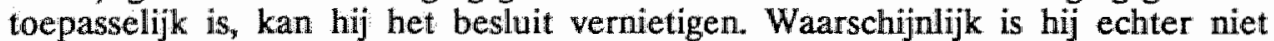
verplicht het besluit te vernietigen in een zodanig geval. Dit volgt mijns inziens uit de zinsnede "kan (....) worden vermietigd". Dit geldt overigens ook bij de hierboven besproken procedures.

Opgemerkt dient nog te worden, dat vernietiging van een besluit niet altijd betekent dat de verzoeker aan het langste eind trekt. De vergadering van eigenaars kan immers hetzelfde besluit nog eens nemen, zij het met omzeiling van de eerder toegepaste vernietigingsgrond ${ }^{252}$.

De hierboven besproken procedures zijn alle in de wet geregeld en maken beroep bij de kantonrechter mogelijk. Voordat beroep bij de kantonrechter kan worden ingesteld, moet in sommige gevallen eerst beroep worden aangetekend bij de vergadering van eigenaars. Beroep op de vergadering van eigenalars is bujvoorbeeld mogelijk, indien een appartementsrecht openbaar wordt verkocht en een gegadigde vooraf aan het bestuur een verklaring moet vragen dat geen bezwaar zal worden gemaakt tegen eventuele ingebruikname door hem van het te veilen appartementsrecht (art. 28 a lid 2 Annex 1 modelreglement 1983; art. 30 lid 1 modelreglement 1987). Als het bestuur de toestemming tot ingebruikneming weigert, kan de gegadigde in beroep komen bij de vergadering van eigenaars. Indien de vergadering negatief beslist in deze beroepsprocedure, kan de gegadigde niet krachtens artikel 875o BW (art. 5.10.1.15 / 5:121 NBW) beroep instellen bij de kantonrechter. Hij is, zolang het appartementsrecht niet aan hem is geleverd, immers geen appartementseigenaar in de zin van artikel $8750 \mathrm{BW}$ (zie par. 3.6.2.5).

Een soortgelijke regeling treft het modelreglement 1987 voor toestemming tot ingebruikneming in het geval dat een eigenaar ("waaronder begrepen koper of andere gerechtigde tot levering van het appartementsrecht") toestemming tot ingebruikneming vraagt (art. 29 lid 1 en 2 modelreglement 1987). Volgens artikel 29 van het modelreglement 1987 heeft iedere eigenaar toestemming tot ingebruikneming nodig. Deze toestemming moet aan het bestuur worden gevraagd. Tegen de beslissing van het bestuur kan vervolgens binnen 14 dagen na verzending van

251. Kantongerecht Amsterdam 8 mei 1978, Praktijkgids 1978, nr. 1274, daarover Stille, WPNR 5444, blz. 495. Zie ook Kantongerecht Utrecht $16 \mathrm{dec}$ 1977, NJ 1979, 180. Een wijziging van het buishoudelijk reglement met betrekking tot service-kosten werd in strijd met het reglement en de goede trouw geacht, ondat juist de openbaar gemaakte regelingen omtrent de service-kosten voor de verzoekers in casu de koop van een appartementsrecht aantrekkelijk hadden gemaakt. Vgl. verder: Kantongerecht Breda 21 sept. 1981, NJ 1982, 331 (in dit vonnis werd een verzoek om vernietiging van welstandsbepalingem afgewezen! Vgl. par. 3.6.3.1; 3.7)

252. Beekhuis/Linders, VI par. 12, nr. 2; Hof 's-Gravenhage 6 juni 1984, NJ 1985, 598, besproken in WPNR 5837, blz 419. 
de beslissing beroep worden ingesteld bij de vergadering van eigenaars (art. 29 lid 6 modelreglement 1987). Indien de vergadering de beslissing van het bestuur bekrachtigt, kan de appartementseigenaar in de zin van artikel 8750 BW (en niet in de zin van art. 29 lid 2 modelreglement 1987), ingevolge datzelfde artikel beroep instellen bij de kantonrechter. Deze beroepsmogelijkheid komt derhalve mijns inziens niet toe aan de koper of andere gerechtigde tot levering, zolang het appartementsrecht niet geleverd is. Vór voltooiing van de levering zijn zij immers geen appartementseigenaars.

Overigens kan in het reglement van splitsing ook worden bepaald, dat geschillen tussen appartementseigenaars aan arbiters worden voorgelegd. Dit geldt voor alle geschillen $^{253}$.

\subsection{Tot slot: appartementsrechten en verzekeringen 254}

Zoals bij alle gebouwen het geval is, kan een appartementsgebouw worden beschadigd door gebeurtenissen die vaak niet voorkomen kunnen worden (aardbeving, brand, waterschade etc). Daarom is het noodzakelijk het appartementsgebouw te verzekeren tegen dergelijke schade. Alle appartementseigenaars als medeëigenaars van het gebouw, moeten in beginsel gezamenlijk zorg dragen voor deze verzekering. In beginsel komt de verzekeringsbevoegdheid daarom toe aan de vergadering van eigenaars ${ }^{255}$. Deze bevoegdheid (en de bevoegdheid om eventuelle verzekeringspenningen te beheren) kan echter ook worden toegekend aan een ander persoon of verenigingsorgaan in plaats van de vergadering (art. $876 \mathrm{j} \mathrm{BW}$; art. 5.10.3.1 / 5:136 NBW). In artikel 8 van de modelreglementen 1983 en 1987 wordt de plicht om het gebouw te doen verzekeren opgelegd aan het bestuur, d.w.z. de administrateur(s). Wel moet de vergadering volgens artikel 8 de verzekeringsmaatschappij vaststellen, waarmee het bestuur de verzekeringsovereenkomst moet afsluiten.

$\mathrm{Na}$ beschadiging van een appartementsgebouw, kunnen de appartementseigenaars tot herstel besluiten. De waarde van de appartementsrechten moet na het herstel in beginsel dezelfde zijn als voor het optreden van de schade (vgl. art. 876j lid 2 BW; art. 5.10.3.1 lid 2 / 5:136 lid $2 \mathrm{NBW}$ ). Indien de vergadering van eigenaars besluit om het gebouw niet of niet geheel te herstellen, of indien na het herstel een overschot van de verzekeringspenningen bestaat, of als de splitsing wordt opgeheven, worden de (resterende) verzekeringspenningen onder de appartementseigenaars, overeenkomstig thet hen toekomende aandeel, verdeeld (art. 876t lid $3 \mathrm{BW}$; art. 5.10.4.2g lid 3 / 5:147 lid $3 \mathrm{NBW}$ ). Eventuele geschillen over herstel of de wijze waarop het herstel dient te gebeuren, kunnen door de belanghebbenden worden voorgelegd aan de kantonrechter (art. $876 \mathrm{k} \mathrm{BW;} \mathrm{art.}$ 5.10.3.1b / 5:138 NBW) ${ }^{256}$.

253. Zie HR 24 sept. 1964, NJ $1965,359$.

254. Vigl over appartementsrecht en verzekeringen: Beekhuis/Linders, VI par. 16; Kremer, blz. 3563; Verzekering bij appartementen, WPNR 5506, blz. 150-152; Stein (Verzekering), blx. 351-353; Catz, blz 412; Nijk, WPNR 4578, blz. 160-163, WPNR 4625, blz. 171-172; Dresselhuys, blz. 220, 221 .

255. Pitlo/Brahn, blz, 399.

256. Zie over de regeling van de verzekeringen in de modelreglementen: art. 8 en 9 modelreglement 1987 en art. 8 modelreglement 1983 . 


\section{De welstandsbepalingen in het appartementsrecht}

\subsection{Algemene opmerkingen}

Zoals in paragraaf 1.1 reeds werd vermeld kunnen op grond van artikel $875 f$ lid 4 BW welstandsbepalingen worden opgenomen in het reglement van splitsing. Deze welstandsbepalingen kunnen worden uitgewerkt in een toelatingsregeling en een ontzeggingsregeling. De toelatingsregeling en de ontzeggingsregeling kunnen bij alle soorten appartementsrechten worden toegepast. (Aspirant-)gebruikers van appartementsrechten die voor bewoning bestemd zijn kunnen eraan onderworpen zijn, maar ook (aspirant-)gebruikers van appartementsrechten die niet voor bewoning bedoeld zijn (bijvoorbeeld van appartementen die bestemd zijn om als kantoorruimte te worden gebruikt). Welstandsbepalingen zijn immers bepalingen die ontzegging van gebruik behelzen. Het doet niet ter zake of dit gebruik bewoning is of andersoortig. De redenen voor ontzegging van gebruik, de toelatings- en ontzeggingscriteria, zullen zich bij bewoning altijd moeten toespitsen op de persoon die om toelating verzoekt of die het appartement bewoont. Bij gebruik van een appartement anders dan voor bewoning, bijvoorbeeld bij gebruik voor het uitoefenen van een bedrijf, zullen de criteria zich moeten toespitsen op de aard van het bedrijf: Indien de aard van het bedrijf een gewichtige reden kan opleveren in de zin van artikel $875 \mathrm{f}$ lid $4 \mathrm{BW}$, zal aan de (rechts)persoon die het bedrijf uitoefent de toestemming tot ingebruikneming kunnen worden geweigerd, respectievelijk het verdere gebruik worden ontzegd. In het navolgende zal voornamelijk worden ingegaan op de welstandsbepalingen bij appartementsrechten die voor bewoning bestemd zijn. Deze welstandsbepalingen blijken in praktijk ook de meeste problemen op te leveren ". Daarom ook zal op sommige plaatsen van aspirant-bewoner in plaats van aspirant-gebruiker worden gesproken.

Het orgaan dat de beslissing tot ontzegging neemt is de vergadering van eigenaars. De vergadering van eigenaars kan deze ontzeggingsbevoegdheid aan de administrateur delegeren, mits tegen de beslissing van de administrateur beroep bij de vergadering openstaat ${ }^{2}$. Alle appartementseigenaars zijn ingevolge artikel 876 lid van de vereniging van eigenaars en op grond van artikel 34, eerste lid van het modelreglement 1983 (artt. 39, 41 modelreglement 1987), stemgerechtigd in de vergadering. In sommige gevallen zijn ook niet-eigenaars, bijvoorbeeld een

1. Vgl. Pres. Rb. Groningen 18 okt. 1961, NJ 1961, 486; Rb. Groningen 15 okt. 1958, NJ 1959, 310; Pres. Rb. Arrihem 20 dec. 1984, Kort Geding 1985, 43; HR 8 aprill 1978, NJ 1978, 545.

2. Asser/Beekhuis II, blz. 329. 
vruchtgebruiker van een appartementsrecht, stemgerechtigd (art. $875 q \mathrm{BW}$ ). In de akte van splitsing kan bovendien worden bepaald dat ook huurders stemrecht hebben ${ }^{3}$. Dat iedere appartementseigenaar stemrecht in de vergadering heeft, betekent dat hij ook over een hemizelf betreffende beslissing tot ontzegging van verder gebruik kan meestemmen; en - indien hij reeds eigenaar is - ook bij een beslüssing over ingebruikneming ${ }^{4}$. Vooral bij kleinere appartementencomplexen kan die ene stem veel uitmaken, zeker als de stemverhoudingen van appartement tot appartement verschillen (bijvoorbeeld naar verhouding van de oppervlakte van appartementen, en men in het bezit is van een riant appartement), hetgeen mogelijk is op grond van artikel 34 lid 2 van het modelreglement van splitsings.

De existentie en het gebruik van welstandsbepalingen wordt zoals in paragraaf 1.1 al is opgemerkt, wel gelegitimeerd met het argument dat bewoners van een appartementencomplex veel sterker van elkaar afhankelijk zijn en meer contact met elkaar hebben dan bewoners van eengezinswoningen ${ }^{6}$. De welstandsbepalingen dienen om een zekere mate van toezicht uit te oefenen op (toekomstige) medebewoners. Deze achtergrond rechtvaardigt de in de literatuur geopperde mening dat welstandsbepalingen strenger moeten worden getoetst, naarmate de band tussen de appartementsgebruikers losser wordt ${ }^{7}$. Bij service-flatgebouwen zal men daarom eerder welstandsbepalingen mogen hanteren en strengere criteria mogen aanleggen dan bij een appartementencomplex dat uit los van elkaar staande woningen bestaat of waarin slechts bedrijven zijn gehuisvest die met elkaar nauwelijks van doen hebben.

In dit hoofdstuk zal op de welstandsbepalingen in het algemeen worden ingegaan. Hierbij zal worden nagegaan aan welke vereisten ontzegging van gebruik in thet Nederlandse recht moet voldoen. Dit zal worden uitgewerkt aan de hand van praktijkvoorbeelden. Allereerst zal de geschiedenis van de welstandsbepalingen aan de orde komen. Daarna zal worden ingegaan op de standaardreglementen van de Koninklijke Notariële Broederschap en de plaats van de wellstandsbepalingen daarin. Vervolgens zal de geldigheid van artikel $875 f$ lid 4 BW en de uitwerking daarvan in de welstandsbepalingen, gerelateerd aan de grondrechten; aan de orde komen. Daarna zullen de regelingen van ontzegging van ingebruikneming en ontzegging van verder gebruik aan de orde komen. Bij de behandeling hiervan zal van het positieve recht worden uitgegaan en zullen vergelijkingen met het NBW worden getrokken, en zal aandacht worden besteed aan de geldigheid van specifieke ontzeggingscriteria in het licht van de grondrechten. Bij de behandeling van de welstandsbepalingen in het positieve recht zullen tevens de rechtsmiddelen tegen de aanwending van welstandsbepalingen aan de orde komen. Tenslotte zal in paragraaf 3.8 aandacht worden besteed aan vervreemdingsbeperkingen als mogelijk alternatief voor de welstandsbepalingen.

3. Kleijn/Verdoes Kleijn, blz. 352; Mertens, blz. 246.

4. Smeets/Mertens, blz. 31; Mertens, blz. 246.

5. Vgl. Mertens, blz. 246.

6. Beekhuis/Linders, VI par. 6, mr. 5; Asser/Beekhuis II, blz. 328.

7. Smeets/Mertens, blz 20 . 


\subsection{De geschiedenis van de welstandsbepalingen}

\subsection{De welstandsbepalingen in de wet van 1951}

In de appartementenwet van 1951 ontbrak een specifieke bepaling als de laatste volzin van artikel $875 \mathrm{f}$ lid 4 van de wet van 1972, waarin de mogelijkheid van het opnemen van welstandsbepalingen wordt erkend. Artikel $638 \mathrm{~g}$ lid 2 sub 2 vermeldde slechts dat het reglement kan inhouden:

"een regeling omtrent het gebruik, het beheer en het onderhoud van de gedeelten van de gemeenschap, welke bestemd zijn om als afzonderlijk geheel te worden gebruikt."

In het oorspronkelijke ontwerp van $1947^{\circ}$ was in artikell $638 \mathrm{~g}$ lid 2 sub 3 een soortgelijke regeling opgenomen die luidde dat het reglement "een regeling omtrent het gebruik van afzonderlijke appartementen", kon inhouden. De memorie van toelichting vermeld hierbij:

"Het is denkbaar, dat partijen voorschriften willen opnemen omtrent het gebruik van de afzonderlijke appartementen (b.v. dat deze niet als kantoor of winkel mogen worden gebruikt). Dergelijke bedingen zijn in het buitenland zeer gebruikelijk. Om hun geldigheid buiten twijfel te stellen is de onderhavige bepaling in het wetsvoorstel opgenomen."

Kennelijk doelde men hierbij derhalve op regelingen betreffende de gebruiksbestemming van de afzonderlijke appartementsrechten. Het nieuwe wetsvoorstel, dat bij de memorie van antwoord ${ }^{10}$ volgde bevatte de bovengeciteerde bepaling van artikel $638 \mathrm{~g}$ lid 2 sub 2, waarin overigens de strekking van de bepaling niet werd gewijzigd. In de memorie van antwoord ${ }^{11}$ werd bij artikel $638 \mathrm{~g}$ lid 2 sub 2 opgemerkt:

"naar aanleiding van de opmerking in het voorlopig verslag, dat het ontwerp met betrekking tot de regelingen omtrent gebruik van afzonderlijke appartementen wel wat te veel aan partijen overlaat en dat een algemene bepaling in de wet, dat eigenaars elkaar geen hinder mogen veroorzaken, in elk geval op haar plaats zou zijn, veroorloven ondergetekenden zich op te merken, dat bij aanvaarding van dit ontwerp, tegen hinder zal kunnen worden opgetreden ex de artikelen 625 en $638 \mathrm{a}$ jo. 1401 $\mathrm{BW}$. Verwezen moge worden naar hetgeen in deze memorie te dien aanzien bij de algemene beschouwingen werd uiteengezet. Hoe overigens de beginselen van burenrecht zullen moeten luiden, zal van geval tot geval verschillen. Op dit punt vrijheid te laten aan het reglement schijnt derhalve geboden."

8. Bijl. Hand. II, 1946-1947, 451, nrs. 1-2.

9. Bijl. Hand. II, 1946-1947, 451, nr. 3, blz. 9.

10. Bijl. Hand. II, 1950-1951, 451, nrs. 5-6.

11. Büjl. Hand. II, 1950-1951, 451, nr. 5, blz. 25. 
In de algemene beschouwingen werd vermeld dat de gezamenlijke eigenaars bij miet naleving van de bepalingen van het reglement tegen de nalatige eigenaar zouden kunnen optreden. $Z_{\bar{u}}$ zou bij niet voldoening aan financiële verplichtingen tot uitwinning van het appartement kunnen worden overgegaan. De algemene beschouwingen ${ }^{12}$ vermeldden bovendien expliciet:

"De flateigenaar zal inderdaad niet bij niet voldoening aan andere dan financiële verplichtingen zonder meer uit zijn flat kunnen worden gezet. Hierin verschilt de positie van de flateigenaar van die van de huurder van een flat; zijn positie te dezen is veeleer gelijk aan die van de eigenaar van een eengezinswoning, die zijn buren overlast zou aandoen."

Derhalve zou tegen de flateigenaar bij onbehoorlijk gebruik van zijn woning,

"voor zover het reglement geen steun geeft aan een vordering uit overeenkomst" kunnen worden opgetreden op grond van de artt. 1401 e.v. jo. 625 en 638 a e.v. BW."

Dat in dat geval voor de in een zekere gemeenschap levende flateigenaar strengere normen van maatschappelijke betamelijkheid zullen gelden is wel aannemelijk, vermelden de algemene beschouwingen bij de memorie van antwoord nog ${ }^{13}$.

Het lijkt er dus sterk op dat men bij artikel $638 \mathrm{~g}$ van de wet van 1951 in het geheel niet dacht aan de mogelijkheid van een clausule in het reglement, waarin werd bepaald dat een aspirant-bewoner toestemming zou moeten vragen om zijn appartement te mogen gebruiken, of aan een reeds zittende bewoner het verdere gebruik van zijn appartementsrecht zou kunnen worden ontzegd.

In 1953 kwam echter het standaardreglement van de Koninklijke Notariële Broederschap tot stand, waarin dergelijke clausules wel waren opgenomen, respectievelijk in artikelen 3 en 6 (toelatingsregeling) en 6 en 7 (ontzeggingsregeling) ${ }^{14}$. De in de artikelen 3 en 6 neergelegde toelatingsregeling was echter facultatief en Bouwer ${ }^{15}$ achtte deze clausules ontoelaatbaar. Hij beriep zich op artikel $638 \mathrm{a}$ lid 2 BW waarin was bepaald dat in het aandeel in het gebouw met toebehoren het recht van uitsluitend gebruik van de prive-gedeelten was begrepen. Daarnaast beriep hij zich op het bovengeciteerde uit de memorie van antwoord en op het voorlopig verslag van de Vaste Commissie voor Privaat- en Strafrecht ${ }^{16}$ waarin staat:

"de commissie meent, dat het reglement als sanctie op overtreding van zijn bepalingen nimmer zal kunnen stellen, dat een eigenaar uit zijn appartement gezet kan worden. Alleen indien hij de hem opgelegde boete niet

12. Bijl. Hand. I: 1950-1951, 451, or. 5, blz. 21.

13. Bijl. Hand. II, 1950-1951, 451, nr. 5, blz 21.

14. Vgl. Asser/Beekhuis II (1963), blz. 107; Asser/Beekhuis. II, blx. 328.

15. Bouwer, biz. 553.

16. Bijl. Hand. II, 1946-1947, 451, nr.4. 
betaalt of zijn andere financiële verplichtingen niet nakomt, zal zijn appartement geëxecuteerd kunnen worden."

Onder ontzegging van gebruik moest volgens Bouwer mede worden verstaan het buiten werking stellen van het zakelijk gebruiksrecht dat in artikel 638a lid 2 werd bedoeld. De eigenaar zou zijn recht van gebruik hoogstens nog aan een ander kunnen afstaan. Bouwer achtte dit niet toelaatbaar. De enige sanctie bij overtreding van het reglement moest volgens hem de boeteregeling uit artikel 37 van het standaardreglement zijn.

Beekhuis ${ }^{17}$ nam het in een reactie op het artikel van Bouwer voor de welstandsbepalingen op. Hij vroeg zich af of het gebruiksrecht kon worden beperkt in de zin dat aan een bepaalde eigenaar het gebruik wegens bijv. wangedrag kon worden ontzegd. Bouwer beweerde immers dat dit niet toelaatbaar was. Beekhuis achtte Bouwer's argumenten echter niet steekhoudend. Het gebruiksrecht op grond van artikel 638 a lid 2 dat werd ontzegd, kon door de gerechtigde immers aan een ander worden afgestaan. De appartementseigenaar bleef dan wel medeëigenaar van het gebouw.

Daarnaast vroeg Beekhuis zich af wat de regering in de algemene beschouwingen bij de memorie van antwoord (bovengeciteerd) met de woorden "zonder meer" had bedoeld in de zin:

"de flateigenaar zal inderdaad niet bij niet voldoening aan andere dan financiële verplichtingen zonder meer uit zijn flat kunnen worden gezet."

Als de regering bedoeld had dat de bevoegdheid van uitsluitend gebruik inherent was aan het recht van appartement en niet krachtens reglement kon worden beperkt, dan zouden de welstandsbepalingen in strijd met de wet zijn. De regering had echter verzuimd deze mening vast te leggen in een bepaalde wetstekst, zodat zij volgens Beekhuis niet behoefde te worden aanvaard. De mening van Beekhuis was derhalve dat datgene wat niet expliciet was verboden, toegestaan was.

Hierop volgde weer een reactie van Bouwer ${ }^{18}$ waarin hij inging op de argumenten van Beekhuis. Wat, zo vroeg Bouwer ondermeer, blijft er over van een recht van gebruik (het recht van gebruik behelst immers het recht van persoonlijk gebruik!) indien aan een eigenaar het recht van gebruik van zijn privé-gedeelten wordt ontzegd. De regeling ingevolge $638 \mathrm{~g}$ tweede lid onder $2 \mathrm{kon}$ volgens Bouwer alleen aangeven, op welke wijze een appartement moest worden gebruikt. Hiervoor beriep hij zich op de memorie van antwoord aan de Eerste Kamer, waarin dit uitdrukkelijk was gesteld. Daarnaast beriep hij zich opnieuw op de uitdrukkelijke verklaringen in het Voorlopig Verslag, waaruit bleek dat aan een appartementseigenaar orm andere dan financiële redenen, niet het gebruiksrecht van zijn appartement kon worden ontzegd. Bouwer achtte het wel mogelijk dat appartementseigenaars bij afzonderlijke overeenkomst overeen zouden komen dat zij hun flat niet persoonlijk zouden gebruiken zonder toestemming van de vergadering van eigenaars, een en ander op straffe van een vastgestelde boete. Rechtverkrijgenden

17. Beekhuis (Opmerkingen), blz, 6.12 .

18. Bouwer, blz 553 . 
onder bijzondere titel zouden hier door middel van een kettingbeding ook door gebonden kunnen worden.

Beekhuis liet zich niet overtuigen. De door Bouwer gehanteerde interpretatie van artikel 638ba BW leek hem gezocht en in strijd met de eisen van de praktijk. Hij betwijfelde daarom of de mening van Bouwer ingang zou vinden bij de rechter.

De vraag komt op of Beekhuis zich hier echter niet te zeer liet leiden door de eisen van de praktijk. Zijn argumenten waren niet zeer sterk. Wat niet expliciet door de wet is verboden, kan immers impliciet door de wet zijn verboden. Blijkens de wetsgeschiedenis van de appartementenwet van 1951 zou wellicht eerder geconcludeerd moeten worden dat ontzegging van gebruik van prive-gedeelten impliciet was verboden. Alleen bij het niet voldoen aan financiële verplichtingen was er dan de mogelijkheid van uitwinning van een appartementsrecht.

Jurisprudentie over de toelaatbaarheid van welstandsbepalingen uit de tijd tussen 1951 en 1972 ontbreekt nagenoeg. In een vonnis in kort geding van de President van de Groningse rechtbank ${ }^{19}$ uit 1961 blijkt dat Beekhuis waarschijnlijk gelijk had met zijn mening dat de rechter de welstandsbepalingen op zich toelaatbaar zou achten. De President van de Groningse rechtbank bepaalde in zijn vonnis dat niet gezegd kon worden

"dat het besluit waarbij eiser door de vergadering van ged. de toestemming om zijn flat te mogen betrekken is geweigerd, zou zijn genomen in strijd met de wet of het reglement van ged. dat de bevoegdheid tot weigeren kent."

Kennelijk accepteerde de rechter de welstandsbepalingen als geldig. Ook uit een ander Gronings vonnis ${ }^{20}$ blijkt niet dat de rechter een ontzeggingsregeling als opgenomen in artikel 7 van het modelreglement van de Koninklijke Notariële Broederschap in strijd met de wet achtte. Helaas heeft de vraag over toelaatbaarheid van welstandsbepalingen tussen 1951 en 1972 de Hoge Raad niet bereikt, zodat de mening van ons hoogste rechtcollege hierover ontbreekt. Feit is dat de welstandsbepalingen als geldig werden gehanteerd, ondanks het feit dat ze wellicht op dat moment nog een instituut praeter legem vormden.

\subsection{De welstandsbepalingen in de wet van 1972}

Bij de vernieuwing van het appartementsrecht in 1972 werd artikel $638 \mathrm{~g}$ van de oude regeling gewijzigd en vervangen door artikel $875 \mathrm{f}$. Aan de tekst van artikel $638 \mathrm{~g}$ lid 2 sub 2 , die alleen in terminologisch opzicht veranderde en werd opgenomen in artikel $875 \mathrm{f}$ lid 4 , werd de zin

"Een zodanige regeling kan inhouden dat de vergadering van eigenaars bevoegd is een appartementseigenaar of degene die zijn rechten uitoefent, om nader in het reglement aangegeven gewichtige redenen het gebruik van deze gedeelten te ontzeggen."

19. Pres. Rb. Groningen 18 mei 1961, NJ $1961,486$.

20. Rb. Groningen 18 okt. 1958, NJ 1959, 310. 
De memorie van toelichting bij de wet van $1972^{21}$ vermeldt bij artikel $875 \mathrm{f}$ lid 4 :

"In het huidige recht bestaat hierover verschil van mening (...)."

Kennelijk wilden de opstellers van het wetsontwerp zo de mogelijkheid van het opnemen wan welstandsbepalingen in het reglement buiten discussie stellen. In de laatste zin bij de toelichting op artikel $875 \mathrm{f}$ lid 4 staat dan ook:

"de strekking van het derde en vierde lid is slechts de rechtsgeldigheid van de hier genoemde regelingen buiten twijfel te stellen. ${ }^{22}$

De mogelijkheid van het scheppen van welstandsbepalingen was nu bij wet in formele zin erkend. Er volgde dan ook geen noemenswaardige discussie meer over de mogelijkheid "an sich" van het scheppen van welstandsbepalingen. De discussie spitste zich nu toe op de vraag welke materiële bepalingen de welstandsbepalingen mogen geven (vgl. par. 3.6.3), met andere woorden welke criteria een gewichtige reden tot ontzegging van gebruik konden opleveren. De formele welstandsbepalingen - de bepalingen dat men toestemming tot ingebruikneming moet vragen en de bepaling dat verder gebruik kon worden ontzegd - stonden nu nagenoeg buiten kijf. Wel gaan er nog steeds stemmen op die beweren dat ontzegging van ingebruikneming in artikel $875 \mathrm{f}$ lid 4 wellicht niet door de wetgever werd beoogd en derhalve expliciet moet worden erkend om deze welstandsbepalingen buiten discussie te stellen ${ }^{23}$. Deze uitdrukkelijke erkenning is mijns inziens echter overbodig, nu de wetgever in 1972 blijkens de memorie van toelichting kennelijk het praktijkgebruik van voor 1972 door opneming van de bovengeciteerde zin in artikel $875 \mathrm{f}$ lid 4 , beoogde te erkennen. Tot dat praktijkgebruik behoorde ook de regeling van ontzegging van ingebruikneming.

\subsection{De welstandsbepalingen in het $N B W$}

In artikel 5.10.1.5 lid 4 / 5:112 lid 4 van het Nieuw Burgerlijk Wetboek komt de tekst van artikel $875 \mathrm{f}$ lid 4 ongewijzigd terug. Een verandering van de regeling der welstandsbepalingen ligt daarom niet voor de hand. Hoogstens zou uit aanpassingen van andere bepalingen uit het appartementsrecht in het NBW een verandering van de welstandsbepalingenregeling kunnen voortvloeien. Zoals reeds is vermeld ondergaat het appartementsrecht in het NBW materieel gezien echter weinig wijzigingen, zodat aangenomen kan worden dat het instituut van de welstandsbepalingen zoals dat in het positieve recht bestaat, gehandhaafd blijft in het NBW. Opgemerkt moet worden dat voor de geldigheid van de criteria op grond waarvan gebruik kan worden ontzegd, artikel 3.1.1.13 / 3:12 (algemene rechtsbeginselen), de evenredigheidsnorm uit 3.1.1.14 / 3:13 en de redelijkheid en billijkheid uit artikel 6.1.1.2 lid 2/6:2 NBW van belang kunnen zijn. In de praktijk zall toepassing van deze bepalingen echter mijns inziens niet leiden tot een andere toetsing van de criteria, dan in paragraaf 3.5 .3 wordt besproken.

21. Büll. Hand. II, 1970-1971, 10987, nr. 3, blz. 15 linkerkolom.

22. Bijl. Hand. II, 1970-1971, 10987, mr. 3, blz. 15 linkerkolom.

23. Vgl. Praktijkboek Onroerend Goed, ID, blz 30. 


\subsection{De welstandsbepalingen in de standaardreglementen van de Koninklijke Notariële Broederschap}

Zoals al werd vermeld in paragraaf 2.4.1 wordt in artikel $875 \mathrm{e}$ eerste lid sub b BW de mogelijkheid geopend om met betrekking tot het reglement, dat deel uitmaakt van de akte van splitsing, te verwijzen naar een nauwkeurig aangeduid modelreglement dat in de openbare registers is overgeschreven. In het NBW komt deze bepaling terug in art. 5.10.1.4 sub d / 5:111 sub d. Een soortgelijke bepaling was in de wet van 1951 opgenomen in art. 638f sub 4. De Koninklijke Notariële Broederschap heeft door de jaren heen verscheidene van dergelijke model/ standaardreglementen opgesteld.

\subsubsection{De toelatingsregeling}

In de Annex I bij het reglement van augustus 1953 was ook al een toelatingsregeling opgenomen. In artikel 3 werd bepaald dat een eigenaar verplicht was toestemming van de vergadering te verkrijgen, voordat hij zijn flat zelf in gebruik kon nemen, dan wel aan. een ander in gebruik kon geven. De eigenaar moest zich hiervoor tot de administrateur wenden. Het vijfde lid van artikel 3 bepaalde :

"weigering vam de gegadigde zal slechts plaats mogen vinden, indien naar redelijkheid en billijkheid van de overige bewoners niet mag worden verlangd, dat zij de gegadigde in hun midden opnemen, en wanneer niet voldaan is aan het bepaalde in art. 4."

In artikel 4 van de annex I was geregeld dat iemand die onder andere titel dan die van eigenaar het gebruik van de privé-gedeelten wenste te verkrijgen, moest verklaren dat de bepalingen in het reglement en het huishoudelijk reglement hem bekend waren.

In de Annex I van het reglement van splitsing van eigendom van februari 1973 was de toelatingsregeling in de artikelen $20-22$ en 25 geregeld. Artikel 20 bepaalde dat indien een eigenaar zijn appartementsrecht aan een ander in gebruik wilde geven, die ander het gebruik slechts kon verkrijgen na voorafgaande toestemming van de vergadering en na verklaard te hebben dat hij het reglement en het huishoudelijk reglement en een besluit als bedoeld in artikel $876 \mathrm{c} \mathrm{BW}$, zou naleven. De gegadigde moest zich ter verkrijging van de toestemming tot ingebruikneming tot de administrateur wenden. De administrateur was vervolgens verplicht om binnen veertien dagen de vergadering bijeen te roepen, die dan over de eventuele toelating van de gegadigde moest beslissen (art. 20a leden 1 en 2). Het derde lid van artikel 20a bepaalde vervolgens weer dat de gegadigde slechts mocht worden geweigerd, indien naar redelijkheid en billijkheid van de overige bewoners niet mocht worden verlangd dat zij de gegadigde in hun midden zouden opnemen, en wanneer niet voldaan zou zijn aan het in de artikelen 20 en 21 bepaalde. Artikel 21 bepaalde dat de administrateur te allen tijde van de gebruiker kon verlangen dat hij zich jegens de vereniging als borg voor de eigenaar zou verbinden. Ook de nieuwe eigenaar die het privé-gedeelte zelf in gebruik wilde nemen, dan wel een ander als gebruiker wilde toelaten, was verplicht toestemming 
tot ingebruikneming te vragen (art. 25a). De artikelen $20 \mathrm{a}$ en 22 waren hierop eveneens van toepassing.

Indien een eigenaar zijn privé-gedeelte derhalve aan een ander in gebruik wilde geven, moest die ander zelf toestemming tot ingebruikneming vragen aan de vergadering. Een nieuwe eigenaar die zijn privé-gedeelte aan een ander in gebruik wilde geven moest deze toestemming echter voor die ander vragen.

In het reglement van splitsing van eigendom van een service-flatgebouw van 1975 was in de annex A nagenoeg dezelfde regeling opgenomen als in thet reglement van splitsing van eigendom van februari 1973.

Het modelreglement bij splitsing in appartementsrechten van november 1983 geeft in de annex een (vooral tekstueel) enigermate afwijkende regeling. Artikel 24 bepaalt dat een eigenaar zijn appartementsrecht aan een ander in gebruik kan geven,

"mits hij erwoor zorg draagt dat die ander het gebruik slechts verkrijgt"

na te hebben verklaard dat hij de bepalingen van het reglement, het huishoudelijk reglement en een besluit als bedoeld in artikel $876 \mathrm{c}$ BW zal naleven (art. 24 eerste lid). Bovendien is vereist, dat de vergadering haar toestemming tot ingebruikneming verleent" (art 24, tweede lid). Om toestemming tot ingebruikneming te verkrijgen djent de gegadigde zich schriftelijk tot het bestuur van de V.v.E. te wenden. Het bestuur moet vervolgens binnen veertien dagen de vergadering bijeenroepen om bij gewone meerderheid van stemmen, in een wergadering waarin tenminste de helft van het total aantal stemmen is vertegenwoordigd, over de toelating te beslissen (art. 24a, eerste en tweede lid Annex 1, art. 37 lid 5 jo. 34 tweede lid. Vgl, echter art. 28a lid 3 Annex 1). Het bestuur wordt overigens blijkens artikel 1 van het reglement gevormd door een of meerdere administrateurs. Het derde lid van artikel 24 a bepaalt dat de vergadering de gegadigde slechts zal mogen weigeren, als in redelijkheid en billijkheid van de overige bewoners niet kan worden verwacht dat zij de gegadigde in hun midden opnemen en als de gegadigde niet de verklaring die op grond van artikel 24 eerste lid is vereist, heeft afgelegd. Artikel 25 geeft de regeling, op grond waarvan het bestuur van de gebruiker kan verlangen dat hij zich als borg voor de eigenaar verbindt.

Artikel 28 a eerste lid regelt tenslotte dat de verkrijger van een appartementsrecht verplicht is toestemming tot ingebruikneming te vragen aan de vergadering van eigenaars, indien hij de privé-gedeelten zelf in gebruik wil nemen of een ander als gebruiker wil toelaten. Ook hier geldt dus weer dat een nieuwe eigenaar die zijn appartementsrecht aan een ander in gebruik wil geven, voor deze andere toestemming tot ingebruikneming moet vragen. Iemand die al langer eigenaar is, hoeft dit niet te doen. De gegadigde zal dan zelf de toestemming tot ingebruikneming moeten vragen. De reden dat de term "nieuwe eigenaar" uit artikel 25a van het reglement van 1973 vervangen is door "verkrijger", is waarschijnlijk het feit dat de term "verkrijger" ruimer is. Onder deze term valt ook de vruchtgebruiker van een appartementsrecht. Het is zeer twijfelachtig of de vruchtgebruiker van een appartementsrecht die het appartementsrecht aan een ander in gebruik wil geven, onder de vigeur van het reglement van 1973 tot het vragen van toestemming tot ingebruikneming kon worden gedwongen. Met de huidige redactie van artikel 28a kan dat waarschijnlijk wel. Bij service-appartementencomplexen is de vrucht- 
gebruiker overigens waarschijnlijk formeel nog steeds niet verplicht voor zichzelf of een ander toestemming tot ingebruikneming te vragen, nu in het reglement van splitsing van eigendom van een service-flatgebouw van 1975 in artikel 25 a een aan artikel 25a van het reglement van 1973 gelijkluidende regeling is opgenomen.

In het reglement 1987 is de toelatingsregeling standaard - dus niet meer in de Annex - opgenomen in artikelen 29-32. Volgens de toelichting bij het modelreglement 1987 van de commissie Beekhuis, is de toelatingsregeling standaard opgenomen omdat het bij service-flats algemeen gebruikelijk zou zijn,

"dat het reglement een bepaling bevat, volgens welke voor toelating van nieuwe bewoners (eigenaars of huurders) toestemming van de algemene vergadering of het bestuur noodzakelijk is."

Omdat de toelating nu in het reglement zelf is geregeld in plaats van in de facultatieve annex, is de toelatingsregeling geherstructureerd. Artikel 29 lid 1 bepaalt dat een appartementseigenaar de toestemming van het bestuur (= administrateur) van de V.v.E. nodig heeft om

"zijn privé gedeelte zelf en met de met name genoemde huisgenoten in gebruik te nemen of een tot dusverre niet tot zijn huisgenoten behorend persoon bij zich te doen inwonen."

Het verzoek tot ingebruikneming moet door de eigenaar schriftelijk aan het bestuur worden gedaan, terwijl hij de namen en andere voor de te nemen beslissing relevante gegevens van huisgenoten aan het bestuur verstrekt (art. 29 lid 2). Interessant is hetgeen tussen haakjes in artikel 29 lid 2 wordt gesteld, namelijk dat onder de eigenaar ook de koper of een andere gerechtigde tot levering van het appartementsrecht wordt begrepen. Tot nu toe (eveneens onder de vigeur van het nog steeds geldende modelreglement 1983 voor gewone appartementen) gold immers dat slechts de eigenaar formeel gerechtigd was om toestermming tot ingebruikneming te vragen ${ }^{24}$.

Het bestuur moet de verzoeker vervolgens binnen 14 dagen in de gelegenheid stellen zijn verzoek mondeling toe te lichten, waarbij hij zich mag laten vertegenwoordigen of bijstaan door een raadsman. Vervolgens moet het bestuur binnen 8 dagen beslissen (art. 29 lid 3). Het bestuur mag de verzoeker of zijn huisgenoten slechts de toestemming tot ingebruikneming ontzeggen,

"indien naar billijkheid van de overige bewoners niet mag worden verlangd, dat zij de betrokkene in hun midden opnemen" (art. 29 lid 4).

24. Overigens blijven de "oude" modelreglementen uilteraard gelden voor appartementsgebouwen, waarvan in de akte van splitsing naar die reglementen is verwezen, behoudens de situatie dat de akte van splitsing tussentijds wordt gewijzigd en naar cen nieuw modelreglement wordt verwezen. 
Bijzonder interessant is vervolgens de eerste zin van artikel 29 lid 5, die luidt:

"Bij de toepassing van de in het vierde lid aangegeven norm zal het bestuur in het bijzonder acht slaan op de gezondheidstoestand en de solvabiliteit van de betrokkene"

Hierbij kan het bestuur een verklaring van een onafhankelijke arts of een accountant verlangen.

Binnen veertien dagen na de beslissing van het bestuur kan de verzoeker in beroep komen bij de vergadering van eigenaars (art. 28 lid 6). Ook de vergadering moet de verzoeker in de gelegenheid stellen het beroep mondeling toe te lichten, waarbij hij zich mag laten helpen door een raadsman (art. 29 lid 7). De vergadering moet vervolgens binnen 14 dagen beslissen (art. 29 lid 8).

Ook indien de appartementseigenaar zijn privé-gedeelte aan een ander in gebruik wil geven, moet deze ander toestemming tot ingebruikneming van het bestuur verkrijgen. De eigenaar en de aspirant-bewoner moeten het verzoek voor deze toestemming gezamenlijk bij het bestuur indienen. Artikel 29 is van overeenkomstige toepassing (art. 31 modelreglement 1987).

De eigenaar of gebruiker moet instaan voor zijn huisgenoten en ervoor zorgen dat zij de bepalingen van het reglement, het huishoudelijk reglement en besluiten van de vergadering als bedoeld in artikel $876 \mathrm{c} \mathrm{BW}$, naleven. Als een huisgenoot van een gebruiker toestemming tot (mede)gebruik van het prive-gedeelte heeft, behoeft hij, als hij zelf gebruiker wordt, geen toestemming tot het gebruik te vragen (art. 32 modelreglement 1987).

\subsubsection{Ontzegging van verder gebruik}

$\mathrm{Al}$ in het reglement van augustus 1953 regelde artikel 7 dat aan een eigenaargebruiker of een andere gebruiker van een appartementsrecht, die :

"a. de bepalingen van dit Reglement of van het Huishoudelijk Reglement niet nakomt of overtreedt;

b. zich niet gedraagt naar vergaderingsbesluiten;

c. zich schuldig maakt aan onbehoorlijk gedrag jegens de medegebruikers van het gebouw;" (art. 7 eerste en zevende lid)

op voorstell van de administrateur door de vergadering een waarschuwing kon worden gegeven. Bij herhaling van een van de genoemde handelingen of verzuimen binnen een jaar na waarschuwing, kon de vergadering besluiten het verdere gebruik van het appartementsrecht te ontzeggen (art. 7 tweede lid). Het derde lid van artikel 7 regelde dat de vergadering het ontzeggingsbesluit niet zou nemen dan na verhoor of behoorlijke oproeping van de eigenaar of andere gebruiker. Een ontzeggingsbesluit moest worden genomen met tweederde van de uitgebrachte stemmen in een vergadering, waarin tenminste tweederde van het totaal aantal stemmen aanwezig moest zijn (art. 7 vierde lid). Het vijfde en zesde lid van artikel 7 gaven vervolgens regels voor de tenuitvoerlegging van het ontzeggingsbesluit. 
De wijziging van het modelreglement met betrekking tot de assurantiebepalingen in mei 1956 veranderde niets met betrekking tot de welstandsbepalingen. In het reglement van splitsing van eigendom van februari $1973 \mathrm{kwam}$ artikel 7 van het reglement van 1953 nagenoeg ongewijzigd terug in artikel 24 . Het eerste lid van artikel 24 was enigermate veranderd ten opzichte van artikel 7. Het bepaalde dat aan de elgenaar-gebruiker of andere gebruiker, die :

"a. de bepalingen van het reglement of het huishoudelijk reglement of de bepalingen bedoeld in artikel $876 \mathrm{c}$ van het BW niet nakomt of overtreedt;

b. zich schuldig maakt aan onbehoorlijk gedrag jegens de andere eigenaars en/of gebruikers",

binnen een jaar na waarschuwing het gebruik van de privé-gedeelten kon worden ontzegd. Verder bleef de inhoud van de ontzeggingsregeling materieel gelijk aan die van de regeling in artikel 7 van het reglement van 1953 . Het reglement van splitsing van eigendom van een service-flatgebouw van januari 1975 hanteert in artikell 24 dezelfde ontzeggingsregeling als het reglement van 1973 in artikel 24. De eerste twee leden van artikel 24 bepalen echter bovendien dat aan iemand die het genot van de gemeenschappelijke huishouding heeft, dit genot kan worden ontzegd bij overtreding van het reglement e.d. Naast het gebruik van de privé-gedeelten kan dus op grond van dit reglement ook het genot van de gemeenschappelijke huishouding worden ontzegd.

In het modelreglement bij splitsing in appartementsrechten van november 1983 is een aan artikel 24 van het reglement van splitsing van eigendom van februari 1973 gelijkluidende bepaling opgenomen in artikel 27.

In het modelreglement bij splitsing in appartementsrechten van een serviceflatgebouw van augustus 1987 (reglement 1987), zijn enige veranderingen aangebracht. In artikel 33 komt een variant van artikel 24 van het modelreglement 1975 terug. In dit artikel worden echter aanvullende ontzeggingscriteria geformuleerd. Artikel 33 lid 1 luidt nu:

"Aan de eigenaar die zelf het recht van gebruik uitoefent en die:

a. de bepalingen van het reglement of van het huishoudelijk reglement of de bepalingen als bedoeld in art. $876 \mathrm{c}$ van het Burgerlijk Wetboek niet nakomt of overtreedt;

b. zich schuldig maakt aan onbehoorlijk gedrag jegens de andere eigenaars en/of gebruikers;

c. door zijn aanwezigheid in het gebouw aanleiding geeft tot ernstige verstoring van de rust in het gebouw;

d. zijn financiële verplichtingen jegens de vereniging niet nakomt, kan door de vergadering een waarschuwing worden gegeven dat indien hij ondanks deze waarschuwing binnen een jaar nadat hij deze heeft ontvangen andermaal een of meer der genoemde gedragingen verricht of voortzet, de vergadering kan overgaan tot de in het volgende lid bedoelde maatregel. Het vorenstaande is eveneens van toepassing indien een of meer van de huisgenoten van de 
eigenaar een of meer der genoemde gedragingen verricht(en) of voortzet(ten)."

De rest van artikel 33 stemt overeen met artikel 24 wan het reglement 1975 . Interessantste veranderingen zijn de twee onder cen d toegevoegde ontzeggingscriteria ${ }^{25}$. Op deze criteria zal in paragraaf 3.6 nader worden ingegaan.

\subsection{Welstandsbepalingen en openbare verkoop}

In artikel $28 \mathrm{a}$ van de annex van het modelreglement bij splitsing in appartementsrechten van november 1983 wordt een afwijkende regeling gegeven voor toestemming tot ingebruikneming bij openbare verkoop. Bij openbare verkoop zal iedere gegadigde zich tot het bestuur van de V.v.E. kunnen wenden ter verkrijging van een verklaring

"'dat geen bezwaar zal worden gemaakt tegen gebruik door de gegadigde met zijn huisgenoten (of de ander die deze als gebruiker wil toelaten en zijn huisgenoten) van het privé-gedeelte waarop het te verkopen appartementsrecht betrekking heeft" (art. 28a, tweede lid).

Als het bestúur toestemming weigert kan de gegadigde beroep instellen bij de vergadering. Bij openbare verkoop moet de gegadigde derhalve zelf toestemming tot ingebruikneming vragen en het orgaan dat deze toestemming verleent of weigert is het bestuur in plaats van de vergadering. Deze regeling is in beginsel van toepassing op alle openbare verkopen.

Om tegemoet te komen aan de zekerheid voor de eerste hypothecaire schuldeiser is voor een openbare verkoop ex artikel 1223 lid 2 in artikel 28 a, vierde lid, echter nog een andere mogelijkheid geschapen. De hypothecaire schuldeiser kan tenminste dertig dagen voor de openbare verkoop aan het bestuur van de V.v.E. mededelen dat hij in de veilingvoorwaarden een bepaling wenst op te nemen, die mogelijk maakt dat kopers een verklaring afleggen

"krachtens welke hij en zijn rechtsopvolgers bevoegd zullen zijn de privé gedeelten - in afwijking van artikel 24 tweede lid en artikel 28a, eerste lid - zelf in gebruik te nemen of aan derden in gebruik te geven zonder dat hiervoor enige toestemming vereist is" (art. 28a, vierde lid).

Als de koper deze verklaring heeft afgelegd moet het bestuur van de V.v.E. binnen een maand na overschrijving in de openbare registers, de vergadering bijeen roepen om te beslissen of ook de andere eigenaars en hun rechtsopvolgers in de toekomst bevoegd zullen zijn hun appartementsrecht zonder voorafgaande toestemming in gebruik te nemen of aan derden in gebruik te geven. Aldus wordt in artikel 28a

25. De Commissie Beckhuis meldt in haar toelichting bij art. 33:

"De mogelijkheid orn het gebruik wan het prive gedeelte aan een gerechtigde te ontzeggen, is uitgebreid met twee gronden, genoemd in $c$ en d. Eerstgenoemde grond is opgenomen omdat er zich in praktijk sorns moeilijkheden voordoen met personen die lijden aan seniliteit en daardoor aanleiding geven tot verstoring van de rust. De regeling is verder uitgebreid tot het geval de huisgenoten zich aan de verboden handelingen schuldig maken." Commissie Beekhuis, blz. 592. 
van het modelreglement een mogelijkheid geereëerd on de toelatingsregeling buiten spel te zetten. De koper van een appartementsrecht dat geveild wordt krachtens artikel 1223 lid 2 BW, kan deze bal aan het rollen brengen.

Ook in de oude standaard reglementen kwamen deze bepalingen voor: Asser/Beekhuis ${ }^{26}$ vermeldt hierbij dat ze indertijd op verzoek van de Vereniging van Hypotheekbanken zijn opgenomen. Als men op dit verzoek niet zou zijn ingegaan, dan was het waarschijnlijk moeilijk geworden een hypotheekbank bereid te vinden om een hypotheek op een appartementsrecht te nemen. Asser/Beekhuis stelt hier echter ook dat een beroep op deze bepaling in praktijk nog vrijwel niet is voorgekomen. Als een hypotheekhouder al een beroep zou willen doen op de aan hem door artikel 28a toegekende bevoegdheid, dan zouden de andere appartementseigenaars hem kunnen aflossen om hun gesloten gemeenschap te behouden. Een andere mogelijkheid hiervoor zou het zelf kopen van het appartementsrecht zijn.

Een inhoudelijk overeenkomstige regeling als in het modelreglement 1983 is in artikel 30 modelreglement 1987 opgenomen. Deze bepaling wijkt inhoudelijk ook niet af van hetgeen in het modelreglement 1975 (art. 25a lid 2-5 Annex) ten aanzien van openbare verkoop is bepaald.

\subsection{Welstandsbepalingen en grondrechten}

\subsubsection{Algemene opmerkingen}

Tot nog toe is er in deze studie van uit gegaan, dat de welstandsbepalingen, dat wil zeggen regelingen en criteria voor ontzegging van gebruik van appartementen, in beginsel geldig in een reglement van splitsing kunnen worden opgenomen. In paragraaf 1.1 werd echter al aan de grondrechten gerefereerd, waarbij werd vermeld dat de ontzeggingsregelingen in het appartementsrecht op gespannen voet staan met grondrechten als het "recht" op huisvesting ${ }^{27}$ (art 25 Universele verklaring van de rechten van de Mens, art. 11 IVESCR en art. 22 lid 2 Grondwet, waaraan art. 8 EVRM (privacy-bescherming), art. 12 Grondwet (huisrecht) verwant zijn) en het recht op eigendom (art. 17 Universele verklaring van de rechten van de mens, art. 1 Eerste Protocol bij EVRM, vgl. ook art. 14 Grondwet). Hieruit volgt dat een onderzoek naar de verenigbaarheid van deze grondrechten met de ontzeggingsregelingen in het appartementsrecht, op zijn plaats is.

$\mathrm{Nu}$ worden aan grondrechten twee werkingswijzen toegekend, namelijk de zogenaamde verticale werking en horizontale werking. De verticale werking van grondrechten betekent dat de burger zich ten opzichte van de overheid op de grondrechten kan beroepen en de overheid zich in haar handelen beperkt ziet door de grondrechten. Artikel 120 van onze Grondwet bepaalt hierbij, dat een rechter niet bevoegd is om wetten in formele zin aan de Grondwet te toetsen. Dät betekent dat een burger zijn grondwettelijke grondrechten ten opzichte van de overheid niet bij de rechter kan afdwingen, althans voor zover hij daarbij de grondwettigheid van een wet in formele zin betwist. Wetten in materiële zin, niet

26. Asser/Beekhuis II, blz 330 .

27. Vgl. hierbij Hof 's-Gravenhage 28 maart 1985, NJ 1986, 282. Het Hof sprak hier over een "zwaarwegend belang" bij huisvesting. 
zijnde wetten in formele zin, mogen door de rechter wel aan de Grondwet (en aan wetten in formele zin of direct werkende bepalingen uit internationale verdragen) worden getoetst. Bij wetten in formele zin wordt de grondwettigheid daarvan derhalve door de wetgever zelf gecontroleerd, terwijl de burger alleen via democratische instrumenten als verkiezingen, petities, demonstraties e.d invloed op de wetgewer kan uitoefenen. Als de Grondwet de enige bron van grondrechten was, zou de burger weinig mogellijkheden hebben om bij de rechter op te komen tegen ongrondwettige wetgeving in formele zin. Grondrechten zijn echter zoals hierboven al werd aangestipt, ook neergelegd in internationale (mensenrechten)verdragen. Aan de bepalingen uit deze verdragen mag de rechter een wet in formele zin wel toetsen, mits deze bepalingen naar hun inhoud een ieder verbindend zijn (art. 93 Grondwet). De burger kan zich derhalve in een procedure tegen de overheid op strijdigheid van diens wetten in formele zin met een ieder verbindende bepalingen uit internationale verdragen en met besluiten van internationale organisaties beroepen (directe werking). Artikel 94 Grondwet bepaalt immers dat wetten die in strijd zijn met zulke verbindende bepalingen, niet toegepast mogen worden. Of verdragsbepalingen directe werking hebben, d.w.z. voor iedereen verbindend zijn, beslist de rechter ${ }^{28}$. Desnoods kan de burger zich bij schending van direct werkende verdragsbepalingen door de overheid, in bepaalde gevallen tot speciale instanties wenden, zoals de Europese Commissie in Straatsburg (waarna het Europese Hof in Straatsburg zich over de zaak kan buigen) en het mensenrechtencomite onder het IVESCR. De onschendbaarheid van wetten is derhalve geen absoluut beginsel.

Met horizontale werking van grondrechten wordt de werking van grondrechten tussen burgers onderling bedoeld ${ }^{29}$. Tegen een dergelijke werking kan men aanvoeren,

"dat grondrechten naar hun historische betekenis beperking van de macht van de overheid beogen. $\mathrm{Zij}$ bedoelen niet de verhouding van de burgers onderling te regelen, al kan een krasse contractuele beperking van de grondrechten de rechter misschien wel eens aanleiding geven de betrokken bepaling in de overeenkomst wegens strijd met de openbare orde nietig te achten." ${ }^{30}$

De Nederlandse wetgever stelt zich blijkens de memorie van toelichting bij de herziene grondwet van 1983 echter op een ander standpunt ${ }^{31}$ :

"Zoals reeds werd opgemerkt lijkt de discussie over de horizontale werking van grondrechten er dikwijls van uit te gaan, dat er slechts twee mogelijkheden openstaan, te weten hetzij een integrale en volledige werking van de grondrechten in horizontale verhoudingen, hetzij een volstrekte

28. Vgl. Koopmans, blz. 62-65; Van der Pot/Donner, blz. 177; Akkermans/Bax/Verhey, blz. 37.

29. Bijl. Hand. II, 1975-1976, 13872, nr. 3, blz. 15.

30. Belinfante, blz. 181; Koopmans, blz 43 .

31. Zie Bijl. Hand. 11, 1975-1976, 13872, nr. 3, blz. 15. Eerder had Boesjes, blz 912, al geconstateerd dat de horizontale werking van grondrechten in de Nederlandse rechtspraak "niet (meer) wordt verworpen". Zo ook Biesheuvel (Horizontale werking), blz. 217. 
afwezigheid van een zodanige werking, toch zijn er vele schakeringen mogelijk."

Vervolgens stelde de regering een glijdende schaal inzake horizontale werking voor ${ }^{32}$. Men kan op deze glijdende schaal tenminste vijf gradaties onderscheiden. De minst vergaande horizontale werking schreef de regering toe aan opdrachten aan de overheid of de wetgever om een bepaald belang te verwezenlijken $(1)^{33}$. Sterker horizontal werken de bepalingen die zich niet slechts tot de wetgever richten, maar ook voor de rechter van belang zijn bij "zijn interpretatie van privaatrechtelijke regels en begrippen ${ }^{\text {"34 }}$ (2). Nog sterker moet horizontale werking worden toegekend aan die grondrechten die een zelfstandig rechtsbelang uitdrukken en die door de rechter bij zijn belangenafweging moeten worden betrokken (3). Verder kan een grondrecht een uitdrukking van een rechtsbeginsel zijn, waarvan de rechter slechts op zwaarwegende gronden mag afwijken (4). Tenslotte zouden er ook nog grondrechten zijn die zodanig sterk horizontaal werken, dat de rechter er slechts van mag afwijken op grond van de grondwettelijke beperkingsclausules $(5)^{35}$. Per artikel en artikelonderdeel zou de mate van horizontale werking van de grondrechten moeten worden bezien ${ }^{36}$.

In beginsel hebben alle in de Grondwet neergelegde grondrechten derhalve horizontale werking. Deze grondrechten kunnen blijkens de memorie van toelichting echter in verschillende gradaties horizontaal werken.

"De vraag is niet zozeer of een grondrecht horizontale werking heeft, maar in hoeverre" (curs. R.M.), aldus De Winter ${ }^{37}$.

Niet alle grondrechten werken derhalve in dezelfde mate horizontaal Een opdracht aan de overheid om een bepaald belang ook in particuliere verhoudingen te verwezenlijken, werkt in mindere mate horizontaal dan een grondrecht dat een algemeen rechtsbeginsel bevat, waarvan slechts op grond van grondwettelijke beperkingsclausules kan worden afgeweken. Bovendien hangt de horizontale werking van een bepaald grondrecht in een concreet geval af van de concrete situatie, waarin het wordt ingeroepen. Van belang hierbij is de mate van (on)gelijkheid van partijen, de aard van de rechtsverhouding e.d. ${ }^{38}$

Voorafgaand aan de behandeling van de problematiek van de welstandsbepalingen in het licht van de grondrechten, moet worden opgemerkt dat grotendeels voorbij wordt gegaan aan de enorme problematiek die horizontale werking van grondrechten en botsing van grondrechten met zich meebrengt. Met het in de hierna volgende paragrafen over welstandsbepalingen en grondrechten beschrevene wordt dan ook niet beoogd een oplossing te bieden. Veeleer wordt getracht een bijdrage

32. Bijl. Hand. II, 1975-1976, 13872, nr. 3, ble. 15. Deze glijdende schaal werd ook door Boesjes, blz. 911, gehanteerd.

33. In deze schaal valt ook art. 22 Grondwet, waarin het recht op huisvesting is meergelegd.

34. Kortmann, blz 44.

35. Bijl. Hand. II, 1975-1976, 13872, nr. 3, blz. 15, 16. Vgl. hierover Kortmann, blz 44.

36. Kortmann, blz 44 .

37. De Winter, blz. 30. Aldus ook Koopmans, blz. 43.

38. Vgl. over factoren die de mate van horizontale werking van een grondrecht kunnen beïnwloeden, Biesheuvel, blz. 45-49. 
te leveren aan een gedachtenvorming over mogelijke antwoorden op de wragen die de toepassing van grondrechten in het privaatrecht oproept.

\subsubsection{Artikel $875 f$ lid $4 \mathrm{BW}$ en grondrechten}

Zoals vermeld bepaalt artikel 94 Grondwet dat binnen het koninkrijk geldende wettelijke voorschriften geen toepassing vinden, als deze voorschriften onverenigbaar zijn met een ieder verbindende bepalingen uit internationale verdragen of besluiten van volkenrechtelijke organisaties.

Inventarisatie van grondrechten, waarmee artikel $875 \mathrm{f} \mathrm{lid} 4$ laatste volzin BW in strijd zou kunnen zijn, levert het recht op eigendom en bescherming daarvan op, zoals het is neergelegd in artikell 17 van de Universele verklaring van de rechten van de mens en in artikel 1 van het Eerste protocol bij het EVRM ${ }^{39}$. Aangezien de Universele verklaring volgens de Nederlandse jurisprudentie geen een ieder verbindende voorschriften bevat ${ }^{40}$, zal verder onderzoek zich concentreren op artikel 1 eerste protocol EVRM ${ }^{41}$. Dit artikel luidt:

"Every natural or legal person is entitled to the peaceful enjoyment of his possessions. No one shall be deprived of his possessions except in the public interest and subject to the conditions provided for by law and by the general principles of international law.

The preceding provisions shall not, however, in any way impair the right of a State to enforce such laws as it deems necessary to control the use of property in accordance with the general interest or to secure the payment of taxes or other contributions or penalties."

Hierbij moet worden aangetekend dat het recht op eigendom vergaande beperkingen verdraagt. Van een "droit inviolable et sacré" 42 is immers, zeker met betrekking tot de eigendom van onroerend goed, weinig meer over. Talrijke beperkingen van privaatrechtelijke en publiekrechtelijke aard zijn in de loop der jaren mede onder invloed van de ontwikkeling van de verzorgingsstaat tot stand gekomen.

Om na te kunnen gaan of artikel $875 \mathrm{f}$ lid 4 tweede volzin BW verenigbaar is met artikel 1 Eerste protocol EVRM, is directe werking van dit laatste artikel blijkens artikel 94 grondwet een vereiste. Dat artikel 1 directe werking heeft, blijkt uit de

39. Opgemerkt dient te worden dat het recht op cerbiediging van de woning, zoats bijvoorbeeld neergelegd in art. 8 EVRM, niet aan algemene verbindendheid van art. $875 \mathrm{f}$ lid 4 BW in de weg kan staan. Art. 8 EVRM is immers een bepaling waarin een huisrecht met een defensief karakter is neergelegd, zodat het slechts kan worden ingeroepen bij inbreuken op een bestaand woonrecht. Nu art. $875 f$ lid 4 BW ook toelatingsregelingen mogelijk maakt, waarbij voor de toelating geen woonrecht ontstast en derhalve ook geen recht op bescherming ervan, kan art. 8 EVRM niet tegen het wetsartikel worden ingeroepen, maar eventueel wel tegen concrete uitwerkingen daarvan in bepalingen tot ontzegging van verder gebruik.

40. Vgl. HR 7 nov. 1984, NJ 1985, 247; HR 23 nov. 1984, NJ 1985, 604. Zie ook Schermers, blz. 212; Van der Pot/Donner, blz. 216.

41. Dit protocol is in Nederland op 18 mei 1954 in werking getreden. Zie Trb. 1952, ar. 80 .

42. Art. 17 van de "Déclaration des droits de Thomme et du citoyen" van 26 augustus 1789. 
Nederlandse jurisprudentie daaromtrent ${ }^{43}$. In beginsel zou de toepasbaarheid van artikel $875 \mathrm{f} \mathrm{lid} 4$ BW derhalve aan artikel 1 eerste protocol EVRM mogen worden getoetst. Beroep op bescherming van eigendom op grond van artikel 1 eerste protocol EVRM is echter slechts tegen staatsingrepen mogelijk die tot een vermogensvermindering leiden.

"Dies ist nicht der Fall, soweit der Staat lediglich seine Zwangsgewalt zur Regelung privatrechtlicher Auseinandersetzungen zur Verfügung stellt und auf Eigentum zurückgegriffen wird, well der betreffende Eigentümer anderweitig nicht in der Lage oder bereit ist, gegen un gerichtete berechtigte Ansprüche zu erfüllen. Der Erlass und die Volstreckung gerichtlicher Entscheidungen berühren also Art. 1 grundsätzlich nicht. ${ }^{144}$

Artikel 1 Eerste protocol EVRM beschermt eigenaars, het leerstuk van de staatsaansprakelijkheid daargelaten, blijkens dit citaat alleen tegen ontneming of beperking van gebruik van eigendom door de staat ${ }^{45}$. Aangezien artikel $875 \mathrm{f}$ lid 4 $B W$ een regeling geeft voor problemen tussen appartementseigenaars, kan een appartementseigenaar die gedupeerd wordt door toepassing van deze regeling, zich niet op artikel 1 eerste protocol EVRM, beroepen.

Bovendien houdt artikel $875 \mathrm{f} \mathrm{lid} 4 \mathrm{BW}$ op zichzelf geen beperking van het recht op eigendom in en gebiedt het geen zodanige beperking. Artikel $875 f$ lid $4 \mathrm{BW}$ maakt een beperking van gebruik slechts wegens een gewichtige reden mogelijk. Om dit artikel wegens strijd met artikel 1 Eerste protocol EVRM in het algemeen buiten toepassing te kunnen laten, zouden alle concrete uitwerkingen van artikel $875 \mathrm{f} \mathrm{lid} 4 \mathrm{BW}$ in strijd met dit artikel moeten zijn. Om aan te nemen dat hiervan sprake is zou voorbarig zijn, omdat artikel 1 Eerste protocol EVRM dan belangrijker zou worden geacht dan alle andere grondrechten, aangezien de "gewichtige reden" uit artikel $875 \mathrm{f}$ lid $4 \mathrm{BW}$ via andere grondrechten kan worden ingekleurd en deze andere grondrechten een beperking van het eigendomsrecht dan kennelijk nooit zouden kunnen rechtvaardigen. Hetzelfde kan overigens ten aanzien van bijna alle andere grondrechten worden opgemerkt. Van Oevelen ${ }^{46}$ vermeldt hierover:

"Indien men het particuliere personen onmogelijk zou maken in hun overeenkomsten beperkingen aan te brengen aan de uitoefening van grondrechten, dan zou een ander recht van het individu in het gedrang

43. Zie Afd. Rechtspraak 26 mei 1978, AB 1979, 396 (Texelse verordening); Afd. Rechtspraak 31 juli 1979, AB 1979, 539 (westigingsregeling Terschelling); HR 13 maart 1963, AB 1963, 610; Pres. RR. Rotterdam 6 meil 1981, Kort Geding 1981, 59. Vgl. colk de jurisprudentie van het Europese hof voor de rechten van de mens en het arrest Liselotte Hauer ws. Rheinland-Pfalz van het Hof van justitie van de EEG, 13 dec. 1979, zaak 44/79, Jurisprudentie van het Hof van Justitie 1979, blz. 3727-3765. Zie voor de jurisprudentie van het Europese hof te Straatsburg: Digest of Strasbourg Case-law, blz 642 e.v.

44. Frowein/Peukert, blz. 267. Vgl. ook de jurisprudentie vermeld in de Digest of Strasbourg Caselaw, blz. 657-660. Zie bijvoorbeeld de op blz 660 aangehaalde beslissing (Dec. Adm. Com. Ap. 6874/75 en 6980/75, 4 maart 1976, niet gepubliceerd): "Article 1 of Protocol ar. I is in essence directed against arbitrary seizure of property and does not in principle elfect the enforcement of judicial decisions on disputes between individuals".

45. Zie ook Moser, blz. 267.

46. Van Oevelen, blz 98. 
worden gebracht, met name de vrijheid van de burger om, binnen zekere grenzen, zelf zijn leven te ordenen en te bepalen."

Van Oevelen noemt dit laatste recht het "zelfbeschikkingsrecht" dat zich uit in de contractsvrijheid en de testeervrijheid ${ }^{47}$. De toetsing van de welstandsbepalingen in het appartementsrecht aan grondrechten, moet zich derhalve toespitsen op de concrete uitwerkingen in reglementen van splitsing. en in besluiten van de vergadering van eigenaars van een appartementencomplex.

\subsubsection{Toelatings- en ontzeggingscriteria en grondrechten}

Oritzegging van verder gebruik of weigering van toelating tot een appartement kan in concrete gevallen strijdig zijn met het recht op eigendom, maar ook met andere grondrechten van degene aan wie het verdere gebruik of de toestemming tot ingebruikneming wordt ontzegd.

Bij toetsing van de geldigheid van specifieke ontzeggingscriteria aan concrete grondrechten, is een zekere mate van horizontale werking van deze grondrechten een vereiste. Door deze horizontale werking kan ongeldigheid van een ontzegging van gebruik worden bewerkstelligd.

Zoals gezegd hebben alle in de grondwet neergelegde grondrechten een zekere mate van horizontale werking. Horizontale werking van grondrechten brengt het algemene probleem met zich mee dat beperking van de grondrechten in beginsel alleen mogelijk is in overeenstemming met de grondwettelijke of verdragsrechtelijke beperkingsclausules. Bij de grondwetsherziening van 1983 heeft de regering immers algemene beperkingen van grondrechten verworpen. Kortmann ${ }^{48}$ merkt hierbij op dat de grondwettelijke beperkingsclausules veelal niet alleen te beperkt zijn

"om de realiteit van de talloze privaatrechtelijke verhoudingen te bestrijken, doch tevens gericht op de vervulling van typische overheidsfuncties, zoals de handhaving van de openbare orde en de verkeersveiligheid alsook de bescherming van de volksgezondheid. Aan te nemen valt dan ook dat de rechter niet snel zal besluiten sterke horizontale werking aan grondrechten toe te kennen. Voorzover hij in de grondrechten vervatte waarden wil laten meewegen kan hij dit zeer well doen bij de 'invulling' van privaatrechtelijke begrippen als de goede zeden, de geoorloofde oorzaak en de maatschappelijke zorgvuldigheid. ${ }^{\text {H49 }}$

Mijns inziens is het echter theoretisch niet nodig dat de rechter zich verschuilt achter vage normen. De horizontale gelding van een grondwettelijke beperkingsclausule is waarschijnlijk immers even sterk als de horizontale werking van het grondrecht zelf. Dat betekent naar mijn mening dat de rechter bij in mindere mate horizontaal werkende grondrechten, de vrijheid heeft om beperkingen toe te staan buiten de grondwettelijke beperkingsclausules om. Naarmate een grondrecht

47. Maris (Preadvies), nr. 19, blz. 33, 34.

48. Kortmann, blz. 49 .

49. Dezelfde mening verkondigt Van Oevelen, blz 104, 105 . 
sterker horizontaal werkt, zal de rechter grosso modo minder speelruimate hebben om een beperking van een grondrecht via dit criterium geldig te achten. De beperkingsclausules bij een dergelijk grondrecht gelden dan waarschijnilijk ook in sterkere mate.

Dat neemt niet weg dat de Nederlandse rechter gemakkelijker via privaatrechtelijke open normen aan grondrechten kan toetsen, omdat hij dan aan een afweging met betrekking tot de mate van horizontale werking van de grondrechten (en dus ook ten aanzien van de ruimte voor beperkingen) ontkomt.

Tegenover de bescherming van grondrechten kan de contractsvrijheid staan. Het beginsel van de contractsvrijheid ligt ten grondslag aan ons gehele privaatrecht. $\mathrm{De}$ contractsvrijheid wordt echter op allerlei manieren ingeperkt, en ook de grondrechten stellen grenzen aan deze vrijheid ${ }^{50}$.

Uit de staats- en bestuursrechtelijke literatuur en jurisprudentie blijkt niet duidelijk hoe een rechter in een concreet geval een beperking van grondrechten in een private verhouding zou moeten of kunnen toetsen. In elk geval kan de rechter direct of indirect toetsen. Hij kan rechtstreeks aan het grondrecht toetsen, of indirect via inkleuring van privaatrechtelijke open normen of via beginselen van ongeschreven privaatrecht ${ }^{51}$. Het praktische gevolg kan in beide gevallen hetzelfde zijn, namelijk goedkeuring van de handeling of ongeldigheid van de met het grondrecht in strijd zijnde handeling. De welstandsbepalingen in het appartementsrecht zouden indirect, bijvoorbeeld via de openbare orde en goede zeden (artt. $1371,1373 \mathrm{BW}, 3.2 .7 / 3: 40 \mathrm{NBW})^{\mathrm{S2}}$, aan de grondrechten kunnen worden getoetst, maar dit kan ook rechtstreeks gebeuren. In de hierna volgende paragrafen 3.6 en 3.7 , bij de bespreking van de specifieke criteria, wordt over het algemeen indirect, via de openbare orde en goede zeden of via andere privaatrechtelijke vage normen, getoetst. De Nederlandse rechter lijkt deze toetsingswijze ook te prefereren ${ }^{53}$.

Volgens Van Oevelen kunnen voor de toetsing aan grondrechten van de geldigheid van overeenkomsten of van rechtshandelingen in het algemeen twee criteria worden gehanteerd, het relevantiecriterium en het proportionaliteitscriterium.

Het relevantiecriterium, ook wel pertinentiecriterium genoemd, houdt in dat de beperking van een bepaald, in zekere mate horizontaal werkend grondrecht door een rechtshandeling (en in het algemeen elke beperking van grondrechten), relevant moet zijn voor het doel dat met deze rechtshandeling wordt nagestreefd.

"Het voorwerp, de aard en het doel van de overeenkomst moeten met andere woorden zodanig zijn dat ze een dergelijke beperking van een grondrecht kunnen rechtvaardigen", aldus Van Oevelen ${ }^{54}$.

50. Elders (Preadvies), blz 13.

51. Vgl. HR 10 dec. 1982, NJ 1983, 687. Zie ook Elders (Preadvies), blz. 28; Biesheuvel, blz 42.

52. Vgl. HR 31 okt. 1969, NJ 1970, 57 (Mensendieck) met noot G.J.S. Daarover Van Develen, blz. 103.

53. Vgl. bijw. HR 30 maart 1984, NJ 1985, 350 (Suikerfeest).

54. Van Oevelen, blz 101; Moser, blz 115 verdedigt een toetsing aan soortgelijke criteria. Vgl, ook het Mensendieck-arrest, HR 31 okt. 1969, NJ 1970, 57 met noot G.J.S. 
Deze omschrijving verdient enige uitleg. Het relevanfiecriterium houdt mijns inziens in dat 1) bet doel van een rechtshandeling waardoor een bepaald grondrecht wordt beperkt, op zichzelf gerechtvaardigd moet zijn en 2) de beperking van een bepaald grondrecht verband moet houden met het nagestreefde doel. Dit laatste betekent dat men zich de vraag moet stellen of het nagestreefde doel verwezenlijkt kan worden door middel van de beperking van het grondrecht via de rechtshandeling en komt derhalve neer op een doelmatigheidstoets.

Deze relevantie zal vaak aanwezig zijn, maar kan in enkele gevallen ontbreken. De relevantie ontbreekt mijns inziens bijwoorbeeld bij de financiële toelatingscriteria in het appartementsrecht. Als een vereniging van appartementseigenaars een aspirant-bewoner het recht op gebruik van zijn appartement ontzegt (hij heeft een "recht" op huisvesting) omdat hij onvoldoende inkomsten heeft, streeft zij na dat de vereniging niet door wanbetaling van de leden in de financiële problemen komt. Op zichzelf kan dit streven gerechtvaardigd worden geacht. Het probleem is echter dat de vereniging door ontzegging van gebruik aan de eigenaar niet bereikt dat deze van zijn kostenbijdrageplicht wordt ontheven. Ook als eigenaar-nietbewoner rust op hem de verplichting om zijn financiële verplichtingen na te komen. De beperking van het recht op huisvesting is aldus niet relevant voor het op zichzelf gerechtvaardigde doel (vgl. par. 3.6.3.3).

Het relevantie-criterium kunnen we, in andere en meer algemene bewoordingen, op verschillende plaatsen in de jurisprudentie, althans gedeeltelijk, terugvinden. Zo overwoog de Hoge Raad in het Mensendieck-arrest ${ }^{55}$ onder andere dat bij toetsing of een beding in strijd is met de openbare orde of goede zeden, mede gelet moet worden op:

"Het belang dat de overeenkomst beoogt te dienen."

Het Belgische Hof van Cassatie en de Belgische Raad van State hebben dit criterium eveneens en reeds meermalen gehanteerd bij de toetsing van de toelaatbaarheid van een beperking van grondrechten ${ }^{56}$. Het criterium werd ook gebruikt door het Europese Hof voor de Rechten van de Mens in de zaak betreffende aspecten van de taalregelling van het Belgische onderwijs ${ }^{57}$. Het Hof besliste in zijn arrest dat een inbreuk op het gelijkheidsbeginsel geldig kan zijn, maar dat daarvoor ondermeer vereist is dat:

"La distinction doit poursuivre un but légitime."

Uit het woord "poursuivre" blijkt mijns inziens dat er relevantie tussen doel en middelen wordt geëist.

Het proportionaliteitscriterium oftewel evenredigheidscriterium houdt in dat er een redelijke verhouding moet bestaan tussen het nagestreefde doel en de daartoe in concreto aangewende middelen ${ }^{58}$. In het Mensendieck-arrest ${ }^{59}$ paste de Hoge

55. HR 31 okt. 1969, NJ 1970, 57 met noot G.J.S.

56. Zie woor vindplaatsen, Van Oevelen, blz. 136; De Jonghe/Reijntjens, RW 1975-1976, $2116,2117$.

57. Opgemerkt moet worden dat in deze zaak geen sprake was van horizontale, maar van verticale werking van grondrechten. EHRM 23 juli 1968, CEDH, Série A, vol. 5, blz. 89.

58. Vgl. over het relevantie- en proportionaliteitscriterium: Van Oevelen, blz. 100-102; Alkema, blz. $256,257$. 
Raad dit criterium mijns inziens ook toe, toen hij overwoog dat bij toetsing of een beding in strijd is met de openbare orde of goede zeden, behalve op het belang dat de overeenkomst beoogt te dienen (relevantiecriterium) ook moet worden gelet op de vraag of

"dat belang zo gewichtig is dat het een beperking(....) als waarvan hier sprake is (curs. van mij R.M), rechtvaardigt."

Een soortgelijk criterium werd door de pachtkamer van het Hof Arnhem in $1948^{60}$ al gehanteerd. Het Hof overwoog toen dat het doel van de Protestantse Vereniging, die aan een pachter een stuk grond had verpacht, om "te waken over het protestantisme", het beding, dat de pachtovereenkomst bij een verandering van geloof door de pachter kon worden opgezegd, niet kon rechtvaardigen omdat het beding de geloofs- en gewetensvrijheid van de pachter te zeer aantastte.

In een andere soortgelijke pachtcasus bij het Hof Arnhem ${ }^{61}$ overwoog de pachtkamer dat zij. het onaanvaardbaar en in strijd met de door de grondwet gewaarborgde vrijheid van godsdienst achtte,

"wanneer aan iemand zijn maatschappelijk bestaan zou kunnen worden ontnomen of hij daarin zou kunnen worden bedreigd of zelfs maar gestoord op grond van afwijkende of veranderde inzichten omtrent de godsdienst."

Ook het Europese Hof voor de Rechten van de Mens paste het proportionaliteitscriterium in de hierboven genoemde Belgische taalzaak toe. Het Hof overwoog in deze zaak expliciet:

"L'article 14 est violé lorsqu'il < <est clairement établi > > qu'il n'existe pas de rapport raisonnable de proportionalité entre les moyens employés et le but vise."

Alkema ${ }^{62}$ refereert eveneens aan het relevantie- en het proportionaliteitscriterium. Volgens hem zijn voor de beoordeling van de rechtmatigheid van de beperking van een grondrecht

"het doel van de overeenkomst en de proportionaliteit van de beperking beslissend. "63

De beide criteria zouden in beginsel zowel bij rechtstreekse als indirecte toetsing aan grondrechten kunnen worden gehanteerd ${ }^{64}$. Bij rechtstreekse toetsing zou de rechter moeten nagaan in welke mate het grondrecht in geding horizontaal werkt,

59. HR 31 okt. 1969 , NJ 1970,57 met noot G.J.S.

60. Hof Arnhem 25 okt. 1948, NJ 1949, 331. Vgl, hierover Polak, blz. 72.

61. Hof Arnhem 24 juni 1958, NJ 1959, 473.

62. Alkema, blz. 256.

63. Vgl ook Biesheuvel (Horizontale werking), blz. 165, 221.

64. Anders Van Oevelen, blz 103. Deze meent dat het relevantie- en proportionaliteitscriterium alleen binnen het bestaande privaatrechtelijke instrumentarium kunnen worden toegepast. 
en of het doel, het woorwerp en de aard van de overeenkomst de beperking rechtvaardigen.

Bij indirecte toetsing (deze vorm van toetsing is inherent aan categorie 2 van de glijdende schail), bijvoorbeeld via de goede zeden en de openbare orde, zou de rechter moeten nagaan in welke mate er een inbreuk mag worden gemaakt op de goede zeden en de openbare orde die zijn ingekleurd door een bepaald grondrecht.

Voorafgaand aan de directe toetsing zou de rechter echter moeten vaststellen in welke mate een grondrecht horizontaal werkt. Uiteraard is het zeer moeilijk vast te stellen in welke mate een grondrecht horizontaal werkt. Percentages kunnen nu eenmaal niet worden gegeven. Dit is ook een zwak punt aan het toetsingsmodel dat Van Oevelen beschrijft, waarbij het relevantie- en het proportionaliteitscriterium worden gehanteerd. Om met deze beide criteria te kunnen werken, zou de rechter eerst moeten bepalen in hoeverre een in het geding zijnd grondrecht horizontaal werkt. Anders zou hij immers de criteria niet kunnen toepassen. Binnen de in paragraaf 3.5.1 genoemide categorieën $\mathbb{1}$ tot en met 4 heeft de rechter de ruimte om via het relevantie- en proportionaliteitsbeginsel beperkingen toe te staan. Binnen categorie $5 \mathrm{zal}$ hij voor hantering van deze criteria veel minder ruimte hebben.

Het probleem doet zich echter voor dat de rechter zelf moet bepalen in welke schaal van hørizontale werking hij een bepaald grondrecht indeelt. Hiervoor zal hij soms bijvoorbeeld naar de (on)gelijkheid van partijen, maar ook naar het doel van de rechtshandeling en het verband tussen het doel en de aangewende middelen (beperking van grondrechten) moeten kijken. Enerzijds beïnvloedt de beantwoording van de vraag naar de horizontale werking dus de toepassing van de door Van Oevelen genoemde criteria, anderzijds is voor toepassing van deze criteria relevant dat bekend is in welke mate een in het geding zijnd grondrecht horizontaal werkt ${ }^{65}$.

Modellen zijn echter vereenvoudigde weergaven van de werkelijkheid en als zodanig is het model van Van Oevelen zeer wel te hanteren. In de praktijk zal dit model wellicht niet altijd functioneren. Wel zal een rechter de problemen omtrent de mate van horizontale werking van een grondrecht kunnen omzeilen, door indirect, via privaatrechtelijke open normen, te toetsen. Bij de indirecte toetsing hoeft hij immers niet vast te stellen in welke mate een grondrecht horizontale werking heeft, maar kan hij zich bij de inkleuring van een open norm door een in het geding zijnd grondrecht laten inspireren.

Desalniettemin hier is ter verdere relativering van de waarde van het hierboven beschreven model en de beide criteria een citaat van Oevelen op zijn plaats:

"Deze twee criteria beogen niet meer te zijn dan een leidraad, bij de behandeling van deze problematiek, een begin van antwoord op de hier aan de orde zijnde vragen, en geenszins de enige mogelijke benaderingswijze van dit vraagstuk." 166

65. Biesheuvel (Horizontale werking), blz 221.

66. Van Oevelen, blz. 100. Vgl. ook Alkema, blz. 257. 
Wellicht is een "volmaakt" toetsingsmodel niet te bedenken, omdat bij toetsing aan grondrechten in private verhoudingen in concrete gevallen zeer veel factoren ${ }^{67}$ van belang kunnen zijn, die samen een brij vormen waaraan zeer moeilijk een toetsingsmodel kan worden aangepast. Bij gebrek aan beter zullen de beide genoemde criteria in het navolgende echter worden gehanteerd.

Mijns inziens zijn de beide criteria ook te hanteren bij een probleem dat zich bij toetsing van de welstandsbepalingen in het appartementsrecht snel zal voordoen, namelijk botsing van grondrechten. Het is bijvoorbeeld zeer well denkbaar dat een gemeenschap van streng rooms katholieke of orthodox protestantse appartementseigenaars een homofiel, of iemand met een ander geloof, niet wil toelaten als bewoner. In dat geval botst de vrijheid van godsdienst (art. 6 grondwet) met het non-discriminatie beginsel (art. 1 Grondwet).

Laten we aannemen dat het non-discriminatiebeginsel en de godsdienstvrijheid grondrechten van gelijke orde zijn. Stel dat de vereniging van appartementseigenaars met een. strenge katholieke signatuur aan een homofiele eigenaar de toestemming tot ingebruikneming weigert, met de motivering dat zijn sexuele gerichtheid niet overeenstemt met de godsdienstige overtuiging van de overige eigenaars. Op zichzelf zijn er nu nog onvoldoende gegevens om te bepalen in wiens voordeel de balans van vrouwe Justitia moet doorslaan. We nemen nu verder aan dat de appartementseigenaars gezamenlijk een appartementsgebouw bewonen met als doel om gezamenlijk hun geloof te belijden en bijvoorbeeld ook in het gebouw religieuze bijeenkomsten of kerkelijke vieringen houden. (In dit geval kan de vrijheid van vereniging ook nog in het voordeel van de appartementseigenaars werken.)

Het doel van de beperking, de handhaving van een samenstelling van de bewonersgroep uit mensen die gezamenlijk het geloof kunnen en willen belijden, wordt op zichzelf door de vrijheid van godsdienst en de vrijheid van vereniging gerechtvaardigd. De beperking van het non-discriminatiebeginsel is ook relevant voor het nagestreefde doel. De vraag is echter of er in dit geval geen sprake zou zijn van disproportionaliteit tussen doel en middelen. Wellicht zou weigering van de toestemming om met de appartementseigenaars aan deze vieringen deel te nemen, immers al voldoende zijn om de onrust te voorkomen. Moet niet worden aangenomen dat proportionaliteit ontbreekt als de verwezenlijking van het nagestreefde doel in voldoende mate ook kan geschieden op een wijze die een geringere inbreuk maakt op een grondrecht?

67. Vgl. Biesheuwel, blz 45-49. 
De "Algemene wet gelijke behandeling" (AWGB) ${ }^{68}$ zal, indien zij ooit wordt aangenornen, mijns inziens geen verandering brengen in het hierboven beschrevene. Deze wet geeft een afweging tussen het "non-discriminatiebeginsel" en de andere grondrechten. Op grond van deze wet zal - behoudens de in de wet zelf gegeven uitzonderingen - onderscheid dat anders dan op grond van godsdienstige overtuiging wordt gemaakt, verboden zijn. Volgens artikel 1 van deze wet moet het begrip onderscheid worden gesplitst in direct en indirect onderscheid. Direct onderscheid is onderscheid op grond van godsdienst, levensovertuiging, politieke gezindheid, ras, geslacht, hetero- of homosexuele gerichtheid of burgerlijke staat (art. 1 sub a AWGB). Indirect onderscheid is onderscheid dat is gebaseerd op een andere hoedanigheid of gedraging dan in artikel 1 sub a genoemd, dat ertoe leidt dat iemand die onder de categorieën van lid 1 sub a valt, toch wordt benadeeld. Beide vormen van onderscheid zijn verboden, behalve indirect onderscheid dat objectief gerechtvaardigd is of bij positieve discriminatie ${ }^{69}$.

De AWGB is niet van toepassing op kerkgenootschappen of andere genootschappen op geestelijke grondslag of op het geestelijk ambt (art. 3 AWGB). Dit laatste betekent mijns inziens niet dat kerkgenootschappen e.d. vrijelijk mogen discrimineren, maar slechts dat voor de afweging van de godsdienstvrijheid tegen het discriminatieverbod, de hiervoor besproken algemene regels gelden, aangezien speciale wettelijke regels ontbreken. Dit betekent naar mijn mening dat de uitkomst vañ het voorbeeld met de katholieke gemeenschap van appartementseigenaars en de homofiele aspirant-bewoner, gelijk blijft. Verenigingen die geen zuiver religieuze of geestelijke grondslag hebben, zijn echter wel aan de in de AWGB genoemde criteria gebonden.

Evenmin brengt de AWGB verandering in het voorbeeld met de oud-strijders en de student. Leeftijd of levenservaring is immers niet in het verbodslijstje van artikel 1 opgenomen. De vraag kan opkomen of de oud-strijders een homofiele oudstrijder zouden mogen weigeren? Deze vraag moet ontkennend worden beantwoord, omdat in dat geval wegens homofilie zou worden gediscrimineerd. Een andere vraag is of ze de hierboven genoemde student wel zouden moeten toelaten als hij homofiel was. Het antwoord hierop luidt mijns inzien eveneens ontkennend. De vereniging van appartementseigenaars (oud-strijders) discrimineert hier weliswaar indirect, maar dit indirecte onderscheid wordt objectief gerechtvaardigd door de samenstelling van de gemeenschap van appartementseigenaars.

Artikel 7 AWGB brengt hierin geen verandering. Dit artikel bepaalt ondermeer dat het verboden is bij het aanbieden van goederen of diensten en bij het sluiten,

68. Er zijn momenteel twee wetsontwerpen, waarin getracht wordt de "gelijke behandeling" te regelen. Enerzijds is er het regeringsontwerp AWGB, Bijl. Hand. II, 1987-1988, 20501, nrs. 1-4; Bijl. Hand. II, 1988-1989, 20501, nr. 5, anderzijds is er het initiatiefvoorstel van de kamerleden Van Nieuwenhoven en Haas-Berger, houdende regels ter bestrijding van seksediscriminatie (wet tegen seksediscriminatie), Bijl. Hand. II, 1986-1987, 20065, nurs. 1-3, Bijl. Hand. II, 1987-1988, 20065, nrs. 4-8; Bijl. Hand. II, 1988-1989, mis. 9-12. In de tweede nota van wijziging is de strekking van het wetswoorstel verruimd, doordat "seksediscriminatic" door "discriminatie" werd vervangen, zodat het ontwerp AWGB en dit initiatiefontwerp nu betzelfde beogen te regelen. In het navolgende zal stechts aandacht worden besteed aan het ontwerp AWGB.

69. Vgl over de AWGB: Elders, blz. 98-102 en thet NJCM commentaar bij het voorontwerp van een wet gelij.ke behandeling, NJCM-Bulletin 1982, blz. 74-116. 
uitwoeren of beëindigen van overeenkomsten onderscheid te maken, indien dit geschiedt

"door instellingen die werkzaam zijn op het gebied van volkshuisvesting..."

Nog daargelaten of de weigering van toestemming tot ingebruikneming of ontzegging van verder gebruik tot een appartementencomplex onder de in de aanhef van lid 7 bedoelde handelingen valt, is het zeer te betwijfelen of een gemeenschap van appartementseigenaars of de daaraan gekoppelde vereniging, een instelling op het gebied van de volkshuisvesting is. Als dit niet het geval is, is de AWGB niet van toepassing op ontzegging van gebruik van appartementsrechten. Zelfs als deze wet daarop wel van toepassing is, geldt de algemene regel dat indirect onderscheid dat objectief gerechtvaardigd is, toegestaan is. In die zin lijkt de AWGB geen veranderingen mee te brengen ten aanzien van de positie van appartementseigenaars en (aspirant-)bewoners volgens het hiervoor beschrevene. Gewone verenigingen mogen mijns inziens ook nu over het algemeen geen direct onderscheid op grond van de genoemde criteria maken, tenzij dit voortvloeit uit een grondrecht als de vrijheid van godsdienst of uit andere factoren, zoals de beslotenheid van de vereniging. Een dergelijke ballotage zal mijns inziens ook nu al de toetsing aan het relevantiecriterium moeten doorstaan, waarbij moet worden afgewogen of de inbreuk op het non-discriminatiebeginsel gerechtvaardigd wordt door het doel, de aard en het onderwerp van de ballotage. Het doel van de ballotage rechtvaardigt dan immers in beginsel niet de inbreuk op het discriminatieverbod, tenzij er naast de reden "wij houden niet van homofielen" ook nog een andere reden is aan te wijzen, bijvoorbeeld godsdienstige overtuiging. In het woord "rechtvaardigen" ligt een afwegingsvrijheid voor de rechter besloten, die naar redelijkheid zal moeten vaststellen welk belang in een concreet geval moet prevaleren.

In de AWGB wordt voor bepaalde gevallen aangegeven dat verenigingen niet mogen discrimineren. Deze gevallen hebben voornamelijk betrekking op arbeidsverhoudingen en het aanbieden van goederen of diensten (zie art. 7 AWGB). Deze discriminatieverboden gelden niet alleen voor verenigingen, maar ook voor andere instellingen, voor zover zij geen geestelijke grondslag hebben. Ballotage door verenigingen zal mijns inziens niet onder de werkingssfeer van de AWGB vallen, waardoor de algemene regels van horizontale werking van grondrechten en afweging van botsende grondrechten, blijven.

\subsection{Toestemming tot ingebruikneming}

\subsection{Algemene opmerkingen}

Zoals reeds is vermeld in de algemene opmerkingen bij dit hoofdstuk wordt de regeling die wordt bedoeld in artikel $875 \mathrm{f}$ lid 4 laatste zin, in praktijk onder meer uitgewerkt in een toelatingsregeling. Deze toelatingsregeling houdt in dat een aspirant-bewoner toestemming tot ingebruikneming van zijn privé-gedeelte moet vragen en hem deze toestemming kan worden geweigerd op grond van in het reglement omschreven gewichtige redenen. De vraag komt op of de zin 
"een zodanige regeling kan inhouden dat de vergadering van eigenaars bevoegd is een appartementseigenaar of degene die zijn rechten uitoefent, om nader in het reglement aangegeven gewichtige redenen het gebruik van deze gedeelten te ontzeggen",

wel de mogelijkheid tot een dergelijke regeling schept. Er wordt wel beweerd dat deze zin slechts een erkenning inhoudt van de regeling van ontzegging van verder gebruik, althans dat uit deze zin niet duidelijk een erkenning van de toelatingsregeling blijkt, en deze toelatingsregeling derhalve expliciet zou moeten worden erkend ${ }^{7}$. Toegegeven moet worden dat de laatste volzin van artikel $875 \mathrm{f}$ lid 4 op het eerste gezicht alleen een erkenning van de regeling van ontzegging van verder gebruik lijkt te geven. Blijkens de wetsgeschiedenis van de appartementenwet uit 1972 wilde de wetgever echter door opneming van de laatste volzin van artikel $875 \mathrm{f}$ lid 4 de toen geldende praktijkregelingen erkennen. Dit blijkt uit het feit dat in de memorie van toelichting ${ }^{71}$ bij de wet van 1972 bij artikel $875 \mathrm{f} \mathrm{lid} 4$ laatste zin wordt gezegd:

"In het huidig recht bestaat hierover verschil van mening."

Nu blijkt uit deze zin op zich nog niet dat de wetgever de gehele geldende welstandsbepalingen-praktijk wilde erkennen, maar bij gebreke van ieder spoor van ontkenning văn een dergelijke algehele erkenning, dient mijns inziens wetshistorisch interpreterend wel degelijk te worden geconcludeerd dat de laatste volzin van artikel $875 \mathrm{f}$ lid 4 de mogelijkheid opent tot het opnemen van zowel toelatingsregelingen als regelingen van ontzegging van verder gebruik.

Krachtens artikel $875 \mathrm{f} \mathrm{lid} 4 \mathrm{BW}$ kan dus wegens een gewichtige reden aan een aspirant-bewoner de ingebruikneming van de privé-gedeelten worden ontzegd. De gewichtige reden moet in het reglement van splitsing wel nader zijn omschreven. De omschrijving van de gewichtige reden kan op twee manieren geschieden. Enerzijds kan de gewichtige reden worden uitgewerkt in een negatief geformuleerde afwijzingsgrond, bijvoorbeeld dat personen ouder dan 55 jaar niet als gebruiker van privé-gedeelten worden toegelaten. Anderzijds kan de gewichtige reden worden uitgewerkt in een positief bepaald toelatingscriterium, bijvoorbeeld dat personen jonger dan 55 jaar worden toegelaten. Materieel maakt dit geen verschil ${ }^{72}$.

Pitlo/Brahn ${ }^{73}$ stelt dat het vrijwel ondoenlijk is om in het reglement van splitsing alle omstandigheden te vermelden, die een gewichtige reden zouden kunnen opleveren om een aspirant-bewoner het gebruik van zijn privé-gedeelten te ontzeggen. Op grond daarvan acht Pitlo/Brahn een algemene clausule, zoals ze door de Koninklijke Notariële Broederschap in zijn standaardreglementen wordt gehanteerd, aanvaardbaar. Hierbij wordt dan vermeld dat bij een eventuele weigering well hoge eisen an de motivering moeten worden gesteld. Bijzonder bevorderlijk voor de rechtszekerheid is dit natuurlijk niet. Op het moment dat de aspirant-bewoner toestemming vraagt tot ingebruikneming van de privé-gedeelten, kan hij immers zelf niet nagaan of de toestemming aan hem zal worden verleend.

70. Praktijkboek Onroerend Goed, ID, blz, 30.

71. Bijl. Hand. II, 1970-1971, 10987, nr. 3, ble 15.

72. Vgl. Pres. Rb. Arnhem 20 dec. 1984, Kort Geding 1985, 43.

73. Pitlo/Brahn, blz 391. 
Desalniettemin lijkt het inderdaad ondoenlijk om in het reglement alle omstandigheden te vermelden, die aanleiding zouden kunnen geven tot weigering van een gegadigde als bewoner. Derhalve moet een algemene clausule, een "Generalklausel" (vgl. hierna par. 3.6.3.1) zoals De Groot het noemt ${ }^{74}$, aanvaardbaar worden geacht. Dat neemt echter niet weg dat men naar mijn mening miet ontslagen zou moeten zijn van de plicht om zoveel mogelijk weigeringsgronden op te sommen. Naast deze nooit volledige opsomming zou dan de regeling van de Koninklijke Notariële Broederschap kunnen worden gehanteerd. Indien dan deze laatste regeling zou worden toegepast zou de afwijzing inderdaad, zoals Pitlo/Brahn stelt, zeer goed gemotiveerd moeten worden.

Een uitwerking van de gewichtige reden op een zodanige wijze dat zoveel mogelijk weigeringsgronden expliciet zijn genoemd en dat daarnaast de "Generalklausel" is opgenomen, zou mijns inziens een grotere rechtszekerheid voor de om toelating verzoekende verschaffen. Daarnaast zou een zodanige uitwerking handvatten bieden aan de rechter, die ingeval van beroep tegen weigering op grond van de "Generalklausel" zou moeten toetsen of in het hem voorgelegde geval in redelijkheid en billijkheid van de bewoners van een appartementencomplex niet zou kunnen worden verlangd, dat zij de aspirant-bewoner in hun midden opnemen.

Alworens op specifieke criteria in te gaan die in de praktijk worden gehanteerd, zullen eerst de theoretisch mogelijke rechtsmiddelen worden beschreven die aan een aspirant-bewoner openstaan, indien hij geen toestemming krijgt om zijn appartement te bewonen. Door de bespreking van deze rechtsmiddelen zal het bij de bespreking van de specifieke criteria gemakkelijker zijn om de eventuele (on)aantastbaarheid van deze criteria vast te stellen.

\subsubsection{Rechtsmiddelen tegen weigering van toestemming tot ingebruikneming}

Een aspirant-bewoner die geen toestemming tot ingebruikneming van een appartement krijgt heeft verscheidene procedures tot zijn beschikking om, indien hij van mening is dat de toestemming ten onrechte is geweigerd, zijn recht te halen. In de appartementenwet zelf staan al twee mogelijkheden genoemd.

\subsubsection{Vervangende machtiging tor ingebruikneming}

Ten eerste kan de appartementseigenaar die geen toestemming tot ingebruikneming verkrijgt, de kantonrechter verzoeken een vervangende machtiging tot ingebruikneming te verlenen ingevolge artikel $8750 \mathrm{BW}$. Deze vervangende machtiging kan worden verleend

"indien de medewerking of toestemming zonder redelijke grond wordt geweigerd of degene die haar moet geven zich niet verklaart" $(8750$, eerste lid BW).

74. De Groot, WPNR 5570 , blz 413 . 
In paragraaf 2.4 .4 werd all vermeld dat de kantonrechter bij een procedure ex artikel $8750 \mathrm{BW}$ in beginsel vol moet toetsen en dat Pitlo/Brahn ${ }^{75}$ enkele richtlijnen heeft gegeven hoe de kantonrechter zou moeten handelen indien hij weigering van toestemming tot bewoning zou moeten toetsen. Allereerst zou de rechter moeten objectiveren :

"kan men in redelijkheid tot de conclusie komen dat een bepaalde grond gewichtig genoeg is om toestemming tot gebruik te weigeren"?

Indien de rechter deze vraag bevestigend zou beantwoorden zou hij vervolgens moeten subjectiveren:

"kan deze groep van appartementseigenaars in redelijkheid menen, dat voor hen de genoemde grond een gewichtige reden tot weigeren oplevert"?

Hieruit lijkt voort te vloeien dat Pitlo/Brahn meent dat de rechter bij welstandsbepalingen marginaal moet toetsen (vgl. par. 2.4.4). Deze veronderstelling vloeit mijns inziens voort uit het feit dat krachtens artikel $875 \mathrm{f}$ lid 4 BW aan een aspirant-gebruiker van een appartementsrecht wegens een gewichtige reden het gebruik kan worden ontzegd, en dat de gewichtige reden in de modelreglementen ondermeer in een "Generalklausel" wordt uitgewerkt. Bij toetsing van een ontzegging van gebruik in de artikel $8750 \mathrm{BW}$-procedure zou de rechter derhalve moeten nagaan of de vergadering van eigenaars c.q. het besturur zonder redelijke grond heeft beslist dat van de overige appartementseigenaars naar redelijkheid en billijkheid niet kan worden verwacht dat zij de gegadigde in hun midden opnemen. Deze cumulatie van vage normen lijkt tot marginale toetsing te leiden, maar mijns inziens ten onrechte. De rechter moet immers nagaan of de vergadering op een redelijke grond heeft aangenomen dat van de overige appartementseigenaars niet kon worden verwacht dat zij de aspirant-bewoner in hun midden zouden opnemen. Hij moet derhalve niet nagaan of de vergadering in redelijkheid tot zijn beslissing heeft kunnen komen, maar of de reden die aan de beslissing van de vergadering tot weigering ten grondslag lag, redelijk is.

De rechter moet met andere woorden nagaan of de weigeringsgrond (en niet de beslissing van de vergadering dat in redelijkheid en billijkheid niet van de bewoners mag worden gevergd dat zij de gegadigde in hun midden opnemen) objectief gezien redelijk is. Vervolgens moet hij nagaan of deze weigeringsgrond subjectief (in het concrete geval) ook redelijk is. Als de weigeringsgrond niet redelijk is, is er geen gewichtige reden tot weigering zoals vereist op grond van artikel $875 \mathrm{f}$ lid $4 \mathrm{BW}$. Als de weigeringsgrond wel redelijk is, kan in redelijkheid niet van de overige bewoners worden gevergd dat zij de gegadigde in hun midden opnemen en is er derhalve sprake van een gewichtige reden. Als de overige bewoners menen dat in redelijkheid en billijkheid niet van hen kan worden gevergd dat zij een gegadigde in hun midden opnemen, betekent dit immers nog niet dat zij dat op een redelijke grond menen.

75. Pitlo/Brahn, blz. 393. 
Bij de objectieve toets moet de rechter allereerst nagaan of de weigeringsreden ertoe leidt dat de weigering zelf - een rechtshandeling - een geoorloofde oorzaak mist. Als de weigering een geoorloofde oorzaak mist vanwege de inhoud van de weigeringsgrond, is deze weigeringsgrond niet redelijk. De rechter moet derhalve toetsen of de specifieke weigering op grond van de opgegeven weigeringsreden, een geoorloofde oorzaak mist. In feite toetst de rechter derhalve niet alleen de weigeringsgrond zelf, maar de gehele weigeringshandeling.

Bij de toetsing van de weigering aan het oorzaakvereiste moet de rechter nagaan of de weigering in strijd is met de wet, de openbare orde of de goede zeden (artt. 1371 en 1373 BW; 3.2.7 / 3:40 NBW). Hierbij kan hij tevens indirect aan de grondrechten toetsen, eventueel via het relevantie-en proportionaliteitsbeginsel en uiteraard alleen indien er grondrechten in het geding zijn. Als er geen grondrechten in het geding zijn en er evenmin op andere gronden sprake is van strijd met de wet, de openbare orde of de goede zeden, is er geen sprake van een ongeoorloofde oorzaak. De rechtshandeling is dan in beginsel geldig (vgl. ook art. 3.1.1.13 / 3:12 NBW). De toetsing aan het relevantiecriterium en het proportionaliteitscriterium, de evenredigheidstoets, zou de rechter overigens mijns inziens ook kunnen toepassen indien bij de weigering geen grondrechten in het geding zijn. $\mathrm{Na}$ onderzoek met betrekking tot de vraag of het doel van de ontzegging op zichzelf gerechtvaardigd is, zou de rechter een doelmatigheidstoets kunnen doen. Deze toets houdt dan in dat de rechter moet nagaan of de reden die men hanteert om mensen de toestemming tot ingebruikneming te weigeren, geschikt is om het doel dat men nastreeft te verwezenlijken. Denk hierbij aan de leeftijdsgrens die is bedoeld om mensen die te zeer verzorgingsbehoeftig zijn, uit de gemeenschap van appartementseigenaars te weren. Aangezien leeftijd geen geschikte graadmeter is om de mate van verzorgingsbehoefte te meten, beantwoordt de reden van weigering (te hoge leeftijd) niet aan het doel (gemeenschap van gezonde en niet verzorgingsbehoeftige mensen). Daarom is een weigering op grond van een reden die de doelmatigheidstoets niet doorstaat, onredelijk. Als de weigering de doelmatigheidstoets doorstaat, en derhalve het doel door de gehanteerde middelen verwezenlijkt kan worden, moet de rechter vervolgens nagaan of de middelen niet te zwaar zijn om het doel te verwezenlijken. Hij moet met andere woorden nagaan of er geen lichtere sanctie mogelijk is dan ontzegging van ingebruikneming. Als een vergadering van eigenaars bijvoorbeeld een prostituee de toestemming tot ingebruikneming onthoudt, omdat zij bang is dat deze aspirant-bewoonster haar beroep in haar appartement zal uitoefenen, kan men deze angst ook wegnemen door de dame in kwestie een verklaring te laten ondertekenen (eventueel verzwaard met een boeteclausule), dat zij haar beroep niet in het gebouw zal uitoefenen. Uiteraard moet de aspirant-bewoonster wel bereid zijn de verklaring te ondertekenen, omdat de weigering van toestemming tot ingebruikneming anders wel gerechtvaardigd zal zijn.

De hier genoemde gevallen zijn echter onzuivere voorbeelden van casus waarin geen grondrechten in het geding zijn, omdat steeds het recht op huisvesting een rol zal spelen. Een beter voorbeeld is wellicht het volgende. Een vereniging van eigenaars van garages weigert aan een huurder van een garage de toestemming tot ingebruikneming, omdat de huurder bekend staat als een notoir knutselaar aan en opknapper van oude auto's. De vereniging wil dat het gemeenschappelijke terrein niet wordt ontsierd door auto-onderdelen etc. Het doel kan op zichzelf redelijk 
worden geacht en de ontzegging van ingebruikneming is eveneens relevant, c.q doelmatig, voor de verwezenlijking van het doel. De vraag is echter of er geen sprake is van disproportionaliteit. Wellicht zou ook hier een overeenkomst met de aspirant-gebruiker voldoende zijn, waarin deze zich zou verplichten de garage slechts voor het parkeren van zijn auto te gebruiken en niet voor zijn hobby.

Als een weigeringsreden en derhalve de weigering zelf, de objectieve toets doorstaat, moet de rechter nagaan of in het concrete geval de weigering ook op een redelijke grond berust. Bij deze subjectivering zou de rechter - bij toetsing van een besluit dat is genomen op grond van de "Generalklausel" (zie par. 3.6.3.1) - te rade kunnen gaan bij de concrete in het reglement opgenomen toelatingscriteria. Indien de reden waarom men heeft geweigerd in het kader van de concrete criteria uit de toon zou wallen, zou de rechter sneller kunnen bepalen dat deze reden gesubjectiveerd geen gewichtige reden tot weigering oplevert. De concrete toelatingscriteria zouden zo een referentiekader voor de subjectiverende rechter kumnen vormen.. Als een vereniging van eigenaars bijvoorbeeld alleen maar specifieke criteria heeft opgenomen waaruit een rooms katholieke overtuiging blijkt, en men vervolgens via de "Generalklausel" een aspirant-bewoner de toestemming tot ingebruikneming ontzegt, omdat hij op grond van zijn maatschappelijke status (omdat hij "slechts" een timmerman is, terwijl de overige bewoners allemaal middenstanders zijn) niet in de gemeenschap van appartementseigenaars zou passen, kan dit voor de kantonrechter aanleiding zijn om te besluiten dat van een gewichtige reden geen sprake is. Uiteraard wordt er bij dit voorbeeld van uitgegaan dat de aspirant-bewoner wel aan de specifieke toelatingscriteria voldoet.

De kantonrechter zou daarentegen eerder tot geldigheid van de weigering kunnen besluiten, indien uit de specifieke toelatingscriteria blijkt, dat de vereniging van eigenaars een samenstelling uit middenstanders nastreeft.

Daarnaast zou de rechter bij de subjectivering uiteraard ook moeten nagaan of het inroepen van een bepaald feit als reden tot weigering niet in strijd met de goede trouw is, bijvoorbeeld omdat er sprake is van willekeur. Men kan zich voorstellen dat een persoon om bepaalde redenen als bewoner wordt geweigerd, terwijl een ander persoon waarbij hetzelfde feit speelde, wel als bewoner is toegelaten ${ }^{76}$. De vorige druk van Pitlo/Brahn noemde hier het voorbeeld van een man met een orgel die niet werd toegelaten, terwijl elders in het gebouw een persoon met een orgel woonde. In de literatuur is er reeds op gewezen dat dit geen gelukkig voorbeeld is, nu welstandsbepalingen zich op de persoon richten, en het hebben van een orgel in het reglement kan worden verboden $\pi$. Beter is daarom het voorbeeld van de operazanger die tegenwoordig bij Pitlo/Brahn optreedt ${ }^{78}$. De rechter zal dus ook aan de goede trouw moeten toetsen. Tevens zal hij moeten bezien of de feiten, waarop een vergadering van eigenaars haar weigering baseert, kloppen en of de feiten onder de gehanteerde reden tot weigering vallen.

76. Pitlo/Brahn, bly 393.

77. Smeets/Mertens, blz. 19.

78. Pitlo/Brahn, blz, 393. 
Indien een weigering van toestemming tot ingebruikneming in het concrete geval de objectieve en/of subjectieve toets niet zou doorstaan, zou de rechter de vervangende machtiging tot ingebruikneming moeten verlenen.

Bij het hier besproken toetsingsmodel moet opgemerkt worden dat de toetsing aan het relevantiecriterium en het proportionaliteitscriterium bij beperking van grondrechten een ongeoorloofde oorzaak kan opleveren, terwijl deze toetsing buiten de grondrechten om slechts de redelijkheid aan de weigeringsgrond kan ontnemen. Dit verschil vloeit voort uit het feit dat een onevenredige of ondoelmatige beperking van een grondrecht strijd met de openbare orde en de goede zeden oplevert.

\subsubsection{Vernietiging van het besluit}

De tweede mogelijkheid die aan de om toelating verzoekende op grond van de appartementenwet openstaat is vernietiging van het besluit van de V.v.E. op de in artikel $876 \mathrm{~d}$ genoemde gronden. Deze gronden zijn:

1. strijd met de wettelijke bepalingen die de bevoegdheid van de vergadering en de wijze van totstandkoming van besluiten regelen;

2. strijd met de akte van splitsing;

3. strijd met de goede trouw.

Om na een weigering van toestemming tot bewoning door de V.v.E van een appartementencomplex toch als bewoner te worden toegelaten, biedt artikel $876 \mathrm{~d}$ BW echter niet de meest geëigende mogelijkheid ${ }^{79}$. Met de vernietiging van het besluit van de V.v.E. om een bepaalde aspirant-bewoner niet toe te laten, heeft deze aspirant bewoner immers nog niet de toestemming om wel van zijn appartement gebruik te maken. Hij is weer terug bij af, en zal opnieuw toestemming tot bewoning moeten vragen. De V.v.E. heeft dan de mogelijkheid om de toestemming tot bewoning opnieuw met een verbeterde motivering te weigeren ${ }^{80}$.

\subsubsection{Onrechtmatige daad}

In sommige gevallen zou een weigering van toestemming tot ingebruikneming een onrechtmatige daad van de zijde van de vergadering van eigenaars kunnen opleveren (1401 BW; 6.3.1.1 / 6:162 NBW). Dit zou bijvoorbeeld het geval zijn als de weigering gebaseerd zou zijn op gronden die als discriminatoir kunnen worden aangemerkt, bijvoorbeeld als men op grond van huidskleur wordt geweigerd. Het probleem is dat discriminatie in het merendeel der gevallen moeilijk aantoonbaar zal zijn. Ingevolge de Binderen-zaak ${ }^{81}$ kunnen echter statistische gegevens als bewijs van discriminatie dienen. Als bij een appartementencomplex zou blijken dat de vergadering van eigenaars onevenredig vaak buitenlanders of mensen met een

79. Vgl. Asser/Beekhuis II, blz. 329; Beekhuis/Linders, VI par, 6, nr. 5; Mertens, blz, 246; Pitlo/Brahn, blz. 393; Smeets/Mertens, blz. 19, 20.

80. Vgl. Mertens, blz 246.

81. HR 10 dec. 1982, NJ 1983, 687 (Binderen-Kaya). 
andere huidskleur als bewoner weigert, zou dit voldoende bewijs kunnen opleveren dat de vergadering discrimineert en derhalve een onrechtmatige daad pleegt. Voordelen van een actie uit onrechtmatige daad zijn dat schadevergoeding, verbod van onrechtmatig handelen en gebod om op bepaalde wijze te handelen kunnen worden geëist ${ }^{82}$. Een gebods- en verbodsactie zal bij verzoek om toestemming tot ingebruikneming echter vaak niet doeltreffend zijn, nu de beslissing van de vergadering van eigenaars een eenmalige beslissing is en men vooraf niet weet wat de vergadering zal beslissen en waarom ze dat zal beslissen. Alleen als er statistische gegevens zijn die aantonen dat de vergadering onrechtmatig handelt, kan men wellicht vooraf een verbods- of gebodsactie instellen. Hetzelfde geldt indien de administrateur in eerste instantie onrechtmatig heeft gehandeld. Voor het beroep bij de vergadering van eigenaars kan men dan een actie uit onrechtmatige daad instellen.

\subsubsection{Dwaling/Ontbindende voonwaarde}

Een andere mogelijkheid voor een koper van een appartement die voor het ondertekenen van de voorlopige koopakte niet op het bestaan van welstandsbepalingen is gewezen door verkoper of tussenpersoon ${ }^{83}$, is een vordering tot vernietiging van de koopovereenkomst wegens dwaling in de zelfstandigheid der zaak $^{84}$. Asser/Beekhuis legt een zekere verantwoordelijkheid bij de notaris om een koper van een appartement op het bestaan van eventuele welstandsbepalingen te wijzen. Deze verantwoordelijkheid rust echter evenzeer bij de makelaar of verkoper, nu bij of met hen het voorlopig koopcontract wordt getekend, en derhalve de koop wordt gesloten ${ }^{85}$. Hierbij kan worden opgemerkt dat de mogelijkheid bestaat om de weigering door de vergadering van eigenaars om toestemming tot ingebruikneming van een appartement te verlenen, als ontbindende voorwaarde in het koopcontract op te nemen ${ }^{36}$. Beekhuis/Linders wijst erop dat eveneens kan worden bepaald, dat

"ingeval van weigering de verkoper verplicht zal zijn op verzoek van de koper ingevolge art. 8750 beroep bij de kantonrechter in te stellen."

De koper zelf heeft deze beroepsmogelijkheid immers niet, zolang hij geen eigenaar is ${ }^{87}$. Mijns inziens is een dergelijke bepaling, hoe wenselijk de gevolgen ervan ook zijn, in het huidige stelsel van het appartementsrecht echter niet mogelijk. Artikel 875o BW spreekt immers duidelijk over de eigenaar die, indien hij medewerking van de vergadering van eigenaars nodig heeft, vervangende machtiging tot ingebruikneming kan vragen. Bij een verzoek om toestemming tot ingebruikneming door een huurder heeft de eigenaar geen medewerking of toestemming van de vergadering nodig, en kan hij dus ook niet vervangende machtiging voor de huurder vragen.

82. Stein, blz, $212,213$.

83. Vigl. Smeets/Mertens, blz. 20; Mertens, blz, 246.

84. Asser/Beekhuis II, blz. 329.

85. Asser/Beekhuis II, blz. 329; Smeets/Mertens, blz. 20; Mertens, blz. 246.

86. Vgl. Smeets/Mertens, blz. 20.

87. Beekhuis/Linders, VI par. 6, nr. 5. 


\subsubsection{Aanwullende opmerkingen}

Vervangende machtiging tot ingebruikneming kan als er een spoedeisend belang is, ook in kort geding worden gevorderd. Daarbij kan men, als er tevens sprake is van een onrechtmatige daad, schadevergoeding vorderen voor de tijd dat men bijwoorbeeld hotel- of andere kosten heeft die een gevolg zijn van een (waarschijnijk) niet op redelijke gronden geweigerde toestemming tot bewoning. De schadevergoedingsvordering dient dan uiteraard wel een spoedeisend karakter te hebben ${ }^{88}$.

De beroepsmogelijkheden van de artikelen $876 \mathrm{~d}$ en 8750 BW staan alleen maar open voor appartementseigenaars, en in het geval van artikel $876 \mathrm{~d}$, andere stemgerechtigden. Dit heeft tot gevolg dat bijvoorbeeld huurders geen beroepsmogelijkheid hebben als hen toestemming tot ingebruikneming wordt ontzegd. Een uitzondering hierop vormt het geval dat in de akte van splitsing aan huurders stemrecht in de vergadering van eigenaars is verleend ${ }^{89}$. Dan hebben de huurders de artikel $876 \mathrm{~d}$ BW procedure nog tot hun beschikking. De huurders zullen de verhuurder (meestal appartementseigenaar) soms echter kunnen aanspreken uit wanprestatie (zie par. 4.4.4.1).

\subsubsection{Toestemming tot ingebruikneming - specifieke criteria (praktijkvoorbeelden)}

De vraag komt op wellke specifieke criteria - negatief geformuleerde afwijzingscriteria of positief geformuleerde toelatingscriteria - toelaatbaar zijn en welke niet. Met andere woorden, welke criteria kunnen een gewichtige reden in de zin van artikel $875 \mathrm{f}$ lid 4 opleveren? De jurisprudentie op dit gebied ontbreekt nagenoeg. In het onderstaande zullen de criteria die in de literatuur en jurisprudentie naar voren zijn gebracht, worden besproken. De opsomming beoogt slechts een voorbeeldfunctie en behandelt derhalve geenszins alle criteria die in de praktijk zouden kunnen worden gehanteerd.

\subsubsection{De "Generalklausel"}

Voordat op de specifieke toelatingscriteria zal worden ingegaan, verdient de "Generalklausel" uit de standaardreglementen van de Koninklijke Notariële Broederschap nog enige aandacht. In paragraaf 3.3.1 werd deze "Generalklausel" al genoemd. In het reglement 1983 luidt deze algemene clausule als volgt:

"De vergadering zal de gegadigde slechts mogen weigeren, indien naar redelijkheid en billijkheid van de overige bewoners niet kan worden verlangd dat zij de gegadigde in hun midden opnemen (...)" (art. 24a lid 3 modelreglement 1983).

88. Stein, blz. 212, 213; Pres. Rb. Groningen 18 mei 1961, NJ 1961, 486. Vgl. ook M'Barek arrest, HR 29 maart 1985, RvdW 1985, 72, A.A. 1985, blz. 488 e.v.

89. Kleijn/Verdoes Kleijn, blz 352. 
Het reglement 1987 bevat, zoals al eerder werd vermeld, een soortgelijke clausule. Voor de duidelijkheid wordt deze hier nog eens herhaald:

"Weigering van de verzoeker of van huisgenoten die hij heeft opgegeven, mag slechts plaatsvinden indien naar billijkheid van de overige bewoners niet mag worden verlangd dat zij betrokkenen in hun midden opnemen" (art. 29 lid 4 modelreglement 1987).

Het vijfde lid van artikel 29 modelreglement 1987 vermeldt daarbij dat het bestuur bij toepassing van deze norm bijzonder acht moet slaan op de gezondheidstoestand en de solvabiliteit wan betrokkenen.

Interessant aan met name de regeling van het reglement 1987 is, dat het kennelijk mogelijk is dat een verzoeker wordt toegelaten, terwijl zijn huisgenoten worden geweigerd. Dit vloeit mijns inziens voort uit de formulering "weigering van de verzoeker of van huisgenoten". In de praktijk zal een weigering van alleen de huisgenoten tot resultaat hebben, dat ook de verzoeker zelf de privé gedeelten niet in gebruik zal nemen. Dit resultaat wordt onder vigeur van het reglement 1983 mijns inziens ook bereikt, hoewel daarin geen speciale regeling voor huisgenoten is opgenomen. Aangenomen moet worden dat, indien het bestuur de huisgenoten niet als bewoners van een appartement wil toelaten, aan de verzoeker de toestemming tot ingebruikneming wordt geweigerd. Praktijkvoorbeelden ontbreken hierbij.

Volgens het reglement 1987 is het mijns inziens niet mogelijk dat huisgenoten worden toegelaten, terwijl de verzoeker als gebruiker wordt geweigerd. De huisgenoten kunnen immers geen huisgenoten van een persoon zijn, die niet in hetzelfde "huis" woont. Als de verzoeker wordt geweigerd, maar hij zijn privé gedeelten toch door personen wil laten gebruiken, die als hij zelf zou zijn toegelaten zijn huisgenoten zouden zijn, dan zal hij ex artikel 31 modelreglement 1987 aan het bestuur toestemming tot zelfstandig gebruik voor hen moeten vragen.

Overigens moet hier nog gewezen worden op een vonnis van het kantongerecht Breda ${ }^{90}$, waarin werd beslist dat de vergadering van eigenaars geldig kan besluiten, dat nieuwe eigenaars verplicht zullen worden om voor ingebruikneming van hun privé gedeelten te verklaren

"geen bijstand van de Overbeid nodig te hebben en met redelijke zekerheid aan te nemen, dat daarop ook in de toekomst geen beroep zal behoeven te worden gedaan."

De kantonrechter achtte een dergelijk besluit niet in strijd met een van de criteria van artikel $876 \mathrm{~d}$ lid 1 sub a-c BW, omdat een dergelijke verklaring een informatie inhoudt die het bestuur mag verlangen om de vergadering van eigenaars in staat te stellen te beslissen, of

"naar redelijkheid en billijkheid van de overige bewoners niet mag worden verlangd dat zij de gegadigde in hun midden opnemen",

90. Kantongerecht Breda 21 sept. 1981, NJ 1982, 331. 
well criterium in artikel 20a van het reglement van splitsing was opgenomen (kennelijk gold de annex van het reglement 1973). De kantonrechter stond derhalve toe, dat de vergadering of het bestuur bij zijn beslissing omtrent toelating, op de solvabiliteit van de verzoeker let (vgl. art. 29 lid 5 modelreglement 1987 en par. 3.6.3.3).

\subsubsection{De leeftijdsgrens}

Een criterium waarover veel wetenschappelijke beroering is ontstaan, is een strakke leeftijdsgrens ${ }^{91}$. Door Smarius, Schenk en De Groot is hierover in het WPNR gediscussieerd n.a.v. een geval, waarin men de leeftijd van 75 had willen stellen als grens waarboven iemand niet meer als bewoner van een service-flat (Burghtweide) kon worden toegelaten ${ }^{92}$. De Tilburgse kantonrechter achtte deze leeftijdsgrens onaanvaardbaar. Smarius ${ }^{93}$ kon zich evenmin met een strakke leeftijdsgrens verenigen. Hij haalde als argument tegen een strakke leeftijdsgrens de kantonrechter Tilburg aan, die in zijn vonnis stelde:

"terecht is opgemerkt geworden, dat, zoals van algemene bekendheid mag worden verondersteld, er mensen van 75 jaar en ouder zijn, die heel wat vitaler zijn dan bijvoorbeeld personen in de leeftijd van 74 jaar en 11 maanden."

Smarius achtte een genuanceerde leeftijdsgrens wel aanvaardbaar. Hiermee bedoelde hij dat een leeftijdsgrens wel zou kunnen worden gehanteerd, indien men boven de leeftijdsgrens desalniettemin met een medische verklaring zou kunnen worden toegelaten.

"Zo'n regeling", aldus Smarius, "komt heel wat redelijker over dan een, die ook die 75-jarigen treft, die nog elk jaar de vierdaagse uitlopen."

Schenk ${ }^{94}$ daarentegen vond een leeftijdsgrens zeer wel aanvaardbaar. Als eerste argument hiervoor voerde hij aan dat het belang van een groepslid moet wijken voor het belang van de groep, waartoe het groepslid behoort, een en ander naar analogie van beperking van eigendomsrecht van een particulier door de overheid op grond van het algemeen belang. Opgemerkt zij hier dat dit niet slechts een argument voor een leeftijdsgrens is maar voor de toelaatbaarheid van welstandsbepalingen in het algemeen.

De strakke leeftijdsgrens werd door Schenk verdedigd met het argument dat

"men de falende zelfkritiek van de betrokkene omtrent zijn capaciteiten door een vaste grens omzeilt en pijnlijke debatten uitsluit daaromtrent..."

91. Vgl. over discriminatie naar leeftijd in het algemeen: Van Maarseveen, bly. 501 .

92. Vg1. Kantongerecht Tilburg 18 sept. 1980, besproken door Smarius, WPNR 5552, blz. 104-110.

93. Simarius, WPNR 5552 , blz. 108.

94. Schenk, WPNR 5570, blz. 414. 
Als compromis stelde hij, dat indien de grens wordt overschreden op de aspirantbewoner de taak zou rusten om aan te tonen, dat in zijn geval bijzondere omstandigheden aanwezig zijn, op grond waarvan voor hem een uitzondering kan worden gemaakt. Ook Schenk stelt hier dus eigenlijk een genuanceerde leeftijdsgrens voor.

Een ander argument voor het opnemen van een strakke leeftijdsgrens was het tegengaan van vergrijzing van de bewoners. Door vergrijzing worden bewoners minder capabel en derhalve slechter in staat de woongemeenschap te besturen. Daarom zou de leeftijdsopbouw in de groep verbeterd moeten worden door het stellen van een leeftijdsgrens als toelatingscriterium. Dit argument wordt echter ontkracht door het argument van Smarius, dat men geen algemene regel voor afnemende bestuurscapaciteit bij een bepaalde leeftijd kan geven. De ene persoon is op zijn tachtigste nog zeer wel in staat goed te functioneren in een bestuur van een vereniging van eigenaars van een appartementencomplex, terwijl een ander al op zijn vijftigste is versleten.

Daarnaast voerde Schenk nog als argument voor een leeftijdsgrens aan dat verzorgingsbehoeftigen wellicht een te grote aanspraak zouden maken op verzorgingsfuncties van een bepaald appartementencomplex, waardoor de verzorgingscapaciteit voor andere bewoners zou verminderen. Dit argument hangt nauw samen thet het kostenbeheersingsaspect met betrekking tot verpleegcapaciteit dat door Smarius in zijn artikel wordt vermeld ${ }^{95}$. Om de kosten te kunnen beheersen zou men, aldus Smarius, een bepaalde verpleegcapaciteit echter kunnen vastleggen als norm voor de toekomst. Dit zou echter niet wegnemen dat bepaalde personen dan wellicht de gehele capaciteit voor zichzelf zouden opeisen.

De Groot ${ }^{96}$ achtte de strakke leeftijdsgrens evenals Smarius niet toelaatbaar, omdat ze geen gewichtige reden in de zin van artikel $875 \mathrm{f} \mathrm{lid} 4$ oplevert. Hij achtte de mate van verzorgingsbehoefte en daarmee samenhangend het vermogen om zelfstandig te wonen wel een toelaatbare welstandsbepaling.

De argumenten in casu voor een leeftijdsgrens kwamen geabstraheerd erop neer dat men mensen.wille die slechts in geringe mate verzorgingsbehoeftig waren. Verzorgingsbehoeftigheid laat zich echter niet aan leeftijd turven, getuige de argumenten door Smarius en de Tilburgse kantonrechter aangehaald. Derhalve lijkt een strakke leeftijdsgrens als graadmeter voor verzorgingsbehoeftigheid en daaruit volgend als criterium voor toelating als bewoner, ontoelaatbaar. Wel toelaatbaar lijkt een genuanceerde leeftijdsgrens, die ook door Schenk als compromis werd voorgesteld. Deze genuanceerde leeftijdsgrens zou inhouden dat een leeftijdsgrens zou kunnen worden gehanteerd, als gegadigden daarboven desalniettemin zouden kunnen worden toegelaten met een medische verklaring.

In de boven besproken casus wilde men verzorgingsbehoeftigheid turven aan leeftijd. Leeftijd is echter als graadmeter voor verzorgingsbehoeftigheid ongeschikt. Dit leidt tot de conclusie dat de leeftijdsgrens de in paragraaf 3.6.2.1 besproken doelmatigheidstoets niet kan doorstaan. Het doel was dat men geen medebewoners zou krijgen, die in te grote mate verzorgingsbehoeftig waren. Het middel, het strakke leeftijdscriterium als toelatingscriterium, was hiervoor ongeschikt omdat

95. Smarius, WPNR 5552, blz. 105 .

96. De Groot, WPNR 5570, blz. 412. 
leeftijd niet noodzakelijkerwijs iets over de mate van verzorgingsbehoeftigheild zegt. Daarom was ook een genuanceerde leeftijdsgrens in dit geval overbodig. Waar het om ging was de mate van verzorgingsbehoeftigheid, die men door middel van een medisch onderzoek kan vaststellen. Derhalve had men in casu geen genuanceerde leeftijdsgrens nodig, maar behoefde men slechts te eisen dat een medische verklaring werd overlegd waaruit bleek dat men niet of slechts in geringe mate verzorgingsbehoeftig was en in staat was tot zelfstandige bewoning. Deze eis was in het onderhavige geval ook gesteld, zodat men de leeftijdsgrens had kunnen schrappen ${ }^{97}$. Het vereiste van een medische verklaring werd in het onderhavige geval ook bestreden met het argument dat men willekeur vreesde ${ }^{98}$. Willekeur zou mijns inziens echter voorkomen kunnen worden door het stellen van de eis dat alle verklaringen in alle gevallen door dezelfde onafhankelijke arts zouden worden opgesteld.

De kantonrechter Tilburg noemde nog andere argumenten tegen een leeftijdsgrens. Ten eerste bepaalde de kantonrechter dat met name een leeftijdsgrens een beperking van het eigendomsrecht zou betekenen,

"doordat men zijn eigendom aan een zekere categorie mogelijke kopers niet zal mogen verkopen."

Tegen dit argument kan ten eerste worden ingebracht dat dit geldt voor alle welstandsbepalingen en ten tweede dat welstandsbepalingen, althans formeel, geen vervreemdingsbeperking inhouden. Wel kan het er in praktijk op neer komen dat men een appartementsrecht slecht kan verkopen omdat er welstandsbepalingen in het reglement zijn opgenomen, maar dit dient gescheidern te worden van de bevoegdheid tot verkoop. De appartementseigenaar is te allen tijde bevoegd zijn appartementsrecht te vervreemden en zodanig wordt het "eigendomsrecht" dan ook niet beperkt. Desalniettemin kan men beweren dat welstandsbepalingen materieel een inbreuk op het "eigendomsrecht" van de appartementseigenaar vormen, indien hem het gebruik van zijn "eigendom" wordt ontzegd. Voor ontzegging van gebruik moet een gewichtige reden aan te wijzen zijn. De kantonrechter was van mening dat een leeftijd sec geen gewichtige reden tot ontzegging van gebruik kon opleveren omdat leeftijd niet als graadmeter voor vitaliteit (en dus omgekeerd "werzorgingsbehoeftigheid") kan gelden.

Een andere leeftijdsgrens werd gehanteerd door appartementencomplex "het Ericapark" te Bennekom. In het reglement van splitsing van "het Ericapark" was een positief geformuleerd toelatingscriterium opgenomen dat behelsde dat als gebruiker uitsluitend natuurlijke personen konden worden toegelaten die (onder meer) tenminste 55 jaar oud waren ${ }^{99}$.

De bedoeling van deze leeftijdsondergrens zal onder andere geweest zijn om in een appartementsgemeenschap alleen mensen op te nemen met een bepaalde dosis levenservaring en met denkbeelden die aan een bepaalde generatie verbonden zijn. Een leeftijdsondergrens als middel om dit doel te bereiken is echter even

97. Vgl. Smarius, WPNR 5552, blz 105, linkerkolom.

98. Smarius, WPNR 5552, blz. 105.

99. Vgl. Pres. Rb. Arnhem 20 dec. 1984, Kort Geding 1985, 43; hierover Mertens, blz. 244248. 
ongeschikt als een leeftijdsbovengrens in het bovenbeschreven geval. Levenserwaring en denkbeelden laten zich tenslotte evenmin turven aan een bepaalde leeftijd. Een persoon wan 53 jaar zou immers in alle opzichten in de appartementsgemeenschap kunnen passen, terwijl een zestigjarige dit niet of in veel mindere mate zou kunnen doen. Een genuanceerde leeftijdsondergrens zou hier wel denkbaar zijn, waardoor personen onder de 55 jaar toch als bewoner zouden kunnen worden toegelaten indien ze zouden voldoen aan door het bestuur van de V.v.E. te stellen eisen op moreel en maatschappelijk gebied. In casu hanteerde het Ericapark ook een criterium dat bepaalde dat aspirant-bewoners ook moesten voldoen aan door het bestuur te stellen eisen op moreel gebied. Door dit criterium werd de leeftijdsgrens in feite overbodig. Men kan zich echter voorstellen dat bewoners van een bepaald appartementencomplex graag met ouderen onder elkaar willen zijn. In een zodanig geval zou een genuanceerde leeftijdsondergrens uitkomst kunnen bieden. Men zou dan kunnen bepalen dat een aspirant bewoner minimaal ongeveer 55 jaar oud zou moeten zijn en zou moeten voldoen aan de door het bestuur te stellen eisen op moreel en maatschappelijk gebied.

\subsubsection{Financiële criteria}

Een criterium van andere aard, dat veelvuldig wordt gehanteerd, is het financiële toelatingscriterium ${ }^{100}$. Er wordt echter wel beweerd dat financiële criteria geen gewichtige reden tot weigering kunnen opleveren, nu financiële verplichtingen primair op de eigenaar ten opzichte van de vereniging en de eigenaars rusten ${ }^{101}$. Ook een eigenaar die geen toestemming tot ingebruikneming verkrijgt, is gehouden zijn financiële verplichtingen na te komen. Weigering van toestemming tot ingebruikneming biedt derhalve geen waarborg aan de V.v.E. dat financiële verplichtingen worden nagekomen. De V.v.E. wint er derhalve niets mee. Bovendien is aan de V.v.E. of de gezamenlijke eigenaars in artikel $1185 \mathrm{sub} 9 \mathrm{een}$ privilege toegekend, dat strekt tot zekerheid voor schulden en kosten die door de eigenaar moeten worden voldaan. Het privilege rust op het appartementsrecht van de schuldenaar ${ }^{102}$.

Beekhuis/Linders ${ }^{103}$ bestrijdt echter de mening dat financiële criteria geen gewichtige reden tot weigering kunnen opleveren.

"In de eerste plaats", aldus Beekhuis/Linders, "is de scheiding tussen eigenaar en bewoner niet te maken, wanneer de eigenaar zelf het privégedeelte in gebruik neemt, maar zelfs wanneer dit niet het geval is, hebben andere appartementseigenaars er belang bij, dat het prive-gedeelte niet betrokken wordt, als de eigenaars of de huurders insolvente personen zijn. De eigenaar blijft immers ook bij bewoning door een ander zelf tot bijdragen verplicht, en ook de huurder heeft krachtens het reglement

100. Vgli. Pres. Rb. Arnhem 20 dec. 1984, Kort Geding 1985, 43; Mertens, blz 247; Verdoes Kleijn (Preadvies 1987), blz 342 en Mertens (Interventie), blz 346. Zie ook Kantongerecht Breda 21 sept. 1981, NJ 1982, 331 en art. 29 lid 5 modelreglement 1987.

101. De Groot (Rechtsvraag), blx. 158; Mertens, blz. 247; Mertens (Interventie), blz. 346. Zie verder Pitlo/Brahn, blz. 392.

102. Beekhuis/Linders, VI par. 10; De Groot (Rechtswraag), blz, 158.

103. Beekhuis/Linders, VI par. 6, nr. SB. 
financiële verplichtingen jegens de andere eigenaars (zie art. 27 modelreglement 1987). In ieder geval $k a n$ na het besluit van de vergadering van eigenaars het laatste woord worden gesproken door de kantonirechter (art. 8750)."

Deze ietwat cryptische argumentatie pleit echter mijns inziens eerder tegen financiële criteria dan voor. Allereerst moet worden opgemerkt dat, indien de eigenaar zijn privé-gedeelten verhuurt, de huurder naast de eigenaar voor de financiële verplichting jegens de vereniging aansprakelijk kan zijn (art. 25 modelreglement 1983; art. 27 modelreglement 1987). Dat betekent dat niettoelating van een eigenaar als bewoner aan de V.v.E. meer financiële zekerheid kan verschaffen. Als de eigenaar zijn privé-gedeelten verhuurt, kan de vereniging van eigenaars immers van de huurder verlangen, dat hij zich voor de schulden van de eigenaar jegens de vereniging als borg verbindt. Als de eigenaar zijn privégedeelten niet verhuurt, blijft alleen hij aansprakelijk voor de financiële verplichtingen ten opzichte van de V.v.E.

De bewering van Beekhuis/Linders dat de andere appartementseigenaars er belang bij hebben, dat het privé-gedeelte niet door een insolvente eigenaar of huurder wordt betrokken, is mijns inziens ten aanzien van de eigenaar onjuist. De vereniging zou er wel belang bij hebben dat de insolvente persoon helemaal geen eigenaar zou worden, zodat op hem geen financiële verplichtingen komen te rusten. Weigering van een eigenaar als bewoner zou integendeel averechts kunnen werken, nu hij gedwongen zal zijn dubbele woonlasten te betalen (namelijk ook ergens anders waar hij well mag wonen), waardoor hij eerder niet aan zijn financiële verplichtingen zal kunnen voldoen.

Een garantie dat de eigenaar (hij blijft eigenaar) zijn schulden jegens de V.v.E. zal voldoen, kan door weigering van toestemming tot bewoning niet worden bereikt. Dat neemt niet weg dat weigering van een eigenaar als bewoner in de praktijk in sommige gevallen wel voordeel voor de V.v.E. kan opleveren, maar dit voordeel doet zich mijns inziens slechts in enkele gevallen voor:

1. de eigenaar ontbindt de koopovereenkomst omdat hij geen toestemming tot bewoning krijgt (een ontbindende voorwaarde is mogelijk. Vgl. par. 3.6.2.4) In dat gevall is de mogelijkheid weer open dat de V.v.E. te maken krijgt met een solvente nieuwe eigenaar. In praktijk wordt aldus bereikt dat de eigenaar geen eigenaar blijft of de koper (vgl. art. 29 lid 2 modelreglement 1987) geen eigenaar wordt;

2. de als bewoner geweigerde eigenaar geeft zijn privé-gedeelten aan een solvent huurder in gebruik, die ex art. 25 modelreglement 1983 of art. 27 modelreglement 1987 aansprakelijk kan worden gesteld voor de schulden van de eigenaar jegens de V.v.E. Een verplichting om de privé-gedeelten te verhuren kan echter nooit aan de eigenaar worden opgelegd;

3. een geïnteresseerde vraagt voor openbare verkoop van een appartementsrecht toestemming tot ingebruikneming. Als hij met het oog op zijn financiële positie als aspirant-bewoner wordt geweigerd, zal hij in de meeste gevallen niet tot koop van het 
appartementsrecht overgaan. Aan de geïnteresseerde kan echter geen verbod worden opgelegd om het appartementsrecht te kopen, waardoor de V.v.E. theoretisch toch weer met een insolvente, althans financieel weinig draagkrachtige eigenaar wordt opgescheept.

Bij toelating van huurders van een insolvent appartementseigenaar, kan het financiële criterium ook in de praktijk voor de V.v.E. voordelig zijn, namelijk in die gevallen dat de eigenaar vervolgens aan een solvent persoon verhuurt. In het geval dat een solvent eigenaar aan een insolvent persoon verhuurt, mag mijns inziens de toestemming tot ingebruikneming niet aan de huurder worden ontzegd, omdat de eigenaar aansprakelijk is voor de schulden jegens de V.v.E.

Mijns inziens moet ten aanzien van financiële criteria derhalve worden geconcludeerd dat zij geen gewichtige reden tot weigering in de zin van artikel $875 f$ lid $4 \mathrm{BW}$ kunnen opleveren, omdat de hantering van deze criteria geen soelaas biedt voor de vereniging van eigenaars om minder draagkrachtige aspiranteigenaars te weren (vgl. ook par. 3.5.3 t.a.v. het relevantiecriterium).

\subsubsection{Lichamelijke en geestelijke gezondheid}

In het geval van "het Ericapark" te Bennekom was ook een bepaling opgenomen, die behelst dat als gebruikers uitsluitend natuurlijke personen worden toegelaten, die onder andere beschikken over voldoende lichamelijke en geestelijke gezondheid om zelfstandig te kunnen wonen ${ }^{104}$. Zowel Smarius en De Groot als Schenk ${ }^{105}$ achtten dit vereiste in beginsel een geldig toelatingscriterium. Hierbij zal echter steeds naar de omstandigheden van het geval moeten worden gekeken. Zo zal een persoon die een eigen verpleegster bekostigt, minder snel op grond van het criterium lichamelijke en geestelijke gezondheid kunnen worden geweigerd, dan een persoon die niet iemand meebrengt om hem of haar te verzorgen ${ }^{106}$. Het is naar mijn mening niet onredelijk voor bewoners van een (bejaarden-)appartementencomplex die een verpleegster uit de gezamenlijke kas bekostigen, om een aspirant-bewoner toestemming tot bewoning te weigeren, als aan te nemen valt dat hij/zij de verpleegster zo veelvuldig zal nodig hebben, dat deze voor de overige bewoners geen of weinig tijd meer zal overhouden ${ }^{107}$.

\subsubsection{Voorwaarden op moreel gebied}

In het geval van mevr. van den B. die toestemming vroeg om haar appartement in "het Ericapark" te Bennekom te mogen bewonen ${ }^{108}$, was in het reglement van splitsing ook een bepaling opgenomen die behelst dat uitsluitend natuurlijke personen als bewoner kunnen worden toegelaten die, behalve aan de reeds vermelde criteria, ook aan door het bestuur te stellen voorwaarden op moreel

104. Vgl. Pres. Rb. Arahem 20 dec. 1984, Kort Geding 1985, 43; Mertens, blz. 245.

105. WPNR 5552, 5570, 5589 .

106. De Groot, WPNR 5570, blz 412; Smarius, WPNR 5552, blz 109; Mertens, blz. 248.

107. De Groot, WPNR 5570, blz 412 .

108. Kort Geding 1985, 43. 
gebied moeten voldoen. Vereisten op moreel gebied kunnen op zich goed verdedigd worden als welstandsbepaling. Men kan zich immers voorstellen dat de bewoners van een appartementencomplex een aspirant-bewoner de toestemming tot ingebruikneming weigeren, omdat bepaalde hoedanigheden op moreel gebied niet met de opvattingen op moreel gebied van de overige bewoners overeenstemmen of zelfs botsen. Dit betekent echter niet dat elke discrepantie of botsing van morele hoedanigheden een weigering van toestemming tot ingebruikneming rechtvaardigt. Het blijft moeilijk te bepalen wanneer een persoon wegens bepaalde morele hoedanigheden in redelijkheid en billijkheid als bewoner van een appartement mag worden geweigerd. Men kan naar mijn mening in een bijzonder geval beslissen dat, zoals in New York gebeurde, een popzangeres die voor haar muzikale carrière in erotische films had geschitterd, niet als bewoonster van een appartement wordt geaccepteerd ${ }^{109}$. Een en ander uiteraard voor zover het gelijkheidsbeginsel zich daartegen niet verzet.

\subsubsection{Twee andere voorbeelden}

De Groot ${ }^{110}$ noemt bij de beantwoording van de Rechtsvraag Privaatrecht in Ars Aequi nog twee andere criteria die behandeling verdienen.

Ten eerste geeft hij als voorbeeld het criterium dat inhoudt dat een ongehuwde volwassene onder de dertig jaar geweigerd zal worden. De Groot acht een dergelijke weigeringsgrond geen gewichtige reden in de zin van artikel $875 \mathrm{f} \mathrm{lid} 4$ BW. Als reden hiervoor voert hij aan, dat een dergelijk criterium waarschijnlijk als achtergrond heeft dat ongehuwde volwassenen onder de dertig

"in de regel "onrustig" zijn en daardoor hinder opleveren voor de buren."

Zo'n criterium werkt volgens hem echter als een botte bijl omdat er immers vele "rustige" ongehuwde volwassenen onder de dertig zijn. Burgerlijke staat en leeftijd kunnen volgens De Groot geen gewichtige reden tot ontzegging van ingebruikneming opleveren. Ten aanzien van de leeftijdsgrens wil ik deze mening graag onderschrijven met verwijzing naar paragraaf 3.6.3.2 en naar de doelmatigheidstoets, als onderdeel van de evenredigheidstoets, in paragraaf 3.6.2.1.

Met betrekking tot de vraag of burgerlijke staat een gewichtige reden tot weigering kan opleveren - quod non volgens De Groot - is het antwoord naar mijn mening echter nog niet geheel duidelijk. Artikel 26 van het Bupoverdrag ondersteunt weliswaar de visie van De Groot, maar met name bij botsing van het in artikel 26 Bupo neergelegde non-discriminatiebeginsel met andere grondrechten, is een beperking van dit grondrecht wellicht mogelijk. Misschien bestaan er derhalve situaties waarin burgerlijke staat een gewichtige reden tot weigering kan opleveren. Prima facie lijkt De Groot echter gelijk te hebben. De rechter zal dit, rekening houdende met de omstandigheden van het geval, moeten uitmaken.

Een ander criterium dat volgens De Groot geen gewichtige reden tot weigering van toestemming tot ingebruikneming kan vormen, is het feit dat de aspirant-bewoner

109. NRC Handelsblad, vrijdag 19 juli 1985 over zangeres Madonna.

110. De Groot (Rechtsvraag), blz 157, 158. 
kennelijk voornemens is om kamers te verhuren. Wel zou de vergadering van eigenaars volgens De Groot ingevolge artikel 24a lid 1 Annex modelreglement gegevens over de andere personen kunnen eisen, alvorens een beslissing over eventuele toestemming tot ingebruikneming te nemen. De Groot ziet in dit geval kamerhuurders dus als huisgenoten. Als ze niet als huisgenoten kunnen worden aangemerkt, zijn de kamerhuurders onderworpen aan de gewone toelatingsregeling van de annex van het modelreglement, uiteraard voor zover deze annex van toepassing is verklaard. Deze visie lijkt juist. Naar mijn mening kan men een persoon in beginsel de toestemming tot ingebruikneming niet weigeren, omdat hij kennelijk voornemens is kamers te verhuren. Men kan echter bij reglement van splitsing de bevoegdheid tot het verhuren van kamers beperken of ontnemen. In dat geval zou overtreding van dit verbod kunnen leiden tot ontzegging van verder gebruik voor de verhuurder en de huurders. Tevens zou dit een reden kunnen zijn om de huurders toestemming tot ingebruikneming te weigeren. Wellicht zou men zelfs bij een evident voornemen om kamers te verhuren in strijd met de bepalingen van het reglement van splitsing, ook de aspirant-verhuurder toestemming tot ingebruikneming kunnen weigeren. In een dergelijk geval zou het kennelijke voornemen om kamers te verhuren derhalve wel een gewichtige reden tot weigering in de zin van artikel $875 f$ lid 4 kunnen opleveren.

\subsection{Ontzegging van verder gebruik}

Zoals reeds is vermeld zijn welstandsbepalingen niet alleen die bepalingen, op grond waarvan een nieuwe bewoner kan worden belet zijn appartement in gebruik te nemen, maar ook die bepalingen, op grond waarvan de vergadering van eigenaars het verdere gebruik van een appartement aan een reeds zittende bewoner kan ontzeggen ${ }^{111}$. Artikel 27 van het Modelreglement bij splitsing in appartementsrechten van 1983 bepaalt dat door de vergadering van eigenaars aan een eigenaar die zijn appartement zelf in gebruik heeft of een andere gebruiker het verdere gebruik van het appartement kan worden ontzegd indien hij :
"a. de bepalingen van het reglement of het huishoudelijk reglement of de bepalingen bedoeld in artikel $876 \mathrm{c}$ van het Burgerlijk Wetboek niet nakomt of overtreedt,
b. zich schuldig maakt aan onbehoorlijk gedrag jegens andere eigenaars of gebruikers"(art. 27 eerste lid).

Het zevende lid van artikel 27 voegt hier voor de gebruiker aan toe, dat aan hem het verdere gebruik ook kan worden ontzegd,

"indien hij niet voldoet aan de financiële verplichtingen voortvloeiende uit de door hem gestelde borgtocht" (zie art. 25 modelreglement 1987).

111. Vgl. Smeets/Mertens, blzz 20; Beekhuis/Linders, VI par. 6 , nr. 5 . 
In artikel 33 van het modelreglement 1987 wordt hierbij nog aanvullend gesteld dat aan de eigenaar of gebruiker het gebruik kan worden ontzegd, indien zij:

c. door hun aanwezigheid in het gebouw aanleiding geven tot ernstige
verstoring van de rust in het gebouw;
d. hun financiële verplichtingen jegens de vereniging niet nakomen.

Voordat tot ontzegging van verder gebruik wordt overgegaan moet de vergadering van eigenaars echter eerst een waarschuwing geven aan de betreffende persoon. Indien hij dan binnen het jaar waarin hij de waarschuwing heeft ontvangen opnieuw een van de bovengeciteerde handelingen verricht of voortzet, kan de vergadering van eigenaars ingevolge artikel 27 lid 1 en 2 modelreglement 1983 (art. 33 lid 1 en 2 modelreglement 1987) overgaan tot ontzegging van verder gebruik.

Alvorens een eigenaar of gebruiker een waarschuwing ontvangt of hem het gebruik wordt ontzegd, dient hij echter eerst door de vergadering van eigenaars gehoord te worden, waarbij hij zich kan laten bijstaan door een raadsman (art. 27, derde lid modelreglement 1983; art. 33 lid 3 modelreglement 1987).

Het besluit tot ontzegging van verder gebruik moet worden genomen met een meerderheid van tenminste twee/derde van het aantal uitgebrachte stemmen, terwijl in de vergadering tenminste twee/derde van het totaal aantal stemmen vertegenwoordigd is (art 27 lid 4 modelreglement 1983; art. 33 lid 4 modelreglement 1987). Indien het gebruik aan de eigenaar ontzegd wordt, kan deze meestemmen in de vergadering van eigenaars, aangezien hij ingevolge artikel 876 BW lid van de V.v.E. is en stemrecht heeft in de vergadering van eigenaars ${ }^{112}$.

De bepaling dat aan een (eigenaar-)gebruiker het verdere gebruik van zijn appartement kan worden ontzegd, vormt het formele gedeelte van de welstandsbepaling. De in het eerste en zevende lid van artikel 27 genoemde gronden voor ontzegging van verder gebruik vormen het materiële gedeelte van de welstandsbepaling.

Er is, behalve het hierna te behandelen Van Maarsseveen-arrest en het Van der Leen arrest, geen jurisprudentie over ontzegging van verder gebruik op grond van een van de hierboven genoemde criteria. Aangenomen moet worden dat deze criteria op zichzelf redelijk zijn. Bij artikel 33 lid 1 sub c modelreglement 1987 wordt in de toelichting vermeld, dat een dergelijke bepaling nodig is om seniele bewoners die de rust verstoren, uit de gemeenschap te kunnen verwijderen ${ }^{113}$.

Ten aanzien van de financiële verplichtingen kan worden verwezen naar paragraaf 3.6.3.3. Hetgeen daar vermeld is gaat mutatis mutandis ook op bij ontzegging van verder gebruik. Tenslotte kan nog op het al eerder aangehaalde vonnis van het kantongerecht Breda worden gewezen ${ }^{114}$, waarin de kantonrechter besliste dat de V.v.E. van aspirant bewoners niet mag verlangen dat zij verklaren er mee bekend te zijn,

112. Een besluit tot ontzegging van verder gebruik kan door de V.v.E. worden geeffectueerd door in cen dagvaardingsprocedure ontruiming te vorderen. Zie noot van W.H.H. onder HR 7 aprill 1.978, NJ $1978,545$.

113. Commissie Beekhuis, blz. 592 .

114. Kantongerecht Breda 21 sept. 1981, NJ 1982, 331. 
"dat in de flat aan de bewoners slechts beperkte diensten worden verleend zonder dat sprake is van op de persoon gerichte verzorging, en met het oog daarop verplicht te zijn te verhuizen naar een verzorgings- of verpleegtehuis, zodra zij niet langer in staat zijn zelfstandig en onafhankellijk in de flat woonachtig te zijn,.."

Omdat deze verklaring niet dienstig was ter beoordeling van de vraag of van de V.v.E. naar redelijkheid en billijkheid kon worden verlangd dat zij de aspirantbewoner in hun midden zouden opnemen, achtte de kantonrechter deze eis al niet mogelijk. Als tweede argument voerde hij aan dat bij

"de gegadigden (zij het rechtens ten onrechte) in vele gevallen de vrees kan worden gewekt, dat in het sub a bedoelde geval (als zij niet meer zelfstandig zouden kunnen wonen, R.M.) niet zijzelf, doch de andere flatbewoners het tijdstip zullen bepalen, waarop zij hun appartement moeten verlaten."

Ervan uitgaande dat in het reglement van splitsing in thet onderhavige geval de ontzeggingstegeling van het modelreglement 1972 van toepassing was, zou de eventueel opgewekte vrees inderdaad rechtens ten onrechte zijn ontstaan. Onder vigeur van het modelreglement 1987 zou deze vrees overigens "rechtens terecht" zijn, gelet op artikel 33 lid 1 sub $c$.

\subsubsection{Het Van der Leen-arrest ${ }^{115}$}

Zoals in paragraaf 3.3.2 en 3.7 reeds werd vermeld, is een van de criteria voor ontzegging van verder gebruik op grond van artikel 27 van het modelreglement 1983 en artikel 33 modelreglement 1987, dat de gebruiker van een appartementsrecht "zich schuldig maakt aan onbehoorlijk gedrag jegens de andere eigenaars en/of gebruikers. Ditzelfde criterium was in het modelreglement 1973 opgenomen in artikel 24.

Dit criterium uit het modelreglement 1973 vormde in 1986 voor de "Vereniging van Eigenaars appartementsgebouwen Padangstraat Baarn" (verder af te korten "V.v.E. Padangstraat") de grondslag om aan J. van der Leen het verdere gebruik van zijn appartementsrecht te ontzeggen. Van der Leen was eigenaar van een appartementsrecht en lid van de V.v.E. Padangstraat. In zijn woning veroorzaakte hij regelmatig met zijn hifi-installatie geluidsoverlast voor de overige bewoners van het appartementencomplex. Bovendien onderhield hij zijn tuin zeer slecht. Op 29 april 1985 werd hem daarom bij brief van een notaris een waarschuwing toegestuurd als bedoeld in artikel 24 lid 1 van het reglement van splitsing (modelreglement 1973). Kennelijk was hij al eerder gewaarschuwd en mocht geen van de waarschuwingen baten. Daarom besloot de vergadering van eigenaars van de V.v.E. Padangstraat op 15 januari 1986 om aan Van der Leen het verdere gebruik van zijn appartementsrecht te ontzeggen. Van der Leen stelde geen beroep ex artikel $876 \mathrm{~d}$ BW in en weigerde om het gebruik van zijn woning te staken.

115. Hof Amsterdam 11 sept. 1986 , rolnr. $470 / 86 \mathrm{KG}$, kort samengevat in het Tijdschrift voor Milieuaansprakelijkheid 1987, blz. 77. 
De V.v.E. Padangstraat eiste daarom bij de President van de Utrechtse rechtbank (rolnr. KG 138/86) in kort geding dat Van der Leen zou worden veroordeeld tot ontruiming van zijn woning. Van der Leen voerde als verweer aan dat de V.v.E. haar bevoegdheid had misbruikt om een persoonlijke vete tussen hem en zijn bovenbuurvrouw te beslechten en beriep zich op de vernietigbaarheid van het besluit. Omdat niet alle mogelijkheden om de verhoudingen te normaliseren waren uitgeput zou de vordering tot ontruiming wegens strijd met de goede trouw moeten worden afgewezen.

De Utrechtse President wees de ontruimingsvordering echter toe, aangezien Van der Leen de termijn van artikel $876 \mathrm{~d}$ BW had laten verlopen en het aannemelijk voorkwam,

"dat de bodemrechter, indien een procedure zou worden aangespannen, zal oordelen dat het besluit van de vergadering onherroepelijk is geworden".

Van der Leen werd daarom veroordeeld om het appartement "met al de zijnen/ hunnen en het zijne/hunne te ontruimen". De V.v.E. werd gemachtigd om de woning eventueel met behulp van de sterke arm te doen ontruimen.

Tegen dit vonnis stelde Van der Leen vervolgens hoger beroep in bij het Amsterdamse Gerechtshof. Hij stelde dat het ontzeggingsbesluit zonder redelijke grond was genomen en dat het nietig was wegens strijd met de wet, de openbare orde en goede zeden. Verder voerde hij ondermeer aan, dat als het besluit al geldig was, de ontzegging en de vordering tot ontruiming in strijd met de goede trouw waren, omdat niet eerst was geprobeerd de situatie op andere wijze te normaliseren.

Het Hof besliste echter dat het besluit niet zonder redelijke grond tot stand was gekomen, omdat Van der Leen het erop had laten aankomen dat de V.v.E. het ontzeggingsbesluit nam. Evenmin was het besluit volgens het Hof nietig, aangezien het naar wijze van totstandkoming, inhoud en strekking niet ongeoorloofd was. Ook het beroep op de goede trouw faalde, omdat Van der Leen zelf in gebreke bleef het geldige ontzeggingsbesluit na te leven, en hij de V.v.E. niet kon verwijten dat zif tenuitvoerlegging van het besluit vorderde.

Van der Leen was verder opgekomen tegen de beslissing van de Utrechtse President, dat hij zijn woning moest ontruimen "met het zijne". Het Hof Amsterdam besliste dat de strekking van artikel 24 lid 2 van het reglement van splitsing kennelijk is

"dat Van der Leen niet meer in het bedoelde privégedeelte aanwezig mag zijn of dit mag betreden. Derhalve zou onjuist zijn aan het besluit de conclusie te verbinden dat Van der Leen ook 'het zijne' dient weg te halen." 


\section{7 .2 Beroep tegen ontzegging van verder gebruik}

De bewoner aan wie het recht op verder gebruik is ontzegd vraagt niets van de vergadering, en de kantonrechter kan derhalve de toestemming van de vergadering niet door een machtiging vervanger.

"De vergadering neemt uit eigen beweging een besluit, waartegen de bewoner in beroep gaat. De vervangende toestemming van de kantonrechter, die bij weigering tot toelating op grond van art. $8750 \mathrm{BW}$ kan worden verzocht, is hier niet aan de orde. "I16

Een appartementseigenaar aan wie het verdere gebruik van zijn privé-gedeelte wordt ontzegd, kan ingevolge artikel $876 \mathrm{~d}$ BW de kantonrechter wel werzoeken om het besluit van de vergadering te vernietigen:

"a. wegens strijd met de wettelijke bepalingen die de bevoegdheid van de vergadering en de wijze van totstandkoming van besluiten regelen;

b. wegens strijd met de akte van splitsing;

c. wegens strijd met de goede trouw" (art. 876d eerste lid BW).

Het verzoek tot vernietiging moet worden gedaan binnen een maand na de dag waarop de verzoeker van het besluit van de vergadering heeft kennis genomen of kennis heeft kunnen nemen (art. 876 tweede lid BW).

De eerste twee vernietigingsgronden spreken voor zichzelf. De vernietigingsgrond onder c. verdient echter nadere uitwerking. Met de goede trouw wordt de verbintenisrechtelijke goede trouw bedoeld, de redelijkheid en billijkheid. Bij toetsing aan de redelijkheid en billijkheid van een besluit van de vergadering van eigenaars tot ontzegging van verder gebruik, kan de rechter ook de grondrechten bij de beschouwing betrekken. Op deze wijze kan hij het begrip "goede trouw" inkleuren met grondrechten en algemene rechtsbeginselen. Bij de toetsing van het besluit aan de grondrechten kan hij eventueel de criteria hanteren die in paragraaf 3.5.3 werden beschreven, namelijk het relevantie- en het proportionaliteitscriterium. Daarna kan de rechter de goede trouw ook nog subjectiveren en nagaan of in het concrete geval, rekening houdende met de persoonlijke belangen van partijen, sprake is van strijd met de goede trouw.

Als voorbeeld kan hier het (voorlopig denkbeeldige) geval worden aangehaald, dat aan een appartementseigenaar het verdere gebruik van zijn service-appartement wordt ontzegd, omdat hij te zeer verzorgingsbehoeftig is geworden om binnen de gemeenschap van eigenaars goed te kunnen functioneren en hij teveel beslag legt op het verplegend personeel dat in het service-flatgebouw aanwezig is. De vergadering van eigenaars baseert haar besluit op het feit dat door de aanwezigheid van de verzorgingsbehoeftige de rust in het gebouw ernstig wordt verstoord, bijvoorbeeld doordat andere personen sterk nadeel leiden door het beroep van de verzorgingsbehoeftige op het verplegend personeel. De verzorgingsbehoeftige

116. Smeets/Mertens, blz, 20. 
appartementseigenaar vraagt wernietiging van het besluit van de vergadering, omdat zijn verzorgingsbehoefte volgens hem weliswaar aanleiding geeft tot ernstige verstoring van de rust in het gebouw, maar slechts van tijdelijke aard is. Bovendien brengt hij zijn recht op woongelegenheid in stelling (art. 22 lid 2 Grondwet). De rechter zal nu bij de toetsing aan het relevantie- en proportionaliteitscriterium kunnen besluiten dat de ontzegging van verder gebruik niet in strijd met de goede trouw is, maar dat deze ontzegging, rekening houdende met de persoonlijke belangen van partijen, wel in strijd met de goede trouw is, omdat de verzorgingsbehoefte van de appartementseigenaar slechts van tijdelijke aard is en derhalve de verstoring van de rust de ontzegging van verder gebruik niet rechtvaardigt. Uiteraard moet hierbij vaststaan dat de verzorgingsbehoefte van tijdelijke aard is en de duur van deze behoefte niet te lang zal zijn.

De hier beschreven toetsing aan de goede trouw is een marginale toetsing, zoals in het algemeen bij toetsing aan de goede trouw het geval is ${ }^{117}$. Het verschil met de toetsing bij beroep tegen niet-toelating is gelegen in het feit dat de rechter bij een procedure ex artikel $8750 \mathrm{BW}$ zelf een subjectief oordeel over de weigering moet uitspreken, terwijl hij bij marginale toetsing slechts moet nagaan of mensen in het algemeen in redelijkheid tot de aangevochten beslissing kunnen komen. Bovendien kan de rechter bij een marginale toetsing niet de proportionaliteit van de aangevochten beslissing toetsen. Bij de toetsing van een besluit aan de grondrechten kan het proportionaliteitscriterium wel worden gehanteerd, omdat dit doelmatigheids- en evenredigheidscriterium deel uitmaakt van de rechtmatigheidstoetsing aan de grondrechten, welke toetsing de rechter altijd moet uitvoeren. Indien er geen grondrechten in het geding zijn, zal de rechter slechts een algemene rechtmatigheidstoetsing moeten doen en vervolgens moeten vaststellen, of men in redelijkheid tot het aangevochten vonnis heeft kunnen komen. De rechter zal echter niet de doelmatigheid van de ontzeggingsbeslissing mogen toetsen. Indien grondrechten in het geding zijn, mag hij in het kader van de rechtmatigheidstoetsing zoals gezegd wel de doelmatigheid van de beperking of inbreuk op een grondrecht toetsen.

\subsubsection{Intermezzo: Het Van Maarsseveen-arrest ${ }^{118}$}

Mevrouw van Maarsseveen was lid van een coöperatieve flatexploitatievereniging en had de bij haar flat behorende garage verhuurd aan de Rotterdamse Electriciteits Maatschappij (REM). Het is onduidelijk of ze hiervoor toestemming had gevraagd aan de CFV. Na de invoering van het nieuwe appartementsrecht in 1972 werden de lidmaatschapsrechten van de CFV omgezet in appartementsrechten. De verhuur van de garage ging gewoon door. Op 15 juli 1974 vorderde de vereniging van eigenaars (V.v.E.) plotseling ontruiming van de garage, omdat de af en aan rijdende auto's veel hinder zouden opleveren. Mevrouw van Maarsseveen reageerde niet op deze sommatie en de REM bleef de garage huren. Op 14 mei 1976 vorderde de V.v.E. opnieuw ontruiming van de garage. Niet geheel duidelijk was wat de vereniging nu van wie vorderde. Ook hierop reageerde mevrouw van

117. Asser/Van der Grinten II, blz. 230; Stille (Rechtspersonen), art. 35 aant. 7. Zie voor jurisprudentie par. 4.2.4.4.

118. HR 8 aprill 1978 , NJ $1978,545$. 
Maarsseveen niet. De REM reageerde evenmin, waarschijnlijk omdat deze van de sommatie niet afwist. De V.v.E. wijdde er een vergadering aan waarbij ook mevrouw van Maarsseveen was uitgenodigd. $\mathrm{Zij}$ liet zich door haar man vertegenwoordigen. De vereniging besloot opnieuw dat mevrouw van Maarsseveen de garage moest ontruimen, omdat haar anders het gebruik van de garage zou worden ontzegd. Mevrouw van Maarsseveen ondernam opnieuw geen stappen. Daarop ontzegde de vereniging haar het gebruik van de garage. De V.v.E. diende een verzoekschrift in bij de Utrechtse kantonrechter, verzoekende mevrouw van Maarsseveen op grond van artikel 8750 het gebruik van de garage te ontzeggen en te doen ontruimen. De V.v.E. vorderde derhalve machtiging tot ontzegging van verder gebruik. De kantonrechter verklaarde de V.v.E. niet ontvankelijk in haar vordering, met het argument dat de procedure niet tegen mevrouw van Maarsseveen had moeten worden aangespannen maar tegen de REM. Vervolgens ging de V.v.E in beroep bij de rechtbank en kreeg haar eis toegewezen. Mevrouw van Maarsseveen stelde beroep in cassatie in en won. De Hoge Raad verklaarde de V.v.E. niet ontvankelijk, omdat artikel $8750 \mathrm{BW}$ voor andere doeleinden dan ontruiming is geschreven. Ingevolge artikel 24 (vgl. art. 27 modelreglement 1983) van het modelreglement van splitsing, dat ook bij mevrouw van Maarsseveen van toepassing was, kon het gebruik van de garage aan de REM worden ontzegd. Waarschijnlijk was de vereniging als winnaar uit de strijd gekomen, als men de REM had gesommeerd de garage te ontruimen. Het vragen van machtiging tot ontruiming op grond van artikel 8750 was hier de volstrekt verkeerde weg in het labyrint van het appartementsrecht.

\subsubsection{Onrechtmatige daad}

Hoewel er uit de jurisprudentie geen geval bekend is, waarbij ex artikel $1401 \mathrm{BW}$ tegen een (dreigende) ontzegging van verder gebruik werd geageerd, lijkt de actie uit onrechtmatige daad een reële mogelijkheid voor sommige gevallen waarin aan de bewoner van een appartement het verdere gebruik wordt ontzegd. Indien de ontzegging van verder gebruik een onrechtmatige daad oplevert, waarvoor moet worden gekeken naar de Lindenbaum-Cohen criteria ${ }^{119}$, kan de actie uit onrechtmatige daad soelaas bieden waar de andere wettelijke beroepsmogelijkheden tekort schieten. Het grootste voordeel van deze actie is wel dat ook bewoners nieteigenaars haar kunnen instellen. In artikel $876 \mathrm{~d}$ lid 1 is immers bepaald dat alleen eigenaars en andere stemgerechtigden de daar geregelde vordering tot vernietiging kunnen instellen. Hierdoor zullen huurders vaak buiten de boot vallen (vgl. par. 3.6.2.5). Een ander voordeel van de actie uit onrechtmatige daad is dat men verbod van onrechtmatig handelen kan eisen, versterkt door een dwangsom. Indien een bewoner ingevolge artikel 27 lid 1 van het modelreglement 1983 (vgl. art. 33 lid 1 modelreglement 1987) een waarschuwing krijgt van de vergadering van eigenaars en hij meent dat deze waarschuwing voortvloeit uit bijvoorbeeld een discriminatoire houding van de (overige) eigenaars jegens hem, kan hij (eventueel in kort geding) een verbod van ontzegging van verder gebruik eisen. Uiteraard kan hij achteraf ook nog vernietiging van het besluit op grond van artikel $876 \mathrm{~d}$, eerste lid; 1371, $1373 \mathrm{BW}$ (3.2.7 / 3:40 NBW, zie ook par. 3.7.2) vorderen, maar het nadeel 
bij deze acties is dat er geen schadevergoeding kan worden gevorderd. Indien men echter achteraf meent dat een ontzegging van verder gebruik een nietige of vernietigbare rechtshandeling is, is het uiteraard mogelijk de vordering uit artikel $876 \mathrm{~d}$ eerste lid of $1371 \mathrm{jo} .1373$, te combineren met een vordering op grond van artikel 1401. Aldus kan men wellicht het ontzeggingsbesluit aantasten en daarnaast nog schadevergoeding verkrijgen.

\subsection{De vervreemdingsbeperking, een mogelijk alternatief voor de toelatings- regeling?}

In paragraaf 2.4 .4 werd aangekondigd dat hier zou worden ingegaan op de vraag, of de bevoegdheid van de appartementseigenaar om zijn appartementsrecht over te dragen, in het reglement van splitsing kan worden beperkt. Meer concreet: kan de appartementseigenaar in het reglement in zijn bevoegdheid zijn appartementsrecht te vervreemden, worden beperkt?

De Vries acht een absoluut vervreemdingsverbod ongeldig wegens strijd met de openbare orde ${ }^{120}$. Hij meent echter wel dat het mogelijk is om met zakelijke werking overeen te komen, dat overdracht slechts mogelijk is met toestemming van de andere appartementseigenaars. Een vervreemdingsbeperking acht De Vries derhalve wel mogelijk. Beekhuis/Linders ${ }^{121}$ sluit zich voor het geldende recht bij De Vries aan. Als argument voor de mogelijkheid van een vervreemdingsbeperking wordt aangevoerd, dat ook een erfpachter in de erfpachtsovereenkomst op zodanige wijze in zijn bevoegdheid tot overdracht kan worden beperkt, dat voor de overdracht toestemming van de eigenaar van de grond nodig is ${ }^{122}$. Volgens Beekhuis/Linders zal een dergelijke vervreemdingsbeperking voor appartementsrechten, behalve bij een gesplitst recht van erfpacht, naar NBW geen zakelijke werking hebben (artt. 3.4.2.1 lid 1 / 3:83 lid 1 en 6.5.3.4 lid 5 / 6:252 lid 5 NBW) ${ }^{123}$.

Hoe moet de vraag naar de zakelijke werking van vervreemdingsbeperkingen naar huidig recht worden beantwoord? In het algemeen kan worden gesteld, dat een beperking van de beschikkingsbevoegdheid in de zin dat de eigenaar of zakelijk gerechtigde voor vervreemding toestemming aan een ander moet vragen, slechts obligatoir werkt, in elk geval indien de vervreemdingsbeperking deel uitmaakt van een obligatoire verhouding en niet is gepubliceerd ${ }^{124}$. Wat echter, indien de beperking deel uitmaakt van een zakenrechtelijke verhouding en wel in de openbare registers is gepubliceerd? Als de beperking deel uitmaakt van erfpachtswoorwaarden, heeft zij volgens de heersende leer zakelijke werking ${ }^{125}$. Hetzelfde geldt voor overtreding van de wettelijke beperking van de splitsings-

120. De Vries (Onroerend Goed), blz. 388. Zo ook Pitlo/Brahn, (1980), blz. 193. Vgl. ook Asser/Beekhuis I, blz 172-174. Deze acht een persoonlijk werkend verweemdingsverbod toelaatbaar, mits het verbod beperkt is in de tijd en door een redelijk doel wordt gerechtvaardigd. Als aan deze vereisten niet is voldaan, acht ook Asser/Beekhuis het wervreemdingsverbod in striijd met de openbare orde.

121. Beekhuis/Linders, VI par. 13, nr. 2.

122. Vgl. Asser/Beekhuis I, blz. 173. Pitlo/Brahn, blz. 174.

123. Zie de MVA m.b.t. art. 5.7.1.5 NBW, Bijl. Hand. II, 1984-1985, 17541, nr. 8, blz. 8, 9.

124. Pitlo/Brahn, blz. 174.

125. Asser/Beekhuis I, blz 173. 
bevoegdheid van de appartementseigenaar, zoals neergelegd in artikel $875 \mathrm{a}$ lid 6 BW (zie par. 2.4.2.1).

Wellicht moet worden aangenomen dat in het algemeen geldt, dat een vervreemdingsbeperking in zakenrechtelijke verhoudingen, die is gepubliceerd in de openbare registers, zakelijke werking heeft. Hoe moet de vervreemdingsbeperking echter met betrekking tot het appartementsrecht worden opgevat? Heeft zij zakelijke werking, indien zij in de openbare registers is gepubliceerd ${ }^{126}$ ?

De gemeenschap van appartementseigenaars is een gebonden ${ }^{127}$ gemeenschap. In beginsel geldt voor deelgenoten in gebonden gemeenschappen de regel, dat zij niet vrij mogen beschikken over hun aandeel (vgl. par. 4.3.2.1). Deze beperking in de beschikkingsbevoegdheid heeft zakelijke werking. Onder vigeur van het NBW zal ongeveer hetzelfde gelden (art. 3.7.1.8 lid 2/3:175 jo. 3.7.1.2 lid 4/3:168 lid 2 NBW). Dit zou betekenen dat deze regel ook voor appartementseigenaars geldt. Artikel $875 \mathrm{k} \mathrm{BW}$ lijkt hieraan echter in de weg te staan ${ }^{128}$. Dit artikel bepaalt immers dat appartementsrechten als zelfstandige registergoederen kunnen worden overgedragen, bezwaard en uitgewonnen. Een vervreemdingswerbod zou daarom ongeldig zijn, hetgeen overeenstemt met de heersende leer met betrekking tot vervreemdingsverboden. Dit betekent echter op zichzelf nog niet dat een toestemmingsregeling voor vervreemding ondenkbaar is. Artikel $875 \mathrm{k} \mathrm{BW}$ heeft blijkens de memorie van toelichting ${ }^{129}$ dezelfde strekking als artikel $638 \mathrm{~b}$ lid $3 \mathrm{BW}$ (oud). Dit artikel bepaalde slechts dat een appartementsrecht als zelfstandige onroerende zaak kan worden beschouwd, waardoor werd bereikt dat een appartementseigenaar zijn appartementsrecht zonder toestemming van de overige eigenaars kon vervreemden of bijvoorbeeld met een recht van hypotheek kon bezwaren, hetgeen bij gebreke van een dergelijke bepaling kon worden betwijfeld. Appartementseigenaars zijn immers deelgenoten in een gebonden gemeenschap en zijn daarom in beginsel onderworpen aan het recht betreffende de gemeenschap. Om te voorkomen dat iedere appartementseigenaar bij iedere vervreemding of bezwaring toestemming van zijn deelgenoten nodig zou hebben ${ }^{130}$, is artikel $875 \mathrm{k}$ c.q. 638b BW (oud) opgenomen. Mijns inziens staat artikel $875 \mathrm{k}$ BW aan de geldigheid van een vervreemdingsbeperkende, - maar niet verbiedende - regeling niet in de weg. Dit artikel moet naar mijn mening blijkens zijn redactie worden opgevat als regelend recht ${ }^{131}$. In principe zou daarom ook een vervreemdingsverbod geldig zijn, ware het niet dat een dergelijk verbod over het algemeen als strijdig met de openbare orde, nietig is. Een vervreemdingsbeperking kan nu echter in elk geval met obligatoire werking tot stand kan komen. Vast staat ook dat een vervreemdingsbeperking in het reglement van splitsing kan worden opgenomen, nu de opsomming in artikel $875 \mathrm{f} \mathrm{BW}$ van hetgeen in het reglement kan worden opgenomen, niet limitatief is ${ }^{132}$.

126. Cahen (Oratie) beantwoordt deze vraag bevestigend. Treurniet, bespreking van de oratie wan Cahen in R.M. Themis 1968, blz 209-211, bestrijdt deze opvatting.

127. Vgl. over het onderscheid tussen de gebonden en vrije gemeenschap par. 4.3.2.

128. Vgll, ook Pitlo/Brahn, blz. 129.

129. Bijl. Hand. II, 1970-1971, 10987, nr. 3, blz. 16 .

130. Vgl. Pitlo/Brahn, bli. 128 . 131. Ook Beekhuis/Linders, VI par. 13, nr. 2 , is kennelijk de mening toegedaan dat dit geen
dwingende bepaling is.

132. Bijl. Hand. II, 1970-1971, 10987, nr. 3, blz 15. 
$\mathrm{Nu}$ een vervreemdingsbeperking in het reglement van splitsing kan worden opgenomen en aldus in de openbare registers kan worden ingeschreven, en bovendien in een zakenrechtelijke verhouding tussen medeëigenaars tot stand komt, moet aan deze beperking zakelijke werking worden toegekend. Dit geldt temeer nu door uitsluiting van artikel $875 \mathrm{k} \mathrm{BW}$ (hetgeen mogelijk moet worden geacht), het algemene recht betreffende medeëigendom herleeft en de appartementseigenaars niet zonder toestemming van hun deelgenoten over hun aandeel in de gemeenschap kunnen beschikken.

Interessant is nu of het hierboven gestelde ook naar toekomstig recht geldt. Ingevolge artikel 3.7.1.8 lid 1/3:175 lid $1 \mathrm{NBW}$ is ieder der deelgenoten immers bevoegd om over zijn aandeel te beschikken, tenzij uit de rechtsverhouding tussen de deelgenoten anders voortvloeit. Aangezien deze bepalingen echter de eenvoudige gemeenschap betreffen, gelden zij niet voor de gemeenschap van appartementseigenaars (vgl. par. 4.3.1). Daarom gelden de algemene regels van artikelen 3.4.2.1 lid 1/ 3:83 lid 1 en 6.5.3.4 lid 5/6:252 NBW, en is een vervreemdingsbeperking slechts met obligatoire werking mogelijk.

Het moge duidelijk zijn dat het bovenstaande betoog van twee veronderstellingen uitgaat, die kunnen worden aangevochten. De eerste veronderstelling is dat artikel $875 \mathrm{k} \mathrm{BW}$ regelend recht inhoudt. De tweede veronderstelling is dat een appartementseigenaar, bij ontbreken van een regeling als artikel $875 \mathrm{k}$ BW, altijd toestemming tot vervreemding van zijn aandeel nodig zou hebben. Bij ontkrachting van met name de eerste veronderstelling zou moeten worden geconcludeerd dat een vervreemdingsbeperking noch met zakelijke werking, noch obligatoir mogelijk is. Ik zou die conclusie niet willen trekken, omdat in dat geval voor het appartementsrecht, waarin aan een vervreemdingsbeperking een gerechtvaardigder belang ${ }^{133}$ ten grondslag ligt dan in veel andere rechtsverhoudingen, strengere regels zouden gelden dan voor die andere rechtsverhoudingen.

Als een vervreemdingsbeperking inderdaad met zakelijke werking in het reglement van splitsing kan worden opgenomen, moet de toepassing ervan in het algemeen aan de goede trouw worden getoetst. In het appartementsrecht kan een appartementseigenaar, aan wie de toestemming tot vervreemding is ontzegd, echter ex artikel 876d BW behalve op de goede trouw ook nog een beroep doen op de vernietigingsgronden van artikel $876 \mathrm{~d}$ lid 1 sub a en b BW.

De vraag die na de bespreking van de toestemmingsregeling opkomt, is in hoeverre een voorkeursrecht of een optierecht met zakelijke werking in het reglement van splitsing kan worden opgenomen ${ }^{134}$ ? Mijns inziens geldt hiervoor hetzelfde antwoord als bij de toestemmingsregeling. Indien het voorkeursrecht in het reglement van splitsing wordt opgenomen en in de openbare registers wordt overgeschreven, zie ik naar huidig recht geen aanleiding om aan een dergelijke clausule zakelijke werking te ontzeggen. Naar toekomstig recht zal artikel 6.5.3.4 lid 5 / 6:252 NBW echter aan zakelijke werking van een voorkeurs- of optierecht in de weg staan.

133. Namelijk de vrede en must in de gemeenschap van appartementseigenaars.

134. Pitlo/Brahn, blz. 173 meent dat een optierecht alleen obligatoir kan werken. 


\section{Interne rechtsvergelijking}

\subsection{Inleiding}

Het appartementsrecht vormt in het Nederlandse recht een bijzonder rechtsinstituut. Het is een hybridische figuur die uit verschillende juridische componenten is samengesteld. Het appartementsrecht zoals dat in het BW is opgenomen, verenigt namelijk ellementen van verscheidene rechtsfiguren met elkaar. Zo bevat het appartementsrecht verenigingsrecht, maar regelt het tevens medeëigendom en de totstandkoming en handhaving van een beperkt zakelijk genotsrecht. Enerzijds omvat een appartementsrecht immers medeëigendom van het gehele appartementencomplex met een beperkt zakelijk genotsrecht ten aanzien van de privégedeelten en sommige andere gedeelten, anderzijds moet een vereniging van eigenaars (V.v.E.) ervoor zorgen dat alles reilt en zeilt binnen het appartementencomplex. De welstandsbepalingen vormen een instrument voor de V.v.E. om dit te bereiken. Door hantering van welstandsbepalingen ten opzichte van een bepaalde appartementseigenaar kan men aan deze appartementseigenaar echter gedeeltelijk de mogelijkheid ontnemen om gebruik te maken van zijn zakelijk genotsrecht. De appartementseigenaar blijft medeëigenaar van het appartementencomplex en lid van de V.v.E. Zolang hij medeeigenaar van het appartementencomplex is, is hij immers tevens van rechtswege lid van de V.v.E. (art. 876a BW).

Het lijkt erop dat de welstandsbepalingen een aan het Nederlandse burgerlijk recht verder vreemde toezichtregeling behelzen. Toezichtregelingen komen, afgezien nog van de misbruik- en hinderregelingen, op meerdere plaatsen in ons recht voor. Allereerst komen zij voor binnen twee componenten van het appartementsrecht, namelijk binnen het verenigingsrecht en binnen het recht dat de medeëigendom regelt. Verenigingen kennen immers de bekende ballotageregelingen die sterk op de figuur "welstandsbepalingen" lijken. Hetzelfde geldt mutatis mutandis voor de coöperatieve vereniging. Binnen het recht dat de medeëigendom regelt, treffen we eveneens controlemogelijkheden voor de medeëigenaars onderling aan. In dit hoofdstuk zullen de onderlinge controlemogelijkheden bij medeëigendom en de ballotage- en opzeggingsregelingen binnen het verenigingsrecht - tezamen met de daartegen openstaande rechtsmiddelen onderzocht worden. Enerzijds omdat de rechtsfiguren waaruit ze voortspruiten samenstellende delen van het appartementsrecht zijn, en anderzijds omdat dit onderzoek wellicht meer licht kan werpen op de in de schaduw van het onzekere verblijvende vraag welke welstandsbepalingen toelaatbaar zijn en wellicht węlke criteria voor toelaatbaarheid kunnen worden gehanteerd.

Voorts komt ter completering van de interne rechtsvergelijking het huurrecht aan de orde, in het bijzonder het aangaan en opzeggen van een huurovereenkomst. Allereerst wordt hierbij behandeld aan welke voorwaarden opzegging van en (eventuele) weigering tot het aangaan van een huurovereenkomst moeten voldoen. 
Analoog kunnen deze voorwaarden wellicht op het appartementsrecht worden toegepast. Een andere vraag die aan de orde komt is of de aanvaarding en opzegging van huurovereenkomsten door de verhuurder aan al dan niet soepelere regels is gebonden dan ontzegging van gebruik van een appartementsrecht door de. vergadering van eigenaars. Het ligt immers voor de hand om ontzegging van een in beginsel persoonlijk recht als het huurrecht minder streng op geldigheid te toetsen dan ontzegging van gebruikmaking van een zakelijk genotsrecht. Aan het einde van dit hoofdstuk zal ook aandacht worden besteed aan verhuur van appartementen.

\subsection{Gewone verenigingen en coöperaties}

\subsection{Gewone verenigingen}

\subsubsection{Algemene opmerkingen}

Voor inwerkingtreding van Boek $2 \mathrm{BW}$ waren op de vereniging drie wettelijke regelingen van toepassing. Deze wettelijke regelingen waren:

1. de bepalingen van de tiende titel van boek $3 \mathrm{BW}$ (oud);

2. de wet van 22 april $1855^{1}$ "tot regeling en beperking van het regt van Vereeniging en Vergadering";

3. de "Duurverlengingswet" van 18 maart $1948^{2}$. Deze wet bevatte voorzieningen voor de na 4 mei 1945 verstreken duur van rechtspersoonlijkheid bezittende verenigingen en naamloze vennootschappen.

In 1976 trad echter Boek 2 van het (nieuwe) Burgerlijk Wetboek in werking. Hierin werd het verenigingsrecht opnieuw geregeld ${ }^{3}$.

Een gewone vereniging is thans

"een samenwerkingsverband opgericht bij meerzijdige rechtshandeling, dat tengevolge van de door de leden-oprichters ervoor gestelde regels een zodanige zelfstandigheid bezit dat het als rechtssubject kan bestaan en dat dient om een bepaald doel na te streven, hetwelk niet is het maken van winst ter verdeling onder de leden en evenmin het behartigen van stoffelijke belangen der leden door met hen overeenkomsten te sluiten in een te hunner behoeve uitgeoefend bedrijf."

Aldus omschrijft Den Tonkelaar ${ }^{4}$ in zijn dissertatie de gewone vereniging. Elk "onderonsje" dat een regeling krijgt die het tot een zelfstandig samenwerkingsverband maakt, is een vereniging in de zin van boek $2 \mathrm{BW}^{5}$.

1. Stb. 1855,32 .

2. Stb. 1948, 107 .

3. Vgl. artt. II, V, hoofdstuk 4 van de Invoeringswet boek 2 BW, Stb. 1976, 228, 229.

4. Den Tonkelaar, blz. 65, 119.

5. Dijk (Ervaringen), denkt hier anders over. Overigens is de term "onderonsje" van hem. Vgl, ook Den Tonkellaar, blz 122. 
In elke vereniging zijn de leden onontbeerlijk. De leden werken in de verenigingrechtspersoon immers samen. Bovendien heeft de algemene ledenvergadering binnen de vereniging de meeste macht. Sommige auteurs zien elk afzonderlijk lid. zelfs als verenigingsorgaan ${ }^{6}$. Hoe het ook zij, de leden van een vereniging zijn de slagaders van de vereniging. Zonder leden is een vereniging nawwelijks denkbaar. Het feit dat een "gewone" vereniging een samenwerkingsverband voor de leden is on een bepaald (ideêel) doel te bereiken, brengt met zich mee dat de leden met elkaar in aanraking komen en van elkaar afhankelijk zijn. Wil het doel bereikt kunnen worden, dan zullen de leden moeten kunnen samenwerken. Om de samenwerking zo goed mogelijk te laten verlopen is het nodig dat de leden onderling met elkaar kunnen opschieten en elkaar kunnen helpen. Daarom ook zullen verenigingen de mogelijkheid dat iedereen lid wordt van de vereniging willen inperken. Het is duidelijk dat het voor de onderlinge afhankelijkheid verschil maakt wat de aard van de vereniging is. Bij de klaverjasklub die 's zaterdagsavonds in het café bij elkaar komt is er een grotere afhankelijkheid van de leden onderling dan bij de "Citroën-Ami-onderdelenclub", welke vereniging - als ze al zou bestaan waarschijnlijk van dien aard zou zijn dat de leden niet of nauwelijks met elkaar in contact zouden komen. Veel verenigingen zullen het gezien de onderlinge afhankelijkheid nodig achten invloed uit te oefenen op de samenstelling van het ledenbestand. Personen die daarin niet passen zullen zij proberen te weren. Hiertoe kunnen zij twee wegen bewandelen die sterk op de welstandsbepalingen in het appartementsrecht lijken. Enerzijds kan de vereniging een ballotage-regeling hanteren, waarbij men een aspirant-lid als lid van de vereniging kan weigeren, en anderzijds kan aan iemand die al lid is, het lidmaatschap worden opgezegd dan wel ontzegd. Deze toelatings- en opzeggingsmogelijkheden hangen nauw samen met de in onze grondwet gewaarborgde vrijheid van vereniging (art. 8 Grondwet). De vrijheid van vereniging impliceert immers tevens de vrijheid van "niet-vereniging". Daaruit volgt dat men niet gedwongen kan worden met bepaalde personen in een vereniging te zitten.

\subsection{De coöperatie}

\subsubsection{Algemene opmerkingen}

Bij het tot stand komen van onze codificatie was de coöperatie, voorheen coöperatieve vereniging genaamd, onbekend. " $\mathrm{Zij}$ dateert uit het midden van de vorige eeuw," aldus Asser/Van der Grinten? ${ }^{7}$ De coöperatie ontwikkelde zich vooral in de agrarische sector en wordt daar, evenals in de meeste andere landen van de wereld, nog steeds het meest toegepast ${ }^{8}$.

In $1876^{\circ}$ werd de eerste wet met betrekking tot coöperatieve verenigingen in het leven geroepen. Aanleiding tot deze wettelijke regeling was de weigering door de kroon om een vereniging die tot doel had de stoffelijke belangen van haar leden

6. Vgl. Den Tonkelaar, blz. 206.

7. Asser/Van der Grinten II, blz. 158.

8. Een cooperatie hoeft niet noodzakelijkerwijs in een verenigingsvorm gegoten te worden. In België bijvoorbeeld heeft men haar in de vorm vam een vennootschap gestalte gegeven.

9. Stb. 1876, 227. 
te behartigen, als rechtspersoon te erkennen ${ }^{10}$. Volgens de Kroon was de coöperatieve verenigingsvorm niet te rijmen met de wet van 22 april $1855^{11}$, op grond waarvan de rechtspersoonlijkheid van een vereniging afhankelijk was van erkenning door de kroon.

In 1925 kwam een nieuwe Wet op de Coöperatieve Verenigingen tot stand ${ }^{12}$. In 1976 werd het recht betreffende coöperatieve verenigingen opnieuw gewijzigd en in titel 2 afdeling 2 van boek 2 van het (toen nog nieuwe) Burgerlijk Wetboek opgenomen. Artikel III, hoofdstuk 4, van de Invoeringswet Boek $2 \mathrm{NBW}^{13}$, bepaalde dat de Wet op de Coöperatieve Verenigingen van 1925 werd ingetrokken. Bij wet van 16 juni $1988^{14}$ werd het recht met betrekking tot de coöperatieve vereniging in het $\mathrm{BW}$ veranderd. De wetswijziging behelsde ondermeer de verandering van de naam "coöperatieve vereniging" in "coöperatie".

De coöperatie is een bijzondere vorm van de vereniging (vgl. art. 2:53 lid $1 \mathrm{BW}$ ). $\mathrm{Zij}$ onderscheidt zich van de "gewone" vereniging door het feit dat haar doelstelling primair.gericht moet zijn op de behartiging van de stoffelijke belangen van de leden (art. 2:53 lid 1 BW). De coöperatie mag tevens ten doel hebben om de ideële belangen van haar leden te behartigen, mits de primaire doelstelling behartiging van de stoffelijke belangen - daardoor niet verdrongen wordt. De gewone vereniging daarentegen dient zich primair te richten op de behartiging van de ideële belangen van haar leden (art. 2:26 BW).

De wettelijke omschrijving van de coöperatieve vereniging is neergelegd in artikel 2:53 lid 1 BW. Dit artikel luidt als volgt:

"De coöperatie is een bij notariële akte als coöperatie opgerichte vereniging. Zij moet zich blijkens de statuten ten doel stellen in bepaalde stoffelijke behoeften van haar leden te voorzien, krachtens overeenkomsten, anders dan van verzekering, met hen gesloten in het bedrijf dat zij te dien einde te hunnen behoeve uitoefent of doet uitoefenen."

Uit deze omschrijving blijken duidelijk de verschillende kenmerken van de coöperatie. De coöperatie heeft als rechtsvorm: de verenigingsvorm (rechtspersoon), die als doel heeft in stoffelijke behoeften van haar leden te voorzien, waarvoor zij als middelen heeft het sluiten van overeenkomsten met leden in het kader van het voeren van een bedrijf ten behoeve van voorziening in de stoffelijke behoeften van de leden.

De coöperatie heeft als rechtsvorm derhalve de verenigingsvorm. De coöperatie had echter ook in een andere vorm kunnen worden gegoten. Nu aan de coöperatie in Nederland als species van de vereniging gestalte is gegeven, zijn de algemene bepalingen van het verenigingsrecht (met uitzondering van artt. 2:26 lid 2 en 2:44 lid $2 \mathrm{BW}$ ) erop van toepassing (zie art. 2:53a BW), voorzover in de specifieke

10. Amerongse coöperatieve credietwereniging. Zie ook Polak (Preadvies), blz. 1.

11. Stb. 1855,32 . Dit was de wet inzake "regeling en beperking van het regt van Vereeniging en Vergadering". Vgl. hierbij ook Rb. Breda 5 okt. 1915, NJ 1916, blz. 1102. Volgens de Bredase rechtbank was de wet van 1855 niet op coöperatieve verenigingen van toepassing.

12. Wet van 25 mei 1925 , Stb. 1925, 204.

13. Stb. 1976, 229 .

14. Stb. 1988, 305. In werking getreden op 1 jan. 1989. 
bepalingen betreffende de coöperatie tenminste niet van die algemene bepalingen is afgeweken.

In de doelstelling van de coöperatie, namelijk dat zij de stoffelijke belangen van haar leden moet behartigen, komt

"het tweeledige karakter van de koöperatieve vereniging (lees: coöperatie, R.M.) tot uitdrukking, te weten enerzijds vereniging, anderzijds een onderneming. (.....) De beide aspekten - de gezamenlijke leden en de onderneming bepalen het 'gezicht' van de koöperatieve vereniging. " 15

Coöperaties voeren ondernemingen op vele gebieden. Als voorbeelden kunnen hier de coöperatieve banken, land- en tuinbouwcoöperaties, arbeidersproductiecoöperaties, coöperaties van taxichauffeurs en visserijcoöperaties worden genoemd, en uiteraard zijn er ook nog de voor dit werk zeker niet onbelangrijke coöperatieve flatexploitatieverenigingen ${ }^{16}$. Aangezien de term "coöperatieve vereniging" door de wet van 16 juni 1988 is vervangen door de term "coöperatie", moet tegenwoordig van "flatexploitatiecoöperatie" of kortweg "flatcoöperatie" worden gesproken. In het navolgende zal de term "flatcoöperatie" daarom ter vervanging van de term "coöperatieve flatexploitatievereniging" worden gehanteerd.

De coöperatie moet overeenkomsten met haar leden sluiten. Naast een lidmaatschapsverhouding met de vereniging verlangt de wet hier derhalve een daarvan gescheiden contractuele verhouding tussen de vereniging en haar leden ${ }^{17}$.

De coöperatie moet bovendien een bedrijf uitoefenen. Als rechtspersoon (art. 2:3 $\mathrm{BW}$ ) is ze zelf aansprakelijk voor de schulden die uit het uitoefenen van het bedrijf voortvloeien. Bij de oprichting van een coöperatieve vereniging is echter geen startkapitaal vereist, zoals bij de NV en BV wel het geval is. Zij zal dan ook vaak het voor het voeren van een bedrijf benodigde kapitaal door middel van kredieten moeten vergaren. $\mathrm{Om}$ aan de kredietverleners enige kredietwaardigheid te verzekeren, heeft de wetgever bepaald dat de leden van de vereniging in geval van vereffening in beginsel onbeperkt aansprakelijk zijn voor de tekorten van de vereniging (art. 2:55 BW). Statutair mag van deze aansprakelijkheidsregeling echter worden afgeweken, hetgeen volgens Polak in praktijk ook veelvuldig gebeurt ${ }^{18}$. Indien statutair niet van deze aansprakelijkheidsregeling is afgeweken, moet de coöperatie aan het slot van haar naam de letters W.A. (wettelijke aansprakelijkheid) voeren (art. 2:55 jo. 56 lid $1 \mathrm{BW}$ ). Zoals vermeld kan echter in de statuten worden bepaald dat de aansprakelijkheid beperkt is of zelfs geheel uitgesloten. In die gevallen moet aan het slot van de naam van de coöperatie de aanduiding B.A. (beperkte aansprakelijkheid) respectievelijk U.A. (uitgesloten aansprakelijkheid) worden vermeld (art. 2:56 lid $1 \mathrm{BW}$ ).

15. De Groot/Stein, blz 190.

16. Vgl. Ter Woorst, blz. 7.

17. Vgl. Stille (Rechtspersonen), art. 53 aant. 4 sub b. Zie ook Willemse, blz 378-383.

18. Polak (Preadvies), blz. 22. 
In de coöperatie wordt, zoals de naam al aanduidt, door de leden samengewerkt. Vaak vindt de samenwerking plaats op die gebieden waar individueel optreden

"vanwege de kosten of andere economische faktoren onwoordelig zou zijn."19

De coöperatie kent weliswaar de hierboven genoemde kenmerkende verschillen met de "gewone" vereniging, maar heeft tevens een aantal kenmerken met de "gewone" vereniging gemeen, hetgeen voortvloeit uit de genus-species verhouding. De belangrijkste gemeenschappelijke kenmerken zijn dat beide vormen leden hebben die "vrij" uit en toe kunnen treden ${ }^{20} \mathrm{en}$, zoals De Groot/Stein vermeldt, het feit dat de beide verenigingen ondanks wisseling van de leden blijven voortbestaan. De Groot/Stein acht dit een tegenstelling tot de v.o.f. die eindigt door uittreden van een van de vennoten. Het feit dat de beide verenigingen blijven voortbestaan ondanks wisseling van de leden, als tegenstelling tot de v.o.f., zou echter mijns inziens ook kunnen worden verklaard uit het verschil rechtspersoon - niet rechtspersoon. De beide verenigingen zijn rechtspersonen en als zodanig blijven zij, net als de BV en de NV, voortbestaan na wisseling van de leden (vennoten). Een v.o.f. als niet-rechtspersoon, als associatie van personen, blijft na wisseling van de vennoten niet voortbestaan omdat de specifieke vennoten nu eenmaal de vennootschap vormen, zonder dat deze zelfstandige rechtspersoonlijkheid bezit. De coöperatieve vereniging heeft echter wel met de v.o.f. gemeen dat zij als personenassociatie kan worden beschouwd, terwijl de NV en de BV kapitaalassociaties kunnen worden genoemd ${ }^{21}$. In dit licht is de vergelijking tussen de v.o.f. en de coöperatie dan ook begrijpelijk.

Tot slot dient bij deze algemene opmerkingen nog aandacht te worden geschonken aan de "onderlinge waarborgmaatschappij". De bepalingen betreffende de onderlinge waarborgmaatschappij zijn opgenomen in titel 3 van boek $2 \mathrm{BW}$, naast de bepalingen betreffende de coöperaties. De onderlinge waarborgmaatschappij kan worden gezien als een coöperatie die zich ten doel stelt met haar leden verzekeringsovereenkomsten te sluiten. In die opvatting geldt zij derhalve als subspecies van de "gewone" vereniging ${ }^{22}$. Op de onderlinge waarborgmaatschappij zal in het navolgende niet expliciet worden ingegaan.

De vraag die in dit onderdeel van hoofdstuk 4 centraal staat is aan welke wettelijke en statutaire eisen de ballotage en opzegging bij zowel de "gewone" verenigingen als de coöperaties moeten voldoen en welke rechtsmiddelen hiertegen open staan. Bij de beide regelingen zal echter eerst op de wettelijke grondslag daarvan voor de "gewone" vereniging, respectievelijk de coöperatie, worden ingegaan.

19. De Groot/Stein, blz. 186

20. Bij toetreding kan echter toezicht worden uitgeoefend door middel van de mog te behandelen "ballotageregelingen".

21. De Groot/Stein, blz. 190, 192.

22. De Groot/Stein, blz. 189. 


\subsubsection{Verkrijging van het lidmaatschap; de ballotage-regeling}

\subsubsection{Ballotage bij "gewone" verenigingen}

Voor toetreding tot een gewone vereniging geeft de wet regelend recht in artikel 2:33 BW: het bestuur van de vereniging beslist over de toelating van een lid en bij niet toelating kan de algemene vergadering alsnog tot toelating besluiten. In de statuten van de vereniging kan echter een afwijkende regeling worden getroffen ${ }^{23}$. Artikel 33 is geënt op artikel 11, vierde lid van de Wet op de Coöperatieve Verenigingen 1925. Voor gewone verenigingen stelde het departement volgens Stille ${ }^{24}$ reeds lang voor de invoering van artikel 33 voor erkenning het vereiste,

"dat de statuten bepaalden wie over de toetreding van nieuwe leden besliste."

In de praktijk blijken de statuten in veel gevallen inderdaad uitvoerigere regelingen met betrekking tot de toetreding van nieuwe leden te bevatten ${ }^{25}$. In elk geval beslist de algemene ledenvergadering meestal in laatste instantie over toelating van leden. Volgens Den Tonkelaar zal men dit uitgangspunt ook meestal in de statuten terugvinden. Hij haalt hierbij als voorbeelden de ballotagecommissies en de "ledenvoordrachten" (nieuwe leden moeten door leden worden voorgedragen/geïntroduceerd) aan, waarbij de ALV toch het laatste woord heeft ${ }^{26}$. De wettelijke grondslag voor "ballotage" is derbalve neergelegd in artikel 2:33 BW.

Het staat de verenigingsinstantie, die bij statuten is aangewezen om over toelating van leden te beslissen, in beginsel vrij om toelating te weigeren. Dit vloeit voort uit het recht van vrijheid van vereniging (art. 8 Grondwet) ${ }^{27}$. De vereniging kan naar eigen inzicht regels stellen voor toelating van leden tot een vereniging. De instantie die is aangewezen om over de toelating te beslissen kan

"naar welbehagen over de toelating beslissen."

Ze heeft een "freies Ermessen". Volgens Asser/Van der Grinten geldt er zelfs geen discriminatieverbod voor verenigingen. Asser/Van der Grinten ${ }^{29}$ stelt:

"met het recht is niet in strijd, dat van een vereniging slechts mannen of vrouwen, gehuwden of ongehuwden, Nederlanders of Chinezen, aangeslotenen bij een bepaald soort kerkgenootschap lid kunnen zijn."

23. Alleen bij schriftelijke statuten kan hiervan worden afgeweken. Vgl. Asser/Van der Grinten II, blz. 219; Den Tonkelaar, blz. 206; Davids, blz. 34. Anders Van Baar/Van Oosten de Boer, blz. 29. Volgens hen schrijft de wet de beroepsmogelijkheid op de ALV dwingend voor.

24. Stille (Rechtspersonen), artikel 33 aant. 1.

25. Den Tonkelaar, blz. 206.

26. Den Tonkelaar, blz. 206.

27. Vgl. Rb. Utrecht 25 juni 1958, NJ 1959, 282; Pres. Rb. Amasterdam 1 dec. 1966, NJ 1967, 310. Hierover Hehemann, blz 56-59. Zie ook Rb. 's-Gravenhage 31 jan. 1968, NJ 1968, 420; Pres. Rb. Utrecht 28 juni 1982, Kort Geding 1982, 121. Vgl. ook oudere literatuur, bijv.: Van der Esch, blz. 289-293.

28. Asser/Van der Grinten II, blz. 220.

29. Asser/Van der Grinten II, blz, 220. 
Een vereniging mag dus volgens Van der Grinten discriminatoire toelatingseisen stellen. Daarnaast mag de vereniging elke kwaliteit voor haar leden verplicht stellen, bijvoorbeeld het hebben van een bepaald beroep of een bepaalde scholing ${ }^{30}$. Indien iemand deze statutair vereiste kwaliteiten niet heeft, maar desalniettemin wordt toegelaten als lid, is deze toelating vernietigbaar ${ }^{31}$.

Verenigingen kunnen derhalve - zo lijkt het - nagenoeg onbeperkt regels stellen voor toelating van nieuwe leden. Een beroepsmogelijkheid tegen weigering van toelating is in de wet niet expliciet geschapen ${ }^{32}$. Er bestaan echter niettemin een aantal mogelijkheden om de rechter het toelatingsbesluit te laten toetsen (vgl. ook par. 4.2.3.3).

\subsubsection{Ballotage bij coöperaties}

Ook bij de coöperatie is ballotage mogelijk. Indien iemand lid wenst te worden van een coöperatie, moet hij hiertoe een schriftelijke aanvraag indienen bij de vereniging (art. 2:61 sub a BW). De coöperatie beslist vervolgens of zij de gegadigde voor het lidmaatschap als lid van de coöperatie toelaat. Hierop is net als bij de "gewone" vereniging artikel 2:33 BW van toepassing. Aan de toetreding zijn echter vaak in de statuten vereisten gesteld. Ook hierbij geldt weer hetzelfde als bij de "gewone" verenigingen vermeld. Vaak zullen de statutaire toelatingseisen bepaalde kwaliteitseisen inhouden, bijvoorbeeld in die zin dat de gegadigde een bepaald bedrijf moet uitoefenen.

\subsubsection{Rechterlijke toetsing van niet-toelating door "gewone" verenigingen en coöperaties}

De beslissing omtrent al dan niet toelating van een persoon als lid van de "gewone" vereniging of coöperatie is een besluit in de zin van artikel 2:11 jo. 2:13 BW (art. 2:15 OINBW). Op grond van die artikelen kan de beslissing dan ook bij rechterlijk vonnis vernietigd worden :

\footnotetext{
"a. wegens strijd met de wettelijke bepalingen die de bevoegdheidl van de algemene vergadering en de wijze van totstandkoming van besluiten regelen;

b. wegens strijd met de statuten;

c. wegens strijd met de goede trouw." (art. 2:11 lid $1 \mathrm{BW} /$ art. 2:15 lid 1 OINBW)
}

Bepalingen die totstandkoming van besluiten regelen, zijn neergelegd in artikel 2:38 BW. Zo zou een besluit kunnen worden vernietigd vanwege het feit dat het niet aan alle leden van de vereniging bij een toelatingsbesluit door de ALV, toegestaan werd om te stemmen (art. 2:38 lid $1 \mathrm{BW}$ ).

30. Asser/Van der Grinten II, blz. 221.

31. Vigl. voor oud recht (toelating was nietig): Hof Leeuwarden 25 juni 1958, NJ 1959, 283; Stille (Rechtspersonen), art. 33, aant. 3.

32. Bij art. 11 van de Wet op de coöperatiewe verenigingen van 1925 was overigens wel een beroepsmogellijkheid geschapen. 
Een voorbeeld van strijd met de statuten - Den Tonkelaar ${ }^{33}$ noemt het voorbeeld bijzonder - is het reeds genoemde geval dat men in de statuten bepaalde kwaliteitseisen (bepaalde scholing, bepaald beroep) stelt, en vervolgens iemand die hieraan niet voldoet toch toelaat. Het besluit omtrent toelating van die persoon is dan vernietigbaar ingevolge artikel 2:11, eerste lid sub b BW (art. 2:15 OINBW).

Ook strijd met de goede trouw is een vernietigingsgrond ingevolge artikel 2:11 BW (art. 2:15 OINBW). Volgens Asser/Van der Grinten ${ }^{34}$ kan een aspirant-lid echter geen vernietiging van een weigeringsbeshuit verkrijgen wegens strijd met de goede trouw. Volgens Asser/Van der Grinten geldt de goede trouw namelijk slechts tussen de personen die deel uitmaken van de vereniging, niet dus ten opzichte van aspirant-leden. Volgens Van Schilfgaarde ${ }^{35}$ is de opvatting die Asser/Van der Grinten huldigt echter niet de heersende. De kring van personen die bij een rechtspersoon zijn betrokken wordt volgens Van Schilfgaarde over het algemeen ruimer getrokken.

Als het besluit waarbij een aspirant-lid als lid van een vereniging geweigerd wordt, vernietigd wordt, heeft dit nog niet het gevolg dat het aspirant-lid het lidmaatschap verkrijgt ${ }^{36}$. Het aspirant-lid is immers weer terug bij af en zal opnieuw om toelating moeten verzoeken. De vereniging kan dan eventueel opnieuw weigeren om de gegadigde het lidmaatschap toe te kennen.

Het aspirant-lid kan echter ook uit onrechtmatige daad tegen het besluit ageren. Als een weigeringsbesluit genomen is in strijd met de goede trouw, zal dit vaak ook strijd met de zorgvuldigheid die in het maatschappelijk verkeer betaamt opleveren. Bovendien zal strijd met de goede trouw als bedoeld in artikel 2:11 BW (art. 2:15 OINBW) volgens Van Schilfgaarde ${ }^{37}$ vaak ook strijd met de algemene goede trouw, c.q redelijkheid en billijkheid, opleveren. In zo'n geval is het volgens Van Schilfgaarde raadzaam om zich op artikel 1401 of artikel $1374 \mathrm{BW}$ te baseren. Het voordeel dat aan dergelijke acties is verbonden is dat men niet aan de verjaringstermijn van artikel 2:11 lid $3 \mathrm{BW}$ (art. 2:15 lid 5 OINBW) is gebonden en evenmin aan artikell 2:12. BW (art. 2:15 lid 3 OINBW) waarin bepalingen betreffende rechterlijke competentie worden gegeven ${ }^{38}$. Een ander voordeel van deze acties is dat men kan vorderen om alsnog toegelaten te worden als lid van de vereniging, en men bij de actie uit onrechtmatige daad bovendien nog schadevergoeding kan vorderen. Tenslotte dient als voordeel van bijvoorbeeld de actie ex artikel 1401 BW te worden aangestipt dat de rechter in een dergelijke procedure voll toetst, terwijl hij bij toetsing aan de goede trouw ex artikel 2:11 BW (art. 2:15 OINBW), slechts marginaal toetst (vgl. par. 4.2.4.4).

Tenslotte kan een besluit van een vereniging nietig of vernietigbaar zijn wegens ongeoorloofde oorzaak, oftewell wegens strijd met de wet, goede zeden of openbare orde (artt. 1371, 1373 BW; art. 3.2.7 / 3:40 NBW). Zo ook kan een aspirant lid van een vereniging dat niet als lid wordt toegelaten, de nietigheid (vernietigbaarheid) van het weigeringsbesluit inroepen, indien het is genomen in strijd met de wet, goede zeden of openbare orde (vgl. ook par. 3.6.2.1). Een besluit dat in strijd is

33. Den Tonkelaar, blz. 208.

34. Asser/Van der Grinten II, blz. 220.

35. Van Schilfgaarde (Rechtspersonen), art. 11, aant. 15.

36. Vgl Asser/Van der Grinten II, blz. 220.

37. Van Schilfgaarde (Rechtspersonen), art. 11 aant. 15.

38. Van Schilfgaande (Rechtspersonen), art. 11 aant. 15. 
met de openbare orde of goede zeden is van rechtswege nietig. Sommige auteurs noemen dit een grondbeginsel van Nederlands privaatrecht ${ }^{39}$. In het toekomstige recht is de nietigheid van een rechtshandeling wegens strijd met openbare orde of goede zeden geregeld in artikel 3.2.7.

Volgens Van Schilfgaarde ${ }^{40}$ is het moeilijk aan te geven wanneer een besluit van een vereniging in strijd met de openbare orde is. Volgens hem zullen besluiten die in strijd zijn met fundamentele (ongeschreven) regels van rechtspersonenrecht als strijdig met de openbare orde moeten worden aangemerkt. Strijd met de goede zeden zou er volgens Van Schilfgaarde kunnen zijn, als het besluit door "onoirbare motieven" is ingegeven. Ook hierbij is het echter moeilijk concrete voorbeelden te geven. Het is desalniettemin geenszins ondenkbaar dat een aspirant-lid van een vereniging zich op de openbare orde of goede zeden kan beroepen ten aanzien van een weigeringsbesluit.

Strijd met een dwingende wetsbepaling zal over het algemeen eveneens nietigheid van een besluit met zich meebrengen (art. 3.2.7 lid 2 / 3:40 lid 2 NBW). De dwingende wetsbepaling kan er een van zowel binnen als buiten het rechtspersonenrecht zijn. Naar NBW is een rechtshandeling die in strijd met een dwingende wetsbepaling wordt aangegaan, evenals naar huidig recht, nietig. $\mathrm{Ze}$ is echter vernietigbaar indien de dwingende wetsbepaling slechts strekt tot bescherming van een der partijen. Een aspirant-lid dat niet tot een vereniging wordt toegelaten zal echter nooit een beroep op artikel 3.2.7 lid $2 / 3: 40$ lid 2 NBW kunnen doen, nu het nemen van een weigeringsbesluit op zichzelf niet in strijd met de wet is. Het besluit kan slechts naar inhoud of strekking in strijd met de wet zijn, waardoor de nietigheid ervan niet volgt uit strijd met de wet, maar uit strijd met de openbare orde of goede zeden (art. 3.2.7 lid 1/3:40 lid 1 NBW). Naar huidig recht zal echter een toelatingsbesluit, dat naar inhoud of strekking in strijd met de wet is, een ongeoorloofde oorzaak hebben en daarom nietig zijn ${ }^{41}$.

Een beroep op de nietigheid (vernietigbaarheid) van een besluit waarbij aan een aspirant-lid van een vereniging het lidmaatschap wordt ontzegd, is - ook indien het slaagt - niet bijzonder vruchtbaar voor de betrokkene, aangezien het nietige (vernietigde) besluit niet wordt vervangen door een toelatingsbesluit. De vereniging (ballotage-commissie) zal opnieuw omtrent toelating moeten beslissen (vgl. par. 3.6.2.2). In gevallen waarin een beroep op strijd met de wet, openbare orde of goede zeden mogelijk is, zal vaak ook een actie uit onrechtmatige daad mogelijk zijn. Deze actie biedt aanzienlijk betere mogelijkheden dan een beroep op de ongeoorloofde oorzaak (vgl. ook hier par. 3.6.2.3). Men zou hierbij zelfs aan een veroordeling tot toelating kunnen denken ${ }^{42}$.

Zowel bij toetsing aan de goede trouw, als bij toetsing aan de openbare orde en goede zeden en aan de zorgvuldigheid die in het maatschappelijk verkeer betaamt, heeft de rechter de ruimte om de ballotage te toetsen aan de grondrechten. Bij deze toetsing zal echter altijd sprake zijn van botsing van grondrechten, nu het

39. Vgl. Van Schilfgaarde (Rechtspersonen), art. 11 aant. 17; Dijk/Van dler Ploeg, blz. 85, 86.

40. Van Schilfgaarde (Rechtspersonen), art. 11, aant 15.

41. Vgl. voor de ongeoorloofde oorzaak naar huidig recht en strijd met de wet, openbare orde en goede zeden naar toekomstig recht onder andere: Asser/Rutten, blz. 195-218; Asser/Hartkamp, blz. 208-232. Zie hierbij ook Drion/Hijma/Olthof, blz. 140-144.

42. Aldus Van der Esch, blz 292. 
geschonden grondrecht van het aspirant-lid botst met de vrijheid van vereniging. Bij de toetsing aan de grondrechten zal de rechter moeten nagaan in hoeverre de botsende rechten horizontaal werken, om vervolgens bijvoorbeeld met toepassing van het relevantie- en proportionaliteitscriterium tot een beslissing te komen (vgl. par. 3.5.3). Bij toetsing aan de goede trouw ex artikel 2:11 BW moet de rechter marginaal toetsen en kan hij derhalve niet op de doelmatigheid en evenredigheid van de ballotage ingaan, indien er geen grondrecht van het aspirant-lid in het geding is.

Indien er wel grondrechten van het aspirant-lid in het geding zijn, kan de rechter de doelmatigheid en de proportionaliteit van de beperking wel toetsen. De toetsing aan de grondrechten is immers een rechtmatigheidstoetsing, die de rechter altijd zal moeten uitwoeren en waarvan de toetsing aan de doelmatigheid en de proportionaliteit een onderdeel uitmaakt. De rechter toetst hier niet de doelmatigheid van het toelatingsbesluit in het algemeen, maar de doelmatigheid en de evenredigheid van de beperking of inbreuk op een grondrecht (zie par. 3.5.3).

\subsection{Einde van het lidmaatschap; opzegging en royement}

\subsubsection{Algemene opmerkingen}

Zowel de "gewone" verenigingen als de coöperaties kunnen een toelatingsregeling voor nieuwe leden hanteren. De eigenaars van de appartementsrechten in een appartementencomplex (niet de V.v.E.) kunnen een toelatingsregeling voor nieuwe bewoners hanteren (let wel: niet ten aanzien van het lidmaatschap van de V.v.E; vergelijk art. $876 \mathrm{BW}$ ). De eigenaars van de appartementsrechten in een appartementencomplex kunnen in het reglement van splitsing ook nog een regeling omtrent ontzegging van verder gebruik opnemen. Bij verenigingen doet zich eenzelfde verschijnsel voor. Het lidmaatschap van een coöperatie of "gewone" vereniging kan op verscheidene wijzen eindigen ( $\operatorname{art} .2: 35 \mathrm{BW})^{43}$. Allereerst eindigt het lidmaatschap door overlijden van het lid (art. 2:35 lid 1 sub a BW; echter OINBW, art. 2:35 lid 1 sub a: tenzij de statuten overgang krachtens erfrecht mogelijk maken). Ten tweede eindigt het lidmaatschap door opzegging door het lid (art. 2:35 lid 1 sub b BW). Ten derde kan het lidmaatschap namens de vereniging worden opgezegd (art. 2:35 lid 1 sub c BW). Deze opzegging valt in twee categorieën te onderscheiden. Enerzijds is er de gewone opzegging, bijvoorbeeld omdat een lid ophoudt aan in de statuten gestelde kwaliteitseisen te voldoen. Anderzijds is er de ontzetting, ook wel royement genoemd (art. 2:35 lid 1 sub d BW). Royement is opzegging met een diffamerend karakter. Royement vindt plaats wegens wangedrag van het lid ${ }^{44}$. In het onderstaande zal worden nagegaan wanneer lidmaatschap door de vereniging kan worden opgezegd (gewone opzegging/royement) en welke beroepsmogelijkheden het "opgezegde" lid hiertegen heeft.

43. Dit artikel geeft dwingendrechtelijke regels. Zie Dijk/Van der Ploeg, blz, 133.

44. Den Tonkelaar, blz 212-215. 
De gewone opzegging door de coöperatie of de "gewone" vereniging kan geschieden in drie gevallen, genoemd in artikel $2: 35$ lid 1 sub c BW.

1. Allereerst is opzegging mogelijk in de gevallen die in de statuten zijn genoemd.

2. Daarnaast is opzegging mogelijk wanneer een lid heeft opgehouden aan de eisen te voldoen die de vereniging voor het lidmaatschap heeft gesteld ${ }^{45}$.

Noch de opzeggingsredenen noch de vereisten voor lidmaatschap hoeven overigens in schriftelijke statuten geregeld te zijn, mits deze regelingen niet afwijken van de in de tweede titel van boek $2 \mathrm{BW}$ gegeven bepalingen (vgl. art. 2:52 BW).

3. Ten derde kan het lidmaatschap door de vereniging aan een lid worden opgezegd als redelijkerwijs van de vereniging niet kan worden gevergd dat zij het lidmaatschap laat voortduren.

De vrijheid om in de statuten gevallen op te nemen waarin kan worden opgezegd door de vereniging, is nergens expliciet door de wet beperkt. Dat betekent dat de vereniging in beginsel alle criteria kan hanteren die haar goeddunken. Deze vrijheid vloeit ongetwijfeld voort uit het recht van vrijheid van vereniging. Dit recht beschermt tegelijkertijd ook de bevoegdheid van de vereniging om de criteria die haar goeddunken, te hanteren. Net als bij de toelating van een lid gelden hier echter ook weer de impliciete door de wet gestelde beperkingen. De ontzetting zal geen te grote inbreuk mogen maken op rechten van anderen of indruisen tegen maatschappelijke verplichtingen en zorgvuldigheid. Waar de vrijheid ophoudt is echter moeilijk te bepalen. Mag een katholieke vereniging met als doelstelling de bevordering van de re-evangelisatie, in de statuten opnemen dat aan mensen die homofiel blijken te zijn, enkel op die grond het lidmaatschap wordt opgezegd? Hier botsen de vrijheid van godsdienst en de vrijheid van vereniging frontaal met het non-discriminatiebeginsel. Bij de toetsing van de opzegging zal de rechter derhalve door hantering van (bijvoorbeeld) het relevantie- en het proportionaliteitsbeginsel, tot een beslissing kunnen komen (vgl. par. 3.7.2 en 4.2.3.3 laatste alinea).

Wanneer een lid ophoudt aan de vereisten voor het lidmaatschap van een bepaalde vereniging te voldoen, eindigt het lidmaatschap niet van rechtswege. Het moet door de vereniging worden opgezegd. Als een vereniging aan haar leden als eis stelt dat zij als advocaat werkzaam moeten zijn, en een van de leden verandert van baan om bedrijfsjurist te worden, kan de vereniging zijn lidmaatschap opzeggen. Van Schilfgaarde ${ }^{46}$ wijst erop dat het soms moeilijk te bepalen zal zijn of een situatie onder $a$ of $b$ valt. Als voorbeeld noemt hij hier de vereniging die als eis voor het lidmaatschap stelt dat iemand niet in staat van faillissement verkeert. Een dergelijke negatieve formulering levert een eis op die onder b valt; onder vereisten voor het lidmaatschap van de vereniging. Indien een vereniging echter in

45. Vgl. Dijk/Van der Ploeg, blz. 134 .

46. Stille (Rechtspersonen), art. 35, aant. 4. 
haar statuten opneemt dat aan een lid dat in staat van faillissement geraakt, het lidmaatschap wordt opgezegd, valt dit onder de opzeggingsgronden die de vereniging in haar statuten kan opnemen (onder a).

Indien een lid zich schuldig maakt aan wangedrag buiten de vereniging, kan dit in sommige gevallen aanleiding geven voor een vereniging om het lidmaatschap van het betreffende lid op te zeggen. In zo'n geval kan van de vereniging redelijkerwijze niet worden verlangd dat zij het lidmaatschap laat voortduren. Zo deed zich na de tweede wereldoorlog in Rotterdam een geval voor, waarbij een coöperatieve vereniging aan een oud NSB-er het lidmaatschap had opgezegd. Het Hof "s-Gravenhage achtte dit toelaatbaar omdat van de vereniging redelijkerwijze niet kon worden verlangd dat zij het lidmaatschap liet voortduren ${ }^{47}$.

\subsubsection{Royement/ontzetting}

Zoals reeds is vermeld is ontzetting opzegging met een diffamerend karakter. Ook als in de statuten geen regeling is opgenomen die royement mogelijk maakt, en evenmin gevallen waarin royement kan plaatsvinden zijn opgenomen, kan ontzetting plaatsvinden, enkel ingevolge artikel 2:35 lid 1 sub d BW. Artikel 2:35 lid 1 sub d BW is een bepaling van dwingend recht, zulks in tegenstelling tot artikel 15 vat de wet op de coöperatieve verenigingen van 1925 , dat slechts een bepaling van regelend recht inhield ${ }^{48}$.

Royement is mogelijk wegens wangedrag van een lid binnen de vereniging of ten aanzien van de vereniging. Wangedrag van een lid buiten de vereniging kan geen reden tot ontzetting opleveren, wel echter tot (gewone) opzegging ${ }^{49}$. Het wangedrag van het lid moet zich uiten in een handeling die in strijd is met de statuten, reglementen of besluiten van de vereniging, of in een handeling die de vereniging op onredelijke wijze benadeelt (art. $2: 35$ lid $1 \mathrm{sub} \mathrm{d} \mathrm{BW})^{50}$. Overigens moet het tot ontzetting bevoegde orgaan wel de regels die de goede trouw met zich meebrengt, in acht nemen ${ }^{51}$.

Zowel de (gewone) opzegging als de ontzetting geschiedt door het bestuur van de vereniging, tenzij de statuten de bevoegdheid tot opzegging aan de algemene vergadering opdragen, casu quo de ontzetting aan een ander orgaan opdragen (art. 2:35 lid 1 sub $\mathrm{c}$ en lid 2BW). De procedure van (gewone) opzegging door de vereniging is vrijwel ongeregeld in de wet. De procedure voor ontzetting is daarentegen uitgewerkt in artikel 2:35 lid 2 BW. Dit artikellid bepaalt dat de ontzetting door het bestuur geschiedt, tenzij de statuten deze bevoegdheid aan een ander orgaan van de vereniging opdragen. Voorts moet de betrokkene zo snel mogelijk schriftelijk van het besluit op de hoogte worden gesteld, waarbij tevens de gronden voor ontzetting moeten worden aangegeven. Tenzij het besluit tot ontzetting door de algemene ledenvergadering is genomen, staat bij dit orgaan van de vereniging binnen een maand na ontvangst van de ontzettingskennisgeving beroep open. In de statuten of reglementen kan een andere beroepsregeling

47. Hof 's-Gravenhage 10 jan. 1951, NJ 1952, 100.

48. Asser/Van der Grinten II, blz, 227, Dijk/Van der Ploeg, blz. 133.

49. Vgl. Hof 's-Gravenhage 10 jan. 1951, NJ 1952, 100.

50. Vgl. HR 18 febr. 1966, NJ 1966, 208; Rb. Amsterdam 22 april 1966, NJ 1966, 277.

51. Hof Amsterdam 13 juni 1940, NJ 1940, 731. 
worden getroffen, met die beperking dat de beroepstermijn niet verkort mag worden. Gedurende de beroepstermijn en het beroep is het lid geschorst.

Indien de beslissing tot royement door de algemene ledenvergadering is genomen, staat er derhalve geen beroep open tegen de beslissing. Volgens Asser/Van der Grinten zou in de statuten echter wel een beroepsmogelijkheid geschapen kunnen worden. Hij schrijft:

"Wij verstaan de wetsbepaling (art. 2:35 lid 2 BW, R.M.) aldus, dat bij een beslissing van de algemene vergadering niet krachtens de wet een beroepsrecht bestaat, doch dat de wet zich niet verzet tegen statutaire beroepsbevoegdheid. "s2

Indien een beslissing omtrent royement aan een ander orgaan van de vereniging is overgelaten, staat steeds beroep open op de algemene ledenvergadering. Zoals reeds is vermeld, kan hiervan echter in de statuten worden afgeweken en kan derhalve ook een andere beroepsinstantie worden aangewezen. Volgens Asser/Van der Grinten mag deze andere beroepsinstantie het ontzettingsbesluit echter slechts marginaal toetsen, terwijl de algemene ledenvergadering in volle omvang oordeelt. Volgens Stille valt deze opvatting niet te rijmen met artikel $2: 35$ lid $2 \mathrm{BW}^{53}$.

\subsubsection{Rechterlijke toetsing bij opzegging en royement door de "gewone" vereniging of de coöperatie}

Net als bij de rechterlijke toetsing van een toelatingsbesluit zijn er ten aanzien van de rechterlijke toetsing van opzegging en royement verscheidene mogelijkheden. Allereerst is er de vernietigingsmogelijkheid van artikel 2:11 BW (art. 2:15 OINBW) bij de rechtbank van de woonplaats van de vereniging (artt. 2:12 BW / $2: 15$ lid 3 OINBW). Bij een beroep tegen opzegging toetst de rechter echter marginaal ${ }^{\text {s/4 }}$. Bij opzegging van lidmaatschap door een vereniging omdat van haar redelijkerwijs. niet gevergd zou kunnen worden dat zij een lidmaatschap zou laten voortduren (art. 2:35 lid 1 sub c BW), heeft de rechter echter blijkens een arrest van het gerechtshof te 's-Gravenhage meer vrijheid ten aanzien van de beoordeling van de rechtmatigheid van de opzegging dan bij opzegging op grond van in de statuten genoemde gevallen, of op grond van het niet meer voldoen aan de vereisten die in de statuten aan het lidmaatschap waren gesteld ${ }^{5 s}$. Deze beslissing lijkt mij juist. Bij toetsing aan de statuten of de wettelijke bepalingen die de wijze van totstandkoming van besluiten van de vergadering en de algemene bevoegdheid van de vergadering regelen, kan de rechter slechts een rechtmatigheidstoetsing uitvoeren. Bij toetsing aan de goede trouw moet hij enerzijds een algemene rechtmatigheidstoetsing uitvoeren, en daarnaast nagaan of de vereniging in redelijkheid tot het opzeggings- of ontzeggingsbesluit heeft kunnen komen.

52. Asser/Van der Grinten II, blz. 227.

53. Asser/Van der Grinten II, blz 228; Stille (Rechtspersonen), art. 35 aant. 6.

54. Pres. Rb. 's-Grawenhage 11 aug. 1971, NJ 1971, 383.

55. Vgl. Hof's-Gravenhage 27 mei 1982, Gezondheidsrecht 1983/4. Hierover Stille (Rechtspersonen), art. 35 aant. 7 . 
Overigens gaf de vaststellingswet bij artikel 2:35, lid 2 BW een aparte bepaling, die regelde dat de uitspraak van een (statutaire) beroepsinstantie als vaststellingsovereenkomst in de zin van boek 7, titel 15 NBW moest worden beschouwd. Nu boek 7 NBW nog niet is ingevoerd, heeft de invoeringswet deze bepaling tijdelijk geschrapt. Als de uitspraak als vaststellingsovereenkomst zou moeten worden beschouwd, zou hij op gelijke wijze als een bindend advies kunnen worden aangetast, met dien verstande dat de rechter slechts toetst of men door iemand aan een bepaalde uitspraak te houden, in strijd met de goede trouw handelt ${ }^{56}$.

Het is nu echter maar de vraag of de rechter de ontzettingsuitspraak (opzeggingsuitspraak), aangezien de bepaling over het rechtskarakter van de uitspraak (tijdelijk) is geschrapt, anders zal toetsen. In elk geval maakt het volgens Van der Grinten ${ }^{57}$ niet uit, omdat de rechter bij andere aantastingsmogelijkheden bij beroep op strijd met de goede trouw eveneens marginaal pleegt te toetsen ${ }^{58}$.

Aangezien het bij opzeggings- en ontzettingsbesluiten om rechtshandelingen gaat, geldt ook hier weer dat de rechter in beginsel zou kunnen toetsen of de oorzaak niet ongeoorloofd was, met andere woorden of er sprake was van een handeling in strijd met de wet, openbare orde of goede zeden (art. 3.2.7 / 3:40 NBW, artt. 1371; $1373 \mathrm{BW}$ ). Hierbij gelden dezelfde opmerkingen als die welke bij toetsing van het toelatingsbesluit in paragraaf 4.2.3.3. zijn gemaakt. Hetzelfde geldt voor een eventuele actie uit onrechtmatige daad. Hierbij kan in zijn algemeenheid worden aangetekend dat bij een onterechte ontzetting, in verband met het aan ontzetting inherente diffamerende karakter, wellicht tevens of uitsluitend aan een actie ex artikel $1408 \mathrm{BW}$ (belediging) zou kunnen worden gedacht. Bij een dergelijke actie geldt echter wel wat Langemeijer eens schreef:

"dat niet alleen de kwaal bestaat, maar dat ook het meest gebruikte geneesmiddel niet voldoet, kan men dan verder hieruit wel voldoende afleiden, dat het welhaast als praktische wijsheid geldt, dat men geen klacht (het ging hier over een strafproces op grond van artikel 261 e.v. Sr., R.M.) doet terzake van belediging, smaad of smaadschrift en dat, wanneer de krenking van zijn eergevoel de beledigde te machtig dreigt te worden, een bijna usantiële vriendendienst is hem van de ongewenstheid van een klacht te overtuigen. ${ }^{159}$

56. Stille (Rechtspersonen), art. 35 aant. 7.

57. Asser /Van der Grinten $\mathrm{II}_{*}$ blz. 230. lin gelijke żn: Stille (Rechtspersonen), art. 35 aant. 7.

58. Vergelijk hierbij ook de jurisprudentie zoals ze in Stille (Rechtspersonen), art. 35, aant. 10 is aangegeven: $\mathrm{Rb}$. Amsterdam 13 maart 1928, NJ 1929, blz. 68 (opzegging); voor ontzetting (in verscheidene gevallen slechts marginaal getoetst): HR 18 juni $1982, \mathrm{NJ} 1983,200 ; \mathbf{R b}$. Haarlem 26 juni 1928, W 11920; Hof "s-Hertogenbosch 17 juni 1930, W 12243; Rb. Leeuwarden 25 febr. 1932. NJ 1932, blz. 1038; Hof 's-Gravenhage 9 mei 1932, NJ 1933, blz 85; Rb. Haarlem 28 mei 1935, NJ 1936, 364; Hof Amsterdam 22 juni 1938, NJ 1939, 180; Hof Amsterdam 13 juni 1940, NJ 1940, 731; Rb. "s-Grawenhage 12 dec. 1939, NJ 1940, 660; Hof 's-Gravenhage 10 jan. 1951 , NJ 1952, 100; Pres. Rb. Maastricht 3 sept. 1957, NJ 1958, 204; Pres. Rb. Assen 29 febr. 1968, NJ 1969, 455; Hof 's-Gravenhage 18 mei 1972, NJ 1973, 65; Hof 's-Gravenhage 27 mei 1982, Gezondheidsrecht 1983/4.

59. Langemeijer (Bescherming), blz. 87-93. Vergelijk als algemene literatuur over belediging ed: Aubel; Bloembergen (Onrechtmatige daad), blz. 337-345; De Meij. 


\subsection{Synthese: de flatcoöperatie}

\subsubsection{Algemene opmerkingen}

In paragraaf 2.1.6 zijn inmiddels de redenen behandeld die hebben geleid tot het in het leven roepen van de flatcoöperatie. Door de aanpassingen in het appartementsrecht is de constructie van de flatcoöperatie (CFV) enigszins uit de mode geraakt. Hier en daar wordt deze constructie echter nog wel toegepast (bijvoorbeeld bij service-flats en bij bijzondere woonvormen $\left.{ }^{60}\right)$.

Op de flatcoöperatie is in elk geval het in de vorige paragrafen besprokene van toepassing. Ook flatcoöperaties kunnen - als specifieke toepassing van de coöperatieve vereniging - ballotageregelingen hanteren en het lidmaatschap van leden opzeggen. Ten aanzien van ballotage en opzegging door een flatcoöperatie gelden ook weer dezelfde rechtsmiddelen als in het voorafgaande besproken.

Wat gebeurt er echter als aan een lid het lidmaatschap wordt opgezegd? Wordt het verplicht om zijn gebruiksrecht ten aanzien van "zijn" gedeelte van het flatgebouw te vervreemden? Een andere vraag die opkomt is hoe de baliotage in praktijk wordt uitgewerkt. Ter beantwoording van deze vragen zal allereerst de juridische constructie van de flatcoöperatie worden behandeld en zullen vervolgens de ballotage- en opzeggingsmogelijkheden aan de orde komen, geadstrueerd met praktijkvoorbeelden uit de jurisprudentie.

\subsubsection{De juridische constructie}

De flatcoöperatie moet evenals alle coöperaties bij notariële akte worden opgericht (art. $2: 54$ lid $1 \mathrm{BW}$ ). De naam van de vereniging moet het woord coöperatief bevatten, evenals de aanduiding W.A., U.A. of B.A. ten aanzien van de aansprakelijkheid van de leden. Volgens De Vries ${ }^{61}$ werd in de bloeitijd van de coöperatieve flatexploitatievereniging (CFV) voor de invoering van de appartementenwet in 1952, bijna altijd de aansprakelijkheid uitgesloten.

De flatcoöperatie koopt of bouwt een flatgebouw of woningencomplex (eventueel met geld van leden of aspirant-leden). De leden krijgen op grond van hun lidmaatschap het recht om een bepaald gedeelte van het gebouw of complex als privé-gedeelte te gebruiken en de gemeenschappelijke gedeelten mede te gebruiken. Overigens lijkt het, gezien artikel $2: 53$ lid $3 \mathrm{BW}$, mogelijk voor de flatcoöperatie om in haar statuten een regeling op te nemen, bepalende dat zij wooneenheden ook aan derden (niet-leden) in gebruik mag geven. In die situatie zou het in gebruik geven in de meeste gevallen op verhuur neerkomen.

Van Velten ${ }^{62}$ somt enkele kenmerken van de CFV/flatcoöperatie op. Zo kunnen er volgens Van Velten maximaal zoveel lidmaatschappen zijn als het flatgebouw of woningcomplex wooneenheden telt. Het is de vraag of deze stelling geheel juist is. Wellicht is het mogelijk om twee lidmaatschappen aan een wooneenheid te

60. Büjvoorbeeld de "Coöperatieve Vereniging Vernieuwend Wonen" in Maastricht, die in 1987 in het leven werd geroepen. Vgl. dagblad "De Limburger", vrijdag 12 juni 1987. Vgl. ook Grünhagen, blz. 49-52.

61. De Vries (Preadvies), blz 54.

62. Van Velten (CFV), blz 126 . 
verbinden, of het lidmaatschap ook open te stellen voor personen die niet van de woonfaciliteiten van de flatcoöperatie gebruik maken, maar wel van de diensten die door haar worden verzorgd (bijvoorbeeld bij een service-flat, het gebruik van maaltijden en de verzorging door aanwezige verpleegsters).

Een ander kenmerk van de CFV/flatcoöperatie is volgens Van Velten ${ }^{63}$ dat een lid slechts kan uittreden, als "hij een ander lid in zijn plaats stelt." Daarnaast kunnen aspirant-leden worden geballoteerd, waarbij volgens Van Velten rekening kan worden gehouden met zowel leefwijze als financiële draagkracht.

"Leden die de deelnamesom, of in een later stadium de koopsom niet geheel kunnen betalen, mogen een beroep doen op gelden die de coöperatieve vereniging leende bij een hypotheekbank en waarvoor het gebouw met bijbehorende grond is ondergezet."

Dit vormt volgens Van Velten een ander kenmerk van de $\mathrm{CFV} /$ flatcoöperatie. Bovendien kan aan een lid het lidmaatschap worden opgezegd (ook ontzetting is mogelijk) wegens herhaalde overtreding van de statuten. Het lidmaatschap vervalt dan aan de flatcoöperatie die vervolgens op zoek kan gaan naar een nieuw aspirant-lid dat tegen betaling van de deelname-som het lidmaatschap verwerft. Het lidmaatschap is behalve voor overdracht ook voor vererving vatbaar ${ }^{64}$. Het is eveneens voor beslag en executie vatbaar. De beslaglegger, wiens beslaglegging van waarde verklaard is, heeft het recht het lidmaatschap openbaar te verkopen. Openbare verkoop kan gepaard gaan met opzegging van het lidmaatschap van de flatcoöperatie onder gelijktijdige aanmelding van een nieuw lid. De flatcoöperatie moet dit nieuwe lid - behoudens weigering wegens gegronde redenen - accepteren, hetgeen volgens de $\mathrm{Rb}$. 's-Gravenhage ${ }^{6 s}$ geen inbreuk vormt op de vrijheid van vereniging.

\subsubsection{Toelating en opzegging (inclusief ontzetting)}

In zeer veel statuten van flatcoöperaties is een bepaling opgenomen, dat het verboden is een lidmaatschap te vervreemden, tenzij met toestemming van de flatcoöperatie. Beekhuis ${ }^{66}$ achtte deze voorwaarde niet ongeoorloofd. De Vries ${ }^{67}$ daarentegen heeft bij deze bepaling enige vraagtekens geplaatst in het licht van het voor de (toen nog) coöperatieve vereniging kenmerkende bestaansvereiste van vrije in- en uittreding ${ }^{6}$. In deze bepaling in negatieve zin ligt de ballotageregeling besloten, die veel flatcoöperaties hanteren. De vereniging beslist of ze iemand als lid wil toelaten of niet. Als de vereniging hiertoe niet bereid is, $k$ an de vervreemding van het lidmaatschap niet doorgaan. Tegen weigering van toestemming tot vervreemding staat ingevolge de statuten van veel flatcoöperaties beroep open bij een arbitragecommissie, of anders bij de kantonrechter. Veelal kan het lid als dit beroep wordt afgewezen, volgens de statuten van de vereniging eisen dat zij het

63. Van Velten (CFV), blz. 126.

64. Vgl. De Vries (Preadvies), blz. 53.

65. Rb. "s-Gravenhage 31 jan. 1968, NJ 1968, 420.

66. Beekhuis, WPNR 4226.

67. De Vries (Preadvies), blz. 57.

68. Vgll. HR 21 juni 1918, NJ 1918, blz 777. 
lidmaatschap tegen taxatieprijs of een gedeelte daarvan (bijv. $90 \%$ ) overneemt ${ }^{69}$.

$\mathrm{De} \mathrm{Rb}$. te Utrecht ${ }^{70}$ diende in 1958 te beslissen in een geval, waarin een CFV geweigerd had medewerking te verlenen aan een overdracht van een lidmaatschap aan een niet-lid. In de statuten was zoals gebruikelijk bepaald dat het lidmaatschap onder meer zou eindigen door opzegging met gelijktijdige overdracht van het lidmaatschap en dat het lidmaatschap met de daaraan verbonden rechten kon worden overgedragen na verkregen toestemming van het bestuur van de CFV. Eiseres wilde haar lidmaatschap aan een niet-lid overdragen maar kreeg geen toestemming. Het bestuur van de CFV moest bij het toelaten van nieuwe leden volgens het huishoudelijk reglement normen in acht nemen, die beoogden het karakter van het woningcomplex als tehuis voor bejaarden te handhaven,

"en in het bijzonder te letten op de leeftijd, de maatschappelijke positie nu en voorheen, de financiële positie en de lichamelijke en geestelijke geschiktheid."

Aan het lidmaatschap van eiseres was het gebruik van een tweekamerflat, geschikt voor twee personen, verbonden. De gegadigde wilde de flat alleen bewonen en op die grond werd de toestemming voor de overdracht door het bestuur geweigerd. Eiseres vorderde veroordeling van de CFV tot medewerking, nu de weigering daarvan misbruik van bevoegdheid en détournement de pouvoir zou opleveren en onrechtmatig zou zijn. De rechtbank las hierin dat eiseres strijd met de goede trouw (art. $1374 \mathrm{BW}$ ) stelde. Hiervan was volgens de rechtbank echter geen sprake;

"dat toch bij een coöperatieve woonvereniging als de onderhavige, zijnde een besloten gemeenschap met een beperkt aantal leden, welke blijkens art. 3 der statuten beoogt het behartigen van de gemeenschappelijke belangen (....) aan het bestuur de nodige vrijheid in zijn beleid en in de beoordeling van de doelmatigheid van zijn beslissingen gelaten moet worden, (....) dat in elk geval misbruik van bevoegdheid door het bestuur in de zin van een kennelijke onredelijke beslissing niet is gebleken."

Uit het feit dat de Utrechtse rechter hier marginaal toetste en de beslissing van de vereniging bekrachtigde, blijkt de grote vrijheid die aan een coöperatie, en hier in het bijzonder aan een CFV, wordt toegekend. Noch in de statuten, noch in thet huishoudelijk reglement van de CFV was bepaald dat een tweekamerflat niet door een persoon alleen bewoond mocht worden.

In een soortgelijk geval besliste de Rb. Amsterdam ${ }^{71}$ dat de weigering van het bestuur van een CFV om overdracht van een lidmaatschap goed te keuren, niet onrechtmatig was nu het bestuur zich had laten leiden door zijn inzicht in het wezenlijk belang der vereniging.

Behalve door middel van ballotage kan een flatcoöperatie invloed op haar ledenbestand uitoefenen door middel van het opzeggingsinstrument. De in

69. Vgl. hierbij De Vries (Preadvies), blz. 53. Ter zake van beroepszaken bij deze ballotagevorm bestaat weinig jurisprudentie en literatuur.

70. Rb. Utrecht 25 juni 1958, NJ 1959, 282.

71. Rb. Amsterdam 1 dec. 1966, NJ 1967, 310. Zie hierower Hehemann. 
paragraaf 4.2 .4 behandelde algemene regels, inzake opzegging (inclusief ontzetting) zijn hierop van toepassing. Een uit zijn lidmaatschap ontzet persoon, of een lid aan wie het lidmaatschap is opgezegd, heeft zoals de rechtbank Maastricht ${ }^{72}$ bepaalde, geen huurbescherming. Overigens kunnen we bij De Vries ${ }^{73}$ lezen dat in de meeste statuten van coöperatieve flatexploitatieverenigingen (nu: flatcoöperaties) een bepaling is opgenomen, ten gevolge waarvan een lid de verplichting heeft zijn flat te ontruimen na zijn ontzetting of opzegging van zijn lidmaatschap door de vereniging.

Zoals wit de Maastrichtse ontzettingscasus blijkt, hanteerden de CFV's voor invoering van de appartementenwet ballotageregelingen, die als maatstaven voor toelating onder meer ook financiële criteria en leeftijdscriteria, zoals ze ook bij de welstandsbepalingen in het appartementsrecht voorkomen. Het is aannemelijk dat deze criteria door de (nog) bestaande flatcoöperaties nog steeds gehanteerd worden, nu er geen wetswijziging of jurisprudentie is, die hierin verandering had kunnen brengen.

In beginsel gaan tegen een leeftijdscriterium, gehanteerd door een flatcoöperatie, dezelfde argumenten op die gelden bij de leeftijdsgrens in het appartementsrecht. Het is echter nog maar de vraag of de vrijheid van vereniging (art. 8 grondwet) een materiële toetsing van dit criterium toelaat. Als men al tegen een afwijzing als lid van een flatcoöperatie op grond van een leeftijdscriterium zou willen ageren, zou dit waarschijnlijk moeten gebeuren op grond van het non-discriminatiebeginsel van artikel 1 grondwet. Zoals echter uit de schaarse jurisprudentie en literatuur terzake van ballotage door flatcoöperaties en anderszins uit het verenigingsrecht blijkt, wordt aan de verenigingen een grote vrijheid op dit terrein toegekend. Het is niet onwaarschijnlijk dat de rechter een (strakke) leeftijdsgrens, gehanteerd door flatcoöperaties, toelaatbaar zou achten.

Ten aanzien van de financiële maatstaf moet worden geoordeeld dat deze - in tegenstelling tot de financiële maatstaf bij de welstandsbepalingen in het appartementsrecht - zeer wel mogelijk en nuttig kan zijn. Het belangrijkste argument tegen financiële criteria in het appartementsrecht, namelijk dat financiële verplichtingen primair op de appartementseigenaar rusten, ongeacht of deze in zijn appartement woont, en dat de V.v.E. derhalve geen belang heeft bij het stellen van financiele criteria (vgl. par. 3.5.3 en 3.6.3.3) gaat bij de flatcoöperatie niet op. De flatcoőperatie heeft er immers wel degelijk belang bij dat een lid aan bepaalde financiële maatstaven voldoet. $\mathrm{Zij}$ verleent het lid immers krediet om zijn lidmaatschap te verwerven; zij is afhankelijk van de financiële bijdragen (voor service-kosten e.d.) van haar leden. Als de flatcoöperatie insolvent raakt, lopen alle woongerechtigden (de leden) gevaar dat hun woning openbaar zal worden verkocht, nu een lidmaatschapsrecht niet voor verhypothekering vatbaar is, en ter verwerving van de benodigde fondsen (voor bouw en instandhouding van het wooncomplex) een hypotheek op het gehele wooncomplex moet worden verleend. Weigering van een minder draagkrachtig gegadigde als lid van de vereniging is een doeltreffend middel om te trachten aan financiële problemen te ontkomen. Als een gegadigde geen lid wordt van de vereniging, krijgt hij jegens haar geen financiële verplichtingen. De appartementseigenaar, aan wie het gebruik van zijn appartement wordt

72. Rb. Maastricht 3 sept 1957 , NJ 1958, 204.

73. De Vries (Preadvies), blz 54. 
ontzegd, heeft simpelweg ingevolge het feit dat hij "eigenaar" is financiële verplichtingen ten opzichte van de V.v.E. Welstandsbepalingen in de vorm van financiële criteria kunnen daar niets aan veranderen (vgl. par. 3.6.3.3).

Globaal genomen kan geconcludeerd worden dat verenigingen in het algemeen meer vrijheid hebben bij toelating van leden en opzegging van het lidmaatschap aan leden, dan de V.v.E. van een appartementencomplex bij hantering van welstandsbepalingen heeft. Mijns inziens is hier terecht sprake van een verschil. De verenigingen uit boek $2 \mathrm{BW}$ zijn associaties van personen die gezamenlijk een bepaald doel nastreven, en als zodanig genieten zij de bescherming van artikel 8 Grondwet. Een vereniging van appartementseigenaars daarentegen is niet meer dan een bestuursvorm; een instrument om een verzameling woningen te kunnen beheren. De associatie ligt niet zozeer in de persoonlijke als well in de zakenrechtelijke sfeer. Het lidmaatschap van de V.v.E. van een appartementencomplex is accessoir aan een appartementsrecht. Het lidmaatschap van een flatcoöperatie is een zelfstandig recht, waaraan het gebruiksrecht van een woning accessoir is. Van vrije in- en uittreding tot de V.v.E. - zonder verwerving of vervreemding van een appartementsrecht - kan binnen het appartementsrecht geen sprake zijn (art. 876 $B W)$. Als men eigenaar is van een appartement, is men lid van de V.v.E., of men wil of niet. De V.v.E. heeft niet de geringste mogelijkheid om ongewenste personen als lid te weren. Alleen hieruit blijkt naar mijn mening al voldoende dat de wetgever de V.v.E. geen vereniging in de zin van artikel 8 Grondwet acht. Een argument dat deze visie ondersteunt, is dat de algemene bepalingen van het verenigingsrecht uit boek $2 \mathrm{BW}$ in beginsel niet van toepassing zijn op de V.v.E. Het wetsontwerp dat deze toepasselijkheid beoogde te regelen, is ingetrokken (vgl. par. 2.4.3).

\subsection{Gemeenschap}

\subsubsection{Inleiding}

Volgens artikel 5.1.1 / 5:1 NBW is eigendom het meest omvattende recht dat een persoon op een zaak kan hebben. Eigendom rust derhalve op een zaak. De NBWdefiniëring van het begrip "zaak" verschilt echter van die uit het BW. Volgens artikel 3.1.1.1 / 3:2 NBW zijn zaken

"de voor menselijke beheersing vatbare stoffelijke objecten."

Onder het huidige recht daarentegen verstaat men onder zaken

"alle goederen en regten welke het voorwerp van eigendom kunnen zijn" (art. $555 \mathrm{BW}$ ).

Niet alleen stoffelijke objecten kunnen derhalve naar huidig recht het voorwerp van eigendom zijn, maar ook vermogensrechten ${ }^{74}$.

74. Hijma/Olthof, blz 10 . 
Twee of meer personen kunnen echter samen de eigendom van bepaalde zaken hebben. Onder het huidige recht spreekt men dan van medeëigendom of gemeenschap, ongeacht de vraag of het om lichamelijke zaken, dan wel vermogensrechten gaat. De termen "medeëigendom" en "gemeenschap" zijn onder huidig recht synoniem. Volgens het toekomstige recht is eigendom alleen maar mogelijk met betrekking tot stoffelijke objecten; in de NBW-terminologie "zaken" genoemd. Men kan dus ook slechts medeëigenaar van stoffelijke objecten zijn. Degene die onder huidig recht nog eigenaar van een recht wordt genoemd, heet onder NBW immers gerechtigde tot een recht. Indien er meerdere gerechtigden zijn kan men daarom ook niet van medeëigendom van een recht spreken; reden waarom het NBW in deze gevallen alleen de term "gemeenschap" gebruikt. De term gemeenschap heeft onder toekomstig recht een overkoepelende strekking, die ook ten aanzien van zaken wordt gehanteerd ${ }^{75}$.

In het huidige $\mathrm{BW}$ zijn geen afzonderlijke bepalingen met betrekking tot de medeëigendom/gemeenschap in zijn algemeenheid opgenomen. Een algemene regeling voor de gemeenschap ontbreekt. De enige algemene regels zijn die betreffende scheiding en deling (art. 1112 e.v. BW) ${ }^{76}$. Hiernaar wordt ook verwezen in de artikelen 1:100, 628 en $1689 \mathrm{BW}$. Het NBW wijdt er echter de zevende titel van boek 3 aan. Deze bepalingen betreffen de gemeenschap in zijn algemeenheid, waaronder ook de medeëigendom van zaken moet worden begrepen. De term medeëigendom vinden we in het NBW slechts in boek 5 over zakelijke rechten terug (bijv: art. 5.2.10 lid 3/5:14 NBW).

De medeëigendom wordt over het algemeen naar huidig recht opgesplitst in twee vormen, respectievelijk de vrije en de gebonden medeëigendom. Opgemerkt dient hierbij te worden dat beide vormen uitersten zijn. Het NBW maakt geen onderscheid tussen vrije en gebonden medeëigendom. Wel wordt daarentegen onderscheid gemaakt tussen de eenvoudige en de bijzondere gemeenschap.

Van een eenvoudige gemeenschap is sprake indien de gemeenschap bestaat met betrekking tot éến goed (bijv. gemeenschappelijke auto, mandelige muur) of met betrekking tot meerdere goederen indien dit voortvloeit uit de samenhang van de goederen of de rechtsverhouding van de deelgenoten (vgl. art. 3.7.1.1/3:166 NBW) ${ }^{7}$. Van een eenvoudige gemeenschap met betrekking tot meerdere goederen, voortvloeiend uit de samenhang der goederen, kan bijvoorbeeld sprake zijn bij een bibliotheek, een kudde schapen en dergelijke. Een eenvoudige gemeenschap kan voortvloeien uit de rechtsverhouding tussen deelgenoten, indien de deelgenoten bijvoorbeeld bij

"de aanvang van de gemeenschap overeenkomen de goederen te zijner tijd als én geheel te zullen verdelen." 78

75. Van Mourik (Gemeenschap), blz 1.

76. Pitlo/Brahn, blz 124.

77. Hijma/Olthof, blz. 125, 126; Wammes, blz. 9-12.

78. Hijma/Olthof, blz. 126. Vgl. ook Van Mourik (Gemeenschap), blz. 2. 
De bijzondere gemeenschappen zijn limitatief opgesomd in artikel 3.7.2.0 lid $2 /$ 3:189 lid 2 NBW. Hieronder valt bijvoorbeeld de gemeenschap van een nalatenschap. Indien een gemeenschap

"noch uit de samenhang der goederen, noch uit de rechtsverhouding tussen de deelgenoten voortvloeit", en ook geen bijzondere gemeenschap is, "bestaat er ten aanzien van ieder goed een afzonderlijke gemeenschap." "?

Op sommige gemeenschappen zijn de bepalingen van titel 3.7 NBW in het geheel niet van toepassing. Artikel 3.7.2.0 lid 1/3: 189 NBW bepaalt namelijk:

"De bepalingen van deze titel gelden niet voor een huwelijksgemeenschap, maatschap, vennootschap of rederij, zolang zij niet ontbonden zijn, noch voor de gemeenschap van een in appartementsrechten gesplitst gebouw, zolang de splitsing niet is opgeheven."

In deze paragraaf zal de gemeenschap zowel naar huidig als naar komend recht behandeld worden. Uitgegaan zal worden van de vrije medeëigendom (BW) en eenvoudige gemeenschap (NBW). Centraal bij deze behandeling staat de vraag in hoeverre deelgenoten invloed kunnen uitoefenen op de samenstelling van de groep van deelgenoten - dat wil zeggen in hoeverre zij inspraak hebben indien een persoon deelgenoot wil worden - en in hoeverre zij elkaar onderling kunnen controleren. Dit laatste dient te worden verstaan als: welke mogelijkheden van toezicht heeft een deelgenoot ten aanzien van de andere deelgenoten en hun handelen met betrekking tot de gemeenschap? Een en ander zal zoals gezegd zowel naar huidig als toekomstig recht worden behandeld, waarna deze paragraaf zal worden afgesloten met korte conclusies ten aanzien van de verhouding tussen appartementsrechten en gemeenschap.

\subsubsection{Gemeenschap/medeëigendom}

Naar huidig recht wordt, zoals reeds is vermeld, gesproken over gebonden en vrije medeëigendom. Over de criteria, die zouden moeten worden gehanteerd om de vrije gemeenschap van de gebonden gemeenschap te onderscheiden, bestaat geen eenstemmigheid. Volgens Asser/Beekhuis is er geen scherp onderscheid tussen de beide vormen van gemeenschap te maken ${ }^{80}$. Een principieel verschil tussen gebonden en vrije medeëigendom bestaat volgens Asser/Beekhuis niet.

"De rechtsgevolgen van iedere gemeenschap worden beheerst door de rechtsverhouding tussen de deelgenoten."

Om een onderscheid aan te kunnen brengen tussen vrije medeëigendom en gebonden medeëigendom zal men volgens Asser/Beekhuis dus naar de rechtsgevolgen van de gemeenschap moeten kijken ${ }^{81}$.

79. Hijma/Olthof, blz. 126 .

80. Asser/Beekhuis I, blz 413 .

81. Asser/Beekhuis I, blz 338 . 
Scholten zocht het onderscheid in de oorzak van ontstaan van de gemeenschap. Indien de band tussen de deelgenoten geheel voortvloeit uit het feit dat zij medegerechtigd zijn, zou er sprake zijn van een vrije gemeenschap. Indien er echter naast deze uit het medegerechtigd zijn voortwloeiende band, nog een andere band tussen de deelgenoten bestaat, zou er sprake zijn van een gebonden gemeenschap ${ }^{82}$. Ook Pitlo/Brahn verdedigt dit criterium in de achtste druk. In de negende druk uit 1987 is Pitlo/Brahn echter van deze mening afgestapt. Hij vermeldt nu:

"Het probleem van die onderscheiding (tussen gebonden en vrije gemeenschap, R.M.) is echter, dat van werkelijk vrije medeëigendom mimmer sprake is (....) Er is slechts meer of minder gebonden medeëigendom. ${ }^{183}$

Hij noemt hierbij als voorbeeld twee personen die een huis kopen. Hierbij is het ondenkbaar dat

"om deze 'vrije' mede-eigendom niet ook een band komt te liggen, indien die er al niet bij voorbaat lag ten gevolge van allerlei vooraf gesloten overeenkomsten tussen beide personen. ${ }^{84}$

Met Asser/Beekhuis ${ }^{B S}$, is Pitlo/Brahn derhalve tegenwoordig van mening dat een principieel onderscheid tussen de beide medeëigendomsvormen niet kan worden gemaakt. Schoordijk daarentegen spreekt bijvoorbeeld van een gebonden gemeenschap indien er sprake is van een afgescheiden vermogen ${ }^{86}$.

Het nut van een te maken onderscheid tussen vrije en gebonden medeëigendom is beperkt. Het onderscheid heeft alleen zin indien men bepaalde soorten gemeenschap tegenover elkaar wil stellen, om de daarop toepasselijke regels te beschrijven. In het onderstaande zal dit onderscheid ondanks het beperkte nut worden gehanteerd, om duidelijk aan te kunnen geven welke regels op de "vrije" gemeenschap van toepassing zijn.

Voor een aantal gemeenschappen zijn de toepasselijke regels duidelijk. Bijvoorbeeld voor de huwelijksgoederengemeenschappen, ervengemeenschappen, maatschappen, rederijen, firma's en appartementsgemeenschappen. Voor deze gemeenschappen, die ik gebonden gemeenschappen zal noemen, geeft de wet speciale regels. Andere gemeenschappen vallen echter niet onder speciale wettelijke regelingen en dientengevolge moeten er "min of meer algemene regels" voor worden gegeven ${ }^{87}$. Deze gemeenschappen bestaan indien een of meer bepaalde zaken aan meer dan een persoon toebehoren, zonder dat er sprake is van een van de bovengenoemde gemeenschappen. Naar deze gemeenschappen zal

82. Asser/Scholten (1933), blz. 129, 130.

83. Pitlo/Brahn, blz, 125, 126. Zo ook De Groot (Gemeenschap), blz. 242.

84. Pitlo/Brahn, blz 125.

85. Asser/Beekhuis I, blz 414.

86. Schoordijk (Mede-eigendom), blz. 18-25. Zie verder over de vrije en gebonden medeeigendom:

L7ubbers (Giemeen goed), blz. 5. Vgl. hierover ook Van der Grinten (Gemeenschap), blz. 129.
Pitlo/Brahn, blz. 126 . 
hierna worden verwezen als "vrije gemeenschappen". De algemene regels voor deze vrije gemeenschappen spitsen zich toe op een aantal punten:

- beheers-, gebruiks-, genotsbevoegdheid van de deelgenoten

- beschikkingsbevoegdheid ${ }^{88}$ van de deelgenoten (voor geheel of gedeelte)

- Verhaalsmogelijkheden van schuldeisers van een deelgenoot

- scheiding en deling.

Grosso modo kan men de eerste twee punten onder de noemer "rechten van deelgenoten ten aanzien van de goederen" indelen. Bij deze rechten van deelgenoten zijn volgens Asser/Beekhuis minstens vier systemen mogelijk:

1. iedere deelgenoot is bevoegd ten aanzien van het geheel;

2. iedere deelgenoot is slechts bevoegd ten aanzien van zijn eigen aandeel;

3. een deelgenoot is bevoegd ten aanzien van het geheel;

4. alle deelgenoten gezamenlijk zijn bevoegd ten aanzien van het geheel $^{89}$.

Hieraan zou ik met betrekking tot de beschikkingsbevoegdheid nog een vijfde mogelijkheid willen toevoegen, namelijk:

5. een deelgenoot is zonder toestemming van de overige deelgenoten niet bevoegd om over zijn aandeel te beschikken.

Het toekomstige recht maakt zoals vermeld onderscheid tussen de eenvoudige en de bijzondere gemeenschap. In eerdere ontwerpen van het NBW werd onderscheid gemaakt tussen eenvoudige gemeenschap en de gemeenschap van een algemeenheid van goederen. De literatuur en de prạktijk hebben op dit onderscheid kritiek geleverd, waarop in het Ontwerp Invoeringswet NBW de afdeling met betrekking tot de gemeenschap van algemeenheid van goederen, is vervangen door de afdeling betreffende de bijzondere gemeenschap $*$.

In het navolgende zal aan de hierboven vermelde 4 punten voor het huidige en toekomstige recht aandacht worden besteed. Opgemerkt dient hierbij te worden dat bij de behandeling ervan wordt uitgegaan van een niet-ontbonden vrije gemeenschap; een actieve gemeenschap. Voor een ontbonden gemeenschap gelden immers logischerwijze andere regels dan voor de actieve gemeenschap, aangezien de ontbonden gemeenschap "nog slechts wacht op verdeling" 91 . Voor de behandeling van het toekomstige recht wordt uitgegaan van de eenvoudige gemeenschap.

88. De term beschikken dient hier te worden opgevat als verveemden of bezwaren.

89. Asser/Beekhuis I, blz 416. Vgl. ook Drion/Hijma/Olthof, blz. 38.

90. Vgl. Rapport Koninklijke Notariële Broederschap, WPNR 5280 (1974), blz. 685; De Groot (Gemeenschap), blz. 246.

91. Pillo/Brahn, blz. 127. 


\subsubsection{Rechten van deelgenoten ten aanzien van de goederen}

Bij onderlinge overeenkomst kunnen deelgenoten in een gemeenschap het beheer, het gebruik en het genot van de gemeenschappelijke zaken regelen. De rechten en verplichtingen uit deze overeenkomst gelden tevens voor de rechtverkrijgenden onder bijzondere titel ${ }^{92}$. Het huidige recht geeft voor deze stelling weinig houvast. Asser/Beekhuis wijst erop, dat ten aanzien van een overeenkomst overeenkomstig artikel 1112 lid $3 \mathrm{BW}$, waarbij scheiding en deling gedurende zekere tijd wordt uitgesloten, steeds is aangenomen dat rechtverkrijgenden onder bijzondere titel eraan gebonden zijn. Hij neemt dit ook aan voor de overeenkomst die gebruik, genot, en beheer met betrekking tot de gemeenschappelijke zaak regelt.

"Men heeft hierin te zien een zakenrechtelijke verdeling van bewoegdheden, die uit het recht voortvloeien, zodat art. 1354 niet van toepassing is."

Overeenkomsten met betrekking tot beschikking werken volgens Asser/Beekhuis in beginsel slechts tussen de contractanten en niet tegen hun rechtverkrijgenden onder bijzondere titel ${ }^{94}$. Bij gebreke van een overeenkomst wordt ten aanzien van beheer artikel 1676 sub $1 \mathrm{BW}$ analogisch toepasselijk geacht ${ }^{95}$.

Ook naar NBW kunnen deelgenoten het genot, gebruik en het beheer van de gemeenschappelijke goederen bij overeenkomst regelen (art. 3.7.1.2. lid 1/3:168 lid $1 \mathrm{NBW}$ ). Eventueel kan de kantonrechter op verzoek van enkele betrokkenen een regeling met betrekking tot het gebruik, beheer en genot treffen (art. 3.7.1.2. lid 2 / 3:168 lid 2 NBW). Rechtverkrijgenden van een deelgenoot zijn eveneens aan de regeling (door partijen of de kantonrechter getroffen) gebonden (art. 3.7.1.2. lid 4 / 3:168 lid 4 NBW) ${ }^{96}$.

Onder beheer wordt elke handeling begrepen, die dient tot het in stand houden en het normaal exploiteren van de gemeenschappelijke zaak. Onder dit beheer kan tevens het verkopen van vruchten worden verstaan ${ }^{97}$. Verhuring van (een gedeelte van) de gemeenschappelijke zaak valt mijns inziens eveneens onder beheer, aangezien verhuring als normale exploitatie van de gemeenschappelijke zaak moet worden beschouwd. Indien een overeenkomst ontbreekt, geschiedt het beheer van de gemeenschappelijke zaak in beginsel door alle deelgenoten gezamenlijk. Dit geldt echter niet ten aanzien van beheersdaden, die een spoedeisend karakter hebben en evenmin voor daden die worden verricht in het kader van gewoon onderhoud of tot behoud van de gemeenschappelijke zaak. De algemeen geldende regeling van beheer komt dus overeen met het vierde van de in de vorige paragraaf genoemde systemen. In het NBW heeft de wetgever het vierde systeem ten aanzien van beheer gehandhaafd (art. 3.7.1.3a/3:170 NBW) ${ }^{98}$.

92. Asser/Beekhuis I, blz 418.

93. Asser/Beekhuis I, blx, 418.

94. Asser/Beekhuis I, blz 418.

95. Vgl. Asser/Beekhuis I, blz. 343; HR 28 dec. 1859, W 2133.

96. Wammes, blz. 50.

97. Asser/Beekhuis I, blz. 418 .

98. Vgl. Van Mourik (Gemeenschap), blz 14, 15; Wammes, blz 51. 
Ook het gebruik ${ }^{99}$ van de gemeenschappelijke zaak kan bij overeenkomst geregeld zijn op een van de vijf wijzen die eerder werden vermeld. Bij gebreke van een overeenkomst tussen de deelgenoten is ieder der deelgenoten bevoegd om de gemeenschappelijke zaak te gebruiken. Op het gebruik van de gemeenschappelijke zaak is dus - bij ontbreken van een afwijkende regeling - het eerste systeem van toepassing ${ }^{100}$. Ook hier wijkt het NBW niet af van het huidige recht (art. 3.7.1.3 / 3:169 NBW) ${ }^{101}$.

Ten aanzien van het genot van de gemeenschappelijke zaak kan hetgeen hiervoor ten aanzien van gebruik en beheer werd gesteld, worden herhaald. In beginsel zijn namelijk ook hier de bovengenoemde vijf systemen denkbaar. Bij het ontbreken van een overeenkomst dienaangaande, geldt echter de regel dat ieder der deelgenoten in beginsel slechts het genot heeft van zijn eigen aandeel in de gemeenschappelijke zaak. Hier geldt dus het tweede systeem. Het NBW hanteert dezelfde regeling ${ }^{102}$.

De vraag naar de beschikkingsbevoegdheid van de deelgenoten ten aanzien van de gemeenschap, dient in drieën te worden gesplitst. Enerzijds moet hier de beschikkingsbevoegdheid van een deelgenoot met betrekking tot zijn eigen aandeel worden bezien, anderzijds moet aandacht worden besteed aan de beschikkingsbevoegdheid van de deelgenoten ten aanzien van enkele zaken van de gemeenschap. Kan een deelgenoot enkele zaken uit de gemeenschap overdragen (en zelf medeëigenaar blijven) ${ }^{103}$ ? Bovendien zal de vraag wie bevoegd is ten aanzien van de gehele gemeenschap, aan de orde moeten komen.

Volgens Pitlo/Brahn kan een deelgenoot in een gemeenschap in beginsel niet vrij beschikken over zijn eigen aandeel. Hierbij verwijst hij naar de huwelijksgoederengemeenschap, waarbij het ondenkbaar is dat een der beide deelgenoten zijn aandeel in de gemeenschap vrij zou kunnen overdragen. Hetzelfde geldt volgens Pitlo/Brahn bij een maatschap ${ }^{104}$. Beide genoemde gemeenschappen zijn echter gebonden gemeenschappen. Ook bij de min of meer vrije gemeenschap verdedigt Pitlo/Brahn echter dit standpunt. Indien twee personen samen een huis kopen, kan een van beiden niet zomaar over zijn aandeel in de gemeenschap beschikken. Hierbij merkt hij wel op dat dit slechts geldt voor zover er geen afwijkende afspraken zijn gemaakt. Bij een huwelijksgoederengemeenschap zijn

99. Het verschil tussen gebruilk en genot is, dat gebruik "feitelijk gebruik" betekent, terwijl het genot onder andere betekent dat de deelgenoten in de vruchten en voordelen meedelen.

100. Vgl. ten aanzien van gebruik: HR 9 mei 1952, NJ 1953, 563, A.A. 1952/1953, blz, 40 met nool J. Drion; HR 11 nov. 1966, NJ 1967, 361 met noot J.H. Beekhuis; HR 3 april 1968, NJI 1968, 294; Hof 's-Gravenhage 24 okt. 1969, NJ $1970,421$.

101. Van Mourik (Gemeenschap), blz. 13; Wammes, blz. 50, 51.

102. Drion/Hijma/Olthof, bly. 38 .

103. In dat geval zal er veelal geen sprake zijn van een volstrekt vrije gemeenschap, aungezien er spoedig een band tussen de deelgenoten zal zijn die een overkoepelende werking heeft met betrekking tot de gemeenschappelijke zaken.

104. Pitlo/Brahn, blz. 128. 
deze afwijkende afspraken uiteraard ondenkbaar. Bij een maatschap zijn ze echter volgens Pitlo/Brahn "voorstelbaar" en in het geval van de twee personen die samen een huis kopen "zeer wel denkbaar".

"Hoe strakker de band die om de gemeenschap heen ligt, hoe onwaarschijnlijker het wordt dat een deelgenoot deze bevoegdheid heeft. "105

Asser/Beekhuis ${ }^{106}$ zit op dezelfde lijn als Pitlo/Brahn. Anders dan Pitlo/Brahn is Beekhuis echter van mening dat iedere deelgenoot in een vrije gemeenschap zijn aandeel in beginsel mag vervreemden of bezwaren. Hier lijkt sprake te zijn van een contradictie met Pitlo/Brahn. Naar mijn mening is er echter slechts sprake van een schijnbare tegenstrijdigheid. Pitlo/Brahn komt waarschijnlijk tot de conclusie dat een deelgenoot niet vrij over zijn aandeel mag beschikken, op grond van de aanname dat werkelijk vrije medeëigendom niet bestaat. De rechtsverhouding tussen partijen, ook bij zeer vrije medeëigendom, zal met zich meebrengen dat de ene deelgenoot niet buiten de ander om een derde in zijn plaats kan stellen. Asser/Beekhuis gaat mijns inziens uit van de meer theoretische situatie, waarin wel sprake is van zuivere vrije medeëigendom. In dat geval zijn er geen redenen te bedenken om aan te nemen dat een deelgenoot niet vrij over zijn aandeel mag beschikken. Dat Pitlo/Brahn deze visie onderschrijft blijkt mijns inziens uit de hierboven aangehaalde stelling, dat vrije beschikkingsbevoegdheid onwaarschijnlijker wordt, naarmate de band tussen de deelgenoten strakker wordt. De contradictie blijkt aldus slechts een paradox.

Indien de gemeenschap is ontbonden, gelden andere regels. Bij een nalatenschap kan de medeërfgenaam over zijn erfdeel beschikken. Twee personen die samen een huis hebben gekocht, maar vervolgens hun samenwerkingsverband opheffen, kunnen vervolgens afzonderlijk over hun aandeel beschikken ${ }^{107}$.

Naar NBW kan iedere deelgenoot vrij over zijn aandeel in een gemeenschappelijk goed beschikken, tenzij uit de rechtsverhouding tussen partijen anders voortvloeit (art. 3.7.1.8 / 3:175 NBW). Indien uit de rechtsverhouding anders voortvloeit, kan de kantonrechter hierin wijziging aanbrengen op grond van gewijzigde omstandigheden (art. 3.7.1.8 lid 2 / 3:175 lid 2 jo. 3.7.1.2 lid 3 / 3:168 lid $3 \mathrm{NBW}$ ). Bovendien zijn rechtverkrijgenden van een deelgenoot gebonden aan de beperking van de beschikkingsbevoegdheid die uit de rechtsverhouding voortvloeit (art. 3.7.1.8 lid 2 / 3:175 lid 2 jo. 3.7.1.2 lid 4 / 3:168 lid 4 NBW) ${ }^{108}$.

De vraag of een deelgenoot beschikkingsbewoegd is ten aanzien van zijn aandeel in bepaalde zaken van de gemeenschap, zonder dat daarover tussen de deelgenoten iets is afgesproken, wordt door Pitlo/Brahn eveneens ontkennend beantwoord. Hierbij vermeldt hij expliciet dat hij er daarbij van uitgaat, dat elke gemeenschap

105. Pitlo/Brahn, bliz, 128.

106. Asser/Beekhuis 1 , blz. 422

107. Pitlo/Brahn, blz. 128, 129.

108. Vgl. Van Mourik (Gemeenschap), blz. 21, 22, Hijma/Olthof, blz. 127, 128. De beperking van de beschikkingsbevoegdheid kan ook voortvloeien uit de redelijkheid en billijkheid. Zie Wammes, blz. $57,209-214$. 
tenminste enigermate gebonden is ${ }^{109}$. Hij baseert zich hierbij op het turfschuurarrest ${ }^{110}$. De Hoge Raad bepaalde in dit arrest

\begin{abstract}
"dat de regel dat een mede-erfgenaam niet over zijn aandeel in een afzonderlijk goed der nalatenschap kan beschikken, zijn grondslag vindt in het krachtens art. 1112 B.W. aan ieder erfgenaam toekomend recht scheiding en deling van de gehele nalatenschap te verlangen, aan welk recht afbreuk zou worden gedaan, indien door beschikking over aandelen in de afzonderlijke goederen de mede-eigendom van de boedel zou uiteen vallen in verschillende mede-eigendommen."
\end{abstract}

Volgens Pitlo is de rechtsgrond om gedeeltelijke overdracht aan een deelgenoot te ontzeggen de goede trouw, die de rechtsverhouding tussen de deelgenoten beheerst ${ }^{111}$.

Dit is naar NBW in beginsel anders. Onder toekomstig recht is ieder der deelgenoten namelijk in principe bevoegd om over een onverdeeld aandeel in een bepaald gemeenschapsgoed te beschikken. Hier geldt namelijk eveneens artikel 3.7.1.8 lid 1 / 3:175 lid 1 NBW. Ook de beperking dat, dit slechts geldt voor zover uit de rechtsverhouding tussen de deelgenoten niet anders voortvloeit, geldt hier echter. In praktijk zal deze uitzondering de regel waarschijnlijk gaan overwoekeren ${ }^{112}$. Aldus zal de praktijk naar huidig en toekomstig recht op dit punt weinig verschillen vertonen.

Ten aanzien van de gehele gemeenschap zijn slechts alle deelgenoten gezamenlijk beschikkingsbevoegd ${ }^{113}$. Ook naar toekomstig recht zijn de deelgenoten slechts gezamenlijk bevoegd om over het gehele gemeenschapsgoed te beschikken (art. 3.7.1.3a lid $3 / 3: 170$ lid $3 \mathrm{NBW})^{114}$.

\title{
4.3.2.2 Verhaalsmogelijkheden van een schuldeiser op een deelgenoot
}

Een ander kernpunt waarop de regeling van de vrije medeëigendom zich toespitst is de vraag welke verhaalsmogelijkheden een schuldeiser op een medeëigenaar heeft. Hierbij dienen twee situaties te worden onderscheiden. Allereerst het geval, dat een schuldeiser beslag wil leggen op de portie van een deelgenoot in een gemeenschap ${ }^{115}$. In de jurisprudentie is enkele malen bepaald dat een schuldeiser beslag kan leggen op een aandeel in een nalatenschap. Dit betekent echter nog niet dat de beslagleggende schuldeiser daar dan direct profijt van heeft. Het betekent slechts dat de portie van de beslagene na verdeling van de gemeenschap aan de beslaglegger toekomt ${ }^{116}$. Naar nieuw BW kunnen schuldeisers van een deelgenoot diens aandeel in het gemeenschappelijke goed uitwinnen. Beperkingen

109. Pitlo/Brahn, blz. 129. Anders nog Pitlo/Brahn, achtste druk, blz 149.

110. HR $\mathbb{1 1 4}$ nov. 1969, NJ 1970, 283.

111. Pitlo/Boskamp/Cahen (Korte Uitleg), blz. 45. Vgl. hierbiij HR 20 dec. 1946, NJ 1947, 59.

112. Pitlo/Cahen (Korte: Uitleg NBW), blz. 66 .

113. Asser/Beekhuis 1, blz. 421.

114. Hijma/Olthof, blz. 123. Art. 3.7.1.3a lid 3/3:170 NBW is een regel van dwingend recht. Zic Wammes, blz. 53 .

115. Pitlo/Brahn, blz. 130.

116. Vgl. Pitlo/Brahn, blz 130; Rb. Amsterdam 7 mei 1946, NJ 1947, 5. Anders Pitlo/Boskamp/Cahen (Korte Uitleg), blz. 44. 
van beschikkingsbevoegdheid over de aandelen kunnen door de overige deelgenoten na uitwinning niet tegen de verkrijger van het aandeel worden ingeroepen (art. 3.7.1.8a lid 3/3:176 lid $3 \mathrm{NBW}$ ).

De tweede situatie houdt in, dat de schuldeiser beslag wil leggen op het aandeel van de schuldenaar in een van de gemeenschappelijke goederen. Pitlo/Brahn noemt hierbij het voorbeeld dat de schuldeiser beslag wil leggen op het aandeel van de schuldenaar, waardoor hij met anderen gerechtigd is in een tot de nalatenschap behorend huis ${ }^{117}$. Artikel $492 \mathrm{Rv}$. staat aan deze beslaglegging echter in de weg. Dit artikel bepaalt immers :

"Niettemin kan het aandeel van eenen medeërfgenaam in de onroerende goederen eener nalatenschap, door zijne personeele schuldeisers niet ter koop aangeslagen worden, voor dat de boedel door verdeeling gescheiden is, welke scheiding zij, zulks geraden oordeelende, mogen vorderen."

De schuldeiser kan dus wel verdeling vorderen, maar geen beslag leggen. De vraag die nu opkomt is of een schuldeiser wel een roerende zaak in een andere gemeenschap mag beslaan. Dan is immers niet meer aan de letterlijke vereisten van artikel $492 \mathrm{Rv}$. voldaan. Volgens Pitlo/Brahn maakt dit echter allemaal niets uit:

"De regel van artikel $492 \mathrm{Rv}$, die naar de letter uitsluitend verbiedt om het aandeel van een mede-erfgenaam in een onroerende zaak in de nalatenschap te beslaan wordt tot een algemene regel gemaakt die inhoudt een verbod om het aandeel van een deelgenoot in enig goed in enige gebonden gemeenschap te beslaan." 118

Hierbij merkt Pitlo/Brahn nog op dat dit slechts anders is, indien er zo weinig gebondenheid tussen deelgenoten bestaat (en er dus in mijn terminologie sprake is van een "vrije" gemeenschap, R.M.),

"dat redelijkheid en billijkheid zich niet tegen beslag en uitwinning ook van een aandeel in een goed verzetten. "119

Naar NBW mag de schuldeiser op grond van artikel 3.7.1.8 lid 3/3:175 lid 3 het aandeel van een schuldeiser in een bepaald goed uitwinnen ${ }^{120}$. Een schuldeiser die een opeisbare vordering op een deelgenoot heeft, kan bovendien verdeling van de gemeenschap vorderen, echter niet verder dan voor verhaal van zijn vordering nodig is (art. 3.7.1.9b / 3:180 NBW). De rechter kan echter op vordering van een deelgenoot op grond van een belangenafweging een vordering tot verdeling uitsluiten (art. 3.7.1.9 lid 3/3: 178 NBW) ${ }^{121}$.

117. Pitlo/Brahn, blz. 130.

118. Pitlo/Brahn, blz. 130. Vgl. tevens over beslag op het aandeel van de schuldenaar in een gemeenschappelijke zaak: Asser/Meijers/Van der Ploeg (Erfrecht), biz. 327-330.

119. Pitlo/Brahn, blz. 130.

120. Hijma/Olthof, blz. 128.

121. Van Mourik, Kwartaalbericht Nieuw BW 1984, blz. 60 . 


\subsubsection{Scheiding en deling/verdeling}

Ten aanzien van scheiding en deling van een gemeenschap worden in het huidige recht voor een vrije gemeenschap geen algemene regels gegeven. Op sommige plaatsen verwijst de wetgever echter naar de regeling van de boedelscheiding in het erfrecht. Zo verwijst artikel 1:100 lid $2 \mathrm{BW}$ hiernaar voor scheiding en deling van een huwelijksgoederengemeenschap, artikel $1689 \mathrm{BW}$ naar de erfrechtelijke boedelscheiding voor de verdeling van een maatschapsvermogen ${ }^{122}$ en verwijst artikel 628 $\mathrm{BW}$ hiernaar voor een verdeling

"van eene zaak, welke aan meer dan een persoon toebehoort."

Ook deze laatste vrije gemeenschap is dus aan de regels van de boedelscheiding van het erfrecht onderworpen. De bepalingen ten aanzien van de boedelscheiding in het erfrecht (artt. 1112-1171 BW) bevatten echter vele regelingen die niet toepasbaar zijn op verdeling van andere gemeenschappen. Zo is de afdeling van de ouderlijke boedelverdeling niet transponeerbaar naar andere gemeenschappen. Over het algemeen leveren deze aan het erfrecht eigen bepalingen echter geen problemen op. Men laat ze gewoon buiten beschouwing. Eén bijzonder artikel kan echter niet eenvoudig op die wijze worden afgedaan. Dit artikel - $1129 \mathrm{BW}$ bepaalt namelijk:

"1. Ieder erfgenaam wordt geacht onmiddellijk te zijn opgevolgd in de hem toebedleelde, of in de door hem bij aankoop, krachtens art. 1122 verkregene goederen.

2. Geen der erfgenamen wordt alzo gerekend immer den eigendom van de andere goederen gehad te hebben."

Boedelscheiding heeft dus fictief terugwerkende kracht. Deze fictie is in de wet opgenomen om te voorkomen dat een erfgenaam tweemaal belasting zou moeten betalen, namelijk éenmaal successierechten en daarna - bijvoorbeeld bij onroerend goed - overdrachtsbelasting ${ }^{123}$.

De vraag die nu opkomt is of deze terugwerkende kracht ook geldt bij scheiding en deling van andere gemeenschappen dan de nalatenschap. Ook in liet huwelijksgoederenrecht, het maatschapsrecht en in artikel $628 \mathrm{BW}$ wordt immers verwezen naar de bepaling van artikel $1129 \mathrm{BW}^{124}$.

Volgens Pitlo/Brahn moet men bij toepassing van dit artikel op bijvoorbeeld de (gebonden) huwelijksgoederengemeenschap oppassen. De verdeling werkt namelijk niet terug tot het moment van ontstaan van deze gebonden gemeenschap. $\mathrm{Hij}$ motiveert dit als volgt. Bij een nalatenschap zijn er twee relevante momenten, het moment dat de nalatenschap openvalt en het moment dat de nalatenschap wordt verdeeld. Deze twee momenten worden nu door artikel $1129 \mathrm{BW}$ tot éen moment gemaakt. Bij de maatschap en de huwelijksgoederengemeenschap zijn er volgens

122. Hier zij er nogmaals op gewezen dat beide gemeenschappen gebonden zijn, voor zover men het onderscheid tussen wrije en gebonden gemeenschap tenminste kan aanbrengen.

123. Pitlo/Brahn, blze 131.

124. Vgl. hierover ook Lubbers (Gemeen goed), blz. 6 . 
Pitlo/Brahn echter drie relevante momenten, namelijk ten eerste het moment van ontstaan van het gemeenschapsvermogen, ten tweede het moment van ontbinding van de gemeenschap en ten derde het moment van verdeling van het gemeenschapsvermogen. De laatste twee momenten worden nu door artikel $1129 \mathrm{BW}$ gelijk geschakeld. Verdeling wordt derhalve geacht terug te werken tot het moment van ontbinding ${ }^{125}$. Artikel $628 \mathrm{BW}$, dat geen betrekking heeft op een bepaalde soort gemeenschap, verwijst voor de vrije gemeenschap ook naar de regels van de boedelscheiding, en bijgevolg naar artikel $1129 \mathrm{BW}$. Is artikel $1129 \mathrm{BW}$ nu ook op deze medeëigendom van toepassing? Asser/Beekhuis ${ }^{126}$ en Pitlo/Brahn zijn eenstemmig in die zin dat artikel $1129 \mathrm{BW}$ niet toegepast dient te worden op

"mede-eigendom, waaromheen slechts een zeer losse band ligt." ${ }^{27}$

Volgens hen bestaat er in een dergelijke medeëigendomssituatie in het geheel geen behoefte aan de fictie van de ex tunc werking van scheiding en deling. Volgens Pitlo/Brahn en Asser/Beekhuis is een verdeling van een dergelijke vrije gemeenschap niet declaratief, maar translatief ${ }^{128}$. De verdeling is in dat geval een titel voor overdracht. Het voordeel van deze uitleg is bij registergoederen, dat indien men gemeenschappelijke eigendom tot privé-eigendom wil maken, aan alle vereisten van overdracht moet worden voldaan en er derhalve een notariële akte en overschrijving daarvan in de openbare registers is vereist ${ }^{129}$. Hierdoor zal de informatie in de openbare registers over wie eigenaar van het registergoed is, betrouwbaar zijn.

In het NBW komt de term scheiding en deling niet meer terug. In plaats daarvan spreekt het NBW van verdeling. Onder verdeling wordt verstaan iedere rechtshandeling waartoe alle deelgenoten medewerken en krachtens welke een of meer van hen een of meer goederen verkrijgen met uitsluiting van de andere deelgenoten (art. 3.7.1.11/3:182 NBW). De verdeling geschiedt, behoudens uitzonderingen, vormvrij (art. 3.7.1.12 / 3:183 NBW). De verdeling heeft verder geen terugwerkende kracht (art. 3.7.1.14a./3:186 NBW) en heeft translatieve werking. De werking is derhalve van obligatoire aard. De deelgenoten moeten de goederen leveren overeenkomstig afd. 3.4.2 NBW aan degene aan wie ze zijn toebedeeld (art. 3.7.1.14a / 3:186 NBW) ${ }^{130}$.

\subsection{Toelating van nieuwe medeëigenaars en controle van medeëigenaars onderling}

$\mathrm{Nu}$ in vogelvlucht het recht dat de medeëigendom beheerst, is behandeld, kan de vraag die in deze paragraaf centraal staat, aan de orde komen. Voor een goed begrip zij deze probleemstelling hier nog eens herhaald: in hoeverre kunnen

125. Putlo/Brahn, blz.132, 133; Meijer (Kiezen of Delen), blz. 12, 13, betoogt daarentegen dat art. 1129 BW ook op andere gemeenschappen dan de nalatenschap kan worden toegepast, met name op de vrïje gemeenschap.

126. Asser/Beekhuis I, bly, 429, 430 .

127. Pitlo/Brahn, bla 133.

128. Zie ook Pitlo/Boskamp/Cahen (Korte Uitleg), blz. 42. Anders Meijer (Kiezen of delen), blz. 12, 13.

129. Pitlo/Brahn, blz, 133.

130. Vgl. Schoordijk (Mede-eigendom), blz. 100-119; Van Mourik (Gemeenschap), blz. 35 e.v. 
medeëigenaars/ deelgenoten invloed uitoefenen op de samenstelling van de groep medeëigenaars (in hoeverre hebben zij dus inspraak indien een derde-nietmedeëigenaar de positie van medeëigenaar wil verwerven) en in hoeverre kunnen zij onderling controle op elkaar uitoefenen? Het doel van deze vraagstelling is om verwantschap en verschillen met de welstandsbepalingen in het appartementsrecht op te sporen. Bij de beantwoording van deze vraag zal voornamelijk worden uitgegaan van de (theoretische) situatie dat er sprake is van volkomen vrije medeëigendom. Tevens zal echter getracht worden om kort een antwoord te geven op deze vraag met betrekking tot de gebonden medeëigendom.

Als woorbeeld nemen we de situatie dat twee personen samen een huis kopen om er eveneens tezamen, zij het op afzonderlijke verdiepingen, te wonen. Hierbij wordt de veronderstelling ingebouwd dat aan hun gezamenlijke aankoop geen rechtsverhouding ten grondslag ligt en dat zij geen scheiding en deling zullen vragen, althans tenminste deze scheiding en deling na aankoop uitsluiten voor vijf jaren met de bedoeling om deze afspraak te vernieuwen na afloop van deze termijn (art. 1112 lid 3 en $4 \mathrm{BW}$ ) ${ }^{131}$.

Vervolgens leven beide personen gedurende een bepaalde tijd (korter dan vijf jaar) samen in het huis, waarvan zij ieder een afzonderlijk gedeelte bewonen. Plotseling wenst een van beiden zijn aandeel in de gemeenschap te vervreemden. De ander is niet bepaald in zijn sas met dit idee, zeker niet nadat hij kennis gemaakt heeft met zijn aspirant-deelgenoot. Hij wenst zijn veto uit te spreken over de vervreemding. De vraag is echter of hij zo'n vetorecht heeft. Ervan uitgaande dat hier sprake is van vrije medeëigendom, moet deze vraag ontkennend worden beantwoord. Aangezien echter moet worden aangenomen dat deze vrije medeëigendomssituatie van academische aard is, luidt het praktijkantwoord voor degene die zijn vetorecht wil uitspreken, bevestigend. Zelfs deze situatie, waarin twee personen een huis kopen, kan niet bestaan zonder een zekere band tussen beide personen, die de medeëigendom tot een zekere graad van gebondenheid verheft. Zodra er sprake is van gebondenheid kan een medeëigenaar, behoudens andersluidende afspraak, niet vrij over zijn aandeel in de gemeenschap beschikken. Toestemming van de andere deelgeno(o)t(en) is vereist ${ }^{132}$. In een dergelijke situatie blijven voor de deelgenoot die zijn aandeel in de gemeenschap wilde vervreemden, twee mogelijkheden over. Enerzijds kan hij na afloop van de vijf jaren warin scheiding en deling was uitgesloten, scheiding en deling vorderen. Anderzijds kan hij proberen overeenstemming met de andere deelgenoot te bereiken over het opheffen van hun samenwerkingsverband en aldus na ontbinding van de gemeenschap tot verdeling overgaan ${ }^{133}$. Kort samengevat kan een deelgenoot in een volstrekt vrije gemeenschap (hetgeen een theoretische situatie is) vrij over zijn aandeel beschikken, terwijl in een min of meer gebonden gemeenschap behoudens afwijkende afspraken het tegendeel geldt en toestemming van de overige deelgenoten is vereist.

131. Het moge duidelijk zijn, dat door een zodanige afspraak een element van gebondenheid in de gemeenschap wordt geïntroduceerd.

132. Vgl. Pillo/Brahn, blz. 128.

133. Vgl. Pitlo/Brahn, blz. 128, 129. 
Toepassing van het NBW op de casus dat twee mensen gezamenlijk een huis kopen, levert ongeveer hetzelfde resultaat op als bij toepassing van het huidige recht. In beginsel is iedere deelgenoot weliswaar bevoegd om vrij over zijn aandeel in de gemeenschap te beschikken, maar de uitzondering

"tenzij uit de rechtsverhouding tussen de deelgenoten anders voortvloeit",

zal spoedig toepasselijk moeten worden geacht. De Memorie van Antwoord bij het gewijzigd ontwerp noemt zelfs expliciet dit geval als voorbeeld waarbij de uitzondering van toepassing zal zijn.

"Men denke aan de koop van een huis voor gemeenschappelijke rekening teneinde dit gezamenlijk te gaan bewonen. Wenst een deelgenoot een relatie als deze niet langer voort te zetten en verlenen de andere deelgenoten hem geen toestemming om zijn aandeel aan een ander over te dragen, dan zal hij - zo nodig met opzegging van de overeenkomst die hem aan de andere deelgenoten bindt - verdeling van de gemeenschap moeten vorderen. Aan de andere deelgenoten tegen hun wil een nieuwe deelgenoot opdringen kan hij in beginsel niet." 134

Hierbij dient te worden opgemerkt dat het recht om verdeling te vorderen niet altijd aan de deelgenoten toekomt. Artikel 3.7.1.9 NBW geeft hiervoor een uitgebreide regeling. In extremis kan dit tot gevolg hebben dat een deelgenoot; althans gedurende een zekere tijd, opgescheept blijft met een aandeel in een gemeenschap dat hij al lang niet meer wil.

De beantwoording van de vraag in hoeverre deelgenoten inspraak hebben indien een derde de positie van deelgenoot wil verwerven, is betrekkelijk gemakkelijk. De beantwoording van de vraag in hoeverre deelgenoten onderling controle op elkaar kunnen uitoefenen, levert meer problemen op. Allereerst de situatie dat er sprake is van volstrekt vrije medeëigendom. Ook hierbij wordt weer uitgegaan van het geval dat twee personen samen een huis kopen en geen overeenkomst hebben gesloten ten aanzien van gebruik, beheer, genot en beschikking. Wel hebben zij afgesproken om gedurende vijf jaren niet tot scheiding en deling over te gaan. Beide personen hebben dan de bevoegdheden die (zij het op obscure wijze) uit de wet voortvloeien en die in het voorgaande zijn besproken.

Wat gebeurt er nu indien een van beide personen deze bevoegdheden overtreedt? Indien een van beiden zijn beheers-, genots-, gebruiks- of beschikkingsbevoegdheid overschrijdt, kan de ander hem tot herstel in de oude toestand aanspreken. Daarvoor kan deze andere deelgenoot zich dan op de goede trouw beroepen, die blijkens de jurisprudentie van de Hoge Raad de rechtsverhouding tussen de medeëigenaars beheerst (vgl. art. 3.7.1.1 lid 3/3:166 lid 3 NBW) ${ }^{135}$.

Een interessante vraag hierbij is hoe de toepasselijkheid van de goede trouw tussen de medeëigenaars, dogmatisch kan worden gefundeerd. De zakenrechtelijke

134. Parl. Gesch. NBW, MVA II bij art. 3.7.1.8. NBW, blz. 599.

135. Vgl. HR 20 dec. 1946, NJ 1947, 59; HR 9 mei 1952, NJ 1953, 563, A.A. 1952/1953, blz 40 met noot J. Drion. 
handboeken geven op deze vraag geen antwoord. Hierbij dient voor de duidelijkheid nog te worden vermeld, dat het geval besproken wordt dat de medeëigenaars zich niet door een overeenkomst aan elkaar gebonden hebben. In het laatste geval zou de beantwoording van de vraag naar de rechtsverhouding tussen medeëigenaars immers eenvoudig zijn. Zij zou dan van contractuele aard zijn, waardoor de toepasselijkheid van de goede trouw op de onderlinge rechtsverhouding verklaard zou worden. De goede trouw is echter ook van toepassing op rechtswerhoudingen tussen medeëigenaars, die niet op een overeenkomst gegrondvest zijn. Moet er desalniettemin worden gesproken van een rechtsverhouding van contractuele aard, of is de goede trouw hier getransponeerd op een rechtsverhouding die niet als dusdanig kan worden gekwalificeerd? Van praktisch belang is deze vraag bij een juridische procedure van een (vrije) medeëigenaar tegen een andere, die zijn bevoegdheden overschrijdt. Ware hun verhouding van verbintenisrechtelijke aard, dan kon de medeëigenaar ten opzichte van de andere een actie uit wanprestatie starten. Zodra de rechtsverhouding echter niet als een verbintenisrechtelijke wordt gekwalificeerd, rest de vraag waarop een medeëigenaar zich in een procedure tegen de ander moet beroepen. Een actie uit wanprestatie is dan uit den boze. Zonder de toepasselijkheid van de goede trouw op de rechtsverhouding tussen medeëigenaars, zou men spoedig kunnen aannemen dat de aangewezen rechtsgang die ex artikel $1401 \mathrm{BW}$ is. Nu lijkt de toepasselijkheid van de goede trouw echter in een andere richting te wijzen.

Het is mijns inziens verdedigbaar om de bevoegdheden die medeëigenaars hebben, op te vatten als bronnen van rechtsplichten om deze bevoegdheden niet te overschrijden. Niet nakoming van de rechtsplicht zou een actie uit onrechtmatige daad mogelijk hebben gemaakt op grond van misbruik van bevoegdheid ${ }^{136}$. De Hoge Raad heeft echter blijkbaar voor een andere oplossing gekozen. Hij heeft de goede trouw op de rechtsverhouding tussen medeëigenaars getransponeerd, zonder echter aan te geven waarop hij deze toepasselijkheid baseert. Vloeit zij voort uit analogische toepassing van de artikelen 1374,1375 en de bepalingen betreffende de maatschap, of is hier een algemeen rechtsbeginsel aanvaard? Houwing lijkt in zijn noot onder HR 9 mei 1952 (NJ 1953, 563) te concluderen dat hier sprake is van toepasselijkverklaring van ongeschreven recht. Hierop levert hij vervolgens kritiek.

"Aldus kan men zonder op enige bepaling van geschreven recht te steunen tot onbeperkte gelding van het ongeschreven recht besluiten. Waarom b.v. nog in de rechtsverhouding tussen degeen, door wiens toedoen een ander is benadeeld en den door hem benadeelde de verplichting tot schadevergoeding nog, op vaak zo gewrongen wijze, uit art. 1401 B.W. af te leiden ?", aldus Houwing.

136. Vgl. Van der Grinten (Gemeenschap), blz. 137, 138. 
Zelfs in gevallen waarin onrechtmatigheid ontbreekt, zou de Hoge Raad volgens Houwing aldus kunnen beslissen dat de billijkheid vergoeding van schade door de veroorzaker vordert.

"En dat alles met geen andere motivering - .... - dan dat het zo is", schreef Houwing.

De vraag hoe de toepasselijkheid van de goede trouw, anders dan door analogische toepassing op medeëigendomsverhoudingen of door toepassing van algemene rechtsbeginselen, dogmatisch gefundeerd kan worden, is blijkbaar niet eenvoudig te beantwoorden ${ }^{137}$. Bij vrije medeëigendom is een praktische oplossing denkbaar. Vrije medeëigendom bestaat immers niet, aangezien er altijd in meerdere of mindere mate sprake zal zijn van een al dan niet uitdrukkelijk aangegane overeenkomst. Dit betekent dat de goede trouw altijd op de (contractuele) rechtsverhouding tussen "vrije" medeëigenaars van toepassing is, en derhalve ook aanvullend werkt. Bij de (gebonden) ervengemeenschap is er echter geen sprake van een overeenkomst, zodat de toepasselijkheid van de goede trouw tussen erfgenamen anders gefundeerd moet worden. In het NBW bepaalt de wet expliciet deze toepasselijkheid (art. 3.7.1.1 lid 3/ 3:166 lid 3 NBW).

De oplossing ligt mijns inziens in het feit dat medeëigenaars, c.q. deelgenoten, via de gemeenschappelijke zaak in een zakelijke rechtsverhouding tot elkaar staan. Deze rechtsverhouding vertoont nauwe verwantschap met een contractuele rechtsverhouding en heeft daarmee met name gemeen, dat beide rechtsverhoudingen vertrouwensrelaties van de partijen impliceren. Elke medeëigendomsverhouding, c.q. gemeenschap, bevat een vertrouwensrelatie tussen de deelgenoten ${ }^{138}$. Als een van de deelgenoten ten opzichte van de ander het in hem gestelde vertrouwen beschaamt, kan de ander met een beroep op de goede trouw, herstel van het geschonden vertrouwen vorderen ${ }^{139}$.

De rechter dient bij een beroep op de goede trouw in medeëigendomsverhoudingen - evenals in andere gevallen van toetsing aan de goede trouw (zie par. 4.2.4.4) - waarschijnlijk marginaal te toetsen. Dit geldt zowel bij een weigering door deelgenoten om aan een andere deelgenoot toestemming tot vervreemding of bezwaring te geven, als bij gebruik, beheer of genot door een deelgenoot, dat volgens de andere deelgenoten in strijd met de goede trouw is. Naar NBW zal dit niet anders zijn.

137. Drion (Precontractuele verhoudingen), blz. 246 , weet op deze vraag ook geen antwoord te geven.

138. Pitlo, TPR 1973, blz. 185, meent dat de goede trouw op alle rechtsverhoudingen kan worden toegepast, indien de toepasselijkheid in het kader van de wet past en aansluit bij de in de wet geregelde gevallen. Hij baseert zich hierbij op het Quint-Te Poel-arrest, HR 30 jan. 1959, NI 1959,548 .

139. Uit de jurisprudentie is geen geval bekend, waarbij op grond van de goede trouw werd beslist, dat een medeëigenaar zijn bevoegdheid had overschreden. Steeds vond men aansluiting bij bestaande wetsartikelen. Vgl. HR 28 dec. 1859, W 2133; HR 21 now. 1873, W 3659; HR 2 juni 1905, W 8235; HR 28 april 1913, W 9503; HR 11 dec. 1924, NJ 1925, 194; HR 20 dec. 1946, NJ 1947, 59; HR 9 mei 1952, NJ 1953, 563, A.A. 1952/1953, blz 40 met noot J. Drion; HR 26 juni 1953, NJ 1953, 629; HR 11 nov, 1966, NJ 1967, 361 met noot J.H. Beekhuis; HR 3 april 1968, NJ 1968, 294; Hof Amsterdam 26 mei 1955, NJ 1955, 661; Hof 's-Gravenihage 24 okt. 1969, NJ 1970, 421 (over televisieantenne op gemene schoorsteen); Rb. Den Bosch 25 junil 1937, NJ 1938, 256; Rb. Groningen 10 juli 1940, NJ 1942, 2; Rb. Haarlem 29 mei 1945, NJ 1946, 118. 
De toepasselijkheid van de goede trouw in medeëigendomsverhoudingen sluit mijins inziens overigens niet uit dat een deelgenoot in bepaalde gevallen toevlucht kan nemen tot een actie ex artikel $1401 \mathrm{BW}$, bijwoorbeeld omdat een andere deelgenoot hinderveroorzakende activiteiten ontplooit of misbruik makt van zijn medeëigendomsrecht. Dit geldt in beginsel voor zowel de "vrije" gemeenschap, als voor de gebonden gemeenschap. Het is uiteraard wel mogelijk, dat bij een gebonden gemeenschap bijzondere regels gelden ten aanzien van de mogelijkheden van deelgenoten om tegen elkaar op te treden (bijvoorbeeld bij de gemeenschap van appartementseigenaars). Uitzetting van een deelgenoot uit bijvoorbeeld een gemeenschappelijk huis is in beginsel niet mogelijk, behalve via de gewone weg van beslag en na verdeling, executie. Het probleem hierbij is echter dat ontbinding en verdeling van de gemeenschap nodig is om het aandeel van de in gebreke zijnde deelgenoot te kunnen executeren ${ }^{140}$.

Overigens moet de weigering van deelgenoten om aan een andere deelgenoot toestemming te verlenen om over zijn aandeel te beschikken, als een rechtshandeling worden gekwalificeerd. Hierdoor kan de om toestemming verzoekende deelgenoot eventueel proberen het weigeringsbesluit nietig te laten verklaren wegens strijd met de wet, openbare orde of goede zeden (artt. 1371, 1373 BW; art. 3.2.7 / 3:40 NBW). In de praktijk zal het weinig verschil uitmaken of hij deze weg bewandelt, of strijd met de goede trouw aanvoert, omdat een besluit dat nietig is wegens strijd met de wet, openbare orde of goede zeden (bijwoorbeeld wegens inbreuk op grondrechten), tevens in strijd zal zijn met de goede trouw. Hierbij moet worden opgemerkt dat de marginale toetsing aan de goede trouw door de rechter, evenals elke andere wijze van toetsing, een rechtmatigheidstoets inhoudt, waarbinnen toetsing aan de wet, openbare orde of goede zeden mogelijk is ( $\mathrm{vgl}$. par. 3.7.2).

De goede trouw die de rechtsverhouding tussen deelgenoten beheerst, brengt mijns inziens evenals bij de verenigingen (zie par. 4.2.3) met zich mee, dat een afwijzend besluit met betrekking tot toestemming tot vervreemding of bezwaring, gemotiveerd moet worden. Een ongemotiveerd besluit moet aldus in strijd met de goede trouw worden geacht.

Kort resumerend kan worden gesteld dat medeëigenaars, voor zover er geen bijzondere regels bestaan, elkaar kunnen controleren via de goede trouw, die hun rechtsverhouding beheerst. Als een deelgenoot van de andere deelgenoten geen toestemming krijgt om zijn aandeel in de gemeenschap te vervreemden, kan hij deze beslissing trachten aan te vechten met een beroep op de goede trouw.

Bovendien kunnen medeëigenaars elkaar onderling aanspreken wegens strijd met de goede trouw, indien zij hun aandeel of het gehele gemeenschappelijke goed, gebruiken, beheren of ervan genieten op een wijze die zodanig nadeel toebrengt aan de overige deelgenoten, dat dit gebruik, beheer of genot strijd oplevert met de goede trouw.

Naar NBW zal ten aanzien van de beschikkingsbevoegdheid van de deelgenoot met betrekking tot zijn aandeel, spoedig uit de onderlinge rechtsverhouding voortvloeien, dat hij niet zonder toestemming van de andere deelgenoten over zijn

140. Pitlo/Brahn, blz 130 . 
aandeel mag beschikken. Als dit niet rechtstreeks en expliciet uit de rechtsverhouding voortvloeit, zal dit vaak uit de redelijkheid en billijkheid voortvloeien. Ook overschrijding van de bevoegdheden als deelgenoot ten aanzien van gebruik, beheer en genot, zal door de andere deelgenoten kunnen worden bestreden met een beroep op de redelijkheid en billijkheid (vgl. 6.1.1.2 lid 2 / 6:2 NBW).

\subsubsection{Synthese: appartementsrechten en gemeenschap}

Naar huidig recht kan de gemeenschap van appartementseigenaars worden gekwalificeerd als een gebonden gemeenschap, uiteraard voor zover men het onderscheid tussen vrije en gebonden gemeenschap nog wil maken. Naar toekomstig recht is de gemeenschap van appartementseigenaars een bijzondere gemeenschap, waarbij moet worden aangetekend dat het recht betreffende de gemeenschap, zoals neergelegd in titel 3.7 NBW, blijkens artikel 3.7.2.0 / 3:189 NBW niet geldt voor de gemeenschap van appartementseigenaars.

Voor het huidige recht betekent dit, dat het medeëigendomsrecht op de gemeenschap van appartementseigenaars van toepassing is, voor zover de bepalingen van het appartementsrecht daaraan niet derogeren. Dit betekent onder meer, dat een appartementseigenaar bij ontbreken van een bepaling als artike] $875 \mathrm{k} \mathrm{BW}$, voor beschikking over zijn appartementsrecht, toestemming nodig zou hebben van de overige appartementseigenaars. Ook het hierboven beschrevene betreffende de goede trouw en medeëigendomswerhoudingen, is in beginsel op de gemeenschap van appartementseigenaars van toepassing. In elk geval wordt de verhouding tussen de appartementseigenaars beheerst door de goede trouw, hetgeen ook duidelijk blijkt uit artikel 876 d lid 1 sub c BW. De praktijk zal zich echter zelden of nooit van het algemene recht betreffende de medeëigendom hoeven te bedienen, nu het appartementsrecht een zeer uitgebreide bijzondere regeling van de onderlinge rechtspositie van appartementseigenaars geeft, c.q. mogelijk maakt.

Onder toekomstig recht zal het algemene recht betreffende de gemeenschap niet op de gemeenschap van appartementseigenaars van toepassing zijn (art. 3.7.2.0 / 3: $189 \mathrm{NBW}$ ). De redelijkheid en billijkheid is echter wel op de rechtsverhouding tussen de appartementseigenaars van toepassing, niet op grond van artikel 3.7.1.1 lid 3 / 3:166 lid $3 \mathrm{NBW}$, maar blijkens art: 5.10.2.1d lid 1 sub 3/5:130 lid 3 NBW (waar overigens ten onrechte de term "goede trouw" wordt gehanteerd, terwijl redelijkheid en billijkheid wordt bedoeld), en vanwege het feit dat de vertrouwensrelatie tussen de appartementseigenaars deze toepasselijkheid meebrengt.

\subsection{Huur en verhuur}

\subsubsection{Inleiding}

Volgens artikel 1584 lid $1 \mathrm{BW}$ is huur en verhuur een overeenkomst,

"waarbij de ene partij zich verbindt om aan de andere het genot eener zaak te doen hebben, gedurende eenen bepaalden tijd en tegen eenen bepaalden prijs, welke de laatstgenoemde aanneemt te betalen." 
Zowel register- als niet-registerzaken kunnen onderwerp van huur zijn. Bij nietregisterzaken kan men als simpel voorbeeld aan de "Doe het zelf"-winkel denken, die vlakschuurmachines verhuurt. Bij registerzaken kan men denken aan het charteren van vliegtuigen, maar vooral ook aan het huren van onroerend goed. Dit laatste is waarschijnlijk het eerste waaraan iemand denkt bij het horen van het woord "huur". Maar ook het begrip "huur en verhuur van onroerend goed" beslaat een nogal groot gebied. Want hieronder kan (behalve eventueel huur en verhuur van onbebouwd onroerend goed) zowel de huur en verhuur van bedrijfsruimte als de huur en verhuur van woonruimte verstaan worden.

In het navolgende zal slechts worden ingegaan op de huur en verhuur van woonruimte. Bedrijfsruimte blijft buiten beschouwing. Zelfs de "huur en verhuur van woonruimte" bevat echter nog teveel stof om op deze plaats te beschrijven. Uitputtende beschrijving van het huurrecht is echter niet noodzakelijk, nu in het kader van dit intern rechtsvergelijkende hoofdstuk vooral die onderdelen van het huurrecht belangrijk zijn, die een zinnige vergelijking met de welstandsbepalingen in het appartementsrecht mogelijk maken. Vandaar dat allereerst op de totstandkoming van de huurovereenkomst zal worden ingegaan (toelating) en vervolgens op de beëindiging van de huurovereenkomst, anders dan met wederzijds goedvinden of door de huurder zelf. Bij dit laatste zal bijzondere aandacht worden geschonken aan beëindiging van de huurovereenkomst wegens onbehoorlijk gedrag van de huurder, aangezien deze beëindigingsgrond de meeste raakvlakken vertoont met de gronden voor ontzegging van verder gebruik in het appartementsrecht. Tenslotte zal de rechtspositie van de huurder van een appartementsrecht met het oog op de welstandsbepalingen, worden behandeld ${ }^{141}$.

In deze paragraaf zall overigens steeds worden uitgegaan van huidig recht. In het huidige recht wordt het huurrecht met betrekking tot woonruimte geregeld in de artikelen 1584-1623o BW. Het huurrecht zoals dat in de Huurwet is neergelegd, zal in deze paragraaf voor zover mogelijk buiten beschouwing blijven, aangezien de Huurwet in 1979, bij wijziging van het huurrecht in het BW, buiten toepassing is verklaard met betrekking tot huur van woonruimte ${ }^{142}$. Wel zal bij de bespreking van het huidige recht de huurwetjurisprudentie - voor zover relevant- worden betrokken. Van de huurbepalingen in het Burgerlijk Wetboek zijn naast artikel $1596 \mathrm{BW}$ met name de artikelen 1623a - 16230 van belang. Deze artikelen werden in hun huidige vorm bij de wijziging van het huurrecht in 1979 in het BW ingevoerd ${ }^{143}$. $\mathrm{Bij}$ wet van 15 juni $1972^{144}$ waren al enige artikelen met betrekking tot het einde van huur en verhuur van woonruimte in het BW opgenomen in de artikelen 1623a - $1623 \mathrm{~g}$ BW. Deze bepalingen golden echter slechts voor woonruimte in geliberaliseerde gebieden ${ }^{145}$. Om de nieuwe regeling te completeren zijn tevens de Huurprijzenwet woonruimte en de Wet op de Huurcommissies ingevoerd ${ }^{146}$. Op deze wetten zal in het navolgende niet worden ingegaan, aangezien zij niet van

141. De link tussen het appartementsrecht en het huurrecht is eerder door A.H.M. Santen gelegd en summier besproken. Santen (Een behoorlijke buur), blz. 105-116.

142. Asser/Abas, blz. 6; De Mol (Huurrecht), blz. 76.

143. Stb. $1979,330$.

144. Stb. 1972,305 .

145. De Mol (Huurrecht), blz 170 .

146. Stb. $1979,15,16$. Wijzigingswetten onder andere in de wet van 21 juni 1979, Stb. 330 . Zie over de geschiedenis van het huurrecht: Gunning, blz. 331-334. 
belang zijn bij een vergelijking van het huurrecht met de regeling van de welstandsbepalingen in het appartementsrecht.

\subsubsection{Toelating tot een woning; de totstandkoming van de hwwrovereenkomst}

De huurovereenkomst is een obligatoire en wederkerige overeenkomst, die als zodanig tot stand komt door aanbod en aanvaarding. In beginsel mogen partijen in de overeenkomst naar eigen goeddunken hun rechten en verplichtingen regelen. Deze contractsvrijheid wordt slechts beperkt door het vereiste van de geoorloofde oorzaak voor de geldigheid van rechtshandelingen (art. $14 \mathrm{AB}$, art. $1356 \mathrm{BW}$, art. 1371/1373 BW) en door bepalingen van dwingend recht. Het Nederlandse huurrecht bevat vele bepalingen van dwingend recht met betrekking tot huur van woonruimte. De artikelen waarin het huurrecht van woonruimte is geregeld bevatten echter geen bepalingen ten aanzien van de totstandkoming van de huurovereenkomst in het perspectief van partijkeuze. Dit betekent dat een verhuurder in beginsel zijn huurder(s) mag uitzoeken. De vraag is echter of deze vrijheid onbeperkt is. Mag een verhuurder zich bij zijn keuze van huurders laten leiden door discriminatoire motieven? Het burgerlijk wetboek bevat hiertegen geen waarborgen voor de aspirant-huurder.

Evenmin kan een huurovereenkomst tussen huurder en verhuurder nietig worden verklaard wegens het ontbreken van een wan de vereisten voor de geldigheid van rechtshandelingen (art. $1356 \mathrm{BW}$ ), indien de verhuurder aan de ene huurder op discriminatoire gronden de voorkeur geeft boven een andere huurder. De overeenkomst tussen de huurder en de verhuurder is immers geldig, en de gediscrimineerde is hierbij geen partij.

Bij gebrek aan bijzondere bepalingen uit het huurrecht komt men aldus al spoedig uit bij de actie uit onrechtmatige daad, indien men zich als aspiranthuurder gediscrimineerd voelt. Hierbij komt echter de vraag op of discriminatie, althans tot op zekere hoogte, aan de verhuurder niet is toegestaan bij de keuze van zijn huurder ${ }^{147}$. In elk geval zal het vaak moeilijk zijn om discriminatie te bewijzen. Een verhuurder behoeft immers geen redenen op te geven bij zijn keuze voor de ene (aspirant-)huurder in plaats van een andere. De motivering van zijn keuze zal vaak in de donkere hoeken van het brein van de verhuurder verborgen blijven.

In theorie heeft de aspirant-huurder die zich gediscrimineerd voelt de mogelijkheid om ex artikel $1401 \mathrm{BW}$ de verhuurder aan te spreken tot vergoeding van schade. De problemen die hij daarbij echter zal ontmoeten zijn kortweg de volgende:

1. is de discriminatie ongeoorloofd?

2. is de discriminatie bewijsbaar?

3. is er sprake van schade die voor vergoeding in aanmerking komt?

147. Verhuurders die tocgelaten instellingen zijn in de zin van art. 59 Woningwet, zijn overigens op grond van art. 15 Besluit toegelaten instelingen volkshuisvesting (Stb. 1976, 469) verplicht om wonimgen mede aan personem te verhuren die tot die groepen van de bevolking behoren, die moeilijkheden ondervinden bij het vinden van passende woonruimte. 
Het zal duidelijk zijn dat de beantwoording van deze vragen vele juristen en aspirant-huurders van een actie uit onrechtmatige daad zal afschrikken. De jurisprudentie op dit gebied blijkt dan ook bijna non-existent. Er is echter een zeer belangrijk arrest gewezen met betrekking tot discriminatie op grond van afkomst bij het aangaan van een huurovereenkomst ${ }^{148}$. Het ging hierbij om de zogenaamde "Binderen-casus".

\subsubsection{De Binderen-casus ${ }^{149}$}

In casu dagvaardde Kaya, een uit Turkije afkomstig Nederlands ingezetene, de R.K. woningbouwwereniging Binderen te Helmond in kort geding voor de President van de rechtbank 's-Hertogenbosch. Kaya vorderde dat Binderen zou worden veroordeeld (op straffe van een dwangsom) om hem binnen een week na betekening van het vonnis een woning toe te wijzen, omdat Binderen hem op grond van afkomst discrimineerde. De president van de rechtbank Den Bosch wees deze vordering af. Het Hof te 's-Hertogenbosch achtte de vordering van Kaya echter in beginsel toewijsbaar. Binderen stelde tegen het arrest van het hof cassatie in.

Het Hof overwoog in dit geval dat

"indien in het tijdvak vanaf 3 februari 1977 door Binderen ten opzichte van Kaya zou zijn gediscrimineerd, in die zin, dat hem een woning zou zijn onthouden, die hem zonder discriminatie zou zijn toegewezen, voor Binderen een rechtsplicht zou ontstaan om Kaya schadeloos te stellen."

Het Hof achtte derhalve voor toewijzing van de vordering van Kaya noodzakelijk, dat er een oorzakelijk verband bestond tussen de discriminatie en het niettoekennen van een woning.

Op grond van statistische en cijfermatige gegevens nam het Hof prima facie aan dat Binderen zich aan de gestelde discriminatie schuldig had gemaakt. Deze veronderstelde discriminatie en het aanwezig zijn van een oorzakelijk verband tussen deze discriminatie en het niet-toekennen van een woning, werden door Binderen niet op overtuigende wijze weerlegd. Binderen stelde zoals gezegd beroep in cassatie in, maar de Hoge Raad verwierp dit beroep.

Uit dit arrest kunnen enkele belangrijke conclusies worden getrokken. Ten eerste kunnen cijfermatige en statistische gegevens voldoende bewijs opleveren om te vermoeden dat een verhuurder discrimineert, waarna de bewijslast kan worden omgekeerd (zie eerder punt 2). Ten tweede is het mogelijk dat bij wijze van schadevergoeding alsnog een woning aan de gediscrimineerde moet worden verhuurd (punt 3 ).

148. Een interessant wonnis met betrekking tot discriminatie door woningverenigingen werd in 1984 door de Kantonrechter Eindhowen gewezen. Een woningvereniging weigerde toestemming tot woningruil op grond van haar beleid dat geen huishoudens uit Suriname en de landen rondom de Middellandse Zee naast elkaar zouden worden gehuisvest en op grond van een door haar en de buurt vastgestelde limiet van het aantal buitenlandse gezinnen. De Eindhovense kantonrechter beoordeelde dit beleid als apert discriminatoir. Kantongerecht Eindhoven 28 maant 1984, Praktijkgids 1984, nr. 2154.

149. HR 10 dec. 1982, NJ 1983, 687. 
Een andere vraag is echter of alle vormen van discriminatie ongeoorloofd zijn. Discriminatie op grond van afkomst is blijkens het voormelde arrest niet toegestaan. Hierbij knoopten het Hof en de President van de Rechtbank Den Bosch onder andere aan bij artikel 429 quater Sr. Hoe zal echter de beslissing moeten luiden indien een Rooms Katholieke woningbouwvereniging of particuliere verhuurder een persoon wegens homofiele gerichtheid als huurder weigeren, omdat zij acceptatie van deze aspirant-huurder niet met hun geloofsovertuiging in overeenstemming kunnen brengen? In dat geval is er immers sprake van botsing van grondrechten. De rechter zal dan van geval tot geval moeten uitmaken welk grondrecht in het concrete geval bescherming verdient. In de Binderen-casus wist men via artikel 429 quater Sr. en "beginselen van ongeschreven privaatrecht", zoals de President van de rechtbank het noemde, tot derdenwerking van het nondiscriminatiegebod met betrekking tot afkomst, te komen.

Op deze plaats kan bij wijze van intermezzo een interessant vonnis van de President van de Rechtbank Zwolle worden aangehaald. De president van de Zwolsche Rechtbank besliste op 4 mei $1984^{150}$ in kort geding dat de monopoliepositie ten aanzien van een zo onontbeerlijk goed als woonruimte de contractsvrijheid van een woningvereniging beperkt. Woningverenigingen zijn

"niet in dezelfde mate als een particuliere huiseigenaar vrij om te weigeren met een gegadigde die hen niet aanstaat een huurcontract aan te gaan."

Een woningvereniging moet het belang van de volkshuisvesting voorop stellen.

"Dat kan meebrengen dat onder bepaalde omstandigheden de weigering om met een woningzoekende een huurovereenkomst af te sluiten, onrechtmatig is", aldus de President van de Zwolsche Rechtbank.

De vraag die onbeantwoord blijft, is welke selectie door de verhuurder nog wel en welke niet meer als rechtmatig kan worden beschouwd.

De Binderen-casus lost ten aanzien van verhuurders van grote aantallen woningen het bewijsprobleem en het schadevergoedingsprobleem tot op zekere hoogte op. Bij kleine aantallen woningen van dezelfde verhuurder, blijven echter drie problemen over. Ten eerste blijft de vraag bestaan welke discriminatie ongeoorloofd is. Voorlopig is het aan de rechter om dit van geval tot geval te beoordelen. Ten tweede blijft het bewijsprobleem bestaan indien er sprake is van een particuliere verhuurder die slechts een of enkele woningen verhuurt. Statistische of cijfermatige gegevens zullen dan spoedig weinig overtuigingskracht hebben. Ten derde wordt het schadevergoedingsvraagstuk hier zeer problematisch. Een verhuurder die slechts één woning verhuurt, kan immers bezwaarlijk worden veroordeeld om een reeds verhuurde woning te laten ontruimen (waaraan overigens art. $1623 \mathrm{e} \mathrm{BW}$ in de weg zal staan) met het oogmerk om haar vervolgens aan iemand anders (de gediscrimineerde) te verhuren. Wellicht zou een veroordeling om in de toekomst bij het vrijkomen van de woning, deze aan de gediscrimineerde te verhuren, in bepaalde gevallen een oplossing kunnen zijn. Vaak echter zal dit vanwege de onvoorspelbare duur van de bestaande huurovereen-

150. Pres. Rb. Zwolle 4 mei 1984 (eindronnis), Kort Geding 1984, mr. 176. 
komst, een schijnoplossing zijn. Schadevergoeding in geld is bij een gewone onrechtmatige daad in het algemeen slechts mogelijk ten aanzien van geleden materiële schade ${ }^{151}$. Deze zal vaak gering zijn. Juist de immateriële schade zou moeten worden vergoed, maar ons huidige algemene onrechtmatige daadsrecht biedt hiertoe weinig tot geen mogelijkheden ${ }^{152}$.

\subsubsection{Opzegging/ontbinding van de huwrovereenkomst; beëindiging van gebruik}

\subsubsection{Gronden voor beëindiging van de huur}

Niet alleen de toelating als huurder van woonruimte biedt een mogelijkheid tot vergelijking met de welstandsbepalingen in het appartementsrecht. Ook de beëindiging van de huur biedt deze mogelijkheid. Met name is interessant of huurders van een gebouw kunnen bewerkstelligen dat een andere huurder moet vertrekken.

De artikelen 1584 tot 16230 BW bevatten geen bepalingen voor de totstandkoming van een huurovereenkomst. Opzegging van een huurovereenkomst is echter well in deze artikelen geregeld. Ook hier geldt weliswaar het beginsel van de contractsvrijheid, d.w.z. partijen kunnen - ook ten aanzien van opzegging afspreken wat ze willen, maar deze vrijheid wordt danig doorkruist door de huurbeschermingsbepalingen van dwingende aard. Te denken valt aan artikel $1623 \mathrm{i}$ BW (bescherming van medehuurder en samenwoner), artikel $1623 \mathrm{e}$ BW (limitatieve opsomming van opzeggingsgronden) en artikel 1612 jo. $1623 \mathrm{e}$ lid 5 BW (koop breekt geen huur). Met name artikel $1623 \mathrm{e} \mathrm{BW}$ is in dit verband van groot belang. Dit artikel somt limitatief de gronden voor beëindiging van een huurovereenkomst door de kantonrechter (op verzoek van de verhuurder) op. Indien de rechter van mening is dat aan een van de gronden van artikell $1623 \mathrm{e}$ lid $1 \mathrm{BW}$ is voldaan, moet hij het verzoek toewijzen ${ }^{153}$.

De limitatieve gronden voor beëindiging van de huurovereenkomst zijn in artikel 1623 e BW neergelegd in lid 1, onder de nrs. 1-5 ${ }^{154}$.

Deze gronden zijn:

1. De huurder gedraagt zich niet zoals een goed huurder betaamt (art. $1623 \mathrm{e}$ lid 1 sub $1 \mathrm{BW}$ ).

De woorden "zich niet gedragen zoals een goed huurder betaamt", zijn uit artikel $1623 \mathrm{e}$ lid 1 sub 2 (oud) overgenomen. Wanneer er nu sprake is van een "zich niet gedragen zoals een goed huurder betaamt", is daarmee nog niet duidelijk gemaakt. Reeds bij de behandeling van artikel $1623 \mathrm{e}$ lid 1 sub 2 (oud) rezen in de Tweede Kamer vragen omtrent de uitleg van deze bepaling. Had zij een andere betekenis

151. Pitlo/Bolweg, blz 332-335. Vgl. ook HR 4 febr. 1983, RvdW 1983, 46, NJ 1984, 631 en Hof 's-Hertogenbosch 17 mei 1983, NJ 1984, 240.

152. Vgl. Bloembergen (Onrechtmatige Daad II), nr. 16.

153. HR 24 jan. 1986 , RvdW 1986,34 .

154. Zie voor een algemene beschrijving van deze opzeggingsgronden: Van den Heuvel (Huurrecht), art. $1623 \mathrm{e} \mathrm{BW}$, aant. 1-9. 
dan artikel 18 lid 2 sub a Huurwet ${ }^{155}$ ? De toenmalige minister van justitie (Van Agt), wist de discussie te sussen. Enige jaren later stak dezelfde discussie echter weer de kop op, toen het huurrecht in het BW werd vernieuwd ${ }^{156}$.

Minister de Ruiter stelde zich tijdens de discussies op het standpunt dat de tekst die werd voorgesteld (de huidige versie) weliswaar korter was dan de tekst wan artikel 18 lid 2 sub a Huurwet, maar wel precies dezelfde strekking had als die bepaling in de Hurwet ${ }^{157}$.

Asser/Abas meent dat de huidige omschrijving

"in feite verwijst naar de hoofdverplichtingen die art. 1596 de huurder reeds in het algemeen oplegt en welker schending op grond van art. 1597 wanprestatie oplevert." 1.58

Daarom is volgens Asser/Abas de rechtspraak bij artikel 18 lid 2 sub a Huurwet voor de uitleg van artikel $1623 \mathrm{e}$ lid 1 sub $1 \mathrm{BW}$, niet meer bij uitsluiting relevant. De Huurwet-jurisprudentie moet volgens hem bij toepassing op artikel $1623 \mathrm{e}$ lid 1 sub 1 BW dan ook in het kader van de rechtspraak op de artikelen 1596 en 1597 $\mathrm{BW}$ worden geplaatst ${ }^{159}$. Indien men zich niet gedraagt als een goed huurder betaamt, is er volgens Asser/Abas derhalve tevens sprake van wanprestatie ${ }^{160}$. In elk geval is er sprake van "zich niet gedragen als een goed huurder betaamt" bij wanbetaling 161 en bij onregelmatig en niet tijdig betalen en thet veroorzaken van geluidshinder ${ }^{162}$. Indien de wanprestatie niet van zeer ernstige aard is, kan de

155. Art. 18 lid 2 aanhef en sub a Huurwet luidde: "De verhuurder kan de ontruiming door de hunurder of gewezen huurder slechts vorderen: a. indien wegens onbehoorlijk gebruik van het goed, wegens overlast, zijn medebewoners, dan wel de verhuurder aangedaan, of wegens wanbetaling, van de verhuurder niet kan worden gevergd, dat de huurder of gewezen huurder nog langer in het genot van het goed blijft."

156. Hand. II, 1978-1979, blz. 4960-4962. Zie ook amendement Beckers, Bijl. Hand. II, 1978-1979, 14249 , nr. 39.

157. Hand. $\mathrm{II}_{3}$ 1978-1979, blz. 5022 , 5085 .

158. Asser/Abas, blz. 130.

159. Asser/Abas, blz. 131.

160. Vgl. ook Croes (Huor en onderhuur), blz 48; De Mol (Huurrecht), blz. 200. Pres. Rb. 's-Gravenhage 18 april 1986, Kort Geding 1986, 236. Vgl, ook HR 13 fiebr. 1981, NJ 1981, 394. De stelling dat mede sprake is van "zich niet gedragen zoals een goed huurder betaamt", wanneer een verhuurder overlast ondervindt, zonder dat deze overlast veroorzaakt is door laakbare gedragingen van de huurder, werd werworpen. Idem HR 21 mei 1982, NJ 1982, 528. Vgl. over het arrest van 13 febr. 1981: Van den Heuvel (Ernstige overlast), blz 433 e.v.; Bockwinkel (Verkenningen), ble. 109. Vgl. ook: Kantongerecht Leiden 19 sept. 1979, Praktijkgids 1980, nr. 1469; Kantongerecht Amsterdam 3 april 1980, Praktijkgids 1981, nr. 1659; Kantongerecht "sGravenhage 23 okt. 1981, Praktijkgids 1982, nr. 1819; Kantongerecht 's-Gravenhage 27 nov. 1981, Praktijkgids 1982, nur. 1689 (in dit geval werd aangenomen dat de huurder zich niet had gedragen zoals een goed huurder betaamt; zonder dat wanprestatie werd vastgesteld); Kantongerecht Zutphen 27 april 1982, Prakiijkgids 1982, nr. 1810; HR 25 juni 1982, NJ 1983, 152; HR 13 mei 1983, NJ 1983, 668; Rb. 's-Hertogenbosch 4 mei 1983, Praktijkgids 1983, nr. 2027; Rb. 'sGravenhage 22 sept. 1987 , Woonrecht $1988-1$, nr. 5.

161. Hof Amsterdam 7 nov. 1979, NJ 1980, 333.

162. Kantongerecht Leiden 28 nov. 1979, Praktijkgids 1980, nr. 1432. 
verhuurder de huurovereenkornst opzeggen. Bij ernstige wanprestatie kan hij de overeenkomst doen ontbinden ${ }^{163}$.

Beëindiging van een huurovereenkomst is behalve door opzegging ook mogelijk door ontbinding wegens wanprestatie. Deze ontbinding kan ingevolge artikel $1623 \mathrm{n}$ BW echter slechts door de rechter geschieden. Deze bepaling geeft een uitzondering op de normale regel bij wederkerige overeenkomsten dat partijen rechterlijke tussenkomst bij inroeping van artikel $1302 \mathrm{BW}$, kumnen uitsluiten ${ }^{164}$. Ontbinding is echter alleen mogelijk, indien de huurder zodanig is tekortgeschoten in de nakoming van zijn verplichtingen, dat dit de ontbinding van de overeenkomst rechtvaardigt ${ }^{165}$.

Asser/Abas beschouwt het zich niet gedragen als een goed huurder betaamt tevens als wanprestatie, maar

"voor een ontbinding wegens wanprestatie worden naar gangbare rechtspraak strenge eisen gesteld." 166

Hij meent dat ontbinding wel enige voordelen heeft vergeleken met de opzegging en de aansluitende verzoekschriftprocedure, maar een rijke toekomst voorspelt hij de ontbindingsactie niet. Voor de ontbinding zal de verhuurder

"een veel hardere zaak moeten waarmaken dan voor opzegging. ${ }^{n 167}$

De vraag hierbij is welke voordelen een vordering tot ontbinding heeft vergeleken met een opzegging. Volgens Bockwinkel is een voordeel van de ontbindingsprocedure, dat het verkregen vonnis uitvoerbaar bij voorbaat kan worden verklaard. Via de verzoekschriftprocedure van artikel $1623 \mathrm{c} \mathrm{BW}$ wordt nitvoerbaarverklaring bij voorbaat praktisch zeer moeilijk gemaakt door de zinsnede "totdat de rechter onherroepelijk heeft beslist" in artikel $1623 \mathrm{c}$ lid $1 \mathrm{BW}^{168}$. Bovendien meent Bockwinkel dat de terugwerkende kracht van ontbindingen in een aantal gevallen een voordeel kan zijn, indien de verhuurder in de dagvaarding eist dat de

163. Vgl. Asser/Abas, blz. 131, 132, 192, 193, 194. Vgl. ook HR 13 febr. 1981, NJ 1981, 394 en HR 21 mei 1982, NJ $1982,528$.

164. Hofmann/Abas, blz. 312.

165. Asser/Abas, blz, 193.

166. Asser/Abas, blz 193.

167. Asser/Abas, blz. 194. Vgl. hierbij: HR 4 juli 1978, NJ 1978, 645; HR 8 jan. 1982, NJ 1982, 445; HR 25 juni 1982, NJ 1983, 152; HR 9 dec. 1983, RvdW 1984, 4; HR 30 nov. 1984, NJ 1985, 232. In deze laatste zaak bepaalde de Hoge Raad dat "bij de becordeling of een wanprestatic voldoende is om ontbinding van de huurovereenkomst te rechtvaardigen het gewicht van de tekortkoming moet worden afgezet tegen het woonbelang van de huurder". Vgl. verder: Kantongerecht Leiden 24 febr. 1982, Pralktijkgids 1982, nr. 1793; Kantongerecht Tilburg 24 nov. 1983, Praktijkgids 1984, nr. 2101; Kantongerecht Arnhem 17 juni 1985 en 25 okt. 1985, Praktijkgids 1985, nr. 2394.

168. Door HR 8 jan. 1982, NJ 1982, 445 (met noot P.A. Stein) is dit argument voor ontbinding echter verawakt. De HR besliste: "het is niet aannemelijk, en vindt ook geen steun in de parlementaire geschiedenis van de wet, dat dit lid de strekking heeft on aan de rechter elke bevocgdheid te ontnemen om zijm beschikking tot vaststelling van het tijdstip waarop de huurovereenkomst zal eindigen en de ontruiming moet plaatswinden uitwoerbaar bij woorraad te verklaren." Vgl. ook Asser/Abas, blz 194. 
ontbinding geheel ex tunc zal worden uitgesproken. Daarenboven kan bij een ontbindingsprocedure schadevergoeding worden gevraagd ${ }^{169}$.

De tweede opzeggingsgrond uit artikel $1623 \mathrm{e}$ lid $1 \mathrm{BW}$ is:

2. De huurovereenkomst is voor bepaalde tijd aangegaan, terwijl de verhuurder heeft bedongen, dat het gehuurde goed na afloop van de termijn zall worden ontruimd. Uitzondering hierop vormt volgens de laatste zin van art. $1623 \mathrm{e}$ lid 1 , sub 2 de omstandigheid dat de verhuurder geen belang meer heeft bij ontruiming ${ }^{1 \%}$.

Deze opzeggingsgrond uit artikel $1623 \mathrm{e}$ lid $1 \mathrm{BW}$ wordt door het tweede lid van artikel $1623 \mathrm{e}$ BW echter weer grotendeels ontkracht. Dit tweede artikellid bepaalt namelijk dat de verhuurder een zodanig beding slechts in de volgende drie gevallen mag maken:

a. de verhuurder is niet de vorige bewoner van de woning en heeft haar evenmin eerder verhuurd en wenst haar na afloop van de termijn zelf te bewonen;

b. de verhuurder is wel de vorige bewoner van de woonruimte en wil deze na afloop van de termijn weer zelf betrekken;

c. de verhuurder heeft de vorige huurder het recht gegeven om na afloop van de termijn de woning opnieuw in gebruik te nemen ${ }^{171}$.

De ratio van deze toespitsing is duidelijk. De wetgever heeft de verhuurder niet de mogelijkheid willen geven om een huurder na afloop van een bepaalde termijn op straat te zetten om de woning vervolgens weer aan iemand anders te verhuren. Alleen als hij er zelf een redelijk belang bij heeft om de huur aan een bepaalde termijn te binden, is een dergelijke termijn toegestaan.

De derde opzeggingsgrond uit artikel $1623 \mathrm{e} \mathrm{BW}$ is:

3. De verhuurder maakt aannemelijk dat hij het verhuurde in een zodanige mate dringend nodig heeft voor eigen gebruik (waaronder niet valt vervreemding), dat van hem, de belangen van beide partijen in billijkheid afwegend, niet kan worden verlangd dat de huurovereenkomst kan worden verlengd. Als aanvullende voorwaarde wordt hierbij gesteld dat de huurder andere passende woonruimte kan verkrijgen ${ }^{172}$.

169. Bockwinkel (Verkenningen), blz. 98, 99; Asser/Abas, blz 194 is het niet helemaal met Bockwinkel eens.

170. Kantongerecht Steenwijk 21 mei 1980, Praktijkgids 1981, nr. 1571.

171. Vgl. bijj lid 2: Bockwinkell (Verkenningen), blz 112-120; Asser/Abas, blz 133, 134.

172. In de leden 3, 4, 5 van art. $1623 \mathrm{e}$ BW wordt de mogelijkheid van beëindiging van de huur op deze grond verder ingeperkt. Vgl. Asser/Abas, blz 147-150. Zie over de derde ointruimingsgrond ook Bockwinkel (Verkenningen), blz. 121-152 en Van Sion, blz. 169-171. In art. 1623e lid 6 BW wordt bovendien bepaald dat de rechter bij toewijzing van een verzoek op grond van lid 1 sub 3 , een vergoeding in de verhuis- en inrichtingskosten aan de huurder kan toekennen. 
Het "gebruik" wordt in de rechtspraak ruim opgevat. Het hoeft niet om gebruik voor woondoeleinden te gaan ${ }^{173}$. Aan het "eigene" van het gebruik worden daarentegen strengere eisen gesteld. Van eigen gebruik kan ook sprake zijn als iemand anders dan de verhuurder het onroerend goed gebruikt, mits dit gebruik door die ander het belang van de verhuurder dient ${ }^{174}$. Dit belang van de verhuurder wordt niet in zodanige mate gediend dat het een grond tot ontruiming oplevert, indien de verhuurder de huurder will doen ontruimen ten behoeve van familieleden ${ }^{175}$.

Vervreemding wordt blijkens artikel $1623 \mathrm{e}$ lid 1 sub 3 BW niet als "eigen gebruik $k^{\text {th }}$ gezien. Een financieel belang van de verhuurder kan in sommige gevallen wel als eigen belang van betekenis worden opgeval, waardoor ontruiming op grond van dringend eigen gebruik mogelijk wordt ${ }^{176}$. Het eigen belang van de verhuurder moet tegen het belang van de huurder worden afgewogen. Dit blijkt uit de zinsnede uit artikel $1623 \mathrm{e}$ lid 1 sub $3 \mathrm{BW}$

"dat van hem (de verhuurder, R.M.), de belangen en behoeften van beide partijen en van onderhuurders naar billijkheid in aanmerking genomen, niet kan worden gevergd dat de huurovereenkomst wordt verlengd."

De belangenafweging is van feitelijke aard en in cassatie onaantastbaar ${ }^{17}$. De belangen moeten ten tijde van de rechterlijke uitspraak ${ }^{178}$ aanwezig zijn en er moet mede worden gelet op de belangen van onderhuurders ${ }^{179}$. De laatste eis die artikel $1623 \mathrm{e}$ lid 1 sub 3 stelt aan de beëindiging van huur wegens dringend eigen gebruik, is dat de huurder andere passende woonruimte moet kunnen krijgen ${ }^{180}$.

De vierde en vijfde opzeggingsgrond uit artikel $1623 \mathrm{e}$ lid $1 \mathrm{BW}$ zijn:

4. De huurder stemt niet toe in een redelijk aanbod om een nieuwe huurovereenkomst met betrekking tot dezelfde woonruimte aan

173. HR 30 jan. 1975, NJ 1975, 334; HR 19 maart 1976, NJ 1976, 449; HR 1 juli 1977, NJ 1978; 119; Rb. Utrecht 19 sept. 1973, NJ 1974, 49 (deze jurisprudentie kwam tot stand rond art. 1623e lid 1 sub 4 (oud), waarin evenals in de Huurwet, de grond van "dringend eigen gebruik" was opgenomen).

174. HR 5 nov. 1965, NJ 1966, 2 (bij Huurwet); Rb. Amsterdam 28 jan. 1975, Praktijkgids 1975, mr. 1018; Rb. Utrecht 25 febr. 1980, NJ 1980, 406; HR 9 dec. 1983, NJ 1984, 307; HR 20 sept. 1985, NJ 1986, 261; HR 30 mei 1986, RvdW 1986, 116.

175. Kantongerecht Leiden 18 okt. 1972, Praktijkgids 1973, nr. 835; Kantongerecht Leiden 9 aug. 1978, Praktijkgidls. 1979, nr. 1337; Rb. Arnhem 3 juli 1980, Praktijkgids 1981, wr. 1533. Vgl. ook HR 9 dec. 1983, NJ 1984, 307.

176. Vgl. Asser/Abas, blz. 136 en Van Son.

177. HR 12 april 1957, NJ 1957, 311; HR 1 juli 1976, NJ 1977, 129; HR 25 nov. 1983, NJ 1984, 347.

178. Vgl. verder over de belangenafweging: Asser/Abas, blz. 139, 141.

179. Asser/Abas, blz 137, 138; HR 24 mei 1957, NJ 1957, 485; HR 17 febr. 1978, NJ 1978, 39; HR 31 jan. 1958, NJ 1958, 99.

180. Zie hierover Asser/Abas, blz, 141-147. 
te gaan (uitzonderingen: wijziging van de huurprijs ${ }^{181}$ of van kosten als bedoeld in art. 12, lid 1 Huurprijzenwet woonruimte) ${ }^{182}$.

5. De verhuurder wil een krachtens een geldend bestemmingsplan op de woonruimte liggende bestemming verwezenlijken. In HR 24 jan. $1986^{183}$ is deze opzeggingsgrond voor gemeenten nog aangeschierpt ${ }^{184}$.

De vijf belangrijkste huurbeschermingsbepalingen uit artikel $1623 \mathrm{e} B W$ zijn nu aan de orde geweest. Een andere zeer belangrijke bepaling vormt lid 5 van hetzelfde artikel. Hierin wordt bepaald dat een huuropzegging door een verhuurder die rechtsopvolger is van de oorspronkelijke verhuurder en het verhuurde zelf in gebruik wil nemen, nietig is indien zij binnen drie jaren nadat de rechtsopvolging schriftelijk ter kennis van de huurder is gebracht, wordt gedaan ${ }^{185}$. Dit lijkt op het eerste gezicht een beperking van de regel neergelegd in artikel $1612 \mathrm{BW}$ (koop breekt geen huur), die ten aanzien van huur van woonruimte dwingend is (art. 1623 a lid $6 \mathrm{BW}$ ). De uitzondering van artikel $1623 \mathrm{e}$ lid $5 \mathrm{BW}$ beoogt echter niet om de werking van deze regeling naar tijd te beperken, maar juist om de werking van artikel $1623 \mathrm{e}$ lid 1 sub 3 te beperken voor de verkrijger van het verhuurde goed. De verkrijger kan aldus gedurende drie jaren geen beroep doen op de ontruimingsgrond "dringend eigen gebruik" ${ }^{186}$. Op deze wijze wordt de bescherming van de huurder bij verkoop van "zijn" woonruimte dus vergroot in plaats van verkleind. Artikel $1623 \mathrm{e} \mathrm{BW}$ geeft verder nog enige regelingen waarin aan de huurder die woonruimte moet ontruimen, in bepaalde gevallen wordt tegemoet gekomen door de mogelijkheid van een bijdrage in de verhuiskosten door de verhuurder enz.

Overigens moet de opzegging door de verhuurder op grond van artikel $1623 \mathrm{~b}$ BW (op straffe van nietigheid) de gronden vermelden die tot de opzegging hebben geleid ${ }^{187}$. Een opzegging op andere gronden dan die van artikel $1623 \mathrm{e}$ lid 1, is nietig. Tenzij de huurder instemt met de opzegging, blijft de huurovereenkomst van rechtswege van kracht tot de rechter op verzoek van de verhuurder heeft bepaald, of er sprake is van een geldige opzegging op een van de gronden van artikel $1623 \mathrm{e}$ lid $1 \mathrm{BW}$ (vgl. art. $1623 \mathrm{c} \mathrm{BW}$ ).

181. HR 4 jan. 1985, NJ 1985, 789; Hof 's-Gravenhage 21 april 1983, NJ 1984, 520; Pres. Rb. Roermond 21 juni 1984, Kort Geding 1984, 237.

182. Zie ook Asser/Abas, blz 150-152 en de daar aangehaalde jurisprudentie. Vgl. ook Bockwinkel (Verkenningen), blz. 153-162.

183. HR 24 jan. 1986, RvdW 1986, 34, NJ 1986, 746 (met noot P.A. Stein).

184. Vgl. ook HR 16 maart 1956, NJ 1956, 266. Overigens is lid 6 van art. $1623 \mathrm{e}$ BW ook van toepassing bij beëindiging van huur op deze grond. Zie over deze ontruimingsgrond verder Bockwinkel (Verkenningen), blz. 167-174. Vgl. ook over deze opzeggingsgrond bij huur van bedrijfsruimte: HR 12 dec. 1986, NJ 1987, 357.

185. Kantongerecht Nijmegen 4 dec. 1987 , Woonrecht 1988-5, nr. 56.

186. Croes (Huur en onderhuur), blzw 106, 107.

187. Vgl. m.b.t. art. 1623b (oud) HR 10 nov. 1978, NJ 1979, 81. Een verhuurder moet, indien de rechter een hutrovereenkomst voor bepaalde tijd heeft verlengd, de huurovereenkomst opnieuw opzeggen alvorens zich tot de rechter te wenden. Zie HR 18 dec. 1981, NJ 1982,569. 
Zoals uit het voorgaande blijkt, geniet de huurder van woonruimte een vergaande bescherming. De huur kan hem alleen worden opgezegd in de in artikel $1623 \mathrm{e}$ lid 1 genoemde gevallen. Aan ontbinding van de huurovereenkomst wegens wanprestatie, worden nog zwaardere eisen gesteld. Niet alleen de huurder van woonruimte wordt echter goed beschermd. Ook de medehuurder van woonruimte geniet een goede bescherming. De echtgenoot van de huurder is van rechtswege medehuurder (art. $1623 \mathrm{~g} \mathrm{BW).} \mathrm{Anderen} \mathrm{dan} \mathrm{de} \mathrm{echtgenoot} \mathrm{kunnen} \mathrm{eveneens} \mathrm{de} \mathrm{positie} \mathrm{van}$ medehuurder verwerven. De vereisten hiervoor zijn neergelegd in artikel $1623 \mathrm{~h}$ BW. Het derde lid van dit artikel somt limitatief de gronden op, waarop de kantonrechter een verzoek om medehuurder te worden mag afwijzen. De medehuurder zet de huurovereenkomst na overlijden van de huurder als huurder voort (art. 1623i lid 1 BW). Ook iemand die niet de positie van medehuurder heeft, kan na het overlijden van de huurder in bepaalde gevallen de huurovereenkomst voortzetten. Hiervoor is ondermeer vereist dat de persoon met de overleden huurder in de woonruimte een duurzame gemeenschappelijke huishouding voerde en zijn hoofdverblijf in de woonruimte had. Degene die aan deze vereisten voldoet, mag de huurovereenkomst in elk geval gedurende zes maanden na overlijden van de huurder voortzetten. Binnen die termijn van zes maanden kan hij vervolgens een verzoek aan de kantonrechter richten om de huurovereenkomst voort te mogen zetten. De kantonrechter wijst dit verzoek slechts af op de in het derde lid van artikel $1623 \mathrm{i} \mathrm{BW}$ genoemde gronden. De opsomming in dit artikellid is, anders dan de tekst zou doen vermoeden, limitatief ${ }^{188}$.

Het zal voor een verhuurder gezien het voorgaande vaak niet eenvoudig zijn om een huurder, medehuurder of samenwoner-niet medehuurder uit de door hem gehuurde woonruimte te zetten. Zo kan een bepaling uit een huurovereenkomst voor bepaalde tijd, waarin de verhuurder bepaalt dat het verhuurde na deze termijn moet worden ontruimd, slechts afgedwongen worden in de in artikel 1623e lid $2 \mathrm{BW}$ genoemde gevallen. In alle andere gevallen hoeft de huurder zich aan de desbetreffende clausule uit de huurovereenkomst niet te storen. De hele afdeling met betrekking tot huur en verhuur van woonruimte in het BW is op de bescherming van de huurder toegesneden. Dit blijkt niet alleen uit de Memorie van Toelichting bij deze afdeling ${ }^{189}$, maar ook uit de wet zelf. Zo is het de verhuurder die zich tot de rechter moet wenden om de huur aan een huurder op te zeggen of de huurovereenkomst te doen ontbinden. Alleen degene die medehuurder wil worden, en de langstlevende samenwoner-niet medehuurder moeten zich om hun positie te versterken, zelf tot de rechter wenden. Een andere aanwijzing voor de toespitsing van deze afdeling op de huurder, is van terminologische aard. De wetgever spreekt namelijk van woonruimte of zoals in artikel $1623 \mathrm{e}$ lid 1 sub 2 $B W$, van "het gehuurde". Indien dit artikel vanuit het perspectief van de verhuurder was geschreven, zou er waarschijnlijk "het verhuurde" hebben gestaan.

Ondanks het feit dat de huurder goed wordt beschermd, zijn er enkele gevallen, waarin deze huurbescherming opzij wordt gezet. Ten eerste kan hier het geval worden genoemd, dat het verhuurde door een hypotheekhouder ex artikel 1223 lid $2 \mathrm{BW}$ wordt verkocht, en de hypotheekhouder ten behoeve van de veilingkoper het huurbeding inroept. In dat geval zal de huurder de verkochte woonruimte moeten

188. HR 6 maart 1987 , NJ $1988,3$.

189. Bijl. Hand. II, 1976-1977, 14249, nr. 3 . 
ontruimen, tenzij de veilingkoper zich niet op het huurbeding wil beroepen ${ }^{1921}$. Het huurbeding kan derhalve huurbescherming doorbreken.

Een ander geval, waarin een beroep op huurbescherming een huurder niet zal baten; doet zich voor indien het beroep van de huurder op de huurbescherming int strijd met de goede trouw is ${ }^{191}$. Dit heeft tot gevolg dat aan de huurder in sommige gevallen die normaal gesproken onder de huurbescherming vallen, op grond van de goede trouw deze bescherming wordt ontzegd.

\subsubsection{Personen die kunnen bewerksteligen dat de huurder zijn woonnuimte moet ontruimen}

Nu duidelijk is, op welke gronden een huurovereenkomst aan een huurder kan worden opgezegd, rest de vraag wie de huurovereenkomst kan (doen) opzeggen of doen eindigen. Allereerst is dit, in de in artikel $1623 \mathrm{e}$ BW genoemde gevallen (en indien een beroep op huurbescherming in strijd met de goede trouw zou zijn) de verhuurder. Ook kan deze de huurovereenkomst wegens ernstige wanprestatie doen ontbinden. Verder kan de verhuurder de samenwoner-niet medehuurder de woonruimte doen ontruimen, indien er sprake is van een van de gronden in artikel $1623 \mathrm{i}$ lid $3 \mathrm{BW}$ (of uiteraard indien de samenwoner de huurovereenkomst niet wil voortzetten en hij geen verzoek daartoe aan de kantonrechter richt). Ook de veilingkoper van een ex artikel 1223 lid 2 BW verkochte zaak, kan zich op de nietigheid van de in strijd met een huurbeding aangegane huurovereenkomst beroepen, indien de hypotheekhouder in de veilingvoorwaarden een beroep op het huurbeding heeft gedaan of heeft vermeld dat het geèxecuteerde goed

"vrij van huurovereenkomsten, gesloten na vestiging van de hypotheek, zal worden geleverd." 192

In al de voornoemde gevallen kan de verhuurder of de koper van een geëxecuteerde zaak (rechtsopvolger van de verhuurder) de huurovereenkomst doen eindigen.

De vergelijkbaarheid van de situatie waarin appartementseigenaars een andere appartementseigenaar en/of -bewoner het verdere gebruik van zijn appartement ontzeggen, met de situatie dat aan een huurder de huurovereenkomst wordt opgezegd (of de huurovereenkomst op een andere wijze wordt beëindigd), is tot nu toe slechts met betrekking tot de gronden voor beëindiging van gebruik aanwezig.

Nog interessanter zou het zijn, indien de overige huurders van een gebouw een huurder die niet langer in hun midden gewenst is, zijn woonruimte kunnen doen ontruimen. Het huidige huurrecht bevat hieromtrent geen bepalingen ${ }^{193}$. De Mol

190. Vgl. over de werking van het thurbeding naar BW en NBW: Tratnik/Mertens, blz. $46-51$ en de daar aangehaalde literatuur en jurisprudentie.

191. Zie ook HR 1 juli 1983, NJ 1984, 149 (met noot P.A. Stein). De Hoge Raad achtte het mogelijk dat een door de huurder gedaan beroep op ontbreken van een huuropzegging, in strijd met de goede trouw was. Vgl. ook Tekstra, blz $477-482$.

192. HR 14 mei 1976 , NJ 1977 , 150 met noot WMK

193. Santen (Een behoorlijke buur), blz 106, noemt het feit dat ons buidige huurrecht aan de huurder niet de plicht oplegt om zich tegenover zijn medehuurder correct te gedragen een "merkwaardige anomalie". 
heeft hieraan aandacht besteed in een artikel in het blad Sociaal Recht ${ }^{194}$. In dit artikel gaat hij in op drie vraagstellingen. Ten eerste stelt hij de vraag wat een huurder tegen een andere huurder kan ondernemen, indien die ander hem overlast bezorgt. Ten tweede vraagt hij zich af wat een verhuurder kan ondernemen, die na klachten van andere huurders, tegen de veroorzaker van de overlast wil optreden. De derde vraag is of een door overlast geplaagd huurder van de verhuurder kan verlangen dat hij maatregelen neemt tegen de huurder die overlast bezorgt.

De huurder die actie wil ondernemen tegen een andere huurder, kan de ander aanspreken uit onrechtmatige daad (art. $1592 \mathrm{BW}$ ). Hij kan daarbij volgens De Mol een verbod van verdere stoornis, versterkt met een dwangsom vorderen. Deze dwwangsom heeft volgens De Mol echter niet altijd zin, bijvoorbeeld bij psychische gestoordheid of indien degene die de overlast bezorgt, van een uitkering leeft, waarop geen beslag mogelijk is. Een verbod heeft dan niet de verlangde uitwerking. De President van de Amsterdamse Rechtbank ${ }^{195}$ heeft in gevallen waarin een onhoudbare toestand was ontstaan, een vordering tot ontruiming toegewezen bij wijze van herstel in de vorige toestand. Wel overwoog de Amsterdamse President in zijn vonnis van 28 juni 1985, dat indien niet voldoende vaststaat, dat een rechterlijk verbod tot het veroorzaken van overlast geen uitwerking zal hebben, niet met zekerheid kan worden gezegd, dat ontruiming de enig overgebleven oplossing is. In dat geval zal de vordering tot ontruiming niet worden toegewezen. De President van de Haagse rechtbank ${ }^{196}$ heeft de huurder echter in een soortgelijke procedure niet ontvankelijk verklaard, omdat vordering tot ontruiming hem niet toekomt. In sommige gevallen kan de overlast worden beperkt en is ontruiming niet nodig ${ }^{197}$.

Een andere vraag die in de literatuur en jurisprudentie aan de orde is geweest, is of een huurder die andere huurders (c.q. bewoners) overlast bezorgt, tevens wanprestatie ten opzichte van de verhuurder pleegt. De Hoge Raad heeft deze vraag in zijn arrest van 24 juni 1960 (Riton I) ${ }^{198}$ ontkennend beantwoord. De verplichting die is neergelegd in artikel 1596 sub $1 \mathrm{BW}$, bracht volgens de Hoge Raad nog niet de verplichting mee om zich van het bezorgen van overlast aan andere huurders te onthouden. De verbintenisrechtelijke goede trouw bood hier evenmin uitkomst. De goede trouw die de huurovereenkomst beheerst, bracht volgens de Hoge Raad niet met zich mee dat het aandoen van overlast aan andere huurders in strijd zou zijn met deze goede trouw en aldus niet nakoming van een verplichting zou kunnen worden geconcludeerd. Hierbij verwees de Hoge Raad

194. De Mol (Overlast), blz $52-58$.

195. Pres. Rb. Amsterdam 20 juni 1985, Woonrecht 1985, nr. 99; Pres. Rb. Amsterdam 31 okt. 1985, Praktijkgids 1985, nr. 2392; Pres. Rb. Amsterdam 28 juni 1985, Kort Geding 1985, 211, Praktijkgids 1985, nr. 2360. Vgl. De Mol (Owerllast), blz. 52. Zie voor een recentere ontruimingsbeslissing Pres. Rb. Arnhem 19 mei 1987, Woonrecht 1987, nr. 117 en daarover De Mol (Rechtspraak), blz. 173-176.

196. Pres. Rb. 's-Gravenhage 7 okt. 1986, Kort Geding 1986, 484.

197. Vgl. Pres. Rb. Zwolle 19 febr. 1986, Kort Geding 1986, 145; Hof 's-Gravenhage, 5 juni 1986, Kort Geding 1986, 253; Voorzitter Afdeling Rechtspraak van de Raad van State 29 sept. 1986, Kort Geding 1986, 509; Afd. Rechtspraak van de Raad wan State 7 okt. 1986, Weckoverzicht 1986, 4:403. In de beide laatste gevallen kwam de overheid de huurder te hulp bij overtreding van een plaatselijke verordening.

198. HR 24 juni 1960, NJ 1960, 495 (Riton 1). 
naar zijn arrest van 28 juni $1957^{199}$, waarin hij had bepaald dat artikel 18 lid 2 sub a Huurwet niet de strekking had om de verplichtingen voor de huurder, die wit het Burgerlijk Wetboek voortvloeien, uit te breiden. In artikel 18 lid 2 sub a Huurwet was onder andere bepaald dat overlast, bezorgd aan medebewoners of de verhuurder, een grond voor huuropzegging opleverde.

Artikel 18 lid 2 sub a Huurwet komt in het BW in artikel $1623 \mathrm{e}$ lid 1 sub 1 terug. Zoals al eerder werd gesteld volgt uit de wetsgeschiedenis dat men in artikel $1623 \mathrm{e}$ lid 1 sub 1 geen van de Huurwet afwijkende regeling beoogde te geven. Volgens Abas ${ }^{200}$ is de opzeggingsgrond van artikel $1623 \mathrm{e}$ lid 1 sub $1 \mathrm{BW}$ echter ruimer dan die van artikel 18 lid 2 Huurwet. Op grond daarvan meent hij zoals gezegd dat het algemene recht van de artikelen 1596 en $1597 \mathrm{BW}$ weer tot wasdom is gekomen, waardoor de jurisprudentie bij artikel 18 lid 2 Huurwet zijn relevantie heeft verloren ${ }^{201}$. De enige uitzondering hierop heeft Abas (in 1981) de huurwetrechtspraak ten aanzien van ernstige overlast genoemd.

"Men kan immers ${ }_{y}$ zonder zich schuldig te maken aan wanprestatie in de zin der artt. 1596 en 1597, zich niettemin niet gedragen als een goed huurder door zijn medebewoners of verhuurder ernstige overlast aan te doen", aldus $\mathrm{Abas}^{202}$.

Tegenwoordig concludeert Asser/Abas echter dat ook overlast wanprestatie oplevert, zodat de huurwet-jurisprudentie op dit terrein eveneens zijn directe relevantie heeft verloren.

Uiteraard doet de vraag of het veroorzaken van overlast aan andere huurders wanprestatie oplevert, zich niet voor indien in het huurcontract (of bijbehorend huurreglement) een verbod om overlast aan buren toe te brengen, is opgenomen. Indien een dergelijk verbod is opgenomen, lijkt het gerechtvaardigd om aan te nemen dat een verhuurder een huurder wegens wanprestatie kan aanspreken, indien de huurder andere huurders overlast bezorgt. De vraag is echter of een verhuurder een huurder wegens het aandoen van overlast inderdaad wanprestatie kan aanwrijven, als er in het huurcontract geen anti-overlast clausule is opgenomen. Om ontbinding van de huurovereenkomst te rechtvaardigen zou dan wel sprake moeten zijn van ernstige overlast ${ }^{203}$. In andere gevallen zal de verhuurder zijn toevlucht moeten nemen tot opzegging op grond van artikel $1623 \mathrm{e}$ lid $1 \mathrm{sub} 1 \mathrm{BW} 204$. Dit laatste is door de Hoge Raad in het tweede Riton arrest ook al bepaald. Dezelfde feiten, die in Riton I door de Hoge Raad niet als wanprestatie werden aangemerkt, konden volgens hem wel als ernstige overlast in de zin van artikel 18

199. HR 28 juni 1957 , NJ $1957,482$.

200. Abas (Nicuw huurrecht), blz. 85 .

201. Abas (Nieuw huurrecht), blz. 85 .

202. Abas (Nieuw huurrecht), blz. 85. In dezelfde zin De Mol (Overlast), blz 52; Adriaansens, blz, 287.

203. Vgl. ook Kantongerecht Amsterdam 5 jan. 1988, Woonrecht 1988-3, nr. 42.

204. Volgens het Kantongerecht Gorinchem moet de huurder dan wel cerst door de verhuurder zijim gesommeerd om de overlast te staken. Kantongerecht Gorinchem 11 nov. 1985, Woonrecht 19863, ar. 38 . 
lid 2 sub a Hurwet worden aangemerkt. Hierdoor werd opzegging van de huurovereenkomst, gevolgd door ontruiming, wel mogelijk 205 .

Nu artikel 18 lid 2 sub a Hurwet in artikel 1623 e lid 1 sub $1 \mathrm{BW}$ terugkomt, ligt de conclusie voor de hand dat het veroorzaken van overlast aan andere huurders c.q. bewoners van eenzelfde gebouw, geen wanprestatie oplevert indien in het huurcontract geen anti-overlastclausule is opgenomen. Opzegging wegens het "zich niet gedragen als een goed huurder betaamt", zou - conform Riton II - wel mogelijk zijn. Ervan uitgaande echter dat de verplichting, neergelegd in artikel $1623 \mathrm{e}$ lid 1 sub $1 \mathrm{BW}$ echter in het kader van artikelen 1596 en $1597 \mathrm{BW}$ moet worden geplaatst, levert elk "zich niet gedragen als een goed huurder betaamt" tevens wanprestatie op. Van deze opvatting uitgaande moeten we, als overlast veroorzaken in de zin van artikel 18 lid 2 sub a Huurwet tegenwoordig onder artikel $1623 \mathrm{e}$ lid 1 sub 1 valt, concluderen dat het veroorzaken van overlast ook zonder een anti-overlastclausule een grond tot opzegging of ontbinding oplevert, afhankelijk van de ernst van de overlast.

Dat overlast aan andere huurders/bewoners aangedaan onder "zich niet gedragen als een goed huurder betaamt" valt, wordt in de literatuur niet bestreden. De vraag waar de discussie zich in feite steeds op toespitst, is of overlast aan andere huurders ook wanprestatie in de zin van artikelen 1596 en 1597 BW oplevert. Met andere woorden: bewoont een huurder die anderen overlast aandoet het gehuurde als een goed huisvader?

Volgens De Mol ${ }^{206}$ blijkt uit het arrest van de Hoge Raad van 13 febr. $1981^{207}$, dat alleen laakbaar gedrag een opzeggingsgrond oplevert in de zin van artikel $1623 \mathrm{e}$ lid 1 sub e BW. Degene die een andere huurder ernstige overlast aandoet, gedraagt zich daarom niet als een goed huurder betaamt.

"Maar hij schendt", aldus De Mol, "- volgens het arrest van 1960 - niet zijn verplichting (neergelegd in art. $1596 \mathrm{BW}$ ) om het gehuurde als een goed huisvader te gebruiken. Hetgeen zoveel zeggen wil als het behoorlijk omgaan met de eigendom van een ander."2018

In deze opvatting is opzegging wegens overlast derhalve mogelijk, maar ontbinding niet.

De Hoge Raad en zijn Procureur-Generaal Langemeijer meenden in Riton I dat wanprestatie in de zin van artikel $1596 \mathrm{BW}$ alleen mogelijk is, indien de verhuurder op geld waardeerbare schade lijdt. Als deze opvatting nog steeds geldt, dan levert niet elk "zich niet gedragen als een goed huurder betaamt" wanprestatie $o p$, en heeft Asser/Abas ongelijk ${ }^{209}$. In de literatuur is deze beslissing van de Hoge Raad in Riton I onmiddellijk bestreden door Kamphuisen.

205. HR 15 febr. 1963, NJ 1963, 344 (Riton II).

206. De Mol (Overlast), blz 52, 53.

207. HR 13 febr. 1981, NJ 1981, 394. Zie ook HR 21 mei 1982, NJ 1982, 528. In beide arresten werd beslist dat van "zich niet gedragen alls een goed huurder betaamt" geen sprake is, indien de verbuurder voortzetting van de bewoning door de huurder als ernstige overlast ondervindt, zonder dat dit het gevolg is van laakbare gedragingen van de huurder.

208. De Mol (Overlast), blz. 52,53. 
"En nu ben ik van mening", aldus Kamphuisen, "dat in dit geval de tekst van art. $1596 \mathrm{BW}$ zonder veel moeite tot een andere opvatting kan voeren dan die van het besproken arrest." 210

De Mol meent dat tegenwoordig de waarheid zoals zo vaak in het midden ligt, en wel tussen de opvatting van Abas en Kamphuisen en nog enkele anderen en die van de Hoge Raad. Hij meent dat de verplichting om zich te onthouden van het bezorgen van overlast aan andere huurders - indien deze verplichting al niet voortvloeit uit artikel $1596 \mathrm{BW}$ - uit de goede trouw (art. $1375 \mathrm{BW}$ ) kan voortvloeien. Wel merkt hij hierbij op dat het Riton I-arrest daartoe weinig ruimte laat.

Oldenhuis stelt zich eveneens op het standpunt dat uil de goede trouw de verplichting kan voortvloeien, dat een huurder geen overlast aan andere huurders mag toebrengen ${ }^{211}$. In de lagere rechtspraak is in die zin ook al beslist. De Hoge Raad heeft zich na Riton I niet meer over deze vraag hoeven uitlaten.

Naar aanleiding van het arrest "De Goede Woning/Smits"212 beweert R.J.M. Smit ${ }^{213}$ dat ontbinding wegens wanprestatie ook tegenwoordig alleen mogelijk is als er een anti-overlastclausule in het huurcontract is opgenomen. A.L. Croes ${ }^{214}$ bestrijdt deze mening. Volgens Croes staat dit arrest niet in de weg aan een ruimere uitleg van artikel 1596 sub $1 \mathrm{BW}$, in die zin dat geconcludeerd zou kunnen worden dat een huurder het gehuurde niet als een goed huisvader gebruikt (en derhalve wanprestatie ten opzichte van de verhuurder pleegt), indien hij aan andere bewoners van eenzelfde gebouw overlast bezorgt. Deze conclusie lijkt mij juist. Hoewel de Hoge Raad in "De Goede Woning/Smits" niet aan de vraag toekomt of overlast sec die andere bewoners is aangedaan, wanprestatie oplevert, blijkt uit het arrest niet dat de Hoge Raad de ruimere uitleg van artikel $1596 \mathrm{BW}$ afwijst. In elk geval ben ik met De Mol en Oldenhuis van mening, dat ook bij het ontbreken van een antioverlastclausule in het huurcontract geconcludeerd kan worden dat een huurder wanprestatie pleegt als hij andere huurder/bewoners overlast aandoet, zowell op grond van een ruime uitleg van artikel $1596 \mathrm{BW}$ als op grond van de goede trouw.

De vraag wat de verhuurder kan ondernemen tegen huurders die aan andere huurders overlast bezorgen ${ }^{215}$, wordt (in het kader van vergelijking met de welstandsbepalingen in het appartementsrecht) pas echt interessant zodra de huurders die de overlast wordt aangedaan, de verhuurder tot actie tegen de storende huurder kunnen aanzetten. De Mol behandelt in zijn artikel "Overlast in het huurrecht" ook deze vraag. Hierbij haalt hij het arrest (in kort geding) "De

210. Kamphuisen, blz. 912.

211. Oldenhuis (Kantlekeningen), blz 78. In gelijke zin Oldenhuis, Praktijkgids 1983 (annotatie van HR 17 dec. 1982, NJ 1983, 511), blz. 189. Vgl. ook Smit, WPNR 5673, blz. 701, 702; Croes, WPNR 5686 , bl2 114, 115 .

212. HR 17 dec. 1982, NJ 1983, 511.

213. Smit, WPNR 5673.

214. Croes, WPNR 5686, blz. 115, 116.

215. Interessant is het om hier tevens op een vonnis van de Rotterdamse kantonrechter te wijzen, waarin een woningvereniging, die een huurder had gehuisvest naast een andere huurster, van wie aan de bouwvereniging bekend was dat zij ernstige gelluidsoverlast veroorzaakte, werd veroordeelld tot vergoeding van immateriële schade, door de huurder geleden. Kantongerecht Rotterdam 15 maart 1988, Praktijkgids 1988, nr. 2872. 
Goede Woning/Smits" aan ${ }^{216}$. Dit arrest betrof het volgende geval.

Smits vorderde voor de President van de rechtbank 's-Gravenhage dat zijn verhuurder (De Goede Woning) en het echtpaar G. (eveneens huurders bij de Goede Woning) zouden worden veroordeeld, enerzijds om maatregelen te nemen tegen de overlast door het echtpaar G. veroorzaakt, anderzijds om zich van vedere vorm van overlast tegen Smits te onthouden op straffe van een dwangsom. De President van de Haagse Rechtbank kende de vordering van Smits grotendeels toe.

De woningbouwvereniging ging in beroep en stelde uiteindelijk cassatie in. Het Hof had ondermeer overwogen

"dat in een geval als het onderhavige, waarbij de huurder door een andere huurder van dezelfde verhuurder ernstige overlast ondervindt, van de woningbouwvereniging redelijkerwijs kan worden gevergd, dat zij haar medewerking verleent door maatregelen, die zij als woningbouwvereniging kan nemen ter verschaffing van het rustig woongenot aan haar hurder."

Verder overwoog het Hof dat

"van de woningbouwvereniging redelijkerwijs kan worden gevergd, dat zij ter verschaffing van rustig woongenot aan Smits rechtsmaatregelen neemt tegen het echtpaar G. tot ontbinding van de huurovereenkomst met dat echtpaar."

In onderdeel a. van het cassatiemiddel betoogde de woningbouwvereniging dat zij noch op grond van wettelijke bepalingen, noch op grond van de reclelijkheid en billijkheid verplicht was om een procedure tot ontbinding van de huurovereenkomst in te stellen. De Hoge Raad oordeelde daar anders over.

"Dat een dergelijke verplichting nooit op grond van genoemde rechtsregellen - beginselen kan worden aangenomen, vindt geen steun in het recht. Het Hof geeft ook geen blijk te zijn uitgegaan van een onjuiste rechtsopvatting door onder de in deze procedure vastgestelde omstandigheden het bestaan van de in dit middel betwiste verplichting van de verhuurder aan te nemen. "217

Onder omstandigheden is het derhalve mogelijk dat de huurder die overlast van een andere huurder ondervindt, een vordering instelt tegen de verhuurder om op te treden tegen de storende huurder. De verplichting van de woningbouwwereniging om maatregelen te treffen tegen de storende huurder, werd door het Hof in casu gestaafd met de overweging dat van de woningbouwvereniging redelijkerwijze kan worden gevergd, dat zij ter verschaffing van rustig woongenot aan haar huurder (art. 1586 sub $3 \mathrm{BW}$ ) optreedt tegen een storende huurder.

Interessant hierbij is de verhouding tussen artikel 1586 sub $3 \mathrm{BW}$ en artikel 1592 $B W$. Dit laatste artikel bepaalt immers dat de verhuurder niet verplicht is om de

216. HR 17 dec: 1982, NJ 1983, 511 met noot P.A. Stein. Hierover Smit, WPNR 5673 en Croes, WPNR 5686 (Reactie op Smit) en Oldenhuis (annotatie), Praktijkgids 1983, nir. 1914.

217. Vgl. over dit arrest ook Oldenhuis (Kanttekeningen), blz. 78. 
huurder te waarborgen tegen de belemmeringen die derden hem in zijn huurgenot toebrengen. Langemeijer ${ }^{218}$ meent dat het stelsel van de wet als volgt in elkaar zit. De regel van artikel 1586 sub $3 \mathrm{BW}$ is de hoofdregel. Artikel 1592 vormt hierop een - de positie van de huurder versterkende - vitzondering. Door een eigen vordering tegen een storende derde staat de huurder sterker dan door een vordering tegen de verhuurder om deze te dwingen tegen de storende huurder op te treden. De strekking van artikel $1592 \mathrm{BW}$ is namelijk om de huurder zo goed mogelijk te beschermen tegen storende invloeden van buitenaf. De Mol sluit hierbij aan en beweert dat zodra de bescherming van dit artikel feitelijk niet afdoende blijkt, bijvoorbeeld omdat een dwangsom niet invorderbaar is wegens een te gering inkomen van de storende huurder, de bescherming van artikel 1586 sub $3 \mathrm{BW}$ herleeft. De huurder kan dan de verhuurder verplichten om op te treden tegen de overlast veroorzakende huurder ${ }^{219}$.

Een andere grondslag (dan art. 1586 sub $3 \mathrm{BW}$ ) voor de verplichting van de verhuurder om op te komen voor zijn huurders, is de redelijkheid en billijkheid c.q. de goede trouw. De Mol meent hierbij dat de redelijkheid en billijkheid mede bepalen wat de artikelen 1586 en $1592 \mathrm{BW}$ in concrete omstandigheden naar hun strekking meebrengen. Kamphuisen is een andere mening toegedaan. Hij is van mening dat artikel $1586 \mathrm{sub} 3$ uitsluitend gaat over trouble de droit, terwijl artikel 1592 trouble de fait betreft. Daardoor verschijnen de redelijkheid en billijkheid als zelfstandig beginsel ten tonele. Kamphuisen meent echter dat redelijkheid en billijkheid hier niet kunnen worden toegepast, omdat zij niet de strekking hebben om zelfstandige verbintenissen in het leven te roepen ${ }^{220}$.

Uit het voorgaande volgt dat aan huurders die willen optreden tegen een storende "medehuurder" in beginsel twee middelen ten dienste staan. Allereerst is dit de bijzondere onrechtmatige daadsactie ex artikel $1592 \mathrm{BW}$. Indien deze actie om een of andere reden geen soelaas biedt of zal bieden, kan de huurder zich tot de verhuurder wenden, die vervolgens gedwongen kan worden om een ontbindingsactie tegen de ernstige overlast veroorzakende huurder in te stellen of de huurovereenkomst op te zeggen. P.A. Stein merkt in zijn noot onder het arrest De Goede Woning - Smits echter al op dat men de verhuurder niet kan dwingen om verder te gaan dan het instellen van de ontbindingsactie of opzegging van de huurovereenkomst. Of dergelijke acties daadwerkelijk succes hebben, hangt dan vervolgens van de feitelijke omstandigheden af.

218. Langemeijer (Gerechtigheid), blz. 26.

219. De Moll (Overlast), blz. 56.

220. Vgl. De Mol (Overlast), blz. 57; Kamphuisen, blz. 910, 911. Smit, WPNR 5673, blz 699 is het niet met Kamphuisen eens. De Moll (Overlast), t.a.p. meent dat de mening van Kamphuisen op gespannen voet staat met het arrest van de Hoge Raad van 20 febr. 1976, NJ 1976, 374. Vgl. ook Pres. Rb. "s-Gravenhage 7 okt. 1986, Kort Geding 1986, 484 en daarover Oldenhuis (Kanttekeningen), blz. 78, 79. De President van de Haagse Rechtbank oordeelde dat een huurder jegens zijm verhuurder verplicht is zich te onthouden van gedragingen die overlast voor andere huurders veroorzaken. De andere huurders kumnen er aanspraak op maken dat de verhuurder tegen de overlast veroorzakende huurder optreedt. "Deze verplichtingen vinden hun bron in de goede trouw", aldus de President van de Haagse Rechtbank. 


\subsubsection{Synthese: verhuurde appartementen}

Nu in het kort het recht dat totstandkoming en beëindiging van huurovereenkomsten beheerst, is beschreven, kan het gebied waar huurrecht en appartementsrecht elkaar overlappen, aan de orde worden gesteld. Dit gebied ontstaat zodra appartementsrechten worden verhuurd. Zowel het appartementsrecht als het huurrecht is dan van toepassing. Het probleem dat zich hierbij voordoet, is dat het appartementsrecht en het huurrecht bepaalde gelijke zaken proberen te regelen, waarbij niet vaststaat of beide rechtsgebieden regelingen hanteren die onafhankelijk van elkaar hetzelfde resultaat opleveren of beogen.

Meer concreet speelt dit probleem bij de welstandsbepalingen in het appartementsrecht, toegepast op verhuurde appartementen. Aan de ene kant speelt dan de huurbescherming, aan de andere kant de regeling uit het reglement van splitsing waarin de bescherming van de groep van appartementseigenaars, c.q. -bewoners centraal staat. Het front van de strijd tussen appartementsrecht en huurrecht begint zich aldus al snel te manifesteren. Enerzijds beoogt het huurrecht om een individu te beschermen ten opzichte van anderen, waarbij slechts enkele mogelijkheden zijn opengelaten om aan de bewoner zijn bescherming te ontnemen, anderzijds beogen de welstandsbepalingen in het appartementsrecht juist de overige bewoners te beschermen tegen een individueel bewoner. Dit probleem kan alleen aan de status van academisch probleem ontsnappen, indien het huurrecht en het appartementsrecht in eenzelfde concreet geval tot verschillende oplossingen kunnen leiden.

Voor de nadere bespreking van dit probleem moeten twee vooropmerkingen worden gemaakt. Ten eerste moet worden opgemerkt dat het reglement van splitsing niet alleen tussen appartementseigenaars onderling, maar ook tegen huurders werkt. Dit volgt uit artikel $875 \mathrm{~m}$ lid 2 BW dat de reglementsvoorschriften omtrent gebruik (bijv. welstandsbepalingen), beheer en onderhoud ook gelden voor degene die van de eigenaar het gebruik verkrijgt. Ook aan de na ingebruikgeving/verhuring tot stand gekomen reglementsbepalingen, kan de huurder worden gebonden (art. $875 \mathrm{~m}$ lid $3 \mathrm{BW})^{221}$. Ten tweede moet worden vermeld dat in het navolgende ervan wordt uitgegaan dat huurbescherming slechts inhoudt, dat het woonrecht van de huurder beschermo wordt, via de bescherming van de huurovereenkomst ten bate van de huurder. Indien de huurovereenkomst wegvalt, vervalt het woonrecht. Andersom vervalt niet de huurovereenkomst wanneer het woonrecht aan de huurder wordt ontnomen. Het middel om het woonrecht van de huurder te beschermen is derhalve bescherming van de huurovereenkomst ${ }^{222}$. Deze twee premissen zijn van belang bij de oplossing van het probleem dat confrontatie van huurbescherming met de werking van de welstandsbepalingen oplevert. De welstandsbepalingen richten zich slechts op ontneming van het woonrecht aan de

221. Het reglement kan tegen de huurder worden ingeroepen. Anderzijds kan een huurder zich niet op de bepalingen van het reglement beroepen. Uit art. 876a lid 3 BW volgt wolgens de Hoge Raad wel dat een V.v.E. erop toeziet dat ook huurders de reglementaire bepalingen naleven, maar niet dat de V.v.E. de belangen van de huurders behartigt. De belangen van de huurders moeten door die verhuurder/appartementseigenaar worden behartigd. HR 23 jan. 1987, RvdW $1987,40$.

222. Onder de vigeur van de Huurwet was dit anders. De huurbescherming richtte zich toen op het genot van het onroerende goed, onafhankelijk van het (verder) bestaan van een huurovereenkomst (art. 18 lid 1 Huurwet). Vgl. Völlmar/Van den Heuvel, Huurwet, art. 18, aant. 3. 
huurder. De huurovereenkomst wordt door de welstandsbepalingen niet direct aangetast. Nu het woonrecht via de bescherming van de huurovereenkomst wordt gegarandeerd, ontkomen we aan een afweging tussen de zakenrechtelijke welstandsbepalingen in het appartementsrecht en de dwingende huurbeschermingsbepalingen. De welstandsbepalingen tasten de huurovereenkomst immers niet aan. Als de welstandsbepalingen de huurovereenkomst wel zouden aantasten, zou mijns inziens desalniettemin moeten worden geconcludeerd dat de huurbescherming voor de welstandsbepalingen moet wijken. Deze conclusie trek ik op grond van een analogie van de welstandsbepalingen met het huurbeding in het hypotheekrecht. Beide bepalingen zijn van zakenrechtelijke aard en worden door de wet mogelijk gemaakt. Beide worden zij gepubliceerd in de openbare registers. Het enige verschil tussen het huurbeding en de welstandsbepalingen bestaat hierin, dat het huurbeding verder ingrijpt in de positie van de huurder. Door inroeping van het huurbeding wordt de huurovereenkomst immers vernietigd ten opzichte van degene die het inroept ${ }^{223}$ en aldus het woonrecht aan de huurder ontzegd. Overigens heeft de huurder, indien het huurbeding zijn huurbescherming doorkruist, wel de mogelijkheid om de verhuurder aan te spreken wegens wanprestatie. Tussen huurder en verhuurder blijft de huurovereenkomst immers bestaan ${ }^{224}$. De huurder, aan wie zijn woonrecht wordt ontzegd op grond van de welstandsbepalingen, heeft in beginsel eveneens de mogelijkheid om de verhuurder wegens wanprestatie aan te spreken. Hierop zal in het navolgende nader worden ingegaan.

\subsubsection{Toestemming tot ingebruikneming van een gehuurde service-flat}

Dat het probleem niet van academische aard hoeft te zijn, moge blijken uit het volgende (verzonnen) voorbeeld. Bij een service-flatcomplex doet zich het geval voor dat een eigenaar van een appartementrecht zijn appartement verhuurt aan iemand die zeer verzorgingsbehoeftig is. De huurovereenkomst wordt gesloten en de huurder wil "zijn" appartement betrekken. De vergadering van eigenaars weigert hem echter - gebruik makend van de welstandsbepalingen - de toestemming om het appartement te bewonen.

De situatie is dan dat tussen de appartementseigenaar-verhuurder en de huurder een huurovereenkomst bestaat, waar de verhuurder niet meer vanaf kan. Een ontbindende voorwaarde $k$ an in de huurovereenkomst niet worden opgenomen, omdat artikel 1623n lid $3 \mathrm{BW}$ daaraan in de weg staat. De verhuurder zit dus aan het huurcontract vast. Vervolgens komt de vraag op wat dan de positie van de huurder is. Zoals reeds werd opgemerkt, is de huurder gebonden aan de meeste bepalingen van het reglement van splitsing. De welstandsbepalingen zijn derhalve ook op hem van toepassing. Hij mag het appartement daarom niet bewonen, tenzij hij een van de in paragraaf 2.4 .4 besproken rechtsmiddelen met succes kan aanwenden.

223. Anders Hijma, bliz 243-245.

224. Vgl over de werking van het huurbeding: Tratnik/Mertens en de daar aangehaalde literatuur en jurisprudentie. 
De vraag die vervolgens moet worden gesteld, is of de verhuurder wanprestatie pleegt. Mijns inziens moet deze vraag in beginsel bevestigend worden beantwoord ${ }^{225}$. De verhuurder verschaft aan de huurder immers niet het rustige genot van het gehuurde. De gevolgen van de wanprestatie kunnen voor de verhuurder zeer vervelend zijn. De huurder kan immers ontbinding en schadevergoeding vorderen (nakoming is uitgesloten). Met name de schadevergoeding zal de verhuurder niet gelukkig maken.

De verhuurder kan deze situatie mijns inziens op twee manieren trachten te voorkomen. Ten eerste kan hij de huurovereenkomst onder opschortende voorwaarde van toestemming tot ingebruikneming aangaan. Voor de vervulling van de voorwaarde ontstaan er dan geen verbintenissen uit de overeenkomst (art. 1289 BW), waardoor wanprestatie niet kan intreden.

De tweede mogelijkheid is mijns inziens dat de verhuurder aan de huurder het appartement verhuurt met de uitdrukkelijke afspraak, dat de verplichting van de verhuurder om de huurder het rustige genot te verschaffen slechts de verplichting inhoudt om de huurder in staat te stellen op de een of andere wijze van het appartement gebruik te maken. De verhuurder kan mijns inziens met de huurder overeenkomen, dat hij zijn appartementsrecht met het daaraan inherente gebruiksrecht verhuurt, onverminderd de gebruiksbeperkingen die uit het reglement van splitsing voortvloeien. Op die manier ontstaat de situatie dat de huurder wellicht het appartement niet zelf mag bewonen, maar het wel aan een geschikte kandidaat kan onderverhuren.

Overigens mag een eigenaar van een service-flat zijn appartement slechts aan een derde verhuren, indien de derde met de V.v.E. een overeenkomst is aangegaan, krachtens welke hij gebruik kan maken van de door de vereniging in het kader van de gemeenschappelijke huishouding te verlenen diensten (art. 26 van het Modelreglement van splitsing in appartementsrechten van een service-flatgebouw uit 1987, verder te noemen modelreglement 1987). Bovendien moet de derde ingevolge artikel 31 van het modelreglement 1987 voordat hem een appartement in gebruik wordt gegeven, schriftelijke toestemming hebben van het bestuur van de V.v.E om het appartement in gebruik te nemen. Dit artikel lijkt een goede oplossing voor de problematiek die hierboven wordt beschreven. Het probleem is echter dat lid 2 van artikel 31 van het modelreglement 1987 bepaalt, dat voorafgaande toestemming door de eigenaar en verzoeker gezamenlijk moet worden gevraagd,

"onder overlegging van de overeenkomst of andere titel waaraan de verzoeker zijn recht ontleent of zal ontlenen."

Hieruit blijkt dat de huurovereenkomst of een concept-overeenkomst moet worden overlegd. Na het tot stand komen van de huurovereenkomst komt de verhuurder er echter niet meer onderuit. In praktijk zal de soep gelukkig niet zo heet gegeten worden en zall men vaak toestemming vragen voordat de huurovereenkomst tot stand is gekomen. Of dit strikt genomen in overeenstemming is met artikel 31 lid

225. Wellicht zal in concrete gevallen anders worden geoordeeld. De huurder weet immers van tevoren (of behoort althans te wetem) dat hij toestemming van de V.v.E. zal moeten krijgen om zijn appartement te mogen bewonen. 
2 , is een interpretatiekwestie. Het interpretatievraagstuk spitst zich dan toe op de vraag of onder "overeenkomst" een overeenkomst in juridische zin moet worden verstaan, of dat een document waaruit blijkt dat partijen voornemens zijn om een huurovereenkomst aan te gaan, voldoende is. Voor de laatste uitleg pleit de zinsriede "waaraan de verzoeker zijn recht ... zal ontlenen". Indien een overeenkomst in juridische zin zou zijn vereist, zou het recht van verzoeker immers altijd al bestaan (behalve indien er een opschortende voorwaarde in de overeenkomst is opgenomen): Een concept-overeenkomst lijkt op grond van de woorden."zal ontlenen" eveneens voldoende. Om problemen te voorkomen zou het naar mijn mening beter zijn om de eis van het vooraf overleggen van de concept-overeenkomst uit artikel 31 modelreglement 1987 te schrappen.

Een en ander leidt tot de volgende conclusie:

Indien een appartementseigenaar zijn appartement wil verhuren, dient hij te proberen vooraf toestemming tot ingebruikneming voor de aspirant-huurder te krijgen (een en ander geldt uiteraard alleen indien de toelatingsregeling in het reglement van splitsing is opgenomen, hetgeen bij het modelreglement 1987 standaard het geval is). Indien dit niet lukt, en het bestuur van de V.v.E. weigert een beslissing te nemen zonder overlegging van de huurovereenkomst, zal de verhuurder zich door het opnemen van een opschortende voorwaarde, eventueel alternatief gecombineerd (of eventueel alleen) met de clausule dat hij niet instaat voor de mogelijkheid van persoonlijk gebruik van het appartement door de huurder, kunnen indekken.

Overigens kan men zich afvragen of het bestuur van een V.v.E. die eerst weigert een beslissing te nemen en vervolgens de toestemming tot ingebruikneming weigert, niet in strijd met de goede trouw handelt jegens de verhuurder, waardoor het mogelijk zou worden om een vernietigingsactie ex artikel $876 \mathrm{~d} \mathrm{BW}$ te starten. In hoofdstuk 2 werd echter al gezegd dat een dergelijke actie niet altijd de beste weg is. De procedure op grond van artikel $8750 \mathrm{BW}$ vormt bij weigering van toestemming tot ingebruikneming een meer geëigende weg. $\mathrm{Nu}$ de verhuurder en de huurder gezamenlijk het verzoek om toestemming tot ingebruikneming aan het bestuur van de V.v.E. moeten richten, kan de appartementseigenaar/verhuurder zich vervolgens bij weigering tot de kantonrechter wenden op grond van artikel $8750 \mathrm{BW}$.

\subsubsection{Toestemming tot ingebruikneming van een gehuurd gewoon appartement}

Bij gewone appartementen zijn eveneens gevallen te bedenken, waarin een appartementseigenaar zijn appartementsrecht verhuurt, maar de V.v.E. de huurder niet als bewoner wil toelaten, bijvoorbeeld omdat deze huurder zich prostitueert en aan te nemen valt dat hij/zij zijn/haar beroep in het appartement wil gaan uitoefenen $^{226}$.

Ook met betrekking tot gewone appartementen geldt hetgeen in paragraaf 4.4.4.1 met betrekking tot service-flats werd opgemerkt. Het reglement van splitsing werkt tegen de huurder en deze zal daarom zijn appartement niet mogen bewonen. De

226. Dit geldt alleen voor zover in het reglement van splitsing een toelatingsregeling is opgenomen. In het modelreglement bij splitsing in appartementsrechten uit 1983 (Modelreglement 1983) is de toelatingsregeling slechts in een annex opgenomen. 
huurder kan echter wel de verhuurder wegens wanprestatie aanspreken. De verhuurder kan zich bij verhuur van gewone appartementen op dezelfde wijze indekken tegen wanprestatie als bij verhuur van service-flats. Tot duswer lijkt de situatie bij verhuur van gewone appartementen sterk op de situatie waarin serviceflats worden verhuurd. De bepalingen die het Modelreglement 1983 voor verhuur van gewone appartementen geeft, wijken echter enigszins af van de bepalingen met betrekking tot verhuur in het Modelreglement 1987.

Volgens artikel 24 van het modelreglement 1983, mag een appartementseigenaar zijn appartementsrecht slechts aan een ander in gebruik geven, indien hij ervoor zorgt dat de ander het gebruik slechts verkrijgt na ondertekening van een verklaring, dat hij de bepalingen van het reglement van splitsing en het huishoudelijk reglement, alsmede besluiten in de zin van artikel $876 \mathrm{c} \mathrm{BW}$, zal naleven (vgl. ook art. 26 lid 1 modelreglement 1983). Artikel 25 van het modelreglement 1983 bepaalt vervolgens dat het bestuur te allen tijde (dus eventueel bijvoorbeeld twee jaar na ingebruikneming) van de gebruiker kan verlangen, dat hij zich als borg verbindt voor de schulden die de eigenaar aan de vereniging heeft of zal krijgen (een en ander slechts voor zover de schulden na ingebruikneming zijn ontstaan). Aan een gebruiker die de verklaring ex artikel 24 niet heeft getekend, of die zijn verplichtingen ingevolge artikel 25 niet is nagekomen, kan door het bestuur het gebruik van het appartement worden ontzegd (art. 26 modelreglement 1983).

In de Annex 1 bij het modelreglement 1983 is de toelatingsregeling opgenomen (vgl. par. 3.3.1) Een verschil met het reglement 1987 is dat de aspirant-gebruiker zelf om toelating moet verzoeken, en dat niet verplicht is dat aspirant-gebruiker en appartementseigenaar de toestemming gezamenlijk aanvragen (hoewel dit mijns inziens niet verboden is). Bovendien behoeven huurder en verhuurder geen overeenkomst die aan (het verzoek om toestemming tot) de ingebruikneming ten grondslag ligt, te overleggen (vgl. verder over het verzoek om toestemming tot ingebruikneming par. 3.3.1).

\subsubsection{Ontzegging van verder gebruik van verhuurde service-flats}

De overlapping van het huurrecht en het appartementsrecht treedt niet alleen op indien een huurder toestemming vraagt om een appartement in gebruik te nemen, maar ook indien de vergadering van appartementseigenaars aan de huurder het verdere gebruik van "zijn" appartement ontzegt.

De ontzegging van verder gebruik is ingevolge het modelreglement 1987 mogelijk indien:

1. de huurder de bepalingen van het reglement of het huishoudelijk reglement niet nakomt of de bepalingen betreffende het gebruik van de gemeenschappelijke gedeelten overtreedt (art. 876c BW);

2. de huurder zich schuldig maakt aan onbehoorlijk gedrag jegens de andere appartementsgebruikers;

3. de huurder door zijn aanwezigheid aanleiding geeft tot ernstige verstoring van de rust in het gebouw;

4. de huurder zijn financiële verplichtingen jegens de vereniging niet nakomt (art. 33, lid 1 en 7 modelreglement 1987). 
Aan de ontzegging van verder gebruik gaat een waarschuwing vooraf (zie verder over deze ontzeggingsmogelijkheden en de beroepsmogelijkheden daartegen: par. $3.7)$.

Indien het verdere gebruik van een appartement aan een huurder wordt ontzegd, heeft dit in beginsel tot gevolg dat de verhuurder in de nakoming van zijn verplichtingen tekortschiet. De verhuurder verschaft de huurder dan immers niet meer het rustige genot van het gehuurde, zodat hij wanprestatie pleegt. Hij zal echter in de meeste gevallen niet machteloos staan tegenover de huurder.

Als de huurder "zijn" appartement moet ontruimen omdat hij de bepalingen van het reglement van splitsing, het huishoudelijk reglement of de regelingen die ex artikel $876 \mathrm{c} \mathrm{BW}$ zijn getroffen niet naleeft, moet eerst naar de inhoud van de huurovereenkomst worden gekeken om te kunnen vaststellen of het de huurder of de verhuurder is die wanprestatie pleegt. Als in de huurovereenkomst een bepaling is opgenomen dat de huurder verplicht is de bepalingen van het reglement e.d. na te leven, pleegt hij wanprestatie indien hij deze bepalingen niet naleeft. De verhuurder kan dan ontbinding van de huurovereenkomst wegens wanprestatie vorderen of de huurovereenkomst opzeggen omdat de huurder zich niet gedraagt zoals een goed huurder betaamt. Een en ander zal afhankelijk zijn van de ernst van de wanprestatie (vgl. par.4.4.3.1). Een geslaagde ontbindingsactie of opzegging zal de huurder voldoende vrijwaren voor eventuele vorderingen tot schadevergoeding door de huurder.

Ook in het geval dat de huurder zich schuldig maakt aan onbehoorlijk gedrag jegens de andere appartementsgebruikers en hij uit het gehuurde wordt gezet, zall veelal ontbinding wegens wanprestatie door de verhuurder kunnen worden gevorderd of zal opzegging wegens het zich niet gedragen als een goed huurder betaamt mogelijk zijn. Vaak zal het onbehoorlijke gedrag bijvoorbeeld bestaan uit overlast, die de huurder aan de overige appartementseigenaars bezorgt. Uiteraard heeft "onbehoorlijk gedrag" een bredere strekking dan "overlast", maar in elk geval zal onbehoorlijk gedrag onder "zich niet gedragen als een goed huurder betaamt" vallen (vgl. par. 4.4.3.1). Afhankelijk van de ernst van het onbehoorlijk gedrag zal de verhuurder de overeenkomst kunnen opzeggen, dan wel doen ontbinden ${ }^{227}$. Ervan uitgaande dat een vergadering van eigenaars niet vlug zijn toevlucht neemt tot ontzegging van verder gebruik (in de jurisprudentie zijn geen gevallen bekend), zall het onbehoorlijk gedrag dat tot ontzegging van verder gebruik leidt in voorkomende gevallen waarschijnlijk dermate ernstig zijn dat ontbinding van de huurovereenkomst wordt gerechtvaardigd.

De derde grond voor ontzegging van verder gebruik vertoont nauwe verwantschap met "onbehoorlijk gebruik". Deze derde grond - de huurder geeft door zijn aanwezigheid aanleiding tot ernstige verstoring van de rust in het gebouw - is echter niet gelijk aan de ontzeggingsgrond "onbehoorlijk gebruik". De vraag is wanneer er dan sprake is van het geval dat een huurder door zijn aanwezigheid aanleiding geeft tot ernstige verstoring van de rust in het gebouw. Deze situatie zal zich waarschijnlijk slechts zeer zelden voordoen. Mijns inziens moet hierbij gedacht worden aan extreme gevallen, bijvoorbeeld dat een huurder een oorlogsmisdadiger

227. Vgl. ook HR 28 maart 1980, NJ 1980, 465. Het feit dat een huurder niet in het gehuurde woont, levert volgens de Hoge Raad op zichzelf geen onbehoorlijk gebruik op dat ontbinding van de huurovereenkomst rechtwaardigt. 
blijkt te zijn, terwijl de overige bewoners met sterke emoties aan de oorlog terugdenken.

Het probleem voor de verhuurder is hierbij, dat de huurder geen wanprestatie pleegt. De verhuurder zal daarom altijd wanprestatie plegen, indien de huurder op deze grond gedwongen wordt zijn appartement te ontruimen. De huurder kan de verhuurder zelfs in vrijwaring roepen indien hij gedwongen wordt zijn appartement te ontruimen (art. 1586 jo. 1594 BW). De enige manier waarop de verhuurder kan proberen dit te ondervangen, is het opnemen van een clausule in de huurovereenkomst, dat de huurder geen aanleiding mag geven tot verstoring van de rust in het gebouw. De huurder pleegt dan wanprestatie, indien zijn aanwezigheid tot verstoring van de rust aanleiding geeft. De grote vraag is echter of een rechter deze wanprestatie voldoende zal achten om een huurovereenkomst te ontbinden of opzegging geldig te achten.

De vierde grond voor ontzegging van verder gebruik is dat de huurder zijn verplichtingen jegens de vereniging niet nakomt. Dit geval doet zich bijvoorbeeld voor indien de huurder zich ex artikel 27 modelreglement 1987 borg heeft moeten stellen voor de schulden die de verhuurder na het aangaan van de huurovereenkomst heeft opgebouwd. Als de huurder vervolgens deze schulden niet betaalt kan hij uit het gehuurde worden gezet. Het zal duidelijk zijn dat de verhuurder in dit geval niet aan een actie wegens wanprestatie zal ontkomen. Een ander geval waarin de huurder zijn financiële verplichtingen jegens de V.v.E. niet nakomt, is indien hij de kosten voor de service die hij ontvangt (eten en drinken, verzorging etc.), niet betaalt. In dit geval zal de huurder wamprestatie ten opzichte van de verhuurder plegen, indien in de huurovereenkomst was opgenomen dat de huurder zijn financiële verplichtingen jegens de V.v.E. moet nakomen.

Overigens kan aan een huurder van een service-flat ook het verdere gebruik worden ontzegd, indien hij geen overeenkomst met de V.v.E. is aangegaan, krachtens welke hij gebruik kan maken van de door de vereniging te verlenen diensten. Bovendien moet de huurder een verklaring hebben ondertekend dat hij de bepalingen van het reglement, het huishoudelijk reglement en de regelingen ex artikel $876 \mathrm{c} \mathrm{BW}$ zal naleven (art. 28 lid 1 sub a Modelreglement 1987). Bovendien kan een huurder uit het door hem gehuurde appartement worden verwijderd, indien hij geen toestemming tot ingebruikneming van het bestuur van de V.v.E. heeft gekregen (art. 28 lid 1 sub b modelreglement 1987), maar desalniettemin het appartement in gebruik heeft genomen. De huurder is dus altijd gehouden de bepalingen van het reglement van splitsing ${ }^{223}$ e.d. na te leven. Indien de verhuurder echter will bereiken dat niet-naleving van deze bepalingen wanprestatie jegens hem oplevert, zal hij een en ander expliciet in de huurovereenkomst moeten opnemen. Dit geldt uiteraard alleen voor zover de naleving van deze bepalingen niet onder de verplichtingen valt die voor de huurder uit de artikelen 1596 en $1623 \mathrm{e}$ lid 1 sub $1 \mathrm{BW}$ voortvloeien.

228. Aan het reglement van splitsing was hij toch al gebonden, ook zonder een verklaring met de strekking dat hij zich aan het reglement zal houden. Vgl. par. 2.4.2.1. 
Het modelreglement 1983 kent slechts drie gronden voor ontzegging van verder gebruik van privë-gedeelten van een appartement: Twee van deze gronden zijn gelijk aan de eerste twee ontzeggingsgronden van artikel 33 van het modelreglement 1987 (art. 27 lid 1 modelreglement 1983). De derde grond komt eveneens terug in het modelreglement 1987. Deze ontzeggingsgrond houdt in dat een huurder die geen verklaring heeft ondertekend dat hij de bepalingen van het reglement e.d. zal naleven, uit zijn appartement kan worden verwijderd. Met betrekking tot gewone appartementen geldt hetzelfde als in paragraaf 4.4.4.3 is opgemerkt met betrekking tot service-flats. Indien de Annex van het modelreglement in het reglement is opgenomen, geldt bovendien dat het bestuur een huurder van een appartement uit het appartement kan doen verwijderen, indien de huurder geen toestemming tot ingebruikneming van het bestuur heeft verkregen, en hij desalniettemin het appartement heeft betrokken. 
III BUITENLANDS APPARTEMENTSRECHT 


\section{België}

\subsection{Inleiding}

In tegenstelling tot Nederland, waar de appartementenwet pas in 1951 tot stand kwam $^{1}$, heeft België sinds zijn ontstaan een wettelijke regeling met betrekking tot splitsing van een gebouw in appartementen gekend. Tot 1924 was deze wettelijke regeling gelijk aan artikel 664 van de Franse Code civil ${ }^{2}$. Deze Franse Code civil werd in België in 1804 ingevoerd ${ }^{3}$. België bestond toen uit een aantal Franse departementen. Later is de Code niet door een ander wetboek vervangen, zoals bijvoorbeeld wel in Nederland gebeurde. Veel artikelen van het Belgische BurgerIijk Wetboek (Code civil) zijn echter in de loop der jaren door wetgeving en jurisprudentie veranderd, afgeschaft of "buiten spel gezet" 4

Afschaffing was eveneens het lot dat artikel 664 van het Belgische Burgerlijk Wetboek was beschoren. Op 8 juli 1924 werd dit artikel afgeschaft en werd artikel 577 bis BW ingelast ${ }^{5}$. Hierin werd een algemene regeling betreffende medeëigendom gegeven ${ }^{6}$ en werd eveneens appartementseigendom geregeld. Hiermee was Belgiê, vergeleken met landen als Duitsland, Frankrijk en Nederland een voorloper ten aanzien van de invoering van (nieuw) appartementsrecht?

De redenen voor de afschaffing van artikel $664 \mathrm{BW}$ werden in de Memorie van Toelichting (exposé des motifs) bij de wet van 1924 uiteengezet. Het voornaamste motief voor de wetswijziging was de dringende behoefte aan horizontale splitsing van onroerende goederen in appartementen die na de eerste wereldoorlog was ontstaan. Volgens artikel $664 \mathrm{BW}$ was deze horizontale splitsing weliswaar mogelijk,

1. Stb. 1951, nr. 571 .

2. Vgl. Rogron, blz. 129, 130 .

3. Over de toestand in Vlaanderen en Brabant voor de invoering van het BW, zie Aeby, blz 64, 65 . In de costumen van Antwerpen, Brussel, Gent, Leuven en Ieper waren regelingen met betrekking tot horizontaal gesplitste oniroerende goederen opgenomen.

4. Van Caenegem, blz. 2.

5. Pasin. 1924, nr. 294; Recueil des Lois 1924, blz. 1163.

6. Pasin. 1924, nr. 294; Recueil des Lois 1924, blz. 1158-1164.

7. In Frankrijk werd art. 664 C.c. in 1938 door een appartementenweit vervangen, terwijl in WestDuitsland en Nederland het appartementsrecht pas in het begin van de jaren wijftig tot stand kwam. In Zwitserland kwam hett nieuwe appartementsrecht pas in 1963 tot stand. 
maar dit artikel regelde de horizontale splitsing onvoldoende. De Memorie van Toelichting vermeldt hierover:

"L'article 664 du Code civil a déjà consacré ce genre de propriété; seulement, la reglementation qu'il contient est manifestement insuffisante...."

Inmiddels zijn er in België weer stemmen opgegaan om de regeling van 1924 te vervangen door een nieuwe, uitgebreidere ${ }^{9}$. De belangrijkste aanzet in die richting was wel het "Voorstel van wet betreffende de horizontaal gesplitste gebouwen en de onroerende complexen", ook genoemd "het voorstel Pede" (naar de naam van de ontwerper van de wet) van 19 juni $1974^{10}$. In de toelichting bij dit wetsvoorstel werd betoogd dat het nodig was om de wet van 1924 aan te vullen. De bedoeling was dus niet om de regeling van 1924 af te schaffen, maar slechts om haar aan te vullen;

"De wet van 1924 heeft nagelaten iets te voorzien voor het beheer van onroerende goederen opgericht onder het stelsel van de horizontalle eigendom." ${ }^{11}$

In dit beheer wilde het "voorstel Pede" voorzien. Dit voorstel is echter niet aangenomer. Voorlopig zal men in België dus moeten blijven werken met de regeling van artikel 577 bis $\mathrm{BW}$ betreffende medeëigendom, zonder enige wettelijke aanvulling met betrekking tot beheer van de gesplitste gebouwen.

In dit hoofdstuk zal allereerst worden ingegaan op de hoofdlijnen van het Belgische appartementsrecht, waarbij in de eerste plaats de algemene wettelijke regeling wordt besproken en aandacht wordt geschonken aan de algemene bepalingen van het zogenaamde reglement van medeëigendom (zie par. 5.2.1). Vervolgens zal de algemene structuur van appartementseigendom aan de orde komen (par. 5.2.2), waarna op het ontstaan en tenietgaan van appartementseigendom wordt ingegaan (par. 5.2.3). Daarbij aansluitend zal aandacht worden geschonken aan administratie en beheer van appartementsgebouwen en aan de regeling van het modelreglement daaromtrent (par. 5.2.4). In paragraaf 5.2.5 zullen de rechten en verplichtingen van de appartementseigenaars aan de hand van de wet en het reglement van medeeigendom worden besproken.

Na de bespreking van de hoofdlijnen van het Belgische appartementsrecht zal worden onderzocht of het Belgische appartementsrecht een rechtsinstituut kent dat vergelijkbaar is met de Nederlandse welstandsbepalingen. In paragraaf $5.3 \mathrm{zal}$ op de toelating en ontzegging van verder gebruik worden ingegaan, terwijl in paragraaf 5.4 tenslotte aandacht zal worden besteed aan de rechtsmiddelen tegen ontzegging van verder gebruik of weigering van toelating.

8. Pasin. 1924, nr. 294, blz. 343. Zie over de redenen van afschaffing van art. 664 BW ook: Cambron, bly. 5-9 en 174, 175. Vgl. over (de totstandkoming van) art. 577bis BW in het algemeen Hauchamp.

9. Vgl. Top, 1685.

10. Parl. St., Senaat B.Z. 1974, 276.

11. Parl. St., Senaat B.Z. 1974, 276, nr. 1 . 


\subsection{De hoofdijnen van het Belgische appartementsrecht}

\subsection{Algemene opmerkingen}

De wet van 1924 (art. 577bis BW) is blijkens de memorie van toelichting bedoeld als codificatie van de regels die in de rechtspraktijk en jurisprudentie waren geformuleerd ${ }^{12}$. Deze bepalingen van artikel 577 bis $\mathrm{BW}$ zijn van aanvullende aard. De memorie van toelichting vermeldt hierover:

"Les regles formulées dans le projet ne valent qu'a défaut de toutes dispositions légales, conventionelles, judiciaires ou testamentaires, ainsi que l'ename l'article $1 \mathrm{er}^{\text {"13 }}$.

De eerste paragraaf van artikel 577bis BW stelt dan ook uitdrukkelijk:

"Bij ontstentenis van overeenkomsten en van bijzondere bepalingen, wordt de eigendom van een zaak die onverdeeld aan verscheidene personen toebehoort, geregeld als volgt:" ${ }^{4}$

Daarna volgen de $\S \S 2-11$ waarin bepalingen voor de medeëigendom in het algemeen en meer in het bijzonder voor de appartementsmedeëigendom zijn neergelegd ${ }^{15}$.

Deze appartementsmedeëigendom wordt in artikel 577bis $\$ 11 \mathrm{BW}$ uitdrukkelijk geregeld. Deze paragraaf luidt:

"Wanneer de onderscheidene verdiepingen of gedeelten van verdiepingen van een huis aan verschillende eigenaars toebehoren, worden de zaken die tot gemeenschappelijk gebruik van de onderscheidene verdiepingen of gedeelten van verdiepingen bestemd zijn, zoals grond, de grondvesten, de zware muren, het dak, de binnenplaatsen, de putten, de gangen, de trappen, de liften, de leidingen en welke andere ook, als gemeenschap-

12. Pasin. 1924, nr. 294, bilz. 344.

13. Pasin. 1924, nr. 294, blz. 344 en 345 linkerkolom. Zie ook Cambron, blz. 10.

14. Vgl. hierbij Cass. 10 april 1975, RW 1975-1976, 414.

15. In België onderscheidt men (a) tocvallige, (b) vrijwillige en (c) verplichte (gedwongen) medeëigendom. Toevallige medeêigendom (a) doet zich onder andere voor bij hett openvallen van een nalatenschap en bij het ontbinden van een rechtspersoon. Vrijwillige medeéigendom (b) treedt op indien meerdere personen eenzelfde goed verwerven, zonder hiervoor een rechtspersoon in het leven te roepen (in dit laatste geval zou er sprake zijn van gezamenlijke eigendom in plaats van medeëigendom). Indlien enkele vrienden bijvoorbeeld samen een jachtterrein kopen, doet zich vrijwillige medeëigendom voor. Van verplichte eigendom (c) is sprake indien 1) bepaalde goederen bestemd zijn woor gebruik door bepaalde personen. Bijwoorbeeld: grafstede, familiearchief e.d. De medeëigendom is dan hoofdzaak. 2) Onroerende goederen zijjn bestemd tot gemeenschappelijk gebruik van twee of meer erven (art. 577bis $\$ \S 9-11 \mathrm{BW}$ ). De medeeigendom is dan bijzaak. 3) Bij huwelijksgemeenschap. Vgl. hierover Dekkers, blz. 546555; De Page/Dekkers, blz. 1026, 1027; Vileyn, TPR 1983, blz. 16; Baert, blz 124. Overigens kan vrijwillige medeëigendom ook ontstaan, zonder dat partijen hiertoe duidelijk hun wil hebben verklaard. Zie Cass. 12 sept. 1974, Rec. Gén. Enr. Not. 1976, 22023. Het Hof van Cassatie watle hier een tussen partijen afgesproken erfdienstbaarheid op als medeéigendom. 
pelijk beschouwd en zijn zij onderworpen aan de bepalingen van dit hoofdstuk, inzonderheid aan de $\$ \$ 9$ en 10 ."

De bepalingen van artikel 577 bis $\mathrm{BW}$ zijn zoals werd vermeld in de inleiding, te summier om een voldoende regeling te geven voor de verhoudingen en de rechten en verplichtingen van de appartementseigenaars onderling en voor het beheer van het appartementsgebouw. Vandaar dat voor deze rechten en verplichtingen en het beheer, vooral ten aanzien van de gemeenschappelijke delen, over het algemeen een reglement van medeëligendom (ook genoemd "basisakte" of "onroerend statuut" $)$ wordt opgesteld ${ }^{16}$. In dit reglement van medeëigendom kunnen allerlei zaken worden geregeld. Het is een contract tussen de appartementseigenaars en aangezien artikel 577 bis BW van aanvullende aard is, kan men het reglement van medeëigendom in beginsel naar eigen goeddunken opstellen ${ }^{17}$.

Wel zal deze akte aan de vormvereisten van artikel 2 Hypotheekwet moeten voldoen, aangezien ze ingevolge artikel 1 Hypotheekwet in de openbare registers moet worden ingeschreven.

Het reglement van medeëigendom is een aanhangsel van de splitsingsakte ${ }^{18}$, waarin wordt vastgesteld wat tot de medeëigendom behoort en wat tot de privéeigendom behoort, en waarin de rechten en verplichtingen en de administratie van het gebouw, worden geregeld.

In het Belgische notariaat maakt men gebruik van modelreglementen van medeëigendom. Van een grote verscheidenheid van reglementen is volgens Vileyn geen sprake. Volgens hem ${ }^{19} z_{\text {ijn }}$ de teksten "van een treffende eenvormigheid". In dit hoofdstuk zal worden uitgegaan van hetgeen in het modelreglement, dat is opgenomen in Aeby op blz. 549-618 (Franse en Nederlandse tekst), is geregeld. In het vervolg zal aan dit reglement worden gerefereerd als het "modellreglement Acby".

Er wordt in de Belgische rechtsleer een onderscheid gemaakt tussen zakelijke en persoonlijke bepalingen van het reglement van medeëigendom. De zakelijke bepalingen houden direct verband met de eigendom van het appartement. Daartegenover staan de persoonlijke bepalingen, die een regeling voor de onderlinge rechtsverhoudingen tussen de appartementseigenaars, geven ${ }^{20}$. De in de openbare registers conform de artikelen 1 en 2 Hypotheekwet ingeschreven zakelijke bepalingen zijn ook tegen derden inroepbaar. De persoonlijke bepalingen

16. Vgl. Dekkers, blz, 557; De Page/Dekkers (V), blz. 1046; Bossard, blz. 17.

17. Vgl. Pasin. 1924, nr. 294, blz 348; Hauchamp, blz. 175; De Page/Dekkers (V), blz. 1047; LurquinStavaux, blz. 8; Haumont, blz 93; Bossard, blz. 18. Wanneer het reglement voorschrijft dat onderlinge onenigheden eerst aan de algemene vergadering moeten worden voorgelegd, en van het besluit van de algemene vergadering proces-verbaal zal worden opgemaakt, waarna men zich ewentueel alsnog tot de rechter kan wenden, brengt het ononvankelijkheid met zich mee als men zich cerst tot de rechter wendt. Indien de algemene vergadering echter heeft beslist, maar er geen proces-verbaal van de beslissing is opgemaakt, leidt dit niet tot onontvankelijkheid als men zich vervolgens tot de rechter wendi. Zie Rb. Antwerpen 1.8 dec. 1958, RW 1959-1960, 1457-1462.

18. Vileyn, TPR 1983, blz 37.

19. Vileyn, blz. 37. Anders Heyvaert (Preadvies), 1450.

20. Op deze scheiding tussen zakelijke en persoonlijke bepalingen is in de Belgische doctrine kritiek geleverd; de scheiding zou "verwarrend, artificieel en moeilijk verdedigbaar zijn". Villeyn, blz. 39. Vgl. ook De Page/Dehan, blz. 151; Hansenme, blz. 34, 35; Gotzen, 2342-2346. 
zijn in beginsel niet verbindend voor derden, indien in de akte van verkrijging vergeten wordt om uitdrukkelijk te verwijzen naar het reglement ${ }^{21}$. De persoonlijke bepalingen gelden immers in beginsel slechts tussen de contractanten. Dit neemt niet weg dat ze, indien ze zijn overgeschreven in het hypotheekregister, in sommige gevallen wellicht toch inroepbaar zullen zijn tegen derde-verkrijgers, die niet expliciet met deze bepalingen hebben ingestemd. De publiciteit van de bepalingen kan wellicht het feitelijk gevolg hebben dat de derde-verkrijger geacht wordt stilzwijgend of uitdrukkelijk met de bepalingen te hebben ingestemd ${ }^{22}$. Over het algemeen wordt echter in de akte van verkrijging uitdrukkelijk verwezen naar het reglement van medeëigendom, zodat de derde-verkrijgers aan de bepalingen daarvan gebonden zijn. Ook in huurovereenkomsten wordt veelal aan de huurder de verplichting opgelegd om de persoonlijke bepalingen van het reglement na te leven ${ }^{23}$. In beginsel zijn deze persoonlijke bepalingen immers niet inroepbaar tegen derden, dus ook niet tegen huurders ${ }^{24}$. De zakelijke bepalingen werken daarentegen altijd tegen de huurder, zelfs indien ze niet zijn gepubliceerd. Dit is het gevolg van het feit dat de huurder geen derde in de zin van artikel 1 Hypotheekwet is en daarom niet door dit artikel wordt beschermd ${ }^{25}$.

In het modelreglement Aeby wordt bepaald dat alle bepalingen in dit reglement van zakenrechtelijke aard zijn (vgl. art. $8.01 \& 1$ modelreglement Aeby). De persoonlijke bepalingen worden meestal in bijzondere reglementen, zoals het huishoudelijk reglement, neergelegd (art. $8.01 \& 2$ modelreglement Aeby). Zij kunnen echter ook in het reglement van medeëigendom worden opgenomen.

Het modelreglement Aeby bevat geen regeling met betrekking tot de wijziging van het reglement van medeëigendom, zodat daarvoor de algemene regeling geldt, dat de wijziging bij unaniem besluit van de vergadering van eigenaars moet worden besloten. De wijziging van de zakelijke bepalingen moet in een authentieke akte worden neergelegd en worden ingeschreven in de openbare registers ${ }^{26}$

\subsubsection{Algemene structuur van appartementseigendom}

Uit de eerste zin van artikel $577 \mathrm{bis} \S 11 \mathrm{BW}$ volgt duidelijk dat het naar Belgisch recht mogelijk is om de volle eigendom van een verdieping van een gebouw of een gedeelte daarvan te hebben. Naast deze volle eigendom van hetgeen verder de privé-gedeelten (privatieve delen) zullen worden genoemd, zijn de verscheidene appartementseigenaars medeëigenaar van de gemeenschappelijke delen ${ }^{27}$.

Voor de aanduiding van de gemeenschappelijke gedeelten (medeëigendom) wordt over het algemeen het wettelijk criterium "gemeenschappelijk gebruik"

21. Bossard, blz. 22, 23; Vileyn, blz. 38, 39; Aeby, blz. 485; Delva, blz. 8-12; Berenboom, blz. 291.

22. Aldus Aeby, blz 489, 490 . Anders De Page/Dehan, blz. 159.

23. Bossard, blz. 17-24; Vileyn, blz. 38, 39.

24. Lurquin-Stavaux, blz. 7; Vileyn, blz 40; Rb. Brussel 10 april 1970, Rev. Prat. Not. 1970, 452, J.T. 1970, 688; Rb. Brussel 30 maart 1976, J.T. 1976, 410.

25. Aldus Cass. 8 april 1957, Rev. Crit. Jur. B. 1958, blz. 95-111 met noot Dabin. Zie ook. Rb. Brussell 10 april 1970, Rev. Prat. Not. 1970, blz. 455; De Page/Dehan, blz. 161; Bossard, blz. 22.

26. Aeby, blz 498 .

27. Vgl. Dekkers, blz. 544, 556, 557; De Page/Dekkers, blz. 1045, 1046. Vensters en ramen zijn volgens de Vrederechter te Etterbeek prive-eigendom, omdat het gebruik ervan beperkt is tot de bewoner van het appartement waarin zij zijn aangebracht. Zie Vredlerechter Etterbeek 22 dec. 1977, Res et jura immobilia 1979, nr. 5750. 
gehanteerd. Voor het aanduiden van de privé-gedeelten (privé-eigendom) gebruikt men bijvoorbeeld het criterium "uitsluitend gebruik" (vgl. art. 2.01 modelreglement Aeby) ${ }^{28}$. Het reglement van medeëigendom geeft bovendien de verdeling van de medeëigendom tussen de verschillende gedeelten in privé-eigendom.

"Deze verdeling is meestal gebaseerd op verschillende gegevens zoals waarde, oppervlakte, ligging", aldus Vileyn ${ }^{29}$.

Op dit punt is het nodig een opmerking van terminologische aard te maken. In het Belgische appartementsrechtsysteem hebben de gerechtigden tot een appartementsrecht twee petten op. Enerzijds zijn zij medeëigenaar van de gemeenschappelijke gedeelten, anderzijds zijn zij eigenaar van de privé-gedeelten. In de Belgische praktijk spreekt men dan ook vaak van appartementsmedeëigenaars, als men met betrekking tot gemeenschappelijke delen spreekt; men spreekt daarentegen van appartementseigenaars met betrekking tot de privé-gedeelten ${ }^{30}$. Hoewel het dogmatisch juist is, kan dit onderscheid verwarrend werken. Aangezien ook de Belgische wet slechts over appartementseigenaars spreekt, zal in het navolgende die term gehanteerd worden, ongeacht de vraag of het gaat om een gerechtigde tot een prive-gedeelten of om een gerechtigde tot gemeenschappelijke gedeelten. Mutatis mutandis zal ook steeds de term appartementseigendom gehanteerd worden, ook als er strikt genomen van appartementsmedeëigendom zou moeten worden gesproken.

Het Belgische systeem van volle eigendom van een verdieping, gecombineerd met medeëigendom van de gemeenschappelijke delen, wordt als "dualistisch" betiteld ${ }^{31}$. Dit in tegenstelling tot het Nederlandse systeem, dat monistisch wordt genoemd. In het monistische systeem is er slechts sprake van medeëigendom van het gehele appartementsgebouw, gecombineerd met een beperkt zakelijk gebruiksrecht op de privé-gedeelten ( art. $^{875 a}$ lid $\left.3 \mathrm{BW}\right)^{32}$. In het Belgische systeem heeft men dus een vól eigendomsrecht ten aanzien van de privë-gedeelten, zoals omschreven in artikel $544 \mathrm{BW}$ (vergelijkbaar met art. 625 van het Nederlandse BW). Aangezien paragraaf 9 van artikel 577bis BW van toepassing is op de in paragraaf 11 geregelde appartementseigendom, is de medeëigendom van de gemeenschappelijke gedeelten accessoir aan de (volle) eigendom van de privé-gedeelten en derhalvè niet voor zelfstandige overdraclit of bezwaring vatbaar ${ }^{33}$.

Het feit dat artikel 577 bis BW aanvullend recht inhoudt, betekent dat partijen bij overeenkomst van deze regeling kunnen afwijken. Er kan echter niet worden

28. Vileyn, blz 42.

29. Vileyn, blz 42.

30. Aeby, blz. 191.

31. Aeby, blz 88; Derine e.a., blz. 118-123; Lurquin-Stavaux, blz. 1; Heyvaert (Preadvies), 1454-1459, is een voorstander van het monistische systeem. Zie ook Vileyn/Van Hoestenberghe, 1469-1477. $V_{\text {gl }}$ tevens Top, blz. 1685; Hansenne, blz. 1, 2.

32. Vgl. Aeby, blz 92 .

33. Vgl. De Page/Dekkers, blz 410; Cuvelier (Enrégistrement), blz. 58. 
gesproken van appartementseigendom indien niet aan tenminste twee voorwaarden is voldaan ${ }^{34}$.

De eerste voorwaarde houdt in dat er sprake moet zijn van een gebouw. Dit wordt in de Belgische literatuur een materiële voorwaarde genoemd. De tweede voorwaarde is dat het eigendomsrecht aan verschillende personen toekomt in de vorm van "privatieve en gemene rechten". Dit wordt in de Belgische literatuur een intellectuele voorwaarde genoemd ${ }^{35}$. Beide voorwaarden vloeien rechtstreeks voort uit artikel $577 \mathrm{bis} \S 11 \mathrm{BW}$. De privatieve rechten kunnen niet op een andere wijze gestalte krijgen (bijvoorbeeld als beperkt zakelijk recht), aangezien het zakenrecht een gesloten systeem vormt ${ }^{36}$. Dit betekent dat de regeling van artikel 577 bis BW $\$ 11$ weliswaar van aanvullende aard is, maar in praktijk in de kern niet kan worden omzeild zonder dat tevens de consequentie wordt aanvaard dat er dan geen sprake meer is van appartementseigendom. Zolang aan beide voorwaarden is voldaan kunnen partijen verder geheel en al van artikel 577 bis BW afwijken, terwijl er dan toch over appartementseigendom kan worden gesproken.

Overigens kan ook een opstalrecht in appartementen worden gesplitst. Het gevolg van een dergelijke splitsing is dat een appartementseigenaar medegerechtigde tot het opstalrecht, medeëigenaar van de gemene delen en vol eigenaar van de privé-gedeelten wordt. De appartementseigendom gaat weer teniet bij het einde van het opstalrecht ${ }^{37}$. Een erfpachtsrecht kan in België niet in appartementen worden gesplitst, omdat door een zodanige splitsing geen eigendom van privégedeelten of medeëigendom van gemeenschappelijke gedeelten kan ontstaan.

\subsection{Ontstaan en tenietgaan van appartementseigendom}

De appartementseigendom kan ontstaan door partijwil en door verjaring of onteigening ${ }^{38}$. Partijwil vormt echter in veruit de meeste gevallen de reden van ontstaan van appartementseigendom ${ }^{39}$. Deze partijwil wordt uitgedrukt in een akte waaraan in artikel $577 \mathrm{bis} \mathrm{BW}$ geen vormvereisten worden gesteld. Bij de wet van

34. Derine e.a., blz. 122.

35. Derine e.a., blz 119; Aeby, blz 95 e.y

36. Derine e. $a_{y,}$, blz. 122 .

37. Aeby, blz 519.

38. Appartementseigendom kan niet "toevallig" ontstaan, bijwoorbeeld bij erfenis. Wel kan medeë̈gendom van een erfenis worden omgezet (door partijwill) in appartementseigendom. Vgl. Vileyn, blz 30 . Indien eem erflater meerdere onroerende goederen testamentair aan verschillende personen nalaat, terwijl hij éen perceel niet uitdrukkelijk noemt, ontstaat ten aanzien van dit perceel echter well "toevallig" gedwongen medeëigendom voor de erfgenamen. Rb. Luik 21 jan. 1972, Rec. Gen. Enr. Not. 1973, 21700. Een vraag die hierbij opkomt is of medeèigendom die door teen erfenis is ontstaan, behalve door partijwil ook op grond van art. $815 \mathrm{BW}$ in appartementseigendom kan worden omgezet. Art. 815 bepaalt dat niemand kan worden gedwongen om in onwerdeeldheid te blijven en dat verdeling altijd kan worden gevorderd. Kan de verdeling nu op een dusdanige wijze worden gevorderd, dat appartementseigendom ontstaat of verzet art. 815 BW zich hiertegen? Kluyskens, blz 97-102, lijkt deze vraag bevestigend te beantwworden. In Belgie kent men overigens geen aan de Nederlandse wet op de woningsplitsing equivalente regeling. Eigenaars van een gebouw mogen derhalve zonder overheidstoestemming tot splitsing overgaan.

39. Derine e.a., blz. 126; Vileyn, blz. 31. 
8 juli 1924 is echter tevens artikel 1 van de Hypotheekwet gewijzigd, in die zin dat ook de authentieke

"akten betreffende de wederzijdse rechten der eigenaars van verdiepingen
of van gedeelten van verdiepingen in een opgericht of op te richten
gebouw"

aan overschrijving in de hypotheekregisters zijn onderworpen ${ }^{40}$. Willen de splitsingsaktes (actes de division) tegen derden inroepbaar zijn als bedoeld in artikel 1 hypotheekwet, dan moeten zij in de vorm die door artikel 2 Hypotheekwet is voorgeschreven, worden gegoten.

"Appartementsmedeëigendom onderstelt derhalve in beginsel een vestigings-; verdelings- of splitsingsakte die eigendomsaanwijzend of overdragend werkt:" 41

Door de "acte de division"/splitsingsakte (van een reeds bestaand gebouw) ontstaat de appartementseigendom ${ }^{42}$.

Appartementseigendom kan zoals vermeld, behalve door partijwil ${ }^{43}$ ook door onteigening of verjaring ontstaan. In geval van onteigening ontstaat de appartementseigendóm indien een gedeelte van een bepaald gebouw wordt onteigend. Door verjaring ontstaat de appartementseigendom indien de eigendom van een gedeelte van een gebouw wordt verkregen door acquisitieve verjaring ${ }^{44}$.

Een "papieren" splitsing van een nog niet bestaand gebouw is in zekere zin naar Belgisch recht ook mogelijk. Hiervoor is wel vereist dat degenen die tot de splitsing overgaan, een recht op de grond hebben, waarop het appartementsgebouw zal worden gebouwd. Niets verhindert de medeëigenaars van de grond om reeds voor het tot stand komen van een gebouw tot splitsing over te gaan (vgl. artikel 1130 BW). De eigendom van de appartementen zelf ontstaat echter pas naarmate het gebouw is voltooid ${ }^{45}$. Een nog te bouwen appartement kan eveneens worden verkocht. Deze verkoop heeft echter slechts verbintenisrechtelijke gevolgen ten aanzien van de nog niet voltooide (gedeelten van) een appartement. Ten aanzien

40. Cambron, blz. 225-230; Derine e.a., blz. 126.

41. Derine e.a., bly. 127; Aeby, blz 110-112.

42. Aeby, blz. 111 .

43. In de Belgische rechtspraktijk van 1964 bleek zich volgens Heyvaert, blz 333, vaker het volgende geval voor te doen: "een persoon is eigenaar van een stuk grond. Een aannemer wil daarop, mett zijn materiaal, een appartementsgebouw oprichten. De aannemer wenst nochtans zelf eigenaar te blijven van de tot gebouw verwerkte materialen. Hij will aldus zelf blijven beschikken over het recht tot verkoop of verhuring van de appartementen." Tot verwezenlijking van dit doel wordr daarom in veel contracten de clausule opgenomen, dat de grondeigenaar "zuiver en envoudig allstand doet van zijn recht van natrekking of beter gezegd dit recht verzaakt ten voordele van de aannemer." De vragen die bij deze clausule kunnen worden gesteld zijn: is het beding geildig, en zo ja, wat is de aard van de rechtsfiguur die erdoor in het leven wordt geroepen? Heyvaert plaatst grote vraagtekens bij de geldigheid van het beding. Als het al geldig is, dan moet de rechtsfiguur die aldus ontstaat worden opgevat als een opstalrecht, of tenminste als een recht dat daar sterke verwantschap mee vertoont. Een onbeperkte afstand van het recht van natrekking lijkt echter nietig (vgl. ook t.a.Y. het Nederlandse recht hetgeen hierover in hoofdstuk 2 werd gezegd).

44. Derine e.a., btz. 129 .

45. Aeby, blz. 119-124; Baert, blz. 552. Vgl. cok art. 5 van de hierna besproken Woningbouwwet. 
van de nog te bouwen gedeelten is de (aspirant-)verkoper immers nog niet beschikkingsbevoegd. Om te voorkomen dat particulieren die een woning op tekening kopen financieel nadeel lijden door faillissement of wanprestatie van de verkoper (meestal aannemers of projectontwikkelaars), is in België in 1971 de zogenaamde woningbouwwet tot stand gebracht ${ }^{46}$. Ingevolge artikel 12 van deze wet en artikelen 3 en 4 van het daarbij behorende $K B$ van 21 okt 1971 moet de verkoper bijvoorbeeld zekerheid stellen voor de door de kopers verrichte betalingen. De woningbouwwet is overigens niet van toepassing op verkoop van in aanbouw zijnde appartementen, waarbij op de verkoper niet de plicht rust bouwwerken uit te (doen) voeren ${ }^{47}$.

Appartementseigendom kan op verschillende wijzen eindigen. Allereerst kan appartementseigendom eindigen door de wil van de appartementseigenaars. Zij kunnen een overeenkomst sluiten met de strekking dat de appartementseigendom eindigt. In praktijk kan dit gebeuren ingeval van geheel of gedeeltelijk tenietgaan van het gebouw of indien het gebouw en de appartementsgemeenschap in een andere juridische constructie worden ondergebracht (bijvoorbeeld in een vennootschap). Bovendien kan het voorkomen dat de appartementseigendom voor een bepaalde termijn of onder ontbindende voorwaarde tot stand is gekomen. Appartementseigendom zal tevens tenietgaan door het eindigen van het opstalrecht, waarop appartementsrechten zijn gebaseerd. De appartementseigendom kan verder tenietgaan door vermenging (d.w.z. dat alle appartementen in een hand verenigd worden $)^{48}$ en wellicht door afstand ${ }^{49}$. Indien het appartementsgebouw geheel tenietgaat, kan er door zaaksvervanging gewone medeëigendom ontstaan van de het gebouw vervangende zaak (bijvoorbeeld verzekeringsgeld) ${ }^{50}$.

Op de verdeling (scheiding en deling) van de medeëigendom die ontstaat na het eindigen van de appartementseigendom zijn de regels ten aanzien van de verdeling van nalatenschappen van toepassing (art. 577bis $\$ 8 \mathrm{BW})^{51}$.

\subsection{Administratie en beheer}

Voor de administratie en het beheer is artikel 577bis $\S 6 \mathrm{BW}$ van belang. Deze paragraaf bepaalt dat de afzonderlijke deelgenoten daden van beheer en daden van beschikking over de gemeenschappelijke zaak slechts gezamenlijk (bij unaniem genomen besluit) kunnen verrichten ${ }^{52}$. Indien de rechter de noodzaak tot het verrichten van daden van beheer erkent, kan een appartementseigenaar evenwel

46. Wet van 9 juli 1971, Sib. 1971, blz. 10442-10444, Pasin. 1971, blz. 1227-1229; Baert, bli. 545, 555.

47. Baert, blz, 546.

48. Ook bijwoorbeeld bij onteigening van alle appartementseigendom.

49. Vgl. Aeby, blz. 207-211. Deze meent dat de algemene regel, dat een eigenaar afstand van zijn recht kan doen, op de appartementseigenaars niet van toepassing is. Hij vermeldt hierbij echter dat in de Belgische doctrine hieromtrent verschillende standpunten worden ingenomen. In elk geval kan de mogelijkheid om afstand te doen van appartementseigendom in het reglement worden uitgesloten, aldus Aeby. Vgl. ook De Page/Dekkers, blz. 1032-1034.

50. Derine e.a., blz. 196-199.

51. Vgl. Vileyn, blz. 23; Dekkers, blz. 551; De Page/Dekkers, blz 1035. De regel wan art. 815 BW dat niemand gedwongen kan worden om in onverdeeldheid te blijven, is echter niet toepasselijk op gedwongen of vrijwillige medeëigendom.

52. De Page/Dekkers, blz 1030, 1031. Vgl. ook Lurquin-Stavaix, blz. 6. 
de anderen verplichten om aan de daden van beheer mee te werken ${ }^{53}$. Daden van beheer die slechts door een der medeëigenaars zijn verricht, zonder dat de overige medeëigenaars daarin hebben toegestemd, gelden in beginsel alleen tegen derden. De appartementseigenaars kunnen zich jegens derden niet beroepen op het feit dat een medeëigenaar zijn macht als medeëigenaar te buiten zou zijn gegaan ${ }^{54}$. Omgekeerd kunnen derden zich evenmin op een bevoegdheidsoverschrijding van een medeëigenaar beroepen. De bevoegdheidsregeling geldt immers slechts tussen medeëigenaars onderling. Naar aanleiding hiervan betoogt Dekkers dat het gebied waarop eenstemmigheid van de eigenaars vereist is, inkrimpt. Volgens hem is alleen nog eenstemmigheid vereist met betrekking tot daden van gebruik, genot of beschikking over de onverdeelde zaak zelf ${ }^{55}$. Erg duidelijk is dit betoog echter niet. Als eenstemmigheid met betrekking tot beheer al niet ten opzichte van derden geld dit, betekent dit immers nog niet dat het niet ten opzichte van de overige medeëigenaars geldt. Indien een medeëigenaar zijn beheersbevoegdheid met betrekking tot de gemeenschappelijke zaak overschrijdt kan dit door en tegen derden weliswaar niet worden ingeroepen, maar het valt niet in te zien waarom de overige medeëigenaars degene die zijn bevoegdheid overschrijdt niet zouden kunnen aanspreken wegens wanprestatie, of waarom zij zich door zijn handeling onderling gebonden zouden moeten achten ${ }^{56}$.

Overigens behoeven niet alle daden van beheer door alle medeëigenaars gezamenlijk te worden verricht. Ingevolge artikel $577 \mathrm{bis} \S 5 \mathrm{BW}$ is iedere medeëigenaar namelijk gerechtigd om daden tot behoud van de zaak en daden van voorlopig beheer te verrichten ${ }^{57}$. Onder daden tot behoud moeten onder andere het herstellen van een door storm beschadigd dak en het oogsten van voor bederf vatbare vruchten worden verstaan, echter ook bijvoorbeeld het vernieuwen van een hypothecaire inschrijving bij het hypotheekkantoor ${ }^{58}$. Onder daden van voorlopig beheer kan ondermeer de verkoop van voor bederf vatbare zaken vallen ${ }^{s 9}$. Ook moet

"het doen vaststellen van schade aan een onroerend goed en de vordering tot schadevergoeding"

als daad van voorlopig beheer worden beschouwd ${ }^{60}$.

In het reglement van medeëigendom wordt over het algemeen een uitgewerkte regeling met betrekking tot het beheer van appartementsgebouwen opgenomen. Zo wordt het beheer van het gebouw volgens artikel 7.01 modelreglement Aeby

53. Dekkers, blx. 543, 549, 550; Derine e.a., blz. 46; Cambron, blz, 60.

54. Vgl. Dekkers, blz. 550; De Page/Dekkers, blz. 1031.

55. Dekkers, blx. 543 .

56. Vgl. ook Rb. Brussel 5 nov. 1968, Tijdschrift voor aannemingsrecht 1970, blz. 243 met noot Claude Delcorde en Ailmé De Caluwe; Hof van Beroep Brussel 29 juni 1962, RW 1964-1965, 926; Rb. Ieper 8 febr. 1967, RW 1966-1967, 1730.

57. Vgl. Dekkers, blz. 543, 549; Hof Brussel 15 jan. 1965, J.T. 1965, 523-526.

58. Derine e.a., bli 4.

59. Derine e.a., blz. 36; Vileyn, TPR 1983, blz 21, 22.

60. Vgl. Rb. Ieper 8 febr. 1967, RW 1966-1967, 1730. 
"oppermachtig" door de algemene vergadering van appartementseigenaars geregeld ${ }^{61}$. Iedere appartementseigenaar heeft in de vergadering stemrecht naar rato van het aantal aandelen dat hij in de algemene gemene delen bezit indien er beslissingen worden genomen over de algemene delen of indien de beslissingen voor alle eigenaars van belang zijn (art. 7.05 modelreglement Aeby). Indien er beslissingen worden genomen, die uitsluitend van belang zijn voor een bepaalde reeks privesgedeelten, waaraan "particuliere" gemeenschappelijke delen verbonden zijn, dan heeft iedere appartementseigenaar stemrecht naar rato van het aantal aandelen dat hij in deze bijzondere gemeenschappelijke delen bezit (art. $7.05 \& 1$ modelreglement Aeby). Afhankelijk van de aard van de beslissing zijn er dus verschillende stemverhoudingen binnen een appartementencomplex. Als bijvoorbeeld de verwarmingsketel van de winkelappartementen op de begane grond moet worden vervangen, beslissen alleen de desbetreffende eigenaars daarover. Deze verwarmingsketel komt namelijk ingevolge artikel $2.04 \$ 2$ modelreglement Aeby in "particuliere onverdeeldheid" toe aan de eigenaars van de winkelappartementen op de begane grond (zie ook art. $1.02 \S 1$ sub A modelreglement Aeby).

Indien meerdere personen gezamenlijk gerechtigd zijn tot een appartement, moeten zij een vertegenwoordiger aanwijzen die het stemrecht in de vergadering zal uitoefenen. Dit geldt niet alleen bij medeëigendom van een appartement, maar ook bijvoorbeeld in de verhouding tussen vruchtgebruiker en bloot eigenaar (zie art. 7.05 modelreglement Aeby) ${ }^{62}$.

In de praktijk benoemt de vergadering van eigenaars in België vaak een bestuur, dat bestaat uit een voorzitter van de vergadering en een secretaris. De secretaris is vaak dezelfde persoon als de administrateur (vgl. ook artt. $7.06 \& 3,7.14$ modelreglement Aeby) ${ }^{63}$.

Deze administrateur wordt eveneens door de algemene vergadering van appartementseigenaars benoemd ${ }^{64}$. De administrateur wordt ook wel "syndicus" of "beheerder" genoemd. Hij heeft als algemene taak om de beslissingen van de vergadering uit te voeren en de gemeenschappelijke gedeelten van het appartement te beheren (vgl. art. 7.12 modelreglement Aeby). In het reglement kunnen aan hem meerdere bevoegdheden en verplichtingen worden toegekend, c.q. opgelegd ${ }^{65}$. In het reglement wordt eveneens zijn bezoldiging geregeld ${ }^{66}$. Hij is een vertegen-

61. Vgl. hierbiji Hof van Verbreking 23 april 1945, Arresten van het Hof van Verbreking 1945, blz. 136. 137. In artikel 17 van het reglement van medeëigendom van partijen in casu, was geregeld dat "de algemene vergadering van medeëigenaars souverein meester is in het bestuur van het onroerend goed voor zover het over gemeenschappelijke belangen gaat." De algemene vergadering had op grond hiervan het recht om te beslissen dat het niet betalen van werwarmingskostten van prive-gedeelten aan de gemeenschap, bestraft werd met het afsluiten van de verwarming.

62. Kadaner, blz. 168, 169.

63. Aeby, blz. 403.

64. De administrateur kan tevens appartementseigenaar zijn. Noodzakelijk is dit echter miet. Evenmin is vereist dat de administrateur een natuurlijk persoon is, Ook een rechtspersoon kan administrateur worden. Aeby, biz 431.

65. Kadaner, blz. 201; Aeby, blz, 430 .

66. Aeby, blz 432 . Hij heeft overigens recht op vergoeding van de door hem in zijn hoedanigheid als administrateur ten behoeve van het appartementsgebouw gemaakte kosten. Vgl. hierbij Hof Antwerpen 18 jan. 1984, RW 1983-1984, 2336, Rec. GEn. Enr. Not. 1984, mr. 23055. Het recht op onkostenvergoeding verjaart na 30 jaar. 
woordiger van de appartementseigenaars en als zodanig moet hij rekening en verantwoording afleggen aan de vergadering van appartementseigenaars (1993 BW) ${ }^{67}$. In beginsel kan hij voor onbepaalde tijd worden benoemd. Het is echter eveneens mogelijk dat hij voor bepaalde tijd wordt benoemd. Hierbij kan theoretisch ook bepaald worden dat hij niet voor afloop van zijn benoeming kan worden ontslagen (vgl. ook par. 7.11 modelreglement Aeby) ${ }^{68}$.

De administrateur mag, indien hij handelt overeenkomstig het reglement van medeëigendom, geldig bij de rechter als vertegenwoordiger van de appartementseigenaars optreden. Hij hoeft in de dagvaarding niet de namen van de lastgevers aan te duiden ${ }^{69}$. Indien hij niet optreedt als gemachtigde op grond van het reglement, noch als gemachtigde van de algemene vergadering, is hij niet ontvankelijk in zijn vordering voor de rechter ${ }^{70}$.

Artikel 7.02 modelreglement Aeby bepaalt vervolgens dat er jaarlijks een algemene vergadering van appartementseigenaars moet plaatsvinden, en geeft nadere regelingen met betrekking tot deze algemene vergadering. De vergadering wordt bijeengeroepen door de administrateur of de voorzitter. De agenda van de vergadering moet worden vastgesteld door degene, die de vergadering uitroept (vgl. art. 7.02 modelreglement Aeby) ${ }^{71}$.

De vergadering beslist zoals vermeld "oppermachtig" over de gemeenschappelijke belangen van de appartementseigenaars ${ }^{2}$. Wil de vergadering geldig beslissingen kunnen nemen, dan moet tenminste een aantal personen aanwezig zijn, dat de helft van het aantal stemmen vertegenwoordigt (art. 7.06 modelreglement Aeby). De beslissingen worden door de vergadering genomen bij gewone meerderheid van stemmen, tenzij het reglement anders bepaalt (art. $7.06 \$ 3$ modelreglement Aeby). Afwezigen zijn eveneens gebonden aan de beslissingen van de vergadering (art. 7.01 modelreglement Aeby). Aangezien in artikel 7.01 wordt bepaald dat appartementseigenaars die niet aanwezig zijn geweest bij de algemene vergadering, toch aan het meerderheidsbesluit van de algemene vergadering gebonden zijn, wordt hier dus afgeweken van artikel 577 bis $\$ 6 \mathrm{BW}$. De in dit artikel vereiste unanimiteit wordt voor het beheer van de gemene delen aan de kant gezet. Dit kan ook, aangezien artikel 577bis BW zoals gezegd een bepaling van regelend recht is ${ }^{73}$.

De beraadslagingen en besluiten van de vergadering moeten worden opgenomen in notulen, die in een daartoe bestemd register worden bewaard. Deze notulen moeten door alle ter vergadering aanwezige appartementseigenaars worden ondertekend (zie verder art. 7.09 modelreglement Aeby).

67. Aeby, blz 442. Vgl. over de aansprakelijkheid van de administrateur: Kadaner, blz. 220-225.

68. Aeby, bliz 442.

69. Vrederechter Nijuel 18 april 1983, J.J.P. febr. 1987, blz. 49.

70. Vrederechter Deurne 26 okt. 1973, J.J.P. 1976, blz. 71. Vgl. cok Rechtbank van Koophandel Luik 12 okt. 1965, Tijdschrift voor aannemingsrecht 1970, blz. 235-241 met noot Wery, over de ontvankelijkheid van een rechtsvordering ingesteld door een beheerraad. Omdat de behcerraad door de vergadering van eigenaars gemachtigd was, was hij ontvankelijk in zijn wordering.

71. Als de uitgeschreven algemene vergadering 1 mintut later begint dan was vastgesteld, betekent dit niet dat de beslissingen van de algemene vergadlering daardoor ongeldig zijn. Rb. Antwerpen 18 dec. 1958 , RW 1959-1960, 1457-1462

72. Kadaner, blz. 190, 192. Aangeziem de vergadering geen rechtspersoon is, zijn slechts de appartementseigenaars aansprakelijk voor thaar besluiten.

73. Vgl. Haumont, blz. 93, 96; Bossard, blz, 17; De Page/Dekkers (V), blz. 1056, 1057. 
In artikel 4.06 van het modelreglement Aeby wordt bepaald dat er tussen de verschillende appartementseigenaars een gemeenschappelijke kas wordt geschapen om de administrateur in staat te stellen de normale uitgaven te bestrijden. Alle appartementseigenaars dragen bij aan de gemeenschappelijke kas.

In hoofdstuk $\mathrm{V}$ van het modelreglement wordt de verzekering van het appartementsgebouw geregeld. De verzekering van de privé-gedeelten (exclusief inboedel) en de gemeenschappelijke gedeelten komt ten laste van alle eigenaars gemeenschappelijk, en wordt door de administrateur afgesloten (artt. 5.03, 7.11 sub h modelreglement Aeby). Iedere eigenaar heeft recht op een exemplaar van de verzekeringspolissen (art. 5.06 modelreglement Aeby). Indien er ten gevolge van een oorzaak die bij een der eigenaars ligt, een meerpremie verschuldigd is, dient de betreffende eigenaar deze meerpremie geheel voor zijn eigen rekening te nemen (art. 5.04 modelreglement Aeby). Ingeval van calamiteiten wordt de schadevergoeding door de administrateur in ontvangst genomen (art. 5.15 modelreglement Aeby).

Indien het gebouw gedeeltelijk vernietigd of beschadigd is, wendt de administrateur de schadevergoeding aan om de beschadigde delen te herstellen. Indien het gehele gebouw door een calamiteit is vernietigd, wordt de schadevergoeding voor herbouw gebruikt, tenzij de algemene vergadering met eenparigheid van stemmen anders beslist (artikel 6.05 modelreglement Aeby). Eigenaars die menen dat de overeenkomstig het advies van de algemene vergadering verzekerde bedragen onvoldoende zijn, hebben blijkens artikel 5.14 modelreglement Aeby ook steeds het recht om op eigen rekening een extra verzekering af te sluiten. Bovendien is iedere eigenaar verplicht om zijn inboedel te verzekeren (art. 5.16 modelreglement Aeby). Tevens dient ten laste van alle eigenaars gemeenschappelijk door de administrateur een verzekering te worden afgesloten tegen schade die in of in de naaste omgeving van het gebouw aan eigenaars, gebruikers, of derden kan worden toegebracht door materiaal (bijvoorbeeld brokstukken) dat afkomstig is van het gebouw (art. 5.18 modelreglement Aeby).

Tenslotte verdient nog vermelding dat het naar Belgisch recht mogelijk is dat de appartementseigenaars uit hun midden een raad van beheer benoemen. Deze raad van beheer heeft tot taak de administrateur te assisteren en regelmatig te controleren ${ }^{74}$.

\subsection{Rechten en verplichtingen van de appartementseigenaars}

De rechten en verplichtingen van de appartementseigenaars zijn neergelegd in artikel 577bis BW en in het reglement van splitsing en eventueel een huishoudelijk reglement. Ingevolge artikel $577 \mathrm{bis} \S 4 \mathrm{BW}$ mag jedere medeëigenaar in beginsel vrij over zijn aandeel in de gemeenschap beschikken en het met zakelijke rechten

74. Vgl. Kadaner, blz. 225-227; Aeby, blz. 444; Vileyn, blz. 43. 
bezwaren (art. 577bis $\$ 4 \mathrm{BW}$ ) ${ }^{75}$. Aangezien de deelgenoot vrij is te beschikken ten aanzien van zijn aandeel, mag hij

"a fortiori, het beheer ervan waarnemen. Zo zal hij geldig zijn aandeel in een onverdeeld onroerend goed kunnen verhuren, zelfs aan een deelgenoot", aldus Derine ${ }^{7 \%}$.

Het modelreglement Aeby sluit hierbij met betrekking tot appartementseigendom aan. Dit tweede hoofdstuk begint bij artikel 3.01 van het modelreglement Aeby, dat bepaalt:

"De eigenaars zijn gerechtigd in beschikking en genot van hun onderscheidene appartementen binnen de door de wet en het huidig reglement gevestigde grenzen."

Dit artikel is een belangrijke bepaling, aangezien erin wordt geregeld dat iedere eigenaar in beginsel onbeperkt bevoegd is om over zijn appartement naar goeddunken te beschikken. Alleen het reglement en de wet geven de grenzen van deze bevoegdheid aan ${ }^{7}$. Beperking van de beschikkingsbevoegdheid komt in het modelreglement Aeby bijvoorbeeld tot uiting in artike1 3.02, waarin wordt bepaald dat een appartementseigenaar niet bevoegd is zijn appartement onder te splitsen ${ }^{78}$. Een appartementseigenaar heeft normaal gesproken wel het recht zijn appartement onder te splitsen. In het reglement van splitsing kan de bevoegdheid om onder te splitsen echter geldig worden beperkt of kan ondersplitsing zelfs worden verboden, zoals in het modelreglement Aeby ook het geval is (zie ook par. 5.3.2) ${ }^{79}$.

Het gebruik wordt bijvoorbeeld beperkt in artikel 3.07 modelreglement Aeby, dat ten aanzien van de appartementen van de etages (dus alle appartementen die niet op de begane grond liggen) bepaalt dat zij zijn voorbehouden om dienst te doen voor bewoning, tenzij de vergadering van eigenaars toestemming geeft om in de appartementen een beroep uit te oefenen ${ }^{80}$.

Iedere appartementseigenaar heeft verder bijwoorbeeld het recht om aan zijn deur een naamplaatje aan te brengen (vgl. art. $3.14 \$ 2$ modelreglement Aeby). In het reglement kan echter wel een aanplakverbod worden opgenomen, waarin het recht om affiches e.d. aan te brengen, kan worden beperkt ${ }^{81}$. Dergelijke verboden moeten echter met de nodige voorzichtigheid worden gehanteerd, omdat zij spoedig een aantasting van de grondrechten van de appartementsgebruikers kunnen betekenen.

75. Vgl. Dekkers, blz 543, 547; De Page/Dekkers, blz. 1027.

76. Derine e.a., blz. 21. Anders kennelijk: Dekkers, blz. 550.

77. Een eigenaar van een "autostaanplaats", als afhankelijk prive-deel van zijn appartement, is niet bevoegd om zijn parkeerplaats met een muur van andere parkeerplaatsen af te scheiden, tenzij dit uit het reglement voortwloeit. Vrederechter Antwerpen 19 febr. 1985, Tijdschrift voor Notarissen 1986, blz. 244-248.

78. Aeby, bly. 197, 198 .

79. Acby, blz. 197, 198.

80. Aan een dergelijke clausule, opgenomen in cen koopovereenkomst, werd door bet Hof Brussel het karakter van een erfdienstbaarheid toegekend. Zie Hof Brussel 10 juni 1971, Rev. Crit. Jur. B. 1973, blz. 573-608 met noot P. Dehan, M.L. Stengers.

81. Acby, blz. 298, 299, 488. 
Hierbij kan een vonnis van de rechtbank Brussel ${ }^{82}$ worden aangehaald. In casu moest de Brusselse rechter beslissen in een geval, waarin het reglement van medeëigendom bepaalde:

"Il est interdit de faire de la publicité sur l'immeuble, d'apposer des inscriptions aux fenêtres et balcons, portes, murs et escaliers, seule est autorisé la plaque de chaque copropiêtaire, plaque dont la dimension et le caractère sont determinés par le gérant."

Een appartementseigenaar had aan zijn deur echter een etui ter grote van een sigaret, met daarin een "mezouza" ${ }^{83}$ bevestigd. De bevestiging van de mezouza aan de deur is een voor joden verplichte geloofsuiting. In dit geval leverde de bevestiging van deze mezouza aan de deur volgens de Brusselse rechtbank geen verkeerd gebruik van de gemene delen op. Bovendien, zo overwoog de Brusselse rechtbank, garandeert de Belgische grondwet de vrijheid van godsdienst. Ook daarom was de bevestiging van de mezouza aan de deur toegestaan.

Als overkoepelende regeling wordt vervolgens in het reglement bepaald dat de appartementseigenaars, huurders, het huispersoneel en de andere bewoners het appartement dienen te betrekken en te bewonen als goede huisvaders. $\mathrm{Zij}$ moeten ervoor zorgen dat de rust in het gebouw nooit door hun toedoen wordt gestoord. De huurders zullen door middel van de huurovereenkomsten de verplichting opgelegd krijgen het door hen gehuurde appartement als een goed huisvader te betrekken en te bewonen en de bepalingen van het reglement na te leven (artt. 3.06, 3.09 modelreglement Aeby).

De omvang van de aandelen van de verscheidene (gewone) medeëigenaars wordt ingevolge artikel 577bis $\S 2 \mathrm{BW}$ vermoed gelijk te zijn. Deze bepaling behelst echter slechts een praesumptio juris tantum waarvoor tegenbewijs is toegelaten ${ }^{84}$. In paragraaf 3 van artikel $577 \mathrm{bis}$ BW is neergelegd dat iedere medeëigenaar deel heeft in de rechten en bijdraagt in de lasten van de eigendom naar rato van zijn aandeel. Ten aanzien van de kostenverdeling wordt in artikel 577bis $\$ 7 \mathrm{BW}$ nader bepaald dat iedere medeëigenaar moet meedragen in de kosten voor behoud, onderhoud, beheer en belastingen van de gemeenschappelijke zaak ${ }^{85}$. De kostenverdeling wordt in het modelreglement nog verder uitgewerkt. Zo wordt in

82. Rb. Brussel 11 febr. 1961, J.T. 1961, 686.

83. Oppenheimer, nir. 500 vermeldt hierover." "Mesusa. [ hebr. Türpfosten"] Bezeichnung einer auf Pergament geschriebenen Inschrift, die in eimem mit einer Öffnung versehenen Behälter so gerollt wird, dass das. Wort Schaddai ["Allmächtiger"] sichtbar ist. In wörtlicher Auffassung von Dt. 6, 4-9; 11, 13-21 am rechten "Türpfosten angebracht."

84. Derine e.a., blz 20. Zie ook Cambron, blz. 27. Vgl. art. $875 \mathrm{~g}$ BW dat stelt dat in Nederland de aandelen die. door splitsing in appartementsrechten ontstaan, gelijk zijn, tenzij bij akte van splitsing anders is bepaald.

85. Dekkers, blz. 550; De Page/Dekkers, blz. 1031-1039. Bij verhuring van een appartement moeten de kasten van beheer van het appartement door de huurder en verhuurder gezamenlijk gedragen worden, indien ten aamzien wan deze kosten niets overeengekomen is. Vrederechter Etterbeek 2 juni 1980, J J.P. 1981, 15-19. Vgl. ook artt. 24 en 26 van het hierna besproken reglement. Zie over de verhaalsmogelijkheden op een insolvabele appartementseigenaar, De Vroe, blz 204-215. Zie ook Cuvelier; Beslagrechter Brussel 24 nov. 1983, Rec. Gém. Enr. Not. 1985, 23128. 
de artikelen 4.01 tot en met 4.11 van het modelreglement Aeby een regeling voor de verdeling van de gemene lasten en ontvangsten gegeven. Iedere appartementseigenaar is bijvoorbeeld ingevolge artikel 4.01 gehouden om bij te dragen in de algemene uitgaven voor onderboud, bewaring en herstelling van de gemene delen en in andere gemeenschappelijke kosten, zoals bepaald in het reglement (vgl. artt. 4.01, 4.02 modelreglement Aeby) ${ }^{86}$.

Indien een der medeëigenaars in gebreke blijft zijn aandeel in de algemene kosten bij te dragen, kunnen de overige medeëigenaars een actie tot betaling tegen hem instellen. Deze actie verjaart na 30 jaar. Op grond van het modelreglement Aeby kan de administrateur bovendien gas, water en licht van een in gebreke blijvende appartementseigenaar laten afsluiten (vgl. ook 4.09 modelreglement Aeby) ${ }^{87}$.

Interessant is de regeling die in artikel $4.08 \S 2$ van het modelreglement Aeby wordt gegeven ten aanzien van achterstallige bijdragen van een appartementseigenaar die zijn appartement overdraagt. Volgens deze bepaling is de verkrijger aansprakelijk voor deze achterstallige bijdragen. De Brusselse Rechtbank heeft hieromtrent echter beslist dat een dergelijke bepaling geen zakelijke werking heeft en daarom niet tegen de verkrijger kan worden ingeroepen ${ }^{88}$.

Evenals de kosten worden ontvangsten die voortvloeien uit de gemene delen, in beginsel over alle eigenaars naar evenredigheid van hun aandeel in de gemeenschappelijke delen, verdeeld (art. 4.11 modelreglement Aeby).

Iedere appartementseigenaar heeft behalve recht op het gebruik van zijn privégedeelten, recht op het gebruik en genot van de gemeenschappelijke zaak (aangezien hij tevens medeëigenaar is), met dien verstande dat dit gebruik en genot in overeenstemming moet zijn met de bestemming van de zaak en verenigbaar moet zijn met de rechten van de deelgenoten ${ }^{89}$. In paragraaf 9 van artikel 577 bis BW worden bijzondere bepalingen gegeven met betrekking tot de zogenaamde gedwongen medeëigendom, waaronder de gemeenschappelijke gedeelten van een appartementsgebouw vallen. Deze paragraaf geeft een regeling voor onverdeelde onroerende goederen die als bijzaak bestemd zijn tot gemeenschappelijk gebruik van de eigenaars van twee of meer aan verschillende eigenaars toebehorende erven. Hierbij kan men in het algemeen denken aan een drinkplaats tussen twee weiden of bij appartementen aan een lift in een appartementsgebouw $\%$. De hier bedoelde onroerende goederen zijn niet vatbaar voor verdeling en kunnen niet

86. Als een gedeelte van een gebouw privatief aan een van de appartementseigenaars toebehoort, wil dit niet zeggen dat de kosten van onderhoud van deze gedeelten niet ten laste van de gemene delen komt. De Vrederechter te Schaarbeek theeft beslist dat onderhoud van terrassen op de hoogste verdieping van cen appartementsgebouw, ook als de terrassen privatief zijn, ten laste van de gemene delen komt omdat de terrassen in de eerste plaats als dakbedekking dienen. Virederechter Schaarbeek, Res et jura immobilia, 1978, nir. 5668.

87. Rb. Brussel 4 jan. 1983, Rec. Gen. Enr. Not. 1984, nr. 23054. Vgl. ook Hof Antwerpen 18 jan. 1984, RW 1983-1984, 2336, Rec. Gén. Enr. Not. 1984, nr. 23055.

88. Tegelijkertijd besliste de rechtbank dat de schulden aan de gemeenschap, geen bevoorrechte schulden zijn. Rb. Brussel 20 mei 1988, Rev. Liège 1989, blz 160-163.

89. De Page/Dekkers, blz. 1029.

90. Zie ook Derine e.a., blz. 64 . Vgl. ook de (niet limitatieve) opsomming van de gemeenschappelijke zaken in art. $577 b$ is $\$ 11 \mathrm{BW}$. 
zelfstandig worden vervreemd of bezwaard. De medeëigendom van de gemeenschappelijke zaak is hier dus accessoir aan het eigendomsrecht van de zelfstandige onroerende zaken ${ }^{91}$.

Elke medeëigenaar van een gemeenschappelijke zaak als bedoeld in paragraaf 9 van artikel 577 bis BW mag op eigen kosten veranderingen aan de gemeenschappelijke zaak aanbrengen, voor zover hij daardoor de bestemming van de zaak niet wijzigt en geen afbreuk doet aan de rechten van zijn deelgenoten (art. 577bis $\$ 10 \mathrm{BW})^{92}$. Het plaatsen van een antenne op het dak van een appartementsgebouw is bijvoorbeeld in overeenstemming met artikel 577bis BW. De Vrederechter in Sint Jans Molenbeek overwoog hierover:
"Attendu qu'en plaçant une antenne de television sur le toit, partie commune de l'immeuble, et en faisant procéder au placement de gaines dans le hall commun de cet immeuble pour donner passage a son câble d'antenne, le défendeur m'a fait qu'user du droit que lui donnent les dispositions de l'article 577bis du Code civil, qui prevoient notamment que le coproprietaire peut user et jouir de la chose commune conformé- ment a sa destination et dans la mesure compatible avec les droits de ses consorts (C.civ. art. 577bis, $\S 5$ ) et qui prévoient également que chacun des copropriétaires peut modifier à ses frais la chose commune pourvu qu'il n'en change pas la destination et qu'il nuise pas au droits de ses consorts"...

De televisieantenne mocht op het dak worden geplaatst, omdat zij de bestemming van de gemeenschappelijke zaak niet wijzigde en evenmin afbreuk deed aan de rechten van de overige deelgenoten ${ }^{93}$.

In het modelreglement wordt het gebruik van de onder artikel $577 b i s \S 5$ en 9 $B W$ vallende gemeenschappelijke gedeelten nader uitgewerkt. Op grond van artikel 3.11 modelreglement Aeby vindt de gebruiksbevoegdheid bijvoorbeeld zijn grenzen ook nog in de rechten van de overige appartementsgebruikers. In de gemeenschappelijke gedeelten mogen bijvoorbeeld geen voorwerpen worden achtergelaten of opgeslagen, waardoor het gebruik van deze gedeelten belemmerd wordt. Indien slechts éen medeëigenaar het genot van een gemeenschappelijke zaak heeft, is hij overigens gehouden de ander(en) daarvoor een vergoeding te geven ${ }^{94}$.

91. Derine exa., blz. 64. Vgl. ook Dekkers, blz. 557. Beslag op een prive-gedeelle van een appartementseigenaar brengt tevens beslag op zijn aandeel in de gemeenschappelijke zaak mee, Hof Luik 3 dec. 1981, J.L. 1982, bllz, 177.

92. Vgl. Villeyn, blz 20, 27, 28; Dekkers, blz. 555; Rb. Aarlen 17 jan. 1964, J.L. 1966-1967, blz. 289. Het aanbrengen van een venster met uitzicht op een gemeenschappelijk erf wordt niet beschouwd als het wijzigen van de bestemming van de zaak of het afbreuk doen aan de rechten van de overige deelgenoten; Cass. 22 mei 1975, Arresten van het Hof van Cassatie 1975, 1008, 1009, RW 1975-1976, 1272; Cass. 21 nov. 1929, Pas. 1930, 1, 27. Alls een medeęigenaar zonder toestemming van de overige deelgenoten aan de gemeenschappelijke zaal veranderingen aanbrengt die de bestemming daarvan wijzigen en de overige deelgenoten in hun rechten krenken, kan elke eigenaar die daarvan nadeel ondervindt alleen optreden om afbraak van de aangebrachte veranderingen te vorderen. Zie Cass. 7 jan. 1966, RW 1965-1966, 1849-1853.

93. Vrederechter Sint Jans Molenbeek 29 nov. 1960, J.T. 1961, blz. 354.

94. Rb. Mechelen 21 april 1981, RW 1981-1982, 689. 


\subsection{Toelating en ontzegging van verder gebruik}

\subsubsection{Algemene opmerkingen}

Anders dan in het Nederlandse recht staan er in het Belgische reglement van medeëigendom niet expliciet bepalingen opgenomen die het de algemene vergadering van eigenaars mogelijk maken om bewoners/eigenaars die niet in de appartementsgemeenschap passen, te weren c.q. uit de gemeenschap te zetten. De vraag die hierbij opkomt is of men dan in België geen behoefte aan een soort "welstandsbepalingen" heeft of dat men ze wellicht niet mogelijk acht. Hiervoor moet echter eerst worden nagegaan of een soort "welstandsbepalingen" niet toch voorkomt in België. Indien ze toch voorkomen, dient te worden onderzocht op welke wijze ze gehanteerd worden en waar men in Belgiê de grenzen voor de toelaatbaarheid van ontzeggingsbepalingen trekt. Indien ze niet voorkomen, zal worden onderzocht welke redenen aan het ontbreken van deze ontzeggingsbepalingen ten grondslag liggen.

Een aanwijzing voor het antwoord op de vraag of iets vergelijkbaars met welstandsbepalingen in België voorkomt, kan worden gevonden in het modelreglement. Artikel 3.01 van het modelreglement Aeby bepaalt immers dat iedere eigenaar weliswaar in beginsel vrij kan beschikken over zijn appartement, maar voegt daar áan toe dat deze vrije beschikking zijn grenzen vindt in de bepalingen van het reglement. Artikel 3.07 geeft dan vervolgens al enige grenzen aan. De appartementen zijn immers bestemd om als "woning" dienst te doen (met uitzondering van de appartementen op de begane grond, die een handelsbestemming hebben). Daarenboven moeten ze "op burgerlijke wijze" worden bewoond (art. 3.09 modelreglement Aeby). Bovendien mag men bepaalde beroepen niet witoefenen (in het modelreglement Aeby niet nader ingevuld in art. 3.07). De wraag is echter of de bepalingen van het modelreglement tanden hebben, met andere woorden: welke sancties staan er op overtreding van het in het reglement geregelde of welke waarborgen zijn er dat geen personen de appartementen betrekken, van wie te duchten valt dat zij deze bepaling van het reglement niet naleven. Het reglement zelf biedt geen uitkomst bij de beantwoording van deze vraag.

Ten aanzien van de waarborgen die zouden moeten bewerkstelligen dat personen die zich niet aan de bepalingen van het reglement (zullen) houden, niet een appartement betrekken, zou men aan (in het reglement opgenomen) vervreemdingsbeperkingen kunnen denken. Hierop zal in het navolgende allereerst worden ingegaan.

Daarna zal de vraag worden behandeld wat appartementseigenaars kunnen ondernemen tegen een persoon die de "welstand" van een gebouw in gevaar brengt en welke beroepsmogelijkheden deze persoon tegen die acties van de overige eigenaars heeft.

\subsubsection{Toelating: de venreemdingsbeperkingen}

De appartementseigenaar is in beginsel vrij om zijn appartement te verkopen aan wie hem goeddunkt. Er bestaat geen enkele wettelijke verplichting voor de verkoper om de appartementsgemeenschap of de administrateur in te lichten over 
een voorgenomen overdracht (vgl. echter art. 4.08 modelreglement Aeby). De owerdracht van een appartement heeft tevens tot gevolg dat de accessoria (i.e. onder andere het aandeel in de gemeenschappelijke delen) mede overgedragen worden ${ }^{\text {s5 }}$.

De eigenaars van appartementen in een appartementencomplex zijn echter afhankelijker van elkaar dan eigenaars van gewone huizen. Aeby noemt hierbij het voorbeeld dat bepaalde personen samen het appartementsgebouw hebben gebouwd, terwijl daarbij de combinatie van de verschillende persoonlijkheden een belangrijke rol speelde. Kunnen deze personen niet, zo vraagt Aeby zich af, zij het slechts tijdelijk, iedere nieuwe persoon van de gemeenschap die zij onderling vormen, uitsluiten ${ }^{\%}$ ?

"Quelle est la valeur d'une clause d'inalienabilité en droit belge?" 97

De (absolute) vervreemdingsverboden die slechts niet gelden met betrekking tot testamenten en schenkingen, zijn volgens Aeby in beginsel strijdig met de openbare orde die belang heeft bij een vrij verkeer van goederen (art. $537 \mathrm{BW})^{98}$.

Vervreemdingsbeperkingen/verboden zijn slechts op twee voorwaarden geldig ${ }^{99}$. De eerste voorwaarde is dat de vervreemdingsbeperking in de tijd beperkt moet zijn. Een verbod om een appartement te verkopen gedurende het leven van de eigenaar lijkt vernietigbaar omdat dit verbod als eeuwig moet worden beschouwd ${ }^{100}$. Ten tweede moet aan de vervreemdingsbeperking een rechtmatig belang ten grondslag liggen. Aeby baseert zich op de Franse doctrine als hij vervolgens beweert dat een dergelijk rechtmatig belang is aangetoond, als de verscheidene eigenáars gezamenlijk het appartementencomplex hebben verworven of hebben doen bouwen, samen bepaalde financiële transacties hebben verricht of bepaalde werken hebben gepland ${ }^{101}$.

In de praktijk kan men, aldus Aeby, de vervreemdingsbeperkingen op diverse wijzen gestalte geven. Men kan bijvoorbeeld in het reglement het verbod opnemen om een appartement te vervreemden zonder toestemming van de algemene vergadering van eigenaars, terwijl de akte de vereiste meerderheid en het quorum van de vergadering bepaalt. De wederkerigheid die door partijen is afgesproken onderstreept de rechtmatigheid van het belang, die een vereiste is voor de geldigheid van de vervreemdingsbeperking. Ook voor deze toestemmingsregeling geldt overigens het vereiste dat haar gelding in de tijd beperkt moet zijn ${ }^{102}$.

De geldigheid van vervreemdingsbeperkingen staat echter mijns inziens naar Belgisch recht geenszins vast. Afgezien van een vonnis van een lagere rechter, zijn dergelijke clausules in de Belgische jurisprudentie niet gesanctioneerd. Bovendien baseert Aeby zich voor zijn standpunt op de Franse doctrine, die vervreemdings-

95. Aeby, blz 193.

96. Aeby, blz. 194.

97. Aeby, blz. 194 .

98. Vgl. Derime e.a., blz. 149; Aeby, blz. 194. Deze verwijst naar Franse rechtspraak, die absolute verwreemdingsverboden ongeldig verklaart. Vgl. par. 7.3.2.

99. Rb. Ieper 24 dec. 1858, Rev. Prat. Not. 1959, blz 253-255.

100. Aeby, blz 195.

101. Aeby, blz. 195 en Kischinewski-Broquisse, blz. 239, 240 .

102. Aeby, blz 195. 
beperkingen ten aanzien van het Franse recht verdedigt. Het Franse Hof van Cassatie heeft echter in een vaste jurisprudentie een verbod van veryreemdingsbeperkingen uitgesproken (zie par. 7.3.2). Het is best mogelijk dat de hoogste Belgische rechter het Franse Hof van Cassatie op dit terrein zou volgen.

Indien de appartementseigenaars zich niet op het onzekere terrein van deze vervreemdingsbeperking willen begeven, hanteren zij een formule die buiten elke kritiek staat. Men neemt dan in het reglement een bepaling op die voorziet in een voorkeursrecht op het appartement ten behoeve van de gemeenschap van appartementseigenaars ${ }^{103}$. Het probleem dat aan deze constructie kleeft is echter dat er een grote financiële druk op de overige appartementseigenaars wordt gelegd. Indien zij van thet voorkeursrecht gebruik maken, moeten zij immers de koopprijs voor het appartement betalen. Hierbij doet zich ook nog eens het feit voor dat vooral kleinere appartementsgemeenschappen behoefte zullen hebben aan invloed op de bewonerssamenstelling. In een kleine gemeenschap is men immers meer van een andere appartementseigenaar afhankelijk dan in een grote. Juist het geringe aantal appartementseigenaars in een kleine appartementsgemeenschap zou echter de kosten van de aankoop van een te verkopen appartement moeten dragen. Interessant is dat het voorkeursrecht door Aeby niet onder de noemer vervreemdingswerboden (waaronder hij wel de toestemmingsregeling rangschikt) wordt gebracht. Kennelijk gelden voor deze vervreemdingsbeperking niet de vereisten van legitiem belang en beperkte geldigheid in de tijd.

Overigens kan zoals in de vorige paragraaf werd vermeld, in het reglement ook geldig worden bepaald dat een appartementseigenaar niet bevoegd is zijn appartement onder te splitsen. Ten aanzien van een mogelijke beperking van de bevoegdheid van een appartementseigenaar om zijn appartementseigendom te bezwaren, bestaat in België geen duidelijkheid. Noch in de Belgische doctrine, noch in de jurisprudentie, wordt gewag gemaakt van een mogelijkheid om in het reglement deze bevoegdheid te beperken. Aangezien het naar Belgisch recht mogelijk is om een appartementseigenaar in zijn bevoegdheid tot vervreemding te beperken, zou men wellicht a fortiori kunnen aannemen dat een beperking van de bevoegdheid tot bezwaring ook mogelijk is ${ }^{104}$.

Minder twijfel dan over de geldigheid van vervreemdings- en bezwaringsbeperkingen, bestaat er ten aanzien van de beperking van de bevoegdheid om te verhuren. Tenzij in het reglement anders is bepaald, kan een appartementseigenaar zijn appartement verhuren

"a qui bon lui semble et aux fins les plus diverses." 105

De eigenaar kan zijn huurder toestemming geven om zijn recht aan een onderhuurder over te dragen. Ook mag de eigenaar een gedeelte van zijn appartement verhuren.

103. Aeby, blz 195. Deze wijst erop dat een dergelijk woorkeursrecht in Frankrijk onverenigbaar met de Franse wet is verklaard.

104. Vileyn, blz 48 , stelt dat cen verbod om te verhypothekeren ondenkbaar is.

105. Aeby, blx 219. 
Het reglement kan echter aan de eigenaars de verhuring van hun appartement werbieden ${ }^{106}$. Ondanks het feit dat een dergelijk verbod toegestaan is, komt het volgens Aeby ${ }^{107}$ weinig voor. Eerder treft men in het reglement een bepaling aan, waarin de verhuring aan de voorafgaande toestemming van de algemene vergadering van eigenaars wordt onderworpen. Nog vaker treft men volgens Aeby ${ }^{108}$ echter het verbod aan om een appartement gedeeltelijk te verhuren. Eveneens frequent wordt de keuze van de verhuurder van zijn huurders beperkt door verhuur met het oog op de uitoefening van een beroep of handel, te verbieden. Soms geschiedt dit uitdrukkelijk, soms impliciet door de bepaling dat de appartementen slechts mogen worden verhuurd voor bewoning. Deze clausules moeten volgens Aeby

"être rédigées avec beaucoup de soin, leur imprécision étant de nature a causer du tort aux propriétaires." 109

In het modelreglement van Aeby is in de eerste zes leden van artikel 3.06 een regeling opgenomen met betrekking tot toelating van huurders tot appartementen. Artikel 3.06 luidt:

"\$ 1. Verhuring van de winkel- en woonappartementen door hun eigenaar kan enkel ten voordele van eerbare en solvabele personen geschieden. Dit geldt tevens in geval van onderhuur of afstand van huur.

§ 2. Appartementen mogen niet stuksgewijs worden verhuurd. Dit verbod geldt niet wanneer een kelder, die aan een appartement is verbonden, aan een huisgenoot in huur gegeven wordt.

\$3. De letterlijke tekst van de artikels 3.06 tot en met 3.10 dient in alle huurcontracten van appartementen opgenomen, of er aangehecht te worden.

Aan de huurders van appartementen moet de naleving worden opgelegd van bedoelde artikels en van de desbetreffende wijzigingen, benevens de voorschriften en besluiten van de algemene vergadering wanneer deze de huurders aanbelangen.

De bij geschrift gesloten huurovereenkomst dient te worden opgemaakt naar een door de beheerder ter beschikking gesteld model.

\$4. De eigenaars verbinden zich de huurders de verplichting op te leggen hun huurrisico's en hun verantwoordelijkheid jegens de huisgenoten en de buren, voldoende te verzekeren.

106. Derine e.a., blz. 154.

107. Aeby, blz. 219.

108. Aeby, blz 220.

109. Aeby, blz 220. 
85. Aan de beheerder dient door de eigenaar een afschrift van het huurcontract te worden verstrekt.

Bij mondelinge overeenkomst, behoeft de eigenaar het bewijs te leveren dat aan het voorschrift van $\S 3$ werd voldaan.

\$6. Volmacht wordt hierbij door de eigenaars aan de beheerder verleend om huurders in kennis te stellen van de wijzigingen van onderhavig reglement, verder van de voorschriften en besluiten van de algemene vergadering die hen aanbelangen."

De verhuurder dient zijn potentiële huurders blijkens artikel $3.06 \S 1$ aan een "welstandsonderzoek" te onderwerpen. De tweede paragraaf verbiedt het gedeeltelijk verhuren van appartementen. Om er zeker van te zijn dat de huurders de gebruiks- en genotsbeperkingen uit het reglement kennen, bepaalt $\$ 3$ dat de artikelen 3.06 tot en met 3.10 integraal in de huurcontracten moeten worden overgenomen. Bovendien moet de naleving van de besluiten van de algemene vergadering van eigenaars aan de huurders worden opgelegd.

Kort resumerend kan worden gesteld dat toelatingsregelingen in België nauwelijks worden gehanteerd, terwijl met name de geldigheid van vervreemdingsbeperkingen aan strenge woorwaarden is gebonden. Een absoluut vervreemdingsverbod is nietig, maar een vervreemdingsbeperking is wellicht mogelijk in de vorm van de opneming van een voorkeursrecht ten behoeve van de appartementseigenaars of in de vorm van een toestemmingsregeling voor vervreemding. De vervreemdingsbeperkingen zijn echter slechts geldig indien zij in de tijd beperkt zijn en hun fundamenten vinden in een rechtmatig belang. Aan de andere kant zijn beperkingen van verhuring of zelfs een verbod van verhuur mogelijk. In de praktijk komen verhuringsverboden echter zelden voor. Vaker treft met toestemmingsregelingen voor verhuur of een verbod om gedeelten van een appartement te verhuren, in het reglement aan ${ }^{110}$.

De vraag die nu opkomt, is welk gevolg aan overtreding van de vervreemdingsbeperkingen of verhuurbeperkingen moet worden verbonden? Als een appartementseigenaar zijn appartement verkoopt zonder toestemming aan de overige eigenaars te vragen, gaat dan de eigendom toch over? Mutatis mutandis kan men zich afvragen wat het gevolg is van verhuring in strijd met verhuringsbeperkingen of andere bepalingen van het reglement. In België kent men aan de bepaling van bestemming voor bewoning (vgl. art. 3.07 modelreglement Aeby) en aan andere beperkende clausules ${ }^{111}$ een zakelijk karakter toe en derhalve inroepbaarheid tegen derden (vgl. art. 1 hypotheekwet) ${ }^{112}$. Dit zou betekenen dat ook de zakelijke verhuurbeperkende clausules derdenwerking hebben en tegen een huurder kunnen worden ingeroepen. Zou voor verhuur daarom bij overtreding van een beperking in de verhuringsbevoegdheid, moeten worden aangenomen dat er geen huur-

110. Aeby, blz. 219, 220 .

111. Aeby, blz. 239, $466,467,486,487$.

112. Aeby, blz 239. Zie verder: Lurquin-Stavaux; blz. 8. Zie ook Rb. Brussel 10 april 1970, Rev. Prat. Not. 1970 , blz. 455 . 
overeenkomst tot stand komt of dat er wel een huurovereenkomst tot stand komt, maar deze overeenkomst niet inroepbaar is tegen de overige appartementseigenaars? Zeker is, dat indien er geen verhuurbeperking in het reglement is opgenomen en de huurder vervolgens het gehuurde in strijd met de bepalingen van het reglement (bijvoorbeeld in strijd met de bestemming "bewoning") gebruikt, de verhuurder gedwongen kan worden om dit gebruik door de huurder te doen staken. Daarnaast kan de huurder rechtstreeks gedwongen worden om het met het reglement strijdige gebruik te staken, omdat de gebruiksbestemming derdenwerking heeft en daarom tegen hem kan worden ingeroepen. Bovendien kan de verhuurder aan de huurder ten opzichte van de overige appartementseigenaars, niet meer rechten verschaffen dan hij zelf heeft, en kan ook daarom jegens de huurder een beroep op de gebruiksbeperking worden gedaan ${ }^{113}$. Een en ander betekent overigens niet dat de huurder de verhuurder niet wegens wanprestatie zou kunnen aanspreken ${ }^{114}$. De huurovereenkomst is dan immers tot stand gekomen, terwijl de huurder niet het huurgenot van het appartement heeft.

Als een zakelijke gebruiksbeperking aan een huurder kan worden tegengeworpen, omdat de verhuurder jegens de appartementseigenaars aan de huurder niet meer rechten kan overdragen dan hij zelf heeft en de verhuurbeperkingen derdenwerking hebben, zou wellicht ook kunnen worden aangenomen dat beperkingen in de beschikkingsbevoegdheid (toestemmingsregeling, voorkeursrecht) tot gevolg hebben dat zij rechtstreeks tegen de verkrijger werken. Als een appartementseigenaar zijn appartementseigendom dan in strijd met de zakelijke vervreemdingsbeperking zou verkopen, zou dit tot gevolg hebben dat de eigendom van het appartement niet zou overgaan, omdat de beschikkingsbevoegdheid van de appartementseigenaar ingeperkt is en deze beperking tegen de verkrijger kan worden ingeroepen. Aangezien de beperking derdenwerking heeft kan zij immers ook tegen derden-verkrijgers worden ingeroepen.

Zo kan het voorkeursrecht worden opgevat als een verplichting, die tegen de koper zou kunnen worden ingeroepen. Het gevolg hiervan zou zijn, dat de voorkeursgerechtigde de verkoper eventueel wegens wanprestatie zou kunnen aanspreken, en - als gevolg van de derdenwerking van het voorkeursrecht - de koper zou kunnen verplichten om de verplichting van de verkoper alsnog na te komen en het appartement aan de voorkeursgerechtigde aan te bieden. Deze oplossing wordt ondersteund door een analoge toepassing van de bepalingen omtrent het voorkeursrecht in het pachtrecht. De Belgische pachter heeft ingevolge het Belgische pachtrecht een voorkeursrecht bij verkoop van het verpachte goed (art. 47 van de Wet van 7 juli 1951 betreffende pacht). Dit voorkeursrecht geeft aan de pachter het recht om, indien zijn voorkeursrecht wordt miskend en de eigenaar het verpachte goed aan een derde verkoopt, te vorderen dat hij in de plaats van de koper wordt gesteld. Eventueel kan de pachter in plaats daarvan schadevergoeding van de verkoper vragen (vgl. art. 51 van de wet van 7 juli 1951).

113. Zie Rb. Brussel 10 april 1970, Rew. Prat. Not. 1970, blz. 455.

114. Vgl. Rb. Brussell 10 april 1970 , Rev. Prat. Not. 1970, blz. 452-457. 
De verkoop aan de derde met miskenning van het voorkeursrecht is derhalve wel geldig, maar kan ongedaan worden gemaakt ${ }^{115}$.

Bij een regeling van toestemming tot vervreemding mag de appartementseigenaar in beginsel niet vervreemden, behoudens toestemming van de overige eigenaars. Deze vervreemdingsbeperking werkt tegen derden en kan daarom tegen een koper worden ingeroepen. Aangezien de vervreemdingsbeperking tegen hem kan worden ingeroepen, verkrijgt hij geen eigendomsrecht op zijn appartement. Dit neemt niet weg dat de koopovereenkomst in beginsell geldig is ${ }^{1116}$.

\subsubsection{Ontzegging van verder gebruik}

Zodra een appartementseigenaar een appartement heeft verworven, krijgt hij te maken met het reglement. In het reglement staan ondermeer zijn verplichtingen opgesomd. In de inleiding van deze paragraaf is aan enkele van deze verplichtingen reeds aandacht besteed. Voor de volledigheid zullen ze hieronder nog eens kort en voor zover relevant - worden opgesomd, waarbij ze tevens zullen worden besproken.

Artikel 3.01 van het modelreglement Aeby bepaalt dat ieder der eigenaars het recht heeft om van zijn privé-gedeelte te genieten en erover te beschikken binnen de grenzen vastgesteld door het reglement en de wet. Verder heeft iedere appartementseigenaar of gebruiker het recht om van de gemene delen te genieten als een goed huisvader en ze te gebruiken tot het doel waarvoor ze bestaan (art. 3.09 modelreglement Aeby).

Artikel 3.07 modelreglement Aeby geeft een concretere bepaling. Zoals reeds is vermeld bepaalt dit artikel dat de appartementen, behoudens een andersluidende beslissing van de vergadering van eigenaars, bestemd zijn om dienst te doen als woning. Bovendien moeten zij bewoond worden als door goede burgers. Slechts op de benedenverdieping mag een bedrijf worden uitgeoefend, nu daar ruimte voor handelsdoeleinden is voorzien. Blijkens artikel 3.07 mag echter geen levensmiddelenwinkel in de winkelappartementen worden uitgebaat, en is ruimte opengelaten om andere handelsactiviteiten te verbieden.

Een andere gebruiksbeperking is neergelegd in artikel $3.09 \$ 2$ modelreglement Aeby, waarin staat dat huisdieren slechts worden

"toegelaten wanneer zij niet hinderlijk zijn voor de huisgenoten."

Al met al komen deze verplichtingen van de appartementseigenaars, die eigenlijk gebruiksbeperkingen inhouden, op twee kernthemata neer ${ }^{17}$. Deze kernthemata kunnen als volgt worden omschreven:

1. behoud van het eigen karakter van het gebouw (bestemming van de privatieve delen, uitoefenen van beroepen en bewoning);

115. Een soortgelijke regeling geldt in Nederland. Vgl. Asser/Brumner, blz. 402, 403. Voorwaarde voor overdracht door de derde aan de voorkeursgerechtigde pachter is wel, dat de derde ten opzichte van de pachter onrechtmatig heeft gehandeld. Zie ook art. $56 \mathrm{~b}$ e.v. Pachtwet.

116. De Page/Dehan, blc. 161.

117. Vgl. Aeby, blz. 237. 
2. bescherming van de goede zeden, veiligheid en de rust van de bewoners ${ }^{118}$.

Aeby ${ }^{119}$ vermeldt hierbij tevens dat de Nederlandse regeling de welstandsbepalingen kent, die het doel hebben om bovenstaande oogmerken te verwezenlijken, en dat deze bepalingen hem draconisch toeschijnen. Wel vermeldt hij hierbij ook, dat deze "overdreven strenge" clausules de grote zorg om de gemeenschap van eigenaars te beschermen, weerspiegelen.

Hierbij moet men echter scherp het doel en de middelen onderscheiden. Het doel is immers in beide landen gelijk. Ook in Nederland probeert men het eigen karakter van het gebouw (1) en de goede zeden, de veiligheid en de rust van de bewoners te beschermen (2). Als middel heeft men hiervoor onder andere de welstandsbepalingen. In België heeft men dezelfde doelen. De middelen om deze doelen te verwezenlijken moeten echter nog worden bezien. Pas ma een bespreking van deze middelen kan een conclusie dat de Nederlandse welstandsbepalingen een strenger middel vormen dan eventuele Belgische maatregelen, mogelijk zijn. Bezien wij echter eerst de doelen in België in hun geheel.

\section{Behoud van het eigen karakter van het gebouw}

De bestemming van de appartementen wordt in België in het reglement geregeld. In het in de bijlage opgenomen reglement is de hoofdbestemming "bewoning". Dit komt vaak voor ${ }^{200}$. De uitzondering voor de begane grond, die eveneens in het modelreglement is opgenomen, is kennelijk evenmin ongebruikelijk.

"Dans de nombreux édifices, le rez-de-chaussée échappe à cette limitation." 121

Betekent "bewoning" nu dat er geen enkele beroepsactiviteit mag worden ontplooid in het appartement? Is zij niet verenigbaar met de uitoefening van een vrij beroep? Volgens Aeby ${ }^{122}$ moet het reglement op deze punten duidelijk antwoord geven. In het reglement dat hier als model is gekozen, wordt in artikel 3.07 echter niets over vrije beroepen vermeld.

Vrije beroepen mogen vaak in de appartementen op de begane grond worden uitgeoefend. Aeby ${ }^{123}$ wijst erop dat in het reglement duidelijk moet worden omschreven wat men onder vrij beroep verstaat. Vaak wordt het beroep van arts of dierenarts hierbij niet als vrij beroep bestempeld. Vaak ook worden bepaalde artsen van het gebruik van de appartementen uitgesloten. In elk geval geeft de

118. Deze indeling wordt ook door Aeby, blz. 237, gehanteerd.

119. Aeby, blz. 237.

120. Aeby, blz 238.

121. Aeby, blz. 238.

122. Aeby, blz. 238.

123. Aeby, blz 239, 240. 
verwijzing naar het vrije beroep aan, aldus Aeby ${ }^{124}$, dat men een zekere kwaliteit van gebruik nastreeft ${ }^{125}$.

Gebruik van appartementen voor bedrijfsmatige bezigheden wordt vaak eveneens beperkt. Het komt frequent voor dat bedrijven in beginsel wel toegelaten zijn, maar bepaalde bedrijven van deze toelating uitgezonderd zijn (vgl. art. 3.07 modelreglement Aeby) ${ }^{126}$. Vaak ook mag een privé-gedeelte niet zodanig gebruikt worden, dat daardoor het uiterlijk of de standing van het gebouw wordt benadeeld. Zo komt het volgens Aeby ${ }^{127}$ voor dat men geen provisiekasten op terrassen of balcons mag plaatsen of er was op mag hangen.

\section{Bescherming wan de goede zeden, de veligheid en de interne rust}

Uitgezonderd artikel 3.09 is in het modelreglement Aeby omtrent goede zeden, veiligheid en interne rust niets bepaald. Belgische jurisprudentie hierover ontbreekt helaas eveneens. De Franse rechter heeft echter op dit punt wel een aantal keren beslist. Zo vond de Franse rechter dat een sex-shop niet mag worden uitgebaat in een gebouw dat in een zodanige buurt is gelegen, dat de gebruikers van het gebouw niet op een dergelijke nabuurschap verdacht kunnen zijn ${ }^{128}$. In een geval van prostitutie weigerde de Rechtbank te Grenoble om de appartementseigenaars te machtigen om een eigenaresse die zich prostitueerde in haar appartement, te dwingen hat appartement te verkopen. Wel veroordeelde de Rb. Grenoble haar om haar activiteiten te staken op straffe van een hoge dwangsom ${ }^{129}$.

De veiligheid van de appartementsbewoners mag evenmin in gevaar worden gebracht. Verboden wordt vaak het bezit van ontvlambare, gevaarlijke, ongezonde of hinderlijke zaken. De rust wordt onder andere gewaarborgd door clausules met betrekking tot huisdieren en muziekinstrumenten in het reglement op te nemen (vgl. artt. 3.09 modelreglement Aeby) ${ }^{130}$.

De vraag die nu opkomt, is welke sanctie op het overtreden van het reglement staat. Met andere woorden: wat kunnen de appartementseigenaars ondernemen tegen een appartementseigenaar die in gebreke blijft zijn verplichtingen jegens de overige eigenaars na te komen, bijvoorbeeld omdat hij veel lawaai maakt, omdat hij de standing van het gebouw in gevaar brengt (bijvoorbeeld een gigolo die in zijn appartement zijn beroep uitoefent), omdat hij in strijd met de bestemming van zijn appartement handelt (bijvoorbeeld een eigenaar die in een winkelappartement een houtzagerij heeft)? Na de beantwoording van de vraag wat de overige appartementseigenaars kunnen ondernemen dient aan de orde te komen hoe zij te werk

124. Aeby, bliz. 240.

125. Vgl. Rb. Brussel 10 april 1970, Rev. Prat. Not. 1970, blz. 452-457. De vestiging in een appartement van een ministerie, ambassade of gezantschap valt niet onder de gebruiksbestemming voor "vrij beroep".

126. Vgl. Aeby, blz. 241. Deze verwijst naar Franse jurisprudentie. Vgl. par. 7.3.2. Zie over de ver* houding vrij beroep - bedrijfsmatige bezigheden: Aeby, blz, 242-244. Zie over non-concurrentiebedingen dezelfde op blz. 244,245 . Vgl. ook par. 7.3 .2

127. Aeby, bli 245.

128. Trib. gr. inst. Paris 8 april 1976, Dall 1976, IR blz. 314.

129. Trib. gr. inst. Grenoble 6 april 1964, Dall. 1964, J. blz. 317.

130. Vgl ook Aeby, biz. 247 . 
moeten gaan en welke beroepsmogelijkheden degene heeft, tegen wie men de actie onderneemt.

Bij de vraag wat de overige appartementseigenaars kunnen ondernemen tegen degene die zijn verplichtingen op grond van het reglement niet nakomt, zijn verschillende antwoorden mogelijk. Bij gebreke van maatregelen die voortvloeien uit het reglement, kan de appartementsgemeenschap gebruik maken van de verhaalsmogelijkheden die het gemene recht biedt om het misbruik van het gebruiks- en genotsrecht van de in overtreding zijnde appartementseigenaar te bestraffen. Het misbruik van de appartementseigenaar zal volgens Aeby ${ }^{131}$ in beginsel niet bestraft kunnen worden met de verplichting om het appartement te verkopen ${ }^{132}$. Een dergelijke sanctie is volgens Aeby alleen mogelijk, indien zij ondubbelzinnig voortvloeit uit het reglement ${ }^{133}$.

Hiermee zijn we bij andere sanctiemogelijkheden beland, namelijk bij sanctiemogelijkheden op grond van het reglement. De in gebreke zijnde appartementseigenaar kan in elk geval worden aangesproken wegens niet-nakoming. Hij komt immers de verplichtingen van het reglement - een contract - niet na. Men zou nu herstel in de rechtmatige toestand (nakoming) en/of schadevergoeding kunnen eisen. Kan men de appartementseigenaar ook uit zijn appartement (laten) zetten? De moeilijkheid hierbij is dat de appartementseigenaar in beginsel een normaal eigendomsrecht op zijn appartement heeft. Gedwongen verkoop van zijn appartement of een verbod om het verder zelf te gebruiken zou op "quasi-onteigening" neerkomen. Deze zou mogelijk zijn indien de wet het uitdrukkelijk toestond (quod non) of misschien indien de eigenaar zich in het reglement zou hebben verplicht om een beslissing van de algemene vergadering van eigenaars met deze strekking na te leven. Belangrijk is wat Aeby ${ }^{134}$ hierover opmerkt. Volgens hem haalt de eigenaar die regelingen van het reglement niet naleeft, zich (zoals hierboven reeds vermeld) de sancties van het gemene recht op de hals (schadevergoeding e.d.). Belangrijker nog is zijn opmerking dat het reglement zelf sancties op overtredingen kan stellen ${ }^{135}$. Deze sancties kunnen volgens Aeby variëren van simpelweg schadevergoeding tot de verplichting om het appartement te verkopen ("jusqu'a l'obligation de vendre l'appartement") ${ }^{136}$. Derine meent daarentegen dat een appartementseigenaar nooit gedwongen kan worden zijn appartement te vervreemden ${ }^{137}$. Hij baseert zich voor deze mening op artikel 11 van de Belgische Grondwet, welk artikel grosso modo overeenkomt met artikel 14 van de Nederlandse Grondwet.

Blijkbaar kan de geldigheid van een vervreemdingsverplichting derhalve worden betwijfeld ${ }^{138}$. Helaas zijn hierbij geen Belgische praktijkgevallen te noemen. Dit is

131. Aeby, blz. 236 .

132. Trib. gr. inst. Grenoble 6 april 1964, Dall. 1964, J. blz. 317.

133. Aeby, blz 236.

134. Aeby, blz 480 .

135. Volgens Aeby stelt het reglement vaak inderdaad sancties op overtredingen. Een dwangsom kan in het reglement echter niet als sanctie worden opgenomen. Deze is maar Belgisch recht slechts mogelijk op grond wan een rechterlijke beslissing. Een boetebeding kan echter wel in het reglement worden opgenomen (art. $1152 \mathrm{BW}$ ) Vgl. Aeby, blz. 335.

136. Aeby, blz. 480 .

137. Derine e.a, blz. 156.

138. Of dit minder "overdreven streng" is dan de Nederlandse welstandsbepalingen laat ik hier in het midden. Een alternatief voor gedwongen verkoop zou gedwongen verhuur kunnen zijn aan een door de algemene vergadering goedgekeurde kandidaat. Hoewell de Belgische doctrine over deze 
temeer jammer, omdat daardoor geen antwoord kan worden gegeven op enige vragen die onmiddellijk rijzen, indien de vervreemdingsverplichting geldig moet wordlen geacht. Hoe wordt dan immers de prijs van het te verkopen appartement bepaald? Is de in gebreke zijnde appartementseigenaar desnoods verplicht zijn appartement weg te schenken, of mag hij het verkopen tegen een tevoren vastgestelde prijs? Hierbij aansluitend kan men zich afvragen of, indien hij het appartement niet voor deze prijs kan verkopen, de verplichting tot verkoop wordt opgeschort of zelfs geheel vervalt. Denkbaar is bijvoorbeeld een regeling, op grond waarvan een door de rechtbank te benoemen deskundige een redelijke prijs vaststelt, die het appartement in elk geval moet opbrengen en waarvoor het appartement indien mogelijk moet worden verkocht. Bij onmogelijkheid van verkoop zou vervolgens aan de gemeenschap van appartementseigenaars (exclusief degene wiens appartement moet worden verkocht) naar mijn mening de plicht kunnen worden opgelegd het appartement aan te kopen. Al deze vragen zijn echter overbodig indien een vervreemdingsverplichting in strijd met de Belgische Grondwet moet worden geacht (vgl. par. 9.7).

Evenals bij toelating van aspirant-bewoners tot appartementen, moet op deze plaats aandacht worden besteed aan de positie van de huurder van een appartement. Daarbij moet eerst worden opgemerkt dat de verhuurder aan de huurder niet meer rechten kan toestaan dan hij zelf heeft. Daarom kan hij ook geen rechten aan de huurder toekennen, die indruisen tegen de gebruiks- en genotsbeperkingen van het reglement. Hij kan derhalve evenmin aan de huurder toestaan om het appartement in strijd met de daaraan in het reglement gegeven bestemming te gebruiken ${ }^{139}$.

Over het algemeen legt het reglement aan de verhuurder de verplichting op om in het huurcontract aan de huurder te verplichten om zich aan de bepalingen van het reglement te houden ${ }^{140}$. De verhuurder heeft ten opzichte van de huurder echter ook de plicht om hem in te lichten over het reglement. Als hij dit niet doet, zal hij aansprakelijk zijn voor de schade die de huurder lijdt indien de overige appartementseigenaars de bepalingen van het reglement tegen hem inroepen ${ }^{141}$.

Het is voor de verhuurder eveneens van belang om aan de huurder de plicht op te leggen de beslissingen van de algemene vergadering van eigenaars na te leven. Indien de verhuurder deze verplichting niet aan de huurder oplegt, is deze laatste niet gebonden aan beslissingen van de algemene vergadering, posterieur aan het huurcontract.

Een huurder, die een persoonlijk nadeel lijdt door een andere huurder die zich niet aan het reglement houdt, zou volgens Aeby in rechte tegen de andere huurder kunnen optreden ${ }^{142}$. In België is echter anders beslist. In 1976 moest de Brusselse rechtbank ${ }^{143}$ namelijk beslissen over een strijd tussen twee huurders. De huurder die de actie tegen de ander was begonnen, dagvaardde zijn verhuurder, maar ook de huurder van het andere appartement. De Brusselse rechtbank besliste dat de

mogelijkheid zwijgt, lijkt zij, mits ondubbelzinnig in het reglement opgenomen, geldig.

139. Aeby, blz 208, 220.

140. Over de verplichtingen van de huurder om bij te dragen in de gemeenschappelijke lasten: zie Aeby, blz. 224-229.

141. Aeby, blz. 221.

142. Aeby, blz 224.

143. Rb. Brussel 30 maart 1976, J.T. 1976, 410. 
huurder ten opzichte van de eigenaar-verhuurder geen beroep kon doen op persoonlijke bepalingen van het reglement. Evenmin kon de huurder de verhuurder dwingen op te treden om de bepalingen van het reglement te doen eerbiedigen door zijn medeëigenaar te dagvaarden. De eigenaar was namelijk op grond van artikel $1725 \mathrm{BW}$ niet verplicht om zijn huurder te vrijwaren tegen feitelijke stoornis door derden. De vordering tegen de andere huurder werd eveneens afgewezen, ten eerste vanwege het feit dat de huurder(s),
"tiers à cette convention (het reglement, R.M), destinée à règler les rapports entre copropriétaires, ne sont pas en droit de l'invoquer a leur profit."

Ten tweede werd de vordering afgewezen vanwege het feit dat de rechtbank van oordeel was dat er in casu geen sprake was van abnormale burenhinder ${ }^{144}$. Een gewone actie op grond van burenhinder is dus tussen huurders kennelijk wel mogelijk.

De tekortkoming van de huurder kan worden bestraft met ontbinding van de buurovereenkomst zonder vergoeding van schade aan de huurder. De Rechtbank Brussel moest in $1970^{145}$ beslissen over een geval waarin een eigenaar zijn appartement had verhuurd aan personen die er een handelskantoor hadden ingericht. Een eigenaar van een ander appartement stelde de hoofdvordering in tegen de eigenaar en de huurder wegens overtreding van de bepalingen van het reglement. De verhuurder-eigenaar dagvaardde op zijn beurt weer de huurder met een vordering tot vrijwaring. De rechter was van oordeel dat de huurders het appartement in strijd met zijn bestemming ingevolge het reglement gebruikten. De huurders waren aan deze zakelijke bepalingen uit het reglement gebonden, ongeacht de vraag of het reglement in de huurovereenkomst toepasselijk is verklaard. Het reglement en in elk geval de zakelijke bepalingen

"vormen een last opgelegd aan ieder appartement in het voordeel van alle appartementen en dus een soort wederkerige eridienstbaarheid." 146

De vordering tegen de eigenaar en de huurder werd gegrond verklaard. De eigenaar moest het gebruik in strijd met de bestemming doen beëindigen en schadevergoeding betalen. De huurder werd veroordeeld om het met het reglement strijdige gebruik te staken.

Appartementseigenaars kunnen dus ten allen tijde tegen huurders (van andere appartementen) optreden, indien zij de zakelijke bepalingen van het reglement niet eerbiedigen. Als huurders de persoonlijke bepalingen van het reglement niet naleven, kunnen de appartementseigenaars de eigenaar-verhuurder aanspreken, die op zijn beurt de huurder kan aanspreken, mits het reglement in de huurovereenkomst van toepassing is verklaard.

144. Vgl. ook Vileyn, bla 40.

145. Rb. Brussel 10 april 1970, Rev. Prat. Not. 1970, blz. 452-457.

146. Vileyn, ble 40 . 
Hierbij kan worden verwezen naar $\$ 7$ van artikel 3.06 modelreglement Aeby, die een ontzeggingsregeling ten aanzien van huurders bevat. Deze paragraaf luidt:

"Bij owertredingen door een gebruiker van een beschikking van het charter van het gebouw, kan de eigenaar, na een tweede verwittiging van de beheerder, gedwongen worden de verbreking van de hurovereenkomst te vervolgen."

Een huurder kan dus uit zijn appartement worden gezet, indien hij een van de bepalingen van de hele akte niet naleeft. Alle bepalingen uit het reglement moet derhalve door de huurder worden gerespecteerd, ondanks het feit dat in het reglement nergens expliciet staat vermeld, dat de verhuurder in een huurcontract de verplichting voor de huurder moet opnemen om de bepalingen van het reglement na te leven ${ }^{147}$. Interessant hierbij is tevens de constructie die wordt gehanteerd om een huurder uit zijn appartement te kunnen zetten. De eigenaar krijgt waarschuwingen en zal, indien het gedrag van de huurder niet verbetert, gedwongen worden om het huurcontract met de huurder te verbreken ${ }^{148}$.

Bij deze bepaling uit het reglement Aeby kan tenslotte worden opgemerkt dat enige procedurevoorschriften en ontzettingscriteria in de akte op hun plaats zouden zijn ter bevordering van de rechtszekerheid van de huurder.

Kort samengevat kunnen aan een appartementseigenaar die de bepalingen van het reglement niet naleeft, hetzij omdat hij het eigen karakter van het gebouw (door gebruik van een appartement in strijd met de bestemming bijvoorbeeld) in gevaar brengt, hetzij omdat hij de goede zeden, de veiligheid en de interne rust in gevaar brengt, de sancties van het algemene recht worden opgelegd. Deze sancties variëren van een veroordeling tot schadevergoeding tot - althans volgens Aeby - de oplegging van de verplichting om het appartement te verkopen; dit laatste echter alleen indien deze sanctie in het reglement is opgenomen. Derine meent echter dat een appartementseigenaar nooit tot verkoop van zijn appartement kan worden gedwongen ${ }^{149}$. Deze sanctiemogelijkheid is derhalve discutabel. In elk geval bestaat er in België kennelijk weinig behoefte aan een dergelijke sanctionering van overtredingen van het reglement, nu clausules met een vervreemdingsverplichting voor bepaalde gevallen in reglementen weliswaar blijken voor te komen, maar deze clausules nog nooit tot jurisprudentie aanleiding hebben gegeven.

Een huurder die de bepalingen van het reglement overtreedt, kan in elk geval wel tot ontruiming van het door hem gebruikte appartement worden gedwongen. Veelal zullen de appartementseigenaars de verhuurder tot beëindiging van het gewraakte gebruik aanspreken. De verhuurder kan dan eventueel zelfs gedwongen worden het huurcontract te doen ontbinden.

147. Aangenomen moet worden dat dit slechts geldt, indien de huurder heeft ingestemd met de persoonlijke bepalingen van het reglement. In beginsel werken deze persoonlijke bepalingen immers niet tegen de huurder, indien een plicht tot eerbiediging van deze bepalingen niet in het huurcontract is opgenomen. Vgl. par. 5.2.1.

148. Aeby, blz 492.

149. Vgl. Aeby, blx. 480 en Derine e.a, blz. 156. 


\subsection{Beroep tegen niet-toelating of ontzegging van verder gebruik}

\subsubsection{Algemene opmerkingen}

$\mathrm{Nu}$ aan de orde is geweest welke toelatingsregelingen en ontzeggingsmogelijkheden in het Belgische appartementsrecht mogelijk zijn, dient aandacht te worden besteed aan de vraag welke rechtsmiddelen degene (verkoper) aan wie de toestemming tot vervreemding, c.q. verhuring wordt ontzegd, kan instellen. Eveneens moet aandacht worden geschonken aan de vraag welke rechtsmiddelen een eigenaar of gebruiker/ buurder ter beschikking staan, indien de overige appartementseigenaars menen dat een huurder of eigenaar de bepalingen van het reglement overtreedt.

Op grond van het reglement zullen appartementseigenaars veelal verplicht zijn alle geschillen eerst aan de algemene vergadering van appartementseigenaars voor te leggen. Deze zal, indien een akkoord tot stand komt, hiervan een schriftelijk verslag moeten laten opstellen. Als de onenigheid blijft voortbestaan, zal het geschil aan de bevoegde rechter moeten worden voorgelegd.

Volgens Vileyn bevatten reglementen bovendien vaak arbitrageclausules, op grond waarvan geschillen tussen appartementseigenaars bij gebrek aan overeenstemming in de vergadering van eigenaars, aan een arbiter moeten worden voorgelegd (vgl. art. 8.03 modelreglement Aeby). Het nadeel van arbitrage is echter dat de uitspraken zelden gepubliceerd worden en zelden algemene principes inhouden ${ }^{150}$. Arbitrage kan overigens ook ad hoc worden overeen gekomen ${ }^{151}$

Een appartementseigenaar kan in beginsel rechtstreeks tegen een andere appartementseigenaar optreden. Als appartementseigenaar heeft hij alle rechten die aan een normaal eigenaar toekomen ${ }^{152}$. Deze hoofdregel kent echter de beperking voor appartementseigendom, dat een appartementseigenaar alleen rechtstreeks tegen een ander kan optreden indien hij door de inbreuk van de ander op de verplichtingen van het reglement, aantoonbaar schade lijdt ${ }^{153}$.

In bepaalde gevallen kan echter alleen de gemeenschap van appartementseigenaars als geheel in actie komen, bijvoorbeeld indien een appartement voor commerciële doeleinden wordt gebruikt, terwijl in het reglement aan dat appartement een andere bestemming is toegekend ${ }^{154}$. Een appartementseigenaar die in zo'n geval door een andere eigenaar is benadeeld, kan de overige eigenaars aanzetten om naleving van het reglement af te dwingen. Bij het uitblijven van actie tegen de in overtreding zijnde eigenaar, kan de gemeenschap in rechte tot vergoeding van schade worden aangesproken ${ }^{155}$.

150. Vileyn, blz 50 .

151. Aeby, blz 470 .

152. Aeby, blz 477.

153. Vgl. Cass. 7 jan. 1966, RW 1965-1966, 1849-1852; Rb. Luik 16 febr. 1967, J.L. 1967-1968, blz. 2022.

154. Aeby, blz 478 .

155. Aeby, blz. 479 . 


\subsubsection{Beroep tegen niet-toelating}

Indien een appartementseigenaar geen toestemming krijgt om zijn appartement te vervreemden, kan hij een procedure beginnen bij de rechtbank van eerste aanleg die relatief competent is. Deze rechtbank van eerste aanleg en niet de vrederechter is absoluut competent, aangezien de vrederechter volgens lid 2 van artikel 591 van het Gerechtelijk Wetboek bevoegd is in geschillen

"inzake gebruik, genot, onderhoud, behoud of beheer van het gemeenschappelijk goed in geval van medeëigendom".

De vrederechter mag geen uitspraak doen in geschillen met betrekking tot beschikkingsdaden, deling of handelingen die uitstijgen boven onderhoud of beheer van gemeenschappelijke goederen ${ }^{156}$. De vrederechter mag dus niet beslissen in geschillen omtrent beschikking, gebruik, behoud of beheer van privé-gedeelten. Wel mag hij bijwoorbeeld een voorlopige administrateur benoemen over gemeenschappelijke goederen, indien de medeëigenaars het onderling over het beheer daarvan niet eens zijn ${ }^{157}$. De vrederechter is eveneens competent met betrekking tot vorderingen tot betaling van de gemeenschappelijke kosten. Een vrederechter mag echter njet beslissen in een geschil waarin medeëigenaars tegen een andere medeëigenaar een procedure aanspannen, omdat hij de gebruiksbestemming van zijn privé-gedeelten overtreedt ${ }^{158}$.

De rechtbank van eerste aanleg is derhalve bevoegd om van de geschillen tussen appartemientseigenaars onderling met betrekking tot de privé-gedeelten kennis te nemen. Deze rechtbank is namelijk bevoegd om kennis te nemen van alle geschillen die niet bij wet aan een andere rechter zijn toebedeeld. De algemene bevoegdheid van de rechtbank van eerste aanleg strekt zich uit tot rechtsvorderingen met een waarde van minstens 25000 frank (plusminus 1350 gulden) of waarvan de niet bepaalde waarde duidelijk gelijkwaardig is aan een bedrag hoger dan die som.

Zowel bij vervreemdingsbeperkingen als bij beperkingen van de verhuurbevoegdheid is de rechtbank van eerste aanleg bevoegd om kennis te nemen van de geschillen. Als een appartementseigenaar zijn appartement heeft vervreemd of verhuurd in strijd met de daaromtrent in het reglement opgenomen beperkingen, kunnen de overige appartementseigenaars daarom bij de rechtbank van eerste aanleg op grond van wanprestatie een vordering instellen tot naleving (plus evt. schadevergoeding) van de bepalingen van het reglement. De gedaagde appartementseigenaar kan dan verweer voeren of een tegenvordering instellen (art. 14 Gerechtelijk Wetboek). Anderzijds kan een appartementseigenaar die bijvoorbeeld geen toestemming van de overige eigenaars verkrijgt om zijn appartement te vervreemden of te verkopen, een vordering tegen de overige eigenaars instellen ${ }^{159}$. Nu voor een geldige vervreemdingsbeperking - als zij "überhaupt" mogelijk is -

156. Fettweis, blz, 131. Vgl. over het procesrecht bij medeëigendomsgeschillen in het algemeen: Linsmeau, blx 254 e.v.

157. Rb. Luik 19 nov. 1957, J.L. 1957-1958, blz. 76.

158. Cambier, ble 424. Anders: Vrederechter Sint-Joost-ten-Node 16 maart 1956, J.T. 1956, 346.

159. Aeby, blz. 477 . 
vereist wordt dat zij in de tijd beperkt moet zijn en in elk geval haar oorsprong moet vinden in een rechtmatig belang, kan de appartementseigenaar trachten aan te tonen dat het rechtmatig belang bij de vervreemdingsbeperking ontbreekt, of de beperking niet in de tijd gelimiteerd is. De vervreemdingsbeperking is bij het ontbreken van een van deze geldigheidsvereisten ingevolge artikel 537 BW nietig. Als de vervreemdingsbeperking geldig is, kan hij proberen aan te tonen dat in zijn concrete geval de toestemming onterecht is geweigerd, bijvoorbeeld omdat er geen gevaar bestaat voor overtreding van de bepalingen van het reglement door de koper.

Bij weigering van toestemming tot verhuring is aantasting van de beslissing van de vergadering van eigenaars moeilijker. Aan de geldigheid van een verhuringsbeperking worden immers geen bijzondere vereisten verbonden. In bepaalde gevallen zal een verhuurder echter de beslissing van de vergadering kunnen aantasten, bijvoorbeeld als de toestemming door de vergadering is geweigerd omdat de huurder het gehuurde in strijd met de bestemming zou gaan gebruiken, en de verhuurder kan aantonen dat deze veronderstelling onjuist is.

Indien de appartementseigenaars hun eventuele voorkeursrecht uitoefenen, kan de verkoper daartegen niets ondernemen. Wel kan hij bij een eventuele onjuiste toepassing van de regels omtrent het voorkeursrecht, de rechtbank van eerste aanleg inschakelen.

\section{4 .3 Beroep tegen ontzegging van verder gebruik}

Het is naar Belgisch recht zoals gezegd twijfelachtig, of op niet-naleving van de bepalingen van het reglement de sanctie kan worden gesteld, dat de in overtreding zijnde appartementseigenaar zijn appartement moet verkopen. Als deze sanctie echter mogelijk is, zullen de appartementseigenaars haar slechts via een procedure bij de rechtbank van eerste aanleg kunnen afdwingen. De appartementseigenaar die zijn appartement zou moeten verkopen, kan dan verweer voeren en bijvoorbeeld trachten aan te tonen dat hij de bepalingen van het reglement niet heeft overtreden of dat er sprake was van overmacht ${ }^{160}$. Hetzelfde geldt mutatis mutandis voor de huurder die de bepalingen van het reglement overtreedt en voor de eigenaar die wordt aangesproken om een huurovereenkomst te beëindigen. Voor het overige komen de te volgen procedures overeen met het in paragraaf 5.4 .2 beschrevene. 


\section{Bondsrepubliek Duitsland}

\subsection{Inleiding}

In West-Duitsland is, evenals in Nederland, aan het begin van de jaren vijftig een appartementenwet ingevoerd. Deze wet, het "Wohnungseigentumsgesetz" (WEG), maakt horizontale splitsing van eigendom van onroerend goed mogelijk. Voor invoering van het WEG was appartementseigendom in West-Duitsland niet mogelijk, omdat in de $\$ \$ 93$ e.v. en 946 van het op 1 januari 1900 ingevoerde "Bürgerliches Gesetzbuch" (BGB) de romeinsrechtelijke natrekkingsregel "superficies solo cedit" is neergelegd. De invoeringswet bij het BGB (EGBGB) verbood, aansluitend bij de bepalingen uit het $\mathrm{BGB}$, in $\S 189$ lid 1 sub 3 de stichting van de zogenaamde "Stockwerkeigentum" ${ }^{1}$. Deze "Stockwerkeigentum" waarbij verschillende verdiepingen van een gebouw aan verschillende eigenaars toebehoorden - is historisch gezien de voorloper van de "Wohnungseigentum" 2.

\& 131 EGBGB kende aan de verschillende Duitse landen overigens wel de bevoegdheid toe om oneigenlijke "Stockwerkeigentum" toe te staan ${ }^{3}$. Bij oneigenlijke "Stockwerkeigentum" behoorde een gebouw met de grond in medeëigendom aan de "eigenaars" toe, maar was scheiding en deling uitgesloten. Op grond van $\$$ 182 EGBGB werd voor de invoering van het BGB gestichte "Stockwerkeigentum" echter geëerbiedigd 4 .

Voorafgaand aan de invoering van het BGB was "Stockwerkeigentum" tot het begin van de $19 \mathrm{e}$ eeuw in de meeste Duitse landen mogelijk. Naarmate de tijd vorderde en het Romeinse recht aan invloed won, werd de betekenis van de "Stockwerkeigentum" echter steeds kleiner. In de 19e eeuw werd "Stockwerk-

1. De termen "GeschoBeigentum" en "Raumeigentum" zijn hiervoor als synoniemen gehanteerd. Vgl. Merle (Wohnungseigentum im System), blz. 16, 38 .

2. Ook de "Ganerbenburgen" kunnen in dit verband als voorloper van de huidige Duitse appartenentseigendom worden genoemd. "Ganerbenburgen" waren burchten, die in medeëigendom aan een "Ganerbschaft" toebehoorden. Een "Ganerbenburg" ontstond doordat de burcht door vererving of het in leen geven aan verscheidene leenmanuen, in het bezit wan verscheidene takken van eenzelfde familie of in het bezit van verschillende families terechtkwam, die allen een gebruiksrecht op cen bepaald gedeelte van de burcht hadden. Door latere vererving en/of door verkoop van erfdelien kon het aantal medeëigenalars nog groeien. De bezitters werden "Ganerben" genoemd, hetgeen zoveel betekent als "medeërlgenaam". De "Ganerbenburg"-constructie wordt al aangetroffen in het "Volksrecht" van de Alemannen, Angelsaksen, Beieren, Franken, Friezen, Langobarden, Oostgermanen, Saksen en Skandinaviërs. De benaming kon variëren van "Geanerven" en "Canerben" tot "Ganerven". Langzaam verdween de "Ganerbenburg" echter en kwam de "Stockwerkeigentum" op. Gedurende de middeleeuwen kwam de "Ganerbenburg" relatief veellvuldig voor. Vgl. Alsdorf (Untersuchungen), blz. 43. Zie ook Diester (WEG), blz 2325.

3. Tresper, blz. 21; Diester (WEG), blz. 27-31.

4. Merle (Wohnungseigentum im System), blz. 33, 34; Alsdorf, blz. 179. 
eigentum"- dat wil zeggen afzonderlijke eigendom van êtages of appartementen in de Duitse landen waar gemeen recht van toepassing was, als onverenigbaar met de grondbeginselen van het Romeinse recht, afgewezen. Merle ${ }^{5}$ wijst erop dat de "Gemeinrechtliche Lehre" er sinds Von Savigny" vanuit ging, dat afzonderlijke eigendom van verdiepingen niet mogelijk was, aangezien een eigenaar van grond ook eigenaar van het daarop gebouwde was. Het beginsel "superficies solo cedit", de accessieregel ${ }^{7}$, werd als onomzeilbaar beschouwd. Sommige codificaties uit de $18 \mathrm{e}$ eeuw, bijvoorbeeld de "Würzburger Bau-Ordnung" uit 1722, het Pruische "Algemeine Landrecht" en het Saksische "Bürgerliche Gesetzbuch" kenden de "Stockwerkeigentum" dan ook niet of verboden hem zelfs. "Stockwerkeigentum" werd in deze gebieden geconstrueerd als medeëigendom van de grond en gebouwen, terwill het gebruik van het gebouw of de gebouwen verdeeld was of als "Superficiarrecht" (opstalrecht, tegenwoordig "Erbbaurecht" genoemd) werd beschouwd, waarbij de bewoner van de begane grond als eigenaar werd beschouwd. Andere constructies hanteerden erfdienstbaarheden ${ }^{8}$.

In andere delen van Duitsland, bijvoorbeeld in het Groothertogdom Baden, bleef "Stockwerkeigentum" in de zin van afzonderlijke eigendom van verdiepingen wel mogelijk. In 1810 trad het Landrecht van het Groothertogdom Baden (BLR) in werking, dat grotendeels een copie was van de Franse Code Civil. Voor 1810 viel de "Stockwerkeigentum" onder het gewoonterecht. De "Stockwerkeigentum" werd geregeld in de artikel 553 en 664 BLR. Artikel 664 BLR was een vertaling van artikel 664 Code Civil9. Tot de invoering van het BGB bleef in het Groothertogdom Baden de stichting van "Stockwerkeigentum" mogelijk ${ }^{10}$.

Ondanks het feit dat het BGB de stichting van "Stockwerkeigentum" verbood, verstomde de discussie over de wenselijkheid van "Stockwerkeigentum" niet. In de jaren twintig en dertig van deze eeuw laaide ze integendeel heftig op ${ }^{11}$. Toen na de tweede wereldoorlog grote gedeelten van de Duitse steden waren verwoest, moesten in een snel tempo voor talloze gezinnen nieuwe woningen worden gebouwd. De meeste mensen hadden geen geld om een eigen huis te betalen. Eigendom van goedkope appartementen was een adequate mogelijkheid om de woningnood te helpen bestrijden. Daarom gingen steeds meer stemmen op om eigendom van appartementen mogelijk te maken en aldus de woningnood te verminderen ${ }^{12}$. Als gevolg van een initiatiefwetsontwerp van de F.D.P. begonnen in West-Duitsland in 1949 de beraadslagingen over het WEG ${ }^{13}$. Dit initiatiefwets-

5. Merle (Wohnungseigentum im System), blz. 17.

6. Het gemene recht is het Romeinse recht, in het bijzonder het recht zoals beschreven in de Corpus Juris Civilis, en wordt ook wel pandectenrecht genoemd. Dit Pandectenrecht werd in de $19 \mathrm{e}$ eeuw aan de Duitse juridische faculteiten gedoceerd.

7. Vgl. Weitnauer/Hauger, blz. 25.

8. Merle (Wohnungseigentum im System), blz 18.

9. Merle (Wohnungseigentum im System), blz 18, 19. "Stockwerkeigentum" kwann voorall voor in München, Frankfurt am Main, Regensburg en Würzburg. Tresper, blz. 21-23.

10. Bökkelmann/Schale, blz. 12.

11. Zie bijvoorbeeld Meyer. Zijn eerste zin luidt: "Diese Schrift möchte die gröBte Not unserer Tage, die Wohnungsnot, lindern helfen". Meyer houdt vervolgens een vurig pleidooi voor de wettelijke toelating van appartementseigendom.

12. Bölkelmann/Schale, blz. 11, 12; BGH 3 april 1968, NJW 1968, 1230, 1231.

13. Ontwerp van 30 nov. 1949, Bundestag-Drucksache I/Nr. 252. 
ontwerp maakte een einde aan de langdurige discussie. Het wetsontwerp onderging bij de parlementaire behandeling enige veranderingen en werd vervolgens op 15 maart 1951 aangenomen ${ }^{14}$. Op 16 maart 1951 trad het WEG in werking ${ }^{15}$.

\subsection{De hoofdlijnen wan het Westduitse "Wohnungseigentumsrecht"}

\subsection{Algemene opmerkingen}

Het Westduitse appartementsrecht kent een dualistisch systeem, waarin een appartementseigenaar afzonderlijke eigendom (Sondereigentum) van zijn privegedeelten heeft, en medeëigenaar is van de gemeenschappelijke gedeelten (vgl. par. 6.2.2). De hierop toepasselijke wettelijke regelingen zijn neergelegd in het WEG, dat 64 bepalingen bevat. Deze bepalingen (paragrafen) vormen het Duitse "Wohnungseigentumsrecht". De regeling van het WEG is zeer uitvoerig. Zij kan bovendien door de "Wohnungseigentümer" nog worden aangevuld en uitgewerkt. $\$ 10$ WEG bepaalt namelijk dat de eigenaars een onderlinge overeenkomst kunnen aangaan, waarin zij aanvullende en - voor zover de wet dit niet verbiedt van de wet afwijkende regelingen kunnen treffen. Deze overeenkomst heeft zakelijke werking indien ze als "inhoud" van de afzonderlijke eigendom in het "Grundbuch", is opgenomen. Zij komt meestal tot stand als "Gemeinschaftsordnung" (verder te vertalen met "reglement van splitsing"). In de ex \&10 WEG gesloten overeenkomst kan op grond van \$15 WEG ook een regeling met betrekking tot het gebruik van de "Wohnungseigentum" worden opgenomen.

Voorzover een dergelijke gebruiksregeling niet bestaat, kunnen de appartementseigenaars echter ook met meerderheid van stemmen in de vergadering van eigenaars een gebruiksregeling aannemen ( $\$ 15$ lid 2 WEG). Een dergelijk besluit kan echter niet altijd degenen die tegen hebben gestemd, binden. Het mag niet willekeurig afbreuk doen aan hun gebruiksrechten ${ }^{16}$.

De "Gemeinschaftsordnung" moet in beginsel bij unaniem besluit gewijzigd worden. Bepaalde regelingen die in het reglement van splitsing zijn opgenomen en slechts de dagelijkse administratie betreffen (bijvoorbeeld huishoudelijke bepalingen) kunnen echter blijkens de Westduitse jurisprudentie door meerderheidsbesluit worden veranderd ${ }^{17}$. In het reglement kan eveneens worden bepaald, dat het bij gewoon meerderheidsbesluit kan worden veranderd. Een dergelijke bepaling kan echter alleen gelden ten aanzien van zakelijk gerechtvaardigde

14. Wet van 15 maart 1951, BGBl. $1_{\text {, blz }}$ 175. Vgl. over de Hubernagel, blz. 3-5. Het WEG werd veranderd bij wetten van 7 aug. 1952, BGBI. I, blz. 401; 26 juli 1957, BGBI. I, blz. 861; 30 mei 1973, BGBL. I, blz. 501; 30 juli 1973, BGBl. I, blz. 910; 8 dec. 1982, BGBI. I, ble. 1615; 14 dec. 1984, BGBL. I, blz. 1493. Overigens zijn er inmiddels weer stemmen opgegaan om het WEG opnieuw te veranderen. Vgl. Hohenester, blz 109-112.

15. Merle (Wohnungseigentum im System), blz. 36-38; Diester (WEG), blz. MI. Over het WEG zijn verschillende handboeken geschreven. Vgl. Bärmann (Kommentar); Bärmann/Pick; Weitnauer/Hauger; Augustin; Belz; Müller; Tresper; Wienicke. Naast deze handboeken, waarvan Bărmann (Kommentar) en Weitnauer/Hauger de meest diepgaande en uitgebreide zijn, is er nog een groot aantal praktijkhandleidingen voor leken verschemen. Vgl. Weimar; Bub; Weimar/SeuB; Röll. Verder is door J. Bärmann en H. SeuB een modellenboek samengesteld: Bärmann/Seuß Tenslotte verdient de jurisprudentieverzameling van Derichs (Sammlung), nog vermelding.

16. Bay. ObLG 10 now. 1961, NJW 1962 , blz 492.

17. Zie Bay. ObLG 9 juni 1975, ZMR 1976, blz 10. Vgl. ook Bärmann (Kommentar), blz 50, 51, 84. 
veranderingen, waardoor de afzonderlijke appartementseigenaars niet onredelijk worden benadeeld ${ }^{18}$. Of hiervan sprake is, moet de rechter van geval tot geval beoordelen.

$\$ 15$ WEG vormt, behalve voor de gebruiksregelingen in de in het "Grundbuch" opgenomen overeenkomst (Gemeinschaftsordnung/reglement van splitsing) eveneens de basis voor een eventuele "Hausordnung". Deze "Hausordnung" kan worden vergeleken met het "huishoudelijk reglement" in het Nederlandse appartementsrecht. Hierin kan van alles worden geregeld ${ }^{19}$. Veelal worden er minder belangrijke zaken in geregeld, vooral ook de gebruiksregeling van de gemeenschappelijke gedeelten. Verder worden er vaak regelingen in getroffen met betrekking tot het sluiten van deuren, het bewaren van sleutels, het gebruik wan liften, het sluiten van vensters bij vorst en het aanbrengen van naambordjes ${ }^{20}$. Het huishoudelijk reglement mag echter geen vergaande beperkingen van de afzonderlijke eigendom inhouden. Het mag bijvoorbeeld niet een verbod van het houden van huisdieren bevatten. Een dergelijk verbod mag wel worden opgenomen in het reglement van splitsing, zij het dat daarin dan wel moet zijn aangegeven welke huisdieren (ook goudvissen, kanaries e.d. (?)) onder het verbod vallen 21 .

Het thuishoudelijk reglement werkt volgens Bärmann ook tegen rechtsopvolgers onder bijzondere titel, tegen zakelijk gerechtigden en tegen persoonlijk gerechtigden, zoals huurders. Hij concludeert dit uit het feit dat besluiten van de vergadering van eigenaars en rechterlijke beslissingen ingevolge $\$ 10$ lid 3 WEG ook tegen rechtsopvolgers en zakelijke en persoonlijke gerechtigden werken. Een huishoudelijk reglement kan ingevolge $\$ 15$ lid 2 WEG ook bij besluit van de vergadering van eigenaars tot stand komen, en aldus zakelijke werking verkrijgen.

"Es kann nicht gewollt sein, daß eine als Vereinbarung getroffene Gebrauchsregelung, weniger Wirkung haben soll als eine beschlußmässige", aldus Bärmann ${ }^{22}$.

Het in het "Grundbuch" ex $\S 10$ WEG jo. § 15 WEG opgenomen reglement van splitsing verschilt van het huishoudelijk reglement door het feit dat het de onderlinge rechtsverhoudingen tussen de appartementseigenaars regelt ${ }^{23}$. Voor zover de wet niet anders bepaalt, mag hierin ook van de wet worden afgeweken. Verder kunnen er onder andere ook bepalingen over de financiering en onderhoud

18. Bärmann (Kommentar), blz. 85 .

19. Bärmann (Kommentar), ble. 374, 375 .

20. Bärmann (Kommentar), blz 374, 375.

21. Bärmann (Kommentar), blz 375; LG Wuppertal 5 juli 1977, Rpfleger 1978, blz. 23; OLG Frankfurt 13 juli 1978, Rpfleger 1978, blz 414: Een huisdierenverbod in de "Hausordnung is weliswaar niet mogelijk, maar een beperking van het toegestane aantal huisdieren is wel mogelijk; OLG Karlsruhe 25 febr. 1988, ZMR 1988, blz. 184, 185: een algemeen huisdierenverbod mag niet met meerderheid van stemmen in het huishoudelijk reglement worden opgenomen. Het verbod kan well door overeenkomst tussen alle appartementseigenaars tot stand komen.

22. Bärmann (Kommentar), blz. 377, 482.

23. Het reglement is ook veel moeilijker te veranderen dan bet buishoudelijk reglement. Het huishoudelijk reglement kan bij gewone meerderheid van stemmen worden veranderd en de veranderingen hoeven niet te worden ingeschreven in het "Grundbuch". Vgl, Grebe (Änderungsvorbehalte), blz. 5; dezelfde (Abänderung), blz. 275-291. 
van thet gebouw worden opgenomen. Het reglement van splitsing, aldus WeitnauerHauger ${ }^{24}$, is

"was bei einem Verein die Satzung wäre. Diese Vereinbarungen bilden die Grundordnung der Gemeinschaft".

In het navolgende zall bij wijze van voorbeeld de model-"Gemeinschaftsordnung"/ reglement van splitsing ${ }^{25}$ worden verwerkt, die in Bärmann/Seu $B^{26}$ is opgenomen. Dit modelreglement maakt deel uit van de door het Beierse "Staatsministerium des Innern" conform \& 8 WEG opgestelde model-"Teilungserklärung".

\subsection{Algemene structuur van "Wohnungseigentum"}

De Duitse appartementsgemeenschap is een vorm van een "Gemeinschaft nach

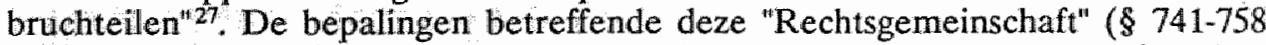
BGB) zijn voorzover het WEG niet anders bepaalt, op de appartementseigendom van toepassing ( $\$ 10$, lid 1 WEG). Het recht om scheiding en deling te vragen is bijvoorbeeld, anders dan bij de "Gemeinschaft nach Bruchteilen", uitgesloten ( $\&$ 11 WEG) ${ }^{28}$.

$\$ 1$ van het "Wohnungseigentumsgesetz" (WEG) geeft de definities van de in die wet gebruikte termen. In لid 2 van $\$ 1$ wordt de "Wohnungseigentum" als volgt omschreven:

"Wohnungseigentum ist das Sondereigentum an einer Wohnung in verbindung mit dem Miteigentumsanteil an dem gemeinschaftlichen Eigentum, zu dem es gehört."

De Duitse "Wohnungseigentum" heeft dus een andere structuur dan het Nederlandse appartementsrecht. De "Wohnungseigentum" behelst afzonderlijke eigendom ${ }^{29}$ van de privé-gedeelten die gekoppeld is aan medeëigendom van de dellen van het complex waartoe het behoort, die niet in afzonderlijke eigendom

24. Weitnauer/Hauger, blz. 187.

25. Hiernaar zal in het verwolg worden verwezen met de vertaling modelreglement.

26. Bärmann/SeuB, blz, 627-636.

27. Vgl. Larenz, blz. 137, 138. De "Einfache Rechtsgemeinschaft" oftewel "Gemeinschaft nach Bruchteilen" is vergelijikbaar met de eenvoudige gemeenschap, zoals die in het Nederlands Nieww BW is geregeld (afd. 3.7.1 NBW). Let wel: het recht betreffende de "einfache Rechtsgemeinschaft" regelt de verhouding van de deelgenoten onderling. De Duitse appartements-medeeigendom is tevens een species van de "Miteigentum nach Bruchteilen". Hiervoor worden in $\$ \$$ 1008-1011 BGB nog enkele extra bepalingen met betrekking tot gemeenschap bij zaken, gegeven. De verhouding gemeenschap-medeëigendom is gelijk aan de verhouding daartussen in het Nederlandse Nieuw BW. Zie ook Röll (Teilungserklầrung), blz. $1,6$.

28. Volgens Belz, blz. 6 is de appartementseigendom in de BRD cen drie-eenheid. Hij bestaat uit medeëigendom, afzonderlijke eigendom en verzakelijkte lidmaatschapsrechten. Met name op deze lidmaatschapsrechten zijn de \$ 741 e.w. BGB betreffende de einfache Rechtsgemeinschaft" toepasselijk. Zo ook Tresper, blz. 25, 26" Bärmann (Kommentar), blz. 39-53.

29. Vgl. Weitnauer/Hauger, blz. 54. "Sondereigentum" in deze zin betekent volle eigendom. Om het verschil met medeëigendom in de vertaling echter goed te doen uitkomen, zal voor "Sondereigentum" in het vervolg het begrip "afzonderlijke eigendom" worden gehanteerd; Röll (Teilungserklärung), blz. 2, 3. 
aan de verschillende appartementseigenaars toebehoren. De afzonderlijke eigendom is accessoir aan het aan de appartementseigenaar toekomende medeëigendomsaandeel ${ }^{30}$. Hoewel het appartementencomplex in medeèigendom aan de afzonderlijke appartementseigenaars toebehoort, wordt deze medeëigendom dus begrensd door de zich in afzonderlijke eigendom bevindende prive-gedeelten ${ }^{34}$ * In lid 5 van $\S 1$ van het WEG wordt de omschrijving van de gemeenschappelijke eigendom gegeven:

"Gemeinschafliches Eigentum im Sinne dieses Gesetzes sind das Grundstück sowie die Teile, Anlagen und Einrichtungen des Gebäudes, die nicht im Sondereigentum oder im Eigentum eines Dritten stehen."

Naast de "Wohnungseigentum" staat in het WEG de "Teileigentum" 32 . Volgens lid 3 van \& 1 van het WEG is "Teileigentum"

"das Sondereigentum an nicht zu Wohnzwecken dienenden Räumen eines Gebäudes in Verbindung mit dem Miteigentumsanteil an dem gemeinschaflichen Eigentum, zu dem es gehört."

"Teileigentum" is derhaive appartementseigendom voor bedrijfsruimten en dergelijke. $\S 1$ lid 5 WEG bepaalt dat de bepalingen betreffende "Wohnungseigentum" van overeenkomstige toepassing op "Teileigentum" zijn. In het navolgende zal daarom steeds over "Wohnungseigentum" worden gesproken, terwijl de "Teileigentum" niet afzonderlijk behandeld zal worden ${ }^{33}$.

30. Augustin, blz. 14; Pritsch, blz. 7. Deze accessoiriteit is echter niet zo dwingend dat de afzonderlijke eigendom nooit los van de medeëigendom zou kunnen worden overgedragen. Het is namelijk mogelijk dat appartementseigenaars bijwoorbeeld onderling kelders of garages e.d. ruilen, die in afzonderlijke eigendom aan hen toekomen. Na de overdracht wordt de afzonderlijke eigendom onmiddellijk afhankelijk van het medeë̈igendomsaandeel van de nieuwe eigenaar. Zie hierover Röll (Handbucb), blz. 32, 33. Voor deze overdracht is geen toestemming vereist van de andere appartementseigenaars of de administrateur. De overdracht heeft immers gecn gevolgen woor de andere eigenaars. Vgl. OLG Celle 29 maart 1974, NJW 1974, 1909.

31. In het navolgende zal voor "Wohnungseigentum" de vertaling "appartementseigendom" worden gehanteerd. De "Wohnungseigentümer" zullen "appartementseigenaars" worden genoemd. Ik ben me ervan bewust dat deze vertalingen verwarring zouden kunnen veroorzaken. Daar staat echter tegenover dat appartementseigendom naar mijn mening zeer goed de structur van de Duitse "Wohnungscigentum" weergeeft. De termen "appartementseigenaar" en "appartementseigendom" zijn voor het Nederlandse appartementsrecht echter weel minder geschikt. Dat deze termen (en met name de term "appartementseigenaar") in Nederland desalniettemin worden gebruikt, mag miet in de weg staan aan het gebruik ervan als correcte vertaling voor een buitenlandse rechtsfiguur. Overigens is het mijns inziens niet juist om de Nederlandse appartementseigenaar als "Wohnungseigentümer" te vertalen. Dit zou namelijk de schijn kunnen opweḱkken (voorzower die al miet is gewekt) dat men in Nederland eveneens een systeem van afzonderlijke eigendom, gecombineerd met medeëigendom, hanteert.

32. Zie ook \& 3 lid 3 Modelreglement.

33. Indien de term Teileigentum ${ }^{m}$ zou moeten worden vertaald, zou daarvoor eveneens de term "appartementseigendom" kumnem worden gebruikt. Anders dan "Wohnung" sluit het woord "appartement" immers het gebruik als bedrijfsruimte niet uit. Vgll. ower "Wohnungseigentum" en "Teileigentum", Weitnauer/Hauger, blz. 53, 54; Diester (Rechtsfragen), blz. 96, 97. 
Ingevolge \& 3 lid 2 WEG kan afzonderlijke eigendom van privé-gedeelten slechts bestaan ten aanzien van ruimten, die van de overige privé-gedeelten en de gemeenschappelijke gedeelten afgesloten zijn. Dit vereiste van afgeslotenheid geldt echter niet voor parkeerplaatsen, die door duurzame markeringen zijn aangegeven. Deze parkeerplaatsen worden ingevolge \& 3 lid 2 WEG geacht een afgesloten geheel te vormen.

Het onderwerp en de inhoud van de afzonderlijke eigendom, dat wil zeggen datgene dat onder het afzonderlijke eigendomsrecht valt, wordt in $\& 5$ WEG beschreven. Onderwerp van afzonderlijke eigendom kunnen zoals blijkt uit het voorgaande, woningen (Wohnungseigentum) of bedrijfsruimten (Teileigentum) zijn met de daartoe behorende bestanddelen van het gebouw, die veranderd, verwijderd of toegevoegd kunnen worden, zonder dat daardoor afbreuk wordt gedaan aan gemeenschappelijke eigendom of een afzonderlijk eigendomsrecht van een andere eigenaar of het uiterlijk van het gebouw wordt veranderd ( $\$ 5$ lid 1 WEG).

Vitale delen van het gebouw, die voor het bestaan of de veiligheid noodzakelijk zijn, en installaties en inrichtingen die bestemd zijn voor gemeenschappelijk gebruik, zijn daarentegen altijd gemeenschappelijk ( $\$ 5$ lid 2 WEG) ${ }^{34}$. De appartementseigenaars kunnen overeenkomstig \& 10 WEG als inhoud van het afzonderlijke eigendomsrecht overeenkomen, dat bepaalde delen wan het gebouw die onderwerp van afzonderlijke eigendom zouden kunnen zijn, gemeenschappelijk zijn ( $\$ 5$ lid 3 WEG) ${ }^{35}$.

Een opstalrecht (Erbbaurecht) kan eveneens in appartementen worden verdeeld. Indien meerdere personen een opstalrecht hebben dat aan ieder van hen gedeeltelijk (nach Bruchteilen) toekomt, dan kunnen deze delen dusdanig beperkt worden, dat ieder der medegerechtigden afzonderlijke eigendom van een bepaald (woon)gedeelte krijgt van een reeds bestaand of nog te stichten gebouw ( $\$ 30$ lid 1 WEG). Indien een opstalrecht aan é́n persoon toekomt kan deze dit met inachtneming van $\$ 8$ WEG delen.

Door deling van een "Erbbaurecht" ontstaat een "Wohnungserbbaurecht" (voor niet als woningen dienende ruimten: "Teilerbbaurecht"), een "opstalappartementsrecht", waarop de overige bepalingen betreffende de "Wohnungseigentum" van overeenkomstige toepassing zijn. Alleen voor de registratie in de openbare registers is een van het Wohnungseigentumsrecht afwijkende regeling getroffen ( $\$ 30$ lid 3 WEG). Volgens Bärmann wordt de gerechtigde tot het "Wohnungserbbaurecht" of "Teilerbbaurecht" deelgerechtigde tot het opstalrecht, en verkrijgt hij afzonderlijke eigendom van zijn privé-gedeelten. Een medeëigendomsaandeel krijgt de appartementseigenaar volgens Bärmann niet ${ }^{36}$. Deze conclusie is echter mijns inziens niet logisch. Als een opstalrecht aan meerdere personen toekomt, zijn zij medeëigenaars van de opstallen. Als zo'n opstalrecht in appartementsrechten wordt gesplitst betekent dit mijns inziens dat zij medegerechtigden tot het opstalrecht blijven, medeëigenaars van de gemeenschappelijke

34. Deze gedeelten zijn ook gemeenschappelijk in een complex van gebouwen waarin zij slechts de woningen van éen bepaald gebouw dienen. BGH 3 april 1968, NJW 1968, bliz 1230, 1232.

35. In bet modelreglement wordt in $\$ 3$ omschreven wat tot afzonderlijke eigendom behoort en wat onder de gemeenschappelijke eigendom valt.

36. Bärmann (Kommentar), blz. 637. 
gedeelten worden, en afzonderlijke eigenaars van de prive-gedeelten. De medeäigendom en de afzonderlijke eigendom zijn wel afhankelijk van het opstalrecht.

\subsubsection{Intermezzo: het "Dauerwohnrecht"}

Uit het voorgaande blijkt dat men volgens het Westduitse appartementsrecht een "Eigentumswohnung" kan verkrijgen, hetgeen inhoudt dat de prive-gedeelten in afzonderlijke eigendom aan de appartementseigenaars toekomen, terwijl ten aanzien van de gemeenschappelijke gedeelten medeëigendom bestaat. In het WEG zijn echter in het tweede deel ook nog bepalingen over het zogenaamde "Dauerwohnrecht" opgenomen. In tegenstelling tot "Wohnungseigentum" verschaft het "Dauerwohnrecht" aan de rechthebbende geen eigendomsrecht van de privégedeelten. Het "Dauerwohnrecht" is namelijk een beperkt zakelijk gebruiksrecht, waarmee een eigenaar van een perceel het daarop gebouwde of een gedeelte daarvan, kan bezwaren. Het vertoont aldus verwantschap met de oneigenlijke "Stockwerkeigentum" en erfdienstbaarheids- en opstalconstructies van voor de invoering van het WEG ${ }^{38}$.

Niet alleen een appartement of een gedeelte van een gebouw (mits "abgeschlossen") kan met een "Dauerwohnrecht" worden bezwaard, maar ook een gebouw in zijn geheel ${ }^{39}$. Het "Dauerwohnrecht" komt grosso modo neer op een "verzakelijkt" huurrecht ${ }^{40}$. Op grond van een "Dauerwohnrecht" verkrijgt de gerechtigde de bevoegdheid om een woning gedurende een bepaalde tijd; bijvoorbeeld 10,20,30 jaar of levenslang te gebruiken, terwijl de gerechtigde verplicht kan worden daarvoor een vergoeding te betalen.

\$31 WEG geeft de begripsomschrijvingen die voor het "Dauerwohnrecht" gelden:

"(1) Ein Grundstück kann in der Weise belastet werden, daß derjenige, zu dessen Gunsten die Belastung erfolgt, berechtigt ist, unter AusschluB des Eigentümers eine bestimmte Wohnung in einem auf dem Grundstück errichteten oder zu errichtenden Gebäude zu bewohnen oder in anderer Weise zu nutzen (Dauerwohnrecht). Das Dauerwohnrecht kann auf einen außerhalb des Gebäudes liegenden Teil des Grundstücks erstreckt werden, sofern die Wohnung wirtschaftlich die Hauptsache bleibt."

Het "Dauerwohnrecht" kan dus mede het gebruik van gedeelten van de grond buiten het gebouw omvatten. Hetzelfde geldt voor niet voor bewoning bedoelde ruimten (bedrijfsruimten bijvoorbeeld). In dat geval heet het recht "Dauernutzungsrecht". De bepalingen betreffende het "Dauerwohnrecht" zijn van

37. Vgl. hierover Weitnauer/Hauger, blz 346-397 en Dammertz. In dexe paragraaf wordt volledigheidshalve kort op het "Dauerwohnrecht" ingegaan. Omdat het moeilijk vergelijkbaar is met het Nederlandse appartementsrecht zal het in de navolgende paragrafen buiten beschouwing blijven.

38. Volgens Bärmann (Kommentar), blz, 648, heeft men het "Dauerwolunrecht" ondermeer in het WEG opgenomen om de oneigenlijke "lichtere" appartementsconstructic na invoering van het WEG te handhaven.

39. Bärmann (Kommentar), blx. 662.

40. Vgl. Beekhuis/Linders, IV par. 3. 
overeenkomstige toepassing op het "Dauernutzungsrecht" ( $\$ 31$ lid 2 en 3 WEG). Het "Dauerwohnrecht" kan, evenalis appartementseigendom (vgl. par. 6.2.3), slechts gevestigd worden, indien de woning als zelfstandig geheel te beschouwen is ("in sich abgeschlossen ist", \$ 32 lid 1 WEG). Het moet in het openbare register voor onroerend goed worden ingeschreven. Bij de inschrijving moet een bouwtekening worden gevoegd, waaruit de indeling van het gebouw en de ligging en de grootte blijken van het gedeelte waarop het "Dauerwohnrecht" wordt gevestigd. Deze bouwtekening moet door de overheidsinstantie voor bouwzaken (Baubehörde) worden ondertekend en gestempeld. Bovendien moet bij de inschrijwing een bewijs van dezelfde overheidsinstantie worden gevoegd, waaruit blijkt dat de woning waarop het "Dauerwohnrecht" wordt gevestigd, als zelfstandig geheel kan worden beschouwd ( 832 , lid 2 en 3 WEG).

Het "Dauerwohnrecht" is, anders dan bijvoorbeeld ons recht van gebruik en bewoning (art. 873 BW; art. 3.8.24 / 3:226 NBW) een recht dat voor vervreemding en vererving vatbaar is. Het kan niet voorwaardelijk worden gevestigd ( $\$ 33$ lid 1 WEG). \& 14 WEG (over de plichten van de appartementseigenaar) is van overeenkomstige toepassing voor de gerechtigde tot het "Dauerwohnrecht". Voor zover niet anders is overeengekomen, kan de gerechtigde medegebruik maken van de gedeelten die voor gemeenschappelijk gebruik bestemd zijn ( $\$ 33$ lid 3 WEG) Het vierde lid van $\$ 33$ WEG geeft aan wat facultatief als inhoud van het "Dauerwohnrecht" geregeld kan worden. Zo kunnen regelingen getroffen worden omtrent:

1. aard en omvang van het gebruik;

2. instandhouding en stichting van de met "Dauerwohnrecht" bezwaarde gedeelten;

3. de plicht van de gerechtigde om publiekrechtelijke of privaatrechtelijke lasten voor zijn rekening te nemen;

4. de verzekering van het gebouw;

5. het recht van de eigenaar om in bepaalde gevallen zekerheidsstelling te eisen.

Indien hierover niets is geregeld, levert dit voor de beheerder van het openbare register voor onroerend goed een reden op om de inschrijving van het "Dauerwohnrecht te weigeren ( $\$ 32$ lid 3 WEG). De bepalingen van het BGB betreffende de verplichtingen van de vruchtgebruiker en de (on)overdraagbaarheid van het recht ( $\$ \$ 1047,1059 \mathrm{BGB})$ zijn van overeenkomstige toepassing op vorderingen die de eigenaar kan hebben wegens veranderingen of verslechteringen aan c.q. van de woning, evenals op de vorderingen die de gerechtigde tot het "Dauerwohnrecht" kan hebben met betrekking tot gebruiksmogelijkheden en de toestemming om een inrichting uit de woning weg te nemen. Als op enige wijze inbreuk wordt gemaakt op het "Dauenwohnrecht", zijn op de aanspraken die daaruit voortvloeien de bepalingen van het BGB betreffende inbreuk op het eigendomsrecht van overeenkomstige toepassing ( $\$ 34$ WEG). $\$ 35$ WEG bepaalt dat als inhoud van het "Dauerwohnrecht" kan worden overeengekomen, dat de gerechtigde voor vervreemding van zijn recht toestemming van de eigenaar of een derde behoeft. De bepalingen van $\S 12$ WEG zijn hierbij van overeenkomstige toepassing. 
Naast hetgeen in $\$ 33$ WEG is genoemd, kan als inhoud van het "Dauerwohnrecht t" $^{\text {th }}$ bovendien worden overeengekomen, dat de gerechtigde in bepaalde vastgestelde gevallen verplicht is, het recht aan de eigenaar van de grond of een door deze aangegeven derde over te dragen (Heimfallanspruch). Deze "Heimfallanspruch" kan niet van de eigendom van de grond gescheiden worden ( $\$ 36$ lid 1 WEG), hetgeen betekent dat het "Heimfallrecht" accessoir is aan de eigendom van het onroerend goed. Het kan dus niet zelfstandig worden overgedragen of verpand ${ }^{41}$. De "Heimfallanspruch" heeft, mits ingeschreven in het "Grundbuch" zakelijke werking en is in de wet geregeld om de eigenaar een mogelijkheid te geven de gerechtigde uit de woning te zetten, bijvoorbeeld bij wanbetaling van de eventueel verschuldigde vergoeding door de gerechtigde. De eigenaar heeft namelijk niet het recht om het "Dauerwohnrecht" op te zeggen, hetgeen hij bijwoorbeeld bij huur wel $\mathrm{kan}^{42}$.

Indien het "Dawerwohnrecht" betrekking heeft op ruimten, waarop huurbeschermingsbepalingen van toepassing zijn, dan kan de eigenaar van de "Heimfallanspruch" slechts gebruik maken, indien daartoe een reden bestaat, die voor een verhuurder voldoende zou zijn om ondanks de huurbescherming een huurovereenkomst op te zeggen $\left(\$ 36\right.$ lid 2 WEG) ${ }^{43}$. Het derde lid van $\$ 36$ WEG handelt over de verjaring van de "Heimfallanspruch". Lid 4 van $\$ 36$ voegt aan het voorgaande nog toe dat als inhoud van het "Dauerwohnrecht" eveneens kan worden overeengekomen, dat de eigenaar aan de gerechtigde bij gebruikmaking van de "Heimfallanspruch" een bepaalde schadevergoeding moet betalen. Indien bij de inschrijving van het "Dauerwohnrecht" met betrekking tot een eventuele "Heimfallanspruch" of een eventuele schadevergoeding niet overeenkomstig $\$ 36$ lid 1 en 4 WEG een regeling is getroffen, moet de beheerder van de openbare registers de inschrijving weigeren $(\$ 32 \text { lid } 3 \text { WEG) })^{44}$.

Een huur- of pachtverhouding met betrekking tot een "Dauerwohnrecht" eindigt, indien het "Dauerwohnrecht" eindigt. Als de eigenaar van zijn "Heimfallanspruch" gebruik maakt, treedt hij of degene, aan wie het "Dauerwohnrecht" overgedragen wordt, als partij in de huur- of pachtverhouding. "Heimfall" breekt dus geen huur (vgl. ook $\$ 37$ lid 3 WEG). Bij vervreemding van het "Dauerwohnrecht" door de gerechtigde, treedt de verwerver in de plaats van de vervreemder ten opzichte van de eigenaar. Hetzelfde geldt spiegelbeeldig indien de grondeigenaar zijn perceel verkoopt ( $\$ 38$ WEG).

Als inhoud van het "Dauerwohnrecht" kan tenslotte ook nog worden overeengekomen, dat het "Dauerwohnrecht" bij gedwongen openbare verkoop (in afwijking van het bepaalde in $\$ 44$ van het "Gesetz über die Zwangsversteigerung und Zwangsverwaltung") van de grond blijft bestaan. Dit geldt echter alleen in bepaalde

41. Bärmann (Kommentar), blz. 716, 717. Vgl. over de "Heimfallanspruch": Staak, blz. 140-142.

42. Bärmann (Kommentar), blz 714, 715 .

43. Dit artikellid is geschreven ten tijde van het zogenaamde "Mieterschutggesetz", waarim vergaande huurbeschermingsbepalingen waren opgemomen. Ook na de afschaffing van deze wet in 1975 blijft deze bepaling van kracht, zij het dat nu voor de huurbescherming naar $\$ 556 \mathrm{a}-556 \mathrm{c} \mathrm{BGB}$ moet worden gekeken. Welitnauer/Hauger, blz. 377; Bärmann (Kommentar), blz. 723.

44. Zie ook hetgeen bij $\$ 33$ lid 4 WEG werd opgemerkt. 
gevallen, bijwoorbeeld als de verkoop wordt ondernomen door een hypotheekhouder ${ }^{45}$, wiens hypotheekrecht van gelijke of hogere rang is dan het "Dauerwohnrecht". Een dergelijke overeenkomst behoeft echter de toestemming van de hypothecaire crediteur. Daarnaast is vereist dat de gerechtigde tot het "Dauerwohnrecht" op het moment van executie al zijn opeisbare betalingsverplichtingen jegens de eigenaar van de grond is nagekomen ( $\$ 39$ WEG). $\$ 40$ WEG geeft vervolgens bepalingen over de wijze waarop bijvoorbeeld een hypotheekhouder zich kan beroepen op de aansprakelijkheid van de "Dauerwohn"-gerechtigde voor de vergoeding voor ket "Dauerwohnrecht". \& 41 WEG bevat bijzondere bepalingen voor langdurende "Dauerwohnrechte". \& 42 WEG bepaalt dat ook een opstalrecht (Erbbaurecht) met een "Dauerwohnrecht" kan worden bezwaard.

\subsection{Ontstaian en tenietgaan van appartementseigendom}

In de eerste afdeling van het WEG wordt de totstandkoming van appartementseigendom geregeld. De appartementseigendom ontstaat door contractuele vestiging (vertragliche Einräumung) of door deling (Teilung). Dit overeenkomstig $\$ 2$ WEG, dat luidt:

"Wohnungseigentum wird durch vertragliche Einräumung vom Sondereigentum $(\$ 3)$ oder durch Teilung $(\$ 8)$ begründet."

In de $\$ \S 3$ en 8 WEG wordt vervolgens de contractuele vestiging, casu quo de deling uitgewerkt.

Voor zowel de "vertragliche Einräumung" als de "Teilung" gelden de vormvoorschriften van $\& 4$ WEG. Dit betekent dat er een overeenkomst of een verklaring moet zijn, die in het "Grundbuch" wordt ingeschreven ( $\$ 4$ lid 1 WEG). De appartementseigendom komt pas tot stand door inschrijving in het "Grundbuch" en - bij splitsing ex $\S 3$ WEG - nadat voor elk medeëigendomsaandeel een apart "Grundbuchblatt" is opgesteld ( $\$ 7$ WEG). Hetzelfde geldt mutatis mutandis voor de splitsing door "Teillung" ( $\$ 8$ lid 2 WEG).

45. Hetzelfde geldt voor de houder van een "Grundschuld, Rentenschuld, of Reallast". De "Grundschuld" is een aan de hypotheek verwant recht. $\mathrm{Zij}$ onderscheidt zich echter van de Hypotheek met name door het feit dat zij geen accessoir recht is. Een eigenaar kan bijvoorbeeld ten behoeve van zichzelf een "Grundschuld" op zijn eigen grond hebben. In beginsel dient de "Gruadschuld" tot zekerheid van betaling van een som geld. Aangezien de "Grundschuld" niet accessoir is, eindigt zij - indien zij tot zekerheid van een geldvordering strekt - miet bij het tenietgaan van de geldvordering. De "Grundschuld" kan gemakkelijk in een hypotheekrecht worden geconverteerd en omgekeerd. Indien een hypotheekhouder eigenaar wordt van de grond waarop de hypotheelk rust, wordt zijn hypotheekrecht zelfs automatisch omgezet in een zogenaamde "Eugentümergrundschuld". De "Rentenschuld" lijkt op de "Grundschuld". Evenals dit recht is de "Rentenschuld" niet accessoir aan een vordering. Het verschill tussen "Grundschuld" en "Rentenschuld" bestaat hierin dat terwijl de aan de houder van een "Grundschuld" een som geld moet worden betaald; dit bij de "Rentenschuld" periodiek moet gebeuren. Een "Reallast" houdi in dat de eigenaar van de bezwaarde grond periodiek bepaalde prestaties moet leveren. Deze prestatie kan bestaan uit het betalen van geld. zij kan echter ook de plicht inhouden om bijvoorbeeld een weg te onderhouden. De "Reallast" is een soort erfdienstbaarheid om te doen, hetgeen we in het Nederlandse recht, behoudens art. $736 \mathrm{BW}$, niet kennen. Het Duitse recht van hypotheek komt in grote lijn overeen met het Nederlandse. In detail bestaan er echter verschillen. Zie Lent/Schwab, blz. 267, 268, 312, 313; Palandt, blz. 1219 e.w. 
Splitsing door contractuele vestiging kan ingevolge $\$ 3$ plaatsvinden als een stuk grond in medeëigendom aan verschillende personen toebehoort. De medeëigenaars kunnen overeenkomen dat de medeëigendom van de grond beperkt wordt, in die zin dat aan elke medeëigenaar in afwijking van $\$ \$ 93$ en 94 BGB afzonderlijke eigendom van een bepaalde woning of van niet tot bewoning dienende ruimten toekomt van een op die grond staande of te stichten gebouw ${ }^{46}$. Lid 2 van $\$ 3$ WEG voegt hier nog aan toe dat afzonderlijke eigendom slechts kan worden gevestigd, indien de woningen of andere ruimten "in sich abgeschlossen" zijn ${ }^{47}$. Zij zijn dit alleen als zij architectonisch van andere woningen en ruimten zijn afgescheiden. Deze afsluiting kan bestaan uit muren en plafonds. Grosso modo moeten de appartementen zelfstandige eenheden vormen. Als de woningen niet "abgeschlossen" zijn, kan geen splitsing in appartementen plaatsvinden. Door inschrijving van de in een authentieke akte opgenomen overeenkomst in het "Grundbuch" ontstaat appartementseigendom ${ }^{48}$. De verklaring of overeenkomst, waarin de eigenaar c.q. de eigenaars tot splitsing overgaan, moet in principe in een notariële akte zijn neergelegd. Ook een schikking in een juridische procedure, neergelegd in een rechterlijk besluit, kan echter worden ingeschreven in het "Grundbuch" ( $\$ 4$ WEG jo. 925 BGB en $29 \mathrm{GBO}$ ). In een testament kan geen splitsing van een gebouw worden opgenomen, in die zin dat door het openvallen van de nalatenschap appartementseigendom ontstaat. Wel kan in een testament aan de erfgenamen de opdracht worden gegeven, tot splitsing over te gaan. In dat geval ontstaat de appartementseigendom pas door de verklaring van de erfgenamen aan het "Grundbuchamt" overeenkomstig $\S 8$ WEG (zie hierover de volgende alinea) of door vestiging conform $\$ 3 \mathrm{WEG}$.

Splitsing door deling kan gebeuren door de eigenaar van een perceel. Deze kan ten overstaan van het "Grundbuchamt", door een verklaring de eigendom van het stuk grond op zodanige wijze delen, dat aan elk deel de afzonderlijke eigendom van een woning of andere ruimte in een op het perceel te stichten of reeds gesticht gebouw, gekoppeld is.

Hieruit lijkt te moeten worden geconcludeerd dat splitsing door contractuele vestiging moet plaatsvinden, indien het stuk grond aan verscheidene eigenaars gemeenschappelijk toebehoort, terwijl splitsing door deling moet plaatsvinden, indien het stuk grond slechts aan een eigenaar toebehoort. Het WEG roept dit vermoeden op. In de praktijk blijkt echter dat de splitsingswijzen van $\$ 3$ en $\$ 8$ gecombineerd kunnen worden ${ }^{49}$.

Een "papieren" splitsing is (door "vertragliche Einräumung. of "Teilung") eveneens mogelijk. In dat geval moeten bij de inschrijving in het "Grundbuch" tevens de bouwtekeningen worden gevoegd. In de bouwtekening moet getekend

46. In $\$ 93 \mathrm{BGB}$ is de algemene natrekkingsregel neergelegd. In $\$ 94 \mathrm{BGB}$ is het beginsel "superficies solo cedit" neergelegd. Zie Palandt, bli. 58-60.

47. Bärmann wijst erop dat deze "Abgeschlossenheit" een "Sollvorschrift" is. Woningen moeten dus afgesloten zijn, maar indien aan dit wereiste niet is voldaan, is een in het "Grundbuch" ingeschreven splitsing geldig. De "Abgeschlossenheit" is derhalve geen "MuBvorschrift" (dwingend

48. Röll (Teilungserklärung), blz. 12.

49. Vgl. Bärmann/Pick, blz 49,83; Weitnauer/Hauger, blz. 63. Deze noemt cen voorbeeld van een gecombineerde splitsing. 
zijn wat in de splitsingsakte (overeenkomst of verklaring) is bepaald ${ }^{50}$. De appartementseigendom komt vervolgens tot stand door inschrijving in het "Grundbuch".

Hoewel appartementseigendom een vorm van medeëigendom en de gemeenschap een "einfache Rechtsgemeinschaft" is, kan geen deelgenoot scheiding en deling vorderen ( $\$ 11 \mathrm{WEG})$. De appartementseigendom gaat verder niet door de enkele verwoesting van het appartementsgebouw teniet. Ook na de verwoesting blijft de appartementseigendom bestaan. Zelfs de afzonderlijke eigendom blijft juridisch bestaan, hoewel het voorwerp van het eigendomsrecht materieel niet meer bestaat. Alsdorf concludeert dit voortbestaan enerzijds uit het feit dat appartementseigendom ook mogelijk is voordat een gebouw is opgericht (papieren splitsing), anderzijds uit het feit dat na verwoesting van het gebouw volgens $\$ 9$ lid 2 sub 2 WEG de appartementseigendom eindigt, indien alle appartementseigenaars dit aan het "Grundbuchamt" verzoeken 51.

Gelukkig komen catastrofes waardoor een gebouw geheel teniet gaat, in de Bondsrepubliek zeer weinig woor. In praktijk zal appartementseigendom daarom veelal eindigen door een overeenkomst (die ingeschreven wordt in het "Grundbuch") tussen alle appartementseigenaars. De appartementseigenaars kunnen op deze wijze te, allen tijde de appartementseigendom doen eindigen $(\$ \S 4,9 \mathrm{WEG})^{52}$. Indien alle appartementen in eigendom aan én persoon toekomen, kan deze de splitsing door een eenzijdige verklaring aan de beheerder van de openbare registers (het "Grundbuchamt") opheffen ( $\$ 9$ lid 1 sub 3 WEG) ${ }^{53}$. Indien er sprake is van een gesplitst opstalrecht, gaat het "Wohnungserbbaurecht" teniet indien het opstalrecht eindigt of de gerechtigden tot het "Wohnungserbbaurecht" besluiten de splitsing op te heffen ${ }^{54}$.

Als het appartementsgebouw voor meer dan de helft van zijn waarde vernietigd is, terwijl de schade niet door verzekering of anderszins wordt vergoed, kan van een appartementseigenaar niet worden geëist dat hij meewerkt aan het herstel ( $\$$ 22 lid 2 WEG). Scheiding en deling is echter alleen mogelijk, indien dit voor dit geval uitdrukkelijk is overeengekomen ( $\$ 11$ lid 1 WEG) $)^{55}$.

\subsection{Administratie en beheer}

De administratie en het beheer berust bij de appartementseigenaars, de administrateur en een eventueel beheersadviescollege ("Verwaltungsbeirat", $\$ 20$ lid 1 WEG). De administratie en het beheer door de appartementseigenaars moet door hen gezamenlijk geschieden ( $\$ 21$ lid 1 WEG). $\$ 21$ lid 5 WEG geeft bij wijze van

50. Müller, blz. 7. Dat een "papieren" splitsing mogelijk is werd ook bepaald in OLG Frankfurt 10 april 1978, Rpfleger 1978, blz 381. Juridisch bestaat na de papieren splitsing voor de appartementseigenaars (bij "vertragliche Einräumung") echte appartementseigendom met een onderling vorderingsrecht tot stichting van het appartementsgebouw.

51. Bärmann (Kommentar), blz 266, 267; Hauger, blzz 132; Alsdorf (Rechtsverhältnisse), blz. 88 .

52. Bärmann (Kommentar), blz. 266. Ook bij de opheffing gelden overigens de vormvoorschriften van $\$ 4$ WEG.

53. Hauger, blz. 134.

54. Hauger, blz. 132

55. Hauger, blz. 134, 135; Alsdorf, (Rechtswerhältnisse), blz. 89. Vgl. \$12 modelreglement. 
voorbeeld aan wat onder behoorlijke administratie en behoorlijk beheer moet worden verstaan. Allereerst wordt het opstellen van een "Hausordnung" ${ }^{56}$ (vgl. \$ 6.2.1) genoemd. Ten tweede moeten de eigenaars zorg dragen voor een goede instandhouding van de gemeenschappelijke eigendom. Ten derde dienen zij gezamenlijk ervoor te zorgen dat een brandverzekering en een verzekering tegen aansprakelijkheid van de appartementseigenaars als huis- en grondbezitters, wordt afgesloten ${ }^{57}$. Als vierde voorbeeld van behoorlijk beheer noemt $\$ 21$ lid 5 WEG het creëren van een financiële onderhoudsreserve. Ten vijfde moet een jaarlijkse begroting worden opgesteld ${ }^{58}$ en tenslotte wordt vermeld dat de gezamenlijke eigenaars alle maatregelen moeten dulden, die nodig zijn voor het verkrijgen van een tellefoonaansluiting, radio- en televisieontvangst e.d. door een individuele appartementseigenaar. Deze appartementseigenaar is dan wel gehouden de eventuele door aanleg ontstane schade te vergoeden ( $\$ 21$ lid 6 WEG).

Het overleg tussen de appartementseigenaars gebeurt net als in Nederland in een vergadering van appartementseigenaars, de zogenaamde "Wohnungseigentümerversammlung" ${ }^{59}$. Deze vergadering is het hoogste orgaan van de gemeenschap van medeëigenaars ${ }^{60}$. Zij beslist in gevallen waarin volgens de wet of onderlinge overeenkomst door de appartementseigenaars besloten kan worden ( $\$$ 23 lid 1 WEG). Het is niet nodig om voor alle besluiten de vergadering van eigenaars bijeen te roepen. Een besluit is namelijk eveneens geldig, indien alle appartementseigenaars er schriftelijk mee hebben ingestemd ${ }^{61}$. Een dergelijk schriftelijk besluit moet dus unaniem worden genomen ( $\$ 23$ lid 3 WEG). Een besluit van de appartementseigenaars kan echter op verzoek van een appartementseigenaar of de administrateur door het "Amtsgericht" ongeldig worden verklaard. Het verzoek tot ongeldigverklaring moet dan wel binnen een maand na de dag waarop het besluit werd genomen, worden gedaan ( $\$ 23$ lid 4 WEG). De rechter toetst het genomen besluit vervolgens aan de billijkheid ( $\$ 43$ lid 2 WEG). Indien het besluit in strijd is met een norm waarvan de naleving gewaarborgd moet blijven, geldt geen bijzondere termijn waarbinnen het verzoek tot ongeldigverklaring moet worden gedaan ( $\$ 23$ lid 4 WEG). Hiervan is volgens Bärmann alleen sprake, indien het besluit toch al nietig is wegens strijd met dwingende bepalingen uit het WEG $(\$ \S 6,11,20$ lid 2 en 27$)$ of wegens strijd met de wet of de goede zeden $(\$ \S 134,138 \mathrm{BGB})^{62}$.

De vergadering van eigenaars wordt minstens een keer per jaar door de administrateur bijeengeroepen $(\$ 24 \text { lid } 1 \text { WEG })^{63}$. In elk geval moet de administrateur de vergadering echter bijeenroepen in bepaalde door de appartementseigenaars bij overeenkomst geregelde gevallen en indien de bijeenroeping door meer dan een vierde van de appartementseigenaars schriftelijk met ver-

56. Hiernaar zal in het vervolg worden verwezen met de vertaling huishoudelijk reglement.

57. Vgl. \& 11 modelreglement.

58. Vgl. \& 15 modelreglement.

59. Vgl. $\$ 17$ Modelreglement.

60. Noch de gemeenschap, noch de vergadering heeft rechtspersoonlijkheid. Bärmann (Kommentar), blz 517 .

61. \$ 17 lid 8 modelreglement wijkt hiervan af en eist slechts drievierde van de appartementseigenaars voor cen geldig schriftelijk besluit.

62. Bärmann (Kommentar), blz 530 .

63. Vgl. 17 lid 2 Modelreglement. 
melding van redenen wordt verlangd ( $\$ 24$ lid 2 WEG). Indien de administrateur vervolgens weigert de vergadering bijeen te roepen, kan de voorzitter van een eventueel beheersadviescollege deze taak van hem overnemen ${ }^{64}$. De bijeenroeping moet altijd schriftelijk en behoudens dringende gevallen minstens een week voordat de vergadering plaatsvindt, gebeuren ( $\$ 24$ lid 4 WEG). De aldus bijeengeroepen vergadering wordt dan voorgezeten door de administrateur ( $\$ 24$ lid 5 WEG). De besluiten van de vergadering moeten worden genotuleerd en de notulen moeten ter goedkeuring worden ondertekend door de administrateur, én appartementseigenaar en - indien een beheersadviescollege is ingesteld - door de voorzitter van het beheersadviescollege of diens vervanger ( $\$ 24$ lid 6 WEG).

De besluiten moeten in de vergadering bij meerderheid van stemmen worden genomen. De vergadering kan slechts geldig besluiten, indien ter vergadering meer dan de helft van de medeëigendomsaandelen, berekend naar de in de openbare registers ingeschreven grootte van de aandelen, vertegenwoordigd is ( 825 lid 3 WEG). Indien een vergadering aan deze eis niet voldoet, moet de administrateur een nieuwe vergadering uitschrijven, die ongeacht de omvang van de vertegenwoordigde aandelen bevoegd is om besluiten te nemen ( $\$ 25$ lid 4 WEG) ${ }^{65}$. Iedere appartementseigenaar heeft ter vergadering slechts éen stem. Men kent dus een "Stimmrecht nach Köpfen". Weitnauer/Hauger ${ }^{66}$ wijst erop dat dit hoofdelijk stemrecht een afwijking vormt van $\S 745$ lid 1 BGB, op grond waarvan de meerderheild van stemmen bij een "einfache Rechtsgemeinschaft" aan de hand van de grote van de aandelen wordt bepaald (vgl, ook \& 25 lid 3 WEG). Hier wijkt het Duitse appartementsrecht derhalve af van het algemene recht betreffende de "eenvoudige" gemeenschap ${ }^{67}$. In het geval dat meerdere personen een appartement gezamenlijk in eigendom hebben, komt hen desalniettemin slechts éen stem toe $\left(\$ 25\right.$ lid 1 en 2 WEG) ${ }^{68}$.

Een appartementseigenaar is echter niet stemgerechtigd als de vergadering moet beslissen over een met hem te verrichten rechtshandeling ten aanzien van het gemeenschappelijk beheer of administratie (bijvoorbeeld het uitbesteden van onderhoudswerkzaamheden aan een aannemer die tevens appartementseigenaar is), of indien de vergadering moet beslissen in een procedure van de overige eigenaars tegen hem of indien hij conform $\$ 18$ WEG tot vervreemding van zijn appartement is gedwongen (zie hierover $\$ 25$ lid 5 WEG). De appartementseigenaar mag dus

64. Bovendien kan iedere appartementseigenaar zich ingevolge $\$ 43$ lid 1 sub 2 WEG tot de rechter wenden met het verzoek om machtiging tot bijeenroeping van de vergadering. Zie Weitnauer/Hauger, blz 287; Gaisbauer, blz. 168, 169; Een appartementseigenaar mag zonder rechterlijke machtiging geen vergadering van eigenaars bijeenroepen: KG 27 aug. 1986, NJW 1987 , blz, 386, 387.

65. $\$ 17$ lid 4 Modelreglement sluit hierbij aan en bepaalt dat bij de bijeenroeping wan de eerste vergadering voor de zekerheid ook een tweede vergadering wordt bijeengeroepen, die een uur na de eerste vergadering aanvangt en onalhankelijk van het aantal vertegenwoordigde aandelen, mag besluiten.

66. Weitnauer/Hauger, blz. 293.

67. In het reglement van splitsing kan hiervan echter worden afgeweken. In art. 17 lid 1 Modelreglement wordt bijvoorbeeld als alternatief voor het hoofdelijke stemrecht, een stemrecht per appartement of een stemrecht naar rato van de grootte van het aandeel, aangedragen.

68. Zie $\$ 7$ modelreglement: Indien meerdere personen gezamenlijk een appartement in eigendom hebben, moeten zij bij authentieke akte een vertegenwoordiger benoemen. 
niet meestemmen als men beslist over zijn uitsluiting uit de gemeenschap, of indien men reeds heeft besloten hem uit de gemeenschap uit te sluiten ( $\$ 25$ lid 5 WEG).

De administrateur, die naast de appartementseigenaars en een eventueel beheersadviescollege, voor de administratie en het beheer van de appartementsgemeenschap zorg draagt, wordt door de appartementseigenaars benoemd ${ }^{69}$. De benoeming geschiedt bij meerderheid van stemmen ${ }^{20}$ en mag slechts voor de duur van maximaal vijf jaar gelden ${ }^{71}$. Na afloop van de benoeming kan de administrateur echter opnieuw worden benoemd ( $\$ 26$ lid 1 en 2 WEG). Indien de benoeming van de administrateur uitblijft kan elke appartementseigenaar het "Amtsgericht" om een vervangende benoeming verzoeken ( $\$ 43$ lid 1 sub 1 jo. 26 lid 3 WEG). Het "Amtsgericht" heeft niet de bevoegdheid om ambtshalve een administrateur te benoemen. Hierdoor kan, zoals Bärmann/Pick vermeldt, benoeming uitblijven, indien de appartementseigenaars geen administrateur benoemen en evenmin een verzoek tot vervangende benoeming aan het "Amtsgericht" wordt gericht. De appartementseigenaars zijn niet schadeplichtig voor schade die uit het niet benoemen van een administrateur voortvloeit ${ }^{72}$.

De administrateur is onder andere verplicht om de besluiten van de vergadering van eigenaars uit te voeren en voor de naleving van het huishoudelijk reglement en de instandhouding van de gemeenschappelijke eigendom te zorgen. In dringende gevallen moet hij noodzakelijke maatregelen treffen. Bovendien is hij verplicht om de gemeenschappelijke geldmiddelen te beheren ( $\$ 27$ lid 1 WEG). Het tweede lid wan $\$ 27$ WEG beschrijft de gevallen waarin de administrateur bevoegd is om de appartementseigenaars te vertegenwoordigen ${ }^{73}$. De volgende drie leden van $\$ 27$ WEG geven nadere regelen omtrent de rechten en verplichtingen en de vertegenwoordigingsbevoegdheid van de administrateur. Naast de in $\$ 27$ neergelegde rechten en plichten voor de administrateur bepaalt $\$ 28$ WEG dat hij jaarlijks een begroting moet opstellen. Aan deze begroting worden in $\$ 28$ nadere eisen gesteld ${ }^{74}$.

69. Bijy. 18 modelreglement. Overigens kunnen ook rechtspersonen tot administrateur worden benoemd. Weitnauer/Hauger, blz. 299; Kürzel, blz. 25; Merle (Bestellung und Abberufung), blz. 21.

70. Het meerderheidsbesluit waarbij een administrateur wordt benoemd, kan wegens een gewichtige reden in een procedure ex $\$ 43$ WEG ongeldig worden verklaard. OLG Stuttgart 18 dec. 1985 , NJW-RR 1986, blz. 315.

71. Vroeger kon de administrateur voor onbeperkte duar worden benoemd. Dit leidde in een aantal gevallen echter tot problemen, hetgeen in 1973 tot een wetswijziging, theeft geleid. Vgl. Hohenester, blz 110 .

72. Bärmann/Pick, blz. 173; Weitnauer/Hauger, blz. 300. In beginsel kan een administrateur ten allen tijde weer door de vergadering van eigenaars ontslagen worden, ook voordat zijn termijn is afgelopen. Ingevolge \$26 lid 1 WEG kan de bevoegdheid om de administrateur tussentijds te ontslaan worden beperkt tot de mogelijkheid van ontslag wegens gewichtige redenen. Zie Kürzel, blz. 26; Merle (Bestellung und Abberufung), blz. 94.

73. De administratetur kan bijwoorbeeld bij meerderheidsbesluit gemachtigd worden om de appartementseigenaars in een juridische procedure te vertegenwoordigen of als vertegenwoordiger een advocal in te schakelen. OLG Zweibrücken 10 juni 1987, ZMR 1988, blz. 24, 25.

74. Bij plichtsverzuim kan de administrateur wegens wanprestatie worden aangesproken. Kürzel, blz. 26. Hij is eveneens aansprakelijk voor schade die ontstaat tengevolge van onbevoegde vertegenwoordiging van de gemeenschap wan appartementseigenaars (\$ 179 BGB). Keith, blz. 2124. 
Anders dan de benoeming van een administrateur is het instellen van een beheersadviescollege (Verwaltungsbeirat) niet verplicht. Dit college kan echter worden ingesteld om de administrateur bij te staan bij de administratie en het beheer en om als kascommissie te fungeren bij de door de administrateur opgestelde begroting. Het college wordt samengesteld uit drie appartementseigenaars ${ }^{75}$.

\subsection{Rechten en verplichtingen van de appartementseigenaws}

De onderlinge verhouding tussen de appartementseigenaars wordt in het WEG geregeld door de bepalingen van de tweede afdeling. Bovendien zijn de bepalingen uit het BGB betreffende de "einfache Rechtsgemeinschaft" van toepassing. De bepalingen uit het WEG vormen een lex specialis ten opzichte van de algemene bepalingen betreffende de "einfache Rechtsgemeinschaft" uit het BGB. Voor zover niet anders is bepaald kunnen de appartementseigenaars echter (van WEG en $B G B)$ afwijkende regelingen treffen.

Iedere appartementseigenaar heeft het recht om zijn afzonderlijke eigendom te gebruiken, in het bijzonder om zijn privé-gedeelten te bewonten, verhuren, verpachten of op andere wijze te benutten, voor zover de wet, het reglement, het huishoudelijk reglement of rechten van derden aan dit gebruik niet in de weg staan ( $\$ 13$ lid 1 WEG) ${ }^{76}$. Bärmann ${ }^{77}$ voegt hier nog de bestemming van het gebouw als beperking van de gebruiksbevoegdheid aan toe. Indien bijvoorbeeld woonruimte in bedrijfsruimte wordt veranderd, is daarvoor een bijzondere toestemming van de overige appartementseigenaars vereist ${ }^{78}$. Evenmin mag een appartement met bestemming winkelruimte zomaar worden veranderd in een stomerij, waarin grote chemische reinigingsapparatuur wordt gebruikt ${ }^{79}$. Hetzelfde geldt voor bijvoorbeeld discotheken, cafés en sauna's die worden uitgebaat in winkelruimte ${ }^{80}$. Van geval tot geval moet worden bekeken of de bestemmingsverandering toelaatbaar is ${ }^{81}$.

Naast het recht om in beginsel vrij van zijn eigendom gebruik te maken, heeft de appartementseigenaar tevens het recht om zijn appartementseigendom vrij te

75. Belz, blz 176-179. Vgl. over de "Verwaltungsbeirat": Weimar (Verwaltungsbeirat), blz 97, 98; in de "Verwaltungsbeirat" mogen ook niet-appartementseigenaars zitting hebben. Vgl. Bay ObLG 28 okt. 1987, ZMR 1988, blz. 70.

76. Vigl. $\$ 5$ lid 1 modelreglement.

77. Bărmann (Kommentar), blz 330, 331.

78. Bay ObLG 23 maart 1983 , Bay ObLGZ 1983, blz. 79. Vgl. ook \& 5 lid 2 modelreglement. De appartementseigenaar die in zijn woning een beroep of bedrijf will uitoefenen, heeft daarvoor toestemming van de administrateur nodig. Deze mag de toestemming slechts wegens een gewichtige reden weigeren.

79. OLG Hamm 11 okt. 1977, Rpfleger 1978, blz 60.

80. Bay ObLG 7 nov. 1985, NJW-RR 1986, blz. 317, Het Bay ObLG verbood het gebruik van "Teilleigentum" met bestemming "gewerblich genutzter Laden" als Sauna. "Entscheidend ist hier nicht der Hinweis, dab das Teileigentum gewerblich genutzt werde, sondern seine Bezeichnung als "Laden". " Een sauna is geen winkel, aldus het Bay ObLG 19 juli 1978, Rpfleger 1978, blz 414; OLG Zweibrücken 28 jan. 1987, ZMR 1987, blz. 228: Een "Biljart-cafe" komt niet overeen met de bestemming "Laden, Büro, Arzt(praxis) oder Wohnung". Een bordeel mag niet worden uitgebaat in een ruimte die "zu beliebigen geschäftlichen Zwecken" gebruikt moet worden, KG 6. mei 1987, ZMR 1987, blz 384. Zie ook OLG Stuttgart 4 nov. 1986, NJW 1986, blz 385, 386; OLG Zweibrücken 6 okt. 1987, MDR 1988, blz. 147 .

81. Bärmann (Kommentar), blz 331 . 
vervteemden en te bezwaren ${ }^{82}$, tenzij als inhoud van de afzonderlijke eigendom is overeengekomen dat hij voor de vervreemding toestemming nodig heeft van de andere appartementseigenaars of een derde ( $\$ 12$ lid 1 WEG. Zie hierover uitvoerig par. 6.3.2). Een appartementseigenaar mag bovendien van de andere bewoners een gebruik van hun appartementen verlangen, dat overeenstemt met de voorschriften van de wet, onderlinge overeenkomsten en besluiten van de vergadering van eigenaars of dat voortvloeit uit een belang dat aan de gezamenlijke eigenaars naar billijkheid toekomt ( $\$ 15$ lid 3 WEG).

Een appartementseigenaar heeft tevens de bevoegdheid zijn appartement onder te splitsen. Bij ondersplitsing splitst de eigenaar zijn appartement in meerdere appartementen. Aldus wordt bewerkstelligd dat de eigenaar een gedeelte van zijn appartement zonder toestemming van de overige appartementseigenaars kan vervreemden. Deze vervreemding kan, anders dan de ondersplitsing zelf, echter wel aan de vervreemdingsbeperking ex $\$ 12$ WEG worden onderworpen ${ }^{83}$ Bij de ondersplitsing is wel weer vereist dat de nieuw ontstane ruimten "in sich abgeschlossen"' $\mathrm{zijn}^{84}$.

Anderzijds is de appartementseigenaar verplicht om de afzonderlijke eigendom in stand te houden en van deze en de gemeenschappelijke eigendom slechts op zodanige wijze gebruik te maken, dat daardoor voor de overige appartementseigenaars geen onevenredig nadeel ontstaat ${ }^{85}$. Hij moet er bovendien zorg voor dragen dat deze plicht ook door personen die tot zijn huishouden of bedrijfsvoering behoren, of aan wie hij zijn appartement in gebruik heeft gegeven, wordt nageleefd ( $\$ 14$ lid 1 en 2 WEG) ${ }^{86}$. Daarnaast moet hij inbreuken op de appartementseigendom dulden, die voortvloeien uit het overeenkomstig $\$ 14$ lid 1 en 2 WEG gemaakte gebruik door andere appartementseigenaars ${ }^{87}$. Bovendien moet hij betreding en gebruik van zijn afzonderlijke eigendom dulden, voor zover dit nodig

82. Vgl.. $\$ 6$ lid 1 modelreglement: "Das Wohnungseigentum ist frei veräuBerlich und vererblich".

83. Bärmann (Kommentar), blz, 310, 311.

84. Vgl. BGH 17 jan. 1968, BGHZ 49 (1968), blz. 250; OLG Schleswig 11 sept. 1964, MDR 1965, blz 46; BGH 24 nov. 1978, NJW 1979, 870; Bay ObLG 12 jan. 1977, 1; LG Lübeck 16 nov 1987, Rpfleger 1988, blz. 102; Bay ObLG 10 nov. 1987, Rpfleger 1988, blz. 102: Indien bij ondersplitsing een ruimte, die voorheen onder de afzonderlijke eigendom vieh, niet bij de splitsing betrokken wordt, dan is de ondersplitsing nietig.

85. Onder "onevenredig nadeel" moet iedere niet "unerhebliche Beëinträchtigung" worden verstaan. Vgl. Bay ObLG 11. dec. 1980, NJW 1981, blz. 690. Zie ook Bärmann (Kommentar), blz. 364. Vgl. $\$ 8$ modelreglement.

86. Dit geldt met name ook met betrekking tot buurders en onderhuurders. Bay ObLG 18 maart 1970 , MDR 1970, blz. 586, 587 .

87. Gebruik door andere appartementseigenaars dat boven de rechten van 14 lid 1 en 2 uitstijgt, kan als inbreuk op het eigendomsrecht worden bestreden. Vgl. Bay OBLG 19 aug. 1971, MDR 1972 , blz 52; KG Berlijn 16 maart 1972, WM 1972, blz. 709. 
is voor de instandhouding van de gemeenschappelijke eigendom ${ }^{88}$. Hij heeft echter recht op vergoeding van daaruit voortvloeiende schade ( $\$ 14$ lid 3 en 4 WEG).

Een appartementseigenaar is gereehtigd om de gemeenschappelijke eigendom mede te gebruiken behoudens de bepalingen van de $\$ \S 14$ en $15 \mathrm{WEG}^{89}$. Ander gebruik van de gemeenschappelijke eigendom komt de appartementseigenaars toe overeenkomstig \& 16 WEG ( $\$ 13$ lid 2 WEG). Overeenkomstig deze paragraaf komt aan iedere appartementseigenaar het gebruik van de gemeenschappelijke eigendom naar evenredigheid van de grootte van zijn aandeel toe $(\S 16$ lid 1 WEG). Daartegenover staat echter wel de plicht om naar verhouding van de grootte van zijn aandeel bij te dragen in de lasten en kosten van instandhouding, herstel, beheer en gebruik van de gemeenschappelijke delen. De leden 4 en 5 van $\$ 16$ WEG geven aan welke bijzondere kosten hieronder vallen ${ }^{* 0}$.

Iedere appartementseigenaar heeft verder het recht om zonder toestemming van de andere eigenaars maatregelen te treffen, die dringend nodig zijn om dreigende schade te voorkomen ( $\$ 21$ lid 2 WEG). De kosten die dan voortvloeien uit de voorkoming van de schade, moeten door de appartementseigenaars gezamenlijk worden gedragen ${ }^{91}$.

\subsection{Toelating en ontzegging van verder gebruik}

\subsubsection{Algemene opmerkingen}

De Duitse appartementseigendom wijkt qua structuur af van die van het Nederlandse appartementsrecht. Anders dan in Nederland heeft men in Duitsland gekozen voor een dualistische structuur, waarbij in plaats van een beperkt zakelijk gebruiksrecht van privé-gedeelten, volle eigendom aan de appartementseigenaar wordt toegekend. De vraag die in deze paragraaf aan de orde komt is welke toelatings-en ontzeggingsregeling men in West-Duitsland hanteert. In $\S 6.2 .5 \mathrm{kwam}$ al aan de orde dat vervreemding van een appartement in West-Duitsland aan toestemming van de overige appartementseigenaars kan worden onderworpen. In $\$ 6.2 .4$ werd bovendien al vermeld dat een appartementseigenaar kan worden

88. De appartementseigenaar moet echter ook bouwkundige veranderingen en maatregelen, die bowen de normale instandhouding van de gemeenschappelijke eigendom uitstijgen, dulden, voor zover deze veranderingen en maatregelen voortvloeien uit normaal gebruik overeenkomstig $\$ 14$ WEG door de amdere appartementseigenaars. Andere bouwkundige veranderingen en maatregelen ten aanzien van de gemeenschappelijke eiggendom behoeven toestemming van de appartementseigenaar ( $\$ 22$ lid 1 WEG). In kosten van bouwkundige maatregelen, die niet worden ondernomen in het kader van normale instandhouding, herstel en beheer, behoeft een appartementseigenaar niet bij te dragen. Indien hij niet in deze kosten bijdraagt, mag hij echter van de door de matregelen tot stand gekomen voorzieningen geen gebruik maken $(\& 16$ lid 3 jo. 22 lid 1 WEG). Vgl. ook $\$ 9$ modelreglement en Demharter, blz. 265-270.

89. Vgll. \$ 5 modelreglement.

90. De rechtsopvolger onder bijzondere titel van een in gebreke gebleven appartementseigenaar is niet aansprakelijk voor de schuld van zijn rechtswoorganger. Vgl. Bärmann (Erwerberhaftung), blz. 7, 8; BGH 22 jan. 1987, Rplleger 1987, blz. 208. Zie ook: Happ, blz. 76, 77. Vgl. ook \$14 modelreglement ower de kostenverdelingsregeling.

91. Bärmann (Kommentar), blz. 422. 
gedwongen om zijn appartement te vervreemden. Op deze regelingen zal in het navolgende nader worden ingegaan.

\subsection{Toelating}

Een belangrijk artikel bij toelating tot appartementseigendom in de Duitse Bondsrepubliek vormt $\S 12$ WEG. Dit artikel luidt:

"1) Als Inhalt des Sondereigentums kann vereinbart werden, daß ein Wohnungseigentümer zur Veräußerung seines Wohnungseigentums der Zustimmung anderer Wohnungseigentümer oder eines Dritten bedarf.

2) Die Zustimmung darf nur aus einem wichtigen Grund versagt werden. Durch Vereinbarung gemäß Absatz 1 kann dem Wohnungseigentümer darüber hinaus für bestimmte Fälle ein Anspruch auf Erteilung der Zustimmung eingeräumt werden.

3) Ist eine Vereinbarung gemäB Absatz 1 getroffen, so ist eine VeräuBerung des Wohnungseigentums und ein Vertrag, durch den sich der Wohnungseigentümer zu einer solchen Veräußerung verpflichtet, unwirksam, solange nicht die erforderliche Zustimmung erteilt ist. Einer rechtsgeschäftlichen Veräußerung steht eine Veräußerung im Wege der Zwangsvollstreckung oder durch den Konkursverwalter gleich." ${ }^{2}$

Een vervreemdingsbeperking is in beginsel niet in strijd met het BGB of het "Grundgesetz". § 903 BGB laat beperkingen (bij of krachtens de wet) uitdrukkelijk toe:

"Der Eigentümer einer Sache kann, soweit nicht das Gesetz oder Rechte Dritter entgegenstehen, mit der Sache nach belieben verfahren und andere von jeder Einwirkung ausschließen."

Artikel 14 "Grundgesetz" (GG) bepaalt:

"Das Eigentum und das Erbrecht werden gewährleistet. Inhalt und Schranken werden durch die Gesetze bestimmt." ${ }^{93}$

De bevoegdheid om over een zaak te beschikken kan echter ingevolge $\$ 137 \mathrm{BGB}$ in beginsel niet bij overeenkomst worden beperkt. \& 12 WEG houdt dan ook geen doorbreking van de regel van $\$ 137$ BGB in (vgl. over $\$ 137$ BGB hetgeen daarover verderop in deze paragraaf gezegd wordt).

Een nieuwe bewoner heeft dus blijkbaar geen toestemming tot ingebruikneming nodig. Bij overeenkomst (bijv. in het reglement) of bij de splitsing door eén

92. Dit artikel is in het WEG opgenomen om een gemeenschap van appartementseigenaars in staat te stellen om uit financieel of personnlijk opzicht ongewenste personen uit hun midden te weren. Vizethum, blz. 70.

93. Vgl. Schwarz, blz. 186; Bärmann (Grundgesetz) blz 22, 23. Bärmann meent eveneens dat 12 WEG niet in strijd is met $\$ 14 \mathrm{GG}$. 
eigenaar overeenkomstig $\& 8 \mathrm{WEG}^{94}$, die als inhoud van de afzonderlijke eigendom wordt opgenomen, kan echter worden bepaald dat een appartementseigenaar toestemming tot vervreemding van zijn appartement nodig heeft van de overige appartementseigenaars of een derde, bijvoorbeeld de administrateur ${ }^{95}$. De bepaling dat toestemming tot vervreemding vereist is, moet als inhoud van de afzonderlijke eigendom worden overeengekomen en daarvoor is inschrijving in de openbare registers (het "Grundbuch") vereist ${ }^{\%}$. Is de bepaling niet als inhoud van de afzonderlijke eigendom overeengekomen, dan werkt zij slechts tussen contractanten en niet tegen rechtsverkrijgers van contractanten ${ }^{97}$. Dit heeft tevens tot gevolg dat de overeenkomst tussen de appartementseigenaars niet tegen de derde-koper kan worden ingeroepen. Uiteraard pleegt de vervreemder in een dergelijk geval wel wanprestatie ten opzichte van zijn medecontractanten ${ }^{98}$.

De ratio van de vervreemdingsbeperking is het voorkomen van toetreding van ongewenste nieuwkomers tot de gemeenschap ${ }^{99}$.

"Gerade weil die Gemeinschaft der Wohnungseigentümer eine unauflösbare und somit auf Dauer berechnet ist, besteht ein Interesse der Gemeinschaft daran, ein gewisses Mitbestimmungsrecht in Hinsicht auf künftige Wohnungseigentümer, also Erwerber von Wohnungseigentum, auszuüben. Dies können soziale Gründe (Homogenität der Wohnungs-

94. In het navolgende zal gemakshalve steeds worden gesproken over een wervreemdingsbeperking die bij overeenkomst tussen de eigenaars tot stand komt.

95. Diester (Grenzen), blz. 245. De vervreemdingsbeperking geldt niet bij eigendomsovergang door vererving en bij bezwaring van appartementseigendom. Bärmann (Kommentar), blz. 308. De toestemmingsbewoegdheid kan waarschijnlijk ook aan de hypotheekhouder worden toegekend: Sohn, blz. 26-30; Bay OblG 29 jan. 1987, Rpfleger 1987, blz. 356, 357. Als de toestemming volgens de splitsingsakte door de administrateur moet worden gegeven, maar deze bij vervreemding van een appartement (nog) niet is benoemd, kan de toestemming door een unaniem besluit van alle appartementseigenaars worden vervangen. OLG Zweibrücken $16 \mathrm{dec}$. 1986, MDR 1987, blz, 326; Ook een andere appartementseigenaar kan worden aangewezen als degene die de toestemming moet verlenen. Bay ObLG 14 sept. 1987, Bay ObLGZ 1987, blz. 291297. Vgl ook OLG Düsseldorf 22 aug. 1984, waarover Sohn (Zustimmung), blz. 19. In casu besliste het OLG Düsseldorf dat, indien de vervreemding van een appartement toestemming van de administrateur behoeft en de administrateur zijn eigen appartement wil verkopen, het voldoende is dat de administrateur in de koopovereenkomst verklaart, dat hij toestemming tot vervreemding geeft. Volgens Peter Sohn staat hieraan echter $\$ 181 \mathrm{BGB}$ in de weg, waarin het aan een vertegenwoordiger wordt verboden (behoudens toestemming) om in maam van de wertegenwoordigde met zichzelf op eigen naam of als vertegenwoordiger van een dlerde een rechtshandeling te verrichten, behoudens kleine uitzonderingen. Het OLG Düsseldorf achtte \& $181 \mathrm{BGB}$ echter in casu niet toepassellijk en oordeelde de vervreemding mogelijk.

96. Vgl. over de inschrijving in het "Grundbuch" en mogelijke problemen daarbij: Weitnauer, blz. 205, 206; Hans Diester (Reactie op Weitnauer), blz. 207.

97. Weitnauer/Hauger, blz. 205 .

98. Palandt, blz. 114.

99. Schwarz, blz. 186. Desalniettemin is ook vervreemding van een appartement aan een andere appartementseigenaar onderworpen aan het toestenmingsvereiste. Bay ObLG 9 maart 1977, in Derichs (Sammlung), deel II, nr. 21. 
eigentümer) sein, aber auch ethische (Gemeinschaftsfrieden) und wirtschaftliche (Sicherstellung der Beitragsleistungen)", aldus Bärmann ${ }^{100}$.

De bewoners van een gebouw moeten een middel hebben om ongewenste aspiranteigenaars buiten de deur te houden. De vervreemdingsbeperking geldt echter niet indien het gehele onroerend goed door alle appartementseigenaars of door de eigenaar van alle appartementen wordt vervreemd. Hetzelfde geldt bij de eerste verkoop door de eigenaar die overeenkomstig \& 8 WEG zijn grond heeft gesplitst en aan de administrateur de bevoegdheid om over toestemming tot vervreemding te beslissen, heeft toegekend ${ }^{101}$. Twijfel ontstond in een geval waarin de eerste verkoop van een appartement pas jaren nadat de overige appartementen waren verkocht, plaatsvond. Het "Landgericht Bielefeld "102 besliste dat de eerste verkoper ook dan nog zijn appartement vrij kon vervreemden. Schopp zette in zijn noot bij dit vonnis vraagtekens bij de juistheid van deze beslissing ${ }^{103}$. Ook Diester ${ }^{104}$ meent dat door verloop van tijd de splitsende grondeigenaar tot gewone appartementseigenaar wordt, die evenzeer als andere eigenaars aan de vervreemdingsbeperking is gebonden. Hij beargumenteert dit door de stelling, dat het doel $\S 12$ WEG meebrengt, dat de vrije vervreemdingsbevoegdheid eindigt, zodra de gemeenschap van appartementseigenaars in zijn geheel is ontstaan, dat wil zeggen wanneer nagenoeg alle appartementen zijn vervreemd.

In het modelreglement is in $\$ 6$ lid 1 bepaald dat iedere appartementseigenaar zijn eigendom in beginsel vrij mag vervreemden of bezwaren. Het tweede lid houdt ten aanzien van de vervreemding echter een beperking in de zin van \&12 WEG in. \$ 6 lid 2 van de model-"Gemeinschaftsordnung" luidt:

"Zur Veräußerung ist die schriftliche Zustimmung des Verwalters erforderlich. Der Verwalter darf die Zustimmung nur aus einem wichtigen Grund versagen. Als wichtiger Grund gilt insbesondere, wenn durch Tatsachen begründete Zweifel daran bestehen, daß

a) der Erwerber die ihm gegenüber der Gemeinschaft der Wohnungseigentümer obliegenden finanziellen Verpflichtungen erfüllen wird, oder

b) der erwerber oder eine zu seinem Hausstand gehörende Person sich in die Hausgemeinschaft einfügen wird.

100. Bärmann (Kommentary), blz 305. Een soortgelijke overweging: Bay ObLG 3 juli 1964, NJW 1964, biz. 1962. A fortiori geldt dit indien de appartementseigenaars gezamenlijk de bouw hebben gefinancierd.

101. Diester (Grenzen) blz 245; LG München I 12 juli 1961, DNOTz 1962, blz. 193; Bärmann (Kommentar), blz 306 . Bij vererving van een appartement heeft de erfgenaam die het appartement verkrijgt, geen toestemming nodig voor de eigendomsovergang. LG Nürnberg-Furth 7 jan. 1976, in Derichs (Sammllung), deel $I_{p}$ ir. 54; Sohn, blz 35-44, 65. Bij eerstwerkoop door eigenaars die bij overeenkomst conform \$15 WEG hebben gesplitst, geldit het toestemmingsvereiste wel. Zie Bay ObLG 9 okt. 1986, Rpfleger 1987, blz. 16.

102. LG Bielefeld 17 okt. 1973, Rpfleger 1974, blz. 111.

103. Schopp, blz 112.

104. Diester (Grenzen), blz. 245, 246. 
Die Zustimmung des Verwalters kann durch Beschluß der Eigentümerversammlung ersetzt werden. Die Zustimmung des Verwalters ist jedoch nicht erforderlich für die Veräußerung:

a) beim Erstverkauf durch das Wohnungsunternehmen,

b) im Wege der Zwangsvollstreckung,

c) durch Konkursverwalter,

d) durch Gläubiger dinglich gesicherter Darlehen, wenn sie ein von ihnen erworbenes Wohnungseigentum weiter veräußern."

Ook in het modelreglement is dus een vervreemdingsbeperking opgenomen. Voor een geldige weigering is altijd ingevolge $\$ 12$ WEG een gewichtige reden vereist ${ }^{105}$. Wat een gewichtige reden kan zijn wordt in het WEG niet nader uitgewerkt.

In het reglement kunnen de appartementseigenaars de gronden opnemen die naar hun mening een gewichtige reden vormen ${ }^{106}$. In het onderhavige modelreglement is echter slechts bepaald dat een gewichtige reden ondermeer aanwezig is, indien er door feiten gestaafde twijfell bestaat of

1. de koper jegens de gemeenschap niet aan zijn financiële verplichtingen zal voldoen ${ }^{107}$ of

2. de' koper en de tot zijn huishouden behorende personen in de gemeenschap passen.

Deze twee criteria zijn beide in de jurisprudentie als in beginsel mogelijke gewichtige reden erkend ${ }^{108}$. Op zichzelf rechtvaardigen deze criteria echter geen weigering van toestemming tot vervreemding. Een gewichtige reden voor weigering van toestemming tot vervreemding kan volgens het Beierse "Oberstes Landesgericht" 109 namelijk slechts dan worden aangenomen, indien de vervreemding van de appartementseigendom voor de belangen van de gemeenschap van de overige appartementseigenaars een gevaar meebrengt. Een zuiver abstract gevaar kan geen gewichtige reden opleveren. Het gevaar moet door feiten kunnen worden gestaafd ${ }^{110}$. Het gevaar dat voor de gemeenschap ontstaat, moet objectiveerbaar zijn. Dat wil zeggen: de reden waarom men zich bedreigd voelt moet objectief "gevaarzettend" zijn. Als gewichtige reden kan objectief bijvoorbeeld niet worden aanvaard, dat

105. Zie ook $\$ 6$ lid 2 model-"Gemeinschaftsordnung. Dit vereiste, dat een gewichtige reden nodig is voor een geldige weigering, is onaantastbaar. Bij overeenkomst kunnen geen lichtere weigeringsgronden worden vastgesteld. Vgl. Bay OBLG 16 nov. 1972, NJW 1973, blz, 152, 153.

106. Diester (Rechtsprechung), blz 120; Weitnauer/Hauger, blz. 207; Augustin, blz. 115.

107. Van een gebrekkige financièle zekerheid is ondermeer sprake als de aspirant-koper notoir aan geldgebrek lijdt of failliet is verklaard.

108. Bay ObLG 16 nov. 1972, NJW 1973, blz. 152, 153; LG Konstanz 6 juni 1984, WM 1985, blz. 485; Sohn, blz. 91. Vgl. ook Liessem (Verwalterzustimmung), blz. 1306-1308; Müller, blz. 49.

109. Bay ObLG 16 nov. 1972, NJW 1973, blz 152, 153, Ein wichtiger Grund zur Versagung der Zustimmung zu den Verkauf einer Eigentumswohnung liegt nur vor, wenn der Kaufinteressent erkennbar rechtlich geschützte Gemeinschaftsinteressen verletzen wird". Vgl. ook WeitnauerHauger, blz. 207.

110. LG Mannheim 9 febr. 1977, BB 1977, blz 319; Sohn, blz. 88. 
men verwacht dat een buitenlandse, mediterrane aspirant-koper niet in de gemeenschap zal passen. Objectief is voor dit gevaar geen grond te ontdekken ${ }^{11 t}$ Bovendien moet de gewichtige reden zijn oorzaak vinden in de persoon van de aspirant-koper ${ }^{112}$, bijvoorbeeld op grond van de twee hierboven genoemde criteria (zie $\$ 6$ lid 2 sub a en $b$ modelreglement) ${ }^{113}$. Gevaar voor verandering van de bestemming van de appartementseigendom door de koper, kan eveneens een gewichtige reden tot weigering van toestemming opleveren, die zijn oorzaak vindt in de persoon van de aspirant-koper ${ }^{114}$.

Resumerend kan worden gesteld dat van een gewichtige reden sprake is als:

1. de vervreemding van de appartementseigendom voor de belangen van de gemeenschap van de overige appartementseigenaars gevaren meebrengt,

2. dit gevaar door feiten kan worden gestaafd,

3. de gewichtige reden zijn oorzaak vindt in de persoon van de koper, bijvoorbeeld doordat

3.1 te verwachten valt dat de aspirant-koper niet aan zijn financiële verplichtingen jegens de gemeenschap zal (kunnen) voldoen ${ }^{115}$;

3.2. de koper en de tot zijn huishouden behorende personen niet in de gemeenschap (zullen) passen;

3.3 de koper de bestemming van zijn appartement onduldbaar zal veranderen.

Indien de bewoners van een appartementsgemeenschap geen toestemming geven voor vervreemding, en een gewichtige reden hiervoor ontbreekt, kan de "verkopende" appartementseigenaar in beroep gaan tegen de beslissing van de gemeenschap. Hierbij kan hij de "gewichtige reden" in rechte tot "niet gewichtige reden" laten verklaren om aldus alsnog toestemming tot vervreemding te krijgen, of om schadevergoeding te verkrijgen ${ }^{116}$.

Schadevergoeding werd bijvoorbeeld toegekend door het "Landgericht Konstanz" 117 . Een appartementseigenares had in casu drie appartementen willen

111. Sohn, blz, 94 .

112. Hierbij is niet van belang of de weigeringsgrond aan de aspirant-koper te verwijten walt. Bay. ObLG 16 nov. 1972, NJW 1973, blz. 152, 153.

113. De opsomming van criteria in $\$ 6$ lid 2 sub a en b is niet limitatief, hetgeen blijkt uit het woord "insbesondere" in de aanhef.

114. Sohn, blz. 91-93.

115. Overigens mag de toestemming niet geweigerd worden indien de koper de achterstallige betalingen van zijn voorganger niet wil voldoen. Liessem (Verwalterzustimmung), blz. 1306.

116. Er zij op gewezen dat de rechter de toestemming niet mag vervangen. Hij kan niet "gestaltend oder ändernd" in besluiten ingrijpen. Hij kan aangevochten besluiten slechts ongeldig verklaren en schadevergoeding toekennen. Bärmann (Kommentar), blz. 803, 804; Sohn, blz 107.

117. LG Konstanz 6 juni 1984, WM 85, blz. 484 e.v. met noot Volkmann. Hitorover Kahlen, blz. 76, 77 . 
verkopen aan een arts, die in de appartementen (waaraan in het reglement van splitsing geen specifieke bestemming was verbonden) een artsenpraktijk annex chirurgische behandelingspraktijk wilde vestigen. De vergadering van eigenaars had toestermming voor de verkoop geweigerd. De appartementseigenares ging in beroep bij het "Amtsgericht" en het "Landgericht", maar kwam tweemaal van een koude kermis thuis. Tegen de beslissing van het "Landgericht" stelde zij het rechtsmiddel "weitere sofortige Beschwerde" in bij het "Oberlandesgericht". Het "Oberlandesgericht" verwees de zaak vervolgens terug naar het "Landgericht". Het "Landgericht" moest vooral nagaan, of het voorgenomen gebruik van de drie appartementen tegen de gerechtvaardigde belangen van de gemeenschap van appartementseigenaars indruiste. Daarbij moest bijzonder worden gelet op het gebruik tot dan toe, alsmede op bijzondere nadelen die uit het voorgenomen gebruik konden voortvloeien, bijvoorbeeld het te verwachten bestemmingsverkeer.

Het "Landgericht Konstanz" besloot met deze punten in het achterhoofd, dat er in casu geen gewichtige reden tot weigering bestond en dat de appartementseigenaars daarom gehouden waren om de voor de eigenares ontstane schade te vergoeden. Als motivering werd hierbij gegeven dat een gewichtige reden slechts dan bestaat, indien de vervreemding van de appartementseigendom een gevaar meebrengt voor de gerechtvaardigde belangen van de gemeenschap van appartementseigenaars. Een dergelijk gevaar kan alleen bestaan, indien de aspirant-koper niet in de gémeenschap zou passen of financieel niet voldoende draagkrachtig zou zijn om zijn bijdragen in de gemeenschappelijke kosten te voldoen of zijn andere verplichtingen jegens de gemeenschap niet zou nakomen (bijvoorbeeld door gebruik van het appartement in strijd met de daaraan in het reglement gegeven bestemming). In casu was van geen van deze drie omstandigheden sprake.

Een juridische grondslag voor de schadevergoeding gaf het "Landgericht" niet. Hermann Kahlen concludeert in zijn bespreking van het onderhavige vonnis, dat de enige grondslag voor schadevergoeding het gewoonterechtelijke instituut van de "positive Forderungsverletzung" kan zijn. Kort weergegeven houdt dit in dat de appartementseigenaars bij ontbreken van een gewichtige reden de plicht hebben om de toestemming tot vervreemding te verlenen. De verkoper heeft een recht op deze toestemming. Indien de appartementseigenaars hun verplichting niet nakomen, plegen ze wanprestatie en ontstaat hieruit een aanspraak op vergoeding van schade ${ }^{118}$

Bij overeenkomst kan aan de appartementseigenaars voor bepaalde gevallen een recht op toestemming tot vervreemding worden verleend. Een dergelijk recht op toestemming is met name van belang bij verhypothekering van een appartement. De hypotheekhouder zal sneller bereid zijn om een hypotheek te nemen op een appartement dat bij wanbetaling door de hypotheekgever zonder vervreemdingsbeperkingen kan worden geveild. Bovendien zal de hypotheeknemer in praktijk betere credietcondities verlenen indien de vervreemdingsbeperkingen niet gelden voor openbare executoriale verkoop ${ }^{119}$

118. Palandt, blz 325-327.

119. Weitnauer-Hauger, ble. 204, 205. 
Het was vroeger enigszins twijfelachtig of als inhoud van afzonderlijke eigendom ook kan worden overeengekomen, dat een appartementseigenaar voor de ingebruikgeving van zijn appartement (bijv. verhuur) aan een derde, toestemming nodig heeft van de overige eigenaars of de administrateur. Het "Oberlandesgericht

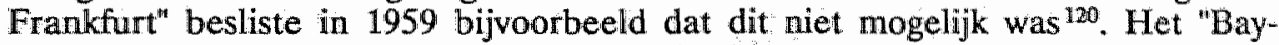
risches Oberstes Landesgericht" meende daarentegen in 1962 dat een dergelijke overeenkomst wel mogelijk was en legde zijn besluit woor aan het "Bundesgerichtshof" (vgl. over het procesrecht paragraaf 6.4.2) ${ }^{121}$. Het "Bundesgerichtshof" hakte tenslotte de knoop door en besliste dat het inderdaad mogelijk is om als inhoud van de afzonderlijke eigendom overeen te komen dat ingebruikgeving aan derden aan toestemming is onderworpen ${ }^{122}$.

Indien het voor een appartementseigenaar nodig is om toestemming tot vervreemding te vragen en hij zijn appartement desalniettemin zonder toestemming vervreemdt, is de vervreemding zolang de toestemming niet is gegeven "schwebend unwirksam"123. Dit geldt niet alleen voor de overeenkomst, maar ook voor de overdracht ${ }^{124} . \S 12$ WEG houdt daarom de mogelijkheid tot doorbreking van $\$ 137$ BGB in. Dit laatste artikel bepaalt namelijk:

"Die Befugnis zur Verfügung über ein veräußerliches Recht kann nicht durch Rechtsgeschäft ausgeschlossen oder beschränkt werden. Die Wirksamkeit einer Verpflichtung, über ein solches Recht nicht zu verfügen, wird durch diese Vorschrift nicht berührt." 125

In beginsel kan bij overeenkomst aan een verkoop (gevolgd door overdracht) niet de werkzaamheid worden ontzegd. \& 12 WEG bepaalt daarentegen dat een vervreemding niet werkt indien daartoe toestemming is vereist, welke toestemmingseis als inhoud van de afzonderlijke eigendom kan worden overeengekomen. Het gevolg van het niet verkrijgen van toestemming is niet de nietigheid van de vervreemding, maar de opschorting van de werking ervan. Het verkrijgen van toestemming tot vervreemding werkt aldus als het ware als een opschortende voorwaarde die van buitenaf wordt ingevoegd in de vervreemding. Wordt toestemming tot vervreemding geweigerd, dan is de vervreemding "absolut unwirksam". De vervreemder pleegt mijns inziens in dat geval echter geen

120. OLG Frankfurt 25 juni 1959, Rpfleger 1959, blz. 279. Het OLG besliste: "Eine solche Vereinbarung verstöBt gegen \& $137 \mathrm{BGB}$ und ist nur mit obligatorischer Wirkung zulissig".

121. Bay ObLG 23 jan. 1962, Rpfleger 1962, blz. 137.

122. BGH 15 juni 1962, NJW 1962, 1613, DNotZ 1963, blz. 180 met noot Weitnatuer; MDR 1962, ble. 810; Rpfleger 1962, blz 373 met noot Diester. Vgl. Bay ObLG 14 sept. 1987, ZMR 1988, bliz 106 108: In het reglement kan worden bepaald dat een appartementseigenaar zijn woning slechts met toestemming van een andere appartementseigenaar aan een derde in gebruik mag geven. Deze toestemming mag slechts op grond van een gewichtige reden wordea geweigerd. Zie ook Riedler, blz. 161-164. Bij verhuur voor korte termijn aan wisselende huurders moet telkens een aparte toestemming worden verleend. Een algemene toestemming tot verhuring kan riet worden verleend, aldus OLG Frankfurt 15 jan. 1987, OLGZ 1987, blz. 269, 270. Zie \$ 5 lid 3 en 4 van het modelreglement.

123. Dit betekent dat de vervreemding, zolang de toestemming niet is werleend, geen rechtsgevolg heeft en de eigendom niet overgaat.

124. Bärmann (Kommentar), blz. 316, 317.

125. Vgll. hierover Furtner, blz 182-189. 
wanprestatie. Indien uit de overeenkomst nog geen plichten zijn oñtstaan, kan er immers ook geen sprake zijn van niet-nakoming van die plichten ${ }^{126}$.

Een overeenkomst, waarin de bevoegdheid tot verhuring of verpachting wordt beperkt, is niet in strijd met $137 \mathrm{BGB}$, omdat verhuur (of verpachting) geen beschikking (Verfügung) in de zin van $\$ 137$ BGB vormen. Omdat bezwaring well beschikken in de zin van $\& 137 \mathrm{BGB}$ is, is een overeenkomst waarin bezwaring aan toestemming wordt onderworpen, niet toegestaan ${ }^{127}$, althans niet in die zin dat de overeenkomst enig effect zou hebben op de geldigheid van de bezwaring.

Overigens wordt door sommigen in West-Duitsland beweerd, dat de vervreemdingsbeperking van \& 12 WEG afgeschaft moet worden. Hiervoor worden geen principiële, maar praktische argumenten aangevoerd. Ten eerste wordt erop gewezen dat de vervreemdingsbeperkingen niet gelden voor mensen die alle appartementsrechten in eigendom hebben en verkopen, noch voor de eerste verkoper die overeenkomstig \& 8 WEG grond en gebouwen heeft gesplitst. Hierdoor worden veel vervreemdingen aan de werkingssfeer van $\$ 12$ WEG onttrokken. Een ander argument is de zogenaamde "Streitwert". In Duitsland worden advocaten- en gerechtskosten aan de hand van deze strijdwaarde van de procedure vastgesteld. Bij procedures met betrekking tot vervreemding van appartementen geldt de verkeerswaarde van het appartement als strijdwaarde. Hierdoor zijn de appartementseigenaars en administrateurs vaak huiverig om toestemming tot vervreemding te weigeren. Als een procedure tegen de weigering wordt gestart en de appartementseigenaars verliezen, moeten zij al gauw 10 procent van de strijdwaarde aan advocaten- en gerechtskosten voldoen. Bij een appartement van plusminus $300.000 \mathrm{DM}$ is dit nog altijd een slordige $30.000 \mathrm{DM}^{125}$.

\subsubsection{Het voorkeursrecht}

Naast de mogelijkheid om de vervreemding aan toestemming te onderwerpen, welke mogelijkheid door $\$ 12$ WEG wordt geopend, hebben de appartementseigenaars nog een andlere mogelijkheid om te voorkomen dat ongewenste personen deel gaan uitmaken van de gemeenschap. $\mathrm{Zij}$ kunnen namelijk een voorkeursrecht overeenkomen, dat inhoudt dat de overige appartementseigenaars bij vervreemding van een appartement het eerste recht van koop hebben. Dit voorkeursrecht is niet door het WEG aan de appartementseigenaars toegekend. Het is echter mogelijk om het bij overeenkomst te regelen. De algemene bepalingen uit het BGB betreffende zakelijk werkende voorkeursrechten zijn hierop van toepassing ( $\$ \S$ 1094-1104 BGB).

De Westduitse heersende leer gaat ervan uit dat het voorkeursrecht niet als inhoud van de afzonderlijke eigendom kan worden overeengekomen, maar slechts als bezwaring van onroerend goed (overeenkomstig \& $1094 \mathrm{BGB})^{129}$. Het

126. Bärmann (Kommentar), blz. 307, 308; Sohn, blz. 96, 97.

127. Bärmann (Kommentar), blz 321 .

128. Vizethum, blz. 70, 72, 73.

129. Zo ook de jurisprudentie: Hans. OLG Bremen 25 mei 1977, Rpfleger 1977, blz 313; OLG Celle 7 april 1955, NJW 1955, blz. 953. Vgl. ook: Weitnauer/Hauger, blz. 209; Augustin, blz 115; Alsdorf (Vorkaufsrecht), blz. 92, 93; Sohn, blz 54. 
voorkeursrecht is een zakelijk recht, waarmee het onnoerend goed kan worden bezwaard ${ }^{20}$. Bärmann ${ }^{131}$ meent daarentegen dat uit de contractsvrijheid voortvloeit dat de appartementseigenaars een voorkeursrecht ook als inhoud van de afzonderlijke eigendom kunnen overeenkomen. In elk geval heeft schending van het voorkeursrecht niet tot gevolg dat de eigendom van het appartement niet overgaat. De gerechtigde tot het voorkeursrecht kan van de koper echter wel overdracht van het verkochte vorderen, en eventueel van de verkoper schadevergoeding ${ }^{132}$.

\subsubsection{Ontzegging van verder gebruik}

Ingevolge $\$ 12$ WEG is het mogelijk dat appartementseigenaars als inhoud van de afzonderlijke eigendom overeenkomen, dat een appartement niet zonder toestemming mag worden vervreemd. Aldus kan men a priori voorkomen dat ongewenste personen deel gaan uitmaken van de gemeenschap. Vaak zal echter pas achteraf, indien een persoon reeds lid van de gemeenschap is, blijken dat een appartementseigenaar niet in de gemeenschap past of zich niet aan de regels houdt. Daarom is ook in het Westduitse recht voor appartementseigenaars de mogelijkheid geopend, om een eigenaar het verdere gebruik van zijn appartement te ontzeggen ${ }^{133}$. De uitsluitingsmogelijkheid is in de memorie van toeliching bij het WEG ${ }^{134}$ als volgt beargumenteerd:

"Da die Gemeinschaft der Wohnungseigentümer grundsätzlich unlöslich ist, muß ein Rechtsbehelf geschaffen werden, der es ermöglicht, einen Wohnungseigentümer aus der Gemeinschaft zu entfernen, wenn er gegen die aus ihr erwachsenden Pflichten verstößt. Gerade das Fehlen einer solchen Vorschrift hat viel dazu beigetragen, die Hausgemeinschaft im Falle des Stockwerkeigentums alter Art zu einer Quelle unerträglicher Streitigkeiten zu machen."

Bij de uitsluiting zijn met name de $\$ 18$ en 19 WEG van belang. $\$ 18$ WEG luidt:

"1) Hat ein Wohnungseigentümer sich einer so schweren Verletzung der ihm gegenüber anderen Wohnungseigentümern obliegenden Verpflichtungen schuldig gemacht, daß diesen die Fortsetzung der Gemeinschaft nicht mehr zugemutet werden kann, so können die anderen Wohnungseigentümer von ihm die Veräußerung seines Wohnungseigentums verlangen.

2) Die Voraussetzungen des Absatzes 1 liegen insbesondere vor, wenn 1. der Wohnungseigentümer trotz Abmahnung wiederholt gröblich gegen die ihm nach $\$ 14$ obliegenden Pflichten verstößt;

130. Pallandt, blz. $1205,1206$.

131. Bärmann (Kommentar), blx 495.

132. Vgl. § 1098 lid 2 BGB jo. \$ 883 lid 2 BGB.

133. Demharter (BundesRatsinitiative), blz 47.

134. Begründung za dem Entwurf eines Gesetzes über das Wohnungseigentum und das Dauerwohnrecht (Wohnungseigentumsgesetz), BRats Drucksache 75/51. Zie ook Weitnauer/Hauger, blz. 243 . 
2. der Wohnungseigentümer sich mit der Erfüllung seiner Verpflichtungen zur Lasten- und Kostentragung ( $\$ 16$ Abs. 2) in Höhe eines Betrages der drei vom Hundert des Einheitswertes seines Wohnungseigentums übersteigt, länger als drei Monate in Verzug befindet.

3) Uber das Verlangen nach Absatz 1 beschlieBen die Wohnungseigentimer durch Stimmenmehrheit. Der Beschluß bedarf einer Mehrheit von mehr als der Hälfte der Stimmberechtigten Wohnungseigentümer. Die Vorschriften des $\$ 25$ Abs. 3, 4 sind in diesem Falle nicht anzuwenden.

4) Der in Absatz 1 bestimmte Anspruch kann durch Vereinbarung der Wohnungseigentümer nicht eingeschränkt oder ausgeschlossen werden."

Het recht om aan een appartementseigenaar het verdere gebruik te ontzeggen, is dus anders dan de toestemming tot vervreemding, niet facultatief geregeld. Dit recht komt de appartementseigenaars ipso iure toe. De uitsluitingsmogelijkheid kan ook niet door overeenkomst worden beperkt of uitgesloten $(\S 18$ lid 4 WEG) ${ }^{135}$. De ontzegging van verder gebruik wordt geconstrueerd als een uitsluiting uit de gemeenschap van appartementseigenaars. De appartementseigenaars kunnen immers ingeyolge lid 1 van $\$ 18$ WEG van een andere appartementseigenaar verlangen dat hij zijn appartementseigendom venveemdt. Uiteraard kan deze uitsluiting niet willekeurig plaatsvinden ${ }^{136}$. In lid 1 van $\S 18$ WEG wordt als eis voor toelaatbaarheid van uitsluiting gesteld dat de uit te sluiten appartementseigenaar zich in zodanige mate schuldig heeft gemaakt aan niet nakoming van zijn verplichtingen ten opzichte van de overige appartementseigenaars, dat van deze appartementseigenaars niet kan worden gevergd dat zij de gemeenschapsverhouding met hem laten voortduren. Bärmann ${ }^{1.37}$ vermeldt dat deze "Generalklausel" in feite niet meer is dan een voor ontzegging van verder gebruik vereiste "gewichtige reden" 138 .

Het tweede lid van $\$ 18$ WEG sluit bij dit globale vereiste aan en geeft twee gevallen waarin in elk geval sprake is van een reden tot uitsluiting. De eerste reden is dat de appartementseigenaar ondanks aanmaningen herhaaldelijk zijn plichten ex \& 14 WEG (instandhouding afzonderlijke eigendom, niet toebrengen van onevenredig nadeel e.d.) verzuimt. De tweede reden is dat de appartements-

135. Zie $\$ 16$ modelreglement.

136. Men mag pas tot uitsluiting overgaan, als alle andere mogelijkheden om de harmonie in de gemeenschap van appartementseigenaars te herstellen, zijn mislukt. AG München 14 dec. 1960 MDR 1961, blz 604: "Die Entziehung des Wohnungseigentums ist nach dem Gesetz das letzte Mittel, das nur anzuwenden ist, wenn andere Rechtsbehelfe nicht gegeben sind". In dezelfde zin LG Passau 12 april 1984, Rpfleger 1984, blz. 412: "Die Entziehung des Wohnungseigentums stellt einen äußerst schwerwiegenden Eingriff in das grundgesetzlich geschützte Eigentumsrecht dar und kann daher nur als letztes Mittel bei wirklich schweren Verfehlungen gerechtfertigt sein*.

137. Bărmann (Kommentar), blz. 432, 433 .

138. Er zij op gewezen dat schuld van de uit te sluiten appartementseigenaar in beginsel een vereiste is voor witsluiting ex $\$ 18$ lid 1 WEG. Vgl. Weitnauer/Hauger, blz. 244. Bij zware tekortkoming kan van het schuldvereiste worden afgeweken. Vgl. bijvoorbeeld in een huurzaak: LG Bielefeld 30 now 1967, ZMR 1968, blz. 172; AG Emmerdingen 31 jan. 1986, ZMR 1986, blz. 212: een ontwrichting van de verhouding tussen de appartementseigenaars kan ook zonder schuld tot uitsluiting van een appartementseigenatar leiden. 
eigenaar in gebreke blijft bij te dragen in de lasten en kosten van de gemeenschap ( $\$ 16$ lid $2 \mathrm{WEG}$ ). Als bijzondere eis hierbij wordt gesteld dat het verschuldigde bedrag drie procent van de eenheidswaarde van zijn appartement te boven gaat en de appartementseigenaar langer dan drie maanden in gebreke moet zijn ${ }^{139}$. Indien aan een van deze twee eisen is voldaan, behoeven de appartementseigenaars niet meer te bewijzen dat van hen niet kan worden gevergd dat zij de gemeenschap met de in overtreding zijnde eigenaar voortzetten ${ }^{140}$.

Het besluit tot uitsluiting van een appartementseigenaar moet bij absolute meerderheid van alle stemmen worden genomen ${ }^{141}$. Het besluit moet derhalve worden genomen door meer dan de helft van de stemgerechtigde appartementseigenaars (ook de niet ter vergadering aanwezigen worden meegeteld). De bepalingen uit § 25 WEG over de vereisten voor de geldigheid van een besluit en over de mogelijkheid om een nieuwe vergadering bijeen te roepen die ongeacht het aantal aanwezige stemgerechtigden geldige besluiten kan nemen, zijn in de uitsluitingsprocedure niet toepasselijk. Voor een uitsluitingsbesluit gelden zwaardere eisen dan voor een normaal besluit. Ten eerste moet een appartementseigenaar uitgesloten worden met absolute stemmenmeerderheid. Volgens $\$ 25$ lid 3 daarentegen zijn besluiten geldig als de helft van de medeëigendomsaandelen. vertegenwoordigd is. In concreto kan dit laatste betekenen dat besluiten kunnen worden genomen door enkele personen die meerdere appartementen in eigendom hebben. Deze mogelijkheid is ten aanzien van uitsluiting door $\S 18$ WEG ondervangen. Bovendien is het niet mogelijk om over uitsluiting te beslissen in een tweede vergadering waarin geen quorum is vereist, zoals ten aanzien van andere besluiten wel het geval is. Indien de vereiste meerderheid in eerste vergadering niet aanwezig is, kan de vergadering in tweede bijeenkomst normaal gesproken immers ten aanzien van hetzelfde onderwerp zonder te voldoen aan een quorumvereiste, beslissen. Bij uitsluiting van een appartementseigenaar zal een tweede vergadering, indien in de eerste geen geldig besluit kon worden genomen, echter opnieuw de eis van absolute meerderheid gelden ${ }^{142}$.

De vraag komt nu op welke specifieke gevallen voldoende aanleiding kunnen zijn om een appartementseigenaar uit de gemeenschap uit te sluiten en hem derhalve te dwingen zijn appartement te vervreemden. Allereerst zijn dit de gevallen genoemd in $\$ 18$ lid 2 WEG. Indien appartementseigenaars een andere eigenaar willen uitsluiten om een reden die niet in $\$ 18$ lid 2 WEG is genoemd, moeten zij zich op de "Generalklausel" van lid 1 beroepen. Dit betekent dat de appartementseigenaar (1) zich schuldig moet hebben gemaakt aan plichtsverzuim tegenover de andere appartementseigenaars en (2) dat van de andere apparte-

139. Müller, blz. 180 raadt het gebruik van de procedure ex $\$ \$ 18,19$ WEG bij niet nakoming van financiële verplichtingen af. Volgens. Müller is deze procedure te omslachtig en duurt ze zeerr lang. Hij beveelt aan om voor de betalingsachterstand een gerechtelijke voor executic valbare titel te vragen en vervolgens het appartement van de in gebreke blijvende appartementseigenaar executoriaal te verkopen. Overigens kan als inhoud van de afzonderlijke eigendom ook worden overeengekomen, dat het ontzeggingsbesluit met meer dan de absolute meerderheid van stemmen moet worden genomen, bijv. 3/4 van de stemmen. Vigl. OLG Celle 7 april 1955, NJW 1955, blz. 953, 954. Vgl. over de gevolgen van alsnog voldoening van de schulden tijdens de procedure: 8 19 lid 2 WEG.

140. Stache, blz. 5; Augustin; blz. 151.

141. Weimar, blz 84; Augustin, blz 152 .

142. Bärmann (Kommentar), blz $438,439$. 
mentseigenaars niet kan worden gevergd dat zij de gemeenschap met de uit te sluiten eigenaar voortzetten. Het plichtsverzuim kan verschillende vormen aannemen. Te denken valt aan zware belediging van de overige bewoners, het herhaaldelijk in gevaar brengen van de gemeenschappelijke eigendom, onzedelijk gedrag en burenruzie. Helaas is over uitsluiting uit de gemeenschap slechts zeer weinig jurisprudentie bekend ${ }^{143}$.

Het "Landgericht Passau" 144 stelde als uitsluitingseis (1) zeer zwaar plichtsverzuim waarvan (2) niet verwacht kan worden dat de overige appartementseigenaars dit dulden. Het "Amtsgericht Emmerdingen" ${ }^{145}$ meende dat een appartementseigenaar die ten gevolge van burenruzies 's machts hevig lawaai veroorzaakte en andere appartementseigenaars bedreigde, zijn plicht zodanig had verzuimd, dat van de andere appartementseigenaars niet kon worden gevergd dat zij de gemeenschap met hem lieten voortduren. Als uitsluitingsgrond werd vreemd genoeg de verstoorde burenrelatie aangemerkt en schuld werd niet noodzakelijk geacht:

"Ein Zerwürfnis zwischen den Wohnungseigentümern kann auch ohne Verschulden die Ausschliessung eines Wohnungseigentümers begründen. Insbesondere kann eine Ausschliessung bei heftigen Nachbarstreitigkeiten gerechtfertigt sein."

Dat de Duitse rechtbanken terughoudend zijn in het uitspreken van een vonnis tot vervreemding, blijkt behalve uit het hierboven genoemde oordeel van het "Landgericht Passau", ook uit een vonnis van het "Landgericht Nürnberg-Fürth" 146. Een appartementseigenares had in casu twee appartementen. Een appartement bewoonde zij zelf en het andere had zij verhuurd. In het verhuurde appartement vonden "unsittliche Zustände" plaats. De eigenares had daar ingevolge $\$ 14$ lid 2 WEG tegen moeten optreden. Dit had zij echter niet gedaan, waarop de overige appartementseigenaars hadden besloten haar uit de gemeenschap te sluiten ${ }^{147}$.

In eerste instantie had het "Amtsgericht" de vordering afgewezen, omdat de huurders ten tijde van de procedure al waren verhuisd. Het "Landgericht NürnbergFürth" veroordeelde de appartementseigenares echter om het verhuurde appartement te verkopen. Het door haar zelf bewoonde appartement hoefde ze echter niet te vervreemden.

"Der Umstand, daß eine Wohnungseigentümerin als Vermieterin einer Eigentumswohnung wegen fortgesetzter Duldung unsittlicher Zustände für die Gemeinschaft untragbar im Sinne des $\$ 18$ WEG geworden ist, zwingt

143. Wellicht is er weinig jurisprudentie vanwege het feit dat de proceskosten hoog kunnen oplopen en een gemeenschap wan appartementseigenaars procedures vermijdt om de proceskosten te vermijden. Zie par. 6.3 .2 laatste alinea.

144. LG Passau 12 april 1984, Rpfleger 1984, blz. 412 met noot Alfred Gerauer.

145. AG Emmerdingen 31 jan. 1986, ZMR 1986, blz. 212.

146. LG Nürnberg-Fürth 20 sept. 1963, in: Diester (Rechtsprechung), blz 130, 131.

147. Zij hadden overigens ook de mogelijkheid gehad om ex $\$ \$ 14$ en 15 lid 3 WEG tegen het gewraakte gebruik op te treden en een verbod ervan te eisen. Vgl. bijv. Bay ObLG 6 nov. 1986, MDR 1987, blz 409 over een verbod van prostitutie en Bay ObLG $11 \mathrm{dec}$. 1986, MDR 1987, blz. 410 over lawaaioverlast door een café. Zie ook Schmidt (Haftung), blz. 894, 895; dezelfde (Mieter), blz. 106,110 . 
nicht ohne weiteres dazu, ihr außer der vermieteten noch eine ihr gleichfalls gehörende zweite und von ihr selbst bewohnte Eigentumswohnung abzusprechen."

Verder besliste het "Landgericht" dat het voor de aanspraak van de overige appartementseigenaars op vervreemding niet relevant is, of het plichtsverzuim ten tijde van de procedure nog voortduurt.

Indien een appartement in medeëigendom toekomt aan meerdere personen, kunnen deze slechts worden uitgesloten indien zij hebben nagelaten tegen hun zich misdragende deelgenoot op te treden. De goede trouw ( $\$ 242$ BGB) eist echter in dit geval wel een afweging van belangen van de gemeenschap en die van de betreffende deelgenoot. Zo moet worden afgewogen of de gemeenschap zonder de zich misdragende deelgenoot kan voortbestaan en of de deelgenoten niet medeschuldig zijn aan de misdragingen van de uit te sluiten deelgenoot ${ }^{148}$.

Als een appartementseigenaar zijn plichten heeft verzuimd en van de overige appartementseigenaars niet kan worden gevergd dat zij de gemeenschap met hem laten voortduren, kunnen zij zoals gezegd de vervreemding van zijn appartement verlangen. Uit $\$ 18$ lijkt op het eerste gezicht voort te vloeien dat een besluit van de overige appartementseigenaars voldoende is om te bewerkstelligen dat de in overtreding zijnde eigenaar zijn appartement moet verkopen. Dit klopt echter alleen indien de appartementseigenaar zich bij het verlangen van de overige eigenaars neerlegt en tot vervreemding van zijn appartement overgaat. Indien hij dit niet doet moeten de overige eigenaars de verkoop afdwingen. Hiervoor moeten zij zich tot het "Amtsgericht" van het district waarin het appartementsgebouw ligt wenden en een vonnis tot vervreemding van het appartement vorderen ( $\$ 51$ WEG). Wie dit vonnis kan vorderen volgt niet uit het WEG. In beginsel zijn er vier mogelijkheden:

1. alle appartementseigenaars tezamen kunnen de vordering instellen;

2. de appartementseigenaars die bij het besluit om vervreemding te verlangen aanwezig waren en voorgestemd hebben, kunnen de vordering instellen;

3. de appartementseigenaars die bij het besluit om vervreemding te verlangen aanwezig waren, kunnen de vordering instellen;

4. iedere appartementseigenaar kan de vordering instellen ${ }^{149}$.

Over de vraag of deze vier mogelijkheden in praktijk ook daadwerkelijk gelden, verschillen de meningen. In elk geval is men het erover eens dat de onder (a) en (b) genoemde mogelijkheden in praktijk gelden ${ }^{150}$. Evenzeer is het mogelijk dat de gezamenlijke eigenaars of de eigenaars die voor het besluit om vervreemding te verlangen hebben gestemd, de administrateur of een appartementseigenaar machtigen om de vordering tot veroordeling tot vervreemding in te stellen ${ }^{151}$.

148. Vgl. $\$ 16$ lid 2 modelreglement.

149. Bãrmann (Kommentar), blz. 440; Stache, blz. 77.

150. Bärmann (Kommentar), blz. 440; Stache, blz 77-80.

151. Vgl. LG Nürnberg-Fürth 20 sept. 1963, Diester (Rechtsprechung), blz. 130, 131. 
Overigens moet de vordering tijdig worden ingesteld. Indien de appartementseigenaars er te lang mee wachten, kunnen zij onder omstandigheden hun rechten verwerken ${ }^{152}$. In plaats van het voorleggen van het geschil aan de "Amtsrichter" kunnen de appartementseigenaars overeenkomen om het geschil aan arbitrage te onderwerpen ${ }^{\mathrm{LS}}$.

De rechter (of de arbitrage-instantie) toetst vervolgens of de uit te sluiten appartementseigenaar zodanig zijn plichten heeft verzuimd, dat van de overige eigenaars niet kan worden verlangd dat zij de gemeenschap met hem laten voortduren ${ }^{154}$. Als de "Amtsrichter" de appartementseigenaar tot vervreemding veroordeelt wordt \& 19 WEG van belang, die luidt:

"1) Das Urteil, durch das ein Wohnungseigentümer zur Veräußerung seines Wohnungseigentums verurteilt wird, ersetzt die für die freiwillige Versteigerung des Wohnungseigentums und für die Übertragung des Wohnungseigentums auf den Ersteher erforderlichen Erklärungen. Aus dem Urteil findet zugunsten des Erstehers die Zwangsvollstreckung auf Räumung und Herausgabe statt. Die Vorschriften des $\$ 93$ Abs. 1 Satz 2 und 3 des Gesetzes über die Zwangsversteigerung und Zwangsverwaltung gelten entsprechend ${ }^{155}$.

2) Der Wohnungseigentümer kann im Falle des $\$ 18$ Abs. $2 \mathrm{Nr} .2$ bis zur Erteilung des Zuschlags die in Absatz 1 bezeichnete Wirkung des Urteils dadurch abwenden, daß er die Verpflichtungen, wegen deren Nichterfüllung er verurteilt ist, einschließlich der Verpflichtungen zum Ersatz der durch den Rechtsstreit und das Versteigerungsverfahren entstandenen Kosten sowie die fälligen weiteren Verpflichtungen zur Lasten-und Kostentragung erfüllt.

3) Ein gerichtlicher oder vor einer Gütestelle geschloßener Vergleich, durch den sich der Wohnungseigentümer zur Veräußerung seines Wohnungseigentums verpflichtet, steht dem in Absatz I bezeichneten Urteil gleich."

152. Bärmann (Kommentar), blx 432; Stache, blz 57,58 .

153. Bärmann (Kommentar), blz. 782, 783.

154. De "Amtsrichter" toetst in de procedure ex $\$ 51$ WEG niet of het besluit om vervreemding te verllangen geldig (overeenkomstig $\$ 18$ lid 3 WEG) tot stand is gekomen. De toetsing ex $\$ 51$ WEG is een volle materietle toetsing. Vgl. hierover par. 6.4.3.

155. Recent is wijziging van het WEG op een aantal punten voorgesteld, waaronder m. b. t. $\$ 19$ WEG. Volgens het wetsontwerp " zur Änderung des Wohmungseigentumsgesetzes und anderer Gesetze", gepubliceerd in Der WEer 1988, blz. 46-52, 59, zou $\$ 19$ lid 1 eerste zin WEG worden veranderd en als volgt komen te luiden:

"(1) Das Urteil, durch das ein Wohnungseigentümer zur Veräußerung seines Wohnungseigentums verurteilt wird, berechtigt die Eigentümergemeinschaft, gem. $\$ \$ 93 \mathrm{ff}$. des Gesetzes über die Zwangsversteigerung oder die Zwangsvollstreckung auf Räumung oder Herausgabe zu betreiben". Volgens hetzelfde wetsontwerp zouden de $\$ \$ 53$ tot $59,60 \mathrm{cn} 63$ WEG vervallen. Volgens de toelichting bij dit wetsontwerp zou de uitsluitingsprocedure aldus minder omslachtig worden (Der WEer 1988, blz 47, 51, 52). Verder beoogt dit wetsontwerp nog enkele kleine wijzigingen aan te brengen in de $\$ \$ 1,10,13,16,21,23,24,25,27,43,47$ en 51 . Materieel zal er, indien dit wetswoorstel door het Duitse parlement wordt aangenomen, weinig veranderen. 
Het vonnis waarin de appartementseigenaar tot vervreemding van zijn appartement wordt veroordeeld, vervangt dus de voor de vrijwillige veiling van appartementseigendom en voor de overdracht aan de verkrijger benodigde verklaringen. Het vonnis tot vervreemding vervangt anders gezegd de toestemming van de appartementseigenaar om zijn appartement te vervreemden. Aldus wordt de procedure die men enigszins misleidend "freiwillige Versteigerung" noemt, mogelijk ${ }^{156}$. Als de appartementseigenaar zijn appartement derhalve niet vervreemdt op grond van het vonnis van de "Amtsrichter", kan zijn appartement slechts via de procedure van de "freiwillige Versteigerung" worden verkocht ${ }^{157}$.

In de $\$ \$ 53-60$ WEG wordt de procedure voor deze "vrijwillige" openbare verkoop uitgewerkt. Voor de "vrijwillige" veiling geldt dat iedere notaris, in wiens district het te verkopen appartement gelegen is, bevoegd is de veiling te leiden ( $\$$ 53 lid 1 WEG). Iedere appartementseigenaar die het vonnis overeenkomstig $\$ 19$ WEG heeft bewerkstelligd, kan de veiling vorderen ( $\$ 54$ lid 1 WEG). Voor de inhoud van de vordering tot openbare verkoop en de veilingvoorwaarden worden in \$ 54 lid 2 en 3 nadere regels gegeven. De $\$ 55$ en 56 WEG regelen vervolgens de vaststelling van de dag van de veiling en geven procedureregels voor de veiling zelf. In beginsel moet tussen de veiling en de vaststelling van de datum een termijn van zes weken liggen. $\$ 57$ WEG geeft vervolgens nadere regels over de toeslag van het appartement. De enkele toeslag bewerkstelligt nog geen eigendomsovergang. De akte van veiling moet in de openbare registers betreffende onroerend goed (het "Grundbuch") worden ingeschreven. Dit zou anders zijn als $\$ 90$ van het "Gesetz über die Zwangsversteigerung und die Zwangsverwaltung" (ZVG) van toepassing zou zijn ${ }^{158}$. De toeslag ter veiling zou dan eigendomsovergang tot gevolg hebben. Nu de veiling echter op "vrijwillige" basis geschiedt, vervangt de toeslag ter veiling slechts de titel van eigendomsoverdracht ${ }^{159}$. In \$ 58 WEG worden voorschriften over de beroepsmogelijkheid tegen de toeslag ter veiling en tegen de veilingvoorwaarden gegeven.

De veilingkoper (of degene die het appartement verkrijgt voordat men aan een veiling toekomt) heeft in het oordeel van de "Amtsrichter" tot verkoop ook een titel tot ontruiming en overgave van het appartement.

Indien een appartementseigenaar wegens het niet nakomen van zijn financiële werplichtingen ( $\$ 18$ lid 2 sub 2 WEG) tot vervreemding van zijn appartement wordt gedwongen, kan hij tot de toeslag ter veiling de verkoop afwenden door alle kosten (inclusief die van de reeds gevoerde procedures) te betalen. Door betaling wordt de werking aan het vonnis tot vervreemding ontnomen ( $\$ 19$ lid 2 WEG) ${ }^{160}$. Op grond van lid 3 van $\$ 19$ WEG vervangen rechterlijke of arbitrale schikkingen het vonnis van lid 1 van $\S 19$ WEG. De rechtsgevolgen van zo'n schikking zijn dezelfde als die van een vonnis tot vervreemding.

156. Weitnauer/Hauger, blz 249.

157. Bärmann (Kommertar), blz 444.

158. Het eerste lid wan $\$ 93$ ZVG is wel van toepassing. Zie $\S 19$ lid 1 WEG.

159. Bärmann (Kommentar), blz. 444, 446, 447.

160. Bärmana (Kommentar), blz. $448,449$. 
Tenslotte dient nog op de toepasselijkheid van eventuele vervreemdingsbeperkingen te worden gewezen. Ook indien een appartement openbaar wordt verkocht volgens de procedure van de "vrijwillige" openbare verkoop, zijn eventuele ex \&12 WEG opgenomen vervreemdingsbeperkingen toepasselijk. Dat betekent dat toestemming tot vervreemding zou moeten worden gevraagd bij een verkoop die men niet zonder te blozen "vrijwillig" kan noemen. Een en ander maakt de toch al vervelende procedure weinig aantrekkelijk, in elk geval voor degene wiens appartement wordt verkocht. Het zou mijns inziens beter zijn als men de vervreemdingsbeperking op zodanige wijze zou beperken (hetgeen volgens $\$ 12$ lid 2 WEG mogelijk is), dat zij niet geldt indien een appartement op grond van $\$ 18$, 19,51 e.v. WEG openbaar wordt verkocht ${ }^{161}$.

\subsection{Beroep tegen niet-toelating tot de gemeenschap of uitsluiting uit de gemeenschap}

\subsubsection{Algemene opmerkingen}

Het is onvermijdelijk dat vroeg of laat in een appartementengemeenschap problemen ontstaan, van welke aard die ook mogen zijn. Deze problemen moeten indien nodig, aan de rechter kunnen worden voorgelegd. Anders dan in het Nederlandse appartementsrecht, waar de bepalingen over de beroepsmogelijkheden op de rechter dwars door het appartementsrecht verspreid staan, heeft men in West-Duitsland een apart deel (het derde) van het WEG ingeruimd voor bepalingen van procesrechtelijke aard. Dit derde deel begint bij \$ 43 WEG, waarin staat aangegeven in welke gevallen de procedure van de "freiwillige Gerichtsbarkeit" moet worden gevolgd ${ }^{162}$. Bij deze procedure is het "Amtsgericht" absoluut competent. De relatieve competentie berust bij de "Amtsrichter" binnen wiens district (Bezirk) het appartementencomplex is gelegen ( $\$ 43$, lid 1 WEG). Het eerste lid van $\$ 43$ WEG somt sub 1 tot en met 4 de gevallen op waarin de procedure van de "Freiwillige Gerichtsbarkeit" moet worden gevolgd.

161. Vgl. hierover uitgebreid: Rudolphi, blz. 369; Sohn, blz. 74, 75. Zie ook \& 6 lid 2 Modelreglement.

162. Weitnauer/Hauger, blz 399-430. Op grond van $\$ 13$ Gerichtsverfassungsgesetz (GVG) moet voor alle burgerlijke rechtsgeschillen een civiele procedure worden gestart, tenzij ze door een bijzonder voorschrift aan de civiele procesgang zijn onttrokken. Over burgerlijke rechtsgesschillen beslist de Westduitse burgerlijke rechter in de "ordentliche Gerichtsbarkeit". Deze "ordentliche Gerichtsbarkeit" valt uitcen in twee los van elkaar stalande procedures; de procedure van de "freiwillige Gerichtsbarkeit" en de procedure van de "streitige Zivilgerichtsbarkeit". In Rosenberg/Schwab, blz. 50, 51, lezen we over het verschil tussen de beide scorten jurisdictie: " Die freiwillige Gerichtsbarkeit ist im Gegensatz zum Zivilproze B, der auf den ErlaB feststellenden Entscheidungen beli einem Streit der Parteien mit der Wirkung der Rechtskraft und der Möglichkeit der Wiederaufnahmeklage gerichtet ist, im wesentlichen eine werwaltende Tätigkeit für alle möglichen Angelegenheiten bildet aber einen Bestandkeil der Rechtspflege* Verderop lezen we echter in hetzelfde boek op blz 53 dat het onmogelijk lijkt "einen durchgreifenden materiellen Unterscheidungsgrund zwischen der Streitigen und der freiwilligen Gerichtsbarkeit im geltenden recht aufzuzeigen". Vergelijk hierover ook: Schellhammer, blz 591; Jauernig, blz. 11. Op de procedure van de "Freiwillige Gerichtsbarkeit" is het "Reichsgesetz über die Angelegenheiten der freiwilligen Gerichtsbarkeit" wan toepassing (vgl. \&58 WEG). Zie over deze wet bijvoorbeeld: Bumiller/Winkler. Het onderscheid tussen "streitige Zivilgerichtsbarkeit" en "freiwillige Gerichtsbarkeit" komt grosso modo overeen met het verschil tussen contentieuze en oneigenlijke jurisdictie in Nederland. Vgl. Hugenhollz/Heemskerk, blz. 20, 21. 
Allereerst moet deze procedure worden gevolgd op verzoek (Antrag) van een appartementseigenaar in kwesties die betrekking hebben op de rechten en plichten die voor de appartementseigenaars uit de gemeenschap en uit het beheer van de gemeenschappelijke eigendom voortvloeien. Uitgezonderd hiervan zijn de aanspraken die appartementseigenaars bij opheffing van de gemeenschap kunnen hebben en de problemen die kunnen rijzen bij onttrekking van appartementseigendom ingevolge $\$ \S 18,19 \mathrm{WEG}$. Voor deze gevallen staan andere rechtsgangen open (o.a. die ex $\$ \S 51,52$ WEG). Ten tweede moet de procedure van de "Freiwillige Gerichtsbarkeit" op verzoek van een appartementseigenaar of de administrateur van een appartementencomplex worden gevolgd in zaken die betrekking hebben op de rechten en plichten van de administrateur bij het beheer en de administratie van de gemeenschappelijke eigendom. Ten derde moet de procedure worden gevolgd op het verzoek ex $\$ 26$ lid 3 WEG van een appartementseigenaar of derde-belanghebbende, om een administrateur te benoemen. Tenslotte moet de procedure ook gevolgd worden op verzoek van een appartementseigenaar of de administrateur in zaken met betrekking tot de geldigheid van besluiten van de vergadering van appartementseigenaars. De rechter beslist, tenzij uit de wet of uit overeenkomst anders voortvloeit, ex aequo et bono ( $\$ 43$ lid 2 WEG).

Aansluitend bij $\S 43$ noemt $\S 44$ WEG de algemene procesbeginselen (Allgemeine Verfahrensgrundsätze) voor de ingevolge $\$ 43$ WEG gevoerde procedures op. Zo dient de rechter op grond van lid 1 naar een schikking tussen de strijdende partijen te streven. Indien een schikking wordt getroffen, moet daarvan een procesverbaal worden opgemaakt ( $\$ 44$, lid 2 WEG). Lid 3 van $\S 44$ voorziet vervolgens in de mogelijkheid voor de rechter om voor de duur van de procedure voorlopige regelingen (Einstweilige Anordnungen) te treffen. In de uiteindelijke beslissing moet de rechter bovendien alle regelingen treffen, die voor de uitvoering van zijn beslissing noodzakelijk zijn. Overigens dient de beslissing gemotiveerd te worden ( $\$ 44$, lid 4 WEG). Indien in een "Rechtsstreit" geschillen aanhangig worden gemaakt, die ex $\$ 43$ WEG in de procedure van de "Freiwillige Gerichtsbarkeit" moeten worden beslist, dan moet de rechterlijke instantie (Prozeßgericht) de zaak aan het ingevolge $\$ 43$ bevoegde "Amtsgericht" doorgeven ( $\$ 46$, lid 1 WEG). Indien de uitslag van een "Rechtsstreit" afhangt van de uitslag van een "freiwillige Gerichtsbarkeit"-procedure, dan kan de rechterlijke instantie besluiten de beslissing aan te houden totdat de uitslag van de procedure van de "freiwillige Gerichtsbarkeit" bekend is ( $\$ 46$, lid 2 WEG). De rechter bepaalt naar billijkheid welke procespartij(en) de proceskosten moet(en) dragen. Hij kan daarbij bepalen dat ook buitengerechtelijke kosten (außergerichtliche Kosten) moeten worden vergoed ( $\$$ 47 WEG). \& 48 WEG geeft aan welke kosten moeten worden vergoed yoor welke procedures. $\$ 49 \mathrm{WEG}$ is ingetrokken ${ }^{163}$. Indien een rechterlijke instantie (ProzeBgericht) de zaak naar het "Amtsgericht" verwijst, worden de kosten voor de tot dan toe gevoerde procedure met die van het "Amtsgericht" gecompenseerd ( $\$$ 50 WEG).

Het "Amtsgericht", in wiens district het appartementencomplex ligt, is behalve in de procedure van de "Freiwillige Gerichtsbarkeit" ook competent in "Rechtsstreitigkeiten" die voortkomen uit onttrekking van de appartementseigendom ingevolge $\$$ 
18 WEG. De waarde van het onderwerp van geschill is hierbij niet relevant $(\$ 51$ WEG). Een soortgelijke bepaling als $\$ 51$ WEG is voor het "Dauerwohnrecht" neergelegd in $\$ 52$ WEG $^{164}$

\subsubsection{Beroep tegen niet-toelating}

Overeenkomstig \& 12 WEG kan zoals vermeld als inhoud van de afzonderlijke eigendom worden overeengekomen, dat een appartementseigenaar voor vervreemding toestemming van de overige eigenaars of de administrateur nodig heeft (vgl. par. 6.3.2). Indien de toestemming niet wordt verleend kan de eigenaar die de toestemming verzoekt zich ingevolge $\$ 43$ lid 1 sub $\mathbb{1}$ WEG in de procedure van de "freiwillige Gerichtsbarkeit" tot het "Amtsgericht" wenden, als de toestemming is geweigerd door de overige appartementseigenaars. In het geval dat de toestemming is geweigerd door de administrateur, moet ingevolge $\S 43$ lid 1 sub 2 WEG dezelfde procedure worden gevolgd. Problematischer wordt het indien de toestemming is geweigerd door een derde, die niet de administrateur is. In dat geval moet namelijk de procedure van de "streitige Zivilgerichtsbarkeit" worden gevolgd ${ }^{165}$.

De rechter toetst in de procedure van de "freiwillige Gerichtsbarkeit" vol ${ }^{166}$. Hij toetst dus niet marginaal. Zijn beslissing neemt hij echter "nach billigem Ermessen" (voor zover uit de wet of uit overeenkomst niet anders voortvloeit), naar redelijkheid en billijkheid derhalve ( $\$ 43$ lid 2 WEG) ${ }^{167}$.

In paragraaf 6.3.2.1 werd ook nog de mogelijkheid besproken dat de appartementseigenaars een voorkeursrecht bedingen voor te verkopen appartementen. Indien een dergelijk voorkeursrecht wordt uitgeoefend, kan hiertegen in beginsel geen beroep worden ingesteld.

Tenslotte werd in paragraaf 6.3 .3 vermeld, dat appartementseigenaars in het reglement of een speciaal daartoe bestemde overeenkomst kunnen regelen, dat geschillen door middel van arbitrage moeten worden opgelost. Bij het bestaan van een dergelijke arbitrageovereenkomst, moeten ook geschillen met betrekking tot toelating aan de arbitrage-instantie worden voorgelegd.

164. Voor de volledigheid zij nog vermeld dat in het vierde deel van het WEG tenslotte de slotbepalingen worden wastgesteld. \$59 WEG geeft uitvoeringsbepalingen voor de "Baubehörden", de autoriteiten die met de bouw van het appartementencomplex van doen hebben. De voorschriften uit de verordening "über die Behandlung der Ehewohnung und des Hausrats" van 21 okt. 1944 zijn volgens $\$ 60$ WEG toepasselijk, indien de echtelijke woning in appartementseigendom aan een van de echtelieden of aan beiden gezamenlijk toekomt. De $\$ \$ 61$ en 62 WEG gaven vroeger fiscale regelen, maar zijn door het "Steuerbereinigungsgesetz" van 14 dec. 1984, BGBI. I, blz. 1493, 1513, ingetrokken. De $\$ \$ 63$ en 64 WEG bevatten tenslotte bepalingen van overgangsrecht en regelen de inwerkingtreding van de wet. Vgl. over het fiscale recht mett betrekking tot appartementseigendom in de BRD o.a: Ernst; Gaydoul/Pabst/Stuhrmann; Herden/Gmach, blz, 1596; Drenzeck, blz, 8-17.

165. Bärmann (Kommentar), blz. 788. De procedure verloopt dan als beschreven in par. 6.4.3. Vgl. ook Sohn, blz. 105-109.

166. Sohn, blz 107.

167. Bärmann (Kommentar), blz. 803 . 


\subsubsection{Beroep tegen witshuting wït de gemeenschap}

De appartementseigenaar die uit de appartementsgemeenschap wordt uitgesloten mag niet meestemmen in de vergadering van eigenaars waarin wordt besloten-over zijn uitsluiting ( $\$ 25$ lid 5 WEG). Indien de appartementseigenaars bij de rechter vervolgens een veroordeling tot vervreemding vorderen ( $\$ 51$ WEG) kan de uit te sluiten appartementseigenaar daar verweer voeren. Het verweer moet dan wel gericht zijn op de grond van de uitsluiting. De appartementseigenaar zal derhalve moeten betogen dat hij niet op zodanige wijze zijn plichten heeft verzuimd, dat van de overige eigenaars niet kan worden gevergd dat zij de gemeenschap met hem voortzetten. Een formeel verweer - over de totstandkoming van het vergaderingsbesluit - kan hij in deze "Rechtsstreit" niet voeren. Als hij toch een formeel verweer voert - bijvoorbeeld dat ter vergadering niet is besloten met de vereiste absolute meerderheid van stemmen - moet de rechter in deze "Rechtsstreit" de zaak ambtshalve doorverwijzen naar de "Amtsrichter" (\$ 46 lid 1 WEG) die er vervolgens over beslist in de procedure van de "freiwillige Gerichtsbarkeit" 168 . Het "Amtsgericht" gaat in de "Rechtsstreit" op alle facetten van de zaak in en toetst evenmin als in de procedure van de "freiwillige Gerichtsbarkeit" met betrekking tot $\$ 12$ WEG marginaal.

Ten aanzien van arbitrage geldt mutatis mutandis hetzelfde als aan het slot van de vorige paragraaf werd opgemerkt.

168. KG 24 aug. 1967, NJW 1967, blz. 2268; Bärmann (Kommentar), blz. 836, 855. De competente rechter in de "Rechtsstreit" is owerigens ook de "Amtsrichter". Vgll. de diss. van Fahle ower het "billige Ermessen" van de rechter bij procedures met betrekking tot appartementseigendom. Doordat de rechter "nach billigem Ermessen" oordeelt, kan hij] volgens Fahle, blz. 9498, in zijn oordeel zelfs afwijken van het door partijen gevorderde. De rechter is dus niet lijdelijk. 


\section{Frankrijk}

\subsection{Inleiding}

Voor de Franse revolutie in 1789 bestond appartementseigendom in Frankrijk slechts in een paar steden zoals bijvoorbeeld Grénoble en Rennes ${ }^{1}$. In die steden was appartementseigendom - "copropriété par étages" genoemd - mogelijk op grond van het gewoonterecht. In Grénoble was appartementseigendom tot ontwikkeling gekomen doordat de stad tussen grote stadswallen lag ingeklemd en het daarbuiten, tengevolge van overstromingen van de aanwezige bergstromen, nauwelijks mogelijk was om te bouwen. Dientengevolge miste de stad de ruimte om in de breedte uit te dijen. In Rennes was appartementseigendom ontstaan als gevolg van een allesverwoestende brand die de stad in de $18 \mathrm{e}$ eeuw in as had gelegd. De grondeigenaarś hadden toen de handen in elkaar geslagen en gebouwen met meerdere woningen gebouwd ${ }^{2}$.

In de "Code civil" (C.c.) van 1804 werd een kort artikel opgenomen dat appartementseigendom mogelijk maakte. De redactie van dit artikel - artikel 664 C.c. - werd door uitspraken van de Hoven van Beroep (Tribunaux d'appel) geïnspireerd en werd mede door de invloed van de uit Rennes afkomstige Bigot de Préameneu, een van de opstellers van de Code civil, opgenomen ${ }^{3}$. Artikel 664 C.c. luidde:

"Lorsque les différents étages d'une maison appartiennent à divers propriétaires, si les titres de propriété ne règlent pas le mode de réparations et reconstructions, elles doivent être faites ainsi qu'il suit:

Les gros murs et le toit sont à la charge de tous les propriétaires, chacun en proportion de la valeur de l'étage qui lui appartient.

Le propriétaire de chaque étage fait le plancher sur lequel il marche.

Le propriétaire du premier étage fait l'escalier qui y conduit; le propriếtaíre du second étage fait, a partir du premier, l'escalier qui conduit chez lui, et ainsi de suite."

Afgezien van een impliciete erkenning van horizontale splitsing van eigendom gaf artikel 664 C.c. dus slechts een zeer summiere regeling voor de verdeling van de lasten en kosten over de verschillende eigenaars. Overigens kon blijkens de

1. Vgll. ook par. 21.1.

2. Logeman, blz. 27.

3. Mazeand/Juglart, blz. 39, 40; Ghestin/Goubeaux, blz 92. 
zinsnede "si les titres de propriété ne reglent pas ...." bij overeenkomst van de regeling van dit artikel worden afgeweken ${ }^{4}$.

De voortschrijdende industrialisering en bureaucratisering van de Franse maatschappij leidde tot de vestiging van vele industrieën en kantoren in de Franse steden. Hierdoor was grond niet meer beschikbaar voor woningbouw, tengevolge waarwan langzaam maar zeker woningnood ontstond. De woningnood dreef de prijzen voor behuizing omhoog waardoor het voor beleggers interessant werd in woningbouw te beleggen. Uit de grond waarop men bouwde wilde men maximaal rendement halen door steeds hoger te bouwen om zoveel mogelijk woningen in eén gebouw onder te brengen.

Artikel 664 C.c. en de costumen van de Franse steden waar appartementseigendom tot ontwikkeling was gekomen, boden onvoldoende oplossingen voor de vele problemen die ontstonden door de steeds groter wordende vraag naar appartementen. Bij wet van 28 juni 1938 werd artikel 664 C.c. daarom afgeschaft en vervangen door een nieuwe regeling, die twee mogelijkheden bood om een gebouw in verschillende woningen te "splitsen". Men kon hetzij een bouwmaatschappij oprichten die aan zijn aandeelhouders het gebruik van appartementen toekende overeenkomstig het aantal aandelen dat zij bezaten, hetzij een systeem van medeëigendom van een appartementsgebouw aannemen. Het eerste systeem de bouwmaatschappij - werd nagenoeg niet toegepast. Waarschijnlijk speelde het verlangen van mensen om "eigenaar" te zijn van hun woning hierbij een grote rol.

In 1951 werd een initiatiefwetsontwerp tot wijziging van de wet van 1938 verworpen. Vervolgens bood de Franse regering in 1964 een nieuw ontwerp aan het parlement aan. Dit ontwerp werd op 26 juni 1965 door het parlement aangenomen. Op 10 juli 1965 werd de aldus tot stand gekomen wet afgekondigd onder nummer 65-557, met als titel "Loi fixant le statut de la copropriêté des immeubles bâtis". Deze wet werd bij decreet van 17 maart 1967 nog aangevuld ${ }^{5}$. Het systeem van de bouwmaatschappij werd gehandhaafd maar het tweede hoofdstuk van de wet van 1938, waarin de appartementsmedeëigendom werd geregeld, werd afgeschaft. De meeste bepalingen uit dit hoofdstuk kwamen in dezelfde wet van 1965 echter weer enigszins veranderd en aangepast aan jurisprudentiële ontwikkelingen terug ${ }^{6}$. Bij wet van 16 juli 1971 werd het systeem van de bouwmaatschappijen uit de wet van 1965 gelicht en naar het vennootschapsrecht verplaatst. De bouwmaatschappij wordt tegenwoordig nog nauwelijks toegepast. Alleen bij time-sharing van onroerend goed wordi deze constructie nog af en toe gebruikt ${ }^{7}$. In 1985 is de wet van 1965 op enige plaatsen gewijzigd ${ }^{8}$.

In dit hoofdstuk zal worden onderzocht of het Franse appartementsrecht regelingen kent die vergelijkbaar zijn met de Nederlandse welstandsbepalingen. Voorafgaand aan de bespreking van eventuele met de Nederlandse welstandsbepalingen

\footnotetext{
4. Vgl. over het Franse appartementsrecht onder de vigeur wan art. 664 C.c.: Bernard.

5. Gewijzigd bij decreet van 9 juni 1986, Dall. 1986, L blz. 382, 383.

6. Vgl. over de geschiedenis van het Franse appartementsrecht: Mazeaud/Juglart, blz. 39-42; Ferid/Sonnenberger, blz. 631, 632; Aeby, blz. 63-68; Marty/Rayiaud, blz. 294-296; Edith Kischinewski-Broquisse, blz. 8, 9; Zurfuh/Traizet-Frot, blz. 27-36; Heck, blz. 6, 7.

7. Ferid/Sonnenberger, blz. 633. Zie ook Cabanac/Lacroix.

8. Zie over de totstandkoming en de wijzigingen wan de wet 1965: Givord/Giverdon, blz. 14, 15; Givord/Giverdon (Ravalement), blz. 43-48.
} 
vergelijkbare regelingen zal echter worden ingegaan op het Franse appartementsrecht in het algemeen en meer in het bijzonder op de algemene structuur van de Franse appartementseigendom, het ontstaan en tenietgaan van de appartementseigendom, beheer en administratie, en rechten en verplichtingen van de appartementseigenaars. Op de bouwmaatschappijen als juridische constructie bij appartementsgebouwen zal in dit hoofdstuk niet nader worden ingegaan, omdat zij tegenwoordig in het Franse appartementsrecht nagenoeg geen rol spelen.

\subsection{De hoofdlijnen van het Franse appartementsrecht ${ }^{9}$}

\subsection{Algemene opmerkingen}

De wet van 1965 regelt de "copropriété des immeubles bâtis" tamelijk uitgebreid. In 48 wetsartikelen worden regelingen gegeven met betrekking tot structuur, organisatie en beheer van de "copropriété". De bepalingen van deze wet zijn van dwingende aard. Alleen waar dit in de wet zelf wordt bepaald, mag van deze wettelijke regeling worden afgeweken ${ }^{10}$. Het decreet van 17 maart 1967 sluit bij de wet aan en regelt een aantal technische bijzonderheden met betrekking tot ontstaan en tenietgaan van de "copropriétée", vergadering van eigenaars en de administrateur. De medeëigendom wordt dus in beginsel beheerst door de wet van 1965 en het decreet van 1967, maar deze regelingen worden aangevuld door een reglement van medeëigendom. Dit reglement moet door de eigenaars van de appartementen worden opgesteld. Het kan echter ook worden opgesteld door de eigenaar van een gebouw, die tot splitsing wil overgaan, of door de aandeelhouders van een bouwmaatschappij ${ }^{11}$.

Artikel 8 van de wet van 1965, waarin het opstellen van een reglement wordt voorgeschreven, is van dwingend recht ${ }^{12}$. Artikel 8 luidt:

"Un règlement conventionnel de copropriété, incluant ou non l'état descriptif de division, détermine la destination des parties tant privatives que communes, ainsi que les conditions de leur jouissance; il fixe également, sous réserve des dispositions de la présente loi, les règles relatives à l'administration des parties communes.

Le règlement de copropriété ne peut imposer aucune restriction aux droits des copropriétaires en dehors de celles qui seraient justifiées par la destination de l'immeuble, telle que'elle est définie aux actes, par ses caractères ou sa situation."

Het reglement is een contract tusen de appartementseigenaars ${ }^{13}$. De bepalingen van dit contract en de veranderingen die daarin kunnen worden aangebracht zijn niet inroepbaar tegen rechtsverkrijgers onder bijzonder titel, voordat zij in de

9. Vgl. hierover in het algemeen: Schwarz (Wohnungseigentum in Frankreich)

10. Ferid/Sonmenberger, blz. 632; Marty/Raynaud, blz 306.

11. Denis, blz, 21, 22.

12. Het grootste gedeelte van de bepalingen uit de wet 1965 en het decreet 1967 zijn van dwingend recht. Vgl. art. 43 Wet 1965 en Marty/Raynaud, blz. 313; Givord/Giverdon, blz. 260.

13. Kischinewski-Broquisse, blz. 549 . 
openbare registers voor onroerend goed zijn ingeschreven (art. 13 wet 1965) ${ }^{14}$. In de praktijk wordt het reglement van splitsing vaak gecompleteerd door een huishoudelijk reglement. Dit huishoudelijk reglement is echter geen onderdeel van het reglement van medeëigendom. De appartementseigenaars kunnen in dit huishoudelijk reglement regelingen treffen met betrekking tot het gebruik van liften, het sluiten van deuren e.d. Al met al verschilt de inhoud van dit huishoudelijk reglement in principe niet van die van de in Nederland gehanteerde huishoudelijke reglementen. In het navolgende zullen de hoofdlijnen van wet, decreet en reglement worden weergegeven. Als modelreglement van medeëigendom zal het in Denis op blz. 135-165 gepubliceerde reglement worden gehanteerd (verder te noemen: reglement Denis).

\subsection{Algemene structuur van appartementseigendom}

Het Franse recht maakt onderscheid tussen gewone medeëigendom (indivision/copropriété ordinaire) en "gedwongen" medeëigendom (copropriêté avec indivision forcée) ${ }^{15}$. Appartementseigendom is een vorm van "gedwongen" medeëigendom, waardoor de regels betreffende deze vorm van medeëigendom, in beginsel ook voor appartementseigendom gelden (vgl. artt. 815-842 en 1873-1 1873-18 C.c.) ${ }^{16}$.

Volgens artikel 1 van de wet van 10 juli 1965 heeft deze wet betrekking op alle gebouwen of groepen van gebouwen waarvan de eigendom aan meerdere personen toekomt en op zodanige wijze is verdeeld, dat ieder aandeel een privé-gedeelte en een evenredig deel van de gemeenschappelijke gedeelten omvat ${ }^{17}$. Bij ontbreken van een afwijkende regeling die een afwijkende organisatie creëert, is de wet van 1965 tevens van toepassing op een geheel van onroerende goederen, uitgezonderd terreinen, ontginningen en gemeenschappelijke diensten (services communs), dat gedeelten bevat (bebouwd of onbebouwd) die in afzonderlijke eigendom an verschillende personen toekomen.

Artikel 2 omschrijft als privé-gedeelten (parties privatives) die gedeelten van gebouwen en de daarbij behorende terreinen, die in afzonderlijk gebruik aan een bepaalde medeëigenaar toekomen. Afzonderlijk gebruik is derhalve een criterium, aan de hand waarvan privé-eigendom van gemeenschappelijke eigendom kan worden onderscheiden ${ }^{18}$. Hiervoor is wel vereist dat het afzonderlijk gebruik juridisch slechts aan eén appartementseigenaar toekomt. Het is niet voldoende dat slechts één eigenaar feitelijk van bepaalde gedeelten gebruik maakt. Overigens kan in het reglement ook worden geregeld dat bepaalde gedeelten door slechts eén appartementseigenaar mogen worden gebruikt, maar toch gemeenschappelijk

14. Zie over hetgeen in thet reglement mag of moet worden opgenomen artt. 1-5 van het decreet van 17 maart 1967. Zie ook Giword/Giverdon, blz. 261, 271, 272. In art. 48 van het reglement Denis (zie hierna) is bovendien bepaald dat in alle contracten, waarin een appartementseigenaar zijn appartement overdraagt of in gebrwik geeft aan derden, de bepaling moet worden opgenomen dat de nieuwe eigenaar of gebruiker verplicht is het reglement na te leven.

15. Mazeaud/Juglart, blz. 31 .

16. Mazeaud/Juglart, blz. 31-63. Vgl. ook Ferid/Sonnenberger, blz. 623-631.

17. Vgl. Cass. civ. $3 \mathrm{e} 1$ febr. 1989, Dall. 1989, IR blz. 44.

18. Vgl. Cass. civ. 3e 7 dec. 1988, Dall. 1988, IR ble. 300. Zie ook artt. 1, 3 reglement Denis. 
blijwen. Givord-Giverdon merkt hierbij echter op dat dergelijke bepalingen de oorzaak van veel jurisprudentie vormen ${ }^{19}$.

De privé-gedeelten "sont la propriété exclusive de chaque copropriétaire". Aansluitend bij artikel 2 geeft,artikel 3 aan welke delen van een appartementsgebouw gemeenschappelijk zijn. De eerste zin van artikel 3 bepaalt dat de gedeelten van gebouwen en bijbehorende terreinen die bestemd zijn voor gebruik door of ten dienste staan aan alle of meerdere medeëigenaars, gemeenschappelijk $\mathrm{zijn}^{20}$. Indien niets afwijkends is overeengekomen worden de grond, de binnenplaats, de tuinen, de gangen, schoorstenen ${ }^{21}$ e.d. gemeenschappelijk geacht. Aan deze gemeenschappelijke gedeelten worden, behoudens afwijkende overeenkomst, verscheidene rechten accessoir geacht ${ }^{22}$. Het recht om een gebouw te verhogen dat bestemd is voor gemeenschappelijk gebruik of dat meerdere gedeelten bevat die verschillende prive-gedeelten vormen en het recht om nieuwe gebouwen op te richten op (gemeenschappelijke) binnenplaatsen of in (gemeenschappelijke) tuinen, zijn bijwoorbeeld aan de gemeenschappelijke eigendom accessoire rechten ${ }^{23}$. Artikel 4 bepaalt vervolgens dat de gemeenschappelijke gedeelten in medeëigendom toekomen aan het geheel van medeëigenaars of enkelen onder hen. Indien niet anders is overeengekomen, is het aandeel in de gemeenschappelijke gedeelten dat aan elk perceel (appartement) toekomt, evenredig aan de relatieve waarde van elk privé-gedeelte met betrekking tot het geheel van waarden van de privé-gedeelten ${ }^{24}$.

De gemeenschappelijke gedeelten en de daaraan accessoire rechten kunnen geen afzonderlijk onderwerp van verdeling of gedwongen verkoop zijn. De privégedeelten zullen altijd bij zo'n verdeling of verkoop moeten worden betrokken (art. 6 van de wet 1965) ${ }^{25}$. Hieruit lijkt voort te vloeien dat de gemeenschappelijke eigendom accessoir is aan de afzonderlijke eigendom van de privé-gedeelten. De Franse literatuur heeft daar echter een tijd lang over getwijfeld ${ }^{26}$. Gezien het feit dat de medeëigendomsconstructie van de gemeenschappelijke gedeelten niet meer inhoudt dan een middel om te bewerkstelligen dat een zo volmaakt mogelijk genot en gebruik van de privé-gedeelten (afzonderlijke eigendom) wordt verwezenlijkt, lijkt het echter mogelijk om aan te nemen dat de medeëigendom accessoir is aan de privé-eigendom, omdat de medeëigendom slechts ondergeschikt is aan de

19. Givord/Giverdon, blz. 43, 44, 57, 58. Vgl. Hof Parijs 26 okt. 1983, Dall. 1984, IR blz 379.

20. Vgl. art. 4 reglement Denis.

21. Ook elementen van een verwarmingsinstallatie, die nodig zijn voor het functioneren van de verwarming, zjjn gemeenschappelijk, omdat ze met de verwarming een geheel vormen ten gunste van alle appartementseigenaars. Zic Cass. civ. 3 e 30 okt. 1978, Dall. 1979, IR blz. 442.

22. Indien de (oorspronkelijke) eigenaar van de grond of een derde zich een dergelijk recht woorbehoudt bij splitsing, verdwijnt dit recht als er gedurende tien jaar geen gebruik van wordt gemaakt (art. 37 wet 1965).

23. Givord/Giverdon, blz. 59.

24. Het geheel van waarden van de prive-gedeelten wordt vastgesteld aan de hand van de waarde die voortvloeit uit de bouwkundige staat van het gebouw e.d. Overigens kent het Franse appartementsrecht behalve de afzonderlijke eigendom en de algemene medeẽigendom ook nog de mandeligheid van scheidingsmuren tussen twee prive-gedeelten. De eigenaars van de twee prive-gedeelten zijn dan de enige medeëigenaars van de scheidingsmuren (art. 7 van de 1965 ). Vgl. Marty/Raynaud, blz, 306-313; Kischinewski-Broquisse, blz. 61, 62.

25. Een uitzondering hierop is neergelegd in art. 16 van de wet 1965, waaruit blijkt dat de vergadering van eigenaars kan beshiten tot het vervreemden van gemeenschappelijke gedeelten (bijwoorbeeld een gemeenschappellijk stuk grond).

26. Vgl. Kischnewski-Broquisse, blz. 89; Mazeaud/Juglart, blz 45. 
afzonderlijke (volle) eigendom van de privé-gedeelten. Dit argument is eerder door Roger Nerson naar voren gebracht:

"Il ne faut pas oublier"', aldus Nerson, "que le but principal, recherché par chacun des communistes, est la jouissance du "volume", soumis à la propriété privative, destiné à lui servir de logement. La copropriété n'est donc que le moyen de parvenir à cette fin et l'on comprend aisément qu'un partage des parties communes ne soit pas concevable: les parties communes font l'objet d'une copropriété avec indivision forcée; la propriété des parties communes est un accessoire de la proprieté de l'étage ou de l'appartement et cet acoessoire ne peut être détaché du principal"27

Hierbij moet well worden aangetekend dat de afzonderlijke eigendom niet zonder een aandeel in de gemeenschappelijke gedeelten kan bestaan. Ieder afzonderlijk aandeel van een appartementsgebouw moet een aandeel in de gemeenschappelijke gedeelten bevatten ${ }^{28}$.

Men hanteert in Frankrijk dus een dualistisch systeem ${ }^{29}$, waarin afzonderlijke eigendom van privé-gedeelten gekoppeld is aan medeëigendom van de gemeenschappelijke gedeelten ${ }^{30}$.

\subsubsection{Ontstaan en tenietgaan van appartementseigendom}

De appartementseigendom kan op verschillende manieren ontstaan. De belangrijkste ontstaanswijzen komen overeen met die, die bij de bespreking van het Belgische recht ook al werden genoemd. De appartementseigendom kan aldus ontstaan door partijwil, onteigening of verjaring.

Van het ontstaan door partijwil is in verschillende gevallen sprake. Ten eerste kan appartementseigendom ontstaan doordat een eigenaar van een gebouw aan een

27. Nerson, blx. 718, 719. Anders: Le Howerou, blz, 16, 17.

28. Zie Cass. civ. 3e 19 jan. 1977, Dall. 1977, IR blz. 154.

29. Op het dualistische systeem is veel kritick geleverd, niet zozeer vanwege doorbreking van de superficies solo cedit-regel, als wel vanwege het feit dat het object van de afzonderlijke eigendom niet precies valt aan te wijzen. Sommigen omschrijven het als cen eigendomsirecht op cen kubus lucht. Vgl. Zurfluh/Traizet-Frot, blz. 142. Zie ook Givord/Giverdon; blz. 136 en Duthil, blz. 64. Deze zegt dat de afzonderlijke eigendom van de prive-gedeelten niet meer inhoudt dan een zakelijk gebruiks- en genotsrecht, waarover de gerechtigde vrij kan beschikken.

30. In Frankrijk spreekt men nu eens van "propriéte par étage", vervolgens van "propriéte par appartements" en dan weer van "Copropriété des immeubles bâtis" (wettelijke betiteling). Aangezien deze aanduidingen allen betrekking hebben op appartementen die in afzonderlijke eigendom, gecombineerd met medeëigendom aan hun eigenaars toekomen, is het mijns inziens gerechtvaardigd om de Franse tegenhanger van het Nederlandse appartementsrecht "appartcmentse"gendom" te noemen. Daarbij aansluitend wordt de eigenaar van cen appartement appartementseigenaar genoemd. Mijns inziens sluit deze vertaling aatm bij de juridische structuur van eigendom van appartementen, evenzeer als bij de Duitse "Wohnungseigentum". Bovendien is de Franse structuur bijna identiek aan die wan de Belgische appartementseigendom, waardoor geen bezwaar bestaat de Franse structuur met de Belgische benaming "appartementseigendom" aan te duiden. In het nawolgende zal dan ook steeds worden gesproken ower appartementseigendom en appartementseigenaar. 
derde toestaat om een of meer étages aan zijn gebouw toe te voegen ${ }^{31}$. Op die wijze ontstaat een gebouw dat aan meerdere personen toekomt en op zodanige wijze is verdeeld, dat ieder aandeel een privé-gedeelte en een evenredig deel van de gemeenschappelijke gedeelten omvat. De wet van 1965 is dan op grond van artikel 1 van die wet imperatief op dit gebouw van toepassing.

Een tweede manier waarop appartementseigendom kan ontstaan is vervreemding van een gedeelte van een gebouw aan derden door de enig eigenaar van het gebouw, of door schenking of testamentaire making van een gedeelte van een gebouw.

Ten derde kan appartementseigendom ontstaan tengevolge van verdeling van een in onverdeeldheid aan meerdere personen toekomend gebouw ${ }^{32}$. Men heeft zich echter in Frankrijk afgevraagd of een dergelijke verdeling (splitsing in appartementen) aan een medeëigenaar zou kunnen worden opgelegd, indien deze de verkoop van het onroerend goed eist. Hierbij aansluitend werd de vraag gesteld of erfgenamen de erfboedel zouden kunnen verdelen door - indien de erfboedel bestaat uit een gebouw - splitsing in appartementen en of deze verdeling als een echte verdeling kan worden beschouwd en ingeroepen tegen een erfgenaam die zich tegen verdeling in appartementen verzet? Het Hof van Cassatie heeft tenslotte een eind aan de discussie hieromtrent gemaakt door te beslissen dat het mogelijk is om aan een ervengemeenschap of gewone gemeenschap een einde te maken door diverse appartementen aan de verschillende deelgenoten toe te kennen ${ }^{33}$. Overigens is deze opsomming van ontstaanswijzen door partijwil in beginsel niet limitatief.

Een papieren splitsing, dat wil zeggen een splitsing van een nog op te richten gebouw, is in beginsel in Frankrijk niet mogelijk. "Copropriéte" in de zin van de wet 1965 , ontstaat pas op het moment dat het gebouw (gedeeltelijk) volltooid is en het eerste appartement aan een verkrijger is toebedeeld. Het belangrijkste gevolg hiervan is, dat de bouwkosten geen uit de medeëigendom voortvloeiende lasten zijn ${ }^{34}$. Vreemd genoeg heeft de administrateur wel de bevoegdheid om tegen de bouwheer op te treden wegens bouwkundige gebreken, ondanks het feit dat de gemeenschap van eigenaars eigenlijk niets met de bouwheer te maken heeft. De gemeenschap is immers geen opdrachtgever ${ }^{35}$. In praktijk richten personen die een appartementsgebouw tot stand willen brengen vaak een maatschappij op die de

31. Hierbij moet de aantekening worden gemaakt dat art. $553 \mathrm{C.c}$, waarin staat dat de eigenaar van de grond ook eigenaar wan het daarop gebouwde is, slechts een praesumptio juris tantum inhoudt. Dit vermoeden is derhalve voor tegenbewijs vatbaar. Voor dit tegenbewijs voldoet een schriftelijke overeenkomst waarin de eigendom van de opstallen (of een gedeelte daarvan) wordt overgedragen door de eigenaar wan de grond aan een derde. Anders dan in het Nederlandse recht gaat eigendom in het Franse recht door consensus van partijen (welke consensus bijvoorbeeld bewezen kan worden door een schriftelijke overeenkomst) over. Vgl. Wietek, blz, 20, 21. Door inschrijving van de overeenkomst in de openbare registers $k$ rijgt de eigendomsoverdracht zakelijke werking. Voor deze inschirijwing in de openbare registers is een notariële akte vereist. Vgl. Wietek, blz. 23; Bärmann (Dogmatik), blz 6.

32. Marty/Raynaud, blz 303-306.

33. Cass. civ. le 19 jan. 1960, Dall. 1960. J blz. 477 met moot R. Savatier; Marty/Raynaud, blz. 304; Rosenfeld/Lidski, blz 33-36.

34. Cass. civ. 20 dec. 1976, in Atias, nr. 6, blz 14-17.

35. Cass. civ. 21 nov. 1969, in Atias, mr. 69, blz 204, 205. 
bouw regelt en die opgeheven wordt nadat het gebouw tot stand is gekomen ${ }^{36}$. Ook komt het voor dat een aantal personen een stuk grond koopt en daar zonder speciale rechtsvorm een gebouw op bouwt, dat vervolgens in appartementen wordt verdeeld. Een derde mogelijkheid is dat een eigenaar van een stuk grond op die grond bouwt, en na oprichting van het gebouw de verschillende étages verkoopt ${ }^{37}$. Het is echter tevens mogelijk dat een appartement wordt verkocht, terwijl het nog niet bestaat. Dit wordt "vente a terme" genoemd en betekent dat de verkoper zich verplicht om het appartement bij voltooiing te leveren, terwijl de koper de plicht op zich neemt om het appartement bij voltooiing aan te nemen en de prijs te betalen. De eigendom gaat pas over zodra bij authentieke akte is vastgesteld dat het appartement is voltooid. Deze eigendomsovergang wordt echter geacht ex tunc (vanaf de datum van verkoop) te zijn geëffectueerd (zie artikel 261-2 "Code de la construction et de l'habitation" (C.C.H.). Bovendien is het mogelijk dat de eigenaar van de grond onmiddellijk zijn rechten op de grond aan de koper overdraagt en deze eigenaar wordt van het appartement, naarmate de bouw daarvan vordert (art. 261-3 C.C.H.). De wet 1965 is op deze situaties van toepassing, zodra de eigendom is overgegaan, c.q. er sprake is van een gebouw ${ }^{38}$.

In alle gevallen, waarin tot splitsing van een gebouw wordt overgegaan, moet een splitsingsbeschrijving (état descriptif de division) in de openbare registers worden ingeschreven, waarin nauwkeurig de verschillende appartementen van een gebouw worden beschreven. dit volgt uit de artt. 7 en 11 van het Decreet van 4 jan. 1955, "portant réforme de la publicité foncière", zoals gewijzigd bij decreet van 7 jan 1959 en aangevuld bij decreet van 14 oktober 1955. De splitsingsbeschrijving kan in een speciaal daartoe opgestelde acte worden opgenomen, maar ook in het reglement van medeëigendom of in enige andere akte (bijvoorbeeld een testament of onteigeningsvonnis. Zie art. 71 decreet 14 okt. 1955, zoals aangevuld bij decreet van 7 jan. 1959). De "état descriptif" moet aan een aantal vereisten voldoen. In deze beschrijving moeten bijvoorbeeld het nummer van elk appartement, het gebouw, het aandeel in de gemeenschappelijke gedeelten van elk appartement en de etage waar het appartement zich bevindt, zijn vermeld (zie art. 71 lid 2 Decreet 14 okt. 1955 , zoals gewijzigd bij decreet van 21 mei 1979) ${ }^{39}$. Elke verandering van het gebouw of de appartementen, moet in de splitsingsbeschrijving worden verwerkt. Overigens is zowel voor inschrijving van de "état descriptif", als voor inschrijving van het reglement van medeëigendom in de openbare registers, vereist, dat zij in een authentieke akte zijn neergelegd (art. 4 Decreet 4 jan. 1955).

De splitsing in appartementen komt al voor de inschrijving van de "état descriptif" in de openbare registers tot stand, maar kan pas na de inschrijving tegen derden worden ingeroepen ${ }^{40}$.

36. Ferid/Sonnenberger, blz. 633. Voor deze maatschappijen is een speciale regeling neergelegd in de wet van 16 juli 1971 (artt. 214-1 e.v. van de Code urb.).

37. Marty/Raynaud, blz. 303 .

38. Weismann, blz, 62, 63; Guide Neret, blz 33, 34 .

39. Vgl. Logeman, blz. 39; Givord/Giverdon, blz, 85-91.

40. Ferid/Sonnenberger, blz. 635 . 
Het opstalrecht is in Frankrijk niet in de wet geregeld ${ }^{41}$. Door de jurisprudentie is het recht echter erkend, omdat artikel 553 C.c. horizontale scheiding van eigendom van de grond van de daarop staande gebouwen uitdrukkelijk toelaat. De duur van thet opstalrecht kan contractueel worden beperkt ${ }^{42}$. In de Franse literatuur wordt geen aandacht besteed aan de combinatie van een opstalrecht en splitsing in appartementen. Aangenomen moet echter worden dat de gerechtigde tot een opstalrecht zijn gebouw in appartementen kan splitsen, en dat de gevolgen daarvan zijn dat de appartementseigenaars over het algemeen medegerechtigden tot bet opstalrecht, medeëigenaars van het gebouw en volle eigenaars van hun privégedeelten worden.

Appartementseigendom gaat teniet door gehele of gedeeltelijke vernietiging van het gebouw of door unaniem besluit van de appartementseigenaars ${ }^{43}$. Bij algehele vernietiging van het gebouw blijft slechts medeëigendom van de grond bestaan. De (voormalige) appartementseigenaars kunnen in dat geval met absolute meerderheid van stemmen tot wederopbouw besluiten. Bij gedeeltelijke vernietiging gaat slechts de appartementseigendom van de eigenaars wier appartementen verwoest zijn, teniet. Zij blijven wel medeëigenaar van grond en gebouwen. Ook hierbij geldt dat de vergadering van eigenaars bij absolute meerderheid van stemmen tot wederopbouw kan besluiten. Indien het gebouw voor minder dan de helft is verwoest, is wederopbouw echter verplicht, indien meer dan de helft van de eigenaars wier appartement werd verwoest, dit wensen (artt. 38-41 Wet 1965) ${ }^{44}$. Appartementseigendom kan verder tenietgaan doordat alle appartementen worden onteigend, door vermenging bij aankoop van alle appartementen door éen persoon, door het eindigen van een opstalrecht dat aan de splitsing ten grondslag lag en door inbreng van alle appartementen in een vennootschap ${ }^{45}$.

\subsection{Administratie en beheer}

De appartementseigenaars vormen een vereniging met rechtspersoonlijkheid ${ }^{46}$. Deze vereniging kan de rechtsvorm van een coöperatieve vereniging aannemen (vgl. ook artt. 40-42 decreet 1967). $\mathrm{Zij}$ stelt indien nodig het reglement vast en past het eventueel aan. Het doel van de vereniging is de instandhouding van het onroerend goed en het beheer van de gemeenschappelijke gedeelten. Indien appartementseigenaars of derden schade lijden ten gevolge van een gebrek in de bouwconstructie of gebrekkig onderhoud van de gemeenschappelijke gedeelten, is de vereniging voor deze schade aansprakelijk, onverminderd eventuele regres-

41. In de wet is wel de "Bail a construction" geregeld. Zie artt. L 251-1, L 251-9, R 251-1 - R 2513 C.C.H. Dit recht geeft aan de pachter van landbouwgrond de mogelijkheid, om eigendom van de door hem gebouwde opstallen te verkrijgen. Zie Ferid/Sonnenberger, blz. 798, 799.

42. Mazeaud/Juglart, blz 95 .

43. Vigl. Cass, civ. 3 e 24 jan. 1978 , J.C.P. 1978, IV blz. 100.

44. Dexe artikelen zijn niet van dwingend recht. In het reglement kan een afwijkende regeling worden getroffen. Zic Kischimewski-Broquisse, blz. 218, 222.

45. Givord/Giverdon, blz. 333, 334.

46. Vgl. over de vereniging van eigenaars in het algemeen: Duthil, diss; Schober, diss. Zie ook art. 19 reglement Denis. 
mogelijkheden (art. 14 wet 1965) ${ }^{47}$. Uiteraard is de vereniging slechts aansprakelijk voor schade die uit gebrekkig onderhoud e.d. van de gemeenschappelijke gedeelten voortvloeit, en niet voor schade die uit gebrekkig onderhoud van de privé-gedeelten voortvloeit ${ }^{48}$.

De vereniging van eigenaars is bevoegd om in rechte op te treden als eiser of gedaagde, ook tegen bepaalde appartementseigenaars. Bovendien kan de vereniging, al dan niet samen met enkele appartementseigenaars, in rechte ageren om rechten met betrekking tot het onroerend goed zeker te stellen (art. 15 wet 1965). De vereniging en zijn voorzitter kunnen verder besluiten memen over wervreemding of verwerving van gemeenschappelijke gedeelten of met betrekking tot vestiging van zakelijke rechten ten behoeve of ten laste van de gemeenschappelijke gedeelten. Tenslotte kan de vereniging privé-gedeelten verwerven zonder dat daardoor hun bestaan als privé-gedeelte eindigt. Zij ontleent aan het in eigendom hebben van privé-gedeelten geen stemrecht in de vergadering van eigenaars (art. 16 wet 1965) ${ }^{49}$. In artikel 16-1 worden regelingen gegeven met betrekking tot de verdeling van de gelden die de vereniging ontvangt bij verkoop van gemeenschappelijke gedeelten.

Tegenover de hier beschreven bevoegdheden van de vereniging van eigenaars staat de plicht om het gebouw en met name de gemeenschappelijke gedeelten in stand te houden en te beheren. Daarom moet zij ook een verzekering afsluiten tegen brand en wettelijke aansprakelijkheid voor schade, toegebracht aan derden door gebreken in het gebouw ${ }^{50}$.

De besluiten van de vereniging van eigenaars worden genomen in de algemene vergadering van appartementseigenaars (verder te noemen: vergadering van eigenaars). Deze vergadering moet tenminste eenmaal per jaar bijeen worden geroepen (art. 7 decreet 1967). De besluiten moeten worden uitgevoerd door een syndicus, een administrateur ${ }^{51}$ die onder controle van een verenigingsraad (conseil syndical) wordt gesteld ${ }^{52}$. De vereniging moet deze verenigingsraad ingevolge artikel 21 Wet 1965 (zoals gewijzigd bij wet van 31 dec. 1985) instellen. De raad adviseert en controleert de administrateur. Zijn leden worden door de vergadering van eigenaars uit de appartementseigenaars benoemd. Ook rechtspersonen kunnen lid van de verenigingsraad zijn. Uiteraard moeten zij zich wel door een natuurlijk persoon laten vertegenwoordigen ${ }^{53}$. Instelling van een verenigingsraad kan achterwege blijven, indien de appartementseigenaars met tweederde meerderheid van alle stemmen van alle appartementseigenaars, dit besluiten ${ }^{54}$.

Benoeming van een administrateur is eveneens verplicht (art. 17 Wet 1965). Indien een administrateur is benoemd voordat de eerste vergadering van eigenaars

47. Vgl. Cass. civ. 3e 23 nov. 1976, Dall. 1977, IR blz. 156.

48. Logeman, blz. 43 .

49. Vgl. Denis, blz 45-47.

50. Vgl. artt. 39 en 40 reglement Denis. De appartementseigenaars moeten zelf zorg dragen voor de verzekering vam hun inboedel (art. 41 reglement Denis).

51. De administrateur is een orgaan van de vereniging. Zie Schober, blz 132.

52. Vgl. over de bevoegdheden en de samenstelling van de verenigingsraad artt. 22-27 decreet 1967 en art. 21 Wet $1965^{,}$zoals gewijzigd bij wet van 31 dec. 1985.

53. Logeman, biz 48,49 . Vgl. over de verenigingsraad art. 38 reglement Denis.

54. Logeman, blz 61 . 
bijeen komt, moet de benoeming worden goedgekeurd door de vergadering van eigenaars ${ }^{55}$ (vgl. hierover artt. 17 Wet 1965 en 46-49 decreet 1967).

De administrateur kan in het reglement worden aangewezen, maar ook door de vergadering van eigenaars of de verenigingsraad worden benoemd. Een en ander is afhankelijk van de bepalingen van het reglement. Bovendien kan de administrateur op verzoek van een eigenaar door het "Tribunal de grande instance" worden benoemd, indien het reglement geen administrateur aanwijst en de vergadering geen administrateur benoemt ${ }^{56}$. De administrateur kan eveneens door de vergadering van eigenaars worden ontslagen ${ }^{57}$. Het ontslagbesluit moet worden genomen bij absolute meerderheid van stemmen van alle appartementseigenaars (art. 25 wet 1965) ${ }^{58}$. In een tweede vergadering (die kan worden belegd indien in de eerste niet voldoende appartementseigenaars verschijnen), is de absolute meerderheid niet meer vereist. Indien de administrateur in het reglement of door de vergadering voor bepaalde tijd is benoemd, eindigt zijn benoeming in beginsel slechts door verstrijken van de benoemingsduur. Hij kan echter ook tussentijds worden ontslagen, indien daarvoor een gewichtige reden bestaat. Als de administrateur door de president van het "Tribunal de grande instance" is benoemd, eindigt zijn benoeming door een normale benoeming van een administrateur door de vergadering van eigenaars ${ }^{59}$.

In artikel 18 van de wet 1965 worden de taken van de administrateur globaal beschreven ${ }^{60}$. De vergadering van eigenaars kan hem nog extra taken opdragen. In elk geval heeft hij op grond van artikel 18 de taak om:

1. de naleving van de bepalingen van het reglement en van de besluiten van de vereniging van eigenaars te verzekeren;

2. het onroerend goed te beheren en in stand te doen houden ${ }^{61}$;

3. de vereniging in alle civiele rechtshandelingen en in juridische procedures die in artikelen 15 en 16 zijn beschreven, te vertegenwoordigen en voor inschrijving van het reglement en wijzigingen

55. Cass. civ. 3e 16 jan. 1979, Dall. 1979, IR blz 447.

56. Schober, blz. 134; Kischinewski-Broquisse, blz. 382. De benoening van een administrateur kan vanwege het feit dat de wet van 1965 overwegend dwingend recht bevat en t.a.v. benoeming van de administrateur geen uitzondering is gemaakt, niet in het reglement of bij besluit van de vergadering van eigenaars, worden uitgesloten. Als de administratie geregeld wordt door een coöperatieve vereniging, moet er een verenigingsraad worden ingesteld die de administrateur uit zijn midden kiest en toezicht houdt op diens functioneren (art. 15 wet 1965).

57. De administrateur die zijn functie wil neerleggen, heeft een opzegtermijn van drie maanden. Zie art. 32 reglement Denis.

58. Zie ook art. 25 sub c reglement Denis.

59. Sizaire, blz. 287. Vgl. ook Bouyeure, blz. 102-126.

60. Vgl. over de verdere plichtem en bevoegdheden en de benoeming van de administrateur de artt. 28.39 decreet 1967. Vgl. ook artt. 18-1 en 18-2 Wet 1985, zoals ingevoegd bij wet van 31 dec. 1985. In deze artikelen wordt het inzagerecht van de appartementseigenaars in de financiële stukken geregeld en de verplichting van de administrateur om een opwolger alle relevante stukken ter beschikking te stellen en hem in te lichten over de financiële staat van de vereniging. Zie over de verdere taken en bevoegdheden van de administrateur de diss. van Verdié.

61. De administrateur is vertegenwoordiger vam de vereniging, en als zodanig worden door hem gedane uitgaven aan de vereniging toegerekend. Trib. gr. inst. Marseille 1 okt. 1977, Dall. 1979, J bly. 447. 
daarvan in de openbare registers zorg te dragen ${ }^{62}$. De administrateur heeft verder in beginsel de plicht om de vergadering van appartementseigenaars bijeen te roepen (art. 7 decreet 1967) ${ }^{63}$.

Om namens de vereniging in juridische procedures op te kunnen treden moet de administrateur door de algemene vergadering van eigenaars zijn gemachtigd. $\mathrm{Na}$ deze machtiging is de administrateur bevoegd voor een bepaalde procedure. Voor nieuwe procedures moet ook een nieuwe volmacht worden verleend (vgl. art. 55 decreet 1967 , zoals gewijzigd bij decreet van 9 juni 1986) ${ }^{64}$.

De administrateur is persoonlijk aansprakelijk voor het door hem gevoerde beheer en kan niemand voor zichzelf in de plaats stellen ${ }^{65}$. Alleen de vergadering van eigenaars kan toestemming geven voor delegatie van bevoegdheden voor een bepaald doel. Indien hij om de een of andere reden verhinderd is of in gebreke blijft zijn taken uit te voeren en het reglement voor die situatie niet in een regeling voorziet, kan door het "Tribunal de grande instance" een administrateur ad interim worden benoemd (artt. 18 wet 1965 en 46 decreet 1967, zoals gewijzigd bij decreet van 9 juni 1986) ${ }^{66}$.

In het reglement moeten regelingen met betrekking tot het functioneren en de rechten van de vergadering van eigenaars worden getroffen. In elk geval heeft iedere appartementseigenaar een aantal stemmen in de vergadering van eigenaars, afhankelijk van de grootte van zijn aandeel in de gemeenschap. Indien een appartementseigenaar meer dan de helft van de aandelen in de gemeenschap bezit, wordt zijn stemmenaantal gereduceerd tot de som van het aantal stemmen van de overige appartementseigenaars ${ }^{67}$. Aldus wordt voorkomen dat één eigenaar binnen de appartementsgemeenschap de dienst uitmaakt. Een appartementseigenaar mag

62. Zie ook art. 34 reglement denis.

63. Vgl. ook art. 22 alinea 1 reglement Denis. De vergadering kan echter ook geldig worden bijeengeroepen door de verenigingsraad en door een of meer appartementseigenaars die tenminste een vierde van de stemmen vertegenwoordigt (art. 8 decreet 1967). Vgl. over de bijeenroeping en de procedure ter vergadering de artt. 9-21 decreet 1967. Vgl. Bouyeure, blz. 164168.

64. Zie Hof Parijs 2 dec. 1988, Dall. 1989, J blz. 56-58.

65. Vgl. Cass. civ. $3 \mathrm{e} 23$ nov. 1976 , Dall. 1977, IR blz. 156. Een administrateur die verzuimd had woor de appartementseigenaars een verzekering af te sluiten woor thun aansprakelijkheid als eigenaars van het gebouw, werd door de appartementseigenaars met succes alangesproken tot vergoeding wan de voor hen ontstane schade. Vgl. over de aansprakelijkheid van de administrateur ook Weismann, blz. 119, 120; Kischinewski-Broquisse, blz. 519-529.

De administrateur heeft aan de andere kant wel recht op vergoeding door de vereniging van de door hem voor afzonderlijke appartementseigenaars voorgeschoten kosten. De wereniging van eigenaars is echter niet aansprakelijk voor kosten, die de administrateur heeft gemaakt voor appartementseigenaars die hun appartement reeds hebben verkocht, en die verkoop aan hem hebben medegedeeld. Zie Hof Lyon 13 april 1976, Dall. 1977, IR bli, 156.

Indien de administrateur zijn werkzaambeden gratis verricht, is hij echter in minder mate aansprakelijk dan wanneer hij zijn werkzaamheden tegen vergoeding verricht. Zie Logeman, blz. 48. De administrateur die slecht beheer heeft gevoerd, kan owerigens slechts door de vereniging van eigenaars wegens wanprestatie worden aangesproken, en niet door een individuele appartementseigenaar. Zie Hof Parijs 20 maart 1985, Dail. 1985, IR blz 431.

66. Zie over de benoeming van de interim-administrateur door de rechter: Hof Parijs 20 okt. 1982, Dall. 1983, IR blz. 458. Zie over de administrateur in het algemeen: artt. 30-37 reglement Denis.

67. Vgl. art. 27 reglement Denis. 
een derde machtigen om voor herm te stemmen. Deze derde mag echter in beginsel wan niet meer dan drie appartementseigenaars een machtiging om te stemmen krijgen. Hij mag echter wel van meer dan drie appartementseigenaars een volmacht krijgen, indien het totaal van de stemmen waarover hij beschikt, niet groter is dan wijf procent van het totaal aantal stemmen, of indien hij als vertegenwoordiger van eigenaars die lid zijn van een ondergeschikte vereniging, optreedt (art. 22 wet 1965) ${ }^{68}$.

Indien meerdere aandelen in de appartementsgemeenschap toekomen aan een wennootschap van verschillende "appartementseigenaars" en de vennootschap juridisch eigenaar is van de aandelen, moeten de vennoten toch zelf ter vergadering stemmen en hebben zij het aantal stemmen dat aan het aandeel waarvan zij het gebruik hebben, toekomt. Indien een appartement in onverdeeldheid toekomt aan meerdere personen of in vruchtgebruik aan én persoon, worden de belanghebbenden (bij vruchtgebruik: bloot eigenaar en vruchtgebruiker) behoudens afwijkende regelingen in het reglement, vertegenwoordigd door een gemeenschappelijk gemachtigde die bij gebreke van een overeenkomst daaromtrent op verzoek van een van de belanghebbenden of de administrateur door de president van het "Tribunal de grande instance" worden benoemd (art. 23 wet 1965) ${ }^{69}$.

De vergadering van eigenaars wordt tenminste een maal per jaar bijeengeroepen (art. 7 decreet 1967). Veelal wordt in de reglementen aan de administrateur de plicht opgelegd om voor de bijeenroeping zorg te dragen ${ }^{70}$. In ieder geval heeft hij altijd thet recht om de vergadering bijeen te roepen. Dit recht wordt in het reglement vaak ook toegekend aan de verenigingsraad en de voorzitter van de vereniging van eigenaars.

In het reglement Denis (art. 22 alinea 2) wordt bijvoorbeeld bepaald:

"Si le syndic n'a pas convoqué pour le 31 mars au plus tard l'assemblée générale annuelle ci-dessus prévue, celle-ci pourra être valablement convoquée par le conseil syndical ou par l'un quelconque des copropriétaires".

Zoạls uit deze alinea blijkt mag zelfs één enkele appartementseigenaar de vergadering bijeenroepen, indien de administrateur nalaat dit te doen.

De verenigingsraad heeft te allen tijde het recht om de administrateur te verzoeken de vergadering bijeen te roepen. Hetzelfde recht komt toe aan een of meer appartementseigenaars, die tenminste eenvierde van de stemmen vertegenwoordigen ${ }^{7}$. Dit vereiste stemmenaantal mag in het reglement echter worden verlaagd (art. 8 Wet 1965). Indien de administrateur of de verenigingsraad nalaten een vergadering van eigenaars bijeen te (doen) roepen, kan iedere appartementseigenaar - als in het reglement niet een regeling als artikel 22 alinea 2 reglement Denis is opgenomen - deze bijeenroeping via de rechter afdwingen (art. 8 alinea 3 Wet 1965$)^{72}$.

68. Vgl. Calfan/Doublier, blz 75 .

69. Vgl. ook art. 22 alinea 8 reglement Denis.

70. Zo ook in alinea 1 van art. 22 reglement Denis.

71. Zie ook art. 22 alinea 3 reglement Denis.

72. Givord/Giverdon, blz. 433, 434. Vgl. over de formele vereisten voor de bijeenroeping artt. 8 e.v. decreet 1967 en Givord/Giverdon, blz 435-443; Bouyeure, blz. 188-190. 
De vergadering moet worden voorgezeten door een van de appartementseigenaars. Volgens het reglement Denis kan de administrateur of zijn echtgeno(o)t(e) het voorzitterschap niet op zich nemen. Bovendien moet er een bestuur worden gevormd, waarin behalve de voorzitter twee notulisten en een secretaris zitting hebben ${ }^{73}$. De vergadering van eigenaars neemt zijn besluiten bij meerderheid van stemmen van de ter vergadering aanwezige of vertegenwoordigde appartementseigenaars, voor zover in de wet niet anders is bepaald (art. 24 wet 1965). In sommige gevallen, neergelegd in artikel 25 is echter een meerderheid van stemmen van alle appartementseigenaars vereist ${ }^{74}$. Voor een aantal besluiten is zelfs een tweederde meerderheid van stemmen van alle appartementseigenaars vereist. Tweederde meerderheid is bijvoorbeeld nodig voor vaststelling of verandering van het reglement voor zover de vaststelling of verandering betrekking heeft op het gebruik, genot en beheer van de gemeenschappelijke gedeelten. In beginsel kan de vergadering van eigenaars aan een appartementseigenaar geen verandering van bestemming of genot van zijn privê-gedeelte opleggen. Artikel 26II Wet 1965 bepaalt hierbij echter dat de vergadering van eigenaars met tweederde meerderheid van alle stemmen, kan besluiten tot werken ter verbetering van de veiligheid van personen en goederen door middel van deursloten e.d., die het mogelijk maken de toegang tot het gebouw te regelen, ook indien dit ten koste gaat van de bestemming of het genot van de privé-gedeelten ${ }^{75}$. Besluiten over vervreemding van gemeenschappelijke gedeelten waarvan het behoud noodzakelijk is met betrekking tot de bestemming van het onroerend goed, kunnen slechts unamiem worden genomen (art. 26 laatste alinea wet 1965).

Indien het onroerend goed uit meerdere gebouwen bestaat kunnen de appartementseigenaars die samen alle aandelen in een of meer gebouwen hebben, besluiten bij meerderheid van stemmen conform artikel 25 , dat een vereniging van eigenaars tussen hen wordt opgericht, een zogenaamde ondergeschikte (secundaire) vereniging van eigenaars. Deze ondergeschikte vereniging heeft tot doel om het beheer, het onderhoud en de interne verbetering van het gebouw of de gebouwen, waarvan de eigenaars tot oprichting van de vereniging hebben besloten. Evenzeer kunnen de appartementseigenaars die alle aandelen van een gebouw hebben in een appartementsgemeenschap van meerdere gebouwen, verlangen dat de medeëigendom van hun gebouw wordt losgekoppeld van de medeëigendom van de groep van gebouwen waarvan hun gebouw deell uitmaakt. De "afscheiding" wordt vastgesteld bij meerderheidsbesluit conform artikel 25 door de algemene vergadering van appartementseigenaars van het gehele appartementencomplex. (zie verder artt. 27 en 28 wet 1965). De verschillende verenigingen en eventueel bouwmaatschappijen die binnen een appartementsgemeenschap bestaan, kunnen zich onderling in samenwerkingsverbanden verenigen (art. 29 wet 1965 en artt. 43-45 decreet 1967) ${ }^{76}$.

73. Zie art. 24 reglement Denis.

74. Vgl. art. 28 reglement Denis voor een opsomming van de gevallen walarin een meerderheid van stemmen van alle appartementseigenaars is vereist.

75. Vgl. Giword/Giverdon, blz. 112. Zie ook Cass. cix. 3e 19 dec. 1978, Dall. 1979, IR blz. 446. Hierin werd een besluit van cen vergadering wan eigenaars om een buitendeur van een prive-gedeelte te sluiten afgewezen, omdat een onherroepelijke sluiting van de deur niet nodig was voor de veilligheid en de rust in het gebouw.

76. Vgl. Denis, blz. 69-71. 
Bij tweederde meerderheid van stemmen conform artikel 26 kan de vergadering van eigenaars besluiten om verbeteringen aan het onroerend goed aan te brengen, bepaalde bestaande uitrustingen van het gebouw te veranderen, nieuwe gemeenschappelijke gedeelten toe te voegen ${ }^{n}$, de inrichting van ruimten die tot gemeenschappelijk gebruik bestemd zijn te verzorgen of te veranderen of dergelijke ruimten toe te voegen. Bovendien kan de wergadering bij dezelfde meerderheid over de verdeling van de kosten van uitvoering van dergelijke besluiten over de verschillende appartementseigenaars nemen. Hetzelfde geldt ten aanzien van de verdeling van de kosten voor onderhoud, gebruik en vervanging van de toegevoegde gedeelten of aangebrachte verbeteringen. Het besluit van de vergadering van eigenaars bij tweederde stemmenmeerderheid kan op verzoek van een of meer appartementseigenaars door een besluit van de president van het "Tribunal de grande instance" worden vervangen. De president stelt bij eventuele toewijzing van het verzoek voorwaarden voor de uitvoering van de verbeteringen of toevoegingen vast (art. 30 wet 1965).

Aan het einde van iedere vergadering van eigenaars moet een verslag (procèsverbal) worden opgesteld. Dit verslag wordt door artikel 17 van het decreet 1967 dwingend voorgeschreven. In de praktijk wordt het meestal opgesteld door de administrateur. Het moet worden ondertekend door de voorzitter en de secretaris van de vereniging van eigenaars en door eventuele andere leden van het bestuur. In het verslag moet iedere beslissing zijn opgenomen, terwijl tevens moet worden vermeld welke appartementseigenaars bij de stemming niet aanwezig waren, welke hebben tegengestemd en welke zich hebben onthouden ${ }^{78}$. De verslagen moeten in een speciaal daartoe door de vereniging ingesteld register worden bewaard (zie art. 17 decreet 1967). Om de geldigheid van de besluiten te kunnen vaststellen, moet bovendien op het verslag worden vermeld op welke datum de vergadering is bijeengeroepen en welke appartementseigenaars aanwezig of afwezig waren ${ }^{79}$.

\subsection{Rechten en verplichtingen van de appartementseigenaars}

Volgens artikel 9 van de Wet 1965 heeft iedere appartementseigenaar in beginsel het recht op vrije beschikking en vrij genot en gebruik van zijn appartementseigendom. Artikel 9 luidt:

"Chaque copropriétaire dispose des parties privatives comprises dans son lot; il use et jouit librement des parties privatives et des parties communes sous la condition de ne porter atteinte ni aux droits des autres coproprietaires ni a la destination de l'immeuble." 80

Het vrije gebruiks-, genots- en beschikkingsrecht wordt dus slechts beperkt door de rechten van andere appartementseigenaars en door de bestemming van het gebouw.

77. Het besluit om nieuwe privé-gedeelten aan het gebouw toe te voegen moet unaniem worden genomen (art. 35 wet 1965). Vgl hierover Herrmann, blz 97-107.

78. Vgl. Cass. civ. 3e 7 nov. 1978, Dall. 1979, IR blz 446 .

79. Givord/Giverdon, blz 448, 449. Zie ook art. 26 reglement Denis.

80. Vgl. ook art. 6 alinea 1 reglement Denis. 
Verdere beperking van deze rechten is niet toegestaan. In het eerder geciteerde artikel 8 Wet 1965 staat immers uitdrukkelijk vermeld dat het reglement geen beperkingen op de rechten van de appartementseigenaars mag aanbrengen buiten de beperkingen die worden gerechtvaardigd door de bestemming van het gebouw zoals deze uit het reglement, uit de eigenschappen van het gebouw en uit de ligging van het gebouw voortvloeit. In het reglement wordt het gebruiks-, genots- en beschikkingsrecht van appartementseigenaars veelvuldig beperkt doordat men het gebouw voor bewoning bestemt (de zogenaamde "clause d"habitation bourgeoise"). Daardoor mag de appartementseigenaar zijn appartement bijvoorbeeld niet als winkelruimte gebruiken ${ }^{81}$.

Als voorbeeld van een besternmingsomschrijwing kan hier de derde alinea van artikel 6 reglement Denis worden aangehaald, die luidt:

"Les appartements dépendant de l'immeuble ne pourront être occupés que bourgeoisement et de façon honnête par des personnes de bonne vie et moeurs, il ne pourra y être exercé aucune activité commerciale ou industrielle, même artisanale, d'une nature quelconque, non plus que l'exercice d'une profession libérale susceptible de changer la destination des locaux attribués...."

Uit deze bestemmingsomschrijving blijkt dat de appartementen slechts voor bewoning en uitoefening van vrije beroepen mogen worden gebruikt, voor zover door de uitoefening van de vrije beroepen tenminste niet de bestemming van het appartement wordt veranderd.

In de op alinea 2 volgende alinea's van artikel 6 reglement Denis wordt het gebruiks- en genotsrecht van de appartementseigenaars verder geregeld en beperkt. Een appartementseigenaar mag bijvoorbeeld geen zware objecten in zijn appartement hebben, die door hun gewicht schade zouden kunnen toebrengen aan de bouwkundige staat van het gebouw. Evenmin mag een appartementseigenaar was te drogen hangen in ramen of gemeenschappelijke gedeelten, indien het uiterlijk van het gebouw daaronder lijdt (alinea 12). Aan de andere kant mag een eigenaar wel een naamplaatje aan zijn deur bevestigen. Dit naamplaatje moet echter overeenkomen met een door de administrateur voorgeschreven model. Spandoeken en reclameborden mogen echter nergens in het gebouw worden aangebracht (alinea 10 en 11$)^{82}$.

Een andere beperkingsmogelijkheid terzake van de vrije beschikking, is het verbod om een appartement onder te splitsen. In beginsel heeft een appartementseigenaar daartoe het recht. Dit volgt impliciet ook uit het begin van alinea 2 van artikel 11 wet 1965 , dat luidt:

"En cas d'aliénation séparée d'une ou plusieurs fractions d'un lot, ..."

81. Vgl. Sizaire, blz. 52-56.

82. Zie over de verdere regeling wan gebruik en genot: art. 6 regl"ment Denis. 
De ondersplitsing van een appartement brengt noodzakelijkerwijze verandering van het reglement van medeëigendom en van de splitsingstekeningen met zich mee ${ }^{83}$. Het verbod tot ondersplitsing is door het Hof van Cassatie gesanctioneerd ${ }^{84}$.

Tegenover deze rechten om de privé-gedeelten te gebruiken e.d., staat zoals vermeld de verplichting om het appartement op zodanige wijze te gebruiken, dat daardoor noch de bestemming van het gebouw, noch de rechten wan andere appartementseigenaars in gedrang komen (art. 9 voormeld). Een appartementseigenaar (of diens rechtsverkrijger of andere gerechtigde) is bovendien verplicht om werkzaamheden in zijn appartement te dulden indien de vergadering van eigenaars heeft besloten dat deze werkzaamheden moeten worden uitgevoerd. Hij mag zich dan ook niet verzetten tegen de uitvoering van onderhoudswerkzaamheden in zijn appartement ${ }^{85}$. Zijn gebruiks- en genotsrecht worden door die werkzaamheden namelijk niet op ongeoorloofde wijze beperkt ${ }^{86}$. Appartementseigenaars die door dergelijke werkzaamheden schade lijden, hebben echter recht op schadevergoeding (art. 12 Wet 1965).

Ingevolge artikel 10 van de wet 1965 zijn de appartementseigenaars verplicht om bij te dragen in de kosten voor gemeenschappelijke diensten en voorzieningen. Bovendien moeten zij bijdragen in de kosten van behoud, beheer en onderhoud van de gemeenschappelijke gedeelten, een en ander naar evenredigheid van de waarde van hun privé-eigendom ${ }^{87}$. De verdeling van de kosten kan slechts bij unaniem door de vergadering van eigenaars aangenomen besluit worden gewijzigd ${ }^{88}$. Artikel 11 geeft over de verdeling van de kosten over de verschillende eigenaars nadere regelingen. Binnen vijf jaar na publikatie van het reglement (met daarin opgenomen de kostenverdeling, zie art. 1 van het decreet van 17 maart 1967) in de openbare registers, kan een appartementseigenaar in bepaalde gevallen de kostenverdeling, in afwijking van het in artikel 11 van de wet 1965 bepaalde, door de rechter doen wijzigen. Een vordering tot wijziging is bijvoorbeeld mogelijk indien aan de appartementseigenaar een kostendraagplicht is opgelegd die meer dan een vierde hoger is dan het aandeel in de kosten dat hij conform artikel 10 van de wet 1965 zou moeten dragen (art. 12 wet 1965 en art. 54 decreet 1967) ${ }^{89}$.

De vereniging van eigenaars heeft tot zekerheid van alle vorderingen die zij op een appartementseigenaar heeft, van rechtswege een recht van hypotheek op diens appartement. Dit hypotheekrecht kan door de administrateur ten behoeve van de vereniging worden ingeschreven na een ingebrekestelling ten aanzien van een opeisbare schuld of zodra de appartementseigenaar op grond van artikel 33 van de

83. Givord/Giverdon, blz. 151, 152. Evenzo Kischinewski-Broquiisse, blz. 244, 245. Anders Weismann, blx. 16.

84. Cass. civ. 3e 8 dec. 1976, J.C.P. 1977, IV, blz. 25; Cass. civ. 3 e 16 maart 1981, Dall 1981, IR blz. 395, Bull. 1981, blz. 39, 40, Hof Parijs 19 juni 1985, Dall. 1985, IR blz. 425.

85. Vgl. art. 6 alinea 7 reglement Denis.

86. Cass. civ. 3e 8 juni 1988, J.C.P. 1988, IV blz. 285. Zie ook Hof Parijs 2 maart 1984, Dall. 1985, IR blz 424 .

87. Vgl. artt. 11-13 reglement Denis.

88. Vgl. Sizaire, blz. 66, 82.

89. Sizaire, blz 82-90. Een appartementseigemaar die zijn appartement heeft werkocht, is volgens het Parijse Hof niet aansprakelijk voor gemeenschappelijke kosten, die moeten worden voldaan op grond van een besluit van de vergadering, dat na de vervreemding is genomen. Hof Parijs 28 okt. 1982, Dall. 1983, IR blz. 335. 
wet 1965 het recht bedingt om zijn aandeel in de kosten voor werkzaamheden die tegen zijn will zijn uitgevoerd, via afbetaling, uitgestreken over tien jaar, te voldoen (art. 19 wet 1965). Verder heeft de vereniging nog een privilege op de opbrengst van de meubels van de appartementseigenaar (art. 19 wet 1965). Via beslaglegging (art. 58 decreet 1967) kan de vereniging het hypotheekrecht en het privilege te gelde maken ${ }^{90}$.

Bij overdracht onder bezwarende titel van een appartement, moet de vervreemder een certificaat dat jonger dan een maand is aan de notaris overleggen, waarin staat dat de vervreemder al zijn verplichtingen jegens de vereniging van eigenaars heeft voldaan. Indien hij dit certificaat niet overlegt moet op aanvraag van de verkrijger van de vervreemding bericht worden gestuurd aan de administrateur. Binnen acht dagen na ontvangst van het bericht kan de administrateur bezwaar maken tegen betaling van de koopsom om betaling van schulden van de vervreemder te verkrijgen (art. 20 wet 1965 en art. 57 decreet 1967) ${ }^{91}$. Dit geldt echter niet bij openbare verkoop. Als een schuldeiser van een appartementseigenaar tot veiling van diens appartement overgaat, kan de vereniging van eigenaars hem overigens niet de plicht opleggen om uit de veilingopbrengst achterstallige servicekosten te voldoen ${ }^{92}$.

In het geval dat de vergadering van eigenaars tot werkzaamheden met betrekking tot onderhoud, beheer, uitbreiding e.d. besluit, is ieder der appartementseigenaars gehouden in de kosten van de uitvoering van de werkzaamheden bij te dragen (art. 32 wet 1965). Anderzijds mogen de appartementseigenaars die tegen de uit te voeren werkzaamheden hebben gestemd, wel verlangen dat zij hun bijdrage in de kosten gedurende tien jaar mogen afbetalen ${ }^{93}$. Tot zekerheid van deze afbetalingsschuld kan de vereniging van eigenaars, zoals zojuist al werd vermeld, een recht van hypotheek op het appartement van de debiteur vestigen (art. 33 jo. 19 wet 1965. Indien de appartementseigenaar vervolgens in gebreke blijft, kan de administrateur namens de vereniging het appartement laten veilen. De administrateur heeft hierbij de bevoegdheid om zelf de prijs vast te stellen waarvoor de veiling zal worden ingezet ${ }^{94}$.

Een besluit van de vergadering van eigenaars tot verbetering of verandering van het gebouw (art. 30 wet 1965), kan niet tegen een appartementseigenaar die tegen dit besluit heeft gestemd, worden ingeroepen, indien hij zich tot het "Tribunal de grande instance" heeft gewend met de bewering dat de verbetering slechts een luxeverhogend karakter heeft gelet op de staat, de eigenschappen en de bestemming van het gebouw. De opschorting van de werking van het besluit tegen de procederende appartementseigenaar geldt zolang de rechter niet heeft beslist (art. 34 jo. 42 wet 1965$)^{95}$.

90. Vgl. Weismann, blz 147-149; Denis, blz. 110-123

91. Indien het bericht aan de verkeerde administrateur wordt gezonden, bijwoorbeeld aan een administrateur buiten functie, geldt de termijn van acht dagen niet. Hof Parijs 26 maart 1981 , Dall. 1981, IR blz. 485 .

92. Cass. civ. 3e 17 febr. 1988, J.C.P. 1988, II 21069.

93. Vgl. over verbeteringen, toevoegingen e.d. artt. 30-37 reglement Denis.

94. Hof Parijs 11 mei 1983, Dall. 1983, IR blz. 339.

95. Zie ook art. 34 reglement Denis. 
Behalve de hier beschreven plichten ten opzichte van de gemeenschap en de gemeenschappelijke gedeelten, heeft een appartementseigenaar het recht om gebruik te maken van de gemeenschappelijke gedeelten. Artikel 7 alinea 1 reglement Denis vermeldt hierover:

"Chacun des copropriétaires, pour la jouissance des locaux privés lui appartenant, pourra user librement des parties communes, sauf à respecter leur destination et à ne pas faire obstacle aux droits des autres copropriétaires."

De volgende alinea's van artikel 7 verbinden hieraan direct weer de plicht om gangen e.d. vrij te houden en er geen voorwerpen in te zetten ${ }^{9}$.

Afgezien van de hìerboven beschreven materièle rechten en plichten, heeft iedere appartementseigenaar ook nog het formele recht in rechte te ageren om de rechten, verbonden aan zijn appartementseigendom (zoals gebruik en genot) zeker te stellen. Van een dergelijke actie moet hij dan wel de administrateur in kennis stellen (art. 15 wet 1965 jo. art. 52 decreet 1967).

Zo kan een appartementseigenaar gedurende twee maanden nadat een besluit door de vergadering van eigenaars is genomen, bezwaar maken tegen dit besluit (art. 42 wef 1965 ). De besluiten van de vergadering van eigenaars zijn niet uitvoerbaar voor het verstrijken van deze termijn, waarbinnen de appartementseigenaars ertegen kunnen ageren ${ }^{97}$. De termijn van twee maanden geldt overigens niet voor appartementseigenaars, die niet regulier voor de vergadering zijn opgeroepen ${ }^{98}$.

Andere rechtsvorderingen die uit de toepassing van de wet 1965 voortvloeien tussen medeëigenaars onderling en tussen medeëigenaars en de vereniging van eigenaars, verjaren na 10 jaar (art. 42 alinea 1 Wet 1965). Sommige rechtsvorderingen, zoals de actie tot vernietiging van clausules van een reglement, die in strijd zijn met de dwingende bepaling van artikel 10 Wet 1965, zijn echter aan een dertigjarige verjaring ex artikel 2262 C.c. onderworpen ${ }^{99}$

\subsection{Toelating en ontzegging van verder gebruik}

\subsubsection{Algemene opmerkingen}

Volgens artikel 9 Wet 1965 kan iedere appartementseigenaar vrij over zijn appartementseigendom beschikken. Hij moet er hierbij alleen voor zorgen dat hij geen afbreuk doet aan de rechten van de andere appartementseigenaars of aan de bestemming van het gebouw. In het reglement mogen de rechten van de appartementseigenaars alleen beperkt worden, indien de beperking wordt gerechtvaardigd

96. Vgl. over de rechten La.v. de gemeenschappelijke gedeelten: Givord/Giverdon, blz 120-130.

97. Trib. gr. inst. Toulouse 21 maart 1978, Dall. 1979, IR blz. 445. Een appartementseigenaar kan zich echter slechts op de nietigheid van een besluit wegens formele gebreken beroepen, indien hij kan aantonen dat hij door dat besluit benadeeld wordt, aldus Cass. civ. 3 e 16 nov. 1976, Dall. 1977, IR blz. 154.

98. Cass. civ. 3e 16 nov. 1988, J.C.P. 1989, IV blz. 21.

99. Hof Versailles 11 april 1988, Dall. 1988, IR blz 149. 
door de bestemming van het gebouw (art. 8 wet 1965). Wettelijke vervreemdïngsbeperkingen of grondslagen voor regelingen vergelijkbaar met de Nederlandse welstandsbepalingen, zijn er niet. De regeling van artikel 20 van de wet 1965 waarin wordt bepaald dat een appartementseigenaar bij overdracht van zijn appartement een certificaat aan de notaris moet overleggen dat hij geen schulden heeft aan de vereniging van eigenaars, is geen geldigheidsvereiste voor de overdracht. De appartementseigenaar kan zijn appartementseigendom vrij overdragen. Wil hij echter bereiken dat deze overdracht ook tegen derden (in casu de vereniging van eigenaars) werkt, dan zal hij aan de wettelijke vereisten van artikel 20 (maar ook bijvoorbeeld van art. 6 decreet 1967) moeten voidoen.

\subsubsection{Toelating}

In beginsel zijn er twee mogelijke manieren om de komst van ongewenste personen in een appartementencomplex te voorkomen. De eerste mogelijkheid is dat de vervreemding van een appartement afhankelijk wordt gemaakt van toestemming van de overige appartementseigenaars. In dit systeem wordt voorkomen dat de ongewenste persoon de eigendom van het appartement krijgt. De tweede mogelijkheid is dat de vervreemding niet wordt gecontroleerd door de overige appartementseigenaars, maar wel de ingebruikneming door de ongewenste persoon. Aan eventuele weigering van toestemming tot ingebruikneming moet dan een reden ten grondslag liggen die voldoende zwaarwegend is en bovendien onlosmakelijk verbonden is met de aspirant-gebruiker. Het mag dus niet zo zijn dat men een aspirant-gebruiker de toestemming tot ingebruikneming ontzegt vanwege het feit dat hij een piano heeft. Eventuele bezwaren tegen het hebben van een piano kunnen immers worden ondervangen door het verbieden van het hebben van piano's. Aan de aspirant-bewoner moet men vervolgens de keuze overlaten of hij in dat geval (als hij geen piano mag hebben en spelen) nog wel in het appartement wil wonen. Het is niet an de andere appartementseigenaars om die beslissing voor hem te nemen.

In Frankrijk kent men gebruiksbeperkende clausules van de aard van het pianoverbod. Deze is aldus geconstrueerd, dat men in het reglement het gebruik aan de bestemming van het gebouw koppelt. Zo hoort bijvoorbeeld bij de bestemming "bewoning" (habitation bourgeoise) het gebruik als woning. Dat betekent dat het gebruik als winkel door de overige appartementseigenaars met een beroep op de bestemming van het gebouw kan worden verboden. Dit is echter een "toestemming tot gebruik" die niet op de persoon betrekking heeft. Men kan immers aan een appartementseigenaar verbieden om in zijn appartement een winkel te voeren, men kan hem niet verbieden om het appartement te bewonen overeenkomstig de bestemming van het gebouw. Deze gebruiksregeling is derhalve geen equivalent van de Nederlandse welstandsbepalingen. Overigens zij vermeld dat deze gebruiksbeperking door middel van bestemmingsomschrijving niet alleen geldt bij ingebruikneming, maar ook bij verandering van gebruik door iemand die al jaren eigenaar is van een appartement. Een praktijkvoorbeeld van een gebruiksbeperking deed zich voor in 1967. Het "Tribunal de grande instance" in Grenoble besliste op 1 maart $1967^{100}$ dat een bestemming van een gedeelte van

100. Trib. gr. inst. Grenoble 1 maart 1967, Dall. 1967, sommaires blz. 77. 
een gebouw als garage betekende dat daar geen winkel mocht worden gevestigd ${ }^{101}$. Dit vonnis werd door de "Cour d'appel" van Grenoble bevestigd op 15 jan. $1968^{102}$. Givord/Giverdon ${ }^{103}$ onderscheidt verschillende gebruiksbeperkende clausules:

\section{a. Clausules met betrekking tot de bestemming van appartementen of gedeelten daarvan}

Indien een appartement bestemd is voor gebruik als woning en gedeeltelijk voor gebruik als winkelruimte, mag de appartementseigenaar zijn appartement niet in zijn geheel als winkel inrichten ${ }^{104}$. Tot deze soort behoorde de gebruiksbestemming als garage in bovenstaand praktijkgeval.

Het begrip "strijd met de bestemming" wordt ruim geïnterpreteerd ${ }^{105}$. Zo heeft het Franse Hof van Cassatie in 1979 beslist, dat een notaris geen muren mocht wegbreken tussen twee aan hem toebehorende appartementen, om vervolgens in beide zijn praktijk uit te oefenen. Het doorbreken van de muren zou voor de overige appartementseigenaars ernstige overlast veroorzaken en bovendien zou vestiging van een notarispraktijk teveel verkeer van personen in de gemeenschappelijke gangen met zich meebrengen. Het wegbreken van de muren werd daarom in strijd met de bestemming van het gebouw geacht ${ }^{106}$. In een ander geval werden werken aan privé-gedeelten, die het uiterlijk van het gebouw zouden veranderen, in strijd met de bestemming van dat gebouw geacht ${ }^{107}$. Bovendien was volgens het Hof van Cassatie in casu geen sprake van werken in de zin van artikel $25 \mathrm{~b}$ wet $1965^{108}$.

Wil men toch een activiteit die in strijd is met de bestemming van het gebouw ontplooien, dan moet eerst het reglement worden gewijzigd door de vergadering

101. Vgl. over het gebruik van garages ook art. 8 sub 1 reglement Denis: "Les garages, boxes et parkings ne pourront servir qu"au rémisage..."

102. Hof Grenoble 15 jan, 1968 , Dall. 1968, J blz. 66 . Vgl. ook Cass. civ. 3 e 8 juli 1987, J.C.P. 1987, IV blz. 321: de verkrijger van een appartement dat bestemd is tot opslagplaats, mag dit niet in een studio veranderen. Als hij dit wel doet kan hij worden veroordeeld tot herstel in de oude toestand. Vgl. verder Hof Parijs 10 mei 1985, Dall, 1986, IR blz. 424. In casu mocht een appartement met bestemming "boutique" niet in eem restaurant worden veranderd.

103. Givord/Giverdon, blz. 105-111, 282-284.

104. Vgl. Cass. civ. 3 e 3 juni 1971 , Dall. 1971 , sommaires blz 179.

105. De specifieke bestemmingsomschrijving wordt echter eng geïnterpreteerd. Als het reglement bijwoorbeeld bepaalt dat de appartementen bestemd zijn voor "habitation bourgeoise", daarbij tevens bepalend dat artsen-, adwocaten-, architecten- en tandartsenpraktijken geacht worden daaronder te wallen; dan moet deze bepalling eng worden geïnterpreteerd en kan een adviesbureau niet worden toegelaten. Zie Hof Parijs 18 mei 1979, Dall. 1980, IR blz. 235. In gelijke zin Cass. civ. 3 e 3 febr. 1981, Dall. 1982, IR blz. 290. Een bestemmingsomschrijving "habitation bourgeoise", waarbij bepaalde beroepen expliciet worden verboden, moet echter ruim worden geïnterpreteerd. Zie Cass. civ. $3 \mathrm{e} 16$ maart 1983, Dall. 1984, IR blz 382.

10G. Cass. civ. 3 e 13 febr. 1979, Dall. 1979, IR blz 443.

107. De beslissing van de vergadering van eigenaars, om aan bepaalde eigenaars toe te staan een schoorsteen aan de buitenkant van het gebouw te bouwen, was echter geldig en niet in strijd met de bestemming van het gebouw, temeer aangezien de tegenstanders van de andere schoorstenen gebruik makkten en daarom door de bouwers van de schoorsteen alleen centrale verwarming zou kunnen worden aangelegd, indien de nieuwe schoorsteen erbij werd gebouwd. Cass. civ. 3 e 7 nov. 1978, Dall. 1979, IR blz. 442, 443.

108. Cass. civ. 3e 19 dec. 1978 , Dall. 1979, IR blz 443. 
van eigenaars ${ }^{109}$. Tot een dergelijke wijziging kan slechts unaniem door alle appartementseigenaars worden besioten ${ }^{110}$

\section{b. Concurrentiebeperkende clausules}

Bij concurrentiebeperkende clausules worden bepaalde activiteiten verboden. Indien in een appartementsgebouw bijvoorbeeld een drogist is gevestigd, en een andere appartementseigenaar eveneens een drogisterij wil beginnen, zou dit met concurrentiebeperkende clausules (bepalingen dat men niet twee gelijksoortige ondernemingen mag uitoefenen in hetzelfde gebouw zonder toestemming van de vereniging van eigenaars) wellicht kunnen worden voorkomen. Het Hof van Cassatie achtte deze clausules echter ongeldig omdat ze niet worden gerechtvaardigd door de bestemming van een gebouw ${ }^{111}$.

\section{c. Men gebiedt een zekere activiteit in bepaalde appartementen}

Van een gebod tot het ontplooien van een bepaalde activiteit is bijvoorbeeld sprake als op de begane grond van een appartementsgebouw een slager, bakker en groenteboer gevestigd moeten zijn. Het Hof van Cassatie heeft zich over de geldigheid van dergelijke clausules nooit hoeven uitlaten.

In het bovenstaande is reeds vermeld, dat het gebruik en het genot van een appartement kan worden beperkt door de bestemming van het gebouw. Deze beperking is op grond van artikel 8 Wet 1965 mogelijk. Dit artikel spreekt ecliter niet alleen over beperking van gebruik en genot, maar algemeen over beperking van de rechten van appartementseigenaars. De vraag die hierbij kan opkomen, is of de beschikkingsbevoegdheid (d.w.z. bevoegdheid tot vervreemden of bezwaren) door de bestemming kan worden beperkt? In principe lijkt een dergelijke beperking niet in strijd met de wet 1965. Artikel 9 van deze wet garandeert weliswaar vrij gebruik, genot en beschikking, maar vermeldt eveneens dat gebruik en genot hun grenzen vinden in de rechten van de overige eigenaars en de bestemming van het gebouw. De tweede alinea van artikel 8 bepaalt bovendien dat de rechten van appartementseigenaars in het reglement slechts mogen worden beperkt, voor zover dit door de bestemming van het gebouw wordt gerechtvaardigd.

Door sommige auteurs wordt beweerd dat beperking van de beschikkingsbevoegdheid ook mogelijk is, vanwege de algemene beperkingsmogelijkheid in de tweede alinea van artikel 8 wet 1965. Bij beperking van de beschikkings-

109. Cass. civ. 3e 3 jan. 1979, Dall. 1979, IR blz. 444.

110. Cass. civ. 3e 2 okt. 1979, Dall. 1980, IR blz. 233.

111. Vgl. Kischinewski-Broquisse, blz. 118; Cass. civ. 3e 11 maart 1971, Dall. 1971, J blz 429; Cass. civ. 3e 16 juni 1971, Dall. 1971, sommaires blz. 171; Cass. civ $3 e$ 27 mei 1971, Dall. 1972, sommaires blz 36; Cass. civ. 3e 15 okt. 1974, Dall. 1975, sommaires blz. 1; Cass. civ. 3e 2 mei 1979, Dall. 1979, IR blx 445. In een zeer witzonderlijk geval heeft het Hof van Cassatie beslist dat een concurrentiebeperkende clausule geldig was. Zie Cas.s. civ. 3 e 14 dec. 1976, Dall. 1977 , IR blz. 155. Een concurrentiebeperkend beding, dat niet wit het reglement maar uit cen huurovereenkomst voortwloeit, is door het Hof van Cassatie eveneens geldig geacht. Zie Cass. civ. 3e 9 nov. 1982, Dall. 1983, IR blz. 422, 423. De wet wan 1965 is namelijk niet op de relatie tussen de huurder en de verhuurder van toepassing. Daarom kan het non-concurrentiebeding in een huurovereenkomst worden opgenomen. Zie Cass. civ. 3 e 7 maart 1984, Dall. 1984, IR bliz 384. 
bevoegdheid zijn echter verschillende mogelijkheden denkbaar. De meest vergaande beperking is de ontneming van de beschikkingsbevoegdheid. Een dergelijk verbod in het reglement van medeëigendom om over een appartement te beschikken, wordt echter nietig geacht. Givord/Giverdon vermeldt hierbij dat ook een in de tijd beperkt vervreemdingsverbod nietig is, wegens strijd met het beginsel van de vrije overdraagbaarheid van goederen ${ }^{112}$.

- Een andere beperkingsmogelijkheid is het verbod om een appartement onder te splitsen. Zoals in paragraaf 7.2.5 werd vermeld, heeft een appartementseigenaar in beginsel daartoe het recht. De ondersplitsing van een appartement brengt noodzakelijkerwijze verandering van het reglement van medeëigendom en van de splitsingstekeningen met zich mee. Daarom kan men volgens Givord/Giverdon verdedigen dat de bestemming van het gebouw een beperking van de bevoegdheid tot ondersplitsing of een verbod daarvan, kan rechtvaardigen ${ }^{113}$.

Volgens Givord/Giverdon is het ook mogelijk om in het reglement een clausule op te nemen die bepaalt dat het verboden is om appartementen aan anderen dan appartementseigenaars te vervreemden. Deze clausules zijn in praktijk handig voor kelders, zolders e.d., die deel uitmaken van een appartement. Ook een regeling in het reglement, waarin de bevoegdheid om over een appartement te beschikken afhankelijk wordt gesteld van de toestemming van een orgaan van de vereniging wan eigenaars (een zogenaamde "clause d"agrément"), is volgens Givord/Giverdon geldig. Uiteraard moeten de hier genoemde beperkingen dan wel door de bestemming van het gebouw worden gerechtvaardigd. Hetzelfde geldt voor een in het reglement opgenomen voorkeursrecht ten gunste van de vereniging van eigenaars ${ }^{114}$.

Het voorkeursrecht en andere beperkingen van de beschikkingsbevoegdheid, waren onder vigeur van de wet 1938 zeker geldig 115 . In de wet van 1938 waren namelijk geen bepalingen als artt. 8 en 9 Wet 1965 opgenomen. Deze bepalingen zijn echter in de wet van 1965 opgenomen, om te voorkomen dat de rechten van de appartementseigenaars te zeer worden beperkt. Onder vigeur van de wet 1938 werden de rechten van de appartementseigenaars in het reglement namelijk vaak vergaand beperkt, terwijl veel van de aspirant-eigenaars deze beperkingen noodgedwongen - wegens een groot tekort aan woningen- accepteerden ${ }^{116}$.

Anders dan de Franse doctrine stelt het Hof van Cassatie zich zeer gereserveerd op ten aanzien van de toelaatbaarheid van beperkingen van de beschikkingsbevoegdheid. In 1972 besliste hij dat een clausule in het reglement, waarin werd bepaald dat kelders en dienstbodekamertjes e.d., alleen aan andere appartements-

112. Givord/Giverdon, ble. 150.

113. Giword/Giverdon, bz. 151, 152. Evenzo Kischinewski-Broquisse, blz. 244, 245. Anders Weismann, blis 16.

114. Givord/Giverdon, blz. 153; Cabanac (Guide Pratique), blz. 16A; Ferid/Sonnenberger, blz. 636. Anders: Kischinewski-Broquisse, blz 242-244 en supplement, blz 34; d"Esperonnat, blz. 144. In dit kader zal miet worden ingegaan op voorkeursrechten die uit publiekrechtelijke regelingen als de "Code de L'urbanisme", of uit privaatrechtelijke regelingen, ten gunste van bepaalde personen voortvloeien. De buurder van een woning heeft bijwoorbeeld een wettelijk voorkeursrecht. Vgl. Cass. civ. 18 juli 1986, Loyers 1986, mr. 372. Zie over deze regelingen Givord/Giverdon, blz. 146149.

115. Vgll. Kischinewski-Broquisse, blz, 242.

116. Givord/Giverdon, blz. 279. 
eigenaars mochten worden verkocht, wegens strijd met de vrije beschikkingsbevoegdheid van de appartementseigenaars, nietig was.

"Le règlement de copropriété ne peut imposer aucune restriction aux droits des copropriêtaires en dehors de celles qui seraient justifiées par la destination de l'immeuble, telle qu'elle est definie aux actes, par ses caractères ou sa situation, et que chaque copropriétaire dispose librement de son lot; (...), toute clause contraire à ces dispositions est reputée non écrite."

Het Hof van Cassatie herhaalde hier eerst de tweede alinea van artikel 8 van de wet 1965 , en voegde daar impliciet aan toe dat de beperkingsmogelijkheden van dit artikel slechts gelden voor gebruik en genot ${ }^{117}$. Een half jaar later besliste het Hof van Cassatie opnieuw in deze $\mathrm{zin}^{118}$.

In zijn noot onder het arrest van 1972 beweert Ernest Frank dat clausules die de beschikkingsbevoegdheid beperken wel geldig zijn, als ze slechts gedurende beperkte tijd gelden en tot doel hebben dat de gemeenschap van appartementseigenaars gedurende een bepaalde tijd dezelfde samenstelling behoudt.

In elk geval besliste het Hof van Cassatie in 1976, dat een verbod tot ondersplitsing geldig in het reglement van medeëigendom kan worden opgenomen, indien dit verbod wordt gerechtvaardigd door de bestemming van het gebouw. In casu was een luxe appartement in een chique residentie in kleine studios opgesplitst, hetgeen volgens het Hof in strijd was met de bestemming, zoals die uit de aard van het gebouw voortvloeide ${ }^{119}$. Dit arrest is voor Givord-Giverdon en Ferid/Sonnenberger aanleiding om te beweren dat beperkingen van de beschikkingsbevoegdheid over het algemeen kunnen worden gerechtvaardigd door de bestemming van het gebouw. De Franse jurisprudentie logenstraft deze opvatting echter. De beslissing met betrekking tot ondersplitsing is ondertussen weliswaar nog herhaald ${ }^{120}$, maar ten aanzien van andere beperkingen van de beschikkingsbevoegdheid heeft het Hof van Cassatie zijn oude beslissingen van 1972 en 1973 gehandhaafd.

Zo besliste hij in 1979 dat een in het reglement opgenomen voorkeursrecht en andere beperkingen van de beschikkingsbevoegdheid, nietig zijn wegens strijd met artikel 8 al. 2 en artikel 42 Wet $1965^{121}$. Het Hof van Cassatie heeft recent dit standpunt nog eens herhaald ${ }^{122}$. Hij lijkt derhalve slechts beperkingen van de bevoegdheid tot ondersplitsing goed te keuren. Een motivering hiervoor is te vinden in een arrest van het Hof Reims, dat besliste dat de restricties van artikel 8 van de Wet 1965 slechts toepasselijk zijn op gebruik en genot. De bestemming van het gebouw kan zo'n beschikkingsbeperking niet rechtvaardigen, omdat een

117. Cass. civ. 3e 17 juli 1972, J.C.P. 1972, II 17241 met noot Guillot; Dall. 1972, J blz. 727 met noot Frank. Zo ook Hof Reims 3 febr. 1977, J.C.P. 1977, II, 18848.

118. Cass. civ. $3 e$ e maart 1973, Gaz. Pal 1973, J blz. 497.

119. Cass. civ. 3e 8 dec. 1976, J.C.P. 1977, IV, blz.25.

120. Vgl. Cass. civ. 3e 16 maart 1981, Dall. 1981, IR blz. 395, Bull. 1981, blz 39, 40; Hof Parijs 19 juni 1985 , Dall. 1985, IR blz. 425.

121. Cass. civ. 3e 29 mei 1979, Dall. 1979, J blz 548, 549. In gelijke zin was in 1974 al door het Hof Parijs beslist: Hof Parijs 1 maart 1974, J,C.P. 1977, II 18740.

122. Cass. civ. Ze 4 jan. 1989, Dall. 1989, IR blz 26. 
nieuwe eigenaar zich ook aan de bestemming van het gebouw moet aanpassen. Daarom achtte het Reimse Hof een voorkeursrecht nietig ${ }^{123}$. Voor beperkingen wan de beschikkingsbevoegdheid geldt dus in het algemeen, dat de bestemming van het gebouw ze niet rechtvaardigt, omdat de bestemming zelf door beschikking niet in gevaar wordt gebracht. Bij ondersplitsing is dit echter anders, omdat door ondersplitsing de bestemming direct kan worden aangetast.

Voorlopig zijn beperkingen van de beschikkingsbevoegdheid, anders dan een verbod tot ondersplitsing, derhalve nietig, ondanks hetgeen in de literatuur wordt beweerd ${ }^{124}$.

Het gebruik kan blijkens het voorgaande wel worden beperkt. Betekent dit nu dat de bevoegdheid tot verhuring van appartementen in het reglement eveneens kan worden beperkt? Het Hof van Parijs heeft twee maal bevestigend op deze vraag geantwoord. In 1976 besliste dit Hof dat een clausule die verhuring verbiedt geldig is, omdat ze gebruik en genot beperkt en door de bestemming van het gebouw kan worden gerechtvaardigd ${ }^{125}$. In 1984 besliste hetzelfde Hof dat een clausule in het reglement, die een verbod inhield om "des chambres des services" te verhuren aan niet-eigenaars, geldig was omdat de beperking werd gerechtvaardigd door de bestemming van het (in casu zeer chique) gebouw, zoals die uit de aktes, de aard en de ligging van het gebouw voortvloeide. Het lijkt er dus op dat een beperking van de bevoegdheid tot verhuren, mogelijk is. Een dergelijke beperking werkt ook tegen de huurder, nu het reglement ook tegen hem kan worden ingeroepen ${ }^{126}$.

Verder is het mogelijk bepaalde soorten gebruik te beperken, maar deze beperkingen spitsen zich niet zozeer toe op de persoon van de (aspirant-)appartementseigenaar, als well op de aard en de bestemming van het appartement. Met deze gebruiksbeperking is het niet mogelijk bepaalde personen uit appartementen te weren, maar kan slechts een bepaald gebruik worden voorkomen.

Een vraag die hierbij kan worden gesteld is of men bepaalde personen uit een appartement kan weren, terwijl ze eigenaar van dat appartement zijn. Met andere woorden: kan het gebruik aan een appartementseigenaar worden ontzegd met een beroep op de bestemming van het gebouw? Kan men bijvoorbeeld een timmerman de ingebruikneming van zijn appartement ontzeggen, omdat het gebouw is bestemd als woonruimte voor academici? Mijns inziens dient hierop ontkennend te worden geantwoord. Artikel 8 alinea 2 van de wet 1965 staat immers slechts beperkingen van gebruik toe, maar niet de ontzegging van recht op gebruik.

\subsubsection{Ontzegging van verder gebruik.}

Zoals in de vorige paragraaf al werd vermeld, is het niet mogelijk om gebruik aan een appartementseigenaar te ontzeggen. Een bepaald gebruik kan worden verboden wegens strijd met de bestemming van het gebouw, maar artikel 8 van de wet 1965

123. Hof Reims 3 febr. 1977, J.C.P. 1978, II, 18848 met noot Atias.

124. Hetzelfde geldt voor beperkingen van het recht om een appartement te bezwaren, aldus d'Esperonnat; blz. 147-150.

125. Hof Parijs 12 febr. 1976, J.C.P. 1977, IV, blz. 138.

126. Hof Parijs 27 april 1984, Dall. 1984, IR blz. 385. Een clausule die verhuur afhankelijk maakt van de toestemming van de verenigingsraad is echter nietig, omdat ze niet wordt gerechtvaardigd door de bestemming van het gebouw, aldus het Hof Lyon in 1969, aangehaald in Weismann, blz. 17. 
laat geen gebruiksontzegging toe. Wel kan gebruik in strijd met de bestemming worden verboden op straffe van een dwangsom.

Zo achtte het "Tribunal de grande instance" van Grenoble het niet mogelijk om de appartementseigenaars te machtigen om een appartementseigenaresse die zich in haar appartement prostitueerde, te dwingen haar appartement te verkopen ${ }^{127}$. Het "Tribunal" veroordeelde de dame wel om haar activiteiten te staken op straffe van een hoge dwangsom" ${ }^{128}$. Een soortgelijke beslissing nam het "Tribunal de grande instance" van Parijs in een geval dat homosexuelen zich in hun appartement prostitueerden ${ }^{129}$. In weer een ander geval verbood het Parijse "Tribunal de grande instance" de uitbating van een sex-shop in een buurt waarin de overige appartementseigenaars niet op een dergelijke nabuurschap verdacht kunnen zijn ${ }^{130}$.

Indien de in overtreding zijnde appartementseigenaar zijn activiteiten niet staakt, verbeurt hij de dwangsom en indien hij deze niet betaalt, kan zijn appartement worden uitgewonnen. Indien de dwangsom aan de vereniging van eigenaars moet worden betaald, heeft zij tot zekerheid van de betaling de mogelijkheid een hypotheekrecht op het appartement van de overtreder te vestigen (art. 19 wet 1965) en bij niet-betaling het appartement uit te winnen. Veroordeling tot het staken van gebruik in strijd met de bestemming, op straffe van een dwangsom, kan uiteraard ook plaatshebben bij gebruik dat niet tegen de opvattingen van goede zeden indruist ${ }^{131}$. De uitbater van een pizzeria in een tot garage bestemd gedeelte van zijn appartement kan evenzeer tot beëindiging van dit gebruik worden gedwongen. Als hij de hem opgelegde dwangsom bij voortdurende overtreding niet betaalt, zal ook zijn appartement kunnen worden uitgewonnen. Hetzelfde geldt bij niet betaling van de bijdragen in de gemeenschappelijke kosten waarvoor de vereniging een hypotheekrecht kan vestigen op een appartement ${ }^{132}$.

Uiteraard zal het afhankelijk zijn van de rang van het hypotheekrecht, of de schulden aan de vereniging uit de opbrengst van het appartement kunnen worden voldaan. In elk geval is de uitwinning wel een mogelijkheid om een vervelende appartementseigenaar kwijt te raken ${ }^{133}$. De vereniging heeft echter behalve het hypotheekrecht ook nog een privilege op de meubels van de schuldenaar, zodat in veel gevallen in elk geval een gedeelte van de schuld uit de opbrengst van appartement en meubels zal kunnen worden voldaan (vgl. par. 7.2.5).

Het reglement van splitsing werkt ook tegen huurders, zelfs als deze daarmee in hun huurcontract niet hebben ingestemd ${ }^{13}$. Als een huurder zijn appartement in strijd met de bestemming gebruikt, kan de vereniging van eigenaars de verhuurder aanspreken om het gebruik te doen staken en de huurovereenkomst te doen

127. Vgl. d'Esperonnat, blz. 141; Kischinewski-Broquisse, blz 241; Givord/Giverdon, blz. 275, 276. Ecn dergelijke sanctie is volgens deze auteurs in strijd met de openbare orde en goede zeden, waarbij zij verwijzen naar art. 545 C.c dat luidt: "nul ne peut être contraint de céder sa propriété si ce n'est pour cause d'utilite publique."

128. Trib. gr. inst. Grenoble 6 april 1964, Dall. 1964, J blz 317.

129. Trib. gr. inst. Parijs 31 okt. 1975, en 5 febr 1976, Dall. 1976, IR bly, 316, 317.

130. Trib. gr. instance Parijs 8 april 1976, Dall. 1976, IR blz. 314. In gelijke zin Hof Parijs 22 juni 1978, Dall. 1980, IR blz. 235 en Hof Parijs 13 okt. 1982, Dall. 1983, IR blz. 337.

131. Kischinewski-Broquisse, blz. 101.

132. Vgl. Givord/Giwerdon, blz. 250.

133. Givord/Giverdon, blz. 251.

134. Vgl. Hof Parijs 27 april 1984, Dall. 1984, IR blz 385, in het bijzonder het commeataar van Giverdon daarbij. Zie ook Cass. civ. 3 e 14 nov. 1985, Dall. 1986, J blz. 368, 369. 
ontbinden, omdat de huurder de bepalingen van het reglement overtreedt ${ }^{135}$. De vereniging kan echter ook rechtstreeks tegen de huurder optreden en respectering van het reglement vorderen, eventueel versterkt met een dwangsom. Als de verhuurder in gebreke blijft op te treden tegen de huurder, kan de vereniging van eigenaars zelf de ontbinding van de huurovereenkomst en ontruiming van het gehuurde vorderen bij het "Tribunal de grande instance". Ingevolge artikel 1166 C.c. is de vereniging als schuldeiser van de verhuurder namelijk gesubrogeerd in diens rechten ${ }^{136}$. In normale gevallen zal de vereniging de verhuurder echter moețen aanspreken om de huurovereenkomst te laten ontbinden ${ }^{137}$.

\subsection{Beroep tegen niet toelating en ontzegging van verder gebruik}

\subsubsection{Algemene opmerkingen}

Uit het voorgaande blijkt dat toelatingsregelingen in het Franse recht niet mogelijk zijn. Het recht om vrij over een appartement te beschikken en het naar eigen inzicht te gebruiken, staan aan toelatingsregelingen in de weg. In het reglement van medeëigendom kunnen echter wel clausules worden opgenomen, die verhuur of ondersplitsing verbieden. Deze verboden kunnen echter niet als toelatingsregelingen worden opgevat, omdat verhuur en ondersplitsing wel kunnen worden verboden, maar niet van toestemming van de vergadering van eigenaars afhankelijk kunnen worden gesteld.

In het Franse recht is het daarentegen wel mogelijk om aan een appartement een bepaalde bestemming te verbinden, die door huurders en eigenaars moet worden gerespecteerd. De bestemming kan, als onderdeel van het reglement van medeëigendom, ook tegen de huurder worden ingeroepen.

Ontzegging van verder gebruik is in zekere zin wel mogelijk, zij het slechts via beslag en uitwinning op grond van het gemene recht. Een appartement van een eigenaar die de bestemming van het gebouw niet respecteert, kan zoals gezegd worden geveild, indien alle andere middelen hebben gefaald. De term "ontzegging van verder gebruik" is dan ook weinig geschikt voor deze situatie. Het gaat immers niet slechts om ontzegging van verder gebruik, maar om ontneming van de eigendom van een appartement.

Tenslotte verdient hier nog vermelding dat appartementseigenaars een geschil door middel van arbitrage kunnen laten beslechten. De beslissing om een geschil door arbiters te laten oplossen, is ad hoc mogelijk. De Wet 1965 staat aan arbitrage niet in de weg ${ }^{138}$.

\subsubsection{Beroep tegen niet toelating}

Indien aan een appartementseigenaar door de vergadering van eigenaars een bepaald gebruik wordt verboden wegens strijd met de bestemming van het gebouw - vgl. het geval van de notaris in paragraaf 7.3.2 sub a - kan hij zich ex artt. 15 en

135. Weismann, blz. 17.

136. Cass. civ. 3e 14 nov. 1985, Dall. 1986, J blz. 368, 369.

137. Givard/Giverdon, bly 175 .

138. Vgl. Givord/Giverdon, blz 555, 556. Zie ook Aeby, blz. 470 . 
42 alinea 2 Wet 1965 binnen 2 maanden tot het "Tribunat de grande instance" wenden ${ }^{139}$. Het "Tribunal" van de plaats waar het gebouw is gelegen, is kierbiy competent (art. 62 decreet 1967$)^{140}$.

Noch wet en decreet, noch doctrine, noch jurisprudentie, bevatten etige aanwijzing dat de rechters zich bij een dergelijke procedure terughoudend moeten opstellen. Zij toetsen derhalve ook aan de bepalingen van het reglement, interpreteren de bestemmingsomschrijving, en onderzoeken kortom alle facetten van de zaak.

\subsubsection{Beroep tegen ontzegging van verder gebruik}

Indien een appartementseigenaar zijn appartement in strijd met de bestemming gebruikt, kumnen de overige appartementseigenaars of de administrateur (met machtiging van de overige eigenaars) het "Tribunal de grande instance" verzoeken dit gebruik te verbieden op straffe van een dwangsom. Als bij voortgezet met de bestemming strijdig gebruik de dwangsom wordt verbeurd maar niet betaald, kan de vereniging van eigenaars een hypotheekrecht op het appartement laten inschrijven in de openbare registers (art. 19 Wet 1965). Dit hypotheekrecht kan echter slechts worden ingeschreven indien de schuld opeisbaar is en de debiteur in gebreke is gesteld ${ }^{141}$. Ingevolge artikel 58 Decreet 1967 zijn de artt. 819, 821, 824 en 825 van de Code de procédure civile van toepassing op de uitwinning van het hypotheekrecht ${ }^{142}$. Het executoriaal beslag kan door de administrateur met toestemming van de president van het "Tribunal de grande instance" worden gelegd (zie art. R 321-2 Code de l'organisation judiciaire). De president van de rechtbank van de plaats waar het appartementsgebouw is gelegen, is competent om de toestemming te verlenen (art. 62 Decreet 1967).

De appartementseigenaar kan zich in deze procedures slechts verweren. In de eerste procedure kan hij trachten te voorkomen dat hij wordt veroordeeld tot het staken van het met de bestemming strijdige gebruik en aldus ook een eventuele dwangsom trachten te vermijden. Deze procedure komt overeen met de in paragraaf 7.4.2 beschrevene, zij het dat zij hier door de vereniging van eigenaars wordt ingesteld (art. 15 Wet 1965) ${ }^{143}$. In de procedure tot beslaglegging en executie, kan hij zich eveneens slechts verweren of bijvoorbeeld alsnog betalen.

139. Hij moet dan wel de administrateur hiervan in kennis stellen. Zie art. 15 Wet 1965 . Het "Tribunal de grande instance" bestaat uit drie rechters. Bij een proces voor deze rechtbank moeten de procespartijen zich verplicht door een adwocaat laten vertegenwoordigen. Zie art. 75 Nowweau Code de procedure civile, en daarover Guilbaud, blz. $51,53$.

140. Givord/Giverdon, blz. S57.

141. Givord/Giverdon, blz. 250, 251.

142. Vgl. Givord/Giverdon, blz. 253.

143. Logeman, blz. 50; Givord/Giverdon, blz 530-545. 


\section{Zwitserland}

\subsection{Inleiding}

Voor de inwoering van het Zivilgesetzbuch kwam horizontaal gesplitste eigendom van gebouwen in sommige gedeelten van Zwitserland als "Geschoss-, Gelass-, Höhen-" en "Etageneigentum" voor ${ }^{1}$. Vooral in de bergen en in de steden kwamen deze vormen van appartementseigendom voor. In de bergen omdat daar gemakkelijk etages met onafhankelijke ingangen op elkaar konden worden gebouwd, en in de steden vanwege gebrek aan bouwgrond ${ }^{2}$. De door de Franse Code civil beïnvloede Westzwitserse kantons kenden in de negentiende eeuw alle de mogelijkheid van horizontale splitsing van gebouwen. Met name in het kanton Wallis kwam, deze horizontale splitsing volgens Brogli zeer veel voor ${ }^{3}$.

Bij de voorbereidingen van het Zivilgesetzbuch (ZGB) meende de schepper van dit wetboek, Eugen Huber, dat horizontale splitsing van onroerend goed in strijd was met de romeinsrechtelijke accessieregel "superficies solo cedit". Bovendien verwachtte men grote problemen bij inschrijving van Stockwerkeigentum in het "Grundbuch". In het ZGB werd dan ook geen mogelijkheid voor horizontale splitsing van gebouwen opgenomen.

Dientengevolge werd de horizontale splitsing van eigendom bij de invoering van het ZGB op 1 januari 1912 onmogelijk gemaakt. Voor die tijd ontstane "Stockwerkeigentum"' werd echter geëerbiedigd ${ }^{4}$. Om te voorkomen dat men toch tot een soort "Stockwerkeigentum" zou komen via de vestiging van opstalrechten, werd dit in artikel 675 lid 2 ZGB uitdrukkelijk verboden ${ }^{5}$. Hoewel "Stockwerkeigentum" vanaf 1912 niet meer in het leven kon worden geroepen, bleef de behoefte aan eigendom van gedeelten van gebouwen bestaan. De praktijk zocht derhalve naar surrogaten. Eerst behielp men zich met medeëigendom, gecombineerd met "Dienstbarkeiten" (persoonlijke en zakelijke dienstbaarheden), die aan elk van de medeëigenaars het recht gaf om een bepaald gedeelte van het gemeenschappelijke gebouw afzonderlijk te gebruiken en te beheren. Aan deze vorm was echter het nadeel verbonden dat ieder der deelgenoten een voorkeursrecht kreeg bij verkoop van aandelen en te

1. Brogli, blz. 1.

2. Ackermann, blix, 6 .

3. Brogli, ble $2,3$.

4. Friedrich, bliz 39. In sommige delen van Zwitserland kwam "Stockwerkeigentum" veel voor. Op appartementseigendom die is gesticht voor de inwoering van het ZGB, is tegenwoordig het appartementsrecht uit het ZGB van toepassing. Zie Bundesgericht 17 febr. 1987, Baurecht 1988, ble 69, ESB 1987, 113. Band, II, ble. 146-151.

5. Zie hierover Liver, blz. 146. Vgl. Brogli, blz. 6. In het overgangsrecht bij de invoering van het ZGB werd bepaald dat de bestaande "Stockwerkeigentum" door invoering van het ZGB niet werd aangetast. 
allen tijde scheiding en deling kon vorderen op grond van artikel $650 \mathrm{ZGB}^{6}$. Een tweede surrogaat werd gevonden in de vorm van "Aktiengesellschaften". en "Genossenschaften", in het bijzonder in de vorm van de "Mieter-Aktiengesellschaft". In deze laatste vorm werd een "Aktiengesellschaft" (AG) opgericht, die eigenaar van grond en gebouwen was, maar waarvan zoveel aandelenpakketten bestonden als er appartementen waren. De aandeelhouders huurden vervolgens van de vernootschap een appartement.

$\mathrm{Na}$ de tweede wereldoorlog verdedigden Zwitserse juristen met een beroep op de kennelijke behoefte aan appartementseigendom een hernieuwde wettelijke regeling van "Stockwerkeigentum". In zijn preadvies aan de Zwitserse juristenvereniging in 1956 beschrijft Friedrich hoe de behoefte aan appartementseigendom na het verbod daarvan in 1912 was gegroeid ${ }^{7}$. De behoefte was aanvankelijk in thet Franstalige deel van Zwitserland het grootst, maar breidde zich langzaam maar zeker uit over geheel Zwitserland.

Op 30 mei 1951 schreef de Zwitserse parlementariër $\mathrm{H}$. Cottier, ondersteund door 16 andere parlementariërs, een brief aan de Zwitserse Bundesrat waarin deze werd verzocht zorg te dragen voor

"Die Anpassung der Bestimmungen des Zivilgesetzbuches und der Grundbuchverordnung zwechs Wiedereinführung des Begriffes Stockwerkeigentum".

De Bundesrat antwoordde op 21 september 1951, dat hij een verandering van het ZGB niet nodig achtte, omdat appartementseigendom ook via vennootschapsconstructies kon worden verwezenlijkt.

In de daarop volgende jaren bleek echter dat de behoefte aan "Stockwerkeigentum" steeds meer toenam. In 1956 bepleitte Friedrich in zijn preadvies dan ook een hernieuwde regeling van het appartementsrecht en stelde hij:

"Die Wiedereinführung des Stockwerkeigentums stehen keine zwingenden Gründe rechtlicher Natur entgegen." ${ }^{\text {s }}$

Tina Peter-Ruetschi sloot zich in 1958 bij Friedrich aan en schreef eveneens een pleidooi voor "Stockwerkeigentum". De Mieter-AG en andere surrogaatvormen voldeden volgens haar niet.

"Diese Gesellschaftsformen können deshalb nicht bieten, auf was es vielen ankommt, nämlich ein Eigentum an Grund und Boden." ${ }^{\text {ng }}$

Tengevolge van deze pleidooien en omdat uit het zoeken naar surrogaten bleek dat er behoefte bestond aan de mogelijkheid van horizontale splitsing van eigendom, althans aan de mogelijkheid om juridisch zelfstandige eenheden van een

6. Brogli, blz. 7, 114-123.

7. Friedrich (Preadvies), blz. 8a, 9a.

8. Friedrich (Preadvies), blz 8a, 11a, 260a.

9. Peter-Ruetschi (Eigentum an Wohnungen), blz. 10. Vgl. over de afschaffing wan de "Stockwerkeigentum" en de wenselijkheid vam cen nieuwe regeling cok: Sattiva. 
gebouw te kunnen verwerven, en bovendien het oude "Stockwerkeigentum" als een "Fremdkörper" in het Zwitserse burgerlijk recht bleef voortbestaan (vooral in Wallis), werd bij wet van 19 december $1963^{11}$ het vierde deel van het $Z$ GB veranderd ${ }^{12}$, en werden de huidige artikelen $647-650,682$ en 712a-712t in het ZGB ingevoerd. Hierdoor werd "Stockwerkeigentum" weer mogelijk. Wel kreeg de "Stockwerkeigentum" een andere inhoud dan voor 1912. Het doel van de herinvoering van "Stockwerkeigentum" was om meer mensen in staat te stellen eigen woningen en bedrijfsruimten te verwerven ${ }^{13}$.

In dit hoofdstuk zal de Zwitserse "Stockwerkeigentum"-regeling zoals die sinds 1965 in werking is, worden besproken. Evenals in de andere hoofdstukken over buitenlands appartementsrecht zal eerst op de hoofdlijnen van het appartementsrecht worden ingegaan, waarna zall worden onderzocht in hoeverre het Zwitserse appartementsrecht regelingen kent die vergelijkbaar zijn met de Nederlandse regeling van de welstandsbepalingen in het appartementsrecht. Hierbij zal eerst worden ingegaan op toelating tot een appartement en vervolgens op ontzegging van verder gebruik. Bij deze bespreking zal ook de rechterlijke toetsing van eventuele ontzegging van ingebruikneming of verder gebruik, worden behandeld.

\subsection{De hoofdlijnen van het Zwitserse appartementsrecht}

\subsection{Algemene opmerkingen}

Op de "Stockwerkeigentum" zijn de bijzondere bepalingen van artikelen 712a-712t ZGB van toepassing en daarnaast de allgemene bepalingen van artikelen 646-651 en 655 en $682 \mathrm{ZGB}$ over de medeëigendom in het algemeen ${ }^{14}$.

Het ZGB regelt de "Stockwerkeigentum" niet uitputtend. Evenals in Nederland, België, West-Duitsland en Frankrijk kunnen de medeëigenaars een reglement van splitsing ${ }^{15}$ opstellen, waarin beheer en gebruik nader worden geregeld. Dit

10. Liver, blz. 145; Romang, par. 8/2, blz. 2 .

11. In werking getreden op 1 januari 1965. Zie Biotschaft des Bundesrates, Bundesblatt $1962 \mathrm{II}, \mathrm{blz}$ 1461-1534 en de handelingen in de "Bundesversammlung", Stenbull. NR 1963, 185-228, blz. 527535 en 685 . Zie ook Stenbull. Str. 1963, blz. 204-225, 283-287 en 376. Zie over de wetsgeschiedenis Brogli, bliz 8; Flattet, bliz. 142. Het doel wan het wetsontwerp was: "Erleichterung des Erwerbs eigenen Wohnraumes fïr möglichst grosse Zahl von Familien." Zie Bundesblatt 1962 II, blz. 1471 .

12. Ook de "Grundbuchverordnung" mocst dientengevolge worden gewijzigd. Zie Verordnung des Bundesrates d.d. 21 april 1964, AS 1964, 413-417.

13. Tuor/Schnyder, blz. 648, 649; Schweizeriches Privatrecht, blz 87. Vgl, over de geschiedenis van het Zwitserse appartementsrecht ook: Kurt Müller, blz. 5-9.

14. Zie over de medeëigendomsverhoudingen in Zwitserland (voor 1965): Liver (Geneinschaftliches Eigentum), blz. 261-269.

15. Zie Peter-Ruetschi (Erfahrungen) over hetgeen in een reglement zou moeten worden geregeld. $\mathrm{Zij}$ wijst met name op:

a. beschrijving van de appartementen en de prive-gedeelten

b. regeling met betrekking tot verandering van het reglement

c. regeling met betrekking tot het gebruik van gemeenschappelijke en privê-gedeelten

d. bestemmingsomschrijving

e. wijze van stemmen in de vergadering

f. regeling met betrekking tot verzekering van het gebouw

g. instelling van een gemeenschappelijk fonds, waaruit gemeenschappelijke kosten worden voldaan 
reglement is ook voor latere verkrijgers en derden-gebruikers van "Stockwerkeigentum" verbindend, indien het in het "Grundbuch" is ingeschreven. Ook besluiten van de vergadering van eigenaars met betrekking tot administratie en beheer en rechterlijke beslissingen betreffende de gemeenschap, zijn tegen rechtsopvolgers en derden-gebruikers inroepbaar (artt. 647 en 649a ZGB). Uit de literatuur over Zwitsers "Stockwerkeigentum" blijkt dat in de praktijk in het merendeel van de gevallen een reglement wordt gehanteerd ${ }^{16}$. Net als in België en anders dan in Nederland is men in Zwitserland echter niet verplicht om een reglement op te stellen. Iedere "Stockwerkeigentümer" is echter bevoegd om opstelling van een reglement en opneming daarvan in het openbare register te vorderen (art. $712 \mathrm{~g}$ lid $3 \mathrm{ZGB}$ ). Het reglement van splitsing kan slechts veranderd worden indien de meerderheid van de "Stockwerkeigentümer", die tevens meer dan de helft van de waarde van het gebouw vertegenwoordigen, voorstemmen. Voor zover de verandering van het reglement echter een afwijking van de wettelijke bepalingen betreffende het beheer en de administratie van medeëigendom inhoudt, is eenstemmigheid vereist (art. $712 \mathrm{~g}$ lid $2 \mathrm{ZGB}$ ) ${ }^{17}$.

In de wet is niet in een regeling van een huishoudelijk reglement voorzien. Het is echter wel mogelijk dat de appartementseigenaars zo'n reglement opstellen. Daarin kunnen bepalingen met betrekking tot het gebruik van de prive-gedeelten en de gemeenschappelijke gedeeiten worden opgenomen. Zo kan het huishoudelijk reglement regelen gedurende welke uren men mag musiceren, wanneer en waar tapijten mogen worden uitgeklopt, wanneer de huisdeuren moeten worden gesloten etc $^{18}$. In dit hoofdstuk zal niet nader op het huishoudelijk reglement worden ingegaan.

In het navolgende zal bij de verschillende onderwerpen wel steeds aandacht worden besteed aan de bepalingen van het reglement van splitsing. Verscheidene boeken over Zwitsers "Stockwerkeigentum" geven modellen voor een reglement. In dit hoofdstuk wordt het reglement dat door Tina Peter-Ruetschi in haar boek is opgenomen, als model gebruikt ${ }^{19}$. Het reglement dat door H.P. Friedrich in zijn boek is opgenomen, komt globaal genomen overeen met het reglement dat door Tina Peter-Ruetschi is opgenomen. Met betrekking tot toelating en ontzegging van verder gebruik geeft het reglement van Friedrich echter een enigermate afwijkende regeling. Vandaar dat in de paragraaf waar de toelating en ontzegging van verder gebruik worden behandeld, wel expliciet op de desbetreffende bepalingen van het reglement van Friedrich ${ }^{20}$ zal worden ingegaan.

b. kostenbijdrageregeling

i. vervreemdingsbeperkingen

j. regeling omtrent benoeming en ontslag van de administrateur en omtrent de duur van zijn benocming.

16. Peter-Ruetschi, blz. 54, 55; Peter-Ruetschi (Erfahrungen), blz 7 .

17. Peter-Ruetschi, blz. 56, 57; Bundesgericht 24 maart 1977, ESB 1977, 103. Band, Ib, blz. 76-82.

18. Romang par. 8/7.3, blz 1-4.

19. Peter-Ruetschi, blx. 59-78. Verder te noemen reglement Peter-Ruetschi.

20. Verder te noemen reglement Friedrich. 


\subsection{Algemene structuur wan "Stockwerkeigentum"}

De gemeenschap van appartementseigenaars is een zogenaamde "Rechtsgemeinschaft". Een dergelijke "Rechtsgemeinschaft" bestaat indien meerdere personen gerechtigd zijn tot hetzelfde recht ${ }^{21}$. Daarnaast is de gemeenschap van appartementseigenaars als species van de "Rechtsgemeinschaft" een "Miteigentümergemeinschaft"22. Ook van deze "Miteigentümergemeinschaft" is de gemeenschap van appartementseigenaars een bijzondere vorm ${ }^{2}$.

De "Stockwerkeigentum" (in het Frans: propriété par êtage) wordt in artikel 712a lid 1 ZGB gedefinieerd.

"Stockwerkeigentum ist der Miteigentumsanteil an einem Grundstück, der dem Miteigentümer das Sonderrecht gibt, bestimmte Teile eines Gebäudes ausschliesslich zu benutzen und innen auszubauen." 24

Uitgangspunt bij appartementseigendom is derhalve medeëigendom ${ }^{25}$. Bepaalde gedeelten van een gemeenschappelijk gebouw zijn echter slechts voor afzonderlijk gebruik door én medeëigenaar bestemd. Dit afzonderlijk gebruik wordt gegarandeerd door het "Sonderrecht" dat de medeëigenaar heeft. Het "Sonderrecht" is een beperkt zakefijk genotsrecht, dat accessoir is aan het medeëigendomsrecht ${ }^{26}$. Deze structuur heeft men in Zwitserland aangenomen, omdat de schepping van een mogelijkheid van "Stockwerkeigentum" de doorbreking van de "superficies solo cedit"-regel niet zou rechtvaardigen ${ }^{27}$.

21. Frei, blz. 16.

22. De "Miteigentümergemeinsehalt" omvat medeëigendom van zaken (in de betekenis van het huidige Ned. recht) naar aandelen (mit Quotenteillung). Een andere vorm van "Rechtsgemeinschaft" is de "Gesamteigentum", waarbij geen "Quotenteilung" plaatsvindt. De uitoefening van het eigendornsrecht gebeurt hierbij niet naar aandelen, maar gemeenschappelijk. Getalsmatigg vastgestelde aandelen bestaan bij de "Gesamteigentum" niet. Zie Meier-Hayoz, blz, 141.

23. Frei, blz. 18-21; Hindermann, blz 47-49; Flattet, blz 143.

24. In het verwolg zal voor Stockwerkeigentum de vertaling appartementsrecht worden gehanteerd ("Stockwerk" zal als appartement worden vertaald). Deze term is mijns inziens een goede: Nederlandse vertalling voor "Stockwerkeigentum". Het Nederlandse appartementsrecht en de Zwitserse "Stockwerkeigentum" komen immers wat algemene structuur betreft overeen. Ook het Zwitserse appartementsrecht houdt een medeëigendonsrecht wan het gehele gebouw in, waaraan een zakelijk gebruiksrecht ta.v. de prive-gedeelten is gekoppeld. De gerechtigde tot het Zwitserse appartementsrecht zal, evenals in Nederland, hier worden aangeduid als appartementseigenaar. Deze terminologie is mijns inziens gerechtvaardigd, nu ook in Zwitserland deze gerechtigde "Stockwerkeigentümer" wordt genoemd.

25. Vgl. hierbij \& 3 van het reglement Peter-Ruetschi. Volgens Liver, blz 143, is deze constructie de enige dogmatisch juiste. "Erkemnt man jedem Beteiligten an diesen Bauteilen (van een appartementsgebouw, R.M.) Sondereigentum zu, gibt man ihm Eigentum an einem Gegenstand, der gar nicht eine Sache im Rechtssinne sein kann, man durchbricht damit ferner das Akzessionsprinzip." Liver merkt vervolgens op blz. 149 op: "Das Miteigentum bildet den Stamm und die äste, woraus der Stockwerkeigentum hervorwächst." Vgl. ook Brogli, blz 9, 10.

26. Rey, blz. 249; Hauger, blz. 12-21; Christoph Müller, blz. 14-16.

27. Vgl. Weber, blz. 14; Friedrich (Preadvies), blx. 174a-188a, heeft deze structuur in 1956 al verdedigd. 
Het "Sonderrecht" kan rusten op afzonderlijke verdiepingen of delen van verdiepingen. Hieronder vallen: woningen, bedrijfsruimten en winkelruimten ${ }^{28}$. De afzonderlijke ruimten waarop het "Sonderrecht" rust, moeten wel een afgesloten geheel vormen met een eigen ingang ${ }^{29}$. Het "Sonderrecht" mag echter tevens afgescheiden ruimten omvatten die niet tot het onafgescheiden geheel behoren (bijvoorbeeld garages e.d. Zie art. $712 \mathrm{~b}$ lid $1 \mathrm{ZGB}$ ). De grond en eventuele opstalrechten kunnen niet met het "Sonderrecht" worden belast, evenmin als de delen van het gebouw die voor de stevigheid of het uiterlijk van het gebouw van belang zijn (art. $712 \mathrm{~b}$ lid 2 ZGB). De grond en eventuele opstalrechten zijn dus altijd gemeenschappelijk. Gedeelten die niet met een "Sonderrecht" zijn belast en die evenmin onder de verplicht gemeenschappelijke gedeelten ex artikel $712 \mathrm{~b}$ lid 2 ZGB vallen, kunnen in de "Begründungsakt" - de akte van splitsing - als gemeenschappelijk worden bestempeld. Als dit niet het geval is worden ze vermoed onder een "Sonderrecht" te vallen (art. $712 \mathrm{~b}$ lid $3 \mathrm{ZGB}$ ) ${ }^{30}$.

Alle gedeelten van een appartementsgebouw zijn dus hetzij voor gemeenschappelijk gebruik, hetzij met een "Sonderrecht" belast. In de praktijk is echter gebleken dat de wettelijke omschrijving van de gedeelten die met een "Sonderrecht kunnen worden bezwaard, tot problemen aanleiding kan geven. Bij een woning moet het gedeelte waarop het "Sonderrecht" rust bijvoorbeeld een afgesloten geheel vormen. Dit heeft tot gevolg dat een balkon niet met een "Sonderrecht" kan worden bezwaard.

"Ein Balkon kann nicht zu Sonderrecht ausgeschieden werden, weil er keinen abgeschlossenen Raum darstellt." ${ }^{\text {31 }}$

Evenmin kan een parkeerplaats op een parkeerterrein onder een "Sonderrecht" vallen. Het balkon en het parkeerterrein blijven gemeenschappelijk in de zin dat ze niet met een "Sonderrecht" kunnen worden bezwaard en voor gemeenschappelijk gebruik zijn bestemd. In de Zwitserse praktijk behelpt men zich in deze gevallen met een "Sonderbenützungsrecht", een zakelijk gebruiksrecht, waarmee men de gemeenschappelijke gedeelten als balkons e.d. bezwaart. Feitelijk bestaat er derhalve weinig verschil tussen het "Sonderrecht" en het "Sonderbenützungsrecht". Juridisch is er echter het verschil dat de gedeelten die met een "Sonderrecht" zijn bezwaard weliswaar in medeëigendom aan alle eigenaars toekomen, maar slechts door eén eigenaar op grond wan de wet mogen worden gebruikt, terwijl de gerechtigde tot een "Sonderbenützungsrecht" feitelijk bet alleenrecht heeft, maar de gedeelten waarop het recht rust juridisch als voor gemeenschappelijk gebruik bestemde gedeelten worden beschouwd ${ }^{32}$.

28. Romang, par. $8 / 3.2$, blz. 1 . In het navolgende zullen de winkelruimten gemakshalve tot de bedrijfsruimten worden gerekend.

29. Vgl. \$2 reglement Peter-Ruetschi. Zie over het subject van bet "Sonderrecht" uilgebreid: Hauger, blz 52-64; Romang par. 8/3.2, blx 2 .

30. Romang, par. $8 / 3.3$, blz, 1,2 .

31. Romang, par. $8 / 3,4, b l z .1$.

32. Romang, par. $8 / 3.4$, blz. 3 . 


\subsection{Ontstaan en tenietgaan van appartementsrechten}

Splitsing van een gebouw in appartementsrechten komt tot stand door inschrijving van de zogenaamde "Begründungsakt" in het "Grundbuch", het openbare register woor onroerend goed (art. $712 \mathrm{~d}$ lid $1 \mathrm{ZGB}$ ). Deze inschrijving in het openbare register kan worden verzocht (1) op grond van een overeenkomst tussen medeëigenaars van een onroerend goed die hun aandelen in appartementsrechten willen omzetten of (2) op grond van een verklaring door een eigenaar van een onroerend goed of door de gerechtigde tot een opstalrecht, dat hij medeëigendomsaandelen in de vorm van appartementsrechten wil creëren (art. $712 \mathrm{~d}$ lid 2 ZGB) ${ }^{33}$. De rechtshandeling die splitsing beoogt is slechts geldig, indien ze "öffentlich beurkundigt" is of, indien zij deel uitmaakt van een testament of erfboedelscheiding ${ }^{34}$, volgens de in het $Z$ witserse erfrecht voorgeschreven vorm is tot stand gekomen (art. $712 \mathrm{~d}$ lid 3 ZGB) ${ }^{35}$. Volgens Maria Hauger ${ }^{36}$ kunnen bij testament slechts verbintenissen worden gecreëerd, orn een nagelaten gebouw te splitsen. Hauger baseert zich hierbij op het gesloten systeem van het zakenrecht en de daarbij behorende wijzen van totstandkoming van zakelijke rechten. $\mathrm{Zij}$ beweert:

"Das deutsche Wohnungseigentum und das Stockwerkeigentum sind dingliche rechte und gehören als solche dem Sachenrecht an. Sie unterliegen damit dem Grundsatz der geschlossenen Zahl der dinglichen Rechte und können nur in der vom Gesetz vorgeschriebenen Form begründet werden."

Hauger miskent hier mijns inziens de werking van artikel 712d lid $3 \mathrm{ZGB}$, dat immers uitdrukkelijk bepaalt dat de rechtshandeling om de splitsing tot stand te brengen hetzij "öffentlich beurkundigt" moet zijn (dit geldt voor de overeenkomst tussen medeëigenaars en voor de verklaring door éen eigenaar), hetzij volgens de in het Zwitserse erfrecht voorgeschreven vorm tot stand moet zijn gekomen (dit geldt voor testamentaire splitsing of splitsing bij erfboedelscheiding). De splitsing door de erflater bij testament is in feite niets anders dan een verklaring door een eigenaar, waaraan echter afwijkende geldigheidseisen worden gesteld. De splitsing is pas voltooid als zij op grond van de rechtshandeling is ingeschreven in het Grundbuch. Pas door inschrijving ontstaan appartementsrechten ${ }^{37}$.

In de "Begründungsakt" (de splitsingsakte), waarvan de schriftelijke overeenkomst of verklaring (of testament of erfboedelscheiding) deel uitmaakt, die in het openbare register wordt ingeschreven, moet behalve de ruimtelijke indeling en

33. Hauger, blz. 75-81; Schmid, blz. 26, 27.

34. Een dergelijke scheiding, waarbij een nalatenschap in appartementsrechten wordt gesplitst, kan echter niet aan een medeëigenaar-erfgenaam worden opgedrongen. Splitsing door een rechterlijk oordeel is evenmin mogelijk. Zie Bundesgericht 5 dec. 1968, ESB 1969, 94. Band, II, blz. 231240.

35. Vgl. hierover Schweizerisches Privatrecht, blz, 98; Romang, par, 8/4.1, blz 1, 2.

36. Hauger, blz. 81, 82. Vgl. over splitsing door de erflater: Götte.

37. Götte geeft nergens in zijn werk een oplossing voor dit probleem. Vgl. hierbij ook Peter-Ruetschi (Anwendung), blz. 148-152. 
beschrijving van de verschillende appartementen in een "Aufteilungsplan" 38 (art. $33 \mathrm{~b}$ lid $1 \mathrm{GBV})^{39}$ ook de waarde van het appartement in verhouding tot de waarde van het gehele onroerend goed in honderdsten of duizendsten worden aangegeven (art. 712e lid $1 \mathrm{ZGB}$ ). Deze "Wertquoten" kunnen slechts met instemming van alle betrokkenen en de vergadering van appartementseigenaars worden veranderd (art. $712 \mathrm{e}$ lid $2 \mathrm{ZGB}$ ). De appartementsrechten kunnen overigens alleen op een gebouw in zijn geheel in het leven worden geroepen ${ }^{40}$.

Een "papieren splitsing" is ook mogelijk. De bepalingen uit het ZGB staan aan zo'n papieren splitsing niet in de weg, hoewel nergens expliciet wordt vermeld dat zij mogelijk is. Uit artikel $712 \mathrm{~d}$ ZGB kan echter worden afgeleid dat een papieren splitsing niet verboden is. Aldus kan een appartementsgebouw voor, tijdens of na de bouwwerkzaamheden worden gesplitst ${ }^{41}$. Door inschrijving is het "Grundbuch" ontstaat de "Stockwerkeigentum", ook als het gebouw in werkelijkheid nog niet bestaat ${ }^{42}$.

Een opstairecht kan eveneens in appartementsrechten worden gesplitst. De appartementseigenaars worden dan medegerechtigden tot een opstalrecht, medeëigenaars van het gebouw en "Sonderberechtigte" tot hun privé-gedeelten ${ }^{43}$.

Appartementsrechten gaan teniet indien het onroerend goed tenietgaat ${ }^{44}$ of het opstalrecht eindigt, dat ten grondslag lag aan het in appartementsrechten gesplitst gebouw ${ }^{45}$. Daarnaast wordt de splitsing opgeheven, indien hij uit het "Grundbuch" wordt geschrapt (art. $712 \mathrm{f} \mathrm{lid} 1 \mathrm{ZGB}$ ). De splitsing kan uit het "Grundbuch" worden geschrapt op grond van een opheffingsovereenkomst tussen de appartementseigenaars. Indien alle appartementsrechten echter in handen zijn van eén persoon, kan deze eigenaar de opheffing alleen vorderen. Wel moet hij dan de toestemming verkrijgen van eventuele zakelijk gerechtigden wier rechten niet zonder nadeel op het gehele onroerend goed kunnen worden getransponeerd (art. $712 \mathrm{f}$ lid 2 ZGB). Bovendien kan elk der appartementseigenaars de opheffing wan de splitsing vorderen, indien het gebouw voor meer dan de helft is vernietigd en wederopbouw voor hem een zware belasting zou zijn. Andere appartementseigenaars kunnen de opheffing van de splitsing in dit geval echter verhinderen door degene die wil dat de splitsing wordt opgeheven, schadeloos te stellen (art. 712f lid $3 \mathrm{ZGB})$.

Indien de eigenaars zijn overeengekomen dat zij de splitsing opheffen of indien het gebouw is tenietgegaan, dan moet scheiding en deling plaatsvinden door veiling of onderhandse verkoop van het geheel met verdeling van de opbrengst overeen-

38. De "Aufteilungsplan" heeft tot doel om alle "Sonderrechte", "Sonderbenittzungsrechte" en gemeenschappelijke gedeelten duidelijk vast te leggen. Zie Romang, par. 8/4.3, blz. 1 .

39. In het Grundbuch moet tevens een eigen kaart van ieder appartementsrecht met de benodigde beschrijvingen worden opgenomen (art. 10a lid 2 GBV).

40. Schweizerisches Privatrecht, blz. 99; Hindermann, blz. 39, 40.

41. Schmid, blz. $24,25,188,189$.

42. Vgl. Laurent, blz. 29; Die Eigentumswohnung, blz. 10. Zie ook Hindermann, blz. 38, 39 en blz. 83 waarop hij een model voor een "Begründungserklärung" geeft.

43. Tuor/Schnyder, ble. 651 .

44. Zie Romang, par. 8/5.1, blz 3. Het onroerend goed kan tenietgaan door lawines e.d. \$ 13 sub 1 reglement Peter-Ruetschi bepaalt echter in zijn algemeenheid dat het gebouw bij tenietgaan in beginsel moet worden herbouwd.

45. Tuor/Schnyder, blz. 651; Hauger, blz. 131-139. 
komstig de "Wertquoten", het waarde-aandeel dat iedere appartementseigenaar in de gemeenschap heeft (art. 651 lid 1 ZGB). Als de eigenaars het over de wijze waarop de gemeenschap moet worden verdeeld (door veiling of onderhandse verkoop) niet eens worden, wordt de gemeenschappelijke zaak openbaar of onder de appartementseigenaars geveild (art. 651 lid 2 ZGB) ${ }^{46}$. Overigens kan iedere medeëigenaar bij gewone medeëigendom in beginsel te allen tijde scheiding en deling vorderen. Met betrekking tot appartementsrechten is die mogelijkheid echter uitgesloten (art. 650 lid $\mathbb{1} \mathrm{ZGB})^{47}$.

\subsection{Administratie en beheer}

De bevoegdheid tot administratie en beheer van de gemeenschappelijke eigendom komt de appartementseigenaars in beginsel gezamenlijk toe ${ }^{48}$. Hiervoor komen de appartementseigenaars samen ${ }^{49}$ in de vergadering van appartementseigenaars ${ }^{50}$. Deze vergadering van eigenaars is het hoogste orgaan van de gemeenschap van appartementseigenaars. In deze vergadering worden alle belangrijke beslissingen genomen, die door de andere organen van de gemeenschap, de administrateur en de "Ausschuss", in beginsel slechts worden uitgevoerd. De vergadering van eigenaars komt in grote mate overeen met de algemene ledenvergadering bij Zwitserse verenigingen, zoals die in artikelen 64 e.v. ZGB is geregeld. Deze bepalingen uit het verenigingsrecht zijn dan ook op de vergadering van eigenaars van toepassing, voor zover de wet geen afwijkende bepalingen bevat (art. $712 \mathrm{~m}$ lid $2 \mathrm{ZGB})^{51}$. De vergadering heeft beslissingsmacht in alle administratieve aangelegenheden die volgens de wet, de akte van splitsing of het reglement tot de gemeenschappelijke bevoegdheden behoren en niet aan de administrateur zijn opgedragen (art. $712 \mathrm{~m}$ lid $1 \mathrm{ZGB})^{52}$. Zij heeft voorts de bevoegdheid om een administrateur te benoemen ${ }^{53}$ en een commissie of een afgevaardigde te kiezen om de administrateur te adviseren en te controleren ${ }^{54}$. Ook moet de vergadering jaarlijks de kostenaangelegenheden regelen. Onder deze aangelegenheden valt onder andere de vaststelling van de voorschotten die door de appartementseigenaars voor onderhoud e.d. moeten worden voldaan ${ }^{55}$. Verder heeft de

46. De rechter kan in het algemeen bij medeeigendom ook de materiële verdeling van de zaak bevelen. Voordat hij cen keuze maakt tusen veiling of materiële verdeling tussen de eigenaars, moet hij magaan, of de zaak zonder walardevermindering materieel deelbaar is (bij appartementseigendom is een materiële verdeling na opheffing van de splitsing uiteraard ondenkbaar). Vgl. Bundlesgericht 13 juni 1974, ESB 1974, 100. Band, II, blz 187-195.

47. Zile hierower Liver, ble. 182, 183, 187, Romang, par. 8/5.2, blz. 1.

48. Volgens $\$ 7$ van het reglement Peter-Ruetschi moeten de eigenaars binnen een maand na verkrijging van het appartement een vertegenwoordiger uit hun midden aanwijzen. Vgl. Christoph Miiller, blz. 23.

49. Noch de vergadering, noch de gemeenschap heeft rechtspersoonlijkheid. De vergadering is een orgaan van de gemeenschap. Vgl. Christoph Müller, blz. 28, 87.

50. Zie over de vergadering van eigenaars: Schweizerisches Privatrecht, blz. 100, 101.

51. Vgl. Riemer, ble. 257-268.

52. Romang, par. 8/8.1.1, blz. 1,2 .

53. Vgl. $\$ 16$ reglement Peter-Ruetschi.

54. Zie over deze commissie: Schweizerisches Priwatrecht, blz 102.

55. Volgens $\$ 10$ van het reglement Peter-Ruetschi moet voor reparaties en onderhoud een fonds in het leven worden geroepen, waarin de bijdragen in de reparatiekosten en onderhoudskosten worden gestort. In $\$ 12$ wordt bepaald waarvoor en in welke mate een eigenaar moet bijdragen 
vergadering de bevoegdheid om het gebouw te verzekeren (art. $712 \mathrm{~m}$ lid 1 ZGB) ${ }^{56}$ en om de administrateur te machtigen namens de gemeenschap in rechte op te treden ( $712 t$ lid $2 \mathrm{ZGB}$ ), een huishoudelijk reglement vast te stellen, een plichtenomschrijwing voor de administrateur vast te stellen en te beshissen over beroep tegen beslissingen van de administrateur ${ }^{57}$.

De vergadering wordt door de administrateur bijeengeroepen, tenzij de vergadering zelf anders heeft beslist of in het reglement een afwijkende regeling is opgenomen (art. $712 \mathrm{n}$ lid $1 \mathrm{ZGB}$ ) ${ }^{58}$. Van rechtswege moet de vergadering echter worden bijeengeroepen - hiervan kan in het reglement of door de vergadering niet worden afgeweken - indien een vijfde van de appartementseigenaars dit verlangt (art. 64 lid $3 \mathrm{ZGB})^{59}$. De bijeenroeping moet in de praktijk, hoewel de wet dit niet expliciet voorschrijft, schriftelijk gebeuren. In het reglement kan worden geregeld of een gewone brief voldoende is, of dat de bijeenroeping bij aangetekende brief moet geschieden. De bijeenroeping zou, bij gebreke van een wettelijke bepaling daaromtrent, theoretisch ook mondeling kunnen gebeuren. Bij een mondelinge bijeenroeping zou achteraf echter een bewijsprobleem kunnen ontstaan ten aanzien van de geldigheid van de bijeenroeping, met name met betrekking tot de vraag of alle eigenaars zijn uitgenodigd en of de agenda bekend is gemaakt ${ }^{60}$.

De besluiten moeten worden genotuleerd en bewaard (art. $712 \mathrm{n}$ lid 2 ZGB) en zijn slechts geldig, indien ter vergadering de helft van alle appartementseigenaars (met een minimum van twee), die tegelijkertijd de helft van de aandelen van het gebouw vertegenwoordigen, aanwezig is (art. 712p lid 1 ZGB) ${ }^{6 t}$. Bij onvoldoende opkomst moet binnen tien dagen ${ }^{62}$ een tweede vergadering worden uitgeschreven. Deze tweede vergadering is bevoegd om besluiten te nemen, indien een derde van de appartementseigenaars met een minimum van twee aanwezig of vertegenwoordigd is (art. 712p lid 2 en 3 ZGB). De vergadering wordt voorgezeten door de administrateur (art. 712n lid $1 \mathrm{ZGB}$ ). Als geen administrateur benoemd is, kan een van de appartementseigenaars tot voorzitter worden gekozen. In bepaalde gevallen is het zelfs aan te bevelen, aldus Romang, dat een neutrale derde tot voorzitter voor éen dag wordt benoemd ${ }^{63}$.

In beginsel neemt de vergadering zijn besluiten bij absolute meerderheid van stemmen van de aanwezige appartementseigenaars (art. 67 lid $2 \mathrm{ZGB}$ ). In sommige

in de kasten.

56. VgI 11 reglement Peter-Ruetschi.

57. Romang, par. 8/8.1.1, blz. 3 .

58. Kurt Müller, blz. 129; Romang, par. $8 / 8.1 .2$, blz. 3 .

59. Romang, par: 8/8.1.2, blz. 3 .

60. Zie Michaud, bliz 21, 22.

61. \$16 IIr reglement Peter-Ruetschi.

62. Deze termijn van 10 dagem geldt volgens Romang ook voor de bijeenroeping van de eerste vergadering, waarbij de bijecnroeping dan minstens 10 dagen voor de dag wan de vergadering moet plaatsvinden. Romang, par. 8/8.12, blz. 1. Zie ook Michaud, blz. 23, Deze acht een andere termijn denkbaar. Als degene die de algemene vergadering moet bijeenroepen, zich miet aan een in het reglement neergelegde bijeenroepingstermijn houd, kan iedere appartementseigenaar op grond van art. $75 \mathrm{ZGB}$ vernietiging van de besluiten van de vergadering vorderen wegens vormgebreken (mits hij zelf niet heeft deelgenomen aan de besluitworming). Zie Bundesgericht 10 dec. 1959, ESB 1959, 85. Band, 1I, blz 525-554 (over besluitem van de vergadering van een muziekvereniging). Zie daarover Michaud, blz, 24.

63. Romang, par. $8 / 8.3 .1$, blz. 1. Vgl. ook Michaud, blz. 25 . 
gevallen is echter een grotere meerderheid vereist, waarbij een besluit moet worden genomen door de meerderheid van alle appartementseigenaars, die tevens meer dan de helft van de aandelen van het gebouw vertegenwoordigen. Een dergelijke meerderheid is bijvoorbeeld vereist voor vaststelling of verandering van het reglement van splitsing (art. $712 \mathrm{~g} \mathrm{lid} 3 \mathrm{ZGB}$ ) ${ }^{64}$ en voor het doen uitvoeren van nuttige bouwkundige maatregelen (art. 647d ZGB). Sommige besluiten moeten zelfs unaniem worden genomen. Dit unanimiteitsvoorschift geldt bijvoorbeeld voor verandering van de medeëigendomsaandelen (art. 712e lid $2 \mathrm{ZGB}$ ), voor het laten uitvoeren van luxeverhogende bouwkundige ingrepen (art. 647e lid 1 ZGB), voor de verandering van de bestemming van het gebouw en de afzonderlijke appartementsrechten (art. 648 lid 2 ZGB) en voor opheffing van de splitsing (art. $712 \mathrm{f}$ lid $2 \mathrm{ZGB}^{65}$.

De wettelijke bepalingen die de totstandkoming van de besluiten in de vergadering regelen, zijn over het algemeen niet van dwingende aard. Dit betekent dat zij in de akte van splitsing of bij latere overeenkomst tussen de appartementseigenaars, veranderd kunnen worden in die zin, dat voor bepaalde besluiten een andere meerderheidseis wordt vastgesteld. De meerderheidsvereisten kunnen echter nooit zodanig worden veranderd, dat individuele appartementseigenaars daardoor sterk in bun rechten worden aangetast ${ }^{60}$.

Iedere appartementseigenaar heeft stemrecht in deze vergadering. Indien meerdere pérsonen gezamenlijk gerechtigd zijn tot éen appartement, komt hen desallniettemin slechts én stem toe ${ }^{67}$. Een eigenaar en de "Nutzniesser" van een appartement moeten de stembevoegdheid onderling regelen. Indien zij dit niet doen komt het stemrecht aan de "Nutzniesser" toe (art. 712o ZGB). Als één persoon meerdere appartementen in eigendom heeft, komt hem eveneens slechts éen stem in de vergadering toe. Het stemrecht is gekoppeld aan de persoon, niet aan het appartement ${ }^{68}$. Dit noemt men het "Kopfstimmrecht." ${ }^{69}$

De appartementseigenaars mogen zich in de vergadering laten vertegenwoordigen, hetgeen blijkt uit artikel 712p lid 3 ZGB dat spreekt over "anwesend oder vertreten". Als vertegenwoordiger kunnen derden, familieleden, andere appartementseigenaars of de administrateur optreden. In het reglement van splitsing kunnen echter afwijkende regelingen worden getroffen. Michaud bepleit bijvoorbeeld een reglementair verbod van vertegenwoordiging door de administrateur, omdat anders een verstrengeling van belangen dreigt ${ }^{70}$.

64. Als de verandering van het reglement echter een afwijking van de wetteljike regeling met betrekking tot administratie en beheer inhoudt, moet het veranderingsbesluit eenstemmig worder genomen (art. 712g lid 2 ZGB). Zie Bundesgericht 24 maart 1977, ESB 1977, 103. Band, B, blz. $76-82$.

65. Zie woor andere gevallen, wraarin unanimiteit is vereist: Romang, par. 8/8.1.76, blz, 1-3. Vgl, ook Bezirksgericht Zürich 17 maart 1982, in: Romang, par. 8/13.3.2, blz. 1-14.

66. Romang par. 8/8.1.5, blz. 2; Christoph Müller, blz 36.

67. Peter-Ruetschi (Stimmrecht), blz 141, 142.

68. Vgl \$ 16, IV reglement Peter-Ruetschi.

69. Peter-Ruetschi, blz. 45. De eigenaar die meerdere appartementen heeft, heeft daarvan well voordeel indien voor een besluatt de helft wan de gemeenschappelijke zaak moet zijn vertegenwoordigd (vgl. art. $647 \mathrm{~b} Z \mathrm{ZGB}$ ). Vgl. over vertegenwoordiging van de appartementseigenaar $\$ 17$ reglement Peter-Ruetschi.

70. Michaud, blz.. 33, 34 . 
Zoals vermeld mag de vergadering een administrateur benoemen ${ }^{71}$. Indien deze benoeming niet tot stand komt, kan iedere appartementseigenaar benoeming van een administrateur door de rechter vorderen (art. $712 \mathrm{q}$ lid $1 \mathrm{ZGB}$ ). Dit zelfde recht komt aan toe aan de verzekeraar van het gebouw, de houder van een zakelijk zekerheidsrecht op het gebouw (art. 712q lid 2 ZGB) en aan ieder ander die belang heeft bij de benoeming van een administrateur ${ }^{72}$. In de praktijk wordt de administrateur bijna altijd in het reglement benoemd door de stichter (s) van een appartementsgebouw. Overigens kan iedereen, waaronder rechtspersonen, tot administrateur worden benoemd ${ }^{73}$.

De vergadering kan de administrateur te allen tijde weer ontslaan. Voor ontslag hoeven geen gewichtige redenen te bestaan. In de praktijk wordt echter meestal een "Verwaltungsvertrag" met de administrateur gesloten en zal deze aan willekeurig ontslag in de weg staan, omdat een dergelijk ontslag de gemeenschap van appartementseigenaars schadeplichtig kan maken. Een en ander hangt uiteraard af van de concrete overeenkomst.

Als het ontslag door de vergadering wordt afgewezen, kan iedere appartementseigenaar wegens gewichtige redenen ontslag door de rechter vorderen (art. $712 \mathrm{r}$ lid 1 en $2 \mathrm{ZGB}$ ). De vordering tot ontslag van de administrateur kan echter ook door derde-belanghebbenden - bijvoorbeeld een hypotheekhouder - worden ingesteld ${ }^{74}$. Een administrateur die door de rechter is benoemd kan voor afloop van zijn benoemingstermijn slechts door de rechter worden ontslagen (art. 712r lid $3 \mathrm{ZGB})^{75}$. In bepaalde gevallen kan het noodzakelijk zijn dat de administrateur tijdelijk wordt vervangen, bijvoorbeeld indien hij door ziekte niet in staat is zijn taken te vervullen. De vervanger zal echter altijd door de appartementseigenaars moeten worden aangewezen, ofwel ad hoc in de vergadering van eigenaars, ofwel in het reglement.

De administrateur verricht alle beheers- en administratieve handelingen overeenkomstig de wettelijke en reglementaire voorschriften ${ }^{76}$. Hij verdeelt de gemeenschappelijke kosten en lasten over de individuele appartementseigenaars en beheert de kas van de gemeenschap. Hij zorgt er tevens voor dat de appartementseigenaars de bepalingen van de wet, het reglement en het huishoudelijk reglement naleven (art. 712s ZGB) en vertegenwoordigt de gemeenschap tevens naar buiten toe, voor zover het handelingen betreft die binnen zijn bevoegdheid vallen. Hij is bevoegd om de gemeenschap in juridische procedures te vertegenwoordigen, zij het dat hij in de meeste gevallen (namelijk buiten het "summarisches Verfahren", zie daarvoor art. $712 \mathrm{t} \mathrm{ZGB})^{7}$ een machtiging van de appartementseigenaars nodig heeft. Verklaringen, rechterlijke beslissingen e.d. die aan de administrateur zijn

71. Zie over de benoeming en de bewoegdheden van de administrateur ook Schweizerisches Privatrecht, blz 102-104.

72. Kurt Müller, blz. 112; Romang, par. 8/8.3.1 blz. 1.

73. Romang, par. 8/8.3.1, blz. 6; Kurt Müller, blz. 110 .

74. Kurt Müller, blz 145; Ramang, par. 8/8.3.1, blz. 5,6 .

75. Hindermann, blz. 49,50 .

76. Vgl. Frei, blz 110.

77. Vgl. Gillioz, blz, 284-287. 
gericht, gelden als gericht aan alle appartementseigenaars (art. $712 \mathrm{t} \mathrm{ZGB})^{78}$. De rechten en verplichtingen van de administrateur kunnen in het reglement uitgebreid en nader uitgewerkt worden. Zo wordt, zoals uit het voorgaande blijkt, hem vaak de plicht opgelegd de vergadering van eigenaars bijeen te roepen ${ }^{79}$.

Ingevolge artikel $712 \mathrm{~m}$ lid 1 sub $3 \mathrm{ZGB}$ heeft de vergadering van eigenaars, zoals al eerder werd vermeld, de bevoegdheid een "Ausschuss" (commissie) of een "Abgeordineter" (afgevaardigde) te kiezen, waaraan zij administratieve bevoegdheden kan delegeren. Zo kan aan deze commissie of afgevaardigde bijwoorbeeld de taak worden opgedragen om de administrateur te assisteren, zijn beheer te controleren en de vergadering van eigenaars daarover te berichten. De wet vermeldt verder niets over de commissie of de afgevaardigde. De gemeenschap van appartementseigenaars mag zelf beslissen, of zij naast de administrateur nog een commissie of afgevaardigde wil benoemen. Als lid van een commissie of als afgevaardigde kunnen leden van de gemeenschap of derden worden gekozen.

In beginsel is het mogelijk dat aan de commissie of de afgevaardigde beheersbevoegdheid wordt toegekend. Romang vermeldt daarbij echter dat het in dat geval noodzakelijk is orm in het reglement de bevoegdheden van de administrateur goed van die van de commissie of de afgevaardigde te scheiden, omdat problemen anders onvermijdelijk lijken. Verder kan aan de commissie of de afgevaardigde ook. nog een bemiddelingstaak bij onenigheid tussen appartementseigenaars worden toegekend ${ }^{86}$.

Voor de regeling van de belangrijkste zaken geeft het ZGB speciale regelingen. Artikel $712 \mathrm{~g}$ lid $1 \mathrm{ZGB}$ verklaart voor de bevoegdheid tot beheers- en administratieve handelingen en bouwkundige ingrepen de bepalingen betreffende de medeëigendom van toepassing op appartementsrechten. Deze bepalingen kunnen echter in principe door een reglement worden vervangen in de "Begründungsakt" of door een later eenstemmig besluit van de appartementseigenaars (art. $712 \mathrm{~g}$ lid 2 en 647 ZGB). De gemeenschap van appartementseigenaars is beperkt handelingsbevoegd verklaard om haar taken naar behoren te kunnen vervullen (art. 7121 ZGB) ${ }^{81}$. Voor reparaties en onderhoudswerkzaamheden die voor het behoud van de waarde

78. Vgl. $\$ 18 \mathrm{sub} 2$ reglement Peter-Ruetschi over de rechten en verplichtingen van de administrateur volgens het reglement. Zie $\& 19$ over platatsvervanging van de administrateur. Vgl. ook Kurt Múller, blz. 121-129; Hindermann, blz. 50,51. Vgl. over de bevoegdheid van een administrateur om in een proces op te treden Bezirksgericht Bülach 4 juli 1986 , in: Romang, par. 8/8.5.1, blz $1-8$.

79. Romang par. $8 / 8.3 .2$, blz. 4 .

80. Romang, par. $8 / 8.2$, blz, 1-3.

81. De gemeenschap van eigenaars mag bijvoorbeeld in eigen naam vermogen verwerven, voor zover de administratie en het beheer dit meebrengt. $\mathrm{Zij}$ mag bijwoorbeeld het vermogen verwerven dat ontstaat door bijdragen van de eigenaars in de kosten van thet beheer. Schweizerisches Privatrecht, blz 107. Ze is tevens bevoegd om in procedures op te treden als eiser en gedlaagde, zij het met de beperking dat zij deze bevoegdheid slechts heeft met betrekking tot de administratic en het beheer van de gemeenschap. Vgl. daarover Weber (ProzeBfahigkeii), blz 117-126. Zie ook Obergericht Zürich 28 maart 1978, SJZ 1979, blz 126, 127; Obergericht Zürich 6 juni 1978, SJZ 1979, blz. 127-130; Bundesgericht 25 okt. 1983, Journal des Tribunaux, blz. 48; ESB 1983, 109. Band, II, blz 423-427; Obergericht Zürich 14 nov. 1986, Baurecht 1988, blz. 68. De vergadering van eigenaars kan in al deze gevallen de administrateur machtigen om de gemeenschap in rechte te vertegenwoordigen. $\mathrm{Vgl}$. hierbij hetgeen eerder in deze paragraaf over de procesvertegenwoordigingsbevoegdheid van de administrateur werd vermeld. 
en voor de bruikbaarheid van het gebouw noodzakelijk zijn, geldt een vereiste van een gewone meerderheid van stemmen in de vergadering van appartementseigenaars om ze voor het gehele gebouw te laten uitvoeren (art. $647 \mathrm{c} \mathrm{ZGB})^{82}$. Anders is dit bij bouwkundige ingrepen die weliswaar nuttig zijn voor de gemeenschap, maar eigenlijk alleen maar gericht zijn op waardevermeerdering van het gebouw. Bij deze ingrepen geldt dat zij kunnen worden uitgevoerd, indien de meerderheid van appartementseigenaars die meer dan de helft van de appartementsrechten heeft, daartoe besluit (art. 647d ZGB) ${ }^{83}$. De ratio hiervan is dat een minderheid in een gebouw niet door een meerderheid op kosten moet worden gejaagd voor niet noodzakelijke maatregelen. Vandaar dat voor reparaties een gewone meerderheid in een vergadering voldoende is. Voor ingrepen gericht op waardevermeerdering geldt al een lets zwaardere eis. Geheel in deze lijn ligt de regeling van art. $647 \mathrm{e} \mathrm{ZGB}$, waarin wordt bepaald dat voor bouwkundige ingrepen en werkzaamheden die slechts gericht zijn op verhoging van luxe (aanleg van een daktuin, marmeren betegeling etc.) de toestemming van alle appartementseigenaars nodig is ${ }^{84}$.

\subsection{Rechten en verplichtingen van de appartementseigenaars}

Iedere appartementseigenaar is vrij in het beheer, gebruik en bouwkundige inrichting van zijn ruimten, voor zover hij daarbij aan andere appartementseigenaars de uitoefening van dezelfde rechten niet bemoeilijkt en de gemeenschappelijke bouwdelen, installaties en inrichtingen niet beschadigt en hun functie niet verandert (art. $712 \mathrm{a}$ lid $2 \mathrm{ZGB})^{85}$. Romang vermeldt hierover:

"Das Stockwerkeigentum schaffte eine neue Form des Eigenheims. Die Befugnisse des Stockwerkeigentümers sollen daher soweit als möglich den eines Alleineigentümers gleichkommen." ${ }^{86}$

Het vrije gebruik, beheer en de vrije bouwkundige inrichting van de privé-gedeelten brengt met zich mee, dat een appartementseigenaar zijn appartement mag verhuren. Deze bevoegdheid tot verhuren kan echter in de akte van splitsing ("Begründungsakt") worden beperkt. De beperking houdt dan in dat de appartementseigenaar van de overige eigenaars toestemming tot verhuring moet krijgen (art. $712 \mathrm{c}$ lid $2 \mathrm{ZGB}$. Zie hierover par. 8.3.2.2.).

De appartementseigenaar is verplicht zijn ruimten zodanig te onderhouden, als het voor de instandhouding van het gebouw in onberispelijke toestand en goed

82. Als een reparatie nodig is, maar de vergadering er niet toe wil overgaan, kan iedere appartementseigenaar volgens het reglement aan de rechter vrager om de reparatie te gebieden. $\mathrm{Vgl}$. $\$ 5$, II sub 3 en $\$ 9$, I reglement Peter-Ruetschi.

83. In het reglement Peter-Ruetschi is dit anders geregeld. Voor dit soort van reparaties geldt dat toestemming van die appartementseigenaar nodig is, voor wic de maatregelen ernstig nadeel veroorzaken. Indien de maatregelen voor een eigenaar een ondraagbare financiele last bettckenen, moeten de andere eigenaars het bedrag dat boven zijn draagkracht uitstijgt, voldoen. Vgl. \& 9, II reglement Peter-Ruetschi.

84. Een andere regeling geeft $\$ 9$, III reglement Peter-Ruetschi, waarin wordt bepaald dat een besluit bij gebrek aan unanimiteit in bepaalde gevallen toch kan worden uitgevoerd.

85. Vgl. \$ 5, I sub 1 en 2 reglement Peter-Ruetschi. Zie hierbij Schweizerisches Privatrecht, blz. 92.

86. Romang, par. 8/9.1, blz. 2 . 
aanzien noodzakelijk is (art. $712 \mathrm{a}$ lid $3 \mathrm{ZGB}$ ) ${ }^{87}$. Onder onderhoud valt onder meer het repareren, schilderen en eventueel vernieuwen van vensters en deuren ${ }^{88}$.

Uit de gelijkheid van de appartementseigenaars vloeit verder een "Pflicht zur gegenseitige Rücksichtsnahme" voort. Dit brengt met zich mee dat de appartementseigenaars elkaar geen hinder mogen toebrengen ${ }^{89}$, maar ook dat ze de bestemming, die in het reglement van splitsing aan een appartement is gegeven, moeten respecteren. Door de bestemmingsomschrijving kan het recht tot gebruik van het appartement dus ook worden beperkt. Als in het reglement bijvoorbeeld wordt bepaald, dat de appartementen uitsluitend voor bewoning bestemd zijn, mogen er geen bedrijven in worden gevestigd. Zo kan dus het gebruik van appartementen voor beroeps-en bedrijfsuitoefening worden beperkt ${ }^{90}$. Muziek-, dans- en gymnastieklessen zijn op grond van het reglement Peter-Ruetschi bijvoorbeeld verboden ${ }^{91}$. Omgekeerd is het ook mogelijk dat appartementen alleen als bedrijfsruimte mogen worden gebruikt ${ }^{92}$.

De administrateur kan aan een eigenaar bij overtreding van de bestemmingsomschrijving of bij veroorzaking van overlast, verbieden om het appartement op de storing veroorzakende wijze of in strijd met de bestemming te gebruiken. Hij kan aldus bijwoorbeeld bij overlast veroorzakende danslessen aan de eigenaar verbieden nog verder in het appartement dansles te geven ${ }^{93}$.

De rechten van de huurder van een appartement kunnen eveneens worden beperkt. Zo is in het reglement Peter-Ruetschi in $\$ 4$ sub 3 een non-concurrentiebeding opgenomen dat tegen de huurder kan worden ingeroepen. De huurder die in een appartement een beroep of bedrijf wil uitoefenen, moet hiervoor toestemming vragen aan de administrateur. Deze toestemming kan worden geweigerd indien de huurder anders een appartementseigenaar zou gaan beconcurreren. Overigens mag een appartementseigenaar een gedeelte van zijn appartement volgens het reglement Peter-Ruetschi zonder beperkingen verhuren ${ }^{94}$.

Behalve een vrij gebruiks- beheers- en veranderingsrecht ten aanzien van de privégedeelten, komt aan een appartementseigenaar ook het recht toe vrij over zijn appartementsrecht te beschikken. Hij mag zijn appartement dus in beginsel vrij vervreemden of bezwaren. Dit betekent dat hij zijn appartement vrij mag verhypothekeren of met vruchtgebruik of een recht van bewoning mag bezwaren. Telkens als de bezwaring echter een ingebruikgeving aan een derde inhoudt, kan

87. Vgl. \&6, I reglement Peter-Ruetschi.

88. Schweizerisches Priwatrecht, blz 93.

89. Romang, par. $8 / 9.2$, blz 2 . De appartementseigenaars mogen bijvoorbeeld geen geluidsoverlast of onmodige verstoringen van de rust veroorzaken. Vgl. $\$ 6$, II sub 1 reglement Peter-Ruetschi.

90. Vgl. $\$ 4$ sub 1 en 2 reglement Peter-Ruetschi. De bestemning "museum" is echter te eng. Een appartementseigenaar mag bij een dergelijke te enge bestemmingsomschrijving iedere andere bestemming aan zijn appartementsrecht geven, die de rust en de standing van het gebouw niet in gevaar brengt en in overeenstemming is met de algemene bestemming van het gebouw. Bundesgericht 6 nov, 1985, ESB 1985, 111. Band, II, blz. 330-342.

91. 4 sub 2 reglement Peter-Ruetschi. Vgl ook Romang par. $8 / 9.6 \mathrm{blz} 3$.

92. Romang, par. 8.9.3, blz 1,2 .

93. Vgl. over het verbod een massagesalon in een appartement uit te oefenen: Bundesgericht 15 november 1984, daarover Romang, par. 8/7.5.3, blz 1-14. Zie ook Obergericht Zürich 18 mei 1984, Blätter für Zürcherische Rechtssprechung 1985, nr. 85.

94. Vgl. 4 sub 3 reglement Peter-Ruetschi. 
dit recht - evenals het recht om te vervreemden - worden beperkt (art. $712 \mathrm{c}$ lid 2 ZGB) ${ }^{95}$.

Deze beperking kan in de vorm van een recht van bezwaar worden gegoten, hetgeen inhoudt dat de appartementseigenaar die zijn appartementsrecht met een zakelijk gebruiksrecht wil bezwaren, toestemming daarvoor moet verkrijgen van de overige appartementseigenaars. Via deze constructie kan ook het recht om een appartementsrecht vrij te vervreemden worden beperkt.

Het vrije beschikkingsrecht kan echter ook via een voorkeursrecht in het reglement van splitsing aan controle door de overige appartementseigenaars worden onderworpen (712c lid $1 \mathrm{ZGB}$, zie hierover par. 8.3.2).

Zoals vermeld heeft een appartementseigenaar ook het recht om vrij over de bouwkundige inrichting van zijn prive-gedeelten te beslissen. Artikel 712a lid 2 ZGB geeft daarbij echter aan dat daardoor geen inbreuk mag worden gemaakt op de rechten van de andere appartementseigenaars. In elk geval kan de eigenaar bijvoorbeeld niet-dragende tussenwanden tussen twee kamers van zijn appartement verwijderen, of juist een grote kamer door het plaatsen van tussenwanden in tweeën scheiden. Hij mag echter niet de keuken verplaatsen of een tweede badkamer inrichten, omdat daardoor tevens de gemeenschappelijke leidingen e.d. worden geraakt $\%$.

Niet geheel duidelijk is of een appartementseigenaar het recht heeft zijn appartementsrecht onder te splitsen. In beginsel, aldus Romang ${ }^{97}$ is iedere appartementseigenaar daartoe bevoegd, omdat hij het recht heeft om bouwkundige veranderingen aan te brengen in zijn appartement. Aangezien de ondersplitsing echter noodzakelijkerwijze verandering van de gemeenschappelijke gedeelten met zich meebrengt (er zal bijvoorbeeld een extra toegangsdeur moeten worden aangebracht in de gemeenschappelijke gangen en een extra keuken en badkamer moeten worden ingericht), moet in de praktijk bijna altijd toestemming van de overige appartementseigenaars worden gevraagd ${ }^{98}$.

De appartementseigenaar kan zijn rechten tegenover iedereen geldend maken. Tegen derden kan hij een vordering wegens storing in het bezit (artt. 926 e.v. ZGB) of ongerechtvaardigde inbreuk op zijn eigendomsrecht (art. 641 ZGB), instellen. Tegen andere appartementseigenaars kan hij in beginsel zijin rechten op dezelfde wijze geldend maken, maar tevens door een beroep op het reglement van splitsing. Overtreding van dit reglement - een contract - levert immers wanprestatie op ${ }^{99}$.

Een appartementseigenaar kan bij weigering van toestemming door de administrateur - bijvoorbeeld bij weigering aan een huurder om een bepaald beroep uit te oefenen - de bijeenroeping van de vergadering van appartementseigenaars vorderen, die vervolgens bij meerderheid van stemmen over het verzoek om het beroep te mogen uitoefenen, beslist ${ }^{100}$.

95. Laurent, blz. 53, 54; Romang par. 8/9.1, blz. 2. Zie Mengiardi over de bezwaring van appartementsrechten in het algemeen.

96. Laurent, blz. 30; Romang par. $8 / 9.1$ blz. 3 .

97. Romang par. $8 / 4.7$, blz. 3 .

98. Romang, par. $8 / 4.7$, blz 4 .

99. Romang par. $8 / 9.1$, blz. 4 .

100. $\$ 4$ sub 11 reglement Peter-Ruetschi. 
Iedere appartementseigenaar is bevoegd om de gemeenschappelijke gedeelten (trappehuis e.d.) te gebruiken voor zover dit aan de rechten van andere appartementseigenaars geen afbreuk doet ${ }^{101}$. In het reglement van splitsing kan het gebruik van de gemeenschappelijke gedeelten worden geregeld, eventueel aangevuld door de bepalingen uit het huishoudelijke reglement. De regeling kan ook een verbod van een bepaalde wijze van gebruik inhouden. Parkeerplaatsen die bij het gebouw horen (en niet met een "Sonderrecht" zijn belast), mogen volgens het reglement Peter-Ruetschi bijvoorbeeld niet als tankstation of reparatiewerkplaats worden ingericht ${ }^{102}$. Indien een parkeerplaats niet door een appartementseigenaar wordt gebruikt, kan ze sllechts aan derden worden werhuurd, als andere appartementseigenaars haar niet voor een gereduceerde prijs willen huren ${ }^{103}$. Het reglement Peter-Ruetschi geeft nog een aantal soortgelijke gebruiksbestemmingen. Het huishoudelijk reglement regelt echter het gebruik van de gemeenschappelijke gedeelten ${ }^{104}$. Friedrich heeft in zijn reglement een verbod opgenomen om de gemeenschappelijke gedeelten te veranderen en om er voorwerpen in op te slaan of te deponieren, die het gebruik van deze gedeelten (vooral vrije doorgang) beperken. Bovendien is in zijn reglement een bepaling opgenomen waarin het aanbrengen van reclameteksten en naamplaatjes aan de toestemming van de administrateur wordt onderworpen $^{105}$.

Behalve de bevoegdheid tot gebruik van de gemeenschappelijke gedeelten heeft iedere appártementseigenaar het recht om aan de administratie en het beheer van de gemeenschappelijke gedeelten deel te nemen. Met betrekking tot de administratie en beheer mag hij verlangen dat de waarde en de gebruiksmogelijkheid van de gemeenschappelijke zaak in stand wordt gehouden. Eventueel kan hij zich hiervoor tot de rechter wenden (art. 647 lid 2 sub 1 ZGB) ${ }^{106}$. Bovendien mag hij op grond van artikel 647 lid 2 sub 2 ZGB daden van beheer verrichten die onmiddellijk moeten worden verricht om de gemeenschappelijke zaak voor dreigende of groeiende schade te beschermen (bijvoorbeeld het laten repareren van een gesprongen waterleiding) ${ }^{107}$. Daarnaast mag hij de opstelling van een reglement van splitsing verlangen (art. 712g lid 3 ZGB). Ditzelfde geldt met betrekking tot

101. Vgl. \& 5, II sub 1 reglement Peter-Ruetschi. Zie ook Bezirksgericht Meilen 18 nov. 1982, SJZ 1984, blz. 212-214. Een appartementseigenaar moet dulden dat in de buurt van zijn tuin door andere appartementseigenaars was wordt opgehangen op een terrein, dat daartoe in thet reglement is aangewezen. Als lid van de gemeenschap van appartementseigenaars heeft hij een verdergaande duldingsplicht dan een eigenaar van een affonderlijk huis.

102. Een appartementseigenaar mag evenmin een dakterras (dat gemeensehappelijk is) eigenmacht"gg vergroten. Zie Bundesgericht 4 sept. 1980, in: Romang, par. 8/13,3,1, blz 1-16.

103. Vgl. $\$ 4$ sub 4 reglement Peter-Ruetschi.

104. Dit huishoudelijk reglement kan overigens bij gewone meerderheid wan stemmen worden veranderd. Vgl. \$ 4 sub 10 reglement Peter-Ruetschi.

105. Friedrich, blz. 82; Magnenat, blz, 67; Weber, blz, 248-251.

106. Bundesgericht 16 mei 1978, ESB 1978, 104. Band, II, blz. 163-170. Vgl. ook Weber, blz 303. Volgens deze is de regeling van art. 647 lid 2 ZGB echter onvoldoende, omdat bepaalde handelingen, die niet noodzakelijk zijn, toch afgedwongen zouden moeten kunnem worden. Liver heeft eveneens een uitbreiding van art. 647 lid 2 ZGB verdedigd. Hij noemt hierbij het woorbeeld van nuttige bouwkundige werken, waarwan de uitvoering via de rechter afgedwongen zou moeten kuninen worden. Liver, blz, 174.

107. Vgl. $\$ 5$, II sub 2 reglement Peter-Ruetschi: Hauger, blz, $240,241$. 
de benoeming van een administrateur (art. $712 \mathrm{q}$ ZGB). Deze rechten kunnen niet bij overeenkomst of reglement aan de appartementseigenaar worden ontnomen ${ }^{108}$.

Tegenover deze rechten ten aanzien van de gemeenschappelijke gedeelten, staat de plicht van de appartementseigenaar om beschadigingen aan de gemeenschappelijke zaak te voorkomen en haar zorgvuldig te gebruiken ${ }^{109}$. Bovendien is hij verplicht om evenredig aan zijn waarde-aandeel in de gehele onroerende zaak, bij te dragen in de lasten en kosten van het gemeenschappelijk beheer en de gemeenschappelijke administratie (art. $712 \mathrm{~h} \mathrm{ZGB})^{110}$. Tot de gemeenschappelijke kosten behoren onderhoudskosten (waaronder begrepen reinigingskosten), verwarmingskosten van de gemeenschappelijke gedeelten, kosten van herstel van gemeenschappelijke gedeelten, belastingen die aan de appartementseigenaars gezamenlijk worden opgelegd, rente over gemeenschappelijke schulden, kosten van verzekering etc. ${ }^{111}$

Met betrekking tot de verzekeringskosten kan worden opgemerkt dat de appartementseigenaar, die in zijn appartement veranderingen aanbrengt die tot verhoging van de verzekeringspremie van het gehele gebouw leiden, deze extra premie geheel voor zijn rekening dient te nemen (art. $712 \mathrm{~m}$ lid 1 sub $6 \mathrm{ZGB})^{112}$. Deze regeling kan ook in andere gevallen worden toegepast. Zo is het volgens Weber mogelijk, dat een winkelier meer voor water- en stroomvoorziening moet betalen en een arts die in zijn appartement zijn praktijk uitoefent, meer reinigingskosten te laten betalen dan de overige appartementseigenaars. Evenzeer is het gerechtvaardigd dat een appartementseigenaar, voor wie een "Sonderbenützungsrecht" op een bepaald gemeenschappelijk gedeelte (bijvoorbeeld een balkon) wordt gevestigd, de onderhoudskosten van dat gemeenschappelijk gedeelte moet betalen ${ }^{13}$.

Een appartementseigenaar is tegenover de andere eigenaars aansprakelijk voor schade die hij aan hun privé-gedeelten of aan de gemeenschappelijke gedeelten toebrengt. Hij is eveneens aansprakelijk indien de schade wordt veroorzaakt door personen die tot zijn huishouden behoren. Alleen als hij kan bewijzen dat schuld van zijn kant ontbreekt, is hij niet aansprakelijk ${ }^{114}$. De appartementseigenaar moet tevens instaan voor degenen, aan wie hij zijn privé-gedeelten in gebruik geeft. Als een huurder bijvoorbeeld de bepalingen van het reglement van splitsing niet naleeft," kan de verhuurder worden aangesproken om het met het reglement strijdige gebruik te doen staken ${ }^{115}$.

Overigens is het ook mogelijk om een andere verdeelsleutel te hanteren dan die naar evenredigheid van het aandeel in het gebouw. $\mathrm{Zo}$ is het zeer goed mogelijk de kostenverdeling aan de verkeerswaarde van de appartementsrechten te relateren of om het feitelijke verbruik van appartementseigenaars als verdeelsleutel te

108. Peter-Ruetschi, blz. 24.

109. Vgl. \& 6, II sub 2 reglement Peter-Ruetschi.

110. Schweizerisches Privatrecht, blz. 93; Hauger, blz. 268-270; Christoph Müller, blz. 41-46.

111. Weber, blz $252,253$.

112. Weber, blz. 257.

113. Weber, blz 257.

114. Vgl. \& 8 reglement Peter-Ruetschi.

115. Obergericht Zürich 18 mei 1984, Blätter für Zürcherische Rechtssprechung 1985, nr. 85. 
hanteren ${ }^{116}$. Indien in een gebouw bijvoorbeeld een verwarmingsinstallatie voor alle appartementen is aangebracht, kan men via verdampingsmeters het feitelijk gebruik vaststellen en daarna de kosten over de appartementseigenaars verdelen. De kostenverdeling moet, indien een van de wet afwijkende verdeelsleutel wordi gehanteerd, wel altijd in het reglement worden uitgewerkt ${ }^{117}$.

Als een appartementseigenaar in gebreke blijft zijn bijdragen in de lasten en kosten te voldoen, heeft de gemeenschap van appartementseigenaars het recht om een hypotheekrecht op diens appartementsrecht in het "Grundbuch" te doen inschrijven. Het hypotheekrecht kan echter slechts tot zekerheid dienen voor de kosten van drie op het moment van inschrijving afgelopen jaren (art. 712i ZGB) ${ }^{118}$.

De inschrijving kan door de administrateur of, indien geen administrateur is benoemd, door een appartementseigenaar die daartoe door de vergadering van eigenaars is gemachtigd, worden gevorderd ${ }^{119}$. Het enige vereiste dat voor de inschrijving wordt gesteld, is dat er een opeisbare schuld is die in een authentieke akte wordt bevestigd. Deze authentieke akte is vervolgens voldoende om het hypotheekrecht te doen inschrijven ${ }^{120}$. De rang van het hypotheekrecht wordt bepaald door het moment van inschrijving en eventuele andere, reeds op het appartementsrecht gevestigde hypotheken. Het hypotheekrecht van de gemeenschap van appartementseigenaars komt onmiddellijk in rang na de op het moment van inschrijving reeds gevestigde hypotheken. Bij een executoriale verkoop kan dit tot gevolg hebben dat de vordering van de gemeenschap niet uit de opbrengst kan worden voldaan ${ }^{121}$.

Het hypotheekrecht is echter niet de enige zekerheid die de gemeenschap heeft om voldoening van de schulden te verkrijgen. Artikel $712 \mathrm{k}$ ZGB kent aan de gemeenschap namelijk tevens een retentierecht op de roerende goederen van de in gebreke blijvende appartementseigenaar toe, voor zover die goederen zich tenminste in diens appartement bevinden en zijn bestemd tot inrichting van de privé-gedeelten. Het retentierecht bestaat van rechtswege voor de (opeisbare) schulden van drie aan de inroeping van het retentierecht voorafgaande jaren. De bepalingen betreffende het retentierecht van de verhuurder (artt. 272-274 OR) zijn op het retentierecht van de gemeenschap van appartementseigenaars van overeenkomstige toepassing ${ }^{122}$.

116. Weber, blz. 258. Het Bundesgericht heeft inmiddels besloten, dat bij een appartementencomplex dat uit meerdere gebouwen bestaat, herstelwerkzaamheden aan een bepaald gebouw door de eigenaars van dat gebouw moeten worden gedragen, en niet door de gehele gemeenschap. Zie Bundesgericht 21 mei 1981 , ESB 1981, 107. Band, II, blz. 141-144. In gelijke zin Bundesgericht 14 aug. 1986, ESB 1986, 112. Band, II, blz, 312-318.

117. Weber, blz. 263.

118. Zie hierover Hauger, blz. 293, 294.

119. De inschrijving kan ook worden gevorderd door een daartoe door de rechter gemachtigde appartementseigenaar. De aanspraak op inschrijving van het hypotheckrecht heeft zakelijke werking, zodat hijj ook in faillissement van de debiteur geldend kan worden gemaakt. Kantonsgericht Wallis 3 sept. 1984, Zeitschrift für Walliser Rechtsprechung 1984, blz. 207.212.

120. Giovanola, blz. 36, 37; Ottiker, blz. 81-83,

121. Ottiker, blz, 83.

122. Giovanola, blz. $40-42$. 


\subsection{Toelating en ontzegging van verder gebruik}

\subsubsection{Algemene opmerkingen}

In Zwitserland heeft men voor dezelfde monistische structuur van appartementsrechten gekozen als in Nederland. Zoals blijkt uit paragraaf 8.2 .5 bestaat in het Zwitserse appartementsrecht ook een toelatingsregeling, die inhoudt dat de gemeenschap van appartementseigenaars bezwaar mag maken tegen vervreemding, bezwaring (met een recht van vruchtgebruik of een recht van bewoning) of verhuring. Bovendien kwam in paragraaf 8.2 .5 ook al aan de orde, dat in het reglement van splitsing een voorkeursrecht ten gunste van een of meer appartementseigenaars kan worden bedongen. In het navolgende zal nader op deze toelatingsregelingen worden ingegaan. Tevens zal worden onderzocht of, en zo ja op welke wijze, het $Z$ witserse recht ontzegging van verder gebruik mogelijk maakt.

\subsection{Toelating}

Een belangrijk artikel bij toelating tot een appartement is artikel $712 \mathrm{c} \mathrm{ZGB}$. Dit artikel luidt:

"1) Von Gesetzes wegen hat der Stockwerkeigentümer kein Vorkaufsrecht gegenüber jedem Dritten, der einen Anteil erwirbt, doch kanı es im Begründungsakt oder durch nachherige Vereinbarung errichtet und im Grundbuch vorgemerkt werden.

2) In gleicher Weise kann bestimmt werden, dass die Veräusserung eines Stockwerkes, dessen Belastung mit einer Nutzniessung oder einem Wohnrecht, sowie die Vermietung nur rechtsgültig ist wenn die übrigen Stockwerkeigentümer dagegen nicht auf Grund eines von ihnen gefassten Beschlusses binnen 14 Tagen seit der ihnen gemachten Mitteilung Einsprache erhoben haben.

3) Die Einsprache ist unwirksam, wenn sie ohne wichtigen Grund erhoben worden ist, worüber auf Begehren des Einspruchsgegners der Richter im summarischen Verfahren entscheidet."

Uit dit artikel blijkt dat appartementseigenaars een voorgenomen verkoop van een appartement door een andere eigenaar, slechts kunnen voorkomen indien zij een voorkeursrecht (art. 712c lid 1 ZGB) of een recht van bezwaar (art. 712c lid 2 ZGB) hebben bedongen in de "Begründungsakt" of bij latere overeenkomst. Deze overeenkomst en de "Begründungsakt" moeten, om tegen derden te kunnen worden ingeroepen, wel in de openbare registers voor onroerend goed worden ingeschreven ${ }^{123}$. De appartementseigenaars hebben noch het voorkeursrecht, noch het recht van bezwaar rechtstreeks op grond van de wet. Ze moeten altijd worden overeengekomen.

123. Een voorkeursrecht kan niet in het "Grundbuch" worden ingeschreven, indien bet op een toekomstig appartementsrecht rust, waarvan het waarde-aandeel in de gemeenschappelijke eigendom nog niet vaststaat. Bundesgericht 28 jan. 1988, ESB 1988, 114. Band, II, blz. 127-131. 
Het voorkeursrecht kan slechts worden overeengekomen voor de verkoop vam een appartement. Het recht van bezwaar kan daarentegen tevens voor verhuring of bezwaring met het recht van "Nutzniessung" of een "recht van bewoning", worden bedongen. Het recht van bezwaar moet blijkens artikel $712 \mathrm{c}$ lid 2 ZGB binnen 14 dagen na mededeling van de voorgenomen vervreemding, bezwaring of verhuring, worden uitgeoefend. Zowel het voorkeursrecht als het recht van bezwaar kunnen in het reglement (als onderdeel van de "Begründungsakt" of als latere overeenkomst) worden geregeld ${ }^{124}$.

Het voorkeursrecht is in de wet opgenomen om een gemeenschap van appartementseigenaars in staat te stellen invloed uit te oefenen op de toekomstige samensteliing van de gemeenschap en ongewenste elementen te weren. Dezelfde redenen hebben te grondslag gelegen aan de opneming van de mogelijkheid van het recht van bezwaar in de wet ${ }^{125}$

\subsubsection{Het voorkeursrecht}

In het reglement dat door Tina Peter-Ruetschi in haar boek is opgenomen, is geen voorkeursrecht geregeld. Het reglement Friedrich kent wel een bepaling met betrekking tot het voorkeursrecht. Artikel 47 van het reglement Friedrich luidt:

"1) Das Stockwerkeigentum ist veräusserlich und vererblich. Jeder Stockwerkeigentümer ist befugt sein Stockwerk beliebig zu belasten.

2) Vorbehalten bleiben die Bestimmungen über das Vorkaufs- und Einspracherecht der übrigen Stockwerkeigentümer."

Artikel 48 sluit hier vervolgens bij aan met de regeling van het voorkeursrecht. Dit artikel luidt als volgt:

"1) Den Stockwerkeigentümern steht ein Vorkaufsrecht gegenüber Dritten zu, die ein Stockwerk erwerben.

2) Das Vorkaufsrecht ist ausgeschlossen, wenn der erwerber mit dem bisherigen Stockwerkeigentümer in gerader Linie verwandt oder verschwägert ist.

3) Das Vorkaufsrecht ist innert 30 Tagen, nachdem der Verwalter vom Vorkaufsfall Kenntnis erhalten hat, auszuüben. Dieser hat unverzüglich die Vorkaufsberechtigten Stockwerkeigentümer vom Vorkaufsfall in Kenntnis zu setzen.

4) Machen mehrere Stockwerkeigentümer vom Vorkaufsrecht gebrauch, so erwerben sie das betreffende Stockwerk zu Miteigentum im Verhältnis ihrer Wertquoten.

5) Dieses Vorkaufsrecht ist im Grundbuche auf allen Stockwerkeigentumsparzellen vorgemerkt."

124. Weber, blz, 526, 538; Magnenat, blz. 128, 129; Hindermann, blz, 95.

125. Magnenat, blz. 129; Hindermann, blz. 95; Weber, blz. 523, 536 . 
Het voorkeursrecht is een wettelijk toegelaten vervreemdingsbeperking. Het hangt tussen een wettelijk voorkeursrecht en een contractueel voorkeursrecht in. Enerzijds komt het door overeenkomst tot stand, maar anderzijds heeft het de inhoud van het wettelijke voorkeursrecht van artikel 682 lid $1 \mathrm{ZGB}$. Dit heeft tot gevolg dat het voorkeursrecht voor de duur van het bestaan van de splitsing kan worden opgenomen. Indien het een contractueel voorkeursrecht zou zilin geweest, zou het slechts voor de duur van 10 jaar kunnen worden opgenomen ${ }^{126}$.

De kring van gerechtigden tot het voorkeursrecht kan bij overeenkomst worden beperkt (art. 682 lid 3 ZGB) ${ }^{127}$. In beginsel komt het echter aan iedere appartementseigenaar toe. Het voorkeursrecht kan niet voor de gemeenschap van appartementseigenaars worden opgenomen. Deze gemeenschap heeft namelijk niet de rechtsbevoegdheid om appartementen te verwerven. Wel is het volgens Friedrich mogelijk om een voorkeursrecht op te nemen, dat slechts door alle appartementseigenaars gezamenlijk kan worden uitgeoefend, en dat tot gevolg heeft dat zij medeëigendom van het appartement verwerven ${ }^{128}$.

Een praktisch probleem kan zich voordoen, indien meerdere appartementseigenaars tegelijk hun voorkeursrecht uitoefenen. In dat geval verwerven zij, evenals bij een gezamenlijk voorkeursrecht, volgens Weber het appartementsrecht gemeenschappelijk, naar rato van hun aandelen in de gemeenschap van appartementseigenaars, en vormen ze een gewone "Miteigentümergemeinschaft" (zo ook art. 48 lid 4 reglement Friedrich) ${ }^{129}$.

De kring van gerechtigden tot het voorkeursrecht kan overigens niet worden uitgebreid tot anderen dan appartementseigenaars. Een voorkeursrecht in de zin van artikel $712 \mathrm{c}$ lid $1 \mathrm{ZGB}$ kan dus niet voor een derde/niet-appartementseigenaar in het reglement van splitsing worden opgenomen. Het is wel mogelijk dat aan zo'n derde een zuiver contractueel voorkeursrecht wordt toebedeeld (in een afzonderlijke overeenkomst). Dit contractuele voorkeursrecht blijft dan echter slechts gedurende 10 jaar gelden ${ }^{130}$.

Een maand nadat de voorkeursgerechtigde van de verkoop van een appartementsrecht kennis heeft genomen, vervalt het recht om het voorkeursrecht in te roepen (art. $681 \mathrm{ZGB}$ ). In het bovenstaande artikel 48 is dit zodanig uitgewerkt, dat de termijn begint te lopen vanaf de kennisgeving van de verkoop aan de administrateur. Bij het ontbreken van een dergelijke reglementsbepaling moet de appartementseigenaar, die zijn appartementsrecht aan een niet-eigenaar verkoopt, dit mededelen aan de voorkeursgerechtigde. De termijn van artikel 681 lid 3 ZGB begint echter volgens een vonnis van het Kantonsgericht Wallis reeds te lopen, zodra de voorkeursgerechtigde op een of andere wijze van de vervreemding kennis neemt ${ }^{131}$.

126. Friedrich, blz 184; Weber, blz. 525 .

127. Friedrich, blz 186, acht het denkbaar dat wordt overeengekomen dat het woorkeursrecht slechts door de eigenaars van naburige appartementen kan worden ingeroepen. Zie ook Magnenat, blz. 130.

128. Friedrich, blz. 185, 186.

129. Weber, blz 528 .

130. Weber, blz 527 .

131. Kantonsgericht Wallis 20 maart 1985 , Baurecht 1988 , blz. 18. 
Door inroeping van zijn voorkeursrecht treedt de gerechtigde in de koopovereenkomst die tussen verkoper en derde is afgesloten. De voorkeursgerechtigde neemt de verplichtingen van de derde dan over ${ }^{132}$. Kennelijk wordt het voorkeursrecht over het algemeen slechts opgenomen ten behoeve van de afzonderlijke appartementseigenaars. Een appartementseigenaar die op een dergelijke wijze een andere appartementsrecht verkrijgt, zal daar echter vervolgens iets mee moeten doen. Hij kan het appartement bijvoorbeeld verhuren, maar in dat geval zal hij rekening moeten houden met de mogelijkheid dat de andere appartementseigenaars tegen de verhuring bezwaar maken.

Niet in alle gevallen, waarin een appartementsrecht in eigendom overgaat aan een niet-eigenaar, kan het voorkeursrecht worden uitgeoefend. Blijkens het hierboven geciteerde artikel 48 reglement Friedrich, is uitoefening van het recht bijvoorbeeld niet mogelijk indien de verkrijger in rechte lijn met de vervreemder verwant is. Evenmin kan het voorkeursrecht bij vererving van een appartementsrecht worden uitgeoefend, of indien tegenover de eigendomsovergang geen tegenprestatie staat (bij schenking bijvoorbeeld). Ook bij onteigening ten algemenen nutte, bij fusie van twee ondernemingen, bij verkrijging na verdeling van een gemeenschap en dergelijke, kan het voorkeursrecht niet worden uitgeoefend ${ }^{133}$. Bij uitwinning van een appartementsrecht (niet bij een willige openbare verkoop) kan het voorkeursrecht evenmin worden uitgeoefend. Hetzelfde geldt bij onderhandse verkoop door degenen die een appartementsrecht uitwinnen ${ }^{134}$.

Hierbij moet worden aangetekend, dat het voorkeursrecht in de hier genoemde gevallen wel ontstaat, indien deze vormen van eigendomsovergang slechts worden gebruikt om het voorkeursrecht te ontduiken. In andere dan de hierboven beschreven uitzonderingsgevallen ontstaat het voorkeursrecht op het moment waarop de koopovereenkomst wordt gesloten. Dat will mijns inziens echter niet zeggen, dat de verkoper niet voor die tijd aan de voorkeursgerechtigde zou kunnen vragen, of hij van zijn voorkeursrecht gebruik wil maken ${ }^{135}$.

Aan de uitoefening van het voorkeursrecht zijn geen speciale vereisten verbonden. Een gewichtige reden of een ander rechtvaardigingscriterium is niet vereist. Het is voldoende, dat de voorkeursgerechtigde zijn recht wil uitoefenen. Welke motieven hij daarbij heeft, is irrelevant.

\subsubsection{Het recht van bezwaar}

Het recht van bezwaar is in het reglement van Tina Peter-Ruetschi wel geregeld. $\$ 14$ van het reglement Peter-Ruetschi geeft een uitgebreide uitwerking van dit recht.

Bezwaar kan alleen worden gemaakt wegens gewichtige redenen. Het reglement Peter-Ruetschi noemt twee gevallen waarin in elk geval sprake is van een voldoende gewichtige reden. Het eerste doet zich voor, indien de gegronde vrees bestaat, dat de geïnteresseerde zijn financiële verplichtingen niet zal nakomen. Het tweede houdt in dat een gewichtige reden aanwezig is, indien zich bij de geïnter-

132. Friedrich, blz. 186, 187; Weber, blz, 536 .

133. Zie woor een opsomming: Weber, blz. 530.

134. Weber, blz. 530, 531:

135. Weber, blz, 530,531 . 
esseerde of bij leden van diens gezin omstandigheden voordoen, die volgens $\$ 15$ van het reglement Peter-Ruetschi een reden tot ontzegging van verder gebruik zouden opleveren. Deze redenen zijn, toegespitst op het recht van bezwaar, dat de vrees bestaat dat:

1. de geînteresseerde zijn verplichting om de privé-gedeelten te onderhouden niet zal nakomen, waardoor het uiterlijk van het gebouw zal verslechteren;

2. de geïnteresseerde het appartement in strijd met de bestemming zal gebruiken of andere gebruiksbestemmingen van het reglement (vgl. par. 4 reglement Peter-Ruetschi en daarover par. 8.2.5) niet zal naleven;

3. de geïnteresseerde of zijn gezinsleden de overige bewoners zullen lastig vallen of de rust in het gebouw zullen verstoren door onbetamelijk, grof, ruziezoekend of kwetsend gedrag;

4. de geïnteresseerde personen, aan wie hij zijn appartement geheel of gedeeltelijk in gebruik zal geven, op aanmaning van de administrateur niet uit zijn appartement zal verwijderen.

In het reglement Friedrich wordt het recht van bezwaar in artikel 49 geregeld. Dit artikel luidt:

"1) Die Veräusserung eines Stockwerkes ist nur rechtsgültig, wenn die übrigen Stockwerkeigentümer nicht auf grund eines Beschlusses binnen 14 Tagen seit der ihnen gemachten Mitteilung Einsprache erhoben haben. Die Einsprache ist unwirksam, wenn sie ohne wichtigen Grund erhoben worden ist. Hieruber bestimmt im Streitfall der Richter auf Begehren des Einsprachegegners im summarischen Verfahren.

2) Der Stockwerkeigentümer hat das Rechtsgeschäft, das der Einsprache unterliegt, dem Verwalter zur Kenntnis zu bringen. Dieser hat daraufhin unverzïglich die Versammlung der Stockwerkeigentümer einzuberufen.

3) Das Einspracherecht ist im Grundbuche auf allen Stockwerkeigentumsparzellen vorgemerkt."

Uit deze paragraaf blijkt niet duidelijk wat er onder een gewichtige reden ("wichtiger Grund"') moet worden begrepen. Anders dan in het reglement van Tina Peter-Ruetschi worden hier geen specifieke criteria (bij wijze van voorbeeld) gegeven. Volgens Friedrich ${ }^{136}$ is er sprake van een gewichtige reden

"wenn Veräusserung oder Gebrauchsüberlassung in Folge der Person des Erwerbers oder neuen Benutzers für die übrigen Stockwerkeigentümer unzumutbar ist. $\mathrm{Ob}$ dies zutrifft, kann nur unter Berücksichtigung aller Umstände, insbesondere der Art und Zweckbestimmung der Liegenschaft entschieden werden."

136. Friedrich, blz 190. 
Friedrich geeft aldus niet meer dan een "Generalklausel" voor de uitoefening van het recht van bezwaar. Ook Weber vermeldt ten aanzien van de gewichtige reden:

"Beim wichtigen grund handelt es sich um einen unbestimmten, wertausfüllungsbedürftigen Begriff, der im konkreten Einzelfall nach Recht und Billigkeit $\mathrm{zu}$ individualisieren ist." ${ }^{137}$

Hij voegt daar nog aan toe:

"Meist wird es sich so verhalten, dass je nach Stärke der persönlichen und wirtschaftlichen Bindungen in der Gemeinschaft (häufig abhängig von der Grösse) der Dritte schneller "unerwünscht" (zu verstehen als unzumutbar für die Gemeinschaft) ist."

Vervolgens noemt hij enige gevallen waarin een geïnteresseerde "unerwünscht" kan zijn, namelijk:

1. indien op grond van zijn persoonlijkheid ermee rekening moet worden gehouden, dat hij niet in de gemeenschap past (bijvoorbeeld indien hij door niet-nakoming van zijn verplichtingen de rust in de gemeenschap zal verstoren);

2. indien verwacht moet worden dat hij zijn financiële verplichtingen niet zal nakomen;

3. indien het karakter en de bestemming van het gebouw en de "Lebensstil" van de gemeenschap onverenigbaar zijn met zijn toelating (bijvoorbeeld indien de geïnteresseerde kinderen heeft en in het gebouw uitsluitend oudere mensen wonen die behoefte aan rust hebben).

Deze omschrijving van gewichtige redenen komt grosso modo overeen met de (niet-limitatieve) opsomming in $\$ 14$ reglement Peter-Ruetschi). Artikel 712c ZGB bevat dwingend recht, zodat in het reglement geen lichtere weigeringsgronden dan de gewichtige reden mogen worden opgenomen ${ }^{138}$.

Ook in het bijzondere geval dat een persoon die reeds appartementseigenaar is, als geinteresseerde optreedt, kan bezwaar worden gemaakt.Het is immers mogelijk dat de appartementseigenaars een gerechtvaardigd belang hebben om concentratie wan appartementsrechten in Een hand, te voorkomen. Het is bijvoorbeeld zeer wel denkbaar, dat de gemeenschap vreest dat de geïnteresseerde appartementseigenaar de kosten, die aan het bezit van meerdere appartementsrechten verbonden zijn, niet zal kumnen dragen ${ }^{139}$.

Niet duidelijk is overigens of het recht van bezwaar ook kan worden uitgeoefend, indien een appartementseigenaar van zijn voorkeursrecht gebruik wenst te maken. Noch de Zwitserse literatuur, noch de jurisprudentie geven op deze vraag een antwoord.

137. Weber, bliz 543 .

138. Weber, blz. 544 .

139. Weber, blz 545 . 
De materiële vereisten voor de uitoefening van het recht van bezwaar zijn aldus beschreven. In de Zwitserse jurisprudentie is nog geen geval beslist, althans gepubliceerd, waarin de uitoefening van het recht van bezwaar in een concreet geval aan het vereiste van de gewichtige reden werd getoetst. Uiteraard bestaan er ook nog formele vereisten ten aanzien van de uitoefening van het recht van bezwaar. Deze formele vereisten kunnen in het reglement nader worden uitgewerkt. Zo worden in $\$ 14$ reglement Peter-Ruetschi naast de zojuist genoemde weigeringsgronden, ook nog enige procedurele bepalingen gegeven.

Iedere appartementseigenaar moet op grond van $\$ 14$ een (voorgenomen) verkoop, bezwaring of verhuring van zijn appartement aan de administrateur ten behoeve van de overige appartementseigenaars mededelen onder vermelding van de personalia van de verkrijger c.q. huurder. Binnen veertien dagen ${ }^{140}$ ma deze mededeling moet de administrateur aan de verkoper/verhuurder vervolgens mededelen of de vervreemding, bezwaring of verhuring toegestaan is. Hiervoor moet hij aan de appartementseigenaars vragen of zij bezwaar willen maken. Indien een appartementseigenaar een reden aanwezig acht om de vervreemding c.q. verhuring te verbieden, moet hij deze reden direkt aan de administrateur mededelen. De administrateur roept dan de vergadering van appartementseigenaars bijeen, waarin bij meerderheid van stemmen wordt beslist over het al dan niet maken van bezwaar.

De procedure waarin wordt beslist of er bezwaar zal worden gemaakt, verloopt anders indien een appartementseigenaar persoonlijke redenen heeft om bezwaar te maken tegen de ingebruikneming van een appartement door een bepaalde geïnteresseerde. In dat geval wordt slechts gestemd over het maken van bezwaar, indien de meerderheid van de appartementseigenaars deze stemming wenst. De desbetreffende appartementseigenaar heeft de mogelijkheid om door overleg met andere eigenaars de schriftelijke toestemming tot bezwaar van de helft (in het onderhavige reglement vier) van de appartementseigenaars te verkrijgen en deze aan de administrateur te doen toekomen. De administrateur deelt vervolgens aan de overige appartementseigenaars mede, dat er bezwar zal worden gemaakt wegens gewichtige redenen, die echter niet nader worden uitgelegd. Indien een appartementseigenaar hiermee niet instemt, moet in een vergadering over het al dan niet maken van bezwaar worden beslist ( $\$ 14$ reglement Peter-Ruetschi).

Alleen de vergadering van eigenaars kan een besluit tot het maken van bezwaar nemen. Daarbij is een eenvoudig meerderheidsbesluit van de aanwezige appartementseigenaars voldoende. Weber vermeldt hierbij dat ook degene die zijn appartementsrecht wil verhuren, bezwaren of vervreemden, mag meestemmen ${ }^{141}$. De termijn van 14 dagen, die in $\$ 14$ reglement Peter-Ruetschi is opgenomen, is tevens de wettelijke termijn. Een probleem dat deze termijn met zich meebrengt is, dat bij ontbreken van het vereiste aantal eigenaars in de eerste vergadering, een tweede vergadering bijna niet meer tijdig kan worden belegd ${ }^{142}$. Aan de andere kant kan uit de ontoereikende opkomst mijns inziens worden afgeleid, dat behoefte

140. Blijkens $\$ 14$ mag deze termijn niet tussen 15 juli en 15 augustus of in de weken rond pasen vallen, behoudens dringende redenen.

141. Weber, blz. 546 .

142. Weber, ble 547 . 
aan bezwaar nauwelijks bestaat of zelfs ontbreekt. Hier geldt immers "qui tacet consentire videtur".

Het recht van bezwaar kan in beginsel worden uitgeoefend bij elke vervreemding, verhuring of bezwaring met een recht van vruchtgebruik of een recht van bewoning. Het meest voorkomende geval is uiteraard verkoop en overdracht, maar volgens Weber is bezwaar ook mogelijk bij schenkingen ruil (anders dan bij het voorkeursrecht) Waar het steeds om gaat is dat een bijzondere titel aan de overdracht ten grondslag ligt. Dit betekent dat geen bezwaar kan worden gemaakt tegen een eigendomsovergang tengevolge van vererving of van een fusie van bedrijven ${ }^{143}$.

Bij een executoriale verkoop van een appartementsrecht kan volgens Weber evenmin bezwaar worden gemaakt:

"Die übrigen Stockwerkeigentümer hätten es natürlich in der Hand, nachdem Zuschlag innert 14 Tagen den Erwerber abzulehnen, weshalb von neuem das ganze Steigerungsverfahren durchzuführen wäre, ausser es liesse sich der nächsthöchste Bieter ausmachen (dem gegenüber das gleiche Spiel beginnt). Durch solche Aussichten wurden die Kreditfähigkeit der Raumeinheit und das Vollstreckungsverfahren allzu stark beeinträchtigt, als dass sich dies noch mit dem Interesse am Schutz vor neuen Gemein,schaftern rechtfertigen liesse." ${ }^{144}$

Ten aanzien van de eerste verkoper (opdrachtgever van de bouw) geldt het recht van bezwaar volgens Weber evenmin, tenzij deze enige appartementsrechten zolang niet verkoopt, dat inmiddels een goed functionerende gemeenschap van appartementseigenaars is ontstaan. Om problemen te voorkomen raadt Weber aan het recht van bezwaar tegen verkoop door degene die tot de splitsing is overgegaan, voor bepaalde tijd in het reglement uit te sluiten ${ }^{145}$.

\subsubsection{Algemene conclusies over het voorkeursrecht en het recht van bezwaar}

De "Veräusserungsbeschränkungen", devervreemdingsbeperkingen waaronder zowel het voorkeursrecht als het recht van bezwaar vallen, zijn in de wet opgenomen om de onderling afhankelijke appartementsbewoners te beschermen tegen ongewenste nieuwkomers ${ }^{146}$. Gezien de mogelijkheid van het recht van bezwaar verliest het voorkeursrecht in dit licht bijna geheel zijn functie. Een ongewenste nieuwkomer kan immers uit de gemeenschap worden gehouden door gebruikmaking van het recht van bezwaar. Het enige voordeel dat uitoefening van het voorkeursrecht biedt, is dat een gewichtige reden niet aanwezig hoeft te zijn. Dit betekent dat een ongewenste nieuwkomer via het voorkeursrecht vaker buiten de deur kan worden gehouden dan via het recht van bezwaar.

De eisen die aan de inroeping van het voorkeursrecht worden gesteld zijn immers veel lichter. Aan de andere kant zit er wel een zwaarwegende financiële kant aan vast. De appartementseigenaar die van zijn voorkeursrecht gebruik maakt,

143. Weber, blz. 539; Friedrich, blz 189.

144. Weber, blz. 540. Vgll. ook Hindermann, blz. 95.

145. Weber, blz, 541 .

146. Magnenat, blz. 129; Weber, blz 523, 536 . 
zal immers de koopsom voor het appartement op tafel moeten leggen. Men zou kunnen beweren dat de verkoper bij inroeping van het voorkeursrecht geen nadeel lijdt, omdat hij zijn appartement voor dezelfde prijs kan verkopen, zij het aan een ander dan gepland. Het recht van bezwaar daarentegen vermindert de verkoopbaarheid van een appartement ${ }^{147}$. In elk geval is het twijfelachtig of het voorkeursrecht wel een goede waarborg biedt tegen ongewenste nieuwkomers. Het vormt zeker een effectief middel, maar als er geldige gronden zijn om een gegadigde niet toe te laten, heeft men nog altijd de mogelijkheid van het recht van bezwaar. Juist bij twijfelachtige redenen biedt het voorkeursrecht uitkomst. Het is de vraag of deze situatie gewenst is.

Het bovenstaande zou een reden kunnen vormen om in het reglement geen voorkeursrecht op te nemen, maar wel een recht van bezwaar. Het voorkeursrecht is om nog een andere reden een vreemde eend in de bijt van het appartementsrecht. Het doel van de invoering van dit Zwitserse appartementsrecht was immers om aan zoveel mogelijk mensen de mogelijkheid te verschaffen een eigen woning of bedrijfsruimte te verwerven. Het voorkeursrecht staat echter haaks op dit doel. Uitoefening van dit recht bewerkstelligt immers dat meerdere appartementen in handen van een klein aantal mensen kunnen komen. Dit was ook de reden dat de Zwitserse wetgever het voorkeursrecht niet wettelijk aan de appartementseigenaars heeft toegekend (zoals wel bij gewone medeëigendom het geval is. Vgl. art. 682 ZGB), maar slechts de mogelijkheid daartoe heeft open gelaten ${ }^{148}$.

Een andere opmerking die in deze paragraaf kan worden gemaakt is, dat uit de reglementen blijkt dat het voorkeursrecht en het recht van bezwaar kunnen worden uitgeoefend als de koopovereenkomst, respectievelijk huurovereenkomst of titel van bezwaring, al tot stand zijn gekomen. Die titels hebben slechts rechtsgevolgen, indien het recht van bezwaar of het voorkeursrecht niet worden uitgeoefend. Waarschijnlijk is het echter eveneens mogelijk om voordat de titel tot stand komt, het voorkeursrecht of het recht van bezwaar in te roepen. Al bij een voorgenomen verkoop zou men bijvoorbeeld het voorkeursrecht of het recht van bezwaar kunnen uitoefenen, althans duidelijk kunnen maken of men van plan is om van bijwoorbeeld het voorkeursrecht gebruik te maken.

\subsubsection{Ontzegging van verder gebruik}

Naast de mogelijkheid om ingebruikneming of beter gezegd verkrijging van een appartement door een ongewenst persoon te voorkomen, kent het Zwitserse recht ook een mogellijheid om het verdere gebruik aan een appartementseigenaar te ontzeggen. Anders dan in het Nederlandse recht wordt hiervoor echter niet de constructie van ontzegging van gebruik met instandhouding van het eigendomsrecht gehanteerd, maar wordt de constructie van ontneming van het medeëigendomsrecht (en dientengevolge van het gebruiksrecht) door middel van het opleggen van de

147. Wellicht zou het daarom meer voor de hand liggen om uitoefening van het recht van bezwaar te koppelen aan de plicht om het voarkeursrecht uit te oefenen.

148. Peter-Ruetschi, blz. 26, 27. 
verplichting aan een appartementseigenaar om zijn appartement te verkopen; gehanteerd. De wettelijke grondslag hiervoor is artikel $649 \mathrm{~b}$ ZGB dat luidt:

"1) Der Miteigentümer kann durch richterliches Urteil aus der Gemeinschaft ausgeschlossen werden, wenn durch sein Verhalten oder das Verhalten von Personen, denen er den Gebrauch der Sache überlassen oder für die er einzustehen hat, Verpflichtungen gegenüber allen oder einzelnen Mitberechtigten so schwer verletzt werden, dass diesen die Fortsetzung der Gemeinschaft nicht zugemutet werden kann.

2) Umfasst die Gemeinschaft nur zwei Miteigentümer, so steht jedem das Klagerecht zu; im übrigen bedarf es zur Klage, wenn nichts anderes vereinbart ist, der Ermächtigung durch einen Mehrheitsbeschluss aller Miteigentümer mit Ausnahme des Beklagten.

3) Erkennt der Richter auf Ausschluss des Beklagten, so verurteilt er ihn zur Veräusserung seines Anteils und ordnet für den Fall, dass der Anteil nicht binnen der angesetzten Frist veräussert wird, dessen öffentliche Versteigerung nach den Vorschriften über die Zwangsverwertung von Grundstücken an unter Ausschluss der Bestimmungen über die Auflösung des Miteigentumsverhältnisses."

Artikel $649 \mathrm{c}$ ZGB sluit hierbij aan dat deze bepaling van overeenkomstige toepassing is bij uitsluiting van een "Nutzniesser" of andere zakelijk gerechtigde of van een persoonlijk gebruiksgerechtigde wiens recht in de openbare registers is ingeschreven. In het navolgende zal steeds worden ingegaan op de uitsluiting van een appartementseigenaar. Voor uitsluiting van zakelijk gerechtigden en persoonlijk gerechtigden wiens recht in de openbare registers is ingeschreven, is het hierna vermelde van overeenkomstige toepassing.

Deze mogelijkheid om een appartementseigenaar uit te sluiten uit de gemeenschap van appartementseigenaars door hem te verplichten zijn appartement te verkopen ${ }^{149}$, is voor de medeëigendom in zijn algemeenheid geregeld (art. 649b ZGB). Etageëigenaars hebben daardoor steeds op grond van de wet het recht om een andere appartementseigenaar uit de gemeenschap uit te sluiten, een en ander uiteraard wel slechts in overeenstemming met de wettelijke regeling. De uitsluiting van een appartementseigenaar uit de gemeenschap is een vergaande maatregel. Volgens Friedrich kan men bij de uitsluiting van een soort privaatrechtelijke onteigening spreken. Deze maatregel is volgens hem "durch das Interesse der Gesamtheit der übrigen zu rechtfertigen." ${ }^{150}$

In een van de weinige rechterlijke beslissingen, waarin een besluit moest worden genomen over de toelaatbaarheid van uitsluiting van een medeëigenaar (in casu

149. In het vervolg zal steeds worden gesproken van uitsluiting uit de gemeenschap in plats van uitsluiting uit de gemeenschap door middel van het aan een appartementseigenaar (doen) opleggen van de verplichting om zijn appartement te verkopen.

150. Firiedrich, bliz 195. 
ging het om een gewone "Miteigentümergemeinschaft"), overwoog het Zwitserse Bundesgericht met betrekking tot uitsluiting in het algemeen:

"Das revidierte Zivilgesetzbuch gibt dem Institut des Miteigentums einen gesellschaftlichen Einschlag. Die Miteigentümer haben sich nunmehr in ihren gegenseitigen Beziehungen diesem neuen Verhältnis unterzuordnen, namentlich sich gemeinschaftskonform zu verhalten (...). Die Individualsphäre wird von der Kollektivsphäre umschlossen und beschränkt. Einen Ausgleich schafft der neue Art. $649 \mathrm{~b} \mathrm{ZGB}$, in dem er unter Umständen die Entziehung des Miteigentums ermöglicht und hierzu einen besonderen Rechtsbehelf, die Ausschlussklage, anbietet."

De uitsluiting moet wel, aldus het Bundesgericht, het laatste redmiddel blijven en mag door de rechter slechts worden toegestaan als alle andere middelen (aanmaningen e.d.) niet meer helpen ${ }^{151}$.

Voor uitsluiting uit de gemeenschap moet steeds een gewichtige reden bestaan. Deze gewichtige reden is in de wet uitgewerkt in de "Generalklausel" dat een appartementseigenaar uit de gemeenschap kan worden uitgesloten, indien van de overige medeëigenaars door het gedrag ${ }^{152}$ van een andere eigenaar niet kan worden verlangd dat zij de gemeenschap met die eigenaar laten voortduren. De redenen die uitsluiting rechtvaardigen kunnen in het reglement nader worden geconcretiseerd ${ }^{153}$. In het reglement van Tina Peter-Ruetschi is hiervan inderdaad sprake. Zoals al eerder werd vermeld geeft $\$ 15$ van dat reglement de volgende uitsluitingsgronden:

1. de appartementseigenaar komt ondanks herhaalde aanmaningen door de administrateur zijn verplichting om zijn privé-gedeelte te onderhouden niet na, waardoor onder andere het uiterlijk van het gebouw verslechtert of dreigt te verslechteren;

2. de appartementseigenaar of leden die tot zijn huishouden behoren of personen door wie hij zijn appartement laat gebruiken, maken op een andere wijze dan de daaraan in $\$ 4$ van het reglement gegeven bestemming gebruik van het appartement en leven ondanks aanmaningen ook de andere in $\$ 4$ gegeven verplichtingen niet na;

3. de appartementseigenaar of zijn gezinsleden vallen de overige bewoners ernstig lastig of verstoren de rust in het gebouw door onbetamelijk, grof, ruziezoekend of kwetsend gedrag;

4. de appartementseigenaar verwijdert bepaalde personen aan wie hij zijn appartement geheel of gedeeltelijk in gebruik heeft gegeven binnen een redelijke termijn niet uit het gebouw,

151. Bundesgericht 14 maart 1968, ESB 1968, 94. Band, II, blz. 17-25. Vgl. ook Magnenat, blz. 126; Liver, blz. 181, 182; Kurt Müller, blz. 36; Weber, blz. 498.

152. Hierbij moet het gaian om een voortdurend slecht gedrag en niet slechis om incidenteel slechts gedrag. Magnenat, blz. 126; Hauger, blz. 148, 149.

153. Volgens Magnenat; $\mathrm{blz} .127$, is het niet nodig om in het reglement een specificatie op te nemen van handelingen die een reden voor uitsluiting opleveren. "En effet, seuil le juge est compétent pour apprecier la situation dans son ensemble èt prononcer l'exclusion dans l'esprit de la loi." 
ondanks herhaalde aanmaningen door de administrateur waarin zulks werd geëist met bedreiging van ontzegging van verder gebruik.

Naast deze specifieke uitsluitingsgronden, die bij wijze van voorbeeld zijn opgenomen, is in $\$ 15$ de "Generalklausel" opgenomen dat een appartementseigenaar uit de gemeenschap kan worden uitgesloten, indien door zijn gedrag of het gedrag van personen, aan wie hij zijn appartement in gebruik heeft gegeven of voor wie hij verantwoordelijk is, verplichtingen tegenover alle of enkele andere deelgenoten zozeer worden geschonden, dat van hen niet meer kan worden verlangd dat zij de gemeenschap met hem laten voortduren ${ }^{154}$.

Het reglement Friedrich werkt de gewichtige reden niet nader uit. $\$ 51$ van dit reglement is zeer algemeen geformuleerd en komt grotendeels overeen met artikel 649b ZGB. \& 51 luidt:

"1) Ein Stockwerkeigentümer kann aus der Gemeinschaft ausgeschlossen werden, wenn er durch sein eigenes Verhalten oder durch das Betragen von Personen, denen er den Gebrauch der Sache überlassen hat oder für die er einzustehen hat, seine Verpflichtungen gegenüber allen oder einzelnen Mitberechtigten so schwer verletzt hat, dass diesen die Fortsetzung der Gemeinschaft nicht zugemutet werden kann.

2) Der Ausschluss erfolgt durch Urteil des Richters auf Klage eines oder mehrerer Stockwerkeigentümer, die durch Beschluss der Versammlung mit einfacher Mehrheit nach Personen dazu ermächtigt worden sind. Der Auszuschliessende ist dabei nicht mitzuzăhlen.

3) Falls der Ausgeschlossene sein Stockwerk nicht innert der vereinbarten oder vom Richter angesetzten Frist veräussert, so wird es nach den Vorschriften über die Zwangsversteigerung von Grundstücken versteigert. Der Antrag auf Versteigerung kann vom Verwalter gestellt werden."

Het Bundesgericht heeft als voorbeeld van een geval, waarin van de medeëigenaars niet kan worden gevergd dat zij de gemeenschap van een van hen laten voortduren, de kwetsing van de persoonlijkheidsrechten van de overige medeëigenaars genoemd. Van kwetsing van deze persoonlijkheidsrechten is ondermeer sprake, als een medeëigenaar steeds onverdraagzaam, ruziezoekend, gewelddadig of achterbaks handelt en daardoor een vreedzaam samenleven binnen de gemeenschap onmogelijk maakt ${ }^{155}$. Overigens is schuld voor het storende gedrag aan de kant van degene die de storing veroorzaakt, voor uitsluiting niet vereist. Het gaat erom dat

154. Vgl, ook Michaud, blz. 105, die dezelfde ontzeggingscriteria geeft.

155. Zie Bundesgericht 14 maart 1968, ESB 1968, 94. Band, II, blz. 17-25. Vgl. ook uitsluitingsgrond 3 \& 15 reglement Peter-Ruetschi. Zie verder Weber, blz, 501; Hindermann, blz. 97. 
de rust in de gemeenschap wordt teruggebracht, ook als de uit te sluiten appartementseigenaar voor het storende gedrag geen schuld draagt ${ }^{156}$.

Niet-nakoming van financiële verplichtingen is in Zwitserland geen gewichtige reden tot uitsluiting in de zin van artikel $649 \mathrm{~b}$ ZGB. Voor betaling van de financiële bijdragen staan aan de Zwitserse appartementengemeenschap andere dwangmiddelen en zekerheden ter beschikking, die reeds in paragraaf 8.2 .5 werden beschreven. Daarbij moet worden opgemerkt dat niet-nakoming van de financiële verplichtingen, bij uitwinning van het hypotheekrecht, feitelijk wel tot uitsluiting van een appartementseigenaar kan leiden ${ }^{157}$.

Volgens artikel $649 \mathrm{~b}$ ZGB moet een meerderheid van appartementseigenaars voor de uitsluiting zijn. De appartementseigenaars hebben enige vrijheid om deze eis te veranderen. In plaats van de meerderheid van appartementseigenaars kan men bijvoorbeeld de meerderheid van alle appartementseigenaars, die tegelijkertijd meer dan de helft van de waarde van het gebouw vertegenwoordigen, als eis stellen ${ }^{158}$. Een dergelijke verzwaring van de eisen om tot uitsluiting te komen zal over het algemeen mogelijk zijn. Daarentegen kan men de eisen niet ten nadele van de uit te sluiten appartementseigenaar veranderen ${ }^{159}$. Volgens Friedrich en Müller ${ }^{160}$ volgt echter well uit de artikelen $647 \mathrm{c}$ en $647 \mathrm{~d} \mathrm{ZGB}$, dat voor een toestemming voor vordering tot uitsluiting niet de meerderheid van alle appartementseigenaars nodig is, maar slechts een meerderheid van de ter vergadering aanwezigen. Bij de berekening van de meerderheid mag degene over wiens uitsiuiting wordt vergaderd, niet worden meegeteld (althans volgens art. 51 lid 2 reglement Friedrich) ${ }^{163}$. Volgens het reglement Friedrich is het voldoende dat de meerderheid van de ter vergadering aanwezige appartementseigenaars toestemt in een rechtsvordering tot uitsluiting van een eigenaar. Ook volgens $\$ 15$ van het reglement van Tina PeterRuetschi is een gewone meerderheid van de ter vergadering aanwezigen voldoende.

De vermogensrechtelijke gevolgen van uitsluiting kunnen in beginsel slechts ten voordele van de uitgeslotene worden veranderd. $\mathrm{Zo}$ is het bijvoorbeeld mogelijk, dat degenen die een appartementseigenaar uit de gemeenschap willen uitsluiten, verplicht worden om het aandeel van de uitgeslotene tegen verkeerswaarde over te nemen. Veranderingen in peius van de vermogensrechtelijke gevolgen van de uitsluiting, zullen over het algemeen nietig zijn wegens strijd met de dwingende voorschriften uit artikel $649 \mathrm{~b} \mathrm{ZGB}^{162}$.

De procedure tot uitsluiting van een appartementseigenaar moet als volgt verlopen. Eerst moet de vergadering van appartementseigenaars toestemming

156. Weber, blx 503.

157. Hindermann, blz. 96; Weber, blz. 505. Zie dezelfde, blz. 506 , voor een opsomming van de gevallen, die wolgens hem tot uitsluiting kunnen leiden. De door Weber genoemde gevallen komen grosso modo overeen met de door Peter-Ruetschi in \$15 van haar reglement beschreven gevallen.

158. Friedrich, blz. 200.

159. Het is niet mogelijk on aan én enkele appartementseigenaar (in een gemeenschap van meerdere eigenaars) of aan de administrateur het recht te gewen om een actie te beginnen. Vgl. Magnenat, biz. 127.

160. Friedrich, blz 197; Kurt Müller, blz. 37. Anders Hindermann, blz. 98.

161. Zie ook Hindermann, blz, 98 en art, $649 \mathrm{~b}$ lid 2 ZGB.

162. Vgl. Friedrich, blz. 195, 200. 
geven tot het instellen van een rechtsvordering tot uitsluiting door de appartementseigenaars die de uitsluiting van een deelgenoot wensen. Indien de vergadering de toestemming verleent, kan (kunnen) de klagende eigenaar(s) zich tot de rechter wenden en uitsluiting vorderen van de eigenaar die wegens gewichtige redenen niet meer in de gemeenschap kan worden geduld. De rechter bekijkt vervolgens de gehele situatie en spreekt al dan niet een veroordeling tot vervreemding uit. Indien de appartementseigenaar zijn appartement niet binnen een door de rechter vastgestelde termijn vervreemdt ${ }^{163}$, wordt het volgens de regels van de executoriale verkoop van grond geveild ${ }^{164}$. De procedure voor de veiling kan volgens $\$ 51$ reglement Friedrich door de administrateur aanhangig gemaakt worden. De medeëigendomsverhouding tussen de overige eigenaars eindigt niet door de veiling van een appartement (art. 649b lid 3 ZGB) ${ }^{165}$.

Overigens kan een appartementseigenaar blijkens de tekst van artikel $649 \mathrm{~b} \mathrm{ZGb}$ en de tekst van desbetreffende reglementsbepalingen, ook uit de gemeenschap worden uitgesloten indien door gedragingen van personen voor wie hij verantwoordelijk is of aan wie hij zijn appartement in gebruik heeft gegeven, verplichtingen jegens andere deelgenoten zozeer worden geschonden, dat van de deelgenoten niet meer kan worden verlangd dat zij de gemeenschap met hem laten voortduren. Het is interessant om te constateren dat de eigenaar dus kan worden uitgesloten als anderen zich hebben misdragen. Uiteraard zullen aan de uitsluiting vele aanmaningen móeten zijn voorafgegaan, waarin de eigenaar wordt gesommeerd tegen de gebruikers of tegen de personen die onder zijn verantwoordelijkheid vallen, op te treden ${ }^{166}$. De gemeenschap kan aan de huurder of andere derde-gebruiker (niet zakelijk gerechtigde) zijn huurrecht niet ontnemen. Dit betekent, dat de huurder in sommige gevallen, waarin de appartementseigenaar gedwongen wordt zijn appartementsrecht te vervreemden, niet uit het appartement kan worden gezet, indien er geen sprake is van een tijdig gedane geldige huuropzegging.

De vruchtgebruiker of de gerechtigde tot een recht van bewoning kunnen door de gemeenschap echter wel gedwongen worden een appartement te ontruimen. De bepalingen betreffende de uitsluiting van de appartementseigenaar zijn hierbij van overeenkomstige toepassing (art. $649 \mathrm{c} \mathrm{ZGB})^{167}$.

\subsection{Beroep tegen niet-toelating tot de gemeenschap of uitsluiting uit de gemeenschap}

\subsection{Algemene opmerkingent}

Evenals in het Westduitse recht wordt in het Zwitserse een verschil gemaakt tussen "Streitige" en "Freiwillige Gerichtsbarkeit". De omschrijving van deze contentieuze en oneigenlijke jurisdictie verschilt echter van de Westduitse. "Streitige Gerichtsbarkeit" is jurisdictie, waarbij twee partijen tegenover elkaar staan. Van "Freiwillige Gerichtsbarkeit" is daarentegen sprake bij procedures, waarbij slechts een partij

163. In Bundesgericht 14 maart 1968, ESB 1968, 94, Band, II, blz, 17-25, stelde bet Bundesgericht de termijn, waarbinnen de medeëigenaar zijn aandeell moest wervreemden, op een maand.

164. Magnenat, blz. $127,128$.

165. Vgl. over de formele regels t.a.v. uitsluiting Weber, blz. 513-523.

166. Vgl. \$ 15 sub 4 reglement Peter-Ruetschi.

167. Weber, blz, 511, 512 . 
bestaat, zoals bij "vermist"-verklaring van een persoon, opening van een testament, ontzetting uit de ouderlijke macht, onder curatelestelling etc. De procedures in het appartementsrecht, waarbij aan een appartementseigenaar het recht wordt ontzegd zijn appartementsrecht te vervreemden, een voorkeursrecht wordt uitgeoefend of een appartementseigenaar gedwongen wordt zijn appartementsrecht te vervreemden, vallen noodzakelijkerwijze onder "Streitige Gerichtsbarkeit" 168.

De wetgevende bevoegdheid op het gebied van het procesrecht is in Zwitserland ingevolge artikel $64 \mathrm{BV}$ grotendeels aan de verschillende kantons overgelaten ${ }^{169}$. Dit heeft tot gevolg dat elk kanton zijn eigen burgerlijk procesrecht en zijn eigen rechterlijke instanties heeft. Van kanton tot kanton moet dus eigenlijk worden bezien, waar een procedure over toelating of ontzegging van verder gebruik aanhangig zou moeten worden gemaakt ${ }^{170}$. In deze paragraaf zal bij wijze van voorbeeld het procesrecht van het kanton Zürich worden gehanteerd, zoals dat in de "Zivilprozessordnung" (ZPO) en het "Gerichtsverfassungsgesetz" van Zürich is neergelegd.

\subsubsection{Beroep tegen niet-toelating}

Intern beroep bij de vergadering van eigenaars is ten aanzien van toelating in Zwitserland niet mogelijk. Bij het voorkeursrecht beslist alleen de voorkeursgerechtigde of hij van zijn recht gebruik zal maken, terwijl de vergadering bij het recht van bezwaar toch al in eerste instantie beslist. Het recht om bezwaar te maken kan ook niet aan een gemeenschapsorgaan worden gedelegeerd (zie par. 8.3.2.2).

Tegen uitoefening van het voorkeursrecht door een of meerdere appartementseigenaars kan een eigenaar die zijn appartement wil verkopen, in beginsel geen beroep instellen. Het voorkeursrecht wordt in het reglement aan de appartementseigenaars toegekend en de verkopende eigenaar zal er weinig belang bij hebben tegen de uitoefening van dit recht in beroep te gaan. Hij kan zijn appartement immers toch verkopen, zij het dan aan een andere persoon dan de bedoeling was.

Beroep tegen uitoefening van het voorkeursrecht is slechts mogelijk, indien het recht niet tijdig, binnen $\mathbf{3 0}$ dagen, is uitgeoefend. Voor dit beroep gelden dan, bij ontbreken van een bijzondere procedure, de procedureregels met betrekking tot het "ordentliche Verfahren". Dit betekent dat de rechter van de plaats waar het onroerend goed is gelegen, relatief bevoegd is $(\$ 6 \mathrm{ZPO})$. Voordat men echter (in het kanton Zürich) naar de rechter kan stappen, moet eerst het zogenaamde "Sühnverfahren" bij de vrederechter worden doorlopen. Dit is een zeer kort durende procedure, waarin moet worden vastgesteld of een verzoening tussen partijen kan worden bereikt $(\$ 8 \mathrm{GVG})^{171}$. Blijkt verzoening niet mogelijk, dan kan de vordering aanhangig worden gemaakt bij het "Bezirksgericht", dat absoluut competent is. Deze rechterlijke instantie is namelijk het gerecht van eerste aanleg voor vermogensrechtelijke aanspraken met een strijdwaarde van meer dan 2000

168. Guldener, blz. 41,42 .

169. Zie Vogel, blz. 244-248; Guldener, blz. 584-594.

170. Walder-Bohner, blz 23.

171. Zie Hauser/Hauser, blz, 19. 
Zwitserse francs ( $\$ 32 \mathrm{~b}$ GVG) ${ }^{172}$. In deze procedure bij het "Bezirksgericht" kan degene die zijn appartementsrecht heeft verkocht (maar nog niet heeft owergedragen) of degene aan wie de eigendom inmiddels is overgedragen, een "Verwirkungseinrede" doen, waarbij wordt gesteld dat de voorkeursgerechtigde zijn recht om het voorkeursrecht in te roepen, heeft verspeeld.

Beroep staat in alle gevallen open tegen de uitoefening van het recht van bezwaar. Anders dan het kopje boven deze paragraaf zou doen vermoeden, kan echter niet de koper maar de verkoper beroep instellen. De verkoper van een appartement, die het niet eens is met een bezwaar dat tegen de vervreemding wordt gemaakt, kan zich ingevolge artikel $712 \mathrm{c}$ lid $3 \mathrm{ZGB}$ tot de rechter wenden. De rechter beslist dan in het zogenaamde "summarische Verfahren". Onderwerp van het "summarische Verfahren" zijn over het algemeen geschillen, waarvan de feiten gemakkelijk vast te stellen zijn of waarin snel een beslissing moet worden genomen. Het "summarische Verfahren" is een vereenvoudigde procedure bij een unus judex ${ }^{173}$. Het is een procedure waarin onder andere de toegelaten bewijsmiddelen zijn beperkt. Besluiten in deze procedure staan gelijk aan besluiten van de rechter in het "ordentliche Verfahren" (normale procedure).

Ingevolge $\$ 215 \mathrm{~d}$ sub $34 \mathrm{ZPO}$ is de "Einzelrichter" bij beroep tegen bezwaar bij vervreemding, verhuring of bezwaring, competent. In Zürich is de president van het "Bezirksgericht" de "Einzelrichter"174. Aangezien geen jurisprudentie over uitoefening van het recht van bezwaar is gepubliceerd, kan niet met zekerheid worden vastgesteld hoe de rechter de beslissing van de vergadering van eigenaars zall toetsen. Aangezien hij bij een uitsluitingsprocedure volledig toetst of een gewichtige reden tot uitsluiting aanwezig is (zie par. 8.4.3), is het aannemelijk dat hij bij het recht van bezwaar op dezelfde wijze zal toetsen.

De bevoegdheid om zich tot de rechter te wenden kan bij reglement worden vervangen door een bevoegdheid om zich tot speciaal voor onenigheid tussen de appartementseigenaars benoemde arbiters te wenden. Deze vervanging van de beroepsmogelijkheid bij de rechter door een arbitragemogelijkheid moet wel met toestemming van alle appartementseigenaars tot stand komen ${ }^{i 75}$. Anders zijn alleen degenen die hebben toegestemd aan de arbitrageclausule gebonden. Dit vormt een afwijking van de regel dat voor de instelling van een reglement slechts een meerderheid van stemmen nodig is (art. $712 \mathrm{~g}$ lid $3 \mathrm{ZGB}$ ). Anderzijds zijn latere rechtsverkrijgers wel aan de arbitrageclausule gebonden ingevolge artikel $649 \mathrm{a} \mathrm{ZGB}{ }^{176}$. De vervanging van het beroep op de rechter door arbitrage is mogelijk op grond van het "Konkordat über die Schiedsgerichtbarkeit" van 27 maart $1969^{177}$. Volgens

172. Zie Hauser/Hauser, blz. 74 .

173. Zie Sträuli/Messmer, blz. 359; Habscheid, blz. 307.

174. Hauser/Hauser, blz. $34,35$.

175. Bögli, blz. 169.172.

176. Vgl. Friedrich, blz 217. Uiteraard kan men ook op het moment dat een geschil is ontstaan besluiten om het geschil aan arbitrage te onderwerpen. Hiervoor is dan wel een schriftelijke overeenkomst nodig: Zie ook Jolidon, blz. 41, 42.

177. Een concordaat is een publiekrechtelijke overeenkomst tussen kantons op een gebied dat tot hun bevoegdheden behoort. De regeling van het burgerlijke procesrecht valt in Zwitserland onder deze bewoegdheden. Concordaten zijn mogelijk ingewollge art. 7 lid 2 van de $Z$ writserse federale Grondwet. Het "Konkordaat über die Schiedsgerichtbarkeit" is in de meeste Zwitserse kantons van toepassing. Jolidon, blz $8,46,55$. 
artikel 5 van dit concordaat kan men arbiters bevoegd maken on te oordelen over rechtsgevolgen die door vrijwillig handelen zijn ontstaan ${ }^{178}$. Nu vervreemding een vrijwillig handelen is, is arbitrage hieromtrent eveneens mogelijk. In het reglement Friedrich is een arbitrageclausule opgenomen. De relevante onderdelen van deze clausule ( $\$ 58$ ) luiden:

"1) Alle Meinungsverschiedenheiten und Streitigkeiten, die zwischen den Stockwerkeigentümern aus der Gemeinschaftsordnung entstehen können, sollen ausschliesslich und endgültig durch ein Schiedsgericht entschieden werden.

2) In die Zuständigkeit des Schiedsgerichtes fällt auch der Entscheid über den Ausschluss eines Stockwerkeigentümers und über die Begründetheit einer Einsprache gegen die Veräusserung.

5) Das Schiedsgericht bestimmt selbst über sein Verfahren. Dabei ist dem Interesse an einer raschen Entscheidung durch ein einfaches Verfahren Rechnung zu tragen. Das Schiedsgericht entscheidet auch über Kosten und die eigene Zuständigkeit.

Uit lid 5 blijkt dat de arbiters zelf mogen beslissen welke procedure zij volgen. Bijgevolg is niet vast te stellen of de arbiters zich tot een marginale toetsing beperken of de gewraakte beslissing vol toetsen. Tegen een beslissing van een arbiter staat in beginsel geen rechtsmiddel open (zie $\$ 258 \mathrm{ZPO})^{179}$.

\subsubsection{Beroep tegen witsluiting uit de gemeenschap}

Intern beroep tegen uitsluiting uit de gemeenschap is niet mogelijk, omdat de vergadering van eigenaars in eerste instantie over de uitsluiting moet beslissen en deze beslissingsmacht niet aan een ander gemeenschapsorgaan kan worden gedelegeerd.

Het beroep tegen uitsluiting uit de gemeenschap kan wel aan arbitrage worden onderworpen (vgl. \& 58 lid 2 reglement Friedrich). Voor deze arbitrage geldt hetzelfde als hetgeen in $\$ 8.4 .1$. daaromtrent is opgemerkt.

Indien geen arbitrage is overeengekomen, kan de appartementseigenaar (of zakelijk c.q. persoonlijk gerechtigde wiens recht in de openbare registers is ingeschreven), die men uit de gemeenschap van appartementseigenaars wil uitsluiten, allereerst natuurlijk bij de rechter bij wie de gemeenschap de beslissing tot uitsluiting vordert, verweer voeren. Voor de vordering tot uitsluiting van een appartementseigenaar gelden dezelfde procedureregels en zijn dezelfde instanties competent, als bij beroep tegen inroeping van het voorkeursrecht. Blijkens Bundesgericht 14 maart $1968^{180}$ gaat de rechter in een procedure tot uitsluiting op alle facetten van de zaak in en toetst hij volledig of een gewichtige reden tot uitsluiting aanwezig is.

178. Art. 5 luidt: "Gegenstand eines Schiedsverfathrens kann jeder Anspruch sein, welleher der freien Verfügung der Parteien unterliegt, sofern nicht ein staatliches Gericht nach einer zwingenden Gesetzesbestimmung in der Sache ausschliesslich zuständig ist." Hierover Jolidon, blz. 150-168.

179. Bij evidente onjuistheid van de beslissing is bijvoorbeeld well beroep moggelijk (bij de "Bezirksrichter" in bet "ordentliche Verfahren").

180. Bundesgericht 14 maart 1968, ESB 1968, 94. Band, II, blz. 17-25. 
IV VERGELIJKINGEN EN CONCLUSIES 


\section{Samenvattende vergelijkingen en conclusies}

\subsection{Algemene opmerkingen}

Appartementseigendom was, in een of andere vorm, enkele duizenden jaren geleden in sommige gedeelten van de wereld al mogelijk (par. 2.1). Door de herleving van de aandacht voor het Romeinse recht in de $19 \mathrm{e}$ eeuw, werd "Stockwerkeigentum" in landen als (West-)Duitsland en Zwitserland, althans in de gebieden die tegenwoordig die landen vormen, bij de codificaties aan het begin van de $20 \mathrm{e}$ eeuw in strijd met het "superficies solo cedit"-beginsel geacht en derhalve in hun nieuwe burgerlijke wetboeken (BGB en ZGB) verboden (zie $\$ \$$ 93 e.v., $946 \mathrm{BGB} ; 189$ lid 1 sub $3 \mathrm{EGBGB}$ en artikel $675 \mathrm{ZGB}$. Zie hierover par. 6.1 en 8.1).

Beide landen hebben verder met elkaar gemeen dat zij kort na de tweede wereldoorlog het verbod van "Stockwerkeigentum" hebben opgeheven, en een nieuwe regeling van appartementseigendom hebben ingevoerd. Het Westduitse parlement nam het WEG op 15 maart 1951 aan (par. 6.1), terwijl in Zwitserland het ZGB bij wet van 19 december 1963 werd veranderd en in de artikelen 647. 650, 682 en 712a-712t ZGB de "Stockwerkeigentum" werd geregeld (par. 8.1).

Nederland kan zich voor wat betreft het tijdstip van totstandkoming van de appartementenwet, bij West-Duitsland en Zwitserland scharen. In ons land werd immers op 20 december 1951 de appartementenwet vastgesteld (par. 2.1). Anders dan in West-Duitsland en Zwitserland was appartementseigendom hier te lande echter niet expliciet verboden bij de invoering van het Burgerlijk Wetboek in 1838. Voorzover bekend kwam appartementseigendom in 1838 in ons land niet voor. Daarom was er geen behoefte aan een vertaling van artikel $664 \mathrm{Ccc}$. en evenmin behoefte aan een verbod van appartementseigendom. Appartementseigendom was volgens Carel Asser immers iets, dat

"... bijzonder toepasselijk is op groote gebouwen in de steden van Frankrijk staande ..." (zie par. 2.1.1) ${ }^{\mathrm{t}}$.

Toen na de tweede wereldoorlog een sterke behoefte aan de mogelijkheid van appartementseigendom bleek te bestaan, werd de hierboven genoemde appartementenwet ingevoerd.

In Frankrijk en België ziet de geschiedenis van het appartementsrecht er anders uit. Artikel 664 C.c., in beide landen ingevoerd in 1804, makte appartements-

1. Asser, par. 376 . 
eigendom mogelijk. Bovendien bestond ook voor de invoering van de Code civil in enige Franse steden al appartementseigendom. Artikel 664 C.C. bleek echter in de praktik een onvoldoende regeling van het recht ten aanzien van appartementseigendom te bevatten. België schafte dit artikel daarom al bij wet van 8 juli 1924 af en verving het door een ietwat uitgebreidere regeling in artikel 577 bis BW (zie par. 5.1). Frankrijk volgde enige jaren later en voerde in 1938 een nieuwe appartementenwet in, die in een meer uitgebreide en gedetailleerde regeling van het appartementsrecht voorzag (par. 7.1).

Inmiddels zijn in beide landen stemmen opgegaan om deze wetten te veranderen. In België is echter tot op heden geen verandering in artikel 577 bis BW aangebracht (par. 5.2). Frankrijk heeft zijn appartementsrecht bij wet van 10 juli 1965 ingrijpend veranderd en bij decreet uit 1967 nog aangevuld. Inmiddels zijn ook in deze wet en dit decreet enige wijzigingen aangebracht (par. 7.1).

Het appartementsrecht heeft dus in alle in dit werk beschreven landen zijn grondslag in een wettelijke regeling. In Nederland, West-Duitsland, Frankrijk en Zwitserland is deze regeling tamelijk uitvoerig. In België regelt slechts eén artikel (577 bis BW) de appartementseigendom. De appartementseigenaars regelen in België hun onderlinge verhouding derhalve in de praktijk altijd nader in een reglement van medeëigendom. Het is vreemd om te moeten constateren, dat bij een dermate summiere wettelijke regeling, het reglement niet verplicht is gesteld. Aan de andere kant lijkt de praktijk met dit ontbreken van een wettelijk gebod geen moeite te hebben (zie par. 5.2.1).

De vier andere landen kennen eveneens een reglement van splitsing, c.q. reglement van medeëigendom, waarin de appartementseigenaars hun onderlinge verhouding kunnen regelen. In Nederland en Frankrijk is dit reglement verplicht (zie art. 875e BW en art. 8 Wet 1965, waarover nader in de par. 2.4.1, 2.4.2.1 en 7.2.1 wordt bericht). In West-Duitsland en Zwitserland is het opstellen van een reglement, evenmin als in België verplicht. Waarschijnlijk wordt in West-Duitsland en Zwitserland evenals in België echter in de praktijk altijd een reglement opgesteld.

Het Nederlandse reglement van splitsing heeft, indien het in de openbare registers is ingeschreven, zakelijke werking. Het werkt tegen rechtsopvolgers onder bijzondere titel, zakelijk gerechtigden en persoonlijk gerechtigden (art. $875 \mathrm{~m} \mathrm{BW}$, zie par. 2.4.2.1 en 4.4.4). In de beschreven buitenlandse rechtsstelsels heeft het reglement, indien het is ingeschreven in de openbare registers voor onroerend goed, net als in Nederland zakelijke werking, waarbij het tevens tegen persoonlijk gerechtigden werkt (par. 5.2.1, 6.2.1, 7.2.1, 7.3.3, 8.2.1).

Ten aanzien yan België moet echter worden opgemerkt, dat niet alle reglementsbepalingen zakelijke werking hebben. In België wordt namelijk een onderscheid gemaakt tussen persoonlijke en zakelijke reglementsbepalingen. De persoonlijke reglementsbepalingen gelden in beginsel slechts tussen de contractanten, d.w.z. degenen die het reglement hebben opgesteld en degenen die er later mee hebben ingestemd. Rechtsverkrijgers onder bijzondere titel en persoonlijk gerechtigden zijn er in beginsel niet aan gebonden. De zakelijke bepalingen zijn daarentegen bepalingen "propter rem" en werken wel tegen zakelijke rechtsverkrijgers en persoonlijk gerechtigden (par. 5.2.1). In het modelreglement Aeby wordt bijvoorbeeld bepaald dat alle regelingen van het reglement zakelijke werking hebben (art. 
$8.01 \$ 1$ modelreglement Aeby). Dat zou betekenen dat ook de bepaling, dat de verkrijger van een appartement aansprakelijk is voor de schulden van de vorige eigenaar, zakelijke werking zou hebben (art. $4.08 \$ 2$ modelreglement Aeby). De Brusselse Rechtbank heeft echter beslist dat defgelijke bepalingen geen zakelijke werking toekomt.

Het reglement van splitsing heeft in alle beschreven rechtsstelsels de status van een contract tussen de appartementseigenaars. Door de zakelijke werking ervan kan het reglement zoals gezegd ook tegen persoonlijke en zakelijke gerechtigden worden ingeroepen. Het feit dat het reglement een overeenkomst tussen de appartementseigenaars is, brengt echter tevens met zich mee dat persoonlijk gerechtigden geen beroep erop kunnen doen, hoewel het wel tegen hen kan worden ingeroepen (par. 4.4.4 en 5.3.3) 2 .

Aangezien zakelijk gerechtigden (vruchtgebruikers e.d.) evenmin als de huurders partij zijn bij het reglement, kunnen zij zich naar mijn mening ook niet rechtstreeks op het reglement beroepen. Zowel de huurder ${ }^{3}$ als zakelijk gerechtigden zullen een appartementseigenaar/verhuurder mijns inziens in bepaalde gevallen echter wel kunnen aanspreken, om naleving van het reglement van splitsing door andere appartementseigenaars te laten afdwingen. Een en ander zal evenwel grotendeels afhangen van hetgeen in de overeenkomst tussen de appartementseigenaar en de zakelijk gerechtigde of de huurder is geregeld.

Ten aanzien van West-Duitsland, Zwitserland en Frankrijk is niet met zekerheid vast te stellen, of persoonlijke en zakelijke gerechtigden zich op de bepalingen van het reglement van splitsing kunnen beroepen. Aangezien het reglement in alle drie de landen echter een overeenkomst tussen de appartementseigenaars vormt, valt aan te nemen dat personen, die juridisch geen partij zijn bij het reglement, daarop geen beroep kunnen doen.

In het reglement van splitsing, c.q. reglement van medeëigendom, worden in alle vijf de landen in het algemeen regelingen getroffen ten aanzien van:

1. rechten van de appartementseigenaars met betrekking tot hun prive-gedeelten;

2. plichten ten aanzien van de privé-gedeelten met betrekking tot gebruik, beheer en onderhoud;

3. de bestemming van de appartementen en het appartementsgebouw;

4. rechten en verplichtingen van de appartementseigenaars met betrekking tot de gemeenschappelijke gedeelten en ten opzichte van de gemeenschap;

5. verdeling van de gemeenschappelijke kosten van de gemeenschap, c.q. vereniging van appartementseigenaars (zie over deze eerste vijf punten par. 2.4.4, 5.2.5, 6.2.5, 7.2.5, 8.2.5);

6. administratie en beheer van het appartementsgebouw, zoals: regeling ten aanzien van benoeming en ontslag van de administrateur; regeling ten aanzien van de bijeenroeping van de vergadering (zie par. 2.4.3, 5.2.4, 6.2.4, 7.2.4, 8.2.4);

2. Vgl. HR 23 jan. 1987, RvdW 1987, 40. Zie voor België: Rb. Brussel 30 maart 1976, J.T, 1976, 410.

3. Vgl. hierover echter par. 4.4.3.2. De huurders hebben ex art. 1592 BW ook een eigen mogelijkheid om op te treden tegen derden die hen in hun huurgenot storen. 
7. verzekering en (eventuele) wederopbouw van het appartementsgebouw;

8. toelating en ontzegging van verder gebruik, voor zover mogelijk in het desbetreffende land (zie hoofdstuk 3 en par. 5.3, 6.3, 7.3, 8.3).

Het feit dat het reglement van splitsing een contract tussen de appartementseigenaars is, lijkt met zich mee te brengen, dat alle contractanten met een wijziging van de overeenkomst zouden moeten instemmen. De Nederlandse wetgever heeft inderdaad voor deze oplossing gekozen (art. 876l BW; art. 5.10.4.1 / 5: $139 \mathrm{NBW}$ en par. 2.4.3). Dit betekent echter niet dat én "moeilijke" appartementseigenaar elke verandering kan tegenhouden. Artikel 876m BW (art. 5.10.4.2 / 5:140 NBW) maakt immers een vervangende machtiging tot wijziging van het reglement van splitsing door de kantonrechter mogelijk, indien een appartementseigenaar zonder redelijke grond weigert om aan een bepaalde wijziging mee te werken.

In België kan het reglement van medeëigendom eveneens slechts unaniem worden gewijzigd (zie par. 5.2.1). Het is echter mogelijk, dat in het reglement zelf een andere meerderheidseis, zowel ten aanzien van de zakelijke bepalingen als ten aanzien van de persoonlijke, wordt vastgesteld.

In West-Duitsland moet de "Gemeinschaftsordnung", het reglement van splitsing, in beginsel bij unaniem besluit gewijzigd worden (zie \& $15 \mathrm{WEG).} \mathrm{Bepaalde}$ regelingen die in het reglement zijn opgenomen en slechts de dagelijkse administratie betreffen (bijvoorbeeld huishoudelijke bepalingen) kunnen echter bij gewoon meerderheidsbesluit worden veranderd. In het reglement kan eveneens worden bepaald, dat het bij gewoon meerderheidsbesluit kan worden veranderd. Een dergelijke bepaling kan echter alleen gelden ten aanzien van zakelijk gerechtvaardigde veranderingen, waardoor de afzonderlijke appartementseigenaars niet onredelijk worden benadeeld. Of hiervan sprake is, moet de rechter van geval tot geval beoordelen (zie par. 6.2.1).

In Frankrijk kunnen reglementaire bepalingen met betrekking tot gebruik, beheer en genot van de gemeenschappelijke gedeelten, slechts met tweederde meerderheid van alle appartementseigenaars worden gewijzigd. In alle andere gevallen is slechts een gewone meerderheid van alle appartementseigenaars vereist (par. 7.2.4, zie ook art. 25 Wet 1965).

De Zwitserse wetgever heeft voor weer een andere regeling ten aanzien van wijziging van het reglement geopteerd. In Zwitserland kan het reglement namelijk. in beginsel slechts met een meerderheid van alle appartementseigenaars, die tevens de helft van de waarde aandelen van het appartementsgebouw vertegenwoordigen, worden gewijzigd. Indien de wijziging echter een afwijking van de wettelijke regeling of een wijziging, van de bestemming van het gebouw of de afzonderlijke appartementen inhoudt, moet het wijzigingsbesluit unaniem worden genomen (zie par. 8.2 .4 en art. $712 \mathrm{~g} \mathrm{ZGB})^{4}$.

De bepalingen van het reglement van splitsing kunnen in Nederland, WestDuitsland, Frankrijk en Zwitserland nog worden aangevuld in een huishoudelijk reglement. Opstelling van een huishoudelijk reglement is echter in geen van deze landen verplicht. Het heeft verder geen zakelijke werking en werkt daarom niet

4. Vgl. ook Bundesgericht 24 maart 1977, ESB 1977, 103. Band, Ib, blz. 76-82. 
tegen rechtsopvolgers onder bijzondere titel, zakelijk of persoonlijk gerechtigden, voor zover zij daarmee niet hebben ingestemd (par. 2.4.4, 6.2.1, 7.2.1, 8.2.1)

Het Westduitse huishoudelijk reglement vormt hierop een uitzondering, omdat dit reglement wel tegen rechtsopvolgers onder bijzondere titel, tegen zakelijk gerechtigden en tegen persoonlijk gerechtigden werkt (par. 6.2.1).

In het huishoudelijk reglement worden over het.algemeen zaken van ondergeschikt belang geregeld. Zo kunnen er regelingen met betrekking tot het sluiten van ramen, het gebruik van de liften, het sluiten van de toegangsdeuren tot het gebouw e.d., in worden getroffen (vgl. par. 6.2.1, 7.2.1, 8.2.1).

Belgiê neemt wat betreft het huishoudelijk reglement een bijzondere plaats in. Daar wordt soms namelijk geen afzonderlijk huishoudelijk reglement opgesteld, maar worden de zaken die in andere landen in zo'n reglement worden geregeld, neergelegd in de persoonlijke bepalingen van het reglement. Aangezien deze bepalingen geen zakelijke werking hebben, verschilt de Belgische regeling in de praktijk nauwelijks van die van andere landen, met uitzondering van WestDuitsland (par. 6.2.1). Meestal wordt overigens wel een apart huishoudelijk reglement opgesteld ${ }^{5}$.

In dit boofdstuk zal in het vervolg slechts op de algemene lijnen van het appartementsrecht worden ingegaan, zonder dat in details zal worden vergeleken. Voor de gedetailleerde beschrijvingen zij verwezen naar de voorgaande hoofdstukken. Op toelating en ontzegging van verder gebruik zal uitvoeriger worden ingegaan. Voor detailpunten zij echter ook hierbij naar de desbetreffende hoofdstukken verwezen.

\subsection{De hoofdlijnen van het appartementsrecht}

\subsection{Algemene structuur van appartementseigendom}

De Nederlandse gemeenschap van appartementseigenaars is naar huidig recht een bijzondere vorm van de gebonden medeëigendom, voor zover een onderscheid tusen vrije- en gebonden medeëigendom tenminste kan worden gemaakt (par. 4.3.2 en 4.3.4). Daarom is het algemene recht betreffende de medeëigendom in beginsel van toepassing op de appartementsgemeenschap, uiteraard voor zover het appartementsrecht - zoals neergelegd in de artt. 875a-876t BW - daaraan niet derogeert.

Naar toekomstig recht is de gemeenschap van appartementseigenaars een bijzondere gemeenschap, waarbij moet worden aangetekend dat artikel 3.7.2.0 / 3:189 NBW bepaalt dat de regeling betreffende de bijzondere gemeenschap niet geldt voor de appartementsgemeenschap (par. 4.3.4).

Overigens moge duidelijk zijn, dat naar NBW bij een gesplitst erfpachtsrecht niet van medeëigendom, maar slechts van gemeenschap ten aanzien van het erfpachtsrecht kan worden gesproken, terwijl aan de aandelen in het erfpachtsrecht een zakelijk gebruiksrecht van de privé-gedeelten is gekoppeld.

Een gesplitst opstalrecht brengt mijns inziens naar NBW wel medeëigendom voor de appartementseigenaars met zich mee. Een opstalrecht geeft immers aan de gerechtigde een eigendomsrecht van de opstallen. Als het opstalrecht wordt 
gesplitst, betekent dit dat de daaruit voortvloeiende eigendom ook wordt "gesplitst", in die zin dat meerdere personen gerechtigde tot het opstalrecht, en medeëigenaar van de opstallen worden. Aan deze medegerechtigdheid tot het opstalrecht en de daaruit voortvloeiende medeëigendom, is vervolgens het zakelijk gebruiksrecht van de privé-gedeelten gekoppeld (art. 875a lid 3 BW; art. 5.10.1.1 lid 3/5:106 lid 3 NBW, zie ook par. 1.1) ${ }^{6}$.

Deze structuur van medeëigendom van het gehele onroerend goed (of gemeenschap ten aanzien van het erfpachtsrecht), gecombineerd met een beperkt zakelijk gebruiksrecht op privé-gedeelten, kan monistisch of unitair worden genoemd (vgl. par. 5.2.2) ${ }^{7}$. Tegenover de monistische structuur staat de dualistische structuur, waarin medeëigendom van de gemeenschappelijke gedeelten is gekoppeld aan volle eigendom van privé-gedeelten.

Van de landen, waarvan het appartementsrecht in deze dissertatie is vergeleken, kent - behalve Nederland - alleen Zwitserland nog een monistische structurur. Ook in Zwitserland bevat een appartementsrecht "niet meer" dan een medeëigendomsaandeel van het gehele onroerend goed, gecombineerd met een beperkt zakelijk gebruiksrecht ten aanzien van de privé-gedeelten. Hierbij moet wel worden aangetekend dat het Zwitserse systeem in zoverre van het Nederlandse verschilt, dat niet afgesloten gedeelten, zoals balkons en parkeerplaatsen, niet onder het beperkte zakelijke gebruiksrecht kunnen vallen. Dit heeft in Zwitserland geleid tot vestiging van extra "Sonderbenützungsrechte" - eveneens beperkt zakelijke gebruikstechten - op "geneenschappeiighe balhous", vis daardoor juridisch echter toch "gemeenschappelijk" blijven (par. 8.2.2). In Nederland behoren daarentegen alle gedeelten, die blijkens hun inrichting bestemd zijn om als afzonderlijk geheel te worden gebruikt (dus ook balkons), tot de onder het zakelijk gebruiksrecht vallende privé-gedeelten (zie art. $875 \mathrm{a}$ lid $3 \mathrm{BW}$ ).

De Zwitserse gemeenschap van appartementseigenaars is een "Miteigentümergemeinschaft" en evenals in Nederland een bijzondere vorm van medeëigendom. Van medeëigendom kan zowel ten aanzien van rechten als ten aanzien van stoffelijke voorwerpen (zaken in NBW-terminologie) sprake zijn. De terminologie komt derhalve overeen met die van het huidige Nederlandse BW. Evenals naar huidig Nederlands recht is het algemene medeëigendomsrecht op de gemeenschap van appartementseigenaars van toepassing. Deze toepasselijkheid heeft in Nederland echter slechts theoretische betekenis, terwijl in Zwitserland de bepalingen betreffende de "Miteigentümergemeinschaft" in de praktijk veelvuldig op de appartementsgemeenschap worden toegepast (par. 8.2.1).

Aanvankelijk had de Nederlandse wetgever een andere structuur voor appartementsrechten op het oog. In deze structuur was er sprake van afzonderlijke eigendom van privé-gedeelten, gekoppeld aan medeëigendom van de gedeelten die zouden zijn bestemd voor gemeenschappelijk gebruik. Deze dualistische structuur was opgenomen in het oorspronkelijke ontwerp van 1947, maar werd in 1951 verlaten (par. 2.1.4).

6. Vgl. ook Beekhuis/Linders, V1 par. 3, nr. 4.

7. Vgl. Aeby, blz. 88, 92. Anders Beekhuis/Linders, VI par. 2, nr. 1, die het Nederlandse systeem ten onrechte dualistisch noemt. 
Ongeveer dezelfde dualistische structuur als in het Nederlandse ontwerp van 1947 was neergelegd, is terug te vinden in het appartementsrecht van België, WestDuitsland en Frankrijk.

De Belgische en Franse appartementseigendom vertoont qua structuur grote gelijkenis. In beide landen is appartementseigendom een vorm van gedwongen medeëigendom, voorzover er tenminste sprake is van medeëigendom. Alleen de gedeelten die bestemd zijn voor gemeenschappelijk gebruik, zijn in het Belgische en Franse dualistische systeem namelijk voorwerp van medeëigendom. Beide landen hebben bovendien gekozen voor een dualistische structuur, waarin de medeëigendom van de gemeenschappelijke gedeelten accessoir is an de volle eigendom van de privé-gedeelten (par. 5.2.2, 7.2.2). Uit deze afhankelijkheid blijkt hoezeer men de volle eigendom van de privé-gedeelten op de voorgrond stelt en de medeêigendom van de gemeenschappelijke gedeelten in feite slechts ziet als een hulpmiddel om de volle eigendom mogelijk te maken. (vgl. daarover Nerson, geciteerd in par. 7.2.2).

Dit is anders in West-Duitsland. Daar is de volle eigendom van de privégedeelten aćcessoir aan de medeëigendom van de gemeenschappelijke gedeelten. Deze afhankelijkheid wordt echter niet zover doorgevoerd dat (gedeelten van) de volle eigendom nooit los van de gemeenschappelijke eigendom, zou (den) kunnen worden overgedragen (par. 6.2:2).

De gemeenschap van appartementseigenaars is in West-Duitsland een vorm van "Miteigentum nach Bruchteilen", die op zijn beurt een bijzondere vorm van de "Gemeinschaft nach Bruchteilen" is. Medeëigendom is in West-Duitsland slechts mogelijk ten aanzien van stoffelijke objecten. De verhouding van medeëigendomgemeenschap komt overeen met de verhouding daartussen in het Nederlands NBW.

In het Westduitse appartementsrecht wordt verder onderscheid gemaakt tussen "Wohnungseigentum", "Teileigentum", "Wohnungserbbaurecht"en"Teilerbbaurecht". Deze verschillende benamingen vloeien voort uit het feit, dat men voor appartementseigendom van woningen de benaming "Wohnungseigentum" heeft gekozen. Deze vlag kan de lading niet dekken, als er sprake is van appartementseigendom van bedrijfsruimten. Daarom heeft men daarvoor de term "Teileigentum" ingevoerd. Mutatis mutandis zijn de benamingen "Wohnungserbbaurecht" en "Teilerbbaurecht" ingevoerd voor gesplitste opstalrechten.

Dat van "Wohnungserbbaurecht", c.q. "Teilerbbaurecht" wordt gesproken neemt niet weg dat de bezitters van deze rechten vol eigenaar van hun privé-gedeelten zijn, en medeëigenaar van de gemeenschappelijke gedeelten van het gebouw (uiteraard exclusief de grond, waarop dit gebouw staat) zijn. Deze medeëigendom en afzonderlijke eigendom zijn wel accessoir aan het opstalrecht (par. 6.2.2).

Het criterium om de privé-gedeelten te onderscheiden van de gedeelten die bestemd zijn voor gemeenschappelijk gebruik vertoont in alle vijf de landen, met uitzondering wellicht van West-Duitsland, sterke gelijkenis.

In Nederland rust het beperkt zakelijk gebruiksrecht op

"bepaalde gedeelten van een gebouw die blijkens hun inrichting bestemd zijn om als afzonderlijk geheel te worden gebruikt" (art. 875a lid $3 \mathrm{BW}$, ze par. 1.1). 
In Zwitserland rust het zakelijke gebruiksrecht (het "Sonderrecht") op ruimten die een afgesloten geheel vormen en een eigen ingang hebben. Hieruit kan wordien afgeleid dat het zakelijk gebruiksrecht ook in Zwitserland slechts op blijkens hun inrichting voor afzonderlijk gebruik bestemde ruimten rust. Het enige verschil met het Nederlandse appartementsrecht is, dat de privé-gedeelten in Zwitserland afgesloten moeten zijn. Terwijl balkons in Nederland moeiteloos onder het zakelijk gebruiksrecht vallen, zijn ze in Zwitserland - zoals vermeld - bestemd voor gemeenschappelijk gebruik. Ten aanzien van parkeerplaatsen doet zich in Nederland echter eenzelfde probleem als in Zwitserland voor (zie par. 2.4.2.1 en par. 8.2.2).

In België wordt voor de aanduiding van de gemeenschappelijke gedeelten het wettelijke criterium "bestemd voor gemeenschappelijk gebruik" gehanteerd (art. 577 bis $\$ 11 \mathrm{BW}$ ). Voor aanduiding van de privé-gedeelten wordt het criterium "bestemd voor uitsluitend gebruik" gehanteerd (par. 5.2.2). In feite is dit laatste criterium overbodig, nu al hetgeen niet bestemd is voor gemeenschappelijk gebruik, kennelijk is bestemd voor uitsluitend gebruik. Frankrijk hanteert ongeveer hetzelffe dubbele criterium. Gemeenschappelijke gedeelten zijn daar gedeelten van gebouwen en terreinen, die voor gemeenschappelijk gebruik bestemd zijn (art. 3 Wet 1965). Daaraan voorafgaand omschrijft artikel 2 Wet 1965 de privé-gedeelten als die gedeelten, die in afzonderlijk gebruik aan een appartementseigenaar toekomen. Omdat hierbij bovendien vereist is dat dit gebruik juridisch aan de appartementseigenaar moet toekomen, kan worden geconcludeerd dat in Frankrijk met het criterium "afzonderlijk gebruik" bedoeld wordt dat de prive-gedeelten in de akte van splitsing bestemd moeten zijn om als afzonderlijk geheel te worden gebruikt (zie par. 7.2.2).

Het blijkt dat Nederland, België, Frankrijk en Zwitserland alle vier ongeveer hetzelfde criterium hanteren om de gemeenschappelijke gedeelten van de privégedeelten te onderscheiden. In België en Frankrijk wordt daaraan nog een extra criterium verbonden voor de gemeenschappelijke gedeelten, dat echter feitelijk overbodig is. Het Belgische en Franse criterium is echter wel ruimer dan het Nederlandse en het Zwitserse, hetgeen tot gevolg heeft dat parkeerplaatsen probleemloos onder de privé-gedeelten kunnen worden gebracht.

In het Westduitse "Wohnungseigentumsrecht" zijn grond, vitale delen van het gebouw (bijvoorbeeld dragende muren) en inrichtingen en installaties die bestemd zijn voor gemeenschappelijk gebrük, altijd gemeenschappelijk ( $\$ 2$ WEG). Verder zijn die delen van het gebouw gemeenschappelijk, die niet in volle eigendom aan é̂n appartementseigenaar toekomen ( $\$ 1$ lid 5 WEG). Woningen zijn in elk geval prive-gedeelten, die in volle eigendom aan een appartementseigenaar toekomen ( 1 lid 2 WEG). Een criterium kan aan $\$ 3$ WEG worden ontleend, dat bepaalt dat afzonderlijke eigendom slechts kan bestaan met betrekking tot gedeelten die ${ }^{\text {in }}$ sich abgeschlossen sind". De privé-gedeelten moeten dus afgesloten zijn van de overige prive- en gemeenschappelijke gedeelten. Voor parkeerplaatsen bepaalt $\$$ 3 لid 2 WEG echter uitdrukkelijk, dat zij als afgesloten ruimte gelden, indien hun oppervlakte door duurzame markeringen duidelijk wordt begrensd (zie par. 6.2.2).

In de dualistische structuur is het moeilijk om vast te stellen, welke materiële delen van een privé-gedeelte ook daadwerkelijk de volle eigendom van een appartementseigenaar zijn. Over het algemeen kunnen tussenwandjes, sanitair en keuken- 
woorzieningen als privé-eigendom worden beschouwd (zie bijvoorbeeld par. 6.2.2). Hoe men zich de privé-eigendom ten aanzien van het gehele appartement moet voorstellen, is echter onduidelijk. De scheidingswanden, vloeren, plafonds e.d. komen immers in het merendeel van de gevallen aan twee appartementseigenaars toe. Het plafond van de benedenbuurman is immers de vloer van de bovenbuurman. Zurfluh/Traizet-Frot heeft het eigendomsrecht ten aanzien van privegedeelten daarom ook het recht op een kubus lucht genoemd (zie par: 2.3.2). Alleen de tussenwandjes en het sanitair e.d., kunnen aan het volle eigendomsrecht nog enige materiële inhoud geven.

Bovendien wordt de aard en de omvang van het eigendomsrecht ten aanzien van de privé-gedeelten ingekleurd door de rechten en plichten ten opzichte van de overige appartementseigenaars. Deze rechten en plichten begrenzen het afzonderlijke gebruiks- en beschikkingsrecht van de individuele eigenaar.

Mijns inziens is de Zwitserse en Nederlandse monistische structuur van appartements"eigendom" dan ook beter dan de dualistische structuur. Bovendien moet de monistische structuur ook worden verkozen boven appartementsconstructies die gebruik maken van coöperaties of vennootschapsvormen, omdat aan deze constructies het psychologische bezwaar kleeft, dat geen eigendom of daarop lijkend zakelijk recht wordt verkregen (vgl. par. 2.3.2). Naar Nederlands recht kleven aan deze constructies daarenboven ook nog enige juridische bezwaren (zie par. 2.1.2, 4.2.5.2).

\subsection{Ontstaan en tenietgaan van appartementseigendom of appartementsrechten}

\subsubsection{Ontstaan}

Voor het ontstaan van appartementsrechten kunnen in Nederland, behalve privaatrechtelijke vereisten, ook publiekrechtelijke vereisten worden gesteld. Ingevolge de wet op de woningsplitsing (artt. 56a-56h Woningwet) heeft een eigenaar, erfpachter of opstaller van een gebouw of een stuk grond, in bij Algemene Maatregel van Bestuur aangewezen gemeenten een vergunning van B\&W nodig om tot splitsing over te kunnen gaan. Geen van de andere in dit werk beschreven landen kent een aan de Wet op de woningsplitsing equivalente regeling (zie par. 2.4.2.1).

Op grond van artikel 875a lid 1 BW (5.10.1.1 NBW) mag iedere Nederlandse eigenaar, erfpachter of opstaller (en stadsmeier of gerechtigde tot een beklemrecht) een gebouw in appartementsrechten splitsen. De splitsing geschiedt door een daartoe bestemde notariële akte, die wordt ingeschreven in de openbare registers. Aan de minuut van de akte van splitsing moet een splitsingstekening worden gehecht, waarin de begrenzing van de verschillende gedeelten wordt omschreven (art. 875d lid 2 BW; 5.10.1.2/5:109 NBW, zie par. 2.4.2.1). De appartementsrechten ontstaan pas op het moment dat de akte van splitsing in de openbare registers wordt ingeschreven. Het feit dat iedere eigenaar, erfpachter of opstaller tot splitsing van een gebouw mag overgaan, impliceert dat meerdere (mede)eigenaars van een gebouw (of medegerechtigden tot een erfpachts- of opstalrecht) eveneens tot splitsing kunnen overgaan. De wetgever heeft deze mogelijkheid niet expliciet in de wet opgenomen, maar zulks is mijns inziens ook overbodig. 
De Westduitse en Zwitserse wetgevers hebben wel een uitdrukkelijk verschil gemaakt tussen splitsing door één eigenaar (of opstaller, zie \& 8 WEG en artikel $712 \mathrm{~d}$ lid $2 \mathrm{ZGB}$ ) en splitsing door meerdere medeëigenaars (of opstallers, zie 83 WEG en art. $712 \mathrm{~d}$ lid $2 \mathrm{ZGB}$ ). In West-Duitsland moet de verklaring of overeen. komst, waarin de eigenaar c.q. de eigenaars tot splitsing overgaan, in principe in een notariële akte zijn neergelegd. Ook een schikking in een juridische procedure, neergelegd in een rechterlijk besluit, kan echter worden ingeschreven in thet "Grundbuch" (\$\& 4.WEG jo. $925 \mathrm{BGB}$ en $29 \mathrm{GBO}$, zie par. 6.2.3). In Zwitserland moet de verklaring of overeenkomst in een authentieke akte neergelegd zijn, of deel uitmaken van een testament of verdeling van een nalatenschap (art. $712 \mathrm{~d}$ lid 3 ZGB).

Ook een opstaller kan in West-Duitsland zoals vermeld tot splitsing overgaan. In dat geval heten de rechten die door de splitsing tot stand komen "Wohnungserbbaurrecht" (bij woonruimte) of "Teilerbbaurecht" (bij bedrijfsruimte) ( $\$ 30$ WEG, zie par. 6.2.2). Gerechtigden tot een opstalrecht kunnen in Zwitserland eveneens tot splitsing overgaan. De appartementseigenaars worden dan net als in West-Duitsland medegerechtigden tot het opstalrecht, medeëigenaars van het gebouw en "Sonderberechtigte" tot hun privé-gedeelten. Ze blijven echter "Stockwerkeigentümer" heten (zie par. 8.2.3) ${ }^{8}$.

Door inschrijving van de akte van splitsing in het "Grundbuch", ontstaat in Zwitserland en West-Duitsland, evenals in Nederland, de appartementseigendom of ontstaan appartementsrechten ( $\$ 4$ WEG; art. 712d ZGB, zie par. 6.2.3, 8.2.3).

Terwijl men in Nederland, West-Duitsland en Zwitserland een appartementenwet heeft aangenomen om splitsing van gebouwen in appartementen mogelijk te maken, heeft deze mogelijkheid in België en Frankrijk sinds 1804 op grond van een wettelijke regeling, en daarvoor al op grond van de costumen, bestaan. De Belgische en Franse wetgevers zijn er bij hun wettelijke regeling van het appartementsrecht dan ook van uitgegaan, dat horizontale splitsing van eigendom van onroerend goed reeds mogelijk was. In geen van beide landen is dientengevolge in de wet bepaald, hoe een splitsing in appartementen tot stand moet komen. De wettelijke regelingen zijn eenvoudig van toepassing in alle gevallen, waarin gedeelten van een gebouw aan verschillende personen afzonderlijk toekomen (vgl. art. 1 Wet 1965, par. 7.2.3 en par. 5.2.2). In België is artikel 577 bis $\$ 11 \mathrm{BW}$ bijvoorbeeld van toepassing, indien er een gebouw is, dat aan verschillende personen toekomt in "privatieve en gemene rechten" (par. 5.2.2). In Frankrijk worden blijkens artikel 1 Wet 1965 soortgelijke eisen gesteld. Daar is deze wet van toepassing in alle gevallen, waarin een gebouw of een groep van gebouwen verdeeld is tussen meerdere personen,

"par lots comprenant chacun une partie privative et une quote-part de parties communes" (art. 1 lid 1 Wet 1965).

oofdvereiste is derhalve, dat meerdere personen volle eigendom van bepaalde gedeelten van een gebouw of een groep van gebouwen hebben. Op een gebouw,

8. Erfpachtsrechten zijn in West-Duitsland en Zwitserland onbekend. 
dat in zijn geheel in medeëigendom aan meerdere personen toekomt, is het Franse en Belgische appartementsrecht niet van toepassing.

De situatie, dat verschillende gedeelten van een gebouw aan afzonderlijke personen in volle eigendom toekomen, kan op vele manieren ontstaan. In Belgie ontstaat deze situatie veelal door partijwil, door onteigening van een gedeelte van een gebouw of door acquisitieve verjaring. De partijwil is echter de belangrijkste ontstaansoorzaak van appartementseigendom. Onder partijwil moet verkoop, schenking, testamentaire making van een gedeelte van een gebouw of verdeling van een gebouw door medeëigenaars, worden begrepen. Frankrijk kent in principe dezelfde wijzen van ontstaan van appartementseigendom (par. 5.2.3, 7.2.3).

De appartementseigendom ontstaat in België door de akte, waarin de partijwil wordt uitgedrukt, door onteigening of door acquisitieve verjaring. Indien de eigendom door partijwil ontstaat, is voor zakelijke werking vereist dat de akte (acte de division/splitsingsakte) in de openbare registers voor onroerend goed wordt ingeschreven. Inschrijving kan slechts plaatsvinden, als de partijwil in een notariële akte is uitgedrukt (par. 5.2.3).

In Frankrijk moet in een authentieke akte een "état descriptif de division" worden opgenomen. Deze splitsingsbeschrijving is het document dat bestemd is om de verschillende appartementen in de openbare registers duidelijk van elkaar te kunnen onderscheiden. De splitsing in appartementen komt echter al voor de inschrijving in de openbare registers tot stand, maar kan net als in België pas na de inschrijving tegen derden worden ingeroepen (par. 7.2.3).

Appartementseigendom kan in België ook tot stand komen, indien de eigendom van de grond van de eigendom van de opstallen is gescheiden door een opstalrecht. De appartementseigenaars worden dan over het algemeen medegerechtigden tot het opstalrecht, medeëigenaars van het gebouw en volle eigenaars van hun privégedeelten (par. 5.2.3). Het opstalrecht is in Frankrijk niet in de wet geregeld. Door de jurisprudentie is het recht echter erkend, omdat artikel 553 C.c. horizontale scheiding van eigendom van de grond van de daarop staande gebouwen uitdrukkelijk toelaat. De duur van het opstalrecht kan contractueel worden beperkt. In de Franse literatuur wordt geen aandacht besteed aan de combinatie van een opstalrecht en splitsing in appartementen. Aangenomen moet echter worden dat de gerechtigde tot een opstalrecht zijn gebouw in appartementen kan splitsen, en dat de gevolgen daarvan dezelfde zijn als in België (par. 7.2.3). Een erfpachtsrecht kan in Frankrijk niet in appartementen in de zin van de Wet 1965 worden gesplitst, omdat splitsing van dit recht geen eigendom van privé-gedeelten tot gevolg heeft. Hetzelfde geldt in principe in België (par. 5.2.2, 7.2.3.).

\subsubsection{2 "Papieren splitsing"}

Een splitsing van een gebouw in appartementsrechten of appartementseigendom, voordat het gebouw zelf is opgericht, is in Nederland mogelijk op grond van artikel 875b BW (art. 5.10.1.1a / 5:107 NBW), waarin is bepaald dat een eigenaar, erfpachter of opstaller ook bevoegd is

"in verband met een door hem beoogde stichting of gewijzigde inrichting van een gebouw zijn recht op het gebouw met toebehoren en de daarbij behorende grond met toebehoren te splitsen in appartementsrechten." 
Bij een papieren splitsing moet, evenals bij een gewone splitsing "en splitsings: tekening aan de akte van splitsing worden gehecht (art. 875d lid 2 BW; art. 5.10.12 lid 2/5:109 lid 2 NBW). De appartementsrechten ontstaan vervolgens op het moment dat de akte van splitsing in de openbare registers wordt ingeschreven. De appartementsrechten kunnen dus ook voor voltooiing van het gebouw ontstaan. Deze fictie is van belang voor de overdraagbaarheid van de (zij het papieren) appartementsrechten (par. 2.4.2.1).

In West-Duitsland is een papieren splitsing eveneens mogelijk. In dat geval moeten bij de inschrijving van de akte van splitsing in het "Grundbuch" tevens de bouwtekeningen worden gevoegd. In de bouwtekening moet getekend zijn wat in de splitsingsakte (overeenkomst of verklaring) is bepaald. De appartementseigendom komt vervolgens tot stand door inschrijving van de splitsingsovereenkomst of splitsingsverklaring in thet "Grundbuch" (par. 6.2.3).

Hetzelfde geldt grosso modo voor Zwitserland. Ook daar is een "papieren splitsing" mogelijk. De bepalingen uit het ZGB staan aan zo'n papieren splitsing niet in de weg, hoewel nergens expliciet wordt vermeld dat zij mogelijk is. Uit artikel $712 \mathrm{~d}$ ZGB kan echter worden afgeleid dat een papieren splitsing niet verboden is. Aldus kan een appartementsgebouw voor, tijdens of na de bouwwerkzaamheden worden gesplitst. In de " Begründungsakt" (de splitsingsakte), die in het "Grundbuch" wordt ingeschreven, moet de ruimtelijke indeling en beschrij:ving van de verschillende appartementen in een "Aufteilungsplan" zijn opgenomen (art. 33b lid 1 GBV). Door inschrijving van de akte van splitsing in het "Grundbuch" ontstaat de "Stockwerkeigentum", ook als het gebouw in werkelijkheid nog niet bestaat (par. 8.2.3).

Frankrijk en België nemen ten aanzien van de "papieren" splitsing een bijzondere plaats in. In zekere zin is een dergelijke splitsing van een nog niet bestaand gebouw naar Belgisch recht ook mogelijk. Hiervoor is wel vereist dat degenen die tot de splitsing overgaan, een recht op de grond hebben, waarop het appartementsgebouw zal worden gebouwd. Niets verhindert de medeëigenaars van de grond om reeds voor het tot stand komen van een gebouw tot splitsing over te gaan (vgl. art. 1130 BW). De eigendom van de appartementen zelf ontstaat echter pas naarmate het gebouw wordt voltooid. Hierin verschilt het Belgische recht derhalve van het Nederlandse, Westduitse en Zwitserse recht. Een nog te bouwen appartement kan eveneens worden verkocht. Deze verkoop heeft echter slechts obligatoire gevolgen ten aanzien van de nog niet voltooide (gedeelten van) appartementen. Ten aanzien van de nog te bouwen gedeelten is de (aspirant)-verkoper namelijk nog niet beschikkingsbevoegd. Om te voorkomen dat particulieren die een woning op tekening kopen financieel nadeel lijden door faillissement of wanprestatie van de verkoper (meestal aannemers of projectontwikkelaars), is in de Belgische woningbouwwet in artikel 12 en in artt. 3 en 4 van het daarbij behorende $\mathrm{KB}$ van 21 oktober 1971, geregeld dat de verkoper zekerheid moet stellen voor de door de kopers verrichte betalingen. De woningbouwwet is overigens niet van toepassing op verkoop van in aanbouw zijnde appartementen, waarbij op de verkoper niet de plicht rust bouwwerken uit te (doen) voeren (par. 5.2.3).

Frankrijk kent een aan het Belgische recht verwant systeem. Een papieren splitsing, dat wil zeggen een splitsing van een nog op te richten gebouw, is ook in Frankrijk in zekere zin mogelijk. "Copropriétét" in de zin van de wet 1965 , ontstaat echter pas op het moment dat het gebouw (gedeeltelijk) voltooid is en het eerste 
appartement aan een verkrijger is toebedeeld. In de praktijk richten personen die een appartementsgebouw tot stand willen brengen vaak een maatschappij op die de bouw regelt en die opgeheven wordt nadat het gebouw tot stand is gekomen. Ook komt het voor dat een aantal personen een stuk grond koopt en daar zonder speciale rechtsvorm een gebouw op bouwt, dat vervolgens in appartementen wordt verdeeld. Een derde mogelijkheid is dat een eigenaar van een stuk grond op die grond bouwt, en na oprichting van het gebouw de verschillende étages verkoopt. Het is echter tevens mogelijk dat een appartement wordt verkocht, terwijl het nog niet bestaat. Dit wordt "vente à terme" genoemd en betekent dat de verkoper zich verplicht om het appartement bij voltooiing te leveren, terwijl de koper de plicht op zich neemt om het appartement bij voltooiing aan te nemen en de prijs te betalen. De eigendom gaat pas over zodra bij authentieke akte is vastgesteld dat het appartement is voltooid. Deze eigendomsovergang wordt dan geacht ex tunc (vanaf de datum van verkoop) te zijn geëffectueerd (zie art. 261-2 C.C.H.). Bovendien is het mogelijk dat de eigenaar van de grond onmiddellijk zijn rechten op de grond aan de koper overdraagt en deze eigenaar wordt van het appartement, naarmate de bouw daarvan vordert (art. 261-3 C.C.H.). De wet 1965 is op deze situaties van toepassing, zodra de eigendom is overgegaan, c.q. er sprake is van een gebouw (par. 7.2.3).

Het grote verschil tussen het Belgische en het Franse recht aan de ene kant, en het Nederlandse, Westduitse en Zwitserse aan de andere kant, blijkt in het moment van totstandkoming van de appartementseigendom, c.q. appartementsrechten te zijn gelegen. In Nederland, West-Duitsland en Zwitserland ontstaat appartementseigendom door inschrijving van de akte van splitsing, met daaraan gehecht de splitsingstekening, in de openbare registers. In Frankrijk en België ontstaat de appartementseigendom pas naarmate het gebouw wordt voltooid. Om kopers te beschermen hebben Frankrijk en België in hun woningwetten speciale regelingen ten aanzien van verkoop op tekening, opgenomen.

\subsubsection{Tenietgaan}

Splitsing in appartementsrechten, c.q. appartementseigendom, kan op verschillende wijzen eindigen. In Nederland is de belangrijkste wijze van tenietgaan van appartementsrechten de opheffing van de splitsing. Deze opheffing van de splitsing kan verschillende oorzaken hebben (art. $876 \mathrm{p} \mathrm{BW).}$

A. Ten eerste wordt splitsing in Nederland van rechtswege opgeheven bij het eindigen van een recht van erfpacht of opstal, dat in de splitsing is betrokken (art. 876p lid 1 sub a BW; art. 5.10.4.2c lid 1 sub a / 5:143 lid 1 sub a NBW).

In West-Duitsland geldt hetzelfde. Indien er sprake is van een gesplitst opstalrecht, gaat het "Wohnungserbbaurecht" teniet indien het opstalrecht eindigt of de gerechtigden tot het "Wohnungserbbaurecht" besluiten de splitsing op te heffen. Hetzelfde geldt voor Zwitserland.

Ook in België en Frankrijk kan een opstalrecht, zoals hierboven werd beschreven, aan een splitsing in appartementen ten grondslag liggen. Appartementseigendom gaat dan teniet door het eindigen van het opstalrecht, waarop de appartementseigendom is gebaseerd. 
B. Ten tweede wordt de splitsing in Nederland van rechtswege opgeheven door overschrijving in de openbare registers van een vonnis waarbij een in de splitsing betrokken perceel in zijn geheel is onteigend, terwijl geen andere percelen in de splitsing betrokken zijn (art. 876p lid 1 sub b BW; art. 5.10.4.2c lid 1 sub b / 5: 143 lid 1 sub b NBW).

In Frankrijk en België geldt in de praktijk hetzelfde. Indien alle appartementen worden onteigend, gaat de appartementseigendom door vermenging teniet.

In West-Duitsland en Zwitserland eindigt de splitsing niet van rechtswege bif onteigening. De nieuwe eigenaar, d.w.z. de Staat, kan echter door het afleggen van een verklaring ten overstaan van het "Grundbuchamt", de splitsing opheffer.

C. Volgens artikel 876p lid 2 BW (art. 5.10.4.2c lid 2/ 5:143 lid 2 NBW) geschiedt de opheffing van de splitsing in Nederland in alle andere gevallen door een daartoe bestemde notariële akte, die wordt overgeschreven in de openbare registers. De appartementseigenaars kunnen derhalve door unaniem (zie voor een uitzondering art. $876 \mathrm{~m} \mathrm{BW}$; art. 5.10.4.2 / 5:140 NBW) besluit (art. 8761 BW; art. 5.10.4.1/ 5:139 NBW) tot opheffing van de splitsing overgaan. De opheffing van de splitsing heeft tot gevolg dat tussen de ex-appartementseigenaars gewone medeëigendon ontstaat (zie ook art. 876t BW; vgl. art. 5.10.4.2g / 5:147 NBW).

Een soortgelijke regeling kennen Zwitserland en Duitsland. De splitsing kan uit het "Grundbuch" worden geschrapt op grond van een opheffingsovereenkomst tussen de appartementseigenaars. De appartementseigenaars kunnen door een gezamenlijk besluit op deze wijze te allen tijde de appartementseigendom doen eindigen ( $\$ \S 4,9$ WEG; art. $712 \mathrm{f}$ lid $1 \mathrm{ZGB}$ ). Indien alle appartementen in eigendom aan één persoon toekomen, kan deze de splitsing door een eenzijdige verklaring aan de beheerder van de openbare registers (het "Grundbuchamt") opheffen ( $\$ 9$ lid 1 sub 3 WEG).

Ook in België en Frankrijk kan de appartementseigendom eindigen door een overeenkomst van alle appartementseigenaars. Zij kunnen een akkoord sluiten met de strekking dat de appartementseigendom eindigt.

D. De splitsing wordt in Nederland in beginsel niet opgeheven indien het appartementsgebouw geheel of gedeeltelijk tenietgaat. Dit volgt enerzijds uit artikel $876 \mathrm{q}$ lid 1 sub g BW (art. 5.10.4.2d lid 1 sub g / 5:144 lid 1 sub g NBW), waarin ondermeer is bepaald dat de kantonrechter op verzoek van een appartementseigenaar kan bevelen de splitsing op te heffen, indien het gebouw ernstig is beschadigd of geheel of gedeeltelijk is gesloopt (tenzij binnen redelijke termijn herstel te verwachten is). Anderzijds volgt dit mijns inziens ook indirect uit artikel 875b BW (art. 5.10.1.1a / 5:107 NBW), dat splitsing van een niet bestaand gebouw mogelijk maakt. Het feitelijk bestaan van een gebouw is derhalve geen voorwaarde voor het bestaan van appartementsrechten.

Mijns inziens gaan appartementsrechten wel teniet door het verdwijnen van grond en gebouwen. Nu zal het niet vaak voorkomen dat de grond tenietgaat, maar helemaal uitgesloten is dit niet. Men denke aan (duurzame) overstromingen, aardbevingen, vulkaanuitbarstingen (in Nederland niet voor de hand liggend) e.d. Als de grond tenietgaat, gaat de gehele zaak die in appartementsrechten is gesplitst, teniet. In dat geval gaat het medeëigendomsrecht als component van het appartementsrecht teniet (een eigendomsrecht gaat immers teniet door het 
tenietgaan van de zaak waarop het rust), en moet worden aangenomen dat ook het beperkt zakelijk gebruiksrecht verdwijnt. Deze conclusie is mijns inziens niet in strijd met de bepalingen van het appartementsrecht. Voor deze conclusie kan worden aangeknoopt bij de artikelen $875 \mathrm{a}, 875 \mathrm{~b}$ en $876 \mathrm{q}$ BW (artt. 5.10.1.1, 5.10.1.1a, 5.10.4.2d / 5: 106, 107, 144 NBW). Deze artikelen maken slechts appartementsrechten mogelijk met betrekking tot (nog) niet (of niet meer) bestaande gebouwen. Over het niet of niet meer bestaan van het eigendonsrecht op de grond wordt niet gerept. Gelukkig zullen catastrofes, waardoor de grond duurzaam wordt vernietigd, althans aan het rechtswerkeer wordt onttrokken, in Nederland niet snel voorkomen, waardoor de hier besproken wijze van tenietgaan van academische aard is.

Voor West-Duitsland geldt ongeveer hetzelfde als voor Nederland en gaat de appartementseigendom evenmin teniet door de enkele verwoesting van het appartementsgebouw. Ook na de verwoesting blijft de appartementseigendom bestaan. Zelfs de afzonderlijke eigendom bijft juridisch bestaan, hoewel het object van het eigendomsrecht materieel niet meer bestaat. $\mathrm{Na}$ verwoesting van het gebouw eindigt volgens $\$ 9$ lid 2 sub 2 WEG de appartementseigendom, indien alle appartementseigenaars dit aan het "Grundbuchamt" verzoeken. Als het appartementsgebouw voor meer dan de helft van zijn waarde vernietigd is, terwijl de schade niet door verzekering of anderszins wordt vergoed, kan van een appartementseigenaar niet worden geëist dat hij meewerkt aan het herstel $(\$ 22$ lid 2 WEG). Opheffing van de appartementseigendom en verdeling van de medeëigendom is echter alleen mogelijk, indien dit voor dit geval uitdrukkelijk is overeengekomen ( $\$ 11$ lid $\mathbb{1}$ WEG).

Appartementsrechten gaan in Zwitserland teniet indien het gehele onroerend goed tenietgaat (bijvoorbeeld door aardverschuivingen of lawines). Indien slechts het gebouw of een gedeelte daarvan tenietgaat, eindigt de splitsing in beginsel echter niet. Elk der appartementseigenaars kan in dat geval de opheffing van de splitsing vorderen, indien het gebouw voor meer dan de helft is vernietigd en wederopbouw voor hem een zware belasting zou zijn. Andere appartementseigenaars kunnen de opheffing van de splitsing in dit geval echter verhinderen door degene die wil dat de splitsing wordt opgeheven, schadeloos te stellen (art. $712 \mathrm{f}$ lid $3 \mathrm{ZGB})$.

In België gaat appartementseigendom wel teniet, indien het gebouw geheel of gedeeltelijk wordt verwoest ${ }^{9}$. Naar Belgisch recht geldt namelijk hetzelfde als naar Frans recht, op grond waarvan appartementseigendom eveneens tenietgaat door gehele of gedeeltelijke vernietiging van het gebouw. Bij algehele vernietiging van het gebouw blijft slechts medeëigendom van de grond bestaan (als de grond ook is verdwenen, bestaat er ook geen medeëigendom meer). De (voormalige) appartementseigenaars kumnen in dat geval met absolute meerderheid van stemmen tot wederopbouw besluiten. Bij gedeeltelijke vernietiging gaat slechits de appartementseigendom van de eigenaars wier appartementen verwoest zijn, teniet. Zij blijven wel medeëigenaar van grond en gebouwen. Hierbij geldt dat de vergadering van eigenaars bij absolute meerderheid van stemmen tot wederopbouw kan besluiten. Indien het gebouw voor minder dan de helft is verwoest, is wederopbouw 
echter verplicht, indien meer dan de helft van de eigenaars wier appartement werd verwoest, dit wensen (art. 38-41 Wet 1965)

E. Over de vraag of appartementsrechten in Nederland door non-usus teniet kunnen gaan, zij verwezen naar paragraaf 2.4.2.2.

F. De appartementseigendom kan in België en Frankrijk tenietgaam door vermenging (d.w.z. dat alle appartementen in een hand verenigd worden) bij aankoop van alle appartementen door één persoon. Dientengevolge eindigt de splitsing eveneens bij inbreng van alle appartementen in een vennootschap.

In Nederland, West-Duitsland en Zwitserland eindigt de splitsing niet door vermenging. Ook indien alle appartementen in één hand verenigd worden, blijft de splitsing intact. De eigenaar kan de splitsing vervolgens door een opheffingsverklaring beëindigen (zie hierboven onder $\mathrm{C}$ ).

\subsection{Administratie en beheer van appartementsgebouwen}

In het onderstaande zal op de hoofdpunten van de regelingen ten aanzien van administratie en beheer van appartementen in de verschillende landen worden ingegaan. Voor de meer gedetailleerde uitwerkingen zij verwezen naar de paragrafen $2.4 .3,5.2 .4,6.2 .4,7.2 .4,8.2 .4$.

Iedere appartementsgemeenschap heeft, gezien het feit dat meerdere personen altijd gezamenlijk gerechtigd zijn tot bepaalde gedeelten van een gebouw en zij samen over bepaalde zaken moeten beslissen, een interne organisatiestructuur nodig, die een goede administratie en een goed beheer waarborgt.

In alle in dit werk beschreven rechtsstelsels, zijn de appartementseigenaars tenminste medegerechtigde tot de gemeenschappelijke gedeelten van het appartementsgebouw. Iedere appartementseigenaar is derhalve lid van de gemeenschap van appartementseigenaars.

Aan deze gemeenschap van appartementseigenaars is in Nederland de vereniging van eigenaars als organisatiestructuur gekoppeld. Deze V.v.E. moet blijkens artikel 875f lid 1 sub e BW (art. 5.10.1.5 lid 1 sub e / 5:112 lid 1 sub e NBW) in elke akte van splitsing worden opgericht. Behalve deelgenoot in de appartementsgemeenschap is iedere appartementseigenaar daarom ook lid van de V.v.E. Dit lidmaatschap heeft de appartementseigenaar van rechtswege (art. 876 lid $1 \mathrm{BW}$; art. 5.10.2.1 lid 1/ 5:125 lid $\mathbb{1} \mathrm{NBW}$ ). Naast dit wettelijk vastgestelde lidmaatschap van de V.v.E, kan aan alle of bepaalde appartementsrechten het lidmaatschap van een andere, nader in het reglement omschreven vereniging worden verbonden, voor zover dit lidmaatschap in overeenstemming is met de statuten wan deze vereniging (art. 875f lid 3 BW; art. 5.10.1.5 lid 3/5: 112 lid 3 NBW).

De V.v.E. is een rechtspersoon (art. 876 lid 2 BW; art. 5.10.2.0 lid 1/ 5:124 lid $1 \mathrm{NBW}$ ), die ontstaat zodra de appartementsrechten aan verschillende personen toebehoren.

Behalve Nederland kent alleen Frankrijk nog de koppeling tussen de gemeenschap van appartementseigenaars en een vereniging van eigenaars. Ook in Frankrijk vormen de appartementseigenaars een vereniging met rechtspersoonlijkheid, waarvan de appartementseigenaars qualitate qua lid zijn. Deze vereniging 
kan de rechtsvorm van een coöperatieve vereniging/coöperatie aannemen (vgl. ook artit. 40-42 decreet 1967).

In de praktijk bestaan er echter weinig verschillen in organisatie tussen Frankrijk en Nederland aan de ene kant, en België, West-Duitsland en Zwitserland aan de andere kant. Zonder organen is een vereniging immers een lege huls. Deze organen verschillen, zoals uit het navolgende zal blijken, in taken en bevoegdheden weinig van elkaar.

\section{A. De vergadering van eigenaars}

Alle vijf landen kennen als hoogste bestuursorgaan van de vereniging, c.q. de gemeenschap, de (algemene) vergadering van appartementseigenaars. Deze vergadering van eigenaars heeft alle bevoegdheden, die niet aan andere organen van de vereniging, c.q. gemeenschap zijn toebedeeld (art. 876b lid 1 BW, 5.10.2.1 lid 1 / 5:125 lid 1 NBW; $\$ 23$ lid 1 WEG; art. 712m lid 1 ZGB; Frankrijk art. 7 e.v. Wet 1965).

In België is voor de administratie en het beheer artikel 577 bis $\$ 6$ BW van belang. Deze paragraaf bepaalt dat de afzonderlijke deelgenoten daden van beheer en daden van beschikking over de gemeenschappelijke zaak slechts gezamenlijk (bij unaniem genomen besluit) kunnen verrichten. In het reglement wordt over het algemeen een uitgewerkte regeling met betrekking tot het beheer van appartementsgebouwen opgenomen.

De vergadering van eigenaars komt in Nederland in beginsel eenmaal per jaar bijeen (vgl. art. 33 modelreglement 1983; art. 38 modelreglement 1987). Hetzelfde gelldt voor West-Duitsland ( $\$ 24$ lid 1 WEG), België (artikel 7.01 modelreglement Aeby) en Frankrijk (art. 7 decreet 1967). Ook in Zwitserland moet de vergadering van eigenaars minstens eenmaal per jaar worden bijeengeroepen. Dit blijkt impliciet uit artikel 712m ZGB en $\$ 16$ Reglement Peter-Ruetschi.

ledere appartementseigenaar heeft stemrecht in de vergadering van eigenaars. In Nederland is in het reglement van splitsing geregeld, welk aantal stemmen iedere appartementseigenaar heeft. Vaak zal aan alle appartementseigenaars hetzelfde aantal stemmen toekomen, naar evenredigheid van het aandeel in de gemeenschap. Deze aandelen in de gemeenschap zijn in beginsel eveneens gelijk, tenzij in de akte van splitsing anders is bepaald (art. 875g lid 1 BW; art. 5.10.1.6 lid 1/5:113 lid 1 NBW). Niet in alle gevallen hebben de appartementseigenaars hetzelfde aantal stemmen. In het reglement van splitsing kan namelijk een afwijkende stemverhouding worden neergelegd (vgl. art. 34 lid 2 modelreglement 1983).

In West-Duitsland heeft iedere appartementseigenaar ter vergadering slechts eén stem. Men kent een zogenaamd "Stimmrecht nach Köpfen". Ook in Zwitserland geldt het principe van het "Kopfstimmrecht". Het stemrecht is dus gekoppeld aan de persoon, niet aan het appartement. Het beginsel van dit "Kopfstimmrecht" wordt zelfs zover doorgevoerd, dat in het geval dat éen persoon meerdere appartementen in eigendom heeft, hem eveneens slechts één stem in de vergadering toekómt ( $\$$ 16, IV reglement Peter-Ruetschi; $\$ 25$ lid 2 WEG).

In België geldt evenals in Nederland het beginsel van stemrecht naar rato van aandelen. Iedere appartementseigenaar heeft in de vergadering stemrecht naar rato 
van het aantal aandelen dat hij in de algemene gemene delen bezit, indien er beslissingen worden genomen over de gemeenschappelijke gedeelten of indien de beslissingen voor alle eigenaars van belang zijn. Indien er echter beslissingen worden genomen, die uitsluitend van belang zijn voor een bepaalde reeks privegedeelten, waaraan bijzondere gemeenschappelijke gedeelten verbonden zijn, dan heeft iedere appartementseigenaar stemrecht naar rato van het aantal aandelen dat hij in de bijzondere gemeenschappelijke gedeelten bezit (art. $7.05 \$ 1$ modelreglement Aeby). Als bijvoorbeeld een besluit moet worden genomen over een verwarmingsketel die aan twee bepaalde appartementseigenaars gemeenschappelijk toekomt, kunnen slechts deze twee eigenaars over het te nemen besluit stemmen. Afhankelijk van de aard van de beslissing zijn er dus verschillende stemverhoudingen binnen een appartementen-complex.

In Frankrijk geldt eveneens het stemrecht naar rato van de aandelen. Iedere appartementseigenaar heeft een aantal stemmen in de vergadering van eigenaars, afhankelijk van de grootte van zijn aandeel in de gemeenschap. Indien een appartementseigenaar meer dan de helft van de aandelen in de gemeenschap bezit, wordt zijn stemmenaantal echter gereduceerd tot de som van het aantal stemmen van de overige appartementseigenaars. Aldus wordt voorkomen dat één eigenaar binnen de appartementsgemeenschap de dienst uitmaakt.

Indien één appartementsrecht aan meerdere personen gezamenlijk toekomt, kunnen deze hun gezamenlijk stemrecht in beginsel slechts uitoefenen door schriftelijk uit hun midden een stemgerechtigde aan te wijzen (art. 35 mode]reglement 1983; art. 40 modelreglement 1987). Hetzelfde geldt mutatis mutandis in West-Duitsland ( $\$ 25$ lid 1 en 2 WEG; art. 7 modelreglement), België ${ }^{10}$, Frankrijk (art. 23 Wet 1965) en Zwitserland (art. 712o ZGB). Dit geldt niet alleen bij medeèigendom van een appartement, maar ook bijvoorbeeld in de verhouding tussen vruchtgebruiker en bloot eigenaar (art. 23 Wet 1965) ${ }^{11}$. In Frankrijk geldt bovendien, dat als de eigenaar en de vruchtgebruiker, of de medeëigenaars van een appartement geen overeenstemming kunnen bereiken, op verzoek van een van de belanghebbenden of de administrateur een vertegenwoordiger door de president van het "Tribunal de grande instance" kan worden benoemd (art. 23 wet 1965). In Nederland oefent de vruchtgebruiker krachtens artikel 875q BW (art. 5.10.1.15b / 5:123 NBW) het stemrecht in de vergadering van eigenaars uit, tenzij bij de instelling van het vruchtgebruik anders is bepaald (art. $875 \mathrm{q}$ lid $3 \mathrm{BW}$; art. 5.10.1.15b lid $3 / 5: 123$ lid $3 \mathrm{NBW}$ ). Dezelfde regeling geldt in Zwitserland (art. 7120 ZGB).

In West-Duitsland is het omstreden, of en in hoeverre een vruchtgebruiker bevoegd is om te stemmen in de vergadering van eigenaars. Volgens Bärmann ${ }^{12}$ is de vruchtgebruiker bevoegd in alle gevallen mee te stemmen, waarin beslist wordt over gebruik, beheer en administratie van de gemeenschappelijke gedeelten, dus in alle gevallen op grond van $\$ \$ 15,16$ en 21 WEG. De vruchtgebruiker is echter niet bevoegd bij besluiten ten aanzien van beschikking over de gemeenschappelijke gedeelten te stemmen. Bärmann baseert zich hierbij op $\$ 1066$ lid $1 \mathrm{BGB}$.

10. Aldus Kadaner, ble, 168, 169.

11. Zie voor Belgiê: Kadaner, blz. 168, 169.

12. Bärmann (Kommentar), blz. 552. 
De vergadering van eigenaars beslist in Nederland, West-Duitsland en Zwitserland in beginsel bij gewone meerderheid van de uitgebrachte stemmen (art. 876b lid 2 BW; art. 5.10.2.1b lid 1/ 5:127 lid 1 NBW; art. 37 modelreglement 1983; art. 42 modelreglement 1987; $\$ 25$ lid 3 WEG; art. 67 lid 2 ZGB). Ditzelfde geldt in Belgiè, waar artikel $7.06 \S 3$ modelreglement Aeby bepaalt, dat de vergadering zijn besluiten bij gewone meerderheid van stemmen neemt, tenzij in het reglement anders is bepaald. In artikel 7.06 wordt dus afgeweken van artikel 577 bis $\$ 6 \mathrm{BW}$. De in dit artikel vereiste unanimiteit wordt voor het beheer van de gemene delen aan de kant gezet. Dit kan ook, aangezien artikel 577 bis BW een bepaling van regelend recht is. Ook de Franse vergadering van eigenaars neemt zijn besluiten bij gewone meerderheid van stemmen van de ter vergadering aanwezige of vertegenwoordigde appartementseigenaars, voorzover in de wet niet anders is bepaald (art. 24 wet 1965).

In het reglement van splitsing of in de wet, kan echter een andere stemverhouding verplicht worden gesteld. Zo wordt in Nederland bijvoorbeeld in artikel 27 van het modelreglement 1983 voor ontzegging van verder gebruik een meerderheid van tenminste twee derde van de uitgebrachte stemmen vereist, in een vergadering waarin tenminste tweederde van het totale aantal stemmen vertegenwoordigd is.

In Zwitserland is in sommige gevallen eveneens een gekwalificeerde meerderheid vereist, waarbij een besluit moet worden genomen door de meerderheid van alle appartements-eigenaars, die tevens meer dan de helft van de aandelen van het gebouw vertegenwoordigen. Een gekwalificeerde meerderheid is bijvoorbeeld vereist voor vaststelling of verandering van het reglement van splitsing (art. $712 \mathrm{~g}$ lid $3 \mathrm{ZGB}$ ) en voor het doen uitvoeren van nuttige bouwkundige maatregelen (art. 647d ZGB).

Ook in Frankrijk geldt voor bepaalde besluiten een afwijkend meerderheidsvereiste. In sommige gevallen, neergelegd in artikel 25 is bijvoorbeeld een meerderheid van stemmen van alle appartementseigenaars vereist. Deze meerderheid is ondermeer vereist bij beslissingen over ontslag en benoeming van een administrateur of van leden van de verenigingsraad (zie hierna). Voor een aantal besluiten is zelfs een tweederde meerderheid van stemmen van alle appartementseigenaars vereist. Tweederde meerderheid is bijvoorbeeld nodig voor vaststelling of verandering van het reglement voor zover de vaststelling of verandering betrekking heeft op het gebruik, genot en beheer van de gemeenschappelijke gedeelten. In beginsel kan de vergadering van eigenaars aan een appartementseigenaar geen verandering van bestemming of genot van zijn privé-gedeelte opleggen. Artikel 26-I Wet 1965 bepaalt hierbij echter dat de vergadering van eigenaars met tweederde meerderheid van alle stemmen, kan besluiten tot werken ter verbetering van de veiligheid van personen en goederen door middel van deursloten e.d., die het mogelijk maken de toegang tot het gebouw te regelen, ook indien dit ten koste gaat van de bestemming of het genot van de privé-gedeelten.

Voor zeer belangrijke beslissingen is in Nederland zelfs unanimiteit vereist, bijvoorbeeld bij wijziging van de akte van splitsing en opheffing van de splitsing (artt. 8761 lid 1 en 876p lid 2 BW; artt. 5.10.4.1 lid $1 / 5: 139$ lid 1 en 5.10.4.2c lid $2 / 5: 143$ lid 2 NBW). Ook in West-Duitsland (vgl. \$ 4 WEG) ${ }^{13}$ en Zwitserland

13. Vgl. ook Bärmann (Kommentar), blz. 451, 453. 
moeten sommige besiuiten unaniem worden genomen. Dit unanimiteitsvoorschrift geldt bijwoorbeeld voor verandering van de medeëigendomsaandelen (art. 712e lid 2 ZGB), voor de verandering van de bestemming van het gebouw en de afzonderlijke appartementsrechten (art. 648 lid 2 ZGB) en voor opheffing van de splitsing (art. $712 \mathrm{f}$ lid $2 \mathrm{ZGB}$ ). In België en Frankrijk is in bepaalde gevallen eveneens eenstemmigheid vereist. Ten aanzien van België moet echter worden opgemerkt, dat de appartementseigenaars een grote vrijheid hebben om de stemmenmeerderheid in het reglement te regelen ${ }^{14}$. In Frankrijk kan bijvoorbeeld een besluit on nieuwe prive-gedeelten aan het gebouw toe te voegen, slechts unaniem worden genomen (art. 35 wet 1965).

Het is op deze plaats niet zinvol, om van alle mogelijke besluiten in de verschillende landen, aan te geven welke meerderheid is vereist voor de geldigheid van die besluiten. Als algemene lijn kan worden vastgesteld, dat algemene administratieve besluiten bij gewone meerderheid van stemmen moeten worden genomen, en er zwaardere eisen worden gesteld, naarmate het belang van de te nemen besluiten groter wordt. Dit betekent dat bepaalde besluiten die diepgaand ingrijpen in de (rechts)positie van de individuele appartementseigenaars, zelfs unaniem moeten worden genomen. Dit is bijwoorbeeld het geval bij een besluit tot opheffing van de splitsing.

Zoals al blijkt uit het voorgaande is het stemrecht in Nederland gekoppeld aan het aandeel in de gemeenschap, en niet aan de persoon van de appartementseigenaar. In West-Duitsland en Zwitserland geldt daarentegen het beginsel van het zogenaamde "Kopfstimmrecht". De koppeling van stemrecht aan de aandelen in de gemeenschap, kan tot gevolg hebben dat een eigenaar die tot meerdere appartementsrechten gerechtigd is, de vergadering van eigenaars beheerst. In WestDuitsland en Zwitserland is deze situatie, voor zover in het reglement van splitsing niet van thet "Kopfstimmrecht" wordt afgeweken, uitgesloten. De ratio van dit hoofdelijk stemrecht is voorkoming van de situatie, dat één enkele appartementseigenaar de vergadering van eigenaars beheerst. Deze situatie is in Nederland, België en Frankrijk in beginsel wel mogelijk.

Daarbij moeten we echter bedenken dat dit overwicht in de praktijk nagenoeg. uitsluitend zal bestaan ten aanzien van besluiten van weinig belang. De belangrijkere besluiten moeten immers bij gekwalificeerde meerderheid of zelfs unaniem worden genomen. Daardoor wordt het overwicht van bepaalde eigenaars met zeer veel stemmen enigszins gecompenseerd. Bij minder belangrijke beslissingen kunnen zij onder omstandigheden de dienst uitmaken, maar naarmate de te nemen beslissing belangrijker wordt, wordt het stemoverwicht enigermate teniet gedaan. In West-Duitsland en Zwitserland geldt het "Kopfstimmrecht" in combinatie met deze bijzondere meerderheidsvereisten. De individuele appartementseigenaars worden aldus in grote mate beschermd tegen een overwicht van anderen met meer appartementen. De vraag is of dit wenselijk is. Ik zou deze vraag ontkennend willen beantwoorden. Mijns inziens verdient een eigenaar, die een groter aandeel in de gemeenschap bezit, ook een sterker stemrecht. Zijn belangen zijn immers, absoluut gezien, veell groter dan die van zijn "kleinere" deelgenoten. Dit betekent niet dat daarom alle bescherming aan de eigenaars met een kleiner aandeel zou

1.4. Acby, blz. 402. 
moeten worden ontzegd. Het vereiste van een grotere meerderheid voor belangrijke besluiten bewerkstelligt echter voldoende bescherming.

In Nederland en Frankrijk worden in beginsel geen bijzondere eisen aan de algemene geldigheid van besluiten van de vergadering van eigenaars gesteld. In beginsel is de vergadering altijd bevoegd om besluiten met een gewone meerderheid van stemmen van de aanwezige appartementseigenaars te nemen. Dit is slechts anders indien in de wet of het reglement van splitsing, een bepaalde gekwalificeerde meerderheid wordt voorgeschreven. In Nederland schrijft het modelreglement 1983 bijvoorbeeld in artikel 37 lid 5 voor, dat de vergadering slechts geldig kan besluiten, indien in de vergadering meer dan de helft van het totale aantal stemmen kan worden uitgebracht. Als de vergadering niet aan dit vereiste voldoet, moet een nieuwe vergadering worden uitgeschreven. Deze tweede vergadering kan geldig besluiten, ongeacht het aantal aanwezige of vertegenwoordigde stemmen.

In West-Duitsland daarentegen kan de vergadering slechts geldig besluiten, indien ter vergadering meer dan de helft van de medeëigendomsaandelen, berekend naar de in de openbare registers ingeschreven grootte van de aandelen, vertegenwoordigd is ( $\$ 25$ lid 3 WEG). Indien een vergadering niet aan deze eis voldoet, moet de administrateur een nieuwe vergadering uitschrijven, die ongeacht de omvang van de vertegenwoordigde aandelen bevoegd is om besluiten te nemen ( $\$ 25$ lid 4 WEG).

In België is de algemene vergadering slechts geldig samengesteld indien tenminste een aantal personen aanwezig is, dat de helft van het totale aantal stemmen vertegenwoordigt (art. 7.06 modelreglement Aeby). Als de vergadering niet aan deze eis voldoet, moet tussen 14 en 30 dagen na de eerste vergadering, een nieuwe worden bijeengeroepen. Deze tweede vergadering kan vervolgens ook bij onvoldoende opkomst beslissen over de aangekondigde agendapunten.

Zwitserland kent dezelfde regeling als België. Ten aanzien van de tweede vergadering geldt echter, dat zij niet binnen 10 dagen na de eerste mag plaatsvinden. De tweede vergadering is bevoegd om besluiten te nemen, indien tenminste eenderde van alle appartementseigenaars aanwezig of vertegenwoordigd zijn, met een minimum van twee personen (art. 712p ZGB).

\section{B. De administrateur}

Bebalve een vergadering van eigenaars, hebben de landen waarvan in dit werk het appartementsrecht is besproken, een ander orgaan van de vereniging, c.q. gemeenschap, gemeen. Bedoeld wordt de administrateur, die in alle landen met het dagelijkse bestuur van de vereniging of gemeenschap is belast.

In Nederland wordt het bestuur van de V.v.E. gevormd door één of meer administrateurs (art. 876e lid $1 \mathrm{BW}$; art. 5.10.2.1e / S:131 NBW). In de praktijk is er meestal slechts één administrateur.

De administrateur wordt benoemd door de vergadering van eigenaars en kan te allen tijde door deze vergadering worden geschorst of ontslagen (art. 5.10.2.1e / 5:131 NBW; art. 876e lid $2 \mathrm{BW}$ ). In beginsel kan iedereen - natuurlijk persoon of 
rechtspersoon - tot administrateur worden benoemd. In de praktijk wordt echter veelal een makelaar tot administrateur aangewezen.

Benoeming van de administrateur is in Nederland, West-Duitsland en Frankrijk verplicht. In Zwitserland en België bestaat deze verplichting niet, maar wordt in de praktijk nagenoeg altijd toch een administrateur benoemd. In West-Duitsland mag de benoeming slechts voor de duur van maximaal vijf jaar gelden. $\mathrm{Na}$ afloop van de benoeming kan de administrateur echter opnieuw worden benoend ( $\$ 26$ lid 1 en 2 WEG). Indien de benoeming van de administrateur uitblijft kan elke appartementseigenaar het "Amtsgericht" om een vervangende benoeming verzoeken ( $\$ 43$ lid 1 sub 1 jo. 26 lid 3 WEG). Ook in Zwitserland kan iedere appartementseigenaar benoeming van een administrateur door de rechter vorderen, indien benoeming door de vergadering uitblijft (art. $712 q$ lid 1 ZGB). Dit zelfde recht komt toe aan de verzekeraar van het gebouw, de houder van een zakelijk zekerheidsrecht op het gebouw (art. $712 \mathrm{q}$ lid 2 ZGB) en aan ieder ander die belang heeft bij de benoeming van een administrateur.

In België is omtrent benoeming van de administrateur door de rechter niets bepaald. In beginsel kan hij voor onbepaalde tijd worden benoemd. Het is echter eveneens mogelijk dat hij voor bepaalde tijd wordt benoemd (par. 5.2.4).

Anders dan in België, waar benoeming van een administrateur niet wettelijk is voorgeschreven, maar in de praktijk wel steeds plaatsvindt, stelt artikel 17 Wet 1965 in Frankrijk de benoeming van een administrateur verplicht. Indien een administrateur is benoemd voordat de eerste vergadering van eigenaars bijeen komt, moet de benoeming worden goedgekeurd door de vergadering van eigenaars (vgl. hierover artt. 17 Wet 1965 en 46-49 decreet 1967).

De administrateur kan in Frankrijk in het reglement worden aangewezen, maar ook door de vergadering van eigenaars of de verenigingsraad worden benoemd. Een en ander is afhankelijk van de bepalingen van het reglement. Bovendien kan de administrateur op verzoek van een eigenaar door het "Tribunal de grande instance" worden benoemd, indien het reglement geen administrateur aanwijst en de vergadering geen administrateur benoemt.

Zoals hierboven al werd vermeld, kan de administrateur in Nederland te allen tijde door de vergadering van eigenaars worden ontslagen (art. 5.10.2.1e / 5:131 NBW; art. $876 \mathrm{e}$ lid $2 \mathrm{BW}$ ).

In beginsel kan de administrateur in West-Duitsland ook te allen tijde weer worden ontslagen, ook voordat zijn termijñ is afgelopen. Ingevolge $\$ 26$ lid 1 WEG kan deze ontslagbevoegdheid echter in het reglement worden beperkt tot ontslag wegens gewichtige redenen.

De vergadering van eigenaars kan in Zwitserland de administrateur ook te allen tijde weer ontslaan. Voor ontslag hoeven geen gewichtige redenen te bestaan. In de praktijk wordt echter meestal een "Verwaltungsvertrag" met de administrateur gesloten en zal deze aan willekeurig ontslag in de weg staan, omdat een dergelijk ontslag de gemeenschap van appartementseigenaars schadeplichtig kan maken. Een en ander hangt uiteraard af van de concrete overeenkomst (zie artt. 712q, 712r ZGB).

In België kan de administrateur voor bepaalde tijd worden benoemd, waarbij theoretisch ook kan worden bepaald, dat hij niet voor afloop van zijn benoemings- 
duur kan worden ontslagen. Hij kan echter tevens voor onbepaalde tijd worden benoemd.

In Frankrijk geldt in beginsel hetzelfde. De administrateur kan eveneens door de vergadering van eigenaars worden ontslagen. Indien de administrateur in het reglement of door de vergadering voor bepaalde tijd is benoemd, eindigt zijn benoeming in beginsel slechts door het verstrijken van de benoemingsduur. Hij kan echter ook tussentijds worden ontslagen, indien daarwoor een gewichtige reden bestaat. Als de administrateur in Frankrijk door de president van het "Tribunal de grande instance" is benoemd, eindigt zijn benoeming door een normale benoeming van een administrateur door de vergadering van eigenaars.

Zoals bij Zwitserland al werd vermeld, wordt in de praktijk een overeenkomst met de administrateur gesloten. Dit geldt voor alle in dit werk besproken landen. Daarom ook zal de mogelijkheid om de administrateur in de praktijk te ontslaan, afhangen van hetgeen in de overeenkomst is bepaald, omdat bij niet nakoming van de overeenkomst de vereniging schadeplichtig zal zijn. Dit betekent overigens voor Nederland mijns inziens niet dat de vereniging dan met de administrateur blijft opgescheept, maar wel dat zij bijvoorbeeld de financiële verplichtingen wan de administratieovereenkomst zal moeten nakomen. De vereniging kan de administrateur dus te allen tijde "ontslaan", maar dit betekent niet dat zij daarom nooit wanprestatie ten opzichte van deze administrateur kan plegen.

De administrateur heeft tot taak de geldelijke middelen van de vereniging te beheren en zorg te dragen voor de tenuitvoerlegging van de besluiten van de vergadering van eigenaars. In de statuten kunnen nog andere bevoegdheden aan de administrateur worden toegekend (art. 876e lid 3 en 4 BW; 5.10.2.1e lid 3 en 4 / 5:131 lid 3 en 4 NBW). In elk geval moet de administrateur binnen zes maanden na afloop van elk boekjaar een jaarverslag uitbrengen en rekening en verantwoording afleggen voor het door hem gevoerde bestuur (876e lid $5 \mathrm{BW}$. Naar toekomstig recht geldt hetzelfde op grond van art. 5.10.2.1i / 5:135 NBW jo. 2:48 BW). Bovendien is hij bijvoorbeeld verantwoordelijk voor het bijeenroepen van de vergadering van eigenaars (art. $876 \mathrm{~b}$ lid $3 \mathrm{BW}$; art. 5.10.2.1b lid $2 / 5: 127$ lid 2 NBW). In België (vgl. art. 7.02 modelreglement Aeby), West-Duitsland ( $\$ 24$ lid 2; \$27 WEG), Frankrijk (art. 18 Wet 1965) en Zwitserland (art. 712s ZGB) heeft de administrateur nagenoeg dezelfde taken.

\section{De voorzitter}

Behalve de vergadering van eigenaars en de administrateur, kent het Nederlandse appartementsrecht ook nog een voorzitter van de vergadering van eigenaars. Deze voorzitter van de vergadering van eigenaars wordt, tenzij de statuten anders bepalen, door de vergadering uit haar midden benoemd. Behalve de administrateur heeft ook de voorzitter het recht de vergadering van eigenaars bijeen te roepen. De voorzitter vervangt verder de administrateur bij diens belet of ontstentenis, tenzij in de statuten of door de vergadering anders wordt bepaald (art. $876 \mathrm{~g}$ lid $1 \mathrm{BW}$; art. 5.10.2.1g lid 1/5:133 lid $1 \mathrm{NBW}$ ). 
In België wordt door de algemene vergadering meestal een bestuur benoemd. Dit bestaat uit een voorzitter en een secretaris, welke laatste vaak gelijk is aan de administrateur en geen appartementseigenaar hoeft te zijn ${ }^{15}$.

Ook in Frankrijk wordt de voorzitter van de vereniging van eigenaars door de vergadering van eigenaars uit haar midden benoemd. Volgens het reglement Denis kan de administrateur of zijn echtgeno(o)t(e) het voorzitterschap niet op zich nemen. Bovendien moet er een bestuur worden gevormd, waarin behalve de voorzitter twee notulisten en een secretaris zitting hebben.

In West-Duitsland wordt geen aparte voorzitter van de vergadering benoemd, maar neemt de administrateur deze taak op zich ( $\$ 24$ lid 5 WEG). Hetzelfde geldt in beginsel in Zwitserland, zij het dat ook een derde die geen appartementseigenaar is, desnoods voor één dag, tot voorzitter kan worden benoemd (vgll. $712 \mathrm{n}$ lid $1 \mathrm{ZGB}$ ).

\section{Commissarissen/Venwaltungsbeirat/Ausschuss en Abgeordneter en conseil syndical}

De hierboven genoemde organen van de Nederlandse vereniging van eigemaars moeten verplicht worden ingesteld of bestaan reeds op grond van de wet (de vergadering). In de statuten van de vereniging van eigenaars kan daarenboven worden bepaald dat commissarissen toezicht uitoefenen op de administrateur (vgl. art. 876i BW; art. 5.10.2.1i / 5:135 lid 1 NBW jo. 2:47 en 2:48 BW).

Ook het Westduitse appartementsrecht opent de mogelijkheid om een dergelijk orgaan in het leven te roepen. De instelling van dit zogenaamde beheersadviescollege ("Verwaltungsbeirat") is evenmin als in Nederland verplicht. Dit college kan worden ingesteld om de administrateur bij te staan bij de administratie en het beheer en om als kascommissie te fungeren ten aanzien van de door de administrateur opgestelde begroting. Het college wordt samengesteld uit drie appartementseigenaars.

In Zwitserland heeft de vergadering van eigenaars ingevolge artikel $712 \mathrm{~m}$ lid 1 sub 3 ZGB de bevoegdheid een "Ausschuss" (commissie) of een "Abgeordneter" (afgevaardigde) te kiezen, waaraan zij administratieve bevoegdheden kan delegeren. Zo kan aan deze commissie of afgevaardigde bijvoorbeeld de taak worden opgedragen om de administrateur te assisteren, zijn beheer te controleren en de vergadering van eigenaars daarover in te lichten. De wet vermeldt verder niets over de commissie of de afgevaardigde. De gemeenschap van appartementseigenaars mag zelf beslissen, of zij naast de administrateur nog een commissie of afgevaardigde wil benoemen. Als lid van een commissie of als afgevaardigde kunnen leden van de gemeenschap of derden worden gekozen.

Naar Belgisch recht is het eveneens mogelijk dat de appartementseigenaars uit hun midden een raad van beheer benoemen. Deze raad van beheer heeft tot taak om de beheerder te assisteren en regelmatig te controleren.

In Frankrijk is het instellen van een conseil syndical, een verenigingsraad in beginsel verplicht. De vereniging moet deze verenigingsraad ingevolge artikel 21 Wet 1965 (zoals gewijzigd bij wet van 31 dec. 1985), instellen. De raad adviseert en controleert de administrateur. Zijn leden worden door de vergadering van

15. Aeby, blz. 403,404 . 
eigenaars uit de appartementseigenaars benoemd. Instelling van een verenigingsraad kan achterwege blijven, indien de appartementseigenaars zulks met tweederde meerderheid van alle stemmen van alle appartementseigenaars, besluiten.

Zoals blijkt, kennen alle vijf de landen uaast de administrateur, de vergadering van eigenaars en de voorzitter van de vergadering, nog een vierde verenigings-, c.q. gemeenschapsorgaan, dat hoofdzakelijk belast is met toezicht op en assistentie van de administrateur. Frankrijk is het enige land, waar instelling van dit orgaan in beginsel verplicht is. In Nederland hebben de commissarissen slechts de bevoegdheid de administrateur te controleren. Hoewel uit jurisprudentie en literatuur van de bestudeerde buitenlandse rechtsstelsels niet blijkt dat de assistentietaak in de praktijk veel vruchten afwerpt, is het mijns inziens aan te bevelen deze taak in artikel $876 \mathrm{i}$ BW, c.q. artikel 5.10.2.1i / 5:135 NBW te verankeren. Met name bij grote appartementencomplexen, waar waarschijnlijk de grootste behoefte bestaat aan benoeming van commissarissen, zal de administrateur vaak assistentie kunnen gebruiken. Een voordeel hiervan is dat de administrateur minder werk hoeft te verrichten, waardoor de kosten voor de administrateur dalen, en de commissarissen met de administrateur in een meer collegiale verhouding tot elkaar komen te staan, hetgeen de samenwerking, in elk geval van de zijde van de administrateur, alleen maar ten goede kan komen.

Tenslotte is het interessant om in deze paragraaf te wijzen op de mogelijkheid in het Franse appartementsrecht, om een tweede, secundaire vereniging van eigenaars op te richten. Indien het onroerend goed bestaat uit meerdere gebouwen, kunnen de appartementseigenaars die samen alle aandelen in een of meer gebouwen hebben, besluiten bij meerderheid van stemmen conform artikel 25 , dat een vereniging van eigenaars tussen hen wordt opgericht, een zogenaamde ondergeschikte (secundaire) vereniging van eigenaars. Deze ondergeschikte vereniging heeft tot doel om het beheer, het onderhoud en de interne verbetering van het gebouw of de gebouwen te regelen, waarvan de eigenaars tot oprichting van de vereniging hebben besloten. Evenzeer kunnen de appartementseigenaars die alle aandelen van een gebouw hebben in een appartementsgemeenschap van meerdere gebouwen, verlangen dat de medeëigendom van hun gebouw wordt losgekoppeld van de medeëigendom van de groep van gebouwen waarvan hun gebouw deel uitmaakt. De "afscheiding" wordt vastgesteld bij meerderheidsbesluit conform artikel 25 door de algemene vergadering van appartementseigenaars van het gehele appartementencomplex. (zie verder artt. 27 en 28 wet 1965). De verschillende verenigingen en eventueel bouwmaatschappijen die binnen een appartementsgemeenschap bestaan, kunnen zich onderling in samenwerkingsverbanden verenigen (art. 29 wet 1965 en artt. 43-45 decreet 1967).

In Nederland is "opsplitsing" van de V.v.E. niet mogelijk. De Hoge Raad heeft hieromtrent bepaald dat het niet mogelijk is om in een flatgebouw met drie afzonderlijke trappenhuizen, betrokken in éen splitsing, drie verschillende V.v.E.'s op te richten. Wel is het mogelijk dat naast de V.v.E. andere verenigingen worden opgericht, waarvan het lidmaatschap aan bepaalde appartementsrechten wordt verbonden (art. $875 f$ lid 3 BW; art. 5.10.1.5 lid $3 / 5: 112$ lid 3 NBW) ${ }^{16}$. Evenmin

16. HR 19 dec. 1986, NJ 1987, 947 met noot WMK. 
kunnen de appartementseigenaars van een bepaald gebouw, dat deel uitmaakt van een complex van meerdere gebouwen, "afscheiding" wan dit gebouw vorderen. Daarvoor is immers opheffing van de splitsing vereist, die ingevolge artikel $876 \mathrm{p}$ lid 2 jo. 8761 BW (art. 5.10.4.2c lid 2/5:143 lid 2 jo. 5.10.4.1/5:139 NBW) in beginsel unaniem, door alle eigenaars van het appartementencomplex, moet gebeuren.

Overigens is het theoretisch wel mogelijk, dat een appartementencomplex dat uit meerdere gebouwen bestaat, op zodanige wijze wordt gesplitst dat ieder gebouw een appartementsrecht vormt en vervolgens wordt ondergesplitst. Op die wijze ontstaat een secundaire vereniging van eigenaars, die ondergeschikt is aan de hoofdvereniging. Aan deze constructie kleven in de praktijk echter voorlopig nog veel bezwaren (vgl. par. 2.4.2.1).

\subsection{Rechten en verplichtingen van de appartementseigenaars}

De rechten van de appartementseigenaars komen grosso modo neer op het recht om vrij over een appartement te beschikken, en vrij gebruik te maken van de privé-gedeelten en de gemeenschappelijke gedeelten. Deze rechten kunnen echter enigszins worden beperkt door de bestemming van het appartement en het gebouw, en ter bescherming van de rechten van andere appartementseigenaars. Tegenover deze rechten staat de plicht om de beperkingen van het vrije gebruiks- en beschikkingsrecht te respecteren, en anderzijds om mee te dragen in de kosten en lasten van de gemeenschap, c.q. vereniging en de gemeenschappelijke gedeelten. De hier genoemde rechten en verplichtingen zijn de belangrijkste rechten en plichten. Deze rechten en plichten hebben de appartementseigenaars in alle vijf de landen, die in dit werk zijn besproken, gemeen. Voor andere rechten en plichten, zoals mogelijkheden van een appartementseigenaar om de besluiten van de vergadering van eigenaars aan te tasten, de plicht om privé-gedeelten te onderhouden en minder belangrijke rechten en plichten, zij verwezen naar de desbetreffende paragrafen (par. 2.4.4, 5.2.5, 6.2.5, 7.2.5, 8.2.5).

\section{A. Beschikking}

In Nederland mag iedere appartementseigenaar zijn appartementsrecht overdragen en bezwaren (875k lid $1 \mathrm{BW}$; 5.10.1.9 lid 1 / 5:117 lid 1 NBW). Deze vrije beschikkingsbevoegdheid is in beginsel onbeperkt. Daarom mag een appartementseigenaar zijn recht bijvoorbeeld met erfdienstbaarheden of vruchtgebruik bezwaren. Het recht om vrij over een appartementsrecht te beschikken, kan mijns inziens naar huidig recht middels een zakelijk werkende vervreemdingsbeperking in het reglement van splitsing, worden beperkt. Naar toekomstig recht bestaat deze mogelijkheid alleen bij een gesplitst erfpachtsrecht (par. 3.8).

Ook in West-Duitsland heeft de appartementseigenaar het recht om zijn appartementseigendom vrij te vervreemden en te bezwaren ${ }^{17}$, tenzij als inhoud van de afzonderlijke eigendom is overeengekomen dat hij voor de vervreemding toestemming nodig heeft van de andere appartementseigenaars of van een derde

17. Vgl. \$ 6 lid 1 modelreglement Bärmann/SeuB: "Das. Wohnungseigentum ist frei veräußerlich und vererblich." 
(\$) 12 lid 1 WEG. Zie hierover uitwoerig par. 6.3.2). Een beperking van de bevoegdheid om te bezwaren is, als zijnde in strijd met $\$ 137 \mathrm{BGB}$, in WestDuitsland niet mogelijk, althans niet met zakelijke werking (zie par. 6.3.2).

In Zwitserland komt aan een appartementseigenaar eveneens het recht toe vrij over zijn appartementsrecht te beschikken. Dit betekent dat hij zijn appartement vrij mag verhypothekeren of met vruchtgebruik of een recht van bewoning mag bezwaren. Telkens als de bezwaring echter een ingebruikgeving aan een derde inhoudt, kan dit recht - evenals het recht om te vervreemden - worden beperkt (art. $712 \mathrm{c}$ lid $2 \mathrm{ZGB}$ ).

Deze beperking kan in de vorm van een recht van bezwaar ("Einsprache") worden gegoten, hetgeen inhoudt dat de appartementseigenaar die zijn appartementsrecht met een zakelijk gebruiksrecht wil bezwaren, toestemming daarvoor moet verkrijgen van de overige appartementseigenaars. Via deze constructie kan ook het recht om een appartementsrecht vrij te vervreemden worden beperkt.

Het vrije beschikkingsrecht kan echter ook via een voorkeursrecht in het reglement van splitsing, aan controle door de overige appartementseigenaars worden onderworpen (712c lid 1 ZGB. Zie hierover par. 8.3.2).

Ingevolge artikel 577 bis $\$ 4 \mathrm{BW}$ mag iedere Belgische appartementseigenaar eveneens vrij over zijn aandeel in de gemeenschap beschikken. De beschikkingsbevoegdheid $k a n$ in het reglement van splitsing echter waarschijnlijk worden beperkt middels een vervreemdingsbeperking of een voorkeursrecht. De vervreemdingsbeperking is echter slechts geldig, indien zij in de tijd beperkt is en door een rechtmatig belang wordt gerechtvaardigd. Omtrent de geldigheid van een reglementaire beperking van de bevoegdheid tot bezwaren, bestaat in België echter geen duidelijkheid (zie par. 5.3.2).

In Frankrijk kent artikel 9 van de Wet 1965 aan iedere appartementseigenaar, zoals dat ook in Nederland, België, West-Duitsland en Zwitserland geldt, in beginsel het recht toe om vrij over zijn eigendom te beschikken. Het vrije beschikkingsrecht wordt slechts beperkt door de rechten van andere appartementseigenaars en door de bestemming van het gebouw. Verdere beperking van deze rechten is niet toegestaan. In het eerder geciteerde artikel 8 Wet 1965 staat uitdrukkelijk vermeld dat het reglement geen beperkingen op de rechten van de appartementseigenaars mag aanbrengen buiten de beperkingen die worden gerechtvaardigd door de bestemming van het gebouw zoals deze uit het reglement, uit de eigenschappen van het gebouw en uit de ligging van het gebouw voortvloeien. Vervreemdings- of bezwaringsbeperkingen zijn in Frankrijk niet mogelijk.

Blijkens artikel 875a lid 2 BW (5.10.1.1 lid 2 NBW) heeft de Nederlandse appartementseigenaar het recht (voor zover de akte van splitsing althans niet anders bepaalt) om zijn appartementsrecht "onder te splitsen". Uiteraard moet de bouwkundige toestand van een appartement ondersplitsing in verschillende appartementen wel mogelijk maken, zodat verschillende blijkens hun inrichting voor afzonderlijk gebruik bestemde privé-gedeelten ontstaan. Anders is immers niet voldaan aan het materiële vereiste van artikel $875 \mathrm{a}$ lid $3 \mathrm{BW}$ (art. 5.10.1.1 lid 3 NBW).

De bevoegdheid tot ondersplitsing bestaat ook in West-Duitsland. Aldus wordt bewerkstelligd dat de eigenaar een gedeelte van zijn appartement in beginsel zonder toestemming van de overige appartementseigenaars kan vervreemden. Deze 
vervreemding kan, anders dan de ondersplitsing zelf, echter wel aan de vervreemdingsbeperking ex $\$ 12$ WEG worden onderworpen. Bij de ondersplitsing is evenals bij een gewone splitsing - vereist dat de nieuw ontstane ruimten "in sich abgeschlossen" zijn. Een ondersplitsing is derhalve feitelijk-onmogelijk, als een appartement zich bouwkundig niet leent voor onderverdeling in meerdere afzonderlijke appartementen.

In Zwitserland is het niet geheel duidelijk of een appartementseigenaar het recht heeft zijn appartementsrecht onder te splitsen. In beginsel is iedere appartementseigenaar daartoe bevoegd, omdat hij het recht heeft om bouwkundige veranderingen aan te brengen in zijn appartement. Aangezien de ondersplitsing echter noodzakelijkerwijze verandering van de gemeenschappelijke gedeelten met zich meebrengt (er zal bijvoorbeeld een extra toegangsdeur moeten worden aangebracht in de gemeenschappelijke gangen en een extra keuken en badkamer moeten worden ingericht), moet in de praktijk bijna altijd toestemming van de overige appartementseigenaars worden gevraagd.

In België heeft een appartementseigenaar in beginsel ook het recht zijn appartement onder te splitsen. In het reglement van splitsing kan de bevoegdheid om onder te splitsen, worden beperkt of kan ondersplitsing zelfs worden verboden (zie ook par. 5.3.2).

Hetzelfde geldt in Frankrijk. Dit blijkt impliciet uit artikel 11 Wet 1965. Anders dan ten aanzien van vervreemding, is het in Frankrijk wel mogelijk om in het reglement van splitsing een verbod of een toestemmingsregeling met betrekking tot ondersplitsing op te nemen (zie par. 7.3.2).

\section{B. Vrij gebruik van de privé-gedeelten}

Naast het recht om vrij over een appartementsrecht te beschikken, heeft een appartementseigenaar de bevoegdheid zijn prive-gedeelten vrij te gebruiken of aan een ander in gebruik te geven. In Nederland komt dit exclusieve gebruiks- en beschikkingsrecht ook tot uiting in de bepaling van artikel 8751 lid 1 BW (art. 5.10.1.12 lid $1 / 5: 119$ lid $1 \mathrm{NBW}$ ), waarin aan de appartementseigenaar de bevoegdheid wordt verleend in zijn privé-gedeelten veranderingen aan te brengen. Deze bevoegdheid wordt echter beperkt door de rechten van andere appartementseigenaars, d.w.z. de veranderingen mogen geen nadeel aan andere gedeelten toebrengen. Bovendien mag ingevolge artikel 8751 lid 4 jo. $875 f$ lid 4 BW (art. 5.10.1.12 lid 4 / 5:119 lid 4 jo. 5.10.1.5 lid 4 / 5:112 lid 4 NBW), de bevoegdheid tot het aanbrengen van veranderingen, in het reglement worden beperkt. Zo kan deze bevoegdheid bijvoorbeeld afhankelijk worden gesteld van toestemming van de andere appartementseigenaars.

De exclusieve gebruiksbevoegdheid, die aan iedere appartementseigenaar in principe toekomt (art. 875m lid $1 \mathrm{BW} ; 5.10 .1 .13$ lid 1/ 5:120 NBW), kan verder worden begrensd op grond van artikel $875 f$ lid $4 \mathrm{BW}(5.10 .1 .5$ lid $45: 112$ lid 4 NBW), dat ondermeer de grondslag vormt voor de welstandsbepalingen in het appartementsrecht (zie hoofdstuk 3).

Een belangrijke beperking van het gebruik, die standaard in de modelreglementen 1983 en 1987 wordt geregeld, is de verplichting van de appartementseigenaar om zijn privé-gedeelten volgens de in de akte van splitsing neergelegde 
bestemming te gebruiken ${ }^{18}$. Volgens Beekhuis/Linders is bij "bestemming" primair aan de verdeling in woonruimte of bedrijfsruimte gedacht ${ }^{19}$. Verder moet bij de vaststelling van de bestemming van een appartementsrecht gelet worden op de bepalingen van het bestemmingsplan en eventuele erfpachtswoorwaarden.

In West-Duitsland heeft iedere appartementseigenaar eveneens het recht om zijn afzonderlijke eigendom te gebruiken, in het bijzonder om zijn prive-gedeeiten te bewonen, te verhuren, te verpachten of op andere wijze te benutten, voor zover de wet, het reglement, het huishoudelijk reglement of rechten van derden aan dit gebruik niet in de weg staan ( $\$ 13$ lid 1 WEG) ${ }^{20}$. Een appartementseigenaar mag bovendien van de andere bewoners een gebruik van hun appartementen verlangen, dat overeenstemt met de voorschriften van de wet, onderlinge overeenkomsten en besluiten van de vergadering van eigenaars, of dat voortvloeit uit een belang dat aan de gezamenlijke eigenaars naar billijkheid toekomt ( $\$ 15$ lid 3 WEG). Als bijzondere gebruiksbeperking kan hier evenals in Nederland nog de bestemming van het gebouw aan toe worden gevoegd. Indien bijwoorbeeld woonruimte in bedrijfsruimte wordt veranderd, is daaryoor een bijzondere toestemming van de overige appartementseigenaars vereist. De bevoegdheid tot verhuring, kan in het reglement van splitsing van de toestemming van de vergadering van eigenaars afhankelijk worden gesteld.

In Zwitserland geldt in principe hetzelfde. Daar is iedere appartementseigenaar vrij in het beheer, gebruik en bouwkundige inrichting van zijn ruimten, voorzover hij daarbij aan andere appartementseigenaars de uitoefening van dezelfde rechten niet bemoeilijkt en de gemeenschappelijke bouwdelen, installaties en inrichtingen niet beschadigt en hun functie niet verandert (art. 712a lid 2 ZGB). De vrije gebruiksbevoegdheid brengt verder met zich mee, dat een appartementseigenaar zijn appartement mag verhuren. Deze bevoegdheid tot verhuren kan echter in de akte van splitsing ("Begründungsakt") worden beperkt. De beperking houdt dan in dat de appartementseigenaar van de overige eigenaars toestemming tot verhuring moet krijgen (art. 712c lid 2 ZGB. Zie hierover par. 83.2.2.). Evenals in WestDuitsland en Nederland behelst de bestemming van een appartement of het appartementsgebouw een beperking van de gebruiksbevoegdheid. Dit betekent dat een appartement in beginsel niet in strijd met de bestemming mag worden gebruikt.

België kent een soortgelijke regeling. De gebruiksbevoegdheid vindt slechts zijn grenzen in de bestemming van het gebouw en de afzonderlijke appartementen en de rechten van de overige eigenaars. Verhuring kan in het reglement van splitsing worden verboden of van toestemming van de algemene vergadering van eigenaars afhankelijk worden gesteld (zie par. 5.3.2).

Ook in Frankrijk heeft iedere appartementseigenaar in beginsel thet recht op vrij genot en gebruik van zijn appartementseigendom. Het vrije gebruiks- en genotsrecht wordt slechts beperkt door de rechten van andere appartementseigenaars en door de bestemming van het gebouw (art. 9 van de Wet 1965). Verdere beperking van deze rechten is niet toegestaan. In artikel 8 Wet 1965 staat namelijk uitdrukkelijk vermeld dat het reglement geen beperkingen op de rechten van de

18. Art. 16 lid 4 modelreglement 1983; art. 17 lid 5 modelreglement 1987.

19. Beekhuis/Linders, VI par. 9, nr. 1.

20. Vgl. \& 5 lid 1 modelreglement Bärmann/Seuß. 
appartementseigenaars mag aanbrengen buiten de beperkingen die worden gerechtvaardigd door de bestemming van het gebouw zoals deze uit het reglement, uit de eigenschappen van het gebouw en uit de ligging van het gebouw voortvoeien. De bestemming van het gebouw zou eveneens een verbod van verhuur in het reglement van splitsing kunnen rechtvaardigen. Een clausule die verhuring afhankelijk maakt van de toestemming van de vergadering van eigenaars, is door het Hof Lyon echter ongeldig geacht (zie par. 7.3.2) ${ }^{21}$.

Kort resumerend heeft iedere appartementseigenaar in Nederland, West-Duitsland, Zwitserland, Belgie en Frankrijk het recht om zijn appartement naar eigen goeddunken te gebruiken, voor zover de bestemming van het gebouw of de rechten van de overige appartementseigenaars, aan dit gebruik geen grenzen stellen. Verder kan verhuring in Nederland via de welstandsbepalingen worden beperkt. Dit betekent dat aan een huurder de toestemming tot ingebruikneming van de privegedeelten kan worden ontzegd. In West-Duitsland kan de verhuring op zichzelf aan de toestemming van de vergadering van appartementseigenaars worden onderworpen. Hetzelfde geldt in Zwitserland en België. In België kan bovendien de verhuring worden werboden. Zo'n verbod is in Frankrijk eveneens mogelijk, maar daar kan de verhuring niet aan de toestemming van de vergadering worden onderworpen.

\section{Gebruik van de gemeenschappelijke gedeelten}

Behalve van de privé-gedeelten mag in Nederland iedere appartementseigenaar gebruik maken van de gemeenschappelijke gedeelten, voor zover dit gebruik tenminste geen inbreuk maakt op rechten van andere deelgenoten en de in het reglement neergelegde bestemming van de gemeenschappelijke zaak (art. $875 \mathrm{~m}$ BW; art. 5.10.1.13 / 5:120 NBW).

Een Westduitse appartementseigenaar is eveneens gerechtigd om de gemeenschappelijke eigendom mede te gebruiken. Dit gebruiksrecht ten aanzien van de gemeenschappelijke gedeelten komt de appartementseigenaar toe behoudens de plichten, neergelegd in het reglement en in \$ 14 WEG. Kortweg komt dit neer op de plicht om bij het gebruik wan de gemeenschappelijke gedeelten de bestemming daarvan en de rechten van de overige eigenaars te respecteren.

Hetzelfde geldt in Zwitserland, België en Frankrijk (zie par. 5.2.5, 7.2.5, 8.2.5).

\section{Kostendraagplicht}

Zoals in paragraaf 2.4 .3 wordt vermeld, zijn de aandelen van de appartementseigenaars, die door splitsing in appartementsrechten ontstaan, in beginsel gelijk (art. 875g lid $1 \mathrm{BW}$; art. 5.10.1.6 lid 1/ 5:113 lid $1 \mathrm{NBW}$ ). Aan deze gelijkheid van aandelen is de verplichting gekoppeld om onderling en jegens de V.v.E. voor een gelijk deel in de schulden en kosten van de gezamenlijke appartementseigenaars

21. Hof Lyon, aangehaald in Weismann, blz. 17. 
en de V.v.E. bij te dragen (art. 875g lid 2 BW; 5.10.1.6 lid $2 / 5: 113$ lid 2 NBW) ${ }^{22}$. Deze gelijkheid van bijdragen (per appartement) kan, evenals de gelijkheid van de aandelen, in het reglement van splitsing worden afgeschaft.

Ook in West-Duitsland rust op de appartementseigenaar de plicht om naar verhouding van de grootte van zijn aandeel bij te dragen in de lasten en kosten van instandhouding, herstel, beheer en gebruik van de gemeenschappelijke delen ( $\$$ 16 WEG). In het reglement kan evenals in Nederland een andere verdelingssleutel worden vastgesteld. Hetzelfde geldt voor Zwitserland (art. $712 \mathrm{~h} \mathrm{ZGB),} \mathrm{België} \mathrm{(art.}$ 577 bis $\$ 7$ BW bevat regelend recht) en Frankrijk (vgl. artt. 10, 11, 12 Wet 1965 en 54 Decreet 1967, bij afwijking van de wettelijke verdeelsleutel, kan een appartementseigenaar zich tot de rechter wenden, indien hij door de afwijkende verdeelsleutel onevenredig benadeeld wordt).

\section{E. Zekerheden}

Bij niet-nakoming van de financiële verplichtingen door een appartementseigenaar heeft de Nederlandse vereniging van appartementseigenaars een privilege op de opbrengst van het appartementsrecht ex art. 1185 sub $9 \mathrm{BW}$.

In West-Duitsland bestaat een dergelijke zekerheid niet. Wel is in $\$ 18$ lid 2 sub 2 WEG bepaald, dat een appartementseigenaar bij niet nakoming van zijn financiële verplichtingen, gedwongen kan worden zijn appartement te vervreemden. De procedure ex $\$ \$ 18,19$ WEG bij niet nakoming van financiële verplichtingen is echter omslachtig en duurt zeer lang. Müller heeft daarom aanbevolen om voor de betalingsachterstand een gerechtelijke voor executie vatbare titel te vragen en vervolgens het appartement van de in gebreke blijvende appartementseigenaar executoriaal te verkopen ${ }^{23}$.

Het Zwitserse appartementsrecht biedt voor de gemeenschap van appartementseigenaars een veel uitgebreidere zekerheid dan het Nederlandse of het Duitse appartementsrecht. Als een appartementseigenaar in gebreke blijft zijn bijdragen in de lasten en kosten te voldoen, heeft de gemeenschap van appartementseigenaars namelijk het recht om een hypotheekrecht op diens appartementsrecht in het "Grundbuch" te doen inschrijven. Het hypotheekrecht kan echter slechts tot zekerheid dienen voor de kosten van drie op het moment van inschrijving afgelopen jaren (art. 712i ZGB).

Het hypotheekrecht is niet de enige zekerheid die de gemeenschap heeft om voldoening van de schulden te verkrijgen. Artikel $712 \mathrm{k} \mathrm{ZGB}$ kent aan de gemeenschap namelijk tevens een retentierecht op de roerende goederen van de in gebreke blijvende appartementseigenaar toe, voor zover die goederen zich tenminste in diens appartement bevinden en zijn bestemd tot inrichting van de privé-gedeelten. Het retentierecht bestaat van rechtswege voor de (opeisbare) schulden van drie aan de inroeping van het retentierecht voorafgaande jaren. De

22. Vgl. HR 8 jan. 1982, NJ 1982, 333 met noot WMK. De gezamenlijke appartementseigenaars zijn ais zodanig nict gebonden aan een service-overeenkomst die woor het ontstaan van de V.V.E. tussen de bouwer en een derde werd gesloten. Alleen de vergadering van eïgenaars kan cen dergelijke overeenkomst aangaan. Nu van een dergelijk besluit niet bleek vielen de will de owereenkomst woortwlociende kosten niet onder de in het reglement conform art. 875f lid 1 sub a BW aangeduide schulden.

23. Müller, blz 180 . 
bepalingen betreffende het retentierecht van de verhuurder (artt. 272-274 ORE) zijn op het retentierecht van de gemeenschap van appartementseigenaars van overeenkomstige toepassing.

Ook in Frankrijk heeft de vereniging van eigenaars, tot zekerheid van alle vorderingen die zij op een appartementseigenaar heeft, een wettelijk recht op vestiging van een hypotheek op diens appartement. Dit hypotheekrecht kan door de administrateur ten behoeve van de vereniging worden ingeschreven na een ingebrekestelling ten aanzien van een opeisbare schuld of zodra de appartementseigenaar op grond van artikel 33 van de wet 1965 het recht bedingt om zijn aandeel in de kosten voor werkzaamheden die tegen zijn wil zijn uitgevoerd, via afbetaling, uitgestreken over tien jaar, te voldoen (art. 19 wet 1965). Verder heeft de vereniging nog een privilege op de opbrengst van de meubels van de appartementseigenaar (art. 19 wet 1965). Via beslaglegging (art. 58 decreet 1967) kan de vereniging het hypotheekrecht en het privilege te gelde maken.

Het Belgische appartementsrecht bevat tenslotte de minste zekerheid voor de gemeenschap van appartementseigenaars, om achterstallige bijdragen op een appartementseigenaar te kunnen verhalen. Indien een der appartementseigenaars in gebreke blijft zijn aandeel in de algemene kosten bij te dragen, kunnen de overige medeëigenaars slechts een gewone actie tot betaling tegen hem instellen en eventueel een executoriale titel vorderen, om zijn appartement te kunnen uitwinnen. Deze actie verjaart na 30 jaar.

Een hypotheekrecht voor de gemeenschap van appartementseigenaars, zoals dat in Frankrijk en Zwitserland mogelijk is, lijkt mij in Nederland niet wenselijk. Een dergelijk hypotheekrecht heeft in de praktijk immers alleen zin, indien het recht in rangorde boven andere hypotheekrechten komt. Anders is de zekerheid, die door het hypotheekrecht wordt verkregen immers illusoir. In de wet zou kunnen worden bepaald dat een hypotheekrecht ten behoeve van de vereniging van eigenaars, in rang boven alle andere hypotheken komt. Dit zou echter nadelige rechtseconomische gevolgen hebben, omdat kredietverleners daardoor minder snel geneigd zouden zijn een hypotheekrecht op een appartementsrecht te nemen, waardoor de verhandelbaarheid van appartementsrechten zou dalen.

\subsection{Toelatingsregelingen}

\subsubsection{Algemene opmerkingen: ontzegging van ingebruikneming aan (aspirant-)eigenaars en (aspirant-)gebruikers}

Uit de voorgaande hoofdstukken blijkt dat de meeste in dit werk besproken rechtsstelsels een regeling omtrent ontzegging van ingebruikneming aan (aspirant) eigenaars kennen, althans dat dergelijke regelingen mogelijk zijn. In deze paragraaf zullen deze regelingen met elkaar worden vergeleken. Voorafgaand aan de bespreking van de buitenlandse rechtsstelsels, wordt eerst ingegaan op de verhouding van welstandsbepalingen tot de ballotageregelingen in het verenigingsrecht, en de onderlinge controlemogelijkheden tussen deelgenoten of huurders in het recht betreffende de gemeenschap, respectievelijk het huurrecht.

Nadat de welstandsbepalingen in dit intern rechtsvergelijkende kader zijn geplaatst, komen de toelatingsregelingen in het buitenlandse appartementsrecht 
aan de orde. Bij de bespreking van deze toelatingsregelingen zal eerst worden gelet op de juridische constructie van ontzegging van ingebruikneming. Hierbij zal tevens aandacht worden besteed aan de vraag of alleen aan (aspirant-) eigenaars de ingebruikneming kan worden ontzegd, of ook aan zakelijk (bijv. vruchtgebruikers) en persoonlijk (bijv. huurders) gerechtigden. Nadat de juridische constructie aldus is besproken, wordt aandacht besteed aan de criteria, die in de verschillende landen worden gehanteerd om een ontzegging van ingebruikneming te rechtvaardigen.

\section{Q3.2 De juridische constructie van ontzegging van ingebruikneming}

Bestudering van de toelatingsinstrumenten die in het Nederlandse recht aan de verenigingen/coöperaties, medeëigenaars/deelgenoten en huurders en verhuurders ter beschikking staan, levert het algemene beeld op dat het verenigingsrecht en het medeëigendomsrecht, c.q. het recht met betrekking tot de gemeenschap, controlemogelijkheden ten aanzien van nieuwkomers kennen.

Bij verenigingen kunnen de leden via een ballotageregeling voorkomen dat ongewenste aspirant-leden als lid worden toegelaten. Bij de gemeensehap hebben de deelgenoten naar huidig en toekomstig recht in beginsel de bevoegdheid om aan een deelgenoot die over zijn aandeel wil beschikken, de toestemming daartoe te onthouden. De enige begrenzing van deze bevoegdheid is gelegen in de goede trouw, c.q. de redelijkheid en billijkheid. Alleen deelgenoten in een vrije gemeenschap kunnen vrij over hun aandeel beschikken. Aangezien vrije gemeenschappen echter slechts in theorie voorkomen, zal een deelgenoot in de praktijk altijd toestemming van de overige deelgenoten behoeven om over zijn aandeel te mogen beschikken (zie par. 4.3.2.1).

De leden van verenigingen hebben in beginsel een even grote bevoegdheid als deelgenoten in een gemeenschap. Theoretisch kunnen zij altijd een ballotageregeling hanteren voor toelating van nieuwe leden. Zo"n ballotageregeling is echter slechts een instrument om te bewerkstelligen dat alleen die personen tot een vereniging worden toegelaten, die kunnen samenwerken met de overige leden en de harmonie in de vereniging niet zullen verstoren. Dit betekent dat in de praktijk sommige verenigingen geen of bijna geen ballotageregeling zullen hanteren, omdat zij daaraan geen behoefte hebben (denk bijvoorbeeld aan commerciële omroepwerenigingen). Hoe groter de onderlinge band, en hoe sterker de rechtsverhouding tussen de leden is, des te eerder zullen ballotageregelingen worden gehanteerd. Evenals bij de gemeenschap is er derhalve een relatie tussen de gebondenheid en de behoefte aan toezicht op nieuwe leden, c.q. deelgenoten.

Ten opzichte van het verenigingsrecht en het recht betreffende de gemeenschap, neernt het huurrecht een bijzondere positie in. In het huurrecht zijn het immers niet de huurders van een gebouw, die over toelating van een nieuwe huurder beslissen, maar ligt deze beslissingsbevoegdheid bij de verhuurder. De contractsvrijheid brengt mee dat de verhuurder in beginsel kan verhuren aan wie hem goeddunkt. Een afgewezen aspirant-huurder die zich door de verhuurder gediscrimineerd voelt, heeft slechts een actie uit onrechtmatige daad ter beschikking. Via deze actie kan hij trachten alsnog een huurwoning (of bedrijfsruimte) te verkrijgen, maar dit zal slechts lukken indien de discriminatie ongeoorloofd en bewijsbaar is 
en er bovendien schade is geleden die voor vergoeding in aanmerking komt (par. 4.4.2).

Een aspirant-huurder staat echter juridisch aanmerkelijk zwakker dan eem aspirant-lid van een vereniging/coöperatie of een deelgenoot van een gemeenschap die toestemming vraagt om over zijn aandeel te beschikken. Een verhuurder is immers niet verplicht zijn besluit te motiveren, terwijl verenigingen en gemeenschappen deze motiveringsplicht mijns inziens wel hebben.

Een gemotiveerd besluit is gemakkelijker aan te tasten dan een ongemotiveerd besluit. Uiteraard zall het in de praktijk vaak moeilijk zijn om ballotagebesluiten of beslissingen van deelgenoten aan te tasten, omdat de legitimatie van het besluit een andere kan zijn dan de heuristiek van die beslissing. In dat geval staan aspirantleden van een vereniging en deelgenoten van een gemeenschap echter nog altijd sterker dan de aspirant-huurder, omdat de motiveringsplicht voor de verenigingen en de gemeenschappen met zich meebrengt, dat zij een deugdelijke motivering moeten kunnen verzinnen. Een ondeugdelijke motivering zal immers spoedig de geldigheid aan een beslissing ontnemen, omdat een beslissing die geen grondslag heeft in een goede motivering, in strijd met de redelijkheid en billijkheid kan worden geacht (zie ook hierna par. 9.5.1.3).

Het Nederlandse appartementsrecht bevat zowel medeëigendoms- als verenigingsrechtelijke componenten. Een mogelijke wijze van controle op nieuwkomers, zou theoretisch daarom aan het medeëigendomsrecht of het verenigingsrecht kunnen zijn ontleend. Zoals uit hoofdstuk 3 blijkt, is het in het Nederlands appartementsrecht echter niet mogelijk een nieuwkomer te balloteren als lid van de vereniging van eigenaars. Deze vereniging is immers slechts een bestuursvorm die, afgaande op hetgeen in par. 9.2.3 werd beschreven, niet noodzakelijk is. In andere landen functioneert de gemeenschap van appartementseigenaars immers op nagenoeg dezelfde wijze als de Nederlandse vereniging van appartementseigenaars, zonder dat aan die buitenlandse gemeenschappen een vereniging van eigenaars als bestuursvorm is gekoppeld. Omdat de vereniging van eigenaars in Nederland slechts een organisatiestructuur vormt, zou een ballotageregeling, d.w.z. koppeling van de toestemming tot ingebruikneming aan verkrijging van het lidmaatschap van de vereniging, oneigenlijk zijn. De ballotagemogelijkheid van verenigingen vloeit immers voort uit het grondwettelijk gewaarborgde recht op vrijheid van vereniging. Mijns inziens moet de vereniging van eigenaars echter in beginsel niet worden gezien als een vereniging in de zin van artikel 8 Grondwet. Zoals in par. 4.2.1.1 werd aangegeven, kenmerkt een gewone "echte" vereniging zich immers onder meer door het feit, dat zij een samenwerkingsverband vormt

"opgericht bij meerzijdige rechtshandeling, dat tengevolge van de door de leden-oprichters ervoor gestelde regels een zodanige zelfstandigheid bezit dat het als rechtssubject kan bestaan en dat dient om een bepaald doel na te streven, hetwelk niet is het maken van winst ter verdeling onder de leden en evenmin het behartigen van stoffelijke belangen der leden door met hen overeenkomsten te sluiten in een te hunner behoeve uitgeoefend bedrijf. ${ }^{+24}$

24. Den Tonkelaar, blz. 65, 119. 
De coopperatie heeft daarentegen tot doel de stoffelijke belangen van de leden te behartigen (vgl. par. 4.2.1.1, 4.2.2.1). Blijkens artikel 876a lid 1 BW (art. 5.10.2.1a lid $1 / 5: 126$ lid $1 \mathrm{NBW}$ ) beeft de Vereniging van Eigenaars echter niet zozeer een doel, als wel een taak, die bestaat wit het voeren van het beheer over de gemeenschap. Naast deze wettelijke taakomschrijving moet in de statuten een doelomschrijving van de V.v.E. worden opgenomen (zie art. $875 \mathrm{f}$ lid 2 sub b BW; art. 5.10 .15 lid 2 sub b / 5:112 lid 2 sub b NBW). Artikel 30 modelreglement 1983 amschrijft het "doel" van de vereniging daarom als "het behartigen van de gemeenschappelijke belangen van de eigenaars", waaruit blijkt dat de wettelijke taakomschrijving wordt geparafraseerd. In het modelreglement 1987 treffen we een uitgebreidere doelomschrijving aan. Artikel 35 lid 3 bepaalt namelijk dat ook het verzorgen van de gemeenschappelijke huishouding en het aangaan van overeenkomsten met de eigenaars en met de gebruikers met betrekking tot dienstverlening door de V.v.E. tot het doel van de V.v.E. behoort. Het feit dat het aangan van owereenkomsten als doel is opgenomen, introduceert een coöperatief element in de vereniging van eigenaars van een service-flatgebouw (vgl. par. 4,2.2.1).

Naar mijn mening kan een vereniging van eigenaars, die als doel slechts de wettelijke taakomschrijving heeft, alleen als een organisatiestructuur worden gezien, en niet als een vereniging in de zin van artikel 8 Grondwet. Nu kan worden verdedigd, dat een gemeenschap van appartementseigenaars, waarbinnen de verschillende eigenaars sterk van elkaar afhankelijk zijn en deze afhankelijkheid ook hebben gestructureerd door het ontplooien van gezamenlijke activiteiten e.d. (vgl. art. 35 lid 3 modelreglement 1987), niet slechts een gebonden gemeenschap met de vereniging als door de wet opgelegde organisatiestructuur is, maar in sommige gevallen een gemeenschap vormt waaraan een cchte vereniging met een bepaald doel is gekoppeld. Desalniettemin lijkt mij een ballotageregeling in het appartementsrecht ongewenst, vooral omdat in het merendeel van de gevallen geen sprake zal zijn van een vereniging van eigenaars die een "echte" (d.w.z. volwardige) vereniging vormt, wanneer er een onderlinge afhankelijkheid bestaat die een toelatingsregeling rechtvaardigt. Een sterke onderlinge afhankelijkheid van de appartementseigenaars brengt immers nog niet met zich mee, dat de vereniging automatisch een "echte" vereniging wordt.

Ik ben me ervan bewust dat ten aanzien van de vraag of de vereniging van eigenaars een vereniging in de zin van artikel 8 Grondwet is, andere opvattingen mogelijk zijn. Een andere opvatting kan mijns inziens echter niet tot de conclusie leiden, dat ballotageregelingen in het appartementsrecht kumen worden gehanteerd. Een dusdanige regeling zou namelijk bewerkstelligen, dat een aspirant-koper slechts een appartementsrecht zou kunnen verkrijgen nadat hij tot de vereniging Wan eigenaars zou zijn toegelaten. De medeëigendom van een appartementsgebouw en het beperkte zakelijke gebruiksrecht ten aanzien van de privé-gedeelten, zouden aldus afhankelijk van het lidmaatschap van de vereniging van eigenaars worden. Vanuit dogmatisch oogpunt lijkt mij deze constructie niet gewenst.

Het Nederlandse appartementsrecht kent - zoals gezegd - tevens een medeëigendomscomponent, die in beginsel niet afwijkt van de medeëigendom in andere gemeenschappen. Bij de gemeenschap hebben de deelgenoten naar huidig en toekomstig recht in beginsel de bevoegdheid om aan een deelgenoot die over zijn aandeel wil beschikken, de toestemming daartoe te onthouden. Een dergelijke toestemmingsregeling zou daarom mijns inziens ook heel goed in het appartements- 
recht kunnen worden gehanteerd. Naar mijn mening is een dergelijke toestemmingsregeling in Nederland naar huidig recht mogelijk (zie par. 3.8).

Zowel bij de gemeenschap, als bij de vereniging, geldt dat een toelatingsregeling eerder zal worden gehanteerd, naarmate de onderlinge afhankelijkheid tussen de deelgenoten, c.q. leden, groter wordt. Hetzelfde geldt voor de welstandsbepalingen in het appartementsrecht (vgl. par. 3.1, 4.3.2.1).

De Nederlandse wetgever heeft noch voor de controlemogelijkheden van het medeëigendomsrecht, noch voor de ballotageregeling uit het verenigingsrecht gekozen, om toelatingsregelingen in het appartementsrecht mogelijk te maken. In plaats daarvan heeft hij in artikel $875 f$ lid $4 \mathrm{BW}$ (art. 5.10.1.5 lid 4 / 5:112 lid 4 NBW) de mogelijkheid gecreëerd voor het scheppen van de "welstandsbepalingen" in het appartementsrecht, die ontzegging van (in)gebruik(neming) van een appartement mogelijk maken. Door deze welstandsbepalingen wordt echter niet voorkomen dat een aspirant-gebruiker eigenaar en dus lid van de V.v.E. kan worden. De welstandsbepalingen maken het mogelijk om een gebruiker uit een appartement te weren, ongeacht de vraag of hij eigenaar, zakelijk gerechtigde of persoonlijk gerechtigde is (zie hoofdstuk 3 ).

De Westduitse wetgever heeft voor een andere constructie gekozen. In WestDuitsland kan namelijk in het reglement van splitsing een vervreemdingsbeperking worden opgenomen, die het mogelijk maakt dat een appartementseigenaar, die zijn appartement wil vervreemden, daarvoor toestemming nodig heeft van de overige appartementseigenaars of de administrateur ( $\$ 12 \mathrm{WEG).} \mathrm{Een} \mathrm{soortgelijke}$ regeling is mogelijk ten aanzien van ingebruikgeving aan huurders. Ten aanzien van vestiging van zakelijke rechten kan echter geen toestemmingsregeling worden gehanteerd, omdat $\$ 137 \mathrm{BGB}$ daaraan in de weg staat (zie par. 6.3.2).

Naast deze mogelijkheid om een vervreemdingsbeperking op te nemen, bestaan in West-Duitsland ook de mogelijkheid om een appartement met een zakelijk werkend voorkeursrecht te bezwaren (zie par. 6.3.2.1).

De Zwitserse wetgever heeft, evenals de Westduitse, een voorkeursrecht en een recht van bezwaar ("Einsprache") mogelijk gemaakt (art. 712c ZGB). Anders dan in West-Duitsland is het voorkeursrecht echter wel in de wettelijke bepalingen betreffende het appartementsrecht geregeld. Net als in Nederland en WestDuitsland bestaan deze controlemogelijkheden echter niet van rechtswege, maar moeten zij in het reglement van splitsing worden opgenomen. Het recht van bezwaar ("Einsprache") komt inhoudelijk overeen met de Westduitse vervreemdingsbeperking, zij het dat bezwaar altijd door de vergadering van eigenaars moet worden gemaakt, terwijl dit in West-Duitsland ook door een derde kan gebeuren, indien het reglement zulks bepaalt. Ook ten aanzien van de reikwijdte van het recht van bezwaar ("Einsprache") bestaan verschillen tussen West-Duitsland en Zwitserland. In West-Duitsland is het immers niet mogelijk om bezwaar te maken tegen bezwaring met een zakelijk recht, terwijl dit in Zwitserland wel kan. Artikel $712 \mathrm{c} \mathrm{ZGB}$ bepaalt namelijk dat bezwaar kan worden gemaakt tegen "Veräusserung", "Bellastung mit einer NutznieBung oder einem Wohnrecht" en "Vermietung" (zie par. 8.3.2). Telkens wanneer de bezwaring een ingebruikgeving van het appartement aan een derde inhoudt, kan daartegen bezwaar worden gemaakt. Tegen bezwaring met een hypotheekrecht kunnen de overige appartementseigenaars derhalve niets ondernemen. 
Anders dan in Nederland, West-Duitsland en Zwitserland, is er in de Belgische wet geen mogelijkheid gecreëerd om toezicht op nieuwkomers mogelijk te maken. Volgens Aeby ${ }^{25}$ is het echter mogelijk orm in het reglement van splitsing vervreemdingsbeperkingen op te nemen, indien zij in de tijd beperkt zijn en een rechtmatig belang ten grondslag hebben. De vervreemdingsbeperking kan worden uitgewerkt in een regeling, waardoor de vervreemdende appartementseigenaar voor vervreemding toestemming nodig heeft van de vergadering van eigenaars. Ook voor bezwaring met een zakelijk recht zou een dergelijke regeling kunnen worden gehanteerd. Een andere toezichtsmogelijkheid, die zekerder is dan de vervreemdingsbeperking, is opname van een voorkeursrecht in het reglement van splitsing. Door deze constructie wordt echter een grote financiële druk op de gemeenschap van appartementseigenaars gelegd. Opgemerkt zij hierbij, dat in de Belgische jurisprudentie slechts eenmaal (door een lagere rechter) over de geldigheid van vervreemdings, c.q. bezwaringsbeperkingen is beslist en nooit over de geldigheid van een voorkeursrecht.

De Belgische doctrine twijfelt niet aan de geldigheid van een verbod of beperking van het recht om te verhuren. Desalniettemin lijken dergelijke beperkingen of verboden in de praktijk weinig voor te komen, hetgeen ook blijkt uit het feit dat jurisprudentie daaromtrent, niet bestaat (zie par. 5.3.2).

In Frankrijk zijn vervreemdingsbeperkingen door de rechtspraak, ondanks voorspraak door de Franse doctrine, ontoelaatbaar geacht. Hetzelfde geldt voor een voorkeursrecht ten aanzien van het gehele appartement. Het recht om te verhuren kan in Frankrijk, als een beperking van het gebruik, wel gedeeltelijk in het reglement van splitsing worden beperkt, of zelfs verboden. Toelatingsregelingen zijn echter niet mogelijk (vgl. par. 7.3.2).

Alleen in Nederland, West-Duitsland en Zwitserland zijn de toelatingsregelingen derhalve in de wet mogelijk gemaakt. Het is op zijn plaats om vast te stellen, dat de reden voor opneming van deze mogelijkheid in alle drie de landen dezelfde was, namelijk het feit dat de appartementseigenaars vaak sterk van elkaar afhankelijk zijn en daarom toezicht moeten kunnen uitoefenen op nieuwkomers (zie par. 1.1, $6.3 .2,8.3 .2)$.

\subsubsection{Criteria voor ontzegging van ingebruikneming}

Zoals uit het voorgaande blijkt, kent het Franse appartementsrecht slechts bij verhuring een beperkte mogelijkheid om invloed uit te oefenen op de toelating van de aspirant-huurder. Deze verhuurbeperking kan echter niet op zodanige wijze worden uitgewerkt, dat voor verhuring toestemming van de vergadering van eigenaars nodig is (zie par. 7.3.2). In België zijn wellicht een vervreemdingsbeperking, een voorkeursrecht en een toestemmingsregeling voor verhuring mogelijk, maar ten aanzien van de criteria, die met name bij de vervreemdingsbeperking zouden moeten worden gehanteerd, bestaat geen duidelijkheid. In deze paragraaf kan dan ook noch met betrekking tot Belgiể, noch met betrekking tot Frankrijk, over toelatingscriteria worden uitgeweid. 
In Nederland is voor ontzegging van ingebruikneming aan een appartementseigenaar, zakelijk gerechtigde of huurder, vereist dai deze ontzegging wordt gerechtvaardigd door een gewichtige reden (art. 875f lid $4 \mathrm{BW}$; art. 5.10.1.5 lid 4 / 5:112 lid $4 \mathrm{NBW}$ ). Het is aardig om vast te stellen, dat West-Duitsland en Zwitserland voor ontzegging van ingebruikneming beide een "wichtiger Grund" eisen (zie par. 6.3.2, 8.3.2). Het is niet met zekerheid vast te stellen, wat de oorzaak van deze overeenkomst is. De Nederlandse wetsgeschiedenis vermeldt geen motivering voor de keuze van de "gewichtige reden". Hetzelfde geldt voor Zwitserland en West-Duitsland. Gezien het feit dat West-Duitsland waarschijnlijk als eerste land de gewichtige reden in de wet heeft opgenomen, lijkt de voorzichtige conclusie gerechtwaardigd dat de Nederlandse en Zwitserse wetgever zich door de Westduitse wet hebben laten inspireren. Zowel in Nederland als in Zwitserland, is de gewichtige reden later dan in West-Duitsland opgenomen. In Zwitserland is de gewichtige reden immers pas in 1965 in de wet opgenomen, en in Nederland in 1972. Het Westduitse appartementsrecht kent de gewichtige reden daarentegen sinds 1951 (zie par. 6.1). Voor Zwitserland is het zelfs zeer aannemelijk dat de gewichtige reden uit het Duitse recht is overgenomen, omdat het in 1956 uitgebrachte preadvies van Friedrich zeer grote invloed op de Zwitserse wet heeft gehad, en dit preadvies sterk rechtsvergelijkend van aard was, met name ten aanzien van het Duitse recht (par. 8.1).

De overeenkomst met betrekking tot de criteria bestaat echter niet slechts ten aanzien van de wettelijke open norm, maar ook ten aanzien van de concrete invulling van deze open norm. Hierbij moet worden vermeld dat de in dit werk gegeven opsomming van concrete criteria geenszins limitatief is, maar zich beperkt tot de in de praktijk meest voorkomende of in de doctrine genoemde criteria. In Nederland wordt de gewichtige reden, zoals werd vermeld in paragraaf 3.3.1, in de modelreglementen uitgewerkt in een vage omschrijving, die luidt:

"De vergadering zal de gegadigde slechts mogen weigeren, indien naar redelijkheid en billijkheid van de overige bewoners niet kan worden verlangd dat zij de gegadigde in hun midden opnemen...." (art. 24a lid 3 Annex 1 modelreglement 1983, vgl. ook art. 29 lid 4 modelreglement 1987).

De Westduitse en Zwitserse modelreglementen bevatten geen vage omschrijving van de gewichtige reden.

De vage omschrijving in de Nederlandse modelreglementen, zal in de praktijk echter altijd moeten worden geconcretiseerd. In concrete gevallen zal de vergadering van eigenaars altijd moeten aangeven, waarom van de overige eigenaars naar redelijkheid en billijkheid niet kan worden verlangd dat zij een gegadigde in hun midden opnemen.

In het uit 1987 daterende modelreglement voor service-flatgebouwen is in artikel 29 lid 5 bepaald, dat bij de toepassing van de vage norm op de solvabiliteit en de gezondheidstoestand van de gegadigde moet worden gelet. Ten aanzien van de solvabiliteitseis heb ik in paragraaf 3.6 .3 .3 al betoogd, dat deze binnen het Nederlandse systeem van welstandsbepalingen, over het algemeen weinig zoden aan de dijk zet, omdat een appartementseigenaar zijn financiële verplichtingen ook moet nakomen, als hij zijn appartement niet mag gebruiken. 
In West-Duitsland en Zwitserland wordt het financiele criterium eveneens gehanteerd (zie \$ 6 lid 2 sub a modelreglement West-Duitsland; $\$ 14$ reglement Peter-Ruetschi. Zie par. 6.3.2 en 8.3.2.2). Anders dan in Nederland is dit financiële criterium in West-Duitsland en Zwitserland wel nuttig, omdat door de daar gehanteerde toelatingsregelingen kan worden voorkomen, dat een insolvabele gegadigde tot de gemeenschap van appartementseigenaars gaat behoren.

Over de gezondheidstoestand als mogelijk toelatingscriterium, wordt in WestDuitsland en Zwitserland niets vermeld. Hetzelfde geldt voor de leeftijdsgrens, die in Nederland volgens de heersende leer overigens niet toelaatbaar wordt geacht en door de Koninklijke Notariële Broederschap daarom niet in het modelreglement voor service-flats is opgenomen (zie par. 3.6.3.2). De gezondheidstoestand kan mijns inziens well een geldig criterium opleveren (zie par. 3.6.3.4).

Een ander in Nederland gehanteerd criterium is het vereiste dat de gegadigde voldoet aan voorwaarden op moreel gebied, die door het bestuur worden gesteld. In West-Duitsland wordt dit criterium afgedekt door het ruimere criterium, dat de gegadigde en zijn huisgenoten in de gemeenschap moeten passen. (zie par: 6.3.2; $\$ 6$ lid 2 sub b modelreglement). In Zwitserland wordt daarentegen eerder een concretere invulling van dit vereiste gegeven, doordat wordt gesteld dat een gegadigde kan worden geweigerd, als hijzelf of zijn gezinsleden de overige bewoners onduldbaar zullen lastig vallen (zie par. 8.3.2.2 en $\$ 15$ sub 3 reglement Peter-Ruetschi).

De voorwaarden op moreel gebied zijn, zoals ik in paragraaf 3.6.3.5 al aangaf, mijns inziens in beginsel mogelijk als toelatingscriteria. Van geval tot geval zal echter moeten worden bezien of een concrete weigering geldig is. Hierbij moeten zeker de grondrechten van de gegadigde in acht worden genomen (zie par. 3.5.3).

Het door De Groot ${ }^{26}$ vermelde criterium "burgerlijke staat" kan wellicht in bepaalde gevallen een gewichtige reden tot weigering opleveren. Hierbij moet echter worden bedacht dat dit criterium spoedig inbreuk zal maken op de grondrechten van de gegadigde, en bovendien vaak niet geschikt zal zijn als middel voor het nagestreefde doel (vgl. par. 3.6.3.6).

Het Westduitse en Zwitserse appartementsrecht kennen nog enkele andere criteria voor weigering van toestemming tot vervreemding. In West-Duitsland kan de toestemming tot vervreemding bijvoorbeeld worden geweigerd, indien te verwachten valt dat de gegadigde de bestemming van zijn appartement onduldbaar zal veranderen (par. 6.3.2). In Zwitserland kent men een soortgelijk criterium (zie par. 8.3.2.2; $\$ 15$ sub 2 reglement Peter-Ruetschi). Naar Nederlands recht is een dergelijk criterium mijns inziens eveneens in beginsel mogelijk. Als een appartementseigenaar zijn appartement in strijd met de bestemming wil gebruiken (hij wil in een appartement met bestemming woonruimte bijvoorbeeld een dancing uitbaten) kan dit naar mijn mening een gewichtige reden opleveren om hem de ingebruikneming te ontzeggen.

Zwitserland kent tenslotte nog als gewichtige reden het feit dat de gegadigde zijn verplichting om de privé-gedeelten te onderhouden niet zal nakomen, waardoor het uiterlijk van het gebouw zal verslechteren (zie \& 15 sub 1 reglement Peter- 
Ruetschi). Theoretisch is het denkbaar dat een soortgelijk criterium ook in Nederland wordt gehanteerd.

In West-Duitsland en Zwitserland zijn blijkbaar criteria toelaatbaar, die op verwachtingen omtrent de toe te laten persoon gebaseerd zijn. Om deze criteria geldig te kunnen hanteren, zal er mijns inziens altijd sprake moeten zijn van een objectieve gevaarzetting, zoals ze in West-Duitsland wordt vereist (zie par. 6.3.2). Het is derhalve niet voldoende dat de appartementseigenaars zelf vinden dat een bepaalde reden tot weigering aanwezig is, als daarvoor geen feiten aan te dragen zijn. In dat geval kan die reden niet als "gewichtig" worden betiteld. Hoewel deze objectieve gevaarzetting in Nederland of Zwitserland niet expliciet wordt vereist, kan worden aangenomen dat deze voorwaarde in beide landen evenals in WestDuitsland geldt. Het gevaar, dat men probeert af te wenden door de hantering van toelatingscriteria, zal in het concrete geval altijd aannemelijk moeten worden gemaakt. Als men in Nederland een gegadigde de toestemming tot ingebruikneming wil weigeren, omdat hij een te grote behoefte aan verzorging heeft, zal men deze verzorgingsbehoefte objectief aannemelijk moeten maken aan de hand van bijvoorbeeld een medisch keuringsrapport. Het kan niet voldoende zijn, dat de vereniging de gegadigde weigert, omdat hij "er wat bleekjes uitziet".

In Zwitserland kent men tenslotte ook nog de weigeringsreden die inhoudt dat de toestemming tot vervreemding kan worden onthouden, omdat de gegadigde personen, aan wie hij zijn appartement in gebruik zal geven, op aanmaning van de administrateur niet uit zijn appartement zal verwijderen. Dit criterium is op de Nederlandse situatie niet transponeerbaar, omdat de Nederlandse vergadering van eigenaars een eigen recht heeft om personen uit een appartement te verwijderen; onafhankelijk van de vraag of zij eigenaars of slechts gebruikers zijn.

\subsubsection{Gebruiksbeperking of vervreemdingsbeperking?}

Om toezicht uit te oefenen op nieuwkomers in een appartementsgemeenschap, kunnen zoals in het voorgaande werd beschreven, verschillende constructies worden gehanteerd. Enerzijds is er de Nederlandse constructie van ontzegging van gebruik, anderzijds kan men ook aan de Duitse of Zwitserse constructies denken, waarin gebruik wordt gemaakt van vervreemdingsbeperkingen en voorkeursrechten. Naar huidig Nederlands recht zijn vervreemdingsbeperkingen mijns inziens mogelijk, omdat zij in het medeëigendomsrecht in beginsel ook gelden, en de gemeenschap van appartementseigenaars een "gebonden" gemeenschap is. Ook een voorkeursrecht is naar mijn mening mogelijk (zie 3.8).

Van deze drie toelatingsregelingen verdient de vervreemdingsbeperking - in die zin dat het recht tot vervreemding afhankelijk wordt gesteld van de toestemming van de vergadering van eigenaars - mijns inziens de voorkeur. Het voorkeursrecht biedt naar mijn mening geen goede toelatingsregeling, omdat dit recht een grote financiële last op de gemeenschap van appartementseigenaars legt. Het is uiteraard denkbaar dat een voorkeursrecht slechts ten gunste van een bepaalde appartementseigenaar wordt.opgenomen, maar in dat geval is het geen toelatingsregeling meer, maar een begunstiging van een andere appartementseigenaar, die graag meerdere appartementen wil verwerven. Een dergelijk voorkeurs- of optierecht zou naar mijn mening niet in het reglement van splitsing, maar in een bijzondere 
overeenkomst tussen appartementseigenaar en voorkeursgerechtigde, moeten worden opgenomen.

De huidige regeling van de welstandsbepalingen in ons recht kent twee bezwaren. Enerzijds vormt de regeling van ontzegging van gebruik een in het Nederlandse recht verder ontbrekende toezichtsregeling, anderzijds - en dit argument weegt mijns inziens zwaar - kan een zekere halfslachtigheid bij deze constructie niet worden ontkend. De welstandsbepalingen lijken weliswaar minder vergaand dan de vervreemdingsbeperkingen, maar grijpen de facto dieper in het leven van de aspirant-bewoner in dan eventuele vervreemdingsbeperkingen. Zachte heelmeesters maken stinkende wonden, want bij de welstandsbepalingen kan het voorkomen dat een persoon eigenaar is van een appartement, maar dat hij er verder niets mee kan doen. Hij zal dan in veel gevallen om financiële redenen genoodzaakt zijn het appartementsrecht te verkopen of te verhuren. Bij een regeling van toestemming tot vervreemding, zouden deze problemen voor de eigenaar niet kunnen ontstaan. Hij zou dan immers geen eigenaar worden.

Artikel 29 modelreglement 1987 komt hieraan enigszins tegemoet door te bepalen, dat degene die nog geen eigenaar is, maar wel gerechtigd is tot levering, ook reeds toestemming tot ingebruikneming kan vragen. Hierdoor wordt voorkomen dat bij het uitblijven van de toestemming de kosten voor de transportakte en de inschrijving in de openbare registers (plus eventuele makelaarskosten) weggegooid geld blijken te zijn, bijvoorbeeld omdat de koopovereenkomst wordt ontbonden of de nieuwe eigenaar het appartement gaat doorverkopen. In de praktijk zal ook zonder toepasselijkheid van artikel 29 modelreglement 1987 vaak voor de levering van het appartementsrecht, om toestemming tot ingebruikneming worden gevraagd. In beginsel zijn problemen echter dan nog steeds zeer wel mogelijk.

Mutatis mutandis geldt hetzelfde voor een toestemmingsregeling bij verhuring of bezwaring. Bij hantering van welstandsbepalingen ten opzichte van een huurder ontstaan voor de gemeenschap van eigenaars weliswaar geen problemen, maar blijven de verhuurder en de huurder door het huurcontract in beginsel aan elkaar gebonden, hetgeen tot schadevergoedingsacties aanleiding kan geven (vgl.' par. 4.4.4.1 en 4.4.4.2). Ook bij bezwaring neemt hantering van de welstandsbepalingen niet weg, dat de eigenaar en de zakelijk gerechtigde door hun onderlinge overeenkomst, aan elkaar gebonden blijven.

Beter lijkt mij dan ook de toestemmingsregeling, waarbij de bevoegdheid tot vervreemding, bezwaring met een zakelijk gebruiksrecht, of verhuring aan de toestemming van de vergadering van eigenaars wordt onderworpen. Als criterium voor een geldige weigering van toestemming zou de gewichtige reden kunnen blijven gelden. Het voordeel van deze constructie is bovendien dat zij beter aansluit bij het feit dat het medeëigendomsrecht naar huidig recht mijns inziens in beginsel op de gemeenschap van appartementseigenaars van toepassing is.

Bij medeëigendom in het algemeen geldt $\mathrm{nu}$, dat de medeëigenaar in beginsel toestemming van de overige medeëigenaars nodig heeft om zijn aandeel te vervreemden (zie par. 4.3.2.1). Als extra reden ten faveure van de vervreemdingsbeperking kan worden aangevoerd, dat zij het nut van financiële criteria, waaraan de praktijk blijkbaar waarde hecht (zie par. 3.6.3.3), vergroot. Met vervreemdingsbeperkingen kan immers worden voorkomen dat een insolvabele gegadigde eigenaar van een appartementsrecht wordt. Om elke twijfel ten aanzien van de 
geldigheid van de hier beschreven toestemmingsregeling weg te nemen, zou artikel $875 f$ lid $4 \mathrm{BW}$ ten dien einde moeten worden veranderd. Dit geldt a fortiori woor het toekomstige recht (art. 5.10.1.5 / 5:112 NBW), omdat vervreemdingsbeperkingen onder de vigeur van het NBW slechts bij een gesplitst erfpachtsrecht mogelijk zullen zijn (vgl. par. 3.8).

\subsection{Ontzegging van verder gebruik}

\subsubsection{Ontzegging wan verder gebruik aan appartementseigenaars of degenen aan wie een appartement in gebruik is gegeven}

Behalve toelatingsregelingen zijn in verscheidene van de in dit werk beschreven rechtsstelsels ook regelingen mogelijk, die ontzegging van verder gebruik van een appartement mogelijk maken. In deze paragraaf worden deze verschillende regelingen met elkaar vergeleken. Daaraan voorafgaand zal echter eerst worden ingegaan op de mogelijkheden voor ontzegging van verder gebruik in het verenigings-, medeëigendoms- en huurrecht.

\subsubsection{De juridische constructie van ontzegging wan verder gebruik}

Vergelijking van de onderlinge controlemogelijkheden binnen gemeenschappen, verenigingen en gebouwen met meerdere huurwoningen, maakt duidelijk dat de leden van een vereniging de mogelijkheid hebben om een lid uit hun midden te verwijderen door middel van opzegging of royement. In het huurrecht kan de verhuurder tegen een overlast veroorzakende huurder optreden uit wanprestatie, en kunnen andere huurders eventueel tegen zo'n huurder optreden met een actie uit onrechtmatige daad (art. 1592 BW). Bovendien kunnen zij zich tot de verhuurder wenden en van deze vorderen, dat hij de huurovereenkomst aan de veroorzaker van de overlast opzegt of ontbinding van de huurovereenkomst vordert (par. 4.4.3.2).

Deelgenoten in een gemeenschap kunnen een andere deelgenoot in beginsel niet uit de gemeenschap verwijderen. Uitzetting van een deelgenoot uit bijvoorbeeld een gemeenschappelijk huis, is zoals vermeld niet mogelijk dan via de gewone weg van beslag en executie. Om het aandeel van een deelgenoot te kunnen uitwinnen, zal echter eerst ontbinding en verdeling van de gemeenschap moeten plaatsvinden. De deelgenoten kunnen een andere deelgenoot echter wel op grond van de goede trouw, die hun rechtsverhouding beheerst, aanspreken om activiteiten die in strijd zijn met zijn bevoegdheden, te staken (vgl. par. 4.3.3).

Leden van een vereniging kunnen iemand uit hun midden het lidmaatschap opzeggen of hem als lid royeren, indien redelijkerwijze niet van de vereniging kan worden gevergd dat zij het lidmaatschap laat voortduren, indien het lid niet meer aan bepaalde kwaliteitseisen voldoet en in andere in de statuten genoemde gevallen. In gevallen van wangedrag kan de vereniging een lid royeren.

De leden van een vereniging hebben dus duidelijk de meest uitgebreide mogelijkheden om ongewenste personen uit hun midden te verwijderen. Huurders van een gebouw kunnen een andere huurder slechts uit hun midden (trachten te) verwijderen, door de verhuurder daartoe aan te spreken of door een vordering ex artikel $1592 \mathrm{BW}$ in te stellen (vgl. hierover par. 4.4.3.2). Bij deze laatste actie kan 
worden gevorderd dat de veroorzaker van de overlast zijn woning moet ontruimen. Of deze vordering slaagt lijkt op dit moment echter af te hangen van de rechter die erover moet beslissen.

In elk geval hoeft een huurder zijn woning pas na een rechterlijk vonnis te ontruimen, terwijl een lid van een vereniging zijn lidmaatschap kwijtraakt door de beslissing tot opzegging of royement door de algemene ledenvergadering. Ook hieruit blijkt dat de vereniging meer vrijheid heeft om controle uit te oefenen op haar leden en sancties als opzegging of royement toe te passen, dan huurders hebben om een veroorzaker van overlast zijn woning te doen ontruimen. Deelgenoten in een gemeenschap kunnen een ongewenste deelgenoot daarentegen in beginsel niet uit de gemeenschap verwijderen.

Deze uitkomst is begrijpelijk, aangezien de vereniging door artikel 8 grondwet wordt beschermd en aan de vereniging een grote mate van vrijheid moet toekomen om invloed op haar eigen bouwstenen, de leden, uit te oefenen. Het persoonlijk recht van de huurder kan hem in bepaalde gevallen worden ontnomen, maar deze ontneming is moeilijk en aan strenge criteria gebonden (par. 4.4.3.1). Het zakelijke medeëigendomsrecht of de vermogensrechtelijke medegerechtigdheid tot een goed, kan tenslotte in beginsel niet aan een deelgenoot worden ontnomen. De "zakelijk" gerechtigde wordt aldus het best beschermd, terwijl de huurder met zijn persoonlijk recht minder bescherming geniet. De leden van een vereniging worden het minst beschermd tegen ontneming van hun lidmaatschap.

De huurder behoeft zijn woning (op vordering van de overige huurders, eventueel via de verhuurder) slechts te ontruimen, indien de rechter meent dat hij zich schuldig heeft gemaakt aan de veroorzaking van ernstige overlast. Het lid van een wereniging, aan wie het lidmaatschap is opgezegd of die is geroyeerd, kan zich tot de rechter wenden en vernietiging van het verenigingsbesluit vragen wegens strijd met wettelijke bepalingen, statuten of de goede trouw. De rechter toetst in deze gevallen echter slechts marginaal. Het "opgezegde" lid kan tevens trachten het verenigingsbesluit nietig te laten verklaren (c.q. te laten vernietigen) wegens strijd met de wet, de openbare orde of de goede zeden (artt. 1371, 1373 BW; art. 3.2.7 / 3:40 NBW). Bovendien kan hij in een aantal gevallen zijn toevlucht nemen tot een actie uit onrechtmatige daad (art. $1401 \mathrm{BW}$; art. 6.3.1.1 / 6:162 NBW).

Een deelgenoot in een gemeenschap, tegen wie de andere deelgenoten op grond van de goede trouw willen optreden, kan verder niets doen dan afwachten wat de actie van zijn deelgenoten oplevert. Ook hieruit blijkt de relatief zwakke positie wan een lid van een vereniging, die anders dan een deelgenoot of een huurder actief moet optreden om een besluit in rechte aan te tasten, terwijl de deelgenoot en de huurder kumnen afwachten wat de overige huurders, de verhuurder of de overige deelgenoten in rechte zullen ondernemen.

Ook bij ontzegging van verder gebruik had de wetgever, evenals bij toelating, een ontzeggingsmogelijkheid uit het verenigingsrecht of het medeëigendomsrecht kunnen hanteren. Ten aanzien van het verenigingsrecht kan echter ook hier worden opgemerkt, dat de vereniging van appartementseigenaars in beginsel slechts een organisatiestructuur vormt en geen vereniging in de zin van artikel 8 Grondwet is, waardoor aan deze vereniging ook niet alle rechten van "gewone" verenigingen moeten toekomen. Een regeling die opzegging of royement in het appartementsrecht mogelijk zou maken, zou daarom oneigenlijk zijn. 
Een ontzeggingsmogelijkheid uit het medeëigendomsrecht kon de wetgever miet in het appartementsrecht incorporeren, omdat dergelijke ontzeggingsregelingen in het medeëigendomsrecht niet bestaan.

Het Nederlandse appartementsrecht heeft nu een geheel eigen ontzeggingsmogelijkheid, waarbij aan een appartementseigenaar het verdere gebruik van zijn appartementsrecht wordt ontzegd, zonder dat hem zijn gerechtigdheid ten aanzien van het appartementsrecht wordt ontnomen. Hetzelfde geldt mutatis mutandis voor ontzegging van verder gebruik aan huurders of vruchtgebruikers, waarbij het "huurrecht" of het recht van "vruchtgebruik" niet aan de huurder of vruchtgebruiker wordt ontnomen, maar hem wel het gebruik van het appartement wordt ontzegd (zie hoofdstuk 3 en voor de gevolgen van ontzegging aan een huurder par. 4.4.4).

In andere landen heeft men voor een andere constructie van ontzegging van verder gebruik gekozen.

In België wordt door Aeby ${ }^{27}$ aangenomen dat het mogelijk is om in het reglement van splitsing een bepaling op te nemen, op grond waarvan een appartementseigenaar bij overtreding van de bepalingen van het reglement, gedwongen kan worden zijn appartement te verkopen. Een andere Belgische auteur, Derine ${ }^{28}$, schrijft echter dat een appartementseigenaar nooit gedwongen kan worden zijn appartement te verkopen. Praktijkgevallen hierover zijn niet bekend, terwijl mijns inziens verder betwijfeld kan worden of een dergelijke sanctie zonder een wettelijke grondslag, in een reglement van splitsing kan worden opgenomen. Een dusdanige sanctie behelst immers een soort privaatrechtelijke "onteigening" en een vergaande beperking van het eigendomsrecht.

Dat een huurovereenkomst kan worden opgezegd wegens gebruik van een appartement, dat in strijd is met het reglement van splitsing, is aan minder twijfel onderhevig. Hierbij moet wel worden opgemerkt dat een huurder slechts kan worden aangesproken wegens niet naleving van een bepaling van het reglement, indien hij aan de desbetreffende bepaling gebonden is. In elk geval heeft de Brusselse rechtbank in 1970 een vordering van een appartementseigenaar toegewezen, die een andere eigenaar dagvaardde om zijn huurder de bestemming van het appartement te doen naleven. De gedaagde riep de huurder in vrijwaring met het gevolg dat de huurovereenkomst werd ontbonden (par. 5.3.3).

In Frankrijk is ontzegging van verder gebruik aan appartementseigenaars, c.q. ontneming van de appartementseigendom, in beginsel niet mogelijk. Slechts indien een appartementseigenaar door het "Tribunal de grande instance" op straffe van een dwangsom is veroordeeld tot het staken van een bepaald gebruik, kan het appartement van deze eigenaar, bij niet betaling van de dwangsom, na vestiging van een hypotheekrecht, worden uitgewonnen. Indien een huurder de verplichtingen van het reglement van splitsing niet nakomt, kan de verhuurder door de vereniging van eigenaars worden aangesproken om de huurovereenkomst te doen ontbinden. Hier geldt dus in beginsel eenzelfde systeem als in België (par. 7.3.3).

Ontzegging van verder gebruik aan appartementseigenaars is derhalve in Frankrijk zeer omslachtig, terwijl ten aanzien van België kan worden betwijfeld of ontzegging wel mogelijk is. Alleen tegen huurders kan via de verhuurder worden

27. Aeby, ble 480 .

28. Derine e.a, blz. 156. 
opgetreden. Of, en zo ja hoe, tegen zakelijk gerechtigden zou kumnen worden opgetreden, is onbekend (par. 5.3.3, 7.3.3).

In West-Duitsland en Zwitserland is ontzegging van verder gebruik daarentegen in de wet geregeld. Het Westduitse WEG maakt het in de $\$ \$ 18$ en 19 mogelijk. dat de gemeenschap van appartementseigenaars van een andere appartementselgenaar verlangt, dat hij zijn appartement verkoopt. Dit recht komt aan iedere gemeenschap van appartementseigenaars toe en hoeft niet in het reglement van splitsing te worden geregeld. In Zwitserland geldt grosso modo dezelfde regeling ingewolge artikel 649b ZGB. Zowel in West-Duitsland als in Zwitserland heeft de rechter echter het laatste woord. De Westduitse regeling wijkt in zoverre van de Zwitserse af, dat de Westduitse vergadering van eigenaars in beginsel kan besluiten dat een appartementseigenaar zijn appartement moet vervreemden, en de rechter slechts behoeft te worden ingeroepen, indien de desbetreffende appartementseigenaar vervolgens niet tot vervreemding overgaat. In Zwitserland stelt de wet de rechterlijke beslissing meer op de voorgrond, en is de appartementseigenaar pas verplicht zijn appartement te verkopen, als de rechter hem daartoe heeft weroordeeld. In West-Duitsland is hij daarentegen in beginsel door het besluit van de wergadering reeds gedwongen om zijn appartement te vervreemden (par. 6.3.3, 8.3.3).

Zowel in West-Duitsland als in Zwitserland geldt bovendien, dat de appartementseigenaar tot vervreemding van zijn appartement kan worden gedwongen, indien personen aan wie hij zijn appartement in gebruik heeft gegeven, hun plichten jegens de gemeenschap niet nakomen. In Zwitserland is dit expliciet in artikel $649 \mathrm{~b}$ ZGB bepaald. In West-Duitsland is dit ten aanzien van de huurder in de jurisprudentie bepaald ${ }^{29}$. De appartementseigenaar moet er in WestDuitsland namelijk yoor zorg dragen, dat degenen aan wie hij zijn appartement in gebruik heeft gegeven, hun plichten jegens de gemeenschap nakomen (par. 6.3.3, 8.3.3). Onder personen, aan wie de appartementseigenaar zijn appartement in gebruik geeft (vgl. \$ 14 lid 2 WEG) moeten waarschijnlijk ook zakelijk (gebruiks)gerechtigden worden begrepen. Duidelijkheid bestaat hierover echter niet. In Zwitserland kunnen zakelijk gebruiksgerechtigden, bijvoorbeeld vruchtgebruikers of gerechtigden tot een recht van bewoning, op dezelfde wijze als de appartementselgenaar tot ontruiming van hun appartement worden gedwongen. Artikel $649 \mathrm{c}$ ZGB verklaart deze uitsluitingsregeling namelijk van overeenkomstige toepassing op de zakelijk gerechtigden (par. 8.3 .3 in fine).

Het zal, met name bij verhuur, van de huurbescherming in de beide landen afhangen, of de huurder na een gedwongen vervreemding, uit het appartement. kan worden verwijderd (vgl. par. 8.3.3 in fine).

\section{4 .3 Criteria voor ontzegging van verder gebruik}

In Nederland geldt evenals bij de toelatingsregeling, dat aan een appartementseigenaar/zakelijk gerechtigde/huurder het verdere gebruik kan worden ontzegd wegens een gewichtige reden. Deze gewichtige reden kan in het reglement van splitsing nader worden uitgewerkt. Artikel 27 van het Modelreglement bij splitsing in appartementsrechten van 1983 bepaalt bijvoorbeeld dat door de vergadering van

29. LG Nürnberg-Fürth 20 september 1963, in Diester (Rechtsprechung), blz. 130, 131. 
eigenaars aan een eigenaar die zijn appartement zelf in gebruik heeft of een andere gebruiker het verdere gebruik van het appartement kan worden ontzegd indien hij:

1. "de bepalingen van het reglement of het huishoudelijk reglement of de bepalingen bedoeld in artikel $876 \mathrm{c}$ van het Burgerlijk Wetboek niet nakomt of overtreedt,

2. zich schuldig maakt aan onbehoorlijk gedrag jegens andere eigenaars of gebruikers" (art. 27 eerste lid).

Het zevende lid van artikel 27 voegt hier voor de gebruiker aan toe, dat aan hem het verdere gebruik ook kan worden ontzegd,

3. "indien thij niet voldoet aan de financiële verplichtingen voortvloeiende uit de door hem gestelde borgtocht" (vgl. ook art. 25 modelreglement 1987).

Art. 33 lid 1 modelreglement 1987 voegt hier nog aan toe:

4. "door zijn aanwezigheid in het gebouw aanleiding geeft tot ernstige verstoring van de rust in het gebouw;

5. "zijn financiële verplichtingen jegens de vereniging niet nakomt" (zie par. 3.7).

Het eerste ontzeggingscriterium is derhalve niet-nakoming van de bepalingen van reglement, huishoudelijk reglement of artikel $876 \mathrm{c}$ BW. België kent blijkens paragraaf 5.3.3 een soortgelijk criterium, voor zover wordt aangenomen dat ontzeggingsregelingen "überhaupt" mogelijk zijn. Onder dit criterium vallen in feite ook de andere criteria die hierboven zijn opgesomd, aangezien die criteria uit bepalingen van het reglement van splitsing voortvloeien. Hetzelfde als hier ten aanzien van het Belgische recht wordt opgemerkt, geldt ten aanzien van Frankrijk, waarvoor naar paragraaf 7.3.3 zij verwezen.

Het Westduitse appartementsrecht stelt in lid 1 van $\$ 18$ WEG als eis voor toelaatbaarheid van uitsluiting, dat de uit te sluiten appartementseigenaar zich in zodanige mate schuldig heeft gemaakt aan niet-nakoming van zijn verplichtingen ten opzichte van de overige appartementseigenaars, dat van deze appartementseigenaars niet kan worden gevergd dat zij de gemeenschapsverhouding met hem laten voortduren. Bärmann, 30 vermeldt dat deze "Generalklausel" in feite niet meer is dan een voor ontzegging van verder gebruik vereiste "gewichtige reden". Dezelfde "Generalklausel" als in West-Duitsland wordt gesteld, komt in Zwitserland terug in artikel $649 \mathrm{~b}$ ZGB.

Het tweede lid van $\$ 18$ WEG sluit bij dit globale vereiste aan en geeft twee gevallen waarin in elk geval sprake is van een reden tot uitsluiting.

30. Bärmann (Kommentar), blz. 432, 433. 
1. De eerste reden is dat de appartementseigenaar ondanks aanmaningen herhaaldelijk zijn plichten ex $\$ 14$ WEG (instandhouding afzonderlijke eigendom, niet toebrengen van onevenredig nadeel e.d.) verzuimt.

2. De tweede reden is dat de appartementseigenaar in gebreke blijft bij te dragen in de lasten en kosten ( $\$ 16$ lid 2 WEG). Als bijzondere eis hierbij wordt gesteld dat het verschuldigde bedrag drie procent van de waarde van zijn appartement te boven gaat en de appartementseigenaar langer dan drie maanden in gebreke moet zijn.

Indien aan een van deze twee eisen is voldaan, behoeven de appartementseigenaars niet meer te bewijzen dat van hen niet kan worden gevergd dat zij de gemeenschap met de in' overtreding zijnde eigenaar voortzetten. Ook nietnakoming van de verplichtingen van het reglement van splitsing geldt als uitsluitingsreden, voor zover deze niet-nakoming tot de situatie leidt, dat van de overige appartementseigenaars niet kan worden gevergd, dat zij de gemeenschapsverhouding met een appartementseigenaar laten voortduren. Hetzelfde geldt voor onfatsoenlijk gedrag e.d.

De gevallen waarin een reden tot uitsluiting uit de gemeenschap bestaat, kunnen in Z witserland nader worden uitgewerkt in het reglement van splitsing. Waarschijn1 lijk is het in West-Duitsland ook mogelijk om een uitwerking van de "Generalklausel" in het reglement van splitsing op te nemen, waarbij de rechter uiteraard in concrete gevallen zal moeten nagaan, of er inderdaad sprake is van een situatie, waarin van de appartementseigenaars niet kan worden gevergd, dat zij de gemeenschap met een bepaalde eigenaar laten voortduren.

In het reglement van Tina Peter-Ruetschi is van een dergelijke uitwerking van de "Generalklausel" inderdaad sprake. Zoals in paragraaf 8.3.3 werd vermeld, geeft $\$ 15$ van dat reglement de volgende uitsluitingsgronden:

1. de appartementseigenaar komt ondanks herhaalde aanmaningen door de administrateur zijn verplichting om zijn privé-gedeelte te onderhouden niet na, waardoor onder andere het uiterlijk van het gebouw verslechtert of dreigt te verslechteren;

2. de appartementseigenaar of leden die tot zijn huishouden behoren of personen door wie hij zijn appartement laat gebruiken, maken op een andere wijze dan de daaraan in $\$ 4$ van het reglement gegeven bestemming gebruik van het appartement en leven ondanks aanmaningen ook de andere in $\$ 4$ gegeven verplichtingen niet na;

3. de appartementseigenaar of zijn gezinsleden vallen de overige bewoners ernstig lastig of verstoren de rust in het gebouw door onbetamelijk, grof, ruziezoekend of kwetsend gedrag;

4. de appartementseigenaar verwijdert bepaalde personen aan wie hij zijn appartement geheel of gedeeltelijk in gebruik heeft gegeven binnen een redelijke termijn niet uit het gebouw, ondanks herhaalde aanmaningen door de administrateur waarin 
zulks werd geëist met bedreiging van ontzegging van verder gebruik.

Naast deze specifieke uitsluitingsgronden, die bij wijze van voorbeeld zijn opgenomen, is in \& 15 van het reglement Peter-Ruetschi de "Generalklausel" opgenomen, dat een appartementseigenaar uit de gemeenschap kan worden uitgesloten, indien door zijn gedrag of het gedrag van personen, aan wie hij zijn appartement in gebruik heeft gegeven of waarvoor hij verantwoordelijk is, verplichtingen tegenover alle of enkele andere deelgenoten zozeer worden geschonden, dat van hen niet meer kan worden verlangd dat zij de gemeenschap met hem laten voortduren.

De bijzondere ontzeggingscriteria van het reglement Peter-Ruetschi kunnen in West-Duitsland theoretisch ook als criteria voor uitsluiting worden gehanteerd. Hetzelfde geldt voor Nederland, waarbij een voorbehoud moet worden gemaakt bij de vierde uitsluitingsgrond, die door de afwijkende ontzeggingsregeling in Nederland niet kan worden gehanteerd. Andersom kan de zoëven voor Nederland onder $\mathrm{c}$. genoemde ontzeggingsgrond niet in Zwitserland of West-Duitsland worden gehanteerd, omdat daar de eigenaar bij niet-nakoming van de verplichtingen door een gebruiker, uit de gemeenschap wordt uitgesloten.

Het is interessant om vast te stellen dat in Nederland en West-Duitsland ook een financieel criterium wordt gehanteerd, op grond waarvan aan de appartementseigenaar het gebruik kan worden ontzegd, c.q. de plicht kan worden opgelegd zijn appartement te verkopen. Zoals in paragraaf 3.6.3.3 al werd opgemerkt, zetten financiële criteria in Nederland echter nauwelijks zoden aan de dijk. In WestDuitsland is dit anders, omdat via de uitsluiting ook wordt bewerkstelligd, dat iemand anders, namelijk de nieuwe eigenaar, in het vervolg de financiële lasten zal moeten dragen, terwijl dit in Nederland niet het geval is.

In Zwitserland wordt geen financieel criterium voor uitsluiting gehanteerd, omdat men daar het wettelijke hypotheekrecht kent, dat tot zekerheid strekt van de schulden van een appartementseigenaar jegens de gemeenschap. Door uitwinning van dit hypotheekrecht wordt de facto wel bereikt, dat een appartementseigenaar uit de gemeenschap wordt uitgesloten.

Globaal genomen kan worden gesteld, dat Nederland, West-Duitsland en Zwitserland dezelfde eisen stellen aan een ontzegging van verder gebruik, c.q. uitsluiting uit de gemeenschap. Ook bestaat een grote overeenkomst ten aanzien van de gronden die tot ontzegging of uitsluiting kunnen leiden. Verschillen treden in feite alleen daar $o p$, waar de verschillende constructies deze verschillen noodzakelijkerwijze met zich meebrengen. Dit is bijvoorbeeld het geval bij de in $\$ 15$ sub 4 reglement Peter-Ruetschi genoemde uitsluitingsgrond, die in Nederland, door de afwijkende constructie van ontzegging van verder gebruik, ondenkbaar is.

Over de Belgische en Franse criteria kan weinig worden vermeld, omdat daarvoor helaas te weinig gegevens bekend zijn. 


\subsubsection{Ontzegging van verder gebruik of witsluiting uit de gemeenschap?}

In paragraaf 9.3.4 sprak ik mijn voorkeur uit voor vervreemdingsbeperkingen in plaats van de huidige, in Nederland gehanteerde toelatingsregeling. Als argument voerde ik daarvoor ondermeer de halfslachtigheid van de huidige toelatingsregeling aan. Ook bij de ontzegging van verder gebruik zou ik dit argument willen hanteren. De ontzegging volgens het huidige recht bewerkstelligt, dat degene aan wie het gebruik wordt ontzegd, eigenaar, huurder of zakelijk gerechtigde blijft. Voor de huurder en de zakelijk gerechtigde betekent dit, dat zij in een rechtsverhouding tot de appartementseigenaar blijven staan. Voor de appartementseigenaar betekent dit, dat hij eigenaar van het appartementsrecht blijft, maar er persoonlijk geen gebruik van mag maken. Na een dergelijke gebruiksontzegging zal de appartementseigenaar veelal tot verkoop van zijn appartementsrecht overgaan, omdat hij er niet veel meer aan heeft.

Als hij echter niet tot vervreemding overgaat, kunnen onverkwikkelijke toestanden ontstaan, omdat hij als eigenaar lid van de vereniging van eigenaars en daarom stemgerechtigd in de vergadering van eigenaars blijft. Hij kan in de vergadering steeds dwars gaan liggen en de sfeer in de gemeenschap ernstig verstoren. Ook hier geldt dus dat zachte heelmeesters stinkende wonden maken.

$\mathrm{Nu}$ in Nederland jurisprudentie (zie par. 3.7) over ontzegging van verder gebruik nagenoeg ontbreekt, kan daaruit worden afgeleid dat men in de praktijk zelden tot ontzegging van verder gebruik overgaat. Dit is mijns inziens begrijpelijk en terecht, amdat de ontzegging het laatste redmiddel moet blijven om problemen in de gemeenschap op te lossen (vgl. par. 6.3.3, par. 8.3.3).

Juist omdat het een laatste redmiddel vormt en zeer weinig wordt toegepast, is er mijns inziens veel voor te zeggen om in de gevallen, waarin men een zo zware sanctie aan een appartementseigenaar wil opleggen, aan de gemeenschap van appartementseigenaars de mogelijkheid te geven om de desbetreffende appartementseigenaar geheel uit de gemeenschap uit te sluiten, zoals dat in Zwitserland en West-Duitsland, en wellicht ook in België, mogelijk is. Door een dergelijke uitsluiting kunnen problemen na de uitsluiting worden voorkomen.

Een ander voordeel van de algehele uitsluiting is, dat men een appartementseigenaar, die zijn financiële verplichtingen niet nakomt, uit de gemeenschap zou kunnen verwijderen en aldus van hem (en zijn wanbetaling) af zou zijn, terwijl dit zoals ik in paragraaf 3.6 .3 .3 betoogde, bij de huidige regeling niet opgaat. Ontzegging van verder gebruik van een appartement is in het huidige Nederlandse stelsel immers slechts als dwangmiddel of als straf te zien. De vereniging van eigenaars heeft echter geen financieel voordeel van de ontzegging van verder gebruik.

De uitsluitingsregeling zou naar mijn mening van de volgende beginselen, die grotendeels zijn ontleend aan het Westduitse en Zwitserse appartementsrecht, moeten uitgaan:

1. indien een appartementseigenaar dermate tekortschiet in de nakoming van zijn plichten ten opzichte van de overige appartementseigenaars, dat van hen riet kan worden gevergd dat zij de gemeenschap met hem laten 
voortduren, kan hij gedwongen worden zijn appartementsrecht te vervreemden;

2. de verplichting om het appartementsrecht te vervreemden kan slechts door de kantonrechter worden opgelegd op verzoek van de vereniging van eigenaars. De vereniging van eigenaars moet tot het indienen van dit verzoek hebben besloten met tweederde van de uitgebrachte stemmen in de vergadering van eigenaars, terwijl in deze vergadering een aantal appartementseigenaars tegenwoordig of vertegenwoordigd moet zijn, dat tenminste tweederde van het totaal aantal stemmen kan uitbrengen (vgl. art. 33 lid 4 modelreglement 1987);

3. de kantonrechter stelt, indien hij van mening is dat van de overige appartementseigenaars niet gevergd kan worden dat zij de gemeenschap met de gerequestreerde laten voortduren, een termijn vast waarbinnen de eigenaar zijn appartementsrecht moet vervreemden. Voor het geval dat de appartementseigenaar binnen de gestelde termijn niet tot vervreemding overgaat, verleent de kantonrechter aan de vereniging van eigenaars de machtiging, om het appartementsrecht na afloop van de termijn in het openbaar te doen verkopen;

4. indien een huurder zijn verplichtingen jegens de overige appartementseigenaars of bewoners niet nakomt, kan de verhuurder door de vereniging van eigenaars gedwongen worden om alles in het werk te stellen de huurder zijn verplichtingen te doen naleven of de huurovereenkomst te doen beëindigen. Indien de verhuurder vervolgens binnen een redelijke termijn zijn plicht niet nakomt, kan hij tot vervreemding van zijn appartementsrecht worden gedwongen en krijgt de vereniging van eigenaars een eigen recht om tegen de huurder op te treden en eventueel de huurovereenkomst op te zeggen, c.q. te doen ontbinden (vgl. par. 7.3.3 in fine);

5. hetgeen hier is gezegd met betrekking tot de appartementseigenaar, is van overeenkomstige toepassing op gerechtigden tot een zakelijk gebruiksrecht op een appartementsrecht. Rechten die niet voor vervreemding vatbaar zijn, gaan door het vonnis van de kantonrechter teniet ${ }^{31}$.

\subsection{Beroepsmogelijkheden}

\subsubsection{Beroep tegen ontzegging van ingebruikneming}

\subsubsection{Intern beroep bij de gemeenschap of de vereniging van appartementseigenaars}

In het Nederlandse modelreglement 1983 is in artikel 24 van de annex bepaald dat een eigenaar zijn appartementsrecht aan een ander in gebruik kan geven, "mits hij

31. Dit geldt met name voor het recht van gebruik en bewoning. Zie Pitlo/Brahn, blz 379 . 
ervoor zorg draagt dat die ander het gebruik slechts verkrijgt" na te hebben verklaard, dat die ander

"de bepalingen van het reglement, het huishoudelijk reglement en een besluit als bedoeld in art. $876 \mathrm{c} \mathrm{BW}$ zal naleven (art. 24 eerste lid). Bovendien is vereist, dat de vergadering haar toestemming tot ingebruikneming verleent" (art. 24, tweede lid).

Om toestemming tot ingebruikneming te verkrijgen dient de gegadigde zich schriftelijk tot het bestuur van de V.v.E. te wenden. Het bestuur moet vervolgens binnen veertien dagen de vergadering bijeenroepen om over de toelating te beslissen (art. 24a, eerste en tweede lid).

Artikel 28 a eerste lid regelt tenslotte dat de verkrijger van een appartementsrecht verplicht is toestemming tot ingebruikneming te vragen aan de vergadering van eigenaars, indien hij de privé-gedeelten zelf in gebruik wil nemen of een ander als gebruiker wil toelaten. Ook voor een nieuwe eigenaar die zijn appartementsrecht aan een ander in gebruik wil geven, geldt dus dat hij voor deze andere toestemming tot ingebruikneming moet vragen. Iemand die al langer eigenaar is hoeft dit niet te doen. De gegadigde zal dan zelf de toestemming tot ingebruikneming moeten vragen.

Op grond van het reglement 1983 moet de toestemming tot ingebruikneming derhalve altijd door de vergadering van eigenaars worden verleend (zie par. 3.3.1).

Dit is anders onder vigeur van het modelreglement 1987. In dit reglement is de toelatingsregeling standaard - dus niet meer in de Annex - opgenomen in artt. 2932. Artikel 29 lid 1 bepaalt dat een appartementseigenaar de toestemming van het bestuur ( $=$ administrateur) van de V.v.E. nodig heeft om

"zijn privé-gedeelte zelf en met de met name genoemde huisgenoten in gebruik te nemen of een tot dusverre niet tot zijn huisgenoten behorend persoon bij zich te doen inwonen."

Het verzoek tot ingebruikneming moet door de eigenaar schriftelijk aan het bestuur worden gedaan, terwijl hij de namen en andere voor de te nemen beslissing relevante gegevens van huisgenoten aan het bestuur verstrekt (art. 29 lid 2).

Het bestuur moet de verzoeker vervolgens binnen 14 dagen in de gelegenheid stellen zijn verzoek mondeling toe te lichten, waarbij hij zich mag laten vertegenwoordigen of bijstaan door een raadsman. Vervolgens moet het bestuur binnen 8 dagen beslissen (art. 29 lid 3 ).

Binnen veertien dagen na de beslissing van het bestuur kan de verzoeker in beroep komen bij de vergadering van eigenaars (art. 28 lid 6). Ook de vergadering moet de verzoeker in de gelegenheid stellen het beroep mondeling toe te lichten, waarbij hij zich mag laten helpen door een raadsman (art. 29 lid 7). De vergadering moet vervolgens binnen 14 dagen beslissen (art. 29 lid 8 ).

Ook indien de appartementseigenaar zijn privé-gedeelte aan een ander in gebruik wil geven, moet deze ander toestemming tot ingebruikneming van het bestuur verkrijgen. De eigenaar en de aspirant-bewoner moeten het verzoek voor deze toestemming gezamenlijk bij het bestuur indienen. Artikel 29 is van overeenkomstige toepassing (art. 31 modelreglement 1987, vgl. ook par. 3.3.1). 
Deze constructie, waarbij de beslissingsbevoegdheid omtrent toelating van een aspirant-gebruiker aan de administrateur wordt toegekend, is mijns inziens uit praktische overwegingen te verkiezen boven de toekenning van die bevoegdheid aan de vergadering, omdat in dit laatste geval met grote regelmaat deze vergadering bijeen zou moeten worden geroepen, terwijl dit in de regeling van het reglement 1.987 slechts in probleemgevallen nodig is.

Ten aanzien van intern beroep bij de vergadering van eigenaars in Belgiè kan weinig worden gezegd. Voor zover ontzegging van ingebruikneming al mogelijk is, ontbreekt hierover nagenoeg elke praktische informatie met betrekking tot de vraag welk verenigings- c.q. gemeenschapsorgaan bevoegd is over de toellating te beslissen. Het bevoegde orgaan lijkt echter de vergadering van eigenaars te zijin (zie par. 5.3.2).

In Frankrijk zijn toelatingsregelingen niet mogelijk, zodat beroep tegen een weigering van toelating niet aan de orde is (par. 7.3.2 en 7.4.2).

In West-Duitsland kan op grond van \& 12 WEG in het reglement van splitsing worden geregeld, dat voor een vervreemding, of verhuring de toestemming van de overige eigenaars of een derde (bijv. de administrateur) nodig is (par. 6.3.2). Zowel tegen de beslissing van de vergadering als tegen de beslissing van de derde staat slechts beroep bij de rechter open, en niet bij de vergadering van eigenaars (zie par. 6.4.2). In Zwitserland wordt bij het recht van bezwaar ("Einsprache") grosso modo hetzelfde systeem gehanteerd als in thet Nederlandse modelreglement 1983. Een voorgenomen vervreemding, bezwaring of verhuring moet aan de administrateur worden gemeld, die vervolgens nagaat of er eigenaars zijn die bezwaar willen maken. Als dat het geval is, moet in beginsel de vergadering worden bijeengeroepen om over het al dan niet uitoefenen van het recht van bezwaar ("Einsprache") te beslissen (zie par. 8.3.2.2).

Ten aanzien van uitoefening van voorkeursrechten is uiteraard geen beroep bij de vergadering van eigenaars mogelijk, omdat de uitoefening van dit recht aan bepaalde personen is voorbehouden, die in de uitoefening niet door de vergadering. worden gecontroleerd.

\subsubsection{Bercep op de rechter}

$\mathrm{Bij}$ weigering van toestemming tot ingebruikneming door de vergadering van eigenaars (in eerste of tweede instantie) staan voor de aspirant-gebruiker in Nederland verschillende beroepsmogelijkheden open. Behalve een eventuele vernietigingsvordering ex artikel 876d BW (art. 5.10.2.1d / 5:130 NBW) kan de gegadigde een vordering uit onrechtmatige daad instellen of een beroep doen op dwaling of een ontbindende voorwaarde in een koopovereenkomst. De belangrijkste beroepsmogelijkheid is voor de appartementseigenaar echter neergelegd in artikel 875o BW (art. 5.10.1.15 / 5:121 NBW). Op grond van dit artikel kan de gegadigde aan de kantonrechter verzoeken om aan hem vervangende machtiging tot ingebruikneming te verlenen.

De beroepsmogelijkheden van de artt. 876d en 875o BW staan echter alleen maar open voor appartementseigenaars, en in thet geval van artikel $876 \mathrm{~d}$, andere stemgerechtigden. Dit heeft tot gevolg dat bijvoorbeeld huurders in beginsel geen 
beroepsmogelijkheid hebben als hen toestemming tot ingebruikneming wordt ontzegd. Een uitzondering hierop vormt het geval dat in de akte van splitsing aan huurders stemrecht in de vergadering van eigenaars is verleend. Dan hebben de huurders de artikel $876 \mathrm{~d}$ BW procedure nog tot hun beschikking. De huurders zullen de verhuurder (meestal appartementseigenaar) soms echter kunnen aanspreken uit wanprestatie (zie par. 4.4.4.1). In de praktijk kan of moet de toestemming tot ingebruikneming voor huurders en zakelijk gerechtigden echter door de appartementseigenaar en de aspirant-gebruiker gezamenlijk worden aangevraagd (zie artikel 31 lid 2 modelreglement 1987). Het modelreglement 1983 stelt de aanvraag van de toestemming door de appartementseigenaar en de aspirant-gebruiker echter niet verplicht, zodat hier het probleem kan optreden dat de aspirant-gebruiker slechts via een onrechtmatige daadsactie tot zijn recht kan proberen te komen. Het is dan ook ten zeerste aan te bevelen dat het modelreglement voor gewone appartementen in die zin wordt aangepast, dat eigenaar en aspirant-gebruiker de toestemming tot ingebruikneming gezamenlijk moeten aanvragen. Bij weigering van toestemming tot ingebruikneming kan de appartementseigenaar zich vervolgens ex artikel $8750 \mathrm{BW}$ tot de kantonrechter wenden (vgl. par. 4.4.4.2).

Beter zou het echter zijn om artikel 8750 BW in die zin aan te passen, dat aan de aspirant-gebruiker, niet-eigenaar, een eigen recht op een verzoek ex artikel $875 \circ \mathrm{BW}$ zou worden toegekend. De rechtsbescherming van deze aspirantgebruikers zou daardoor mijns inziens aanmerkelijk worden verbeterd. Het is immers zeer well mogelijk, dat een appartementseigenaar in de praktijk weigert om het verzoek voor de aspirant-gebruiker in te dienen.

In België kan een appartementseigenaar die geen toestemming krijgt om zijn appartement te vervreemden, een procedure beginnen bij de rechtbank van eerste aanleg die relatief competent is. De rechtbank van eerste aanleg is derhalve bevoegd om van de geschillen tussen appartementseigenaars onderling met betrekking tot de privé-gedeelten, kennis te nemen. Deze rechtbank is namelijk bevoegd om kennis te nemen van alle geschillen die niet bij wet aan een andere rechter zijn toebedeeld. De algemene bevoegdheid wan de rechtbank van eerste aanleg strekt zich uit tot rechtsvorderingen met een waarde van minstens 25000 frank (plusminus 1250 gulden) of waarvan de niet bepaalde waarde duidelijk gellikwaardig is aan een bedrag hoger dan die som.

Zowel bij vervreemdingsbeperkingen als bij beperkingen van de verhuurbevoegdheild is de rechtbank van eerste aanleg bevoegd om kennis te nemen van de geschillen. Een appartementseigenaar die bijvoorbeeld geen toestemming van de overige eigenaars verkrijgt om zijn appartement te vervreemden of verkopen, $\mathrm{kan}$ een vordering tegen de overige eigenaars instellen. Nu voor een geldige vervreemdingsbeperking vereist wordt dat zij in de tijd beperkt moet zijn en in elk geval haar oorsprong moet vinden in een rechtmatig belang, kan de appartementseigenaar trachten aan te tonen dat het rechtmatig belang bij de vervreemdings* beperking ontbreekt, of de beperking niet in de tijd gelimiteerd is. De vervreemdingsbeperking is bij het ontbreken van een van deze geldigheidsvereisten ingevolge artikel $537 \mathrm{BW}$ nietig. Als de vervreemdingsbeperking geldig is, kan hij proberen aan te tonen dat in zijn concrete geval de toestemming ten onrechte is geweigerd, 
bijvoorbeeld omdat er geen gevaar bestaat woor overtreding van de bepalingen wan het reglement door de koper (zie par. 5.4.2).

In Frankrijk zijn toelatingsregelingen zoals gezegd niet mogelijk, zodat beroep tegen een weigering van toelating hier niet aan de orde kan zijn (par. 7.3.2 en 7.4.2).

Een Westduitse appartementseigenaar, die voor vervreemding toestemming van dle overige eigenaars of de administrateur nodig heeft (vgl. par. 6.3.2), kan zich, indien de toestemming niet wordt verleend, ingevolge 43 lid 1 sub 1 WEG in een procedure van de "freiwillige Gerichtsbarkeit" tot het "Amtsgericht" wenden, als de toestemming is geweigerd door de overige appartementseigenaars. In het geval dat de toestemming is geweigerd door de administrateur, moet ingevolge $\S 43$ lid 1. sub 2 WEG dezelfde procedure worden gevolgd. Problematischer wordt het indien de toestemming is geweigerd door een derde, die niet de administrateur is. In dat geval moet namelijk de procedure van de "streitige Zivilgerichtsbarkeit" worden gevolgd. Als de Westduitse rechter van mening is dat de toestemming zonder gewichtige reden is geweigerd, kan het appartement alsnog worden verkocht en kan de gemeenschap van appartementseigenaars zelfs worden veroordeeld tot vergoeding van schade (zie par. 6.3.2 en 6.4.2).

In Zwitserland staat in alle gevallen beroep open tegen de uitoefening van het recht van bezwaar ("Einsprache"). De verkoper van een appartement, die het niet eens is met een bezwaar dat tegen de vervreemding wordt gemaakt, kan zich ingevolge artikel $712 \mathrm{c}$ lid $3 \mathrm{ZGB}$ tot de rechter wenden. De rechter beslist dan in een zogenaamd "summarisches Verfahren". Onderwerp van het "summarische Verfahren" zijn over het algemeen geschillen, waarvan de feiten gemakkelijk vast te stellen zijn of waarin snell een beslissing moet worden genomen. Het "summarische Verfahren" is een vereenvoudigde procedure bij een unus judex. Het is een procedure waarin onder andere de toegelaten bewijsmiddelen zijn beperkt. Besluiten in deze procedure staan gelijk aan besluiten van de rechter in het "ordentliche Verfahren" (normale procedure).

Ingevolge $\$ 215 \mathrm{~d}$ sub 34 ZPO is de "Einzelrichter" bij beroep tegen bezwaar bij vervreemding, verhuring of bezwaring, competent. In Zürich is de president van het "Bezirksgericht" de "Einzelrichter" (vgl. par. 8.4.2).

In alle in dit werk beschreven landen is het mogelijk om geschillen aan arbitrage te onderwerpen. Een arbitrageclausule kan ook in het reglement van splitsing worden opgenomen. Voor Nederland is dit in HR 24 sept. 1964, NJ 1965, 359, beslist ${ }^{32}$.

In West-Duitsland zijn arbitrageovereenkomsten eveneens mogelijk voor de procedures, die normaal op grond van \$ 43 WEG door het "Amtsgericht" moeten worden beslist (zie ook $\$ \$ 1025$ e.v. ZPO). De arbitrage kan in een speciaal daartoe bestemde overeenkomst of in het reglement van splitsing worden geregeld ${ }^{33}$ (zie par. 6.3.3 en 6.4.2).

In Zwitserland kan de bevoegdheid om zich tot de rechter te wenden, bij reglement worden vervangen door een bevoegdheid on zich tot speciaal voor onenigheid tussen de appartementseigenaars benoemde arbiters te wenden. De vervanging van het beroep op de rechter door arbitrage is mogelijk op grond van

32. Zie Beekhuis/Linders, VI par. 6, nr. 2.

33. Zie Bärmann (Kommentar), blz. 782. 
het "Konkordat über die Schiedsgerichtbarkeit" van 27 maart 1969. Volgens artikel 5 van dit concordaat kan men arbiters bevoegd maken om te oordelen over rechtsgevolgen die door vrijwillig handelen zijn ontstaan. Nu vervreemding een krijwillig handelen is, is arbitrage hieromtrent eveneens mogelijk. In het reglement Friedrich is een arbitrageclausule opgenomen in $\$ 58$ (vgl: ook par. 8.4.2). Of ook ad hoc tot arbitrage kan worden besloten, is niet duidelijk.

Ook in België bevat het reglement van splitsing vaak een arbitrageclausule, op grond waarvan geschillen tussen appartementseigenaars bij gebrek aan overeenstemming in de vergadering van eigenaars, aan een arbiter moeten worden voorgelegd (vgl. art. 8.03 modelreglement Aeby, zie ook par. 5.4.1). Het is echter ook mogelijk, dat geschillen buiten het reglement om, ad hoc, aan arbiters worden voorgelegd ${ }^{34}$.

In Frankrijk kunnen appartementseigenaars een geschil eveneens door middel van arbitrage laten beslechten. De beslissing om een geschil door arbiters te laten oplossen, is echter slechts ad hoc mogelijk. De Wet 1965 staat aan deze arbitrage niet in de weg (zie par. 7.4.1).

\subsubsection{De wijze van toetsing door de rechter}

Nu de beroepsmogelijkheden in de verschillende landen aan een vergelijking zijn onderworpen, is het interessant om na te gaan op welke wijze de rechter in beroep tegen een toelatingsbesluit mag toetsen. Bij het Nederlandse recht zal hierbij tevens aandacht worden geschonken aan de toetsing door de rechter aan grondrechten, maar zal de bespreking verder worden beperkt tot de meest voor de hand liggende procedure bij ontzegging van ingebruikneming, de 875o BW (art. 5.10.1.15 / 5:121 NBW) procedure. Alvorens hierop zal worden ingegaan, zullen nog enige intern rechtsvergelijkende opmerkingen worden gemaakt.

Uit de intern rechtsvergelijkende opmerkingen in paragraaf 9.3.2 kan worden geconstateerd dat er een parallellie bestaat tussen verenigingen en gemeenschappen op het gebied van vervreemdingsbeperkingen, c.q. ballotageregelingen.

Hoewel bij de gebonden gemeenschap immers in beginsel altijd een toestemmingsvereiste bestaat, kunnen de deelgenoten in "licht" gebonden gemeenschappen afwijkende afspraken maken, terwijl die afspraken bij sterk gebonden gemeenschappen als de huwelijksgoederengemeenschap, ondenkbaar zijn (vgl. par. 4.3.2.1).

Ook bij de vereniging wordt het ontbreken van een ballotageregeling moeilijker voorstelbaar, naarmate de band tussen de leden hechter en de onderlinge afhankelijkheid groter wordt.

Deze parallel kan worden doorgetrokken tot de beroepsmogelijkheden tegen een weigering van de leden of deelgenoten om een nieuw lid toe te laten of aan een deelgenoot toestemming te verlenen, om over zijn aandeel te beschikken. Beide toelatingsregelingen kennen immers een beroepsgrond in de goede trouw.

Zowel bij de vereniging als bij de gemeenschap kan de rechter de weigering van de toelating of de toestemming tot vervreemding of bezwaring toetsen aan de goede trouw (vgl. par. 4.2.3.3 en 4.3.3). Bij de vereniging kan de rechter het toelatingsbesluit eveneens toetsen aan de statuten en de wettelijke bepalingen die

34. Aeby, blz, 470 . 
de bevoegdheid van de algemene wergadering regelen. Bovendien kan de rechter een ballotagebesluit in bepaalde gevallen ook nog toetsen aan de openbare orde en goede zeden. In sommige gevallen zal een aspirant-lid ook een actie uit onrechtmatige daad kunnen instellen. Ook een deelgemoot in een gemeenschap kan zich theoretisch echter op de wet, de openbare orde of de goede zeden beroepen om een besluit van de overige deelgenoten aan te tasten. Bij vereniging en gemeenschap toetst de rechter bij een beroep op de goede trouw, slechts marginaal. Bij deze marginale toetsing beoordeelt hij niet de doelmatigheid van hei besluit; maar wel onder andere de rechtmatigheid (vgl. par. 4.2.3.3, 4.2.4.4, 4.3.3). Een besluit dat onrechtmatig is, kan immers niet in redelijkheid zijn genomen, indien daardoor iemand anders wordt benadeeld. Bij de rechtmatigheidstoets heeft de rechter ook de mogelijkheid om aan de grondrechten te toetsen.

Het verenigingsrecht biedt aan een aspirant-lid zoals vermeld ook nog de mogelijkheid om vernietiging van een besluit te vragen wegens strijd met de wettelijke bepalingen die de bevoegdheid van de algemene vergadering en de wijze van totstandkoming van besluiten regelen, en wegens strijd met de statuten (par. 4.2.3.3). Dat een dergelijke beroepsmogelijkheid bij de gemeenschap niet bestaat, is mijns inziens praktisch verklaarbaar vanwege het feit dat de gemeenschap geen statuten kent en er geen wettelijke bepalingen zijn die de totstandkoming van besluiten van deelgenoten/medeëigenaars in een "vrije" gemeenschap regelen (d.w.z. een gemeenschap waarvoor in de wet geen bijzondere regels zijn gegeven, zoals bij de gemeenschap van appartementseigenaars bijvoorbeeld wel het geval is). Toetsing aan de wettelijke bepalingen en aan de statuten brengt verder geen uitbreiding van de beroepsmogelijkheden of de toetsingsmogelijkheden van de rechter met zich mee. Hetgeen in strijd met wettelijke bepalingen of statuten wordt besloten, is, indien daardoor iemand wordt benadeeld, altijd in strijd met de goede trouw, c.q. de redelijkheid en billijkheid.

De toetsing aan de wettelijke bepalingen en de statuten is echter beperkter dan een marginale toetsing, aangezien toetsing aan wettelijke of statutaire bepalingen noodzakelijkerwijze, slechts een rechtmatigheidstoetsing inhoudt (zie par. 3.7.2, 4.2.4.4) ${ }^{35}$. Bij marginale toetsing zal de rechter ook een objectief oordeel over de redelijkheid van de aangevochten beslissing moeten vellen.

Anders dan bij de vereniging en de gemeenschap, behoeft de rechter in de procedure ex artikel 875o BW (art. 5.10.1.15 / 5: $121 \mathrm{NBW}$ ) niet marginaal te toetsen (zie par. 2.4 .4 en 3.6.2.1). In deze procedure moet de rechter alle omstandigheden van het geval meenemen en zelf een oordeel geven over de redelijkheid van het toelatingsbesluit. Bij zijn oordeelsvorming moet hij ambtshalve de rechtsgronden aanvullen (art. $48 \mathrm{Rv}$ ) en derhalve ook nagaan of grondrechten van de aspirant-gebruiker ontoelaatbaar geschonden zijn. De toetsing aan de grondrechten kan hij inpassen in een onderzoek naar het bestaan van een geoorloofde oorzaak van het toelatingsbesluit. Dit onderzoek naar de geoorloofde oorzaak maakt op zijn beurt deel uit van de objectieve toetsing, die de rechter eerst zou moeten verrichten. Deze objectieve toetsing houdt in dat de rechter zich moet afvragen of het toelatingsbesluit objectief gezien redelijk is. $\mathrm{Na}$ deze objectieve toetsing kan hij vervolgens nagaan of het toelatingsbesluit subjectief gezien, dus in het concrete geval, ook redelijk is. Indien er grondrechten in het

35. Zie ook Hof 's-Gravenhage 27 mei 1982, waarover Stille (Rechtspersonen), art. 35, aant. 7. 
geding zijn, kan de rechter eventueel aan de hand van het proportionaliteits- en het relevantiecriterium vaststellen, of het toelatingsbesluit een ontoelaatbare inbreuk op een of meerdere grondrechten van de aspirant-gebruiker vormt. De beide criteria kunnen mijns inziens ook worden gehanteerd bij toetsing van een toelatingsbesluit, waarbij geen grondrechten in het geding zijn (zie par. 3.5.3 en 3.6.2.1).

Hierbij moet opgemerkt worden dat de toetsing aan het relevantie- en proportionaliteitsbeginsel bij beperking van grondrechten tot de conclusie kan leiden dat er een ongeoorloofde oorzaak is, terwijl deze toetsing buiten de grondrechten om slechts de redelijkheid aan de weigeringsgrond kan ontnemen. Dit verschil vloeit voort uit het feit dat een ontoelaatbare beperking van een grondrecht strijd met de openbare orde en de goede zeden oplevert (zie par. 3.5.3 en 3.6.2.1).

De vraag of een bepaald besluit aan grondrechten kan worden getoetst, is afhankelijk van het staatsrecht van ieder afzonderlijk land. Omdat verschillen in het staatsrecht tot verschillende conclusies met betrekking tot de toelaatbaarheid van een besluit in het licht van grondrechten kan leiden, is in dit werk niet ingegaan op toetsing van toelatingsbesluiten in het appartementsrecht van België, WestDuitsland en Zwitserland. Daarom zal in het hierna volgende bij deze landen ook geen aandacht aan de grondrechtenproblematiek worden besteed.

Evenals in Nederland, toetst de rechter in West-Duitsland in de procedure van de "freiwillige Gerichtsbarkeit" vol. Hij toetst dus niet marginaal. Zijn beslissing neemt hij echter "nach billigem Ermessen" (voor zover uit de wet of uit overeenkomst niet anders voortvloeit), naar redelijkheid en billijkheid derhalve ( $\$ 43$ lid 2 WEG, zie par. 6.4.2).

Aangezien in Zwitserland geen jurisprudentie over uitoefening van het recht van bezwaar ("Einsprache") is gepubliceerd, kan niet met zekerheid worden vastgesteld hoe de rechter de beslissing van de vergadering van eigenaars zal toetsen. Aangezien hij bij een uitsluitingsprocedure volledig toetst of een gewichtige reden tot uitsluiting aanwezig is (par. 8.4.3), is het aannemelijk dat hij bij het recht van bezwaar ("Einsprache") op dezelfde wijze zal toetsen (zie par. 8.4.2).

Uit de aard van de procedure in België, vloeit eveneens voort dat de Belgische rechter een weigering van toestemming tot verhuring, bezwaring of vervreemding, eveneens vol toetst (zie par. 5.4.2). In Frankrijk is toetsing zoals vermeld niet aan de orde.

\subsubsection{Beroep tegen ontzegging van verder gebruik}

\subsubsection{Intern beroep bij de gemeenschap of de vereniging van appartementseigenaars}

In de landen, waar uitsluiting uit de gemeenschap, c.q. ontzegging van verder gebruik mogelijk is, geschiedt deze uitsluiting of ontzegging na een besluit door de vergadering van eigenaars. In Nederland volgt dit uit artikel 27 modelreglement 1983, en 33 modelreglement 1987 (zie par. 3.3.2).

In West-Duitsland beslist de vergadering van eigenaars eveneens over uitsluiting. Dit volgt uit $\S \S 18$ en 19 WEG (zie par. 6.3.3, 6.4.3). Op grond van artikel $649 \mathrm{~b}$ lid 2 ZGB, geldt in Zwitserland hetzelfde (par. 8.3.3 en 8.4.3). 
Ten aanzien van België geldt waarschijnlijk eveneens hetzelfde. Omdat echter niet met zekerheid is vast te stellen of uitsluiting uit de gemeenschap daar "überhaupt" mogelijk is " kan evenmin met zekerheid worden gezegd welk gemeenschapsorgaan het uitsluitingsbesluit zou kunnen nemen (vgl. par. 5.3 .3 en 5.4.3).

In Frankrijk is directe uitsluiting van een appartementseigenaar niet mogelijk. Voor de beroepsmogelijkheden bij indirecte uitsluiting zij verwezen naar paragraaf 7.3 .3 en 7.4.3.

Intern beroep tegen uitsluiting uit de gemeenschap of ontzegging van verder gebruik is derhalve in geen van de besproken rechtsstelsels mogelijk, aangezien de vergadering van eigenaars het ontzeggingsbesluit zelf in eerste instantie al neemt.

\subsubsection{Beroep op de rechter}

Een appartementseigenaar aan wie het verdere gebruik van zijn privé-gedeelte wordt ontzegd, kan in Nederland ingevolge artikel 876d BW (art. 5.10.2.1d / 5:130 NBW) de kantonrechter verzoeken om het besluit van de vergadering te vernietigen:

"a. wegens strijd met de wettelijke bepalingen die de bevoegdheid van de vergadering en de wijze van totstandkoming van besluiten regelen;

b. wegens strijd met de akte van splitsing;

c. wegens strijd met de goede trouw" (art. 876d lid $1 \mathrm{BW}$ ).

Het verzoek tot vernietiging moet worden gedaan binnen een maand na de dag waarop de verzoeker van het besluit van de vergadering heeft kennis genomen of kennis heeft kunnen nemen (art. 876d lid 2 BW; art. 5.10.2.1d lid 2 / 5:130 lid 2 NBW).

De eerste twee vernietigingsgronden spreken voor zichzelf. De vernietigingsgrond onder c. verdient echter nadere uitwerking. Met de goede trouw wordt de verbintenissenrechtelijke goede trouw, de redelijkheid en billijkheid bedoeld (par. 3.7.2).

Het probleem bij de actie ex artikel $876 \mathrm{~d} B W$ is, dat degenen die geen appartementseigenaar zijn, en evenmin op grond van het reglement stemrecht in de vergadering hebben, deze actie niet kunnen instellen. Voor deze personen (huurders, zakelijk gerechtigden die geen stemrecht hebben, vgl. art. 875q BW) kan alleen een onrechtmatige daadsactie of een vordering tot vernietiging op grond van artt. 1371, $1373 \mathrm{BW}$ (art. 3.2.7 / 3:40 NBW) soelaas bieden. Aan de andere kant is het uiteraard wel mogelijk, dat de appartementseigenaar de actie tot vernietiging instelt.

Het verdient mijns inziens aanbeveling om deze hiaat in de rechtsbescherming van de gebruikers-niet-eigenaars van appartementen via een wetswijziging op te vullen, waardoor ook deze gebruikers de mogelijkheid krijgen om voor hun eigen rechten op te komen (vgl. ook par. 9.5.1.2). Als mijn voorstel tot wetswijziging, zoals gedaan in de hierna volgende paragraaf 9.7 , zou worden overgenomen, is 
een aanpassing van artikel 876d BW (art. 5.10.2.1d / 5:130 NBW) echter niet nodig.

Indien de appartementseigenaars in West-Duitsland bij de rechter een veroordeling tot vervreemding van een appartement vorderen ( $\$ 51$ WEG) kan de uit te sluiten appartementseigenaar daar verweer voeren. Het verweer moet dan wel gericht zijn op de grond van de uitsluiting. De appartementseigenaar zal derhalve moeten betogen dat hij niet op zodanige wijze zijn plichten heeft verzuimd, dat van de overige eigenaars niet kan worden gevergd dat zij de gemeenschap met hem voortzetten. Een formeel verweer - over de totstandkoming van het vergaderingsbesluit - kan hij in deze "Rechtsstreit" niet voeren (vgl. par. 6.4.3)

De Zwitserse appartementseigenaar (of zakelijk c.q. persoonlijk gerechtigde wiens recht in de openbare registers is ingeschreven), die men uit de gemeenschap van appartementseigenaars wil uitsluiten, kan evenals zijn Westduitse lotgenoten, bij de rechter bij wie de gemeenschap de beslissing tot uitsluiting vordert, verweer voeren. Voor de vordering tot uitsluiting gelden, bij ontbreken van een bijzondere procedure, de procedureregels met betrekking tot het "ordentliche Verfahren". Dit betekent dat de rechter van de plaats waar het onroerend goed is gelegen, relatief bevoegd is ( $\$ 6 \mathrm{ZPO}$ ). Voordat men echter (in het kanton Zürich, waarvan in dit werk het procesrecht als voorbeeld is verwerkt, zie par. 8.4.1) naar de rechter kan stappen, moet eerst het zogenaamde "Sühnverfahren" bij de vrederechter worden doorlopen. Dit is een zeer kort durende procedure, waarin moet worden vastgesteld of een verzoening tussen partijen kan worden bereikt ( $\$ 8 \mathrm{GVG}$ ). Blijkt verzoening niet mogelijk, dan kan de vordering aanhangig worden gemaakt bij het "Bezirksgericht", dat absoluut competent is (zie par. 8.4.2 en 8.4.3).

Als het naar Belgisch recht mogelijk is, dat een appartementseigenaar tot vervreemding van zijn appartement kan worden gedwongen, geldt grosso modo dezelfde regeling voor beroep als in West-Duitsland en Zwitserland. Indien gedwongen vervreemding van een appartement mogelijk is, zullen de appartementseigenaars haar namelijk slechts via een procedure bij de rechtbank van eerste aanleg kunnen afdwingen. De appartementseigenaar die zijn appartement zou moeten verkopen, zou daar dan ook verweer kunnen voeren (zie par. 5.4.2 en 5.4.3).

In Frankrijk is uitsluiting uit de gemeenschap als directe sanctie voor wangedrag, zoals vermeld niet mogelijk. Voor beroep tegen indirecte uitsluiting, zie paragraaf 7.4.3.

\subsubsection{De wijze van toetsing door de rechter}

Deelgenoten in een gemeenschap kunnen een andere deelgenoot in beginsel niet uit de gemeenschap verwijderen. De deelgenoten kunnen een andere deelgenoot zoals gezegd echter wel op grond van de goede trouw, die hun rechtsverhouding beheerst, aanspreken om activiteiten die in strijd zijn met zijn bevoegdheden, te staken (vgl. par. 4.3.3, 9.4.2 en 9.5.1.3).

Het lid van een vereniging, aan wie het lidmaatschap is opgezegd of die is geroyeerd, kan zich tot de rechter wenden en vernietiging van het verenigingsbesluit vragen wegens strijd met wettelijke bepalingen, statuten of de goede trouw 
(art. 2:11 BW). De rechter toetst in deze gevallen echter hoogstens marginaal ${ }^{36}$. Ditzelfde gelld ook bij een actie van medeëigenaars tegen een van hen.

De toetsing in de procedure ex artikel 876d BW (art. 5.10.2.1d / 5:130 NBW) van een besluit van een vergadering van eigenaars van een appartementencomplex is eveneens ten hoogste een marginale toetsing. Artikel $876 \mathrm{~d}$ BW lijkt overigens sterk op artikel 2:11 BW. De marginale toetsing staat echter niet in de weg aan een toetsing aan grondrechten, omdat marginale toetsing in elk geval een rechtmatigheidstoetsing inhoudt. Bij de toetsing aan grondrechten kan de rechter ook de doelmatigheid van de inbreuk of de beperking van de grondrechten beoordelen. Deze doelmatigheidstoetsing, als onderdeel van toetsing aan het relevantiecriterium, is immers een onderdeel van de rechtmatigheidstoetsing. Evenzeer kan hij het ontzeggingsbesluit via het proportionaliteitscriterium toetsen. Dit is anders indien er geen grondrechten in het geding zijn. In dat geval mag de marginaal toetsende rechter immers niet de doelmatigheid en de proportionaliteit van een besluit beoordelen (zie par. 3.7.2).

De toetsing van een uitsluitingsbesluit aan grondrechten in de buitenlandse rechtsstelsels, is in dit boek zoals gezegd niet behandeld, omdat verschillen in het staatsrecht van de verschillende landen tot verschillende conclusies met betrekking tot de toelaatbaarheid van een uitsluitingsbesluit in het licht van grondrechten kunnen leiden. Daarom zal in het hierna volgende bij deze landen ook geen aandacht aan de grondrechtenproblematiek worden besteed.

De aard van de procedure brengt in Zwitser]and en West-Duitsland bij beroep tegen uitsluiting met zich mee, dat de rechter alle facetten van de zaak meeweegt en vervolgens besluit, of van de gemeenschap van appartementseigenaars kan worden gevergd, dat zij de gemeenschap met de uit te sluiten appartementseigenaar laten voortduren. Uit geen enkele wettelijke bepaling, noch uit de jurisprudentie, blijkt dat de rechter zich in de uitsluitingsprocedure terughoudend zou moeten opstellen of zich zodanig opstelt. Dit is ook begrijpelijk, aangezien de vergadering van eigenaars in West-Duitsland, en sterker nog in Zwitserland, in feite slechts kan besluiten tot het aanhangig maken van een vordering tot uitsluiting. Het laatste woord heeft echter altijd de rechter (par. 6.4.3 en 8.4.3).

In Nederland heeft de wetgever daarentegen aan de vergadering van eigenaars een grote bevoegdheid toegekend, en is de ontzegging van verder gebruik door het vergaderingsbesluit in beginsel een feit. De rechter kan nog slechts toetsen, of de vergadering in redelijkheid tot de ontzegging heeft kunnen komen en of het besluit genomen is in overeenstemming met de akte van splitsing en de wettelijke bepalingen die de bevoegdheid van de vergadering en de wijze van totstandkoming van besluiten regelen (art. 876d BW; art. 5.10.2.1d / 5:130 NBW).

Voor België geldt, indien uitsluiting uit de gemeenschap mogelijk is, hetzelfde als hierboven ten aanzien van het Westduitse en Zwitserse recht werd opgemerkt (zie par. 5.4.3). Voor het Franse recht zij wederom verwezen naar paragraaf 7.4.3.

36. Het "opgezegde" lid kan tevens trachten het verenigingsbesluit nietig te laten verkllaren (c.q. te laten vernietigen) wegens strijd met de wet, de openbare orde of de goede zeden (artt. 1371, $1373 \mathrm{BW}$; art. 3.2.7 / 3:40 NBW). Bovendien kan hij in een aantal gevallen zijn toevlucht nemen tot een actic uit onrechtmatige daad (art. $1401 \mathrm{BW}$; art. 63.1.1 / 6:162 NBW). 


\subsection{Slotopmerkingen}

Uit de voorgaande samenvattende vergelijking kan worden geconchdeerd dat de hoofdlijnen van bet appartementsrecht in Nederland, Belgie, West-Duitsland, Frankrijk en Zwitserland veel overeenkomsten vertonen. Het Nederlandse recht vertoont, qua geschiedenis van de wettelijke regeling de meeste overeenkomsten met het Westduitse en Zwitserse recht. In alle drie de landen is het appartementsrecht betrekkelijk kort na de tweede wereldoorlog tot stand gekomen, waarbij appartementseigendom expliciet mogelijk werd gemaakt. Ook ten aanzien van de structuur van het appartementsrecht vertoont het Nederlandse appartementsrecht verwantschap met Zwitserland en West-Duitsland. De Zwitserse structuur komt nagenoeg overeen met de Nederlandse, terwijl de Westduitse structuur meer dan de Belgische of de Franse aan de Nederlandse verwant blijkt, omdat in WestDuitsland de medeëigendomscomponent op de voorgrond wordt gesteld. In Frankrijk en België wordt de volle eigendom daarentegen op de voorgrond gesteld.

Ook op het gebied van het ontstaan van appartements"eigendom" kan Nederland, met name ten aanzien van het moment van totstandkoming van de splitsing en ten aanzien van de "papieren splitsing" met West-Duitsland en Zwitserland in éen groep worden ingedeeld (vgl. par. 9.2.2.1 en 9.2.2.2). Voor het tenietgaan van de appartements"eigendom" (par. 9.2.2.3) en voor administratie en beheer (par. 9.2 .3 ), geldt dit in veel mindere mate. Alleen op het gebied van het stemrecht bestaan grotere overeenkomsten tussen het Belgische, Franse en Nederlandse appartementsrecht, dan tussen het Nederlandse en het Zwitserse en Westduitse. Op het gebied van de rechten en plichten van de appartementseigenaars vertoont het appartementsrecht van de vijf besproken landen wederom grote verwantschap (par. 9.2.4).

Ten aanzien van toelating en ontzegging van verder gebruik kan Nederland zich duidelijk bij Zwitserland en Duitsland scharen, omdat deze regellingen in Frankrijk niet of nauwelijks mogelijk zijn, en ze in België zeer zwak ontwikkeld en wellicht ook niet mogelijk zijn.

Als een keuze zou moeten worden gemaakt, tot welke (appartements)rechtsfamilie het Nederlandse appartementsrecht moet worden gerekend, lijkt een indeling in de "Deutsche Rechtskreis" het best verdedigbaar. Hierbij moet wel worden opgemerkt, dat een dergelijke indeling moeilijk te maken is, omdat het appartementsrecht van de in deze dissertatie besproken rechtsstelsels, in grate lijnen grote verwantschappen vertoont, terwijl in elk geval een wederzijdse beïnvloeding kan worden geconstateerd (vgl. bijvoorbeeld het wettelijke hypotheekrecht van de Zwitserse gemeenschap van appartementseigenaars, dat waarschijnlijk aan het Franse appartementsrecht is ontleend).

Verder kan met betrekking tot de toelating en ontzegging van verder gebruik worden vastgesteld, dat jurisprudentie op dit gebied zowel in West-Duitsland en Zwitserland als in Nederland, vrijwel ontbreekt. Een oorzaak hiervoor kan wellicht worden gevonden in het feit, dat de meeste mensen deze regelingen nogal vergaand vinden en daarom terughoudend zijn in het toepassen ervan. Een praktischer argument kan wellicht aan de beschrijving van het Westduitse recht worden ontleend, waarin werd vermeld dat de kosten, die aan een ontzegging (van toestemming tot ingebruikneming of van verder gebruik) kunnen zijn verbonden, 
alls "natuurlijke" barrière voor lichtvaardige toepassing van ontzeggingsregelingen fungeren (par. 6.3.2 in fine). Behalve een eventuele veroordeling tot schadewergoeding, zal een gemeenschap van appartementseigenaars bij een eventuele juridische procedure immers al snel haar eigen proceskosten moeten betalen. Deze proceskosten kunnen, in elk geval in West-Duitsland, hoog oplopen.

Tenslotte verdient de Westduitse regeling, dat een appartementseigenaar, over wiens uitsluiting in de vergadering van eigenaars wordt beslist, niet mag meestemmen, nog extra aandacht (zie \& 25 lid 5 WEG). In Nederland mag een appartementseigenaar immers altijd meestemmen, ook als over zijn uitsluiting wordt gestemd. Dit kan in Nederland tot gevolg hebben, dat aan bepaalde appartementseigenaars nooit het verdere gebruik kan worden ontzegd, omdat zij een groot stemmenaantal hebben. Een keuze voor de ene of de andere regeling kan mijns inziens moeilijk worden gemaakt, omdat in de praktijk mensen zullen worden benadeeld, welke regeling men ook hanteert. Enerzijds verdient een appartementseigenaar, die een groter aandeel in de gemeenschap heeft dan andere eigenaars, meer macht dan de anderen. Anderzijds moeten de "kleinere" appartementseigenaars worden beschermd tegen de macht van degenen die meer stemmen hebben.

\subsection{De lege ferenda}

Het Nederlandse recht kent in grote lijnen een goede en bevredigende regeling van het appartementsrecht. Op sommige plaatsen in dit boek heb ik echter al op hiaten gewezen of heb ik voorstellen tot verbetering van de huidige regeling gedaan.

De eerste aanpassing van de wettelijke regeling stelde ik in paragraaf 2.4.2.1 ten aanzien van de mogelijkheid, om parkeergarages in appartementen te splitsen, voor. Mijns inziens zou aan artikel 875a lid 3 BW (art. 5.10.1.1 lid 3 / 5:106 lid 3 NBW) een zin moeten worden toegevoegd die ongeveer als volgt zou kunnen luiden:

"Gedeelten van een gebouw zijn ondermeer blijkens hun inrichting bestemd om als afzonderlijk geheel te worden gebruikt, indien deze bestemming uit duurzame afscheidingen of duurzame en duidelijke markeringen blijkt" (vgl. hierbij \& 3 lid 2 WEG).

Door deze toevoeging zou de mogelijkheid van splitsing van een parkeergarage buiten twijfel worden gesteld.

Ten tweede merkte ik in paragraaf 9.2.3 sub $\mathrm{D}$ op, dat aan de Nederlandse commissarissen ook een plicht tot assistentie aan de administrateur zou moeten worden opgelegd. In artikel $876 \mathrm{i}$ lid $1 \mathrm{BW}$ zou deze plicht kunnen worden verankerd, door dit artikellid bijvoorbeeld als volgt te herzien:

"In de statuten kan worden bepaald dat het toezicht op en assistentie aan het bestuur aan commissarissen wordt opgedragen." 
Aargezien onder vigeur van het NBW ingevolge artikel 5.10.2.1i / 5:135 de algemene regeling van artikel 2:47 BW zal gelden, is aampassing van artikel 5.10.2.1i / 5:135 NBW meer voor de hand liggend dan aanpassing van artikel $876 \mathrm{i}$ BW. Dit laatste artikel zal immers binnen enkele jaren zijn gelding verliezen. Art. 5:10.2.1i / 5:135 NBW zou als volgt kunnen worden aangepast:

"De artikelen 45 lid 4, 47, 48 en 49 van Boek 2 zijn van toepassing. De raad van commissarissen die ingevolge art. 47 van Boek 2 kan worden ingesteld, oefent toezicht uit op het bestuur en staat het bestuur bij in de uitoefening van zijn taken."

Meer ingrijpende wetswijzigingen heb ik tenslotte bepleit ten aanzien van de welstandsbepalingen (vgl. par. 9.3.4 en 9.4.4). Mijns inziens zou uit artikel $875 \mathrm{f}$ lid 4. BW (art. 5.10.1.5 lid 4/5:112 lid 4 NBW) de tweede volzin moeten worden geschrapt. Tussen de artikelen $875 \mathrm{n}$ en 8750 BW (in het NBW tussen artt. 5.10.1.13 / 5:120 en 5.10.1.15 / 5:121) zou een nieuw artikel moeten worden ingevoegd, dat ongeveer als volgt zou kunnen luiden:

1. In het reglement van splitsing kan worden bepaald, dat een appartementseigenaar voor vervreemding, bezwaring met een recht van vruchtgebruik of een recht van gebruik of bewoning en andere ingebruikgeving aan derden van zijn appartementsrecht, toestemming van de vergadering van eigenaars behoeft.

2. De toestemming mag door de vergadering van eigenaars slechts om nader in het reglement aangegeven gewichtige redenen worden geweigerd.

3. In het reglement van splitsing kan tevens worden bepaald, dat een appartementseigenaar door de kantonrechter op verzoek van de vergadering van eigenaars kan worden gedwongen om zijn appartementsrecht te vervreemden.

4. Over het verzoek op grond van lid 3 van dit artikel, moet door de vergadering van eigenaars met tweederde meerderheid, in een vergadering waarin een aantal eigenaars tegenwoordig of vertegenwoordigd is, dat tenminste tweederde van het totaal aantal stemmen kan uitbrengen, worden besloten.

5. De kantonrechter veroordeelt een appartementseigenaar slechts tot vervreemding van zijn appartementsrecht, indien daarvoor een gewichtige reden bestaat. Van een gewichtige reden is slechts sprake, indien door gedragingen van de appartementseigenaar of door gedragingen van personen, voor wiens gedrag hij moet instaan, verplichtingen ten opzichte van een of meerdere andere appartementseigenaars of appartementsgebruikers in zodanige mate geschonden zijn, dat van de overige appartementseigenaars niet kan worden gevergd dat zij de gemeenschap met hem laten voortduren.

6. Indien de kantonrechter van mening is dat een gewichtige reden als in het vorige lid bedoeld, aanwezig is, veroordeelt hij de appartementseigenaar om zijn appartementsrecht binnen een 
door de kantonrechter vast te stellen termijn te vervreemden. Tegelijkertijd bepaalt de kantonrechter, dat de vereniging van appartementseigenaars na afloop van deze termijn tot openbare verkoop van het appartementsrecht van de in de leden 3 tot en met 5 bedoelde eigenaar, mag overgaan. Voor deze openbare verkoop geldt het vonnis als executoriale titel. Regelingen ingevolge de eerste twee leden van dit artikel kunnen niet tegen de verkrijger worden ingeroepen.

7. Op verzoek van de vereniging van eigenaars of de appartementseigenaar kan de kantonrechter bepalen dat de verkoop in het vorige lid bedoeld, onderhands zal geschieden bij een overeenkomst die hem ter goedkeuring wordt voorgelegd. Indien door de appartementseigenaar of door de vereniging van appartementseigenaars voor de afloop van de behandeling van het verzoek aan de kantonrechter een gunstiger aanbod wordt voorgelegd, kan deze bepalen dat de verkoop overeenkomstig dit aanbod zal geschieden ${ }^{37}$. Het in de laatste volzin van het vorige lid bepaalde is bij onderhandse verkoop van overeenkomstige toepassing.

8. Tot de in lid 5 genoemde personen, voor wiens gedrag een appartementseigenaar moet instaan, behoren degenen, die het gebruik anders dan op grond van een zakelijk recht, hebben verkregen.

9. Een appartementseigenaar moet op aanmaning van de vergadering van eigenaars of het bestuur de in het vorige lid genoemde personen, verplichten de voorschriften, waaraan deze ingevolge art. $875 \mathrm{~m}$ zijn gebonden, na te leven. Indien een appartementseigenaar na twee aanmaningen deze verplichting niet nakomt, kan hij op grond van de leden 3 tot en met 7 van dit artikel uit de gemeenschap worden gesloten. De vereniging van eigenaars treedt dan in alle rechten, met uitzondering van het recht op een tegenprestatie, die normaal aan de appartementseigenaar in de verhouding tot de gebruiker toekomen.

10. Het in de leden 3 tot en met 9 bepaalde is van overeenkomstige toepassing ten aanzien van gerechtigden tot een zakelijk gebruiksrecht, dat op een appartementsrecht is gevestigd. Zakelijke rechten die niet voor vervreemding vatbaar zijn, gaan door het vonnis van de kantonrechter, als bedoeld in lid 6 , teniet.

Zie voor een toelichting hierbij de paragrafen 9.3.4 en 9.4.4.

Ook als de hier voorgestelde regeling niet zou worden overgenomen, verdient het aanbeveling om art. 875o BW (art. 5.10.1.15 / 5:121 NBW) aan te passen, zodat aspirant-gebruikers die geen appartementseigenaar zijn, het in dit artikel bedoelde verzoek ook aan de kantonrechter mogen richten (zie par. 9.5.1.2).

37. Vgl. hierbij art. 39.4.11 lid $2 / 3: 268$ lid 2 NBW. 
In lid 1 van art. 8750 BW zouden daarom de woorden "een appartementseigenaar of een derde" moeten worden ingevoegd na de eerste bijzin. De eerste zin zou dan aldus worden aangepast:

In alle gevallen waarin een appartementseigenaar voor het verrichten van een bepaalde handeling met betrekking tot de gedeelten die niet bestemd zijn als afzonderlijk geheel gebruikt te worden en, in het geval van een beding als bedoeld in art. $875 \mathrm{f}$, vierde lid ${ }^{38}$, een appartementseigenaar of een derde met betrekking tot gedeelten die bestemd zijn als afzonderlijk geheel gebruikt te worden, medewerking of toestemming behoeft etc.

Art. 875o BW (art. 5.10.1.15/5:121 NBW) blijft verder ongewijzigd.

38. In het NBW zou hier moetem worden verwezen naar art. 5.10.1.5 lid 4 c.q. 5:112 lid 4. 
SAMENVATTINGEN 

* 
Appartementsrecht en de welstandsbepalingen

In het voorliggende boek wordt ingegaan op het appartementsrecht in het algemeen en op de welstandsbepalingen in het appartementsrecht in het bijzonder. Het boek bevat vier delen. Het eerste, inleidende deel bevat een verduidelijking van de begrippen "appartementsrecht" en "welstandsbepalingen" en een verantwoording van de gehanteerde onderzoeksmethode en de onderzoeksopzet. Zo wordt het begrip "appartementsrecht" opgesplitst in "appartementsrecht in enge zin" en "appartementsrecht in ruime zin".

Het "appartementsrecht in enge zin" vormt de aanduiding voor het recht dat een individu ten aanzien van een appartement kan hebben. De eigenaar van een "appartementsrecht in enge zin" wordt blijkens de bovenstaande omschrijving geen volle eigenaar van "zijn" privé-gedeelten, maar slechts medeëigenaar van grond en gebouwen en beperkt zakelijk gerechtigde ten aanzien van zijn privé-gedeelten. Indien een erfpachts- of opstalrecht ten grondslag ligt aan de splitsing in appartementsrechten, is de appartementseigenaar medegerechtigde tot het erfpachts- of opstalrecht, beperkt zakelijk gerechtigde ten aanzien van de privégedeelten en bij een gesplitst opstalrecht tevens medeëigenaar van in de splitsing betrokken gebouwen.

Het "appartementsrecht in ruime zin" kan worden omschreven als het geheel van rechtsregels dat op het "appartementsrecht in enge zin" van toepassing is. Het "appartementsrecht in ruime zin" is in het huidige Burgerlijk Wetboek neergelegd in de artikelen $875 \mathrm{a}$ tot en met $876 \mathrm{t}$.

Aangezien het onderscheid tussen "appartementsrecht in ruime zin" en "appartementsrecht in enge zin" slechts van belang is bij de verduidelijking van de dubbele betekenis van het begrip "appartementsrecht", en in dit boek telkens uit de context blijkt in welke betekenis deze term wordt gebruikt, wordt na paragraaf 1.1 geen expliciet onderscheid meer gemaakt tussen de beide "appartementsrechten".

De "welstandsbepalingen" in het appartementsrecht bieden de eigenaars van een appartementencomplex een toezichtsinstrument, waarmee enerzijds aan ongewenste aspirant-bewoners de ingebruikneming van een appartementsrecht kan worden ontzegd en anderzijds het verdere gebruik aan een reeds "zittende" bewoner kan worden ontzegd. De welstandsbepalingen bieden echter geen mogelijkheid om te woorkomen dat een aspirant-eigenaar een appartementsrecht verwerft. Evenmin kan door middel van hantering van welstandsbepalingen aan een "zittende" appartementseigenaar zijn appartementsrecht worden ontnomen.

$\mathrm{Na}$ de verduidelijking van de gebezigde terminologie worden het doel, de methode en de opzet van het onderhavige onderzoek omschreven.

Het doel van de onderhavige studie is tweeledig. De eerste doelstelling is om een beter inzicht te verschaffen in regelingen van ontzegging van gebruik van appartementen. Met betrekking tot de welstandsbepalingen in het appartementsrecht wordt in deze studie onderzocht of voor ontzegging van gebruik (naar Nederlands recht) andere, wellicht betere, regelingen mogelijk zijn en welke criteria 
voor deze ontzegging kunnen worden gehanteerd. In de tweede plaats wordt het appartementsrecht in ruime zin vanuit rechtsvergelijkend perspectief beschouwd, waarbij een systematisch overzicht van de hoofdlijnen van het appartementsrecht van een aantal Westeuropese landen wordt gegeven om overeenkomsten en verschillen tussen de verschillende regelingen vast te stellen.

Als onderzoeksmethode is in dit werk de rechtsvergelijking gekozen, waarbij onderscheid wordt gemaakt tussen "interne rechtsvergelijking" en "externe rechtsvergelijking". Beide vormen van rechtsvergelijking worden in dit werk toegepast. Bij de externe rechtsvergelijking worden het Nederlandse appartementsrecht en de welstandsbepalingen in dit boek vergeleken met de overeenkomstige regelingen in België, de Bondsrepubliek Duitsland, Frankrijk en Zwitserland.

De beschrijving van het appartementsrecht en de welstandsbepalingen (c.q. aan de welstandsbepalingen equivalente regelingen) van Nederland, België, de Bondsrepubliek Duitsland, Frankrijk en Zwitserland is in de verschillende hoofdstukken telkens als volgt gestructureerd. $\mathrm{Na}$ een beschrijving van de historische ontwikkeling van het appartementsrecht wordt allereerst ingegaan op de algemene structuur van appartementseigendom, c.q. appartementsrechten. Ten tweede worden de wijzen van ontstaan en tenietgaan van appartementseigendom, c.q. appartementsrechten in de verschillende landen beschreven. Ten derde wordt aandacht besteed aan de administratie en het beheer van appartementencomplexen. Vervolgens wordt ingegaan op de rechten en verplichtingen van de appartementseigenaars. Daarna worden de welstandsbepalingen in het appartementsrecht, respectievelijk de daarmee vergelijkbare buitenlandse regelingen aan een gedetailleerd onderzoek onderworpen. Hierbij wordt een onderscheid gemaakt tussen toelatingsregelingen en regelingen van ontzegging van verder gebruik. Allereerst wordt ten aanzien van beide regelingen nagegaan of zij in de verschillende landen mogelijk zijn. Vervolgens wordt nagegaan hoe deze regelingen worden uitgewerkt (indien zij mogelijk zijn) en daarna wordt beschreven welke criteria voor toelating, c.q. ontzegging van verder gebruik mogen worden gehanteerd. Ook komen de beroepsmogelijkheden tegen niet-toelating en ontzegging van verder gebruik aan de orde. Bij de beschrijving van de beroepsmogelijkheden wordt eerst nagegaan of een (aspirant-)eigenaar tegen niet-toelating of ontzegging van verder gebruik intern (binnen de gemeenschap van appartementseigenaars) en/of bij de rechter in beroep kan gaan. Als beroep bij de rechter mogelijk is, wordt nagegaan of deze marginaal of vol toetst.

Het op de inleidende beschouwingen volgende tweede deel van dit werk bestaat uit drie hoofdstukken (de hoofdstukken 2 tot en met 4), waarin het Nederlandse recht wordt beschreven. In het eerste hoofdstuk van dit deel (hoofdstuk 2) wordt de geschiedenis van het Nederlandse appartementsrecht uitvoerig beschreven, waarna wordt ingegaan op de hoofdlijnen van het geldende en van het toekomstige appartementsrecht. In het tweede hoofdstuk van dit deel (hoofdstuk 3) wordt uitgebreid ingegaan op de welstandsbepalingen in het appartementsrecht, waarna in het derde hoofdstuk van het tweede deel (hoofdstuk 4) het appartementsrecht en met name de welstandsbepalingen worden vergeleken met het verenigingsrecht, het recht betreffende de medeëigendom c.q gemeenschap en het huurrecht.

In het derde deel van deze studie, dat bestaat uit de hoofdstukken 5 tot en met 8 , worden het appartementsrecht en eventuele aan de welstandsbepalingen 
equivalente regelingen van Belgie (hoofdstuk 5), de Bondsrepubliek Duitsland (hoofdstuk 6), Frankrijk (hoofdstuk 7) en Zwitserland (hoofdstuk 8) behandeld. De hoofdstukken in dit deel volgen de hierboven beschreven opzet. Het vierde deel wan dit werk (hoofdstuk 9) bevat samenvattende vergelijkingen en conclusies. Deze samenvattingen en conclusies zijn op dezelfde wijze gestructureerd als hierboven ten aanzien van de externe rechtsvergelijking werd beschreven.

Appartementseigendom blijkt in een of andere vorm in sommige gedeelten van de wereld reeds enkele duizenden jaren geleden te zijn voorgekomen. In Nederland heeft tot deze eeuw nooit veel behoefte bestaan aan een mogelijkheid tot het scheppen van appartementseigendom in de een of andere vorm. In landen als West-Duitsland, Zwitserland, België en Frankrijk was appartementseigendom enkele eeuwen geleden echter al mogelijk. In West-Duitsland en Zwitserland werd de mogelijkheid tot het scheppen van appartementseigendom bij het tot stand komen van de codificaties aan het begin van deze eeuw; wegens strijd met het Romeinsrechtelijke beginsel "superficies solo cedit" verboden. In België en Frankrijk werd appartementseigendom daarentegen bij de totstandkoming van de Code civil expliciet erkend in art. 664. Sindsdien is de regeling van het appartementsrecht in België in 1924 door invoering van art. 577 bis BW veranderd. In Frankrijk werd het appartementsrecht in 1938 voor het eerst opnieuw vastgesteld. Een nieuwe regeling volgde in 1965 .

Nederland, West-Duitsland en Zwitserland hebben pas na de tweede wereldoorlog een (nieuwe) regeling van het appartementsrecht geschapen. In Nederland kwam de appartementenwet in 1951 tot stand. Deze regeling werd in 1972 ingrijpend herzien. West-Duitsland voerde de regeling voor het appartementsrecht, het "Wohnungseigentumsgesetz" in 1951 in, terwijl Zwitserland zijn regeling betreffende "Stockwerkeigentum" in 1963 vaststelde.

De wettelijke regelingen worden in de praktijk in alle vijf landen over het algemeen aangevuld door een reglement van splitsing, dat op zijn beurt weer kan worden aangevuld door een huishoudelijk reglement.

Uit het voorliggende werk blijkt dat met betrekking tot de algemene structuur van appartements"eigendom" een onderscheid kan worden gemaakt tussen een monistische en een dualistische structuur. Het Nederlandse en het Zwitserse appartementsrecht maken gebruik van de monistische structuur, waarin een appartementseigenaar medeëigenaar, c.q. medegerechtigde ten aanzien van de grond en de gebouwen is en een beperkt zakelijk genotsrecht op de privé-gedeelten heeft. In West-Duitsland, België en Frankrijk hanteert men de dualistische structuur. In de dualistische structuur is de appartementseigenaar medeeigenaar van grond en gebouwen en vol eigenaar van zijn privé-gedeelten. In paragraaf 2.3 .2 van dit boek wordt gesteld dat de monistische structuur dogmatisch beter is dan de dualistische, waarvoor ondermeer als argument wordt aangevoerd dat in de dualistische structuur moeilijk is aan te geven wat het voorwerp van het volle eigendomsrecht is. Het plafond van de benedenbuurman is immers meestal de vloer van de bovenbuurman.

Ten aanzien van het ontstaan van appartementseigendom, c.q. appartementsrechten, kan worden opgemerkt dat de ontstaanswijzen in Nederland, WestDuitsland en Zwitserland grote gelijkenis vertomen. In alle drie landen is voor het 
ontstaan van appartementsrechten of appartementseigendom een notariële akte vereist, die wordt ingeschreven in de openbare registers.

In Frankrijk en Belgile wordt daarentegen niet expliciet geregeld hoe appartementseigendom ontstaat. Appartementseigendom kan daar (onder andere) door ceñ eenvoudige overdracht van een gedeelte van een gebouw ontstaan, waardoor de wettelijke regeling automatisch van toepassing wordt. In beide landen is weliswaar evenals in Nederland, West-Duitsland en Zwitserland de inschrijving van een akte wan splitsing in de openbare registers vereist, maar anders dan in deze laatste drie landen is de inschrijving niet van belang voor het ontstaan wan de appartementseigendom, $c_{.} q$. appartementsrechten, maar voor de inroepbaarheid van de splitsing tegen derden.

Een "papieren splitsing", dat wil zeggen een splitsing op tekening is eveneens mogelijk in alle vijf landen. Tussen Frankrijk en België aan de ene kant en Nederland, West-Duitsland en Zwitserland aan de andere kant bestaat echter het verschil dat de appartementseigendom, c.q. de appartementseigendom in de laatste drie landen door inschrijuing in de openbare registers ontstaat - ook indien er nog in het geheel geen sprake is van een gebouw - terwijl de appartementseigendom in België en Frankrijk ontstaat naarmate de bouw vordert.

In alle vijf landen kan een opstalrecht ten grondslag liggen aan appartementseigendom. Een erfpachtsrecht kan alleen in Nederland in appartementsrechten worden gesplitst. Als een zakelijk recht dat aan een splitsing ten grondslag ligt ophoudt te bestaan, eindigt in alle vijf landen de splitsing. Daarnaast kan de splitsing eindigen ten gevolge van onteigening, onderlinge overeenkomst tussen de appartementseigenaars en in België en Frankrijk bovendien ook door vermenging.

Ten aanzien van administratie en beheer van appartementsgebouwen blijken in het appartementsrecht van de verschillende landen geen grote verschillen bestaan. Een verschil tussen Nederland en Frankrijk aan de ene kant en Belgie, WestDuitsland en Zwitserland aan de andere kant bestaat hierin dat Nederland en Frankrijk aan de gemeenschap van appartementseigenaars een vereniging van eigenaars als organisatiestructuur koppelen, terwijl deze vereniging in de overige landen niet bestaat. De vijf landen hebben echter als orgaan van de gemeenschap, c.q. vereniging, well de vergadering van eigenaars gemeen. In deze vergadering worden alle belangrijke beslissingen ten aanzien van het appartementsgebouw of appartementencomplex genomen.

Behalve de vergadering van elgenaars heeft de gemeenschap van appartementseigenaars in alle vijf landen de administrateur gemeen. Deze administrateur regelt het dagelijks beheer van het appartementsgebouw en heeft grosso modo in alle landen dezelfie bevoegdheden en plichten.

In Nederland, Belgie en Frankrijk wordt verder in het algemeen een voorzitter van de vergadering van eigenaars benoemd. In West-Duitsland en Zwitserland neemt de administrateur de rol van voorzitter van de vergadering op zich, zij het dat in Zwitserland ook een derde tot voorzitter kan worden benoemd.

Tenslotte kunnen in alle bestudeerde landen commissarissen worden benoemd, die als hoofdtaak het assisteren en controleren van de administrateur hebben. In Frankrijk is benoeming van commissarissen zelfs verplicht. De Nederlandse commissarissen hebben overigens geen assisterende maar slechts een controlerende taak. In de paragrafen 9.2 .3 en 9.7 wordt voorgesteld om ook aan de Nederlandse commissarissen een assisterende rol toe te kennen. 
De rechten van de appartementseigenaars komen grosso modo neer op het recht om vrij over een appartement te beschikken, alsmede vrij gebruik te maken van de privé-gedeelten en de gemeenschappelijke gedeelten. Deze rechten kunnen enigszins worden beperkt door de bestemming van het appartement en het gebouw, en ter bescherming van de rechten van andere appartementseigenaars. Tegenover deze rechten staat enerzijds de plicht om de beperkingen van hel vrije gebruiks- en beschikkingsrecht te respecteren, en anderzijds om mee te dragen in de kosten en lasten van de gemeenschap, c.q. vereniging en van de gemeenschappelijke gedeelten.

De Nederlandse wetgever heeft als instrument om controle uit te oefenen op (aspirant-)appartementseigenaars c.q. gebruikers de welstandsbepalingen in het appartementsrecht mogelijk gemaakt. Hij had in plaats van de gebruiksontzegging ook voor een controlemogelijkheid uit het verenigingsrecht of het medeëigendomsrecht kunnen kiezen. Deze controlemogelijkheden worden in hoofdstuk 4 besproken. Daarnaast wordt in hetzelfde hoofdstuk op de totstandkoming van huurovereenkomsten en de controlemogelijkheden voor huurders onderling ingegaan. Tenslotte wordt in hoofdstuk 4 ingegaan op de problemen die zich kunnern voordoen bij toepassing van de welstandsbepalingen op huurders.

Bij ontzegging van ingebruikneming heeft de Westduitse wetgever voor een andere constructie gekozen dan de Nederlandse. In West-Duitsland kan namelijk in het reglement van splitsing een vervreemdingsbeperking worden opgenomen, die het mogelijk maakt dat een appartementseigenaar, die zijn appartement wil vervreemden, daarvoor toestemming nodig heeft van de overige appartementseigenaars of van de administrateur ( $\$ 12$ WEG). Een soortgelijke regeling is mogelijk ten aanzien van ingebruikgeving aan huurders. Ten aanzien van vestiging van zakelijke rechten kan echter geen toestemmingsregeling worden gehanteerd, omdat $\$ 137$ BGB daaraan in de weg staat. Naast deze mogelijkheid om een vervreemdingsbeperking op te nemen, bestaat in West-Duitsland ook de mogelijkheid om een appartement met een zakelijk werkend voorkeursrecht te bezwaren.

De Zwitserse wetgever heeft, evenals de Westduitse, een voorkeursrecht en een recht van bezwaar ("Einsprache") mogelijk gemaakt (art. 712c ZGB). Het recht van bezwaar komt inhoudelijk overeen met de Westduitse vervreemdingsbeperking, zij het dat bezwaar altijd door de vergadering van eigenaars moet worden gemaakt, terwijl dit in West-Duitsland ook door een derde kan gebeuren, indien het reglement zulks bepaalt. Ook ten aanzien van de reikwijdte van het recht van bezwaar bestaan verschillen tussen West-Duitsland en Zwitserland. In WestDuitsland is het namelijk niet mogelijk om bezwaar te maken tegen bezwaring met een zakelijk recht, terwijl dit in Zwitserland wel kan.

Anders dan in Nederland, West-Duitsland en Zwitserland, is er in de Belgische wet geen mogelijkheid gecreëerd om toezicht op nieuwkomers mogelijk te maken. Volgens één Belgische auteur is het echter mogelijk om in het reglement van splitsing vervreemdingsbeperkingen op te nemen, indien zij in de tijd beperkt zijn en een rechtmatig belang ten grondslag hebben. De Belgische doctrine twijfelt niet aan de geldigheid van een verbod of beperking van het recht om te verhuren. 
Desalniettemin lijken dergelijke beperkingen of verboden in de praktijk weinig voor te komen, hetgeen ook blijkt uit het feit dat jurisprudentie daaromtrent niet bestaat.

In Frankrijk zijn vervreemdingsbeperkingen door de -rechtspraak, ondanks voorspraak door de Franse doctrine, ontoelaatbaar geacht. Hetzelfde geldt voor een voorkeursrecht ten aanzien van het gehele appartement. Het recht om te verhuren kan in Frankrijk, als een beperking van het gebruik, wel gedeeltelijk in het reglement van splitsing worden beperkt, of zelfs werboden. Toelatingsregelingen zijn echter niet mogelijk.

De criteria voor ontzegging van ingebruikneming komen zoals blijkt uit het in par. 9.3 .3 beschrevene grotendeels overeen.

Het Nederlandse appartementsrecht heeft een geheel eigen ontzeggingsmogelijkheid, waarbij aan een appartementseigenaar het verdere gebruik van zijn appartementsrecht wordt ontzegd, zonder dat hem zijn gerechtigdheid ten aanzien van het appartementsrecht wordt ontnomen. Hetzelfde geldt mutatis mutandis voor ontzegging van verder gebruik aan huurders of vruchtgebruikers, waarbij het "huurrecht" of het recht van "vruchtgebruik" niet aan de huurder of vruchtgebruiker wordt ontnomen, maar hem wel het gebruik van het appartement wordt ontzegd. In de overige bestudeerde landen heeft men voor een andere constructie van ontzegging van verder gebruik gekozen.

In België bestaat onenigheid over de mogelijkheid om aan een appartementseigenaar het verdere gebruik van zijn appartement op een of andere wijze te ontzeggen. Praktijkgevallen hierover zijn niet bekend. Dat een huurovereenkomst kan worden opgezegd wegens gebruik van een appartement, dat in strijd is met het reglement van splitsing, is aan minder twijfel onderhevig.

In Frankrijk is ontzegging van verder gebruik aan appartementseigenaars, c.q. ontneming van de appartementseigendom, in beginsel niet mogelijk. Slechts indien een appartementseigenaar door het "Tribunal de grande instance" op straffe van een dwangsom is veroordeeld tot het staken van een bepaald gebruik, kan het appartement van deze eigenaar, bij niet betaling van de dwangsom worden uitgewonnen. Indien een huurder de verplichtingen van het reglement van splitsing niet nakomt, kan de verhuurder door de vereniging van eigenaars worden aangesproken om de huurovereenkomst te doen ontbinden.

In West-Duitsland en Zwitserland is ontzegging van verder gebruik daarentegen in de wet geregeld. Het Westduitse WEG maakt het in de $\$ \S 18$ en 19 mogelijk, dat de gemeenschap van appartementseigenaars van een andere appartementseigenaar verlangt, dat hij zijn appartement verkoopt. In Zwitserland geldt grosso modo dezelfde regeling ingevolge artikel $649 \mathrm{~b}$ ZGB. Zowel in West-Duitsland als in Zwitserland heeft de rechter echter het laatste woord. Zowel in West-Duitsland als in Zwitserland geldt bovendien, dat de appartementseigenaar tot vervreemding van zijn appartement kan worden gedwongen, indien personen aan wie hij zijn appartement in gebruik heeft gegeven, hun plichten jegens de gemeenschap niet nakomen.

In paragraaf 9.4.3 worden de criteria voor ontzegging van verder gebruik in de verschillende landen met elkaar vergeleken en in paragraaf 9.5 worden de beroepsmogelijkheden tegen niet-toelating, c.q. weigering van toestemming tot 
wervreemding, bezwaring, verhuring of uitoefening van een voorkeursrecht en tegen ontzegging van verder gebruik besproken.

Bij de slotopmerkingen in paragraaf 9.6 wordt gesteld dat als een keuze zou moeten worden gemaakt, tot welke (appartements) rechtsfamilie het Nederlandse appartementsrecht moet worden gerekend, een indeling in de "Deutsche Rechtskreis" het best verdedigbaar lijkt. Hierbij wordt opgemerkt, dat een dergelijke indeling moeilijk te maken is, omdat het appartementsrecht van de in deze dissertatie besproken rechtsstelsels op hoofdpunten grote verwantschap vertoont, terwijl bovendien een wederzijdse beïnvloeding kan worden geconstateerd.

Tenslotte worden in paragraaf 9.7 de volgende voorstellen tot wijziging van het Nederlandse appartementsrecht gedaan:

1. artikel 875a lid 3 BW (art. 5.10.1.1 lid 3 / 5:106 lid NBW) op zodanige wijze aan te passen, dat parkeerplaatsen afzonderlijke appartementsrechten kunnen vormen;

2. artikel 876i lid 1 BW (art. 5.10.2.1i / 5:135 NBW) zodanig aan te passen, dat aan de commissarissen behalve een controlerende taak ook een assisterende taak wordt opgelegd;

3. de huidige regeling van de welstandsbepalingen (ingevolge art. $875 \mathrm{f} \mathrm{lid} 4$ BW; art. 5.10.1.5 lid 4 / 5:112 lid $4 \mathrm{NBW}$ ) te vervangen door een regeling op grond waarvan vervreemding, bezwaring met een recht van vruchtgebruik of een recht van gebruik of bewoning en andere ingebruikgeving aan derden van een appartementsrecht aan de toestemming van de vergadering van eigenaars wordt onderworpen. Verder wordt een regeling voorgesteld, op grond waarvan het voor de vergadering van eigenaars mogelijk zou worden om een appartementseigenaar te dwingen zijn appartementsrecht te vervreemden. Voor zowel de weigering van toestemming tot vervreemding e.d. als de gedwongen vervreemding moet een gewichtige reden vereist zijn. 
Stockwerkeigentum und die "Welstandsbepalingen"

In diesem Buch wird das Stockwerkeigentumsrecht ${ }^{1}$ im allgemeinen sowie die Regelungen, die in den Niederlanden mit dem Begriff "welstandsbepalingen" im Stockwerkeigentumsrecht angedeutet werden, untersucht. Das Buch hat vier Teile. Im ersten, einführenden Teil wird unter anderem der niederländische Begriff "welstandsbepalingen" verdeutlicht und die Forschungsmethode erörtert. Ebenso werden das Ziel und der Aufbau dieser Dissertation beschrieben.

Die "welstandsbepalingen" im niederländischen "appartementsrecht", also im niederländischen Stockwerkeigentumsrecht, bieten den Eigentümern einer Stockwerkeigentümergemeinschaft die Möglichkeit, einem unerwünschten zukünftigen. Bewohner den Gebrauch eines Stockwerks zu untersagen. Auch kann aufgrund der "welstandsbepalingen" die Stockwerkeigentümergemeinschaft einem Bewohner eines Stockwerks dessen weitere Nutzung verbieten. Die "welstandsbepalingen" bieten jedoch keine Möglichkeit, um den Eigentumserwerb durch einen zukünftigen Eigentümer zu verhindern. Ebensowenig kann die Stockwerkeigentümergemeinschaft einem Stockwerkeigentümer, der sein Stockwerk bereits bewohnt, zur Veräußerung seines Stockwerks zwingen, noch kann sie ihm sein Stockwerkeigentum entziehen. Aufgrund der "welstandsbepalingen" ist es also lediglich möglich, einem bestimmten (Kandidat)Bewohner die Benutzung eines Stockwerks zu verbieten.

Nach der Verdeutlichung der Terminologie werden das Ziel, die Forschungsmethode sowie der Aufbau dieses Buches erörtert.

Das Ziel dieser Arbeit ist zweigliedrig. Erste Zielsetzung ist, eine bessere Einsicht in die Zulassungs- und Untersagungsregelungen im Stockwerkeigentumsrecht zu gewinnen. An zweiter Stelle steht eine allgemeine Untersuchung des Stockwerkeigentumsrechts.

Als Forschungsmethode wurde die Rechtsvergleichung gewählt, wobei ein Unterschied zwischen "interner Rechtsvergleichung" und "externer Rechtsvergleichung" gemacht wird. Beide Formen der Rechtsvergleichung werden in dieser Arbeit angewendet. Bei der externen Rechtsvergleichung werden das niederländische Stockwerkeigentumsrecht und die "welstandsbepalingen" mit den entsprechenden Regelungen in Belgien, der Bundesrepublik Deutschland,

1. In dieser Zusammenfassung wird der schweizerische. Begriff' "Stockwerkeigentum(srecht)" als Übersetzung für das niederländische "appartement(srecht)" benutzt. Der deutsche Begriff "Wohnungseigentum" wird nicht verwendet, weil dieser Begriff nur auf zu Wohnzwecken dienenden Räumen Anwendung findet und nicht zum Beispiel auf nücht zu Wohnzwecken dienenden Räumen. Bei diesen spricht man in der Bundesrepublik Deutschland dann von Teilleigentum. Der Begriff "Stockwerkeigentum" dagegen ist neutral. Vgl. dazu auch Coing, Europäisches Privatrecht, Band 2, 19. Jahrhundert, München 1989, S. 386 
Frankreich und in der Schweiz verglichen. Im Rahmen der internea Rechtsvergleichung werden die "welstandsbepalingen" neben andere niederländische Rechtsinstitute gestellt.

Die Beschreibung des Stockwerkeigentumsrechts und der "welstandsbepalingen" (beziehungsweise die Beschreibung der den "welstandsbepalingen" entsprechenden Bestimmungen) der Niederlande, Belgiens, der Bundesrepublik Deutschland, Frankreichs und der Schweiz ist jeweils pro Kapitel für jeden Staat wie folgt untergliedert. Nach einer Beschreibung der historischen Entwicklung des Stockwerkeigentumsrechts, wird zunächst auf die allgemeine Struktur des Stockwerkeigentums eingegangen. An zweiter Stelle werden die Entstehungs- beziehungsweise Begründungsweisen sowie die Möglichkeiten für eine Aufhebung des Stockwerkeigentums erörtert. Drittens werden die Verwaltungsformen von Stockwerkeigentümergemeinschaften sowie die Rechte und Pflichten der Stockwerkeigentümer beschrieben.

Danach werden die "welstandsbepalingen" oder die damit vergleichbaren Regelungen im ausländischen Recht ausführlich untersucht. Dabei wird ein Unterschied zwischen Zulassungsregelungen und Untersagungs- beziehungsweise Entziehungsbestimmungen gemacht. Zunächst wird untersucht, ob derartige Regelungen in den unterschiedlichen Staaten überhaupt bestehen. Danach wird auf die genauere Ausgestaltung dieser Bestimmungen eingegangen und werden die Kriterien, die für ihre Anwendung angelegt werden, aufgezeigt. Weiterhin werden die Berufungsmöglichkeiten im Falle der Zulassungsverweigerung und der Untersagung der Benutzung beziehungsweise Entziehung des Stockwerkeigentums besprochen. Bei dieser Beschreibung der Berufungsmöglichkeiten wird zuerst untersucht, ob ein (Kandidat)Bewohner gegen die Zulassungsverweigerung oder Untersagung beziehungsweise Entziehung des Stockwerkeigentums intern bei der Stockwerkeigentümergemeinschaft oder eventuell extern bei einer gerichtlichen Instanz Berufung einlegen kann.

Im zweiten Teil wird in drei Kapiteln, den Kapiteln 2 bis einschließlich 4, das niederländische Stockwerkeigentumsrecht beschrieben. Kapitel 2 ist einer allgemeinen Beschreibung des niederländischen Stockwerkeigentumsrechts nach geltendem und zukünftigem Recht gewidmet ${ }^{2}$. Im dritten Kapitel wird ausführlich auf die "welstandsbepalingen" im niederländischen Stockwerkeigentumsrecht eingegangen. Das niederländische Stockwerkeigentumsrecht und insbesondere die "welstandsbepalingen" werden im vierten Kapitel intern mit dem Vereinsrecht, dem Miteigentum beziehungsweise dem Gemeinschaftseigentum und mit dem Mietrecht verglichen. Im dritten Teil, der aus den Kapiteln fünf bis einschlieBlich acht besteht, werden das Stockwerkeigentumsrecht und die Zulassungs- und Untersagungsregelungen beziehungsweise Entziehungsbestimmungenvon Belgien (Kapitel 5), der Bundesrepublik Deutschland (Kapitel 6), Frankreich (Kapitel 7) und der Schweiz (Kapitel 8) behandelt.

Vergleiche und SchluBfolgerungen folgen im vierten Teil dieser Arbeit (Kapitel 9), wobei die selbe Untergliederung wie in den Länderberichten zugrundegelegt wird.

2. In einigen Jahren wird das niederländische Bürgerliche Gesetzbuch (BW) aus dem Jahre 1838 durch ein Neues Bürgerliches Gesetzbuch (NBW) ersetzt. 
Obwohl das Phänomen Stockwerkeigentum schon seit tausenden von Jahren in einigen Teilen dieser Welt in der einen oder der anderen Form bekannt ist, bestand in den Niederlanden bis zum Beginn dieses Jahrhunderts nie ein groBes Bedürfnis an einem derartigen Rechtsinstitut. In Deutschland, der Schweiz, Belgien und Frankreich gab es dagegen bereits seit einigen Jahrhunderten verschiedene Formen des Stockwerkeigentums. In Deutschland und der Schweiz wurde die Möglichkeit, Stockwerkeigentum zu begründen, jedoch mit den Kodifikationen zu Beginn dieses Jahrhunderts wegen Streitigkeit mit der "superficies solo cedit" Regel verboten. Dagegen wurde in Belgien und Frankreich das Stockwerkeigentum im Code civil ausdrücklich in Artikel 664 anerkannt. In Belgien wurde diese Regelung des Stockwerkeigentums im Jahre 1924 durch Einfügung des Artikels 577bis in das Bürgerliche Gesetzbuch erneuert. In Frankreich wurde das Stockwerkeigentumsrecht im Jahre 1938 zum ersten Mal reformiert. Eine weitere Gesetzesänderung folgte im Jahre 1965.

Die Niederlande, die Bundesrepublik Deutschland und die Schweiz haben erst nach dem zweiten Weltkrieg neue Regelungen bezüglich des Stockwerkeigentumsrecht geschaffen. In den Niederlanden kam das "appartementenwet", das Stockwerkeigentumsgesetz, im Jahre 1951 zu Stande. Dieses Gesetz wurde 1972 in einigen Teilen geändert. Die Bundesrepublik Deutschland schuf ebenfalls im Jahre 1951 das Wohnungseigentumsgesetz, während die schweizerische Regelung des Stockwerkeigentums aus dem Jahr 1963 stammt. Diese gesetzlichen Regelungen werden in der Praxis in allen fünf Staaten durch eine Gemeinschaftsordnung ergänzt, die wiederum eine Ergänzung in einer Hausordnung finden kann.

Aus der vorliegenden Arbeit ergibt sich, daß das Stockwerkeigentum in einigen Staaten eine monistische und in anderen eine dualistische Struktur besitzt. Das niederländische sowie das schweizerische Stockwerkeigentumsrecht kennen eine monistische Struktur, wobei die Stockwerkeigentümer Miteigentümer des Gebäudes und des Bodens sowie dinglich Berechtigte in Beziehung zu den einzelnen privaten Stockwerken sind. In der Bundesrepublik Deutschland, Belgien und Frankreich dagegen gilt eine dualistische Struktur des Stockwerkeigentums. Nach der dualistischen Struktur ist der Stockwerkeigentümer Miteigentümer von Boden und Gebäuden und Sondereigentümer seines privaten Stockwerks. In Paragraph 2.3.2 dieses Buches wird die Ansicht vertreten, daß die monistische Struktur dogmatisch überzeugender ist als die dualistische, da in der dualistischen Struktur der Umfang des Sondereigentums schwer abzugrenzen ist. Die Decke des unteren Nachbarns ist schließlich meistens der Fußboden des oberen.

Das Stockwerkeigentum wird in den Niederlanden, der Bundesrepublik Deutschland und in der Schweiz auf ähnliche Weise begründet. In diesen drei Staaten entsteht Stockwerkeigentum durch Eintragung einer notariellen Akte in das Grundbuch. In Frankreich und Belgien ist dagegen nicht ausdrücklich geregelt wie Stockwerkeigentum begründet werden kann. Stockwerkeigentum kann dort beispielsweise durch eine einfache Übertragung von einem Teil eines Gebäudes entstehen. Die gesetzliche Regelungen sind dann automatisch und zwingend auf dieses Gebäude anzuwenden. In beiden Staaten ist zwar wie auch in den Niederlanden, der Bundesrepublik Deutschland und der Schweiz die Eintragung einer notariellen Akte in das Grundbuch vorgeschieben, aber diese Eintragung hat keine 
konstitutive Wirkung für die Entstehung des Stockwerkeigentums. Dỉe Eintragung ist nur im Hinblick auf die dingliche Wirkung gegenüber Dritten von Bedeutung.

Begründung von Stockwerkeigentum ohne die Existenz eines Gebäudes, ist in allen fünf Staaten möglich. Zwischen Frankreich und Belgien auf der einen Seite und den Niederlanden, der Bundesrepublik Deutschland und der Schweiz auf der anderen besteht jedoch der Unterschied, da $B$ das Stockwerkeigentum in den letzten drei Staaten durch Eintragung des Begründungsaktes im Grundbuch, während dagegen in Belgien und Frankreich auch nach Eintragung im Grundbuch erst entsprechend dem Fortschritt der Bauarbeiten entsteht. In allen fünf Staaten kann auch ein Erbbaurecht der Begründung von Stockwerkeigentum zugrundeliegen. In diesem Falle werden die Stockwerkeigentümer in der dualistischen Struktur Mitberechtigte des Erbbaurechts, Miteigentümer des Gebäudes und Sondereigentümer des privaten Stockwerks. In der monistischen Struktur werden die Stockwerkeigentümer ebenfalls Mitberechtigte des Erbbaurechts, Miteigentümer des Gebäudes und dinglich Berechtigte in Beziehung zu den privaten Gebäudeteilen. In den Niederlanden kann auch ein dingliches Erbpachtrecht der Begründung von Stockwerkeigentum zugrundeliegen.

Bei Erlöschen des dinglichen Rechts, endet in allen fünf Staaten das Stockwerkeigentum. Außerdem kann das Stockwerkeigentum in allen fünf Staaten durch Vertrag der Stockwerkeigentümer oder durch Enteignung beendigt werden.

In Beziehung zu der Verwaltung der Stockwerkeigentümergemeinschaft bestehen keine großen Unterschiede in den Bestimmungen der verschiedenen Staaten. Der größte Unterschied zwischen den Niederlanden und Frankreich auf der einen Seite und Belgien, der Bundesrepublik Deutschland und der Schweiz auf der anderen Seite liegt darin, daß in den erstgenannten Staaten immer an die Stockwerkeigentümergemeinschaft ein Verein als Organisationsstruktur gekoppelt ist. Als Organ der Gemeinschaft beziehungsweise des Vereins fungiert in allen fünf Staaten die Stockwerkeigentümerversammlung. In dieser Versammlung werden alle wichtigen Entscheidungen bezüglich der Gemeinschaft oder des Gebäudes getroffen. Außer der Versammlung besteht das Institut des Verwalters in allen fünf Staaten. Dieser beschäftigt sich mit der täglichen Verwaltung der Gemeinschaft und des Gebäudes. Weiterhin wird in den Niederlanden, Belgien und Frankreich im allgemeinen ein Vorsitzender der Stockwerkeigentümerversammlung ernannt. In der Bundesrepublik Deutschland und der Schweiz ist der Verwalter der Vorsitzende der Versammlung.In der Schweiz kann jedoch auch ein Dritter als Vorsitzender ernannt werden. Schließlich kann in allen fünf Staten ein Ausschuß (Verwaltungsbeirat) ernannt werden, der die Aufgabe hat den Verwalter zu kontrollieren und zu unterstützen. In Frankreich ist die Einsetzung eines derartigen Ausschusses sogar gesetzlich vorgeschrieben. In den Niederlanden haben die Mitglieder des Ausschusses haben übrigens keine unterstützende Aufgabe, vielmehr ledüglich eine kontrollierende Funktion. In den Paragraphen 9.2.3 und 9.7 wird vorgeschlagen, auch in den Niederlanden dem Ausschuß diese unterstützende Aufgabe zu erteilen.

Die Rechte der Stockwerkeigentümer sind grosso modo in den fünf Staaten identisch. Jleder Stockwerkeigentümer hat das Recht sein Stockwerk frei zu veräußern und sein Stockwerk und die gemeinschaftlichen Teile frei zu nutzen. Diese Rechte können jedoch bis zu einem gewissen Grade durch die Zweckbestimmung der Stockwerke und des Gebäudes sowie zum Schutz der Rechte der übrigen Stockwerkeigentümer beschränkt werden. Gegenüber diesen Rechten steht 
die Pflicht einen Beitrag für die Unterhaltskosten der Gemeinschaft sowie der gemeinschaftlichen Teile zu leisten und gegebenenfalls Beschränkungen des freien Nutzungs- und VeräuBerungsrecht im Interesse der Gemeinschaft zu dulden.

Der niederländische Gesetzgeber hat als Kontrollinstrument der Gemeinschaft über den einzelnen Eigentümer die bereits erläuterten "welstandsbepalingen" gewählt. An Stelle dieser "welstandsbepalingen" hätte er sich auch für ein Kontrollinstrument aus dem Vereinsrecht oder dem Miteigentumsrecht entscheiden können. Diese werden in Kapitel 4 behandelt. Außerdem wird im gleichen Kapitel das Zustandekommen von Mietverträge und die für Mieter bestehenden Kontrollmöglichkeiten besprochen. Zuletzt werden in Kapitel 4 die beil Anwendung der "welstandsbepalingen" auf Mieter entstehenden Probleme behandelt.

Für die Zulassungsregelung hat der deutsche Gesetzgeber sich für eine andere Konstruktion als der niederländische entschieden. In der Bundesrepublik Deutschland können in der Gemeinschaftsordnung nämlich Veräußerungsbeschränkungen aufgenomen werden, die es möglich machen, daß ein Stockwerkeigentümer (Wohnungseigentümer, Teileigentümer, Wohnungserbbauberechtigter oder Teilerbbauberechtigter) für Veräußerung seines Stockwerks die Zustimmung der übrigen Eigentümer oder des Verwalters oder eines Dritten bedarf ( $\$ 12$ WEG). Eine ähnliche Regelung ist möglich bei Vermietung. Bei Belastung mit beschränkten dinglichen Rechten ist eine derartige Regelung jedoch nicht möglich. Eine derartige Bestimmung wäre im Streit mit § 137 BGB.

Neben dieser Veräußerungsbeschränkung besteht in der Bundesrepublik Deutschland auch die Möglichkeit, ein Stockwerk mit einem dinglichen Vorkaufsrecht zu belasten. Der schweizerische Gesetzgeber hat ebenso wie der deutsche, ein dingliches Vorkaufsrecht und eine Veräußerungsbeschränkung in der Form eines Einspracherechts geschaffen (art. $712 \mathrm{c}$ ZGB). Das Einspracherecht stimmt inhalt tich größtenteils mit der deutschen Veräußerungsbeschränkung überein. In der Schweiz muß die Einsprache jedoch immer von der Stockwerkeigentümerversammlung erhoben werden und kann sie nicht, wie manchmal in Deutschland, durch den Verwalter oder einen Dritten erhoben werden. Außerdem ist es in der Bundesrepublik Deutschland nicht möglich Einspruch gegen die Belastung eines Stockwerkes mit einem beschränkten dinglichen Recht zu erheben. Diese Möglichkeit besteht dagegen in der Schweiz.

Anders als in den Niederlanden, der Bundesrepublik Deutschland und der Schweiz ist in Belgien keine gesetzliche Möglichkeit geschaffen, neue Bewohner zu kontrollieren. In der belgischen Literatur wird die Ansicht vertreten, daß es möglich ist, in der Gemeinschaftsordnung Veräußerungsbeschränkungen auf zu nehmen, solange diese zeitlich begrenzt wirken und durch ein rechtmäßiges Interesse legitimiert sind. Auch zweifelt die belgische Lehre nicht an der Gültigkeit von Vermietungsverboten oder Vermietungsbeschränkungen. Trotzdem scheinen derartige Verbote oder Beschränkungen in der belgischen Praxis nicht zu existieren, da jede Rechtsprechung auf diesem Gebiet fehlt.

In Frankreich sind Veräußerungsbeschränkungen, obwohl diese in der französichen Lehre befürwortet werden, durch die Rechtsprechung als unzulässig beurteilt. Das gleiche gilt auch hinsichtlich des Vorkaufsrecht für ein ganzes 
Stockwerk. Eine Vermietungsbeschränkung ist unter Umständen in Frankreich jedoch möglich.

Dïe Kriterien für die gültige Anwendung der Zulassungsregelungen stimmen weitgehend überein (Paragraph 9.3.3)

Das niederländische Stockwerkeigentumsrecht kennt eine besondere Möglichkeit für die Stockwerkeigentümergemeinschaft, einen Stockwerkeigentümer aus seinem Stockwerk zu entfernen, wobei die persönliche Nutzung dem Eigentümer entnommen wird. Das gleiche gilt mutatis mutandis bei Mietern und Nießbrauchern. In anderen Staaten hat man sich für eine andere Lösung entschieden.

In Belgien besteht keine Einigkeit hinsichtlich der Frage, ob einem Stockwerkeigentümer der Gebrauch seines Stockwerks auf die eine oder andere Weise zu entnehmen ist. Fälle aus der Praxis sind nicht bekannt. Es wird jedoch weniger bezweifelt, daß ein Mietvertrag bei gemeinschaftswidrigem Gebrauch durch einen Mieter gekündigt werden kann.

In Frankreich ist Gebrauchsentnehmung eines Stockwerks, beziehungsweise Entziehung des Stockwerkeigentums im Prinzip nicht möglich. Nur im Falle, daß ein Stockwerkeigentümer, der vom "Tribunal de grande instance" zur Zahlung einer Zwangssumme verurteilt wird, um eine bestimmte Nutzung zu beenden, kann das Stockwerk dieses Eigentümers, falls er dieser Zahlungsverpflichtung nicht nachkommt, in bestimmten Fällen versteigert werden. Wenn ein Mieter die Verpflichtungen der Gemeinschaftsordnung nicht einhält, kann der Vermieter vom Stockwerkeigentümerverein gezwungen werden, den Mietvertrag zu kündigen.

In der Bundesrepublik Deutschland und der Schweiz ist die Gebrauchsentnehmung dagegen gesetzlich geregelt. Das deutsche WEG ermöglicht in den $\$ \$ 18$ und 19, daß die Gemeinschaft der Stockwerkeigentümer vom Stockwerkeigentümer (Wohnungseigentümer) verlangt, $\mathrm{da} B$ er sein Stockwerk verkauft. In der Schweiz kennt man eine ähnliche Entziehungsmöglichkeit gemäß Artikel $649 \mathrm{~b}$ ZGB. Sowohl in der Bundesrepublik Deutschland als in der Schweiz hat der Richter jedoch das letzte Wort hinsichtlich der Entziehung des Stockwerkeigentums. In beiden Staaten gilt außerdem, daß ein Stockwerkeigentümer zur Veräußerung seines Stockwerks gezwungen werden kann, wenn Personen denen er sein Stockwerk zum Gebrauch überlassen hat, ihre Pflichten der Gemeinschaft gegenüber schwer verletzt haben.

In Paragraph 9.4.3 werden die Kriterien für die Entziehung des Stockwerkeigentums oder Untersagung der weiteren Nutzung der verschiedenen Staaten mit einander verglichen. Die Berufungsmöglichkeiten gegen eine Zulassungsverweigerung oder gegen Entziehung des Stockwerkeigentums beziehungsweise Untersagung des weiteren Gebrauchs werden in Paragraph 9.5 beschrieben.

In Paragraph 9.6 wird der Schluß gezogen, daß wenn eine Wahl getroffen werden müßte, in welcher Rechtsfamilie das niederländische Stockwerkeigentumsrecht einzuteilen ist, eine Einteilung im deutschen Rechtskreis am besten zu verteidigen ist. Allerdings ist dabei zu bemerken, daß eine derartige Einteilung nur schwer zu treffen ist, da das Stockwerkeigentumsrecht der besprochenen Staaten große Verwandtschaft zeigt und dazu moch eine gegenseitige Beeinflussung konstatiert werden kann. 
Zum Schluß werden im Paragraph 9.7 folgende Vorschläge zur Änderung des niederländischen Stockwerkeigentumsrechts formuliert:

1. Das niederländische Gesetz (Artikel 875a Absatz 3 Bürgerliches Gesetzbuch) derartig zu ändern, daß auch Parkplätze Stockwerke im Sinne des Gesetzes sein können.

2. Dem AusschuB der Stockwerkeigentümerversammlung neben der kontrollierenden Aufgabe auch eine unterstützende Funktion gegenüber dem Verwalter zu erteilen. Anpassung des Artikels 876i Absatz 1 des Bürgerlichen Gesetzbuches, beziehungsweise des Artikels 5.10.2.1i / 5:135 des Neuen Bürgerlichen Gesetzbuches wäre dafür erforderlich.

3. Die heutige Regelung der "welstandsbepalingen" durch eine Regelung zu ersetzen, die Veräußerungsbeschränkungen und Entziehungsmöglichkeiten, wie sie in der Bundesrepublik Deutschland und der Schweiz bestehen, gewährt. 


\section{LITERATUUR}

Abas (Nieuw huurrecht)

Ackermann

Adriaansens

Acby

Akkermans/Bax/Verhey

Akkermans/Van Iersel

Alkema

Alsdorf (Rechtsverhältnisse)

Alsdorf (Umtersuchungen)

Alsiorf (Vorkaulsrechi)

Asser

Asser/Abas

Asser/Beekhuis I
P. Abas, Het nieuwe huurrecht in vogelvlucht, Bouwrecht 1981, ble 81-90

F. Ackermann, Über das Stockwerkseiggentum, insbesondere nach preussischem Recht; diss. Göttingen 1891

C.A. Adriaansens, Het nieuwe huurrecht, acht jatar later, Sociaal Reche 1.987, blx. 286-295

F. Aeby, La proprietes des appartements, met medewerking van Emile Gevers et Coni Tombroff, derde druk, Bruylant, Bruxelles 1983

P.W.C. Akkermans, CJ. Bax, L.F.M. Verhey, Grondrechten, Wolters-Noordholt/Open Uniwersiteit, Groningen/Hecrlen 1988

A.J. Akkermans, H.A. van Iersel, De coöperaticve onroerend goed exploitatievereniging, WPNR 5817 (1987), blz. 92-94

EA. Alkema, Studies over Europese grondrechten, diss. Leiden 1978, Kluwer, Deventer 1978

F.K. Alsdor R, Rechtsverhäll nisse beim zerstörten Wohnungseigentum, BLGBW 1977, blz. 88-91

F.K. Alsdorf, Untersuchangen zur Rechtsgestalt und Teilung deutscher Ganerbenburgen, Verlag Peter D. Lang (Rechtshistorische Reihe, Band 9), Frankfurt am Main/Bern/Cirencester (U.K.) 1980

F.K Alsdorf, Zum Vorkaufsrecht beim Wohnungseigentum, BLGBW 1978, blz. 92, 93

C. Asser, Het Nederlandsch Burgerlijk Wetboek vergeleken met het Wetboek Napoleon, De Gebroeders van Cleef, 's- Gravenhage en Amslerdam 1838

Mr. C. Asser's Handleiding tot de beoefening van het Nederlands burgerlijk recht, bijzondere overeenkomsten, deel II, huur en pacht, zesde druk, bewerkt door P. Abas en C.J.H. Brunner, W.E.J. Tjeenk Willink, Zwolle 1986

Mr. C. Asser's Handleiding tot de beoelening van het Nederlands burgerlijk recht, zakenrecht, algemeen deel, twaalfde druk, bewerkt door J.H. Beekhuis, F.H.J. Mijnssen, P. de Haan, W.E.J. Tjecnk Willink, Zwolle 1985 
Mr. C. Asser"s Handleiding tot de beoefening van het Nederlands burgerlijk recht, tweede deel, zakenrecht, bijzonder deel, eerste stuk, negende druk, bewerkt door J.H. Beekhuis, W.EJ. Tjeenk Willink, Zwolle 1963

Asser/Beekhuis II

Asser/Van der Grinten II

Asser/Hartkamp

Asser/Van Heusde

Asser/Meijers/

Vaun der Ploeg (Erfrecht)

Asser/Mijnssen/Van Velten

Asser/Rutten

Asser/Scholten

Asser/Scholten
Mr. C. Asser"s Handleiding tot de beofening wan het Nederlands burgerlijk recht, zakenrecht, tweede deel, eigendom en beperkte zakelijke genotsrechten, elfde druk, bewerkt door J.H. Beekhuis, W.E.J. Tjeenk Willink, Zwolle 1983

Mr. C. Asser's Handboek tot de beofening van het Nederlands burgerlijk recht, vertegenwoordiging en rechtspersoon, de rechtspersoon, zesde druk, bewerkt door W.C.L. van der Grinten, W.EJ. Tjeenk Willink, Zwolle 1986

Mr. C. Asser's Handleiding tot de beoefening van het Nederlands burgerlijk recht, verbintenissenrecht deel II, zewende druk, bewerkt door A.S. Hartkamp, W.EJ. Tjeenk Willink, Zwolle 1985

C. Asser, Handleiding tot de beoefening van hot Nederlandsch burgerlijk recht, eerste deel, vermogensrecht, eerste druk, bewerkt door $\mathrm{Ph}$.W. van Heusde, W.EJ. Tjeenk Willink, Zwolle 1885 (tweede druk 1890, derde druk 1896)

Mr. C. Asser's Handleiding tot de beoefening van het Nederlands burgerlijk recht, erfrecht, negende druk, bewerkt door E.M. Meijers, bijgewerkt door P.W. van der Ploeg en S. Perrick, W.EJ. Tjeenk Willink, Zwolle 1984

Mr. C. Asser"s Handleiding tot de beoefening van het Nederlands burgerlijk recht, zakenrecht, zekerheidsrechten, elfde druk, bewerkt door F.H.J. Mijnssen en A.A. wan Velten, W.E.J. Tjeenk Willink, Zwolle 1986

Mr. C. Asser"s Handleiding tot de beoefening van bet Nederlands burgerlijk recht, verbintenissenrecht deel II, zesde druk, bewerkt door L.E.H. Rutten, W.E.J. Tjeenk Willink, Zwolle 1982

C. Asser, Handleiding tot de beoefening van het Nederlandsch burgerlijk recht, zakenrecht, vierde druk, bewerkt door.P. Scholten, W.EJ. Tjeenk Willink, Zwolle 1905

Mr. C. Asser's Handleiding tot de beoefening van het Nederlandsch burgerlijk recht, zakenrecht, vijlde druk, bewerkt door P. Scholten, W.E.J. Tjeenk Willink, Zwolle 1913 (zesde druk 1927, zevende druk 1933, achtste druk 1945) 
Alias

Aubel

Augustin

Van Baar/Van Oosten de Bioer

Baert

Bărmann (1958)

Bärmann (Dogmatik)

Bärmann (Erwerberhaftung)

Bärmann (Grundgesctz)

Bärmann (Kommentar)

Bärmann/Pick

Bärmann/SeuB

Beekhwis (Eigendom)

Beekhuis. (Herinneringen)

Beekhuis (Opmerkingen)
C. Atias, La Copropriete des immeubles batis dans la jurisprudence, Librairies Techniques, Parijs 1979

C.P. Aubel, Persoon en Pers, diss. Nijmegen 1968, Kluwwer, Deventer 1968

G. Augustin, Gesetz über das Wohnungseigentum und das Danerwohnrecht, Walter de Gruyter, Berlin/New York 1983

T. van Baar, P. van Oosten de Boer, Uw Vereniging, het recht en de liscus, Kluwer Belastingwijzers 11, Deventer 1984

G. Baert, Privaatrechtelijk Bouwrecht, derde druk, E. Story Scientia, Brussel 1986.

J. Bärnann, Wohnungseigentumsgesetz, C.H. Beck'sche Verlagsbuch handlung, München/Berlin 1958

J. Bärmann, Zur Dogmauk des gemeinen Raumeigentums, AcP 155,1956 , blz. 1-27

J. Bärmann, Erwerberhaftung im Wohnungseigentum für rückständige Lasten und Kosten, uitgegeven in de scrie "Partner in Gespräch" "Hammonia-Verlag, Hamburg 1985

J. Bärmann, Grundgesetz und

Wolmungseigentumsrecht, in: Festschrift für Hanns

SeuB (red. J. Bärmann, H. Weitnauer), C.H.

Beck'sche Verlagsbuchhandlung, München 1987, blz. 19-32

J. Bärmann, E. Pick, W. Merle,

Wohnungscigentumsgessutz, 6. Aullage, C.H. Beck'sche Verlagsbuchhandlung, München 1987

J. Bärmann, E. Pick, Wohnungseigentumsgesetz, elfde druk, C.H. Beck'sche Verlagsbuchhandlung, München 1985

J. Bärmann, H. SeuB, Praxis des Wohnungseigentums, mit Formularen und Mustern, derde druk, C.H. Beck'sche Verlagsbuchhandlung, München 1980

J.H. Beekhuis, Eigendom wan appartementen en lidmaatschapsrechten in een coopperatiewe vereniging, WPNR 4226 (1952), blz 25-28

J.H. Beekhuis, Herinneringen aan mijn werk voor het nieuwe BW, in: Goed \& Trouw, opstellen aangeboden aan W.C.L. van der Grinten, W.EJ. Tjeenk Willink, Zwolle 1984, blz. 325-339

J.H. Beekhuis, Opmerkingen n.a.v. Bowwer in WPNR 4322, WPNR 4327 (1953), blz. 612 
Beekhuis (Preadvies)

Beekhuis/Linders

Belinfante

Belz

Berenboom

Berenschot/Hoekstra/

Bernard

Besier

Birsheuvel

Biesheuvel (Horizontale werking)

Bloembergen

(Interne rechtsvergelijking)

Bloembergen (Onrechtmatige daad)

Bloembergen

(Onrechtmatige Daad II)

Bloembergen, WPNR 4648

Bloembergen, WPNR 5372
J.H. Beekhuis, Horizontale Eigendom, Preadvies voor de Broederschap van Notarissen 1940

J.H. Beekhuis, G. Verdoes Kleijn, J.H. Linders, Appartementsrecht, Kluwer, Dieventer, losbladige edilite

A.D. Belinfante, Beginselen van helt Nederlands staatsrecht, achtste druk, Samsom Uitgeverij, Alphen aan den Rijn 1980

A. Belz, Das Wohnungseigentum, tweede druk, Boorberg Bücherei, Stuttgart 1982

A. Berenboom, Droits réels 1967-1972, J.T. 1974, blz. 289-296

E.B. Berenschot, J.M. Hoekstra, J.B. VegterVegter, Eigendom en beperkte rechten naar BW en NBW, Kluwer, Deventer 1986

R. Bernard, Le proprietaire d'appartement, Librairie Génćrale de droit et de jurisprudence, Paris 1929

L.Ch. Besier, Superficies solo cedit, R.M. 1892, blz. 445-493

M.B.W. Biesheuvel, Burgerlijk recht en grondrechten: "een constitutioneel vraagstuk van den eersten rang", Preadvies woor de vereniging voor burgerlijk recht, Konïnklijke Vermande, Lelystad 1986

M.B.W. Biesheuvel, Horizontale werking van grondrechten, NJCM-Bulletin 1981, blz, 147-170, 205225.

A.R. Bloembergen, Interne rechtsvergelijking, een comparatieve kijk op het privaatrecht, administratief recht en bouwrecht, Bouwrecht 1977, blz. 125-142

A.R. Bloembergen, Onrechtmatige daad: publicatie van het vonnis; recht op rectificatie, NJB 1964, blz. 337-345

A.R. Bloembergen (red.), Onrechtmatige daad, samengesteld door A.R. Bloembergen e.a., Kluwer, Deventer, losbladige editie

A.R. Bloembergen, Vergaderingen en besluiten van appartementseigenaars naar het oude en nieuwe recht, WPNR $4647 / 4648$ (1960), blz. 437-440, 449-452

A.R. Bloembergen, De eenheid van privaatrecht en administratief recht, WPNR $5372,5373,5374,5375$ (1977), ble. 1-5, 17-23, 33-36, 49-54 


\section{Bockwinkel}

Bögli

Bökkelmann/Schale

Bore

Bos

\section{Biossard}

Bouckaert/Van Hoecke

Bouwer

Bouyeure

Brandenburg

Brogli

Bruijins

Bub

Buining

Bumiller/Winkler
A. Bockwinkel, Verkenningen omtrent het nieuwe huurrecht woonumimte, Kluvier, Deventer 1982

D. Bögli, Das Schiedsgericht, in: Aktuelles Stockwerkeigentum (red. W. Diggelmann, H. Kunz, T. Peter-Ruetschi), Schulthess Polygraphischer Verlag. Zürich 1984, ble. 169-172

H. Bökkelmann, H. Schale, Wohnungseigentum und Dauerwolnnrecht, Verlagsgesellschaft Rudolf Müller, Köln-Braunsfeld 1951

J. Boré, La cassation en matière civile, Editions Sirey, Paris 1980

D. Bos, Coôperatieve flatverenigingen of gesplitste eigendom in appartementen in theorie en praktijk, WPNR 4271 (1952), blz. 537-539

Ph. Bossard, La force obligatoire dès règlements de coproprićtc, J.T. 1986, blz. 17-23.

B. Bouckaert, M, van Hoecke, Inleiding tot het recht, tweede druk, Acco, Lewwen 1986.

A. Bouwer, De beperking of ontzegging van het gebruiksrecht van de appartementseigenaren, WPNR $4322 / 4338(1953 / 1954)$ ble. 553,124

J.R. Bouyeure, L'administration de la coproprifte, Éditions du moniteur, Parijs 1974

C.A. Brandenburg, Eigendom van gebouwen op andermans grond, NJB 1957, blz. 885-889

E. Brogli, Das intertemporale Stockwerkeigentumsrecht der Schweiz am Beispiel des Kantons Wallis, diss. Freiburg 1985

W.B. Bruijns, De coöperatieve

flatexploitaticvereniging, terugblik naar 1945, TVVS 1968, blz. 116-120

W.R. Bub, Wohnungseigentum von $A-Z, D T V$, wijfde druk, C.H. Beck München 1985

J.R.H. Buining, De overgang naar de eigendom van appartementen, WPNR 4228 (1951), blz. 51, 52.

U. Bumiller, K. Winkler, Freiwillige Gerichtsbarkeit, vierde druk, C.H. Beck'sche Verlagsbuchthandlung München 1987 
Cabanac/Lacroix

Vam Caenegem

Cathen

Calfan/Doublier

Cambier

Cambron

Catz

Coing

Commissie Beekhuis

Commissic Coöp.

Flatexpl.ver.

Creutaberg

Croes (Huur en

onderhuur)

Croes, WPNR 5686

Cuvelier
J. Cabanac, E. Kischinewski-Broquisse, G. Lacroix, Traite de la construction en copropriete et du nouveau régime de la copropriété, tome 1, Promoteurs, Societés de constructions, Editions de lactualité juridique, Paris 1967

R.C. Van Cacnegem, Geschiedkundige inleiding tot het privaatrecht, Wetenschappellijke Uitgeverii StoryScientia, Gent 1981.

J.L.P. Cahen, Deblokkering van de blokkeringsclausule, oratie Groningen, Gouda Quint, Arrihem 1966

H. Calfan, R. Doublier, Le copropriétaire, le syndic de copropriété, Librairie Géneral de Droit et de Jurispnudence, Parïs 1979

C. Cambier, Droit judiciaire civil, tome $\mathrm{II}_{\text {, }}$ la competence, Maison Ferdinand Larcier, Bruxelles 1981

O. Cambron, Traite theorique et pratique de la copropriếté et de la division des maisons par étages ou par appartements, Imprimerie Brian Hill, Bruxelles 1925.

H.S. Catz, Verzekering wan appartementen, WPNR 4599 (1959), blz 412

H. Coing, Europäisches Privatrecht, Band 2, 19. Jahrhundert, C.H. Beck'sche Verlagsbuchhandlung, München 1989

Commissie Beekhuis, Nieuw modelreglement toe te passen bij splitsing in appartementsrechten van een service-flatgebouw, WPNR 5847 (1987), blz. 591,592

Commissie Coöperatieve Flatexploittatieverenigingen, Rapport gepubliceerd in WPNR 4973 (1967), blz. 506508

A.A. Creutzberg, De wet op de woningsplitsing, WPNR 5834 (1987), blz. 355-360

A.L. Croes, Over huur en onderhuur, grondtrekken van het geldende huurrecht, derde druk, Gouda Quint, Arnhem 1985

A.L. Croes, Ower de positie van de verhuurder in de twist tussen zijn huurders, WPNR 5686 (1984), blz. 113-118

A. Cuvelier, Copropriété forcée - saisie-exécution d'un appartement - quid des arrieres de charges connmunes dus par le saisi?, Rec. Gén. Enr. Not. 1985, nr. 23127 
Cuvelier (Enrégistrement)

Dammertz

Dawid/Brierley

Davids

Dekkers

Demharter

Dembarter

(Bundesratsinitiative)

Denis

Derichs (Sammlung)

Derine exa.

Diephuis

Diester (Grenzen)

Diester (Reactie op Weitnauer)

Diester (Rechtsfragen)

Diester (Rechtsprechung)

Diester (WEG)
A. Cuvelier, Lo droit d'enrégistrement sur les partagges et les cessions entre coproprietaires, Rec. Gen. Enr. Not. 1988, nr. 23551, blz 41-103.

K. Dammertz, Wohnungsreclit und Dauerwohnrecht, Verlag Neue Wirtschafts-Briefe Herne, Berlin 1970

R. David, J.E.C. Brierley, Major legal systems in the world today, derde druk, Stewens \& Sons, London 1985

WJ.M. Davids, Spelregels voor verenigingen, W.EJ. Tjeenk Willink, Zwolle 1982

R. Dekkers, Handboek burgerlijk recht, tweede uitgave, deel 1, E. Bruylant/Standaard-Bockhandel, Brussel 1972

J. Demharter, Zur Kostenbeteiligung des Wohnungseigentïmers der einer baulichen Veränderung nicht zugestinumt hat, MDR 1988, bla. 265-270

J. Dembarter, BundesRatsinitiative zur Anderung des Wohnungseigentumsgesetzes, Rphleger 1977, blz 41-50

F. Denis, La copropriété des immeubles bâtis, Librairie du Journal des Notaires et des avocats, Paris 1967 (modelreglement blz. 135-165)

F.L. Derichs, Wohnungsengentumsrechts Sammlung, deel I en II, Werner-Verlag Düsselidorf 1979

R. Derine, F. van Neste, H. VandenBerghe, Beginselen van het Belgisch privaatrecht, $\mathrm{V}$, deel II a zakenrecht, Wetenschappelijke Uitgeverij E. StoryScientia, Gent 1984

D. Diephuis, Het Nederlandsch burgerlijk recht, derde deel, zakenrecht, J.B. Wolters, Groningen 1880

H. Diester, Grenzen der Anwendbarkeil des $\$ 12$ WEG (VeräuBerungsbeschränkungen bei Wohnungseigentum), Rpfleger 1974, bli. 245, 246

H. Diester, Rpfleger 1968, blz. 207

H. Diester, Wichtige Rechtsfragen des

Wohnungseigentums, NJW-Schriftenreihe, Verlag C.H. Beck, Mänchen 1974

H. Diester, Die Rechtsprechung zum WEG, Verlag C.H. Beck, Münchea 1967

H. Diester, Wohnungseigentumsgesetz, Verlagg Dir. Otto Schmidt, Köln 1952 
Digest of Strasbourg Case-law

Dijk

Van Dijk/Van Hoof

Dijk/Van der Plocg

Dralit:

Drenzeck

Dressellhuys

Van den Dries

Drion (Precontractuele verhoudingen)

Drion/Hijma/Olthof

Van Dunné (Interview met

J.H. Beekhuis)

Duthil

Eigentumswohnung

Eilders

Elders (Preadvies)

Enst
Digest of Strasbourg Case-law relating to the

European Convention on Human Rights, vol. 5, Carl Heymans Verlag, Köln/Berlin/Bonn/München 1985

P.L. Dijk, Ervaringen mei Boek 2 Burgerlijk Wetboek terzake wan werenigingen en stichtingen, WPNR $5427 /$ 5428 (1978), blz, 181-186, 197-201

P. van Dijk, G.J.H. van Hoof, De Europese conventie in theorie en praktijk, tweede druk, Ars Aequi LibriRechten van de Mens-2, 1982

P.L. Dijk, TJ. van der Ploeg, Van de vereniging en de stichting, Gouda Quint, Arnhem 1982

J. Draht, Zum Wohnungseigentum auf Grund der gräko-ägypitischen Papyri, diss. Marburg/Lahn, E. Symon-Fotodruck, Marburg/Lahn 1970

W. Drenzeck, Neuregelungen der Besteuerung des selbst bewohnten Wohnraums, NJW 1987, blz \&-17

P. Dresselhuys, Eigendom van appartementen en art. 297 WvK, WPNR 4398 (1955), blz 220, 221.

N.C.M.A. van den Dries, Het arrest wan den Hoogen Raad van 11 april 1913, WPNR 2281 (1913) blz. 445447

H. Drion, Precontractuele verhoudingen naar Nederlands recht, in: Geschriften van H. Drion, Kluwer, Deventer 1982, blz. 231-258

H. Drion, Jac. Hijma, M.M. Olthof, Compendium van het Nederlands Vermogensrecht, zevende druk, Kluwer, Dewenter 1985

J.M. van Dunne, Interview met J.H. Beekhuis, in: Geschriften van J.H. Beekhuis, W.EJ. Tjeenk Willink Zwolle 1989, blz. 1-23

G. Duthil, Le syndicat de copropriétaires, personne morale, diss. Rennes 1978

St. Gallische Kantonalbank, Die Eigentumswohnung, uitgave van de st. Gallische Kantonalbank, 1981

J.L.M. Elders, Het ontwerp "Algemene wet gelijke behandeling' en de vrijheid van vereniging en onderwijs, Stichting \& Vereniging 1988, blz. 98-102

J.L.M. Elders, Burgerlijk recht en grondrechten, preadvies voor de vereniging voor burgerlijk recht, Koninklijke Vermande, Lelystad 1986

P. Ernst, Der Einfluß der Besteuerung auff den Erwerb inländischen privaten Wohneigentums, Verlag V. Florentz, München 1982 
Van der Esch

d'Esperonnat

Eyssell

Fahile

Ferid/Sonnenberger

Fettwcis

Fischer-Keuls

Flattet

Fockema

Frei

Friedrich:

Friedrich (Preadvies)

Frowein/Peukert

Furtner
J. van der Esch, Het reclit om tot een vereniging als lid toe te treden, NJB 1950, ble 289-293

P. d'Esperonnat, Personnalite et droits individuels dans le statut de la copropriéte des imneubles bätis, essai d'analyse, diss. Toulouse 1974

A.P.Th. Eyssell, Servituutswerken: artt. $626,656,735$, 736 B.W. (n.a.w. della Faille w. Staat, Hof Den Bosch, 20 april 1886, W 5385), Thernis 1887, bla, 235-250

K.H. Fahle, Die Entscheidung nach billigem Ermessen in Wohnungseigentumsgesetz, diss. Münster 1953

M. Ferid, H.J. Sonnenberger, Das Französiche Zivilrecht, tweede druk, Verlagsgescilschaft Recht und Wissenschaft, Heideiberg 1986

A. Fettweis, Handboek voor gerechtelijk recht, deel II, bevocgdheid, Standaard wetenschappelijke uitgeverij, Antwerpen/Utrecht 1971

E. Fisher-Keuls, De jongste ontwikkelingen inzake zakelijke rechten in het ontwerp NBW (11-silot), NJB 1973 , blz. 1133-1143, 1161-1171

G. Flattet, Copropricte par appartements et coproprieté horizontale, Receuil des Travaux suisses présentés au VIIIle congrès internationalde troit compare, Verlag Helbing \& Lichtenhahn, Bascl $1970^{\text {n }}$ blz. 141-152

A. Fockema, De horizontale grenzen van grondeigendorn, diss. Groningen, M.. de Waal, Groningen 1913

H. Frei, Zun Ausscaverhällnis der Gemeinschaft der Stockwerkeigentümer, diss. Zürich 1\%9, Juris Druck und Verlag, Zürich 1970

H.P. Friedrich, Das Stockwerkeigentum, tweede druk, Verlag Stämpfli \& Cie, Bern 1972

H.P. Friedrich, Die Wiedereinführung des Stockwerkeigentums in der Schweiz, Verhandlungen des Schweizerischen Juristenvereins, Holbing \& Lichtenhahn, Basel 1956

J.A. Frowein, W. Peukert, Europäische

MenschenRechisKonwention, N.P. Engel Verlag, Kehl/Strassburg/Arlington 1985

G. Furtner, Die rechtsgeschäftliche

Verfügungsbeschrănkung und ihre Sicherung, NJW 1966, blz, 182-189 
Gaisbauer

Gaydoul/Pabst/Stuhrmann

Ghestin/Goubeaux

Gillioz

Giovanola

Givord/Giverdon

Givord/Giverdon (Ravalement)

Götte

Gotzen

Goudeket

Grebe (Abänderung)

Grebe (Änderungsvorbehalte)

Van der Grinten

Van der Grinten (Gemeenschap)

Van der Grinten

(Marginale toetsing)

De Groot (Gemeenschap)
G. Gaisbauer, Nichteinberufung einer

Wohnungseigentümerversammlung, BLGBW 1978 , Blz. 168, 169

P. Gaydoul, G. Pabst, G. Stuhrmann,

Eigentumswohnung als steuerbegünstigte

Kapitalanlage, tweede druk, Dr. Peter Deubner Verlag, Köln 1984

J. Ghestin, G. Goubeaux, Traite de droit civil, introduction générale, tweede druk, Paris 1982

V. Gillioz, L'autorisation d"ester en justice au nom de la communaute des copropriete par etage, SJZ 1984, biz. 284-287

P. Giovamola, Les obligations reciproques des copropriétaires d'étages et leurs sanctions, diss.

Lausanne 1986, imprimerie Chabloz, Lausanne 1986

F. Givord, Cl. Giverdon, La coproprićte, derde druk, Dalloz Paris 1987

Cl. Giverdon, $F_{w}$ Givord, Le <ravalement> de la loi du 10 juillet 1965, Dall. 1986, Chr. blz $43-48$.

U. Götte, Die Teilung von Nichtlandwirtschaflichen

Liegenschaften in Erbgang, Schulthess

Polygraphischer Verlag, Zürich 1977, diss. Zürich 1977.

F. Gotzen, Zakelijke rechten: plats en aantal in het Burgerlijk recht, $\mathbb{R} W$ 1978-1979, 2337-2346

J. Goudeket, Eigendom van gebouwen en beplantingen op eens anders grond, WPNR 2221-2223 (1912), blz. 337, 338, 349, 350, 361, 362

W. Grebe, Wege zur Abänderung der

Gemeinschaftsordnung im Wolnungseigentumsgesetz, DNotZ 1988, blz. 275-291

W. Grebe, Rechtsgeschäftliche Änderungsworbchalte im Wohnungseigentumsrecht, DNotZ 1987, blz. 5-25

W.C.L. van der Grinten, De vereniging van eigenaars en boek 2 BW, WPNR 5474 (1979), blz. 234, 235

W.C.L. Van der Grinten ${ }_{x}$ De titel gemeenschap, R.M. Themis 1960 , ble 119-159

W.C.L. van der Grinten, Marginale toetsing, in: Op de grenzen van komend recht, opstellen aangeboden aan J.H. Beekhuis, Kluwer, Deventer 1969, ble. 109-123

J.J.A. de Groot, De gemeenschap, WPNR 5431 (1978), blz. 241-246 
De Groot (Rechtsvraag)

De Groot WPNR 5570

De Groot/Stein

Grünhagen

Guide Neret

Guilbaud

Guldener

Gunning

Mabscheid

Van Hal

Van Ham-Wagner

Hansenne

Happ

Harkamp

Van Hasselt

Hachamp
G.R. de Groot, Beantwoording rechtsviaag, A.A. 1985, blz. 154-160

G.R. de Groot, Service-koopllats en de welstandsbepalingen, WPNR 5570 (1981), blz 411-413

H. de Groot, P.A. Stein Grondtrekken van het handelsrecht, vierde druk, W.E.J. Tjeenk Willink, Zwolle 1989

H. Grünhagen, "Vernieuwend Wonen" breekt net volkshuisvestingstradities, Woningraad 1989 , nr. 5, blz. 49.52

Guide Néret de la copropriéte, Editions Nếret 1977

J. Guilbaud, Guide Pratique de Procedure, Temps actuels, Paris 1981

M. Guldener, Schweizerisches Zivilprozessrecht, derde druk, Schulthess Polygraphischer Verlag, Zürich 1979

M. Gunning, De huurbescherming. gehandhald en werbeterd, Recht en Kritiek 1979, blz. 331-334.

W.l. Habscheid, Schweizerisches Zivilprozess- und Gerichtsorganisationsrecht, Verlag Helbing \& Lichtenhahn, Basel/Frankfurt am Main 1986

EJ.L. van Hal, Het appartementsrecht als rechtsworm woor uitgiffe en beheer van onroerend goed, A.A. 1983, blz. 641-649

W. van Ham-Wagner, Het initiatiefwetsontwerp Nijpels inzake woningsplitsing, Bouwrecht 1985, blz. 24.

J. Hanscnne, La propriéte par appartements, Université de Liége 1985

J. Happ, Zur Haltung des Erwerbers einer Eigentumswohnung für die Schulden seines Rechtsworgängers, Der WEer 1988, blz. 76, 77

A.S. Hartkamp, Aard en opzet van het nieuwe vermogensrecht, monografieén Nieuw BW, Kluwer, Deventer 1982

N.G. vam Hasselt, Artt. $626 \mathrm{en} 656 \mathrm{BW}$, WPNR 2281 (1913), bil... 447, 448

C. Hauchamp, Copropriete et division des maisons par appartement, Ann. Not. 1924, blz 143 -163, 169-187, 194-216 
Hauger

Haumont

Hauser/Hauser

Heck

Hehemann

Herden/Gmach

Heringa

Herrmann

Van den Heuvel (Ernstige overlast)

Van den Heuvel (Huurrechi)

Heyvacrt

Heywaert (Preadvics)

Hijma

Hijma/Olthof

Hindermann
M. Hauger, Schweizerisches Stockwerkeigemtum und devtsches Wohmungseigentum im Rechiswergleich, diss. Heidelberg 1977, Verlag Peter Lang, Frankfurt am Main 1977

F. Haumont, Les espaces collectifs privế au delà de la copropriété, Oyez, Louvain, 1978

W. Hauser, R. Hawser, Gerichtswerfassungsgesetz, Erläuterungen zum Gerichtsverfassungsgesetz des Kantons Zürich, derde druk, Schulthess Pollygraphischer Verlag, Zürich 1978

D. Heck, La copropriété en France et a l'étranger, Epinal 1977

FJ. Hehemann, Toelating van leden tot de coöperatieve flatexploitatievereniging, TVVS 1969, blz. $56-59$

C. Herden, G. Gmach, Die Entwicklung des Steuerrechts, NJW 1987, blz 1590-1607

A.W. Heringa, Terug naar af: waarom het begrip een ieder verbindende bepalingen van verdragen slechts tot verwarring leidt, in: Staatkundig jaarboek 1985, uitg. Kobra, Amsterdam 1985, blz. 133-146

B.C. Herrmann, Les travaux dans les immeubles en copropriêté, Editions de l'actualité juridique, Paris 1977

H. van den Heuvel, Ernstige overlast, deur open, deur dicht?, Praktijkgids 1981, blz 433-435

H. van den Heuvel, Huurrecht in het BW, Kluwer, Deventer, losbladige editie

A. Heyvaert, Beschouwingen over de afstand van het recht van natrekking en de horizontaal gescheiden onroerende eigendom, TPR 1964, blz, 333-349

A. Heyvaert, Mede-eigendom bii appartementsgebouwen, Preadvies aan het Congres van de Vlaamse juristenvereniging 15 april 1967 Gent, RW 1966-1967, 1448-1470

J. Hijma, Nietigheid en vernietigbaarheid van rechtshandelingen, diss. Leiden 1988, Klluwer. Deventer 1988

J. Hijma, M.M. Olthof, Compendium van het Nederlands vermogensrecht, derde druk, Kluwer, Deventer 1988

W. Hindermann, Leitfaden zum Baurecht und Stockwerkeigentum, Verlag Organisator, Glattburg 1975 
Hofmann

Hofmanu/Abas

Hohenester

Le Houerou

Hubernagel

Hugentholiz/Heemskerk

Jauernig

Jolidion

De Jong

De Jonghe/Reijntjens

Kadaner

Kahlen

Kamphuisen

Kaser I

Kaser II

Kaith
1.C. Hofmann, Het Nederlandsch Zakenrecht, J.B. Wolters Uitgevers Maatschappij, Groningen/Den Haag/Batavia 1933

L.C. Hofmann, P. Abas, Het Nederlands: verbintenissenrecht, deel 1, tweede gedeelte, negende druk, H.D. Tjeenk Willink, Groningen 1977

H. Hohenester, Das Wohnungseigentumsgesetz Änderungsbedürftig?, ZMR 1985 , blz 109-112.

M. Ie Houerou, Copropriétaire at action en justice, diss. Rennes 1976

G. Hubernagel, Wohnungseigentumsgesetz, Schaller a Co, Stultgart 1952

W. Hugenholu, Hoofdlijnen van Nederlands burgerlijk procesrecht, wijfuicnde druk, bewerkt door W.H.

Heemskerk, Vuga, "s-Gravenhage 1988

O. Jaucrnig, ZivilprozeBrecht, negentiende druk, C.H. Beck'sche Verlagsbuchhandlung, Minnchen 1981.

P. Jolidon, Commentaire du concordat Suisse sur l'arbitrage, Editions Stacmpfli \& Cic, Bern 1984

J. de Jong, Enkele ontwikkclingen aangaande het recht van erfpacht, Bouwrecht 1986, blz. 166-170, 175, 176

J. de Jonghe, F. Reijntjens, De twijlels van het Hof van Cassatic, RW 1975-1976, 2114-2130

M. Kadaner, L'administration de l'immeuble divise, in: P. Dehan (red.), La copropriété, Editions Bruylant, Brussel 1985, blz, 166-227

H. Kahlen, Schadensersalz wegen versagter VeräuBerungszustimmung, ZMR 1986, blz. 76, 77

P.W. Kamphuiscn, De huarder als gocd huisvader, NJB 1960, blz, 909-913

M. Kaser, Das Römische Privatrecht, erster Abschnil, tweede druk, C.H. Beck'sche Verlagsbuchliandlung, Mürichen 1971

M. Kaser, Das Römische Privalrecht, zweiter Abschnitt, tweede druk, C.H. Beck'sche Verlagsbuchhandlung, München 1975

S. Keith, Rechtsfolgen unguiliger Beschlüsse der Wohnungseigentümer, diss. Mansier 1983, uitgegeven in de serie "Partner in Gespräch", Hammonia Verlag, Hamburg 1983 
KischinewskimBroquisse

Kischinewski-Bsroquisse (Supplement)

Kissel

Kleijn

Kleijn/Kroes

Kleijn/Olthof

Kleijn/Verdoes Kleijn

Kluyskens

Konings

Koopmans

Kortmann

Kremer

Kürzel

Kwakernaak

Land
E. Kischinewski-Broquisse, La coproprietté des immeubles bâtis, derde druk, Librairies Techniques, Paris 1978.

idem, supplement 1983.

OR. Kissel, Gerichtsverfassungsgesetz (Kommentar), C.H. Beck'sche Verllagsbuchhandlung, München 1981.

W.M. Kleijn, Priwaatrechtelijke rechtswormen voor uitgifte en beheer van bouwgrond en gebouwen ten behoeve van owerheid en particulieren, Preadvies voor de Vereniging voor Bouwrecht, Kluwer, Deventer 1979

G.P. Kleïn, M. Kroes, Mensenrechten in de Nederlandse rechtspraktijk, W.EJ. Tjeenk Willink, Zwolle 1986

W.M. Kleijn, M.M. Olthof, Enige beschouwingen over het nieuw burgerlijk wetboek, WPNR 5561/5562, blt. $249-253,269-273$

W.M. Kleyn, G.G.J.D. Verdoes Kleijn, Gezamelijke eigendomsvormen en beheer wan onroerend goed, Vastgoed 1980/12

P. Kluyskens, Verzet art. 815 B.W. zich tegen verdeling van gebouwen bij verdiepingen of appartementen?, Tijdschrifft voor Notarissen 1956 , blz. $97-102$

P.G.H.T. Konings, De kadastrale aanduiding van het appartementsrecht, beslissende civielirechtelijke betekemis?, WPNR 1989

T. Koopmans, Compendium van het staatsrecht, vijfde druk, Kluwer, Deventer 1987

C.A.J.M. Kortmann, De grondwetsherzieningen 1983 en 1987, tweede druk, Kluwer, Dewenter 1987

F.Th. Kremer, Verzekering van appartementen in theorie en praktijk, Werzekeringsarchief 1983 , blz 37 63

O. Kürzel, Bestellung und Abberufung des Verwalters nach dem Wohnungseigentumsgesetz, BLGBW 1972 , bli. 25,26

E. Kwakernaak, De auto en zijn appartement, Bouwrecht 1985, blz. 441, 442.

N.F.K. Land, Verklaring van het Burgerlijk Wetbock, tweede deel, eerste stuk, De Erven F. Bohn, Haarlem 1889 
Langemeijer (Bescherming)

Langemeijer (Gerechtigheid)

\section{Larenz}

\section{Laurent}

Lent/Schwab

Liessem (Verwalterzustimmung)

Linsmeau

Liver

Liver

(Gemeinschaftliches Eigentum)

Lodder

Logeman

Lubbers (Gemeen goed)

Lubbers/Zweers

Luijten/Pons

Lurquin-Stavaux
G.E. Langemeijer, De bescherming van eer en goede naam in ons land, NJB 1961, ble 87-93.

G.E. Langemeijer De gerechtigheid in ons burgerlijk vermogensrecht, Studiepocket Privaatrecht, vijfde druk, Tjeenk Willink, Zwolle 1985

K. Larenz, Allgemeiner Teil des deutschen Bürgerlichen Rechts, zesde druk, C.H. Beck"sche Verlagsbuchhandlung, München 1983

J.F. Laurent, Les gages grevant la propriéte par stages, diss. Lausanne 1979

F. Lent, Karl Heinz Schwab, Sachenrecht, C.H. Beck'sche Verlagsbuchhandlung, München 1981

G. Liessem, Zur Verwalterzustimmung bei VeräuBerung von Wohnungscigentum, NJW 1988, blz. 1306-1308

J. Linsmeau, Droit judiciaire, in: P. Dehan (red.), Lat copropricte, Editions Bruylant Brussel 1985, blz. 254 292

P. Liver, Das Miteigentum als Grundlage des Stockwerkeigenłums, in: Gedächtnisschrift Ludwig Marxer, Schultess \& Co AG, Zürich 1963

P. Liver, Gemeinschaftliches Eigentum, Zeitschrift des bernischen Juristenvereins 1964, blz. 261-269.

D.H. Lodder, Een notariele acte van werkoop wit het oude Egypte, A.A. 1987, blz. 386-390

J.J.A. Logeman, La condition juridique du coproprietaire incorporé a une association syndicale ca France, diss. Leiden 1987

A.G. Lubbers, Gemeen goed, Kluwer, Deventer 1979

A.G. Lubbers, H.J Zweers, Preadviczen uilgebracht voor de jaarlijkse algemene vergadering van de Broederschap der Notarissen in Nederland, 23 sept. 1954

E.A.A. Luijten, J.C.F. Pons, Modalites de la construction des régimes de construction de la propricte urbaine (coproprieté verticale et horizontale; emission de titre immobiliaires), Rapport voor het $\mathrm{Xe}$ Congrès International du Notariat Latin, Montevideo 1969

D. Lurquin-Stavaux, L'administration des immeubles a travers la jurisprudence de ces cinq dernières annees, J.T. 1975, blz, 1-9 
Van Mararseven

Magnenat

Maris (Preadvies)

Marty/Raynaud

Mazeaud/Juglant

Meier-Hayoz:

De Meij

Meijer (Kiczen of delen)

Mengiardi

Merle (Bestellung und Abberufung)

Merle (Wohnungseigentum im System)

Mertens

Mertens (Interventic)

Meyer

Michaud

Moens
H. vani Maarseveen, Ageism (age + ism), NJB 1987, ble: 501 .

H.E Magnenat, La Proprieté par tage, Nouvelle Bibliotheque de droit et de jurisprudence, Lausanne 1965

A.G. Maris, Preadwies aan de Nederlandse Juristenvereniging, I eerste stuk, HNJV 1969

G. Marty, P. Raynaud, Droit civil, Les Biens, tweede druk, Sirey Paris 1980

H. Mazeaud, L. Mazeaud, J. Mazeaud, Leçons de droit civil, tweede deel, vijfde druk, bewerkt door $M$. de Juglart, Editions Montchrestien, Paris 1976

A. Meier-Hayoz, Das Sachenrecht (Berner Kommentar), 1e Abteilung, das Eigentum, wijfde druk, Verlag Stämphi \& Cie, Bern 1981

J.M. de Meij, De vrijheid en verantwoordelijkheid van de pers, een onderzoek naar de betekenis van de Raad voor de Journalistiek in het kader van de informatievrijheid, diss. Utrecht 1975.

W.R. Meijer, Kiczen of delen, enkele beschouwingen over de boedelscheiding, oratie Open Universitcit 1986

R. Mengiardi, Die Errichtung von beschränkten dinglichen Rechten zugunsten und zu Lasten von Miteigentumsanteilen und

Stockwerkeigentumseigheiten, diss. Bern 1972, Buchdruckerei Stämpfli + Cie, Bern 1972

W: Merle "Bestellung und Abberufung des Verwalters nach $\$ 26$ des Wohnungseigentumsgesetzes "Dunker \& Humbllot, Berlin 1977

W. Merle, Das Wohnungseigentum im System des bürgerlichen Rechts, Dunker \& Humblot, Berlin 1978

R.F.H. Mertens, Verdwaald in het labyrint van het appartementsrecht, WPNR 5779 (1986), blz. 244-248

Interventie R.F.H. Mertens, Bouwwrecht 1987, blz. 340

W. Meyer, Das Stockwerks-Eigentum. Ein Vorschlag zur förderung des Wohnungsbaues, Bauwelt-Verlag, Berlin 1935.

P. Michaud, L'organisation de la communauté des proprietaires par étages, Editions Delta, Vevey 1975

P.L. Moens, Eigendom van servituutswerken (reactice op Eyssell), R.M. 1888, blz. 171-188 
De Mol (Huarrectit)

De Mol (Overlast)

De Mol (Rechtspraak)

De Moll (Rechtspraak woonirecht)

Moser

Van Mourik (Gemecnschap)

Van Mourik, Kwartaalbericht NBW 1984

Müller

Christoph Müller

Kurt Müller

Neleman

Nerson

Nijk

Nolet

Noordzick
J.A. de Mol, Huurrecht, tweede druk, H.D. Tyeenk Wilink, Alphen aan de Rijn 1980

J.A. de Mol, Owerlast in het buurrecht, Social recht 1987, blz $52-58$.

J.A. de Mol, Rechtspraak Woonrecht, Sociaal Recht 1988, blz 173-176

J.A. de Mol, Rechtspraak woonrecht, Sociaal Recht 1987, ble 312-315

B. Moser, Die europäische Menschenrechiskonvention und das bürgerliche Recht, Manzsche Verlags- und Universitätsbuchtandlung, Wien 1972

M.J.A. van Mourik, Gemeenschap, Monografiecen Nieuw BW, Kluwer, Deventer 1982

MJ_A. wan Mourik, Gemeenschap, Kwartaalbericht Nieuw BW 1984, blz. 58-61

H. Müller, Praktische Fragen des Wohnungseigentums, NJW-Schriftcareihe, C.H. Beck'sche Verlagsbuchhandlung, München 1986

C. Müller, Zur Gemeinschaft dicr

Stockwerkeigemntümer, diss. Zürich 1973, Verlag Stämpli \& Cic, Bern 1973

K. Müller, Der Verwalter von Liegenschaften mit Stockwerkeigentum, diss. Zürich 1965, derde druk, Verlag Stämpli \& Cie, Bern 1975

P. Nelemann, Aanvulling Woningwet, A.A. 1975, blz. $37-43$

R. Nerson, Observations sur quelques espèces. particulières d'indivision, in: Mélanges offerts a Rene Savatier, Librairie Dalloz, Paris 1965, blz. 707-721.

G. Nijk, Appartementenverklaring en art. 294 WuK, WPNR 4578 (1959), blz. 160-163, WPNR 4625 (1960), ble. $171-172$

W.A.A. Nolet, (Amsterdamse) ervaringen met de artikellen S6a en 566 Woningwet, Bouwrecht 1980, bl $x$, $2-5$

J.J.F. Noordziek, Geschiedenis der beraadslagingen gevoerd in de Tweede Kamer der Staten-Generaal over het ontwerp van Burgerlijk wetbock, zittingjaar 1823-1824, Martinus Nijhoff, 's-Gravenhage 1875 
Van Oevelen

Oldenhuis

(Kanttekeningen)

Oppenheimer

Opzoomer

Oitiker

De Page/Dehan

De Page/Dokkers

De Page/Dekkers (V)

Pak

Palandt

Parl, Gesch. NBW

Peter-Ruetschi

Peter-Ruetschi

(Anwendung)
A. van Oevelen, Eerbüediging van de grondrechten en het woonrecht, in: $K$ Rimanque (red.), De toepasselijkheid wan de grondrechten in private verhoudingen, Kluwer Rechiswetemschappen, Antwerpen 1982, blz. 93-147

F.T. Oldenhuis, Enkele kanttekeningen bij lagere (huur) recthispraak inzake lawaaioverlast, Sociaal Recht 1987, blz. $78-80$

J.F. Oppenheimer (red.), Lexicon des Judentums, Bertelsmann Lexicon-Verlag, Gütersloh/Berlin 1971

C.W. Opzoomer, Het Burgerlijke Wetboek werklaard, derde deel, art. 555-783, tweede herziene druk, J.H. Gebhard \& Comp., 1876

M. Ottiker, Pfandrecht und Zwangswollstreckung bei Miteigentum und Stockwerkeigentum, diss. Zürich 1972, Buchdruckerei Stāmpfli \& Cỉe, Bern 1972

Ph. de Page, P. Dehan, L'opposabilitê du règlement de coproprieté, du rêglement d'ordre interieur et des decisions des assemblées générales des copropriétaires, in: P. Dehan (red.), La coproprieté, Editions Bruylant, Brussel 1985, blz. 150-165

H. de Page, R. Dekkers, Traité Elementaire de droit Civil Belge, VII (Volume I), Etablissements Emile Bruylant, Brussel 1943

H. de Page, R. Dekkers, Traité Elementaire de droit civil Belge, V, Etablissements Émile Bruylant, Brussel 1975

A. Pak, Ondererfpacht een zakelijk recht?, WPNR $5210(1972)$, blz. 137-1140

Palandt, Bürgerliches Gesetzbuch, zesenvecrtigste druk, C.H. Beck'sche Verlagsbuchhandlung, München 1987

C.J. Van Zeben, W.G. Belinfante, O.W. van Exrijk, Parlementaire Geschiedenis van het nieuwe Burgerlijk Welboek, Uitgewersmatschappij AE. E. Kluwer, Deventer-Antwerpen

T. Peter-Ruetschi, Das Schweizerische Stockwerkeigentum, vijfde druk, Schulthess Polygraphischer Verlag, Zürich 1980

T. Peter-Ruetschi, Die Anwendung von Stockwerkeigentum in Erbrecht, In: Aktuelles Stockwerkeigentum (red. W. Diggelmann, H. Kunz, T. Peter-Ruetschi), Schulthess Polygraphischer Verlag, Zürich 1984, blz. 148-152 
Peter-Ruetschi (Eigentum an. Wohnungen)

Peter-Ruetschi

(Erfahrungen)

Peter-Ruetschi

(Stimmrecht)

De Pinto

Pillo

Pitlo TPR 1973

Pitlo/Bolweg

Püllo/Boskamp/Cahen

(Korte Uitleg)

Pitlo/Brabn

Pilto/Brahn (1980)

Pitlo/Cahen

(Korte uilleg NBW)

Pitlo/Gerver
T. Peter-Ruetschi, Für ein Eigentum an Wohnungen und Geschäftsräumen in der Schweiz, Schulthess \&. $\mathrm{Co}$, Zürich 1958

T. Peter-Ruetschi, Erfahrungen mit denr Reglement der Stockwerkeigentümer-Gemeinschaft und Anregungen, vierde druk, Schulthess Polygraphischer Verlag, Zürich 1986

T. Peter-Ruetschi, Betrachtungen zum Stimmrecht der Stockwerkeigentïmer, in: Aktuelles

Stockwerkeigentum (red. W. Diggelmann, H. Kunz, T. Peter-Ruetschi), Schulthess Polygraphischer Verlag, Zürich 1984, blz. 141, 142.

A. de Pinto, Handleiding tot het Burgerlijk Welbock, zesde druk door A. Teixeira de Mattos, W.EJ. Tjeenk Willink, Zwolle 1885

A. Pitlo, Het systeem van het Nederlandse privaairecht, derde druk, H.D. Tjeenk Willink \& Zoon, Haarlem 1966

A. Pillo, De ontwikkeling van een gesloten naar ecn open systeem van verbintenissen in de rechtspraak van de Hoge Raad, TPR 1973, blz. 163-193

A. Pillo, Het Nederlands burgerlijk wetboek, ded 3, algemeen deel van het verbintenissenrecht, achtstc druk, bewerkt door M.F.H.J. Biolweg, Gouda Quint, Arnhem 1979

A. Pitlo, Korte uitleg van enige burgerlijk-rechtclijke hoof ästukken, negende druk, bewerkt door H.J.N. Boskamp en J.L.P. Cahen, Gouda Quint, Arnhem 1982

A. Pitlo, Het Nederlands Burgerlijk Wetbock, decl 2, het zakenrecht, negende druk, bewerkt door O.K. Brahn in samenwerking met G.R. de Groot, A.H.T. Heisterkamp en G.E. van Maanen, Gouda Quint, Arnhem 1987

A. Pitlo, Het Nederlands Burgerlijk Wotbock, ded 2, het zakenrecht, achtste druk, bewerkt door O.K.

Brahn in samenwerking met G.R. de Groot $\mathrm{cn}$ W. Breemhaar, Gouda Quint, Arnhem 1980

A.Pitlo, Korte uitleg van enige burgerlijk-rechtelijke hoofdstukken volgens het nieuwe BW, elfde druk, bewerkl door J.L.P. Cahen, Gouda Quint, Arnhem 1988

A. Pillo, Het systeem van het Nederlandse privaatrecht, achtste druk, bewerkt door P.H.M. Gerver, Gouda Quint, Arnhem 1981 
Pitlo/Hidma

Plantenga/Treurniet

Pleysicr

Polak

Polak (Preadvies)

Van der Pot/Donner

Praktijkbock Onrocrend Gocd

Pritsch

Rey

Rheinstein

Riedler

Riemer

Rogron

Röll (Handbuch)
A. Pitlo, Het Nederlands burgerlijk wetboek, deel 4 , Bewijs en werjaring, zesde druk, bewerkt door T.R. Hidma, Gouda Quint, Anhem 1981

W.B. Plantenga, W.C. Treurniet, Erfpacht en erfpachtswoorwaarden, Preadviczen aan de algemene vergadering van de Broederschap wan CandidaatNotarissen, Arnhem 1957

A.J.H. Pleysier, Gestapelde rechten in het nieuw burgerlijk werboek, WPNR 5651 (1983), blz. 297-302

J.M. Polak, Dient de wet bijzondere regelen te bevatten ten aanzien wan de ciwielrechtelijke werking van grondrechten en, zo ja, welke?, HNJV 1969 I eerste stuk

I.M. Polak, De coöperatieve vereniging, preadvies aan de Broederschap der Candidaat-Notarissen, Arnhem 1965

C.W. van der Pot, Handboek van het Nederlandse Staatsrecht, elfide druk, bewerkt door A.M. Donner, W.E.J. Tjeenk Willink, Zwolle 1983

Praktijkboek Onroerend Goed, onder redactic wan J.M. Middag, bewerkt door W.J.B. Cornelissen e.a., Kluwer, Deventer, losbladige editie

E. Pritsch, Gesetz über das Wohnungseigentum und das. Dauerwohnrecht, Walter de Gruyter \& $\mathrm{Co}_{\text {, Berlin }}$ 1956

H. Rey, Structuren des Stockwerkeigentums, ZSR 99, $I_{n} 1980$, blz. 249-265

M. Rheinstein, Einführung in die Rechtsvergleichung, tweede druk, bewerkt door R. von Bories en H.E. Niethammer, C.H. Beck'sche Verlagsbuchhandlung, München 1987

F. Riedler, Die Zustimmung zur Vermietung der Eigentumswohnung, ZMR 1978, blz 161-164

H.M. Riemer, Die Anwendung des Vereinsrechtes auf die Gemeinschaft der Stockwerkeigentümer, Schweizerische Zeitschrift für Beurkundungs- und Grundbuchecht 1975, blz. 257-268

J.A. Rogron, Le Code civil expliqué, Société Typographique Belge, 1839.

L. Röll, Handbuch für Wohnungseigentümer und Verwalter, 4. Auflage, Verlag Dr. Otto Schmid, KöIn 1986 


\section{Rôll (Teilungserklärung)}

Romang

Roos/Florijn (Interview met J.H. Beekhuis)

Rosenberg/Schwab

Rosenfeld/Lidski

Rudolphi

Santem

Santen (Een behoorlijke buur)

Saltiva

Schellhammer

Schellema

Schenk WPNR 5570

Schenk WPNR 5589

\section{Schermers}

Van Schilfgaarde

(Rechtspersonen)

Schmid
L. Röl, Teillungserklärung und Entstehung des Wohnungseigentums, Verlag Dr. Otto Schunidt, Bonn 1975

W. Romang e.a., Stockwerkeigcntum, Haus- und Grundbesitz in Recht und Praxis, deel 1 par. 8 , Stockwerkeigentum, door Wener Ronang, Weka Verlag, Zürich, losbladige editie

N.H.M. Roos, E. Florijn, Interview met de heer J.H. Beekhuis, Kwartaalbericht Nieuw BW 1989, blz 65-71

L. Rasenberg, K.H. Schwab, ZivilprozeBrecht, dertiende druk, C.H. Beck'sche Verlagsbuchhandlung, München 1981

P.A. Rosenfeld, S. Lidski, Indivision, copropriéte et partage successoral par appartements, Dall. 1955, Chr. ble. $33-36$

HJ. Rudolphi, Die Wirkung einer

Eigentumsbeschränkung nach \&12 WEG aul dic Zwangsversteigerung des Wohnungseigentums, BLGBW 1960, blz 369-373

A.H.M. Santen, lnleiding over einige civiclrechtelijke aspecten en praktijkvragen bij stedelijke erfpacht, Bouwrechit 1975, ble. 510.516

A.H.M. Santen, Een behoorlijke buur better dan cen verre vriend, in: Naar Behoren, W.E.J. Tjeenk Willink, Zwolle 1982, blz. 105-116

H. Saltiva, Recherches sur la propricté par ettages, sa prohibition et son remplacement en droit suisse, diss. Lausanne 1954, Imprimerie Henri Jaunin, Lausanne 1954

K. Sichellhammer, ZivilprozeB, tweede druk, C.F. Müller Juristischer Verlag, Heidelberg 1984

Scheltema, Bouwrecht 1975, blz. 521 .

W. Schenk, Leeftijdsgrens voor toelating tot serviceflats, WPNR 5570,5589 (1981), bly. 413 415 , 887,888

H.G. Schermers, Internationaal publickrecht voor de rechtspraktijk derde druk, Kluwer Dewenter 1985

P. Van Schilfgararde, Rechtspersonen, algemene bepalingen, Kluwer, Deventer, losbladige editic

Fritz Schmid, Die Begründung von

Stockwerkeigentum, diss. Zürich 1972, Schulthess Polygraphischer Verlag; Zürich 1972 
Schmidt (Haftung)

Schmidt (Mieter)

Schober

Scholten

Scholten (Eigendom)

Scholten (Uilbouw)

Schoordijik

(Mede-eigendom)

Schopp

Schwarz

Schwarz

(Wohnungseigentum in Frankreich)

Schweizerisches Privatrecht

Sizaire

Smarius WPNR 5552

Smarius WPNR 5570

Smarius WPNR 5589

Smeets/Mertens

De Smidt

Smit WPNR 5637
MJ. Schmidt, Díe Haftung der Wohnungseigentümer fuir das Verthalten Dritter, MDR 1987, blz 894, 895

MJ. Schmidt, Wenn dem Mieter erlaubt wird, was dem Wohnungseigentümer verboten ist, Der WEer 1987, blz. 106-110.

B.G. Schober, Die Gemeinschaft der

Wohnungseigentümer im franzözischem Recht, diss. Montpellier 1984, nitgegewen in de serie "Partner in Gespräch", Hammonia Verlag, Hamburg 1986

P. Scholten, Nog eens de arresten wan den HR over den uitboww, WPNR 2343 (1915), blz 535, 536

P. Schoiten, Eigendom van den grond en eigendom van den opstal, WPNR 2521 (1918), blz. 189-191

P. Scholten, Uitbouw en bouwen over de erfscheiding, WPNR 2550-2552(1918), blz. 493-495, 505, 506, 513516

H.C.F. Schoordijk, Mede-eigendom, gemeenschap, rechispersoonlijkheid, W.E.J. Tjeenk Willink, Zwolle 1983

H. Schopp, noot bij LG Bielefeld 17 okt 1973, Rpfleger 1974, blz. 111, 112

E. Schwarz, Veräußerungsbeschränkungen im Wohnungseigentumsgesetz, BLGBW 1971, blz. 186, 187

E. Schwarz, Wohnungseigentum in Frankreich, BLGBW 1970, blz. 130, 131

A. Meier-Hayoz (red.), Schweizerisches Privatrecht $\mathrm{V} / \mathbb{1}$, Sachenrecht, Helbing en Lichtenhahn Verlag, Basel 1977

D. Sizaire, Le statut de la copropriété des immeubles batis, Librairies. Techniques, Paris 1969

J.M.C.M. Smarius, Service-koopflats en leeftijdsgrens, WPNR 5552, 5570, 5589 (1981), blz. 104-110, 415-419, 888

C. Smeets, R. Mertens, De welstandsbepalingen in het appartementsrecht, De Notarisklerk 1985, blz.17-21, 31,32

J.Th. de Smidt, Compendium van de geschiedenis van het Nederlands privaatrecht, derde druk, Kluwer, Deventer 1977

R.J.M. Smit, Een (on)besproken arrest, WPNR 5673 (1983), blz 697-702 
Sohn

Sohn (Zustimmung)

Van Son

Spruit/Bongenaar

Staak.

Stache

Stcin

Stcin (Verzekcring)

Stieglis

Stille

Stille (Rechispersonen)

Sulle WPNR 5406

Stille WPNR 5441

Sitille WPNR 5481

Stolker

Sträuli/Messmer

Suyling
P. Sohn, Die VeräuBerungsbeschränkung inß Wohnungseigentumsrecht, diss. Münster 1982 , uitgegeven in de serie "Partner in Gespräch", Hammonia Verlag, Hamburg 1983

P. Sohn, Die Zustimmung des Verwalters bei VeräuBerung der eigenen Wohnung, Der WEer $1980^{\circ}$ ble. 19,20

H. van Son, Dringend eigen gebruik van een verhuurde woning, Adwocatenblad 1986, blz 169.171

J.E. Spruit, $\mathbb{K}$. Bongenaar, De instituten van Gaius, De Walburg Pers, Zutphen 1982

G.W. Staak, Der Heimfallanspruch des Grundstückseigentümers beim Dałerwohnreclyt, SchlHA 1959, bli.. 140-142.

K. Stache, Die Problematik der $\S \S 18,19$ des Wohnungseigentumsgesetzes, diss. Münster 1968

P.A. Stein, Compendium van het burgerlijk procesrecht, zevende druk, Kluwer, Deventer 1987

P.A. Stein, Verzekering van appartementen, WPNR 4594 (1959), blz 351-353

E.W. Stieglis, Behartiging wan zaken; door wic?, WPNR 5606 (1982), bl2. 279-281.

A.L.G.A. Stille, WPNR 5444 (1978), blz. 495 over Kantongerecht Amsterdam, 8 mei 1978, Praktijkgids 1978 , nr. 1274

A.L.G.A. Stille, Rechtspersonen, verenigingen, Kluwer, Deventer, losbladige editie

A.L.G.A. Stille, De coöperatieve exploitatievereniging in het nieuwe rechtspersonenrecht, WPNR 5406(1977) blz. $577-581$

A.L.C.A. Stille, Veremiging van Eigenaars nu al inschrijven? WPNR 5441 (1978), blz. 448-450, WPNR 5481 (1979), biz. 334, 335 .

C.J.J.M. Stolker, Een civielrechtelijke benadering van de gemeentelijke verkoopregulerende bepalingen, WPNR 5601 (1982), blz. 181-187

H. Sträuli, G. Messmer, Kommentar zürcherischen Zivilprozessordnung, Schulthess Polygraphischer Verlag, Zürich 1976

J.Ph. Suyling, Bespreking van "De horizontale grenzen van grondeigendom van A. Fockema, Themis 1916, bliz. 344-360 
Suyling (Inleiding)

Swart/Gerver

Tak

Taubenischlag I

Tekstra

Den Tonkelaar

Den Tonkelaar WPNR 5467

Top

Tratnik/Mertens

Tresper

Treurniet

Tuor/Schnyder

Veegens

Veegens/Pitlo

(Oppenheim)

Van der Velden
J.Ph. Suyling. Inleiding tot het burgerlijk recht, vijfe stuk, zakenrecht, De Erven Bohm, Haarlem 1940

P.B.A. Swart, P.H.M. Gerver, Het appartement van de erfpachter en de erfpacht van het appartement, WPNR 5829 (1987), blz. 281-285

A.Q.C. Tak, Overheidsbestuur en priwaatrecht, Sanisom uitgeverij, Alphen aan den Rijn 1978

R. Taubenschlag, Opera Minora, I. Band, Allgemeiner Teil, Panstwowe Wydawnictwo Naukowe, Warszawa,

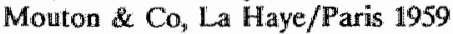

T. Tekstra, Een beroep op huurbescherming in strijd met de goede trouw, A. A. 1986, blz. $477-482$

J.D.A. den Tonkelaar, Vrijheid en gebondenheid in het verenigingsrecht, de gewone vereniging onder boek 2 BW, diss. Leiden, H.D. Tjeenk Willink, Alphen aan den Rijn 1979

J.D.A. den Tonkelaar, Geldt thans bet algemene verenigingsrecht wan Boek 2 BW voor de vereniging van appartementseigenaars?, WPNR 5467 (1979), blz. $128-131$

Fr. Top, Mede-eigendom bij appartementsgebouwen, Congres van de Vlaamse juristenveremiging , Gent 15 aprii 1967, Verslag van Sectie A, RW 1966-1967, 16851687

M. Tratnik, R.F.H. Mertens, Naar een achtste versie van art. 3.9.4.8 NBW?, Kwartaalbericht Nieuw BW 1988, ble. $46-51$

S. Tresper, Wohnungseigentum in der Praxis, achtste druk, Hammonia Verlag, Hamburg 1983

W.C. Treurniet, Bespreking van de oratie van Cahen in R.M. Themis 1968, blz. 203 e.v.

Tuor, Schnyder, Das Schweizerische Zivilgesetzbuch, negende druk, Schult hess Polygraphischer Verlag, Zürich 1979

J.D. Veegens, Schets wan het Nederlandsche burgerlijk recht, tweede deel, recht op zaken, eerste druk, H.D. Tjeenk Willink \& Zoon, Haarlem 1909

J.D. Veegens, A. Pitlo, Schets van het Nederlands. burgerlijk recht, tweede deel, zaken-en erfrecht, vierde druk, H.D. Tjeenk Willink \& Zoon, Haarlem 1941

P.A.L.M. van der Vellden, De vereniging-rechtspersoon en haar leden, diss. Nijmegen 1969, Kluwer, Deventer 1969 
Wain Velten

Van Velten (CFV)

Van Velten (Diss.)

Van Velten (Projectontwikkeling)

Van Velten (Recente

ontwikkclingen)

Van Velten (Subsidiëring)

Van der Ven

Verdic

Verdoes Klcijn

(Appartementsrecht)

Verdoes Klcijn (Dijk Bundel)

Verdoes Kleijn

(Preadvies 1979)

Verdoes Kleijnn (Stemrecht)

Vardoes Kleijn/

Wollfensperger

Vileyn
A.A. van Velten, Civielrechtelijke aspecten van de splitsing van bestaande gebouwen in Amsterdam, Bouwrecht 1979, blz. 745-749

A.A. van Velten, De coöperatieve hat- en serviceflatexploitatieverteniging, TVVS 1981, blz: 125 131

A.A. van Velten, Kopers en economische eigenatrs wan onroerend goed, diss. Amsterdam 1982, Kluwer. Deventer 1982

A.A. van Velten, Projectontwikkeling en bouwpraktijk, Gouda Quint, Arnhem 1989

A.A. van Velten, Recente ontwikkelingen bij de coopperatieve onroerend goed exploitatievereniging, WPNR 5793 (1986), blz. 487-493

A.A. van Velten, Subsidiëring van particulicre woningverbetering: privaatrechtelijke aspecten, Bouwrecht 1987, bll. 735-738

J.J.M. vain der Vien, Rechtsvergelijking, een rechtstheoretisch probleem, in: 't Exenupel dwinght (Kisch bundel), W.E.J. Tjeenk Willink, Zwolle 1975, ble. $375-388$

M.C. Verdie, Les pouvoirs du syndic dans l'immeultse en copropriête, diss. Toulouse 1975

G.GJ.D. Verdoes Kleijn, Appartementsrecla, thet verenigingsrecht wan boek 2 BW en de Vereniging want Eigenaars, TVVS 1980, blz. 113-119, 134-137.

G.G.J.D. Verdoes Kleijn, Het exclusief gebruiksrecht in het appartementsrecht, in: Met recht verenigd, Dijk bundel, Gouda Quint, Armhem 1986, blz. 147-156

G.GJ.D. Verdoes Kleijn, Het appartementsrecht als rechtsvorm voor uitgifte en beheer van bouwgrond en gebouwen ten behoeve van overheid en particulieren, Preadvies aan de vereniging voor Bouwrceht 1979 , Klilwer, Deventer 1979

G.G.J.D. Verdoes Kleijn, Het stemrecht in de vergadering van appartementseigenaren, WPNR 5015 (1989), blz. 279-281

G.G.J.D Verdoes Kleijn, G.J. Wolffensperger, Preadviezen aan de 1e kwartalualvergadering 1987 van de Vereniging voor Bouwrecht, gepubliceerd in Bouwrecht 1987, blx. $337-343$

M. Vileyn, Het appartementsrecht en de medeëigendom, TPR 1983, blz. 13-52 
Vileyn/Van Hoestenberglie

Vizethum

Vogel

Vollmar/Van den Heuvel

Voorduin

Vreede

De Vries (Naschrift bij Van Velten (Recente ontwikkelingen))

De Vries (Omzetting)

De Vries (Ondererfpacht)

De Vries (Onroerend goed)

De Vries (Preadvies)

De Vroe

Walder-Bohner

Wammes

Weber
M. Vileyn, A.E. Wan Hoestenberghe, Mede-eigendon biij appartementsgebouwen, 2e preadvies aan hel Congres van de Vlaamse juristenvereniging, 15 april 1967 Gent, RW 1966-1967, 1469-1478

Vizethum, Zur VeräuBerungsbeschränkung des $\$ 12$ WEG, Der WEer 1984, blz. 70-74

O. Vogel, Grundriss des Zivilprozessrechts, Verlag Stämpfli \& Cie, Bern 1984

H.F.A. Völlmar, H. van den Heuvel, Huurwet, Kluwer, Deventer, losbladigge editie

J.C. Voorduin, Geschiedenis en beginselen der Nederlandsche wetboeken, Robert Natan AkademieBoekhandeliaar, Utrecht 1838

F.G. Vreede, Kan een gemeente ook appartementsrechten in erfpacht uitgeven? WPNR 5389 (1977), blz. 273-276

J.J.M. de Vries, Naschrift bij A.A. van Velten (Recente ontwikkelingen), WPNR 5793 (1986), blz $494-496$

R.H. de Vries, Onvetting van rechtspersonen als bedoeld in de artikelen 19 en 20 van bock $2 \mathrm{BW}$, WPNR 5455 (1978), blz 661-669.

D. de Vries, Nogmaals: ondererfpacht een zakelijk recht?, WPNR S225 (1973), bilz 325, 326

J.J.M. de Vries, Appartementenrccht en coöperatieve natexploitatie- verenigingen, in: Onroerend Goed, opstellen ter gelegenheid van het 125 jarig bestaan van de Broederschap der Notarissen in Nederland, blz. 371-391

J.J.M. de Vries, De coöperatieve

Matexploitatievereniging, preadvies aan de Broederschap der Candidaat-Notarissen, Arnhem, 21 mei 1965

J. de Vroe, Medeëigendom in appartementsgebouw. Waarheen met de achterstand van de insolvabele medeëigenaar?, Tijdschrift voor Notarissen 1984, blz.. 209-215

H.U. Walder-Bohner, Zivilprozessrecht, derde druk, Schulthess Polygraphischer Verlag, Zürich 1983

H. Wammes, De gemeenschap naar komend recht, diss. Nijmegen 1988, Kluwer, Deventer 1988

R.H. Weber, Die Stockwerkeigentümergemeinschaft, diss. Zürich 1979, Schulthess Polygraphischer Verlag, Zürich 1979 
Weber (Prozeßahigkeit)

Wan Weesep (Sphitsingsregime)

Weimar

Weimar (Verwaltungsbcirat)

Weimar/Scuß

Wcismann

Weitnatuer

Weitnaner/Hauger

Wenger

Wiarda

Wienicke

Wiersma

Wicrsma (Mcijers)

Wictck

Willemse

De Winter
R.H. Weber, Zur Prozelfalhigkeit der

Stockwerkeigentümergemeinschaft, SJZ 1979, blz, 117. 126

J. van Weesep, Appartementsrechten, het gebruik wan het splitsingsregime, met medewerking van K.J.V.G.

Nielsen, S. Reith en M. Wiegersma, Nederlandse

Geografische Studies 65, Koninklijk Nederlands

Aardrijkskundig Genootschap/Geografisch Instituut

RUU, Amsterdam/Utrecht 1988

W. Weimar, Die Eigentumswohnung, Deutscher

Taschenbuch Verlag, (DTW), zesde druk, C.H.

Beck'sche Verlagsbuchhandlung. München 1982

W. Weimar, Der Verwaltungsbeirat gemäB $\$ 29$ WEG, ZMR 1981, blz, 97, 98

W. Weimar, Hanns SeuB, Die Eigentunnswohnung Deutscher Taschenbuch Verlag (DTV), achtste druk, C.H. Beck'sche Verlagsbuchhandlung, München 1985

M. Weismann, Tous les problemes juridiques de la coproprićte, dertiende druk, J. Delmas et cie, Paris 1987

H. Weilnauer, Wiedergabe von

VeräuBerungsbeschränkungen nach $\$ 12$ WEG im Grundbuch und im Hypothckenbrief, Rpleger 1968, blz. 205,206

H. Weitnauer, M. Hauger, Wohnungseigentumsgesett, zesde druk, Verlag Franz Vahlen, München 1982

L. Wenger, Die Quellen des Römischen Rechts, Adolf Holzhausens, Wien 1953

G.J. Wiarda, Drie typen van rechtsvinding, derde druk, W.EJ. Tjeenk Willink, Zwolle 1988

H. Wicnicke, Das Wohnungseigentumsgesetz, Verlag Komentator, Frankfurt am Main 1974

K. Wiersma, Bouwrecht 1973, blz. 218 annotatic HR 7 meil 1971, NJ 1973, 15, Bowwecht 1971, blx. 779

K. Wiersma, Meijers en de hercodificatic, WPNR 5504 (1980), blz 22-31

S.M. Wictek, Wohnungseigentum in Frankreich, Edition lür internationale Wirtschaft, Frankfurt 1976

P. Willemse, Is de cooperatie in boek 2 Nieuw BW well het normaaltype?, TVVS 1978, b1\% 378-383

R. de Winter, Huisdierenverbod, Binnenlands bestunr $1988,5 \pi / 52$, blz. 30 
De Witte van Citters

Ter Woorst

Zurfluh/Traizet-Frot

Zweigert/Kötz
J. de Witte van Citters, Opmerkingen over bet bezit en den eigendom van gedeelten wan huizen (pro diviso), Themis 1852 , blz. $203 * 229$

G.J. Ler Woorst, De coöperatieve onderneming, $5 \mathrm{MO}$ boek 23, 1982

A. Zurfluh, T. Traizet-Frot (e.a.), Le Statut de la copropriété, Editions Sirey, Paris 1968

K. Zweigert, H. Kötz, Einführung in die

Rechtswergleichung Band I, tweede druk, J.C.B. Mohr (Paul Siebeck), Tübingen 1984 


\section{Curriculum vitae}

Roel Mertens werd op 14 april 1964 in Reuver geboren. Nadat hij in 1982 aan het Bisschoppelijk College Broekhin te Roermond zijn diploma gymnasium a had behaald, begon hij in hetzelfde jaar aan zijn studie Nederlands recht aan de faculteit der rechtsgeleerdheid van de Rijksuniversiteit Limburg, waar hij op 30 juni 1986 afstudeerde. Vanaf 1 september 1986 is hij als assistent in opleiding werkzaam bij de vakgroep privaatrecht van de Maastrichtse juridische faculteit.

Hij publiceerde reeds eerder over zakenrechtelijke onderwerpen. In 1986 verscheen van zijn hand in het WPNR een artikel over welstandbepalingen, terwijl hij in 1988 tezamen met $M$. Tratnik een opstel over het huurbeding in het Kwartaalbericht Nieuw BW publiceerde. 